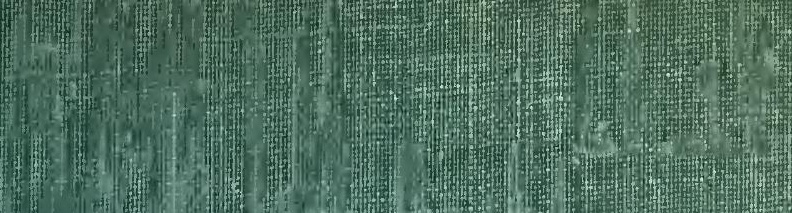

2.7.

(1)

$$
\text { (t) }
$$

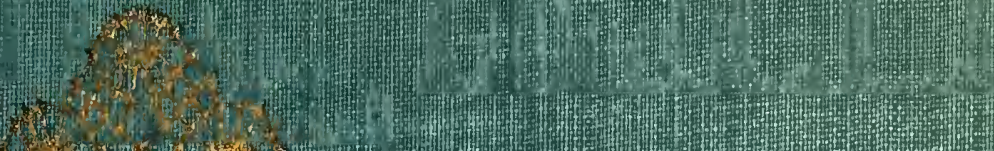

3) thet

6

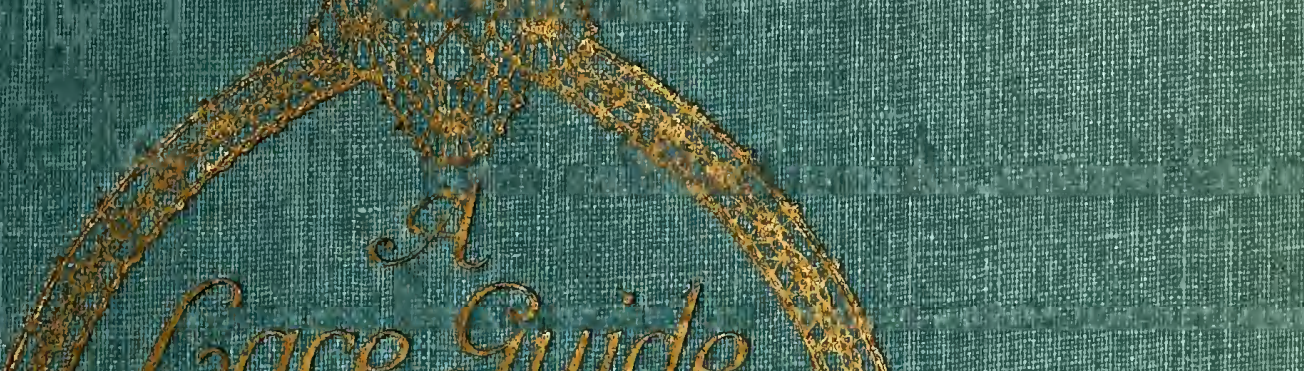
$4+2408$ inice

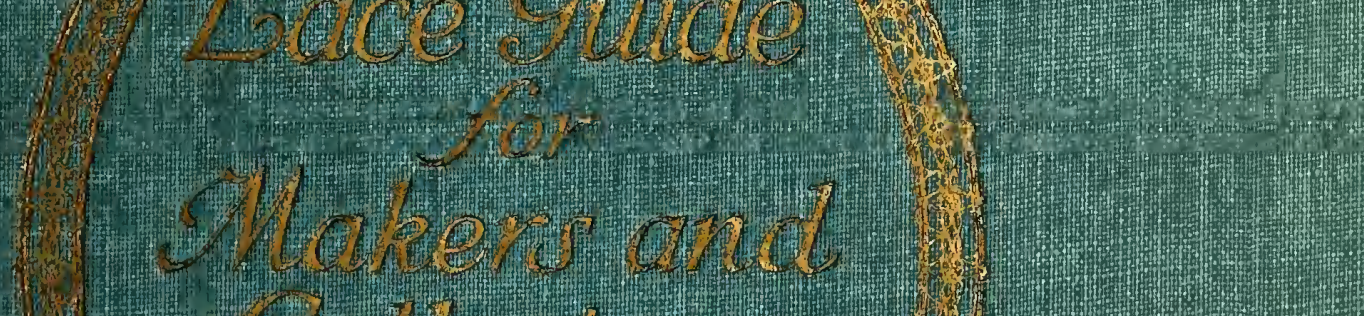

1. Cotrecions

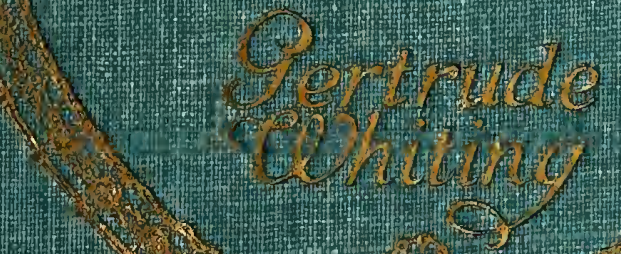

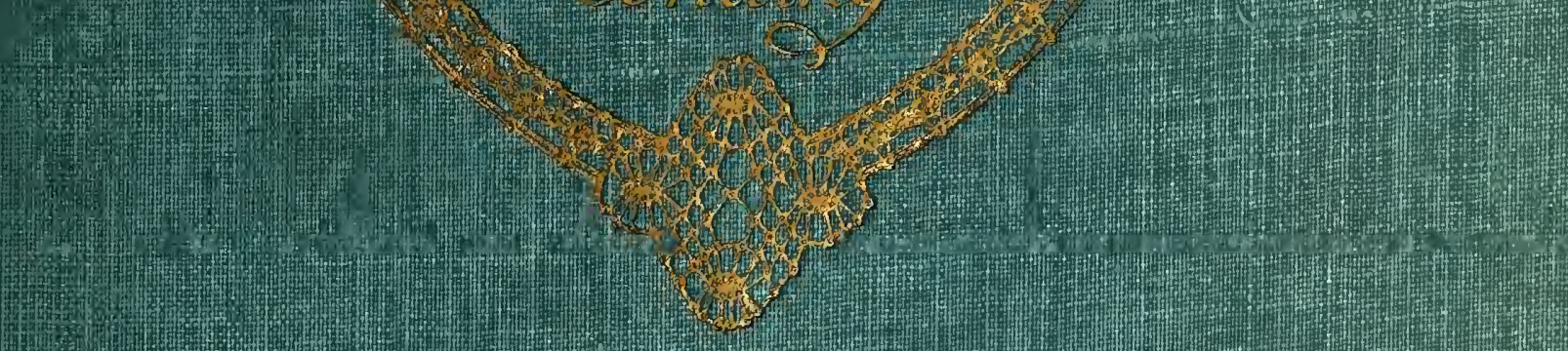

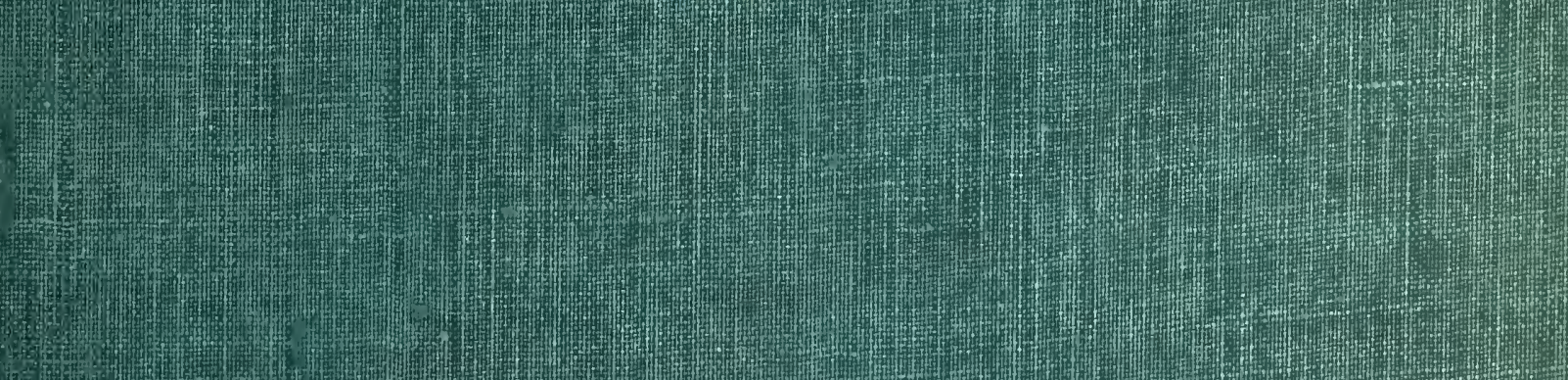
(1) 
LIBRARY OF THE

COOPER-HEWITT MUSEUM OF DESIGN

- SMITHSONIAN INSTITUTION •

Pequest of

Estate of Marian Hague 

A LACE GUIDE

for

MAKERS and COLLECTORS 



\title{
A LACE GUIDE for
}

\section{MAKERS AND COLLECTORS}

\author{
WITH BIBLIOGRAPHY AND \\ FIVE-LANGUAGE NOMENCLATURE
}

Profusely illustrated with halftone plates and key designs

\section{By \\ GERTRUDE WHITING}

Graduated as Professor by the Institut Professional Neuchattelois de Dentelles: Founder and President of the Needle and Bobbin Club: Lace specialist on the Committee on Occupation of the Department of Public Charities, New York City.

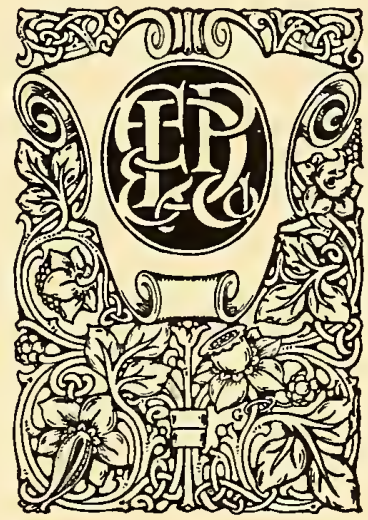

$$
\text { NEW YORK }
$$

E. P. DUTTON \& COMPANY 681 FIFTH AVENUE 

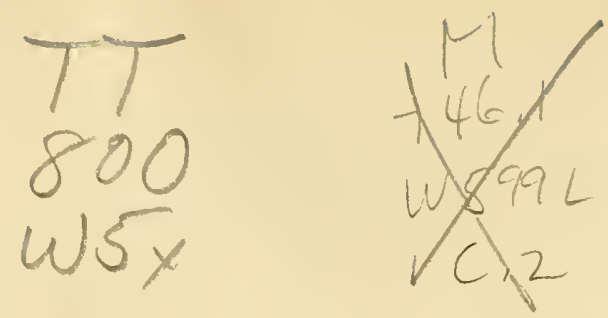

COPYRIGHT 1920

By E. P. Dutron \& Company

All Rights Reserved 


\section{DEDICATION}

Minnewaska, New York, August 31st, 1917.

My Dear Miss Burt :

Most of us must put aside costly pleasures now that America is fighting by the side and under the tutelage of the fine, old, lace-making countries; offering them willing hands, keen eyes, and much besides; reâdy to succor and nurse them until they can again clothe fair lands with rich artistic skill; ready among other things to bring home something of the old world's mellow charm, that the joy of beauty as well as practical ability and high morale may be instilled in American boys and girls. America is eager indeed to encourage art; that is, the harmony of the material, a link drawing the physical towards the spiritual, and adding to the utilitarian a simple grace, an uplifting charm.

But in spite of the sacrifices necessary to aid and save our elder sisters and to develop the best that is in us, we shall not have to forego love and friendly fellowship and gratitude. So the costs of war (and doctors) cannot take from me either the pleasure of association with you or gratitude for your freely given afternoons, helping me to mount these illustrations for the printer when my arms were too lame to work, and for your unselfish patience and encouragement. Having unruly arms and other ailments, is truly worth while when it points the way to generous hearts and kind, new friends!

Sincerely,

Gertrude Whiting.

To Miss Juliet Burt, Cincinnati, Ohio. 



\section{CONTENTS}

PAGE

Diagram of Sampler $\ldots \ldots \ldots \ldots \ldots \ldots \ldots \ldots \ldots$. . back cover pocket

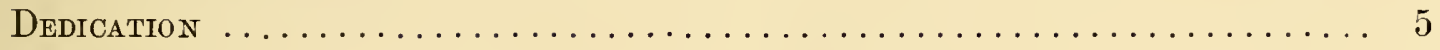

Chapter I-By Way of Introduction................... 13

Poem-The Lace Maker. . . . . . . . . . . . . . . . . . . . . . . 19

Chapter II-Suggestions $\ldots \ldots \ldots \ldots \ldots \ldots \ldots \ldots \ldots \ldots \ldots \ldots \ldots \ldots \ldots$

Chapter III-Explanations and Nomenclature $\ldots \ldots \ldots \ldots \ldots \ldots$

Nomenclature $\ldots \ldots \ldots \ldots \ldots \ldots \ldots \ldots \ldots \ldots \ldots \ldots \ldots \ldots \ldots$

Chapter IV-Rules............................. 69

Chapter V-Bibliography $\ldots \ldots \ldots \ldots \ldots \ldots \ldots \ldots \ldots \ldots \ldots \ldots \ldots \ldots$

Index of Bobbin Lace Grounds and Fillings $\ldots \ldots \ldots \ldots \ldots \ldots \ldots \ldots \ldots \ldots \ldots .403$ 



\section{LIST OF ILLUSTRATIONS}

PAGE

The Lace Maker, by Pieter van den Bosch . ................ 18

Old Bobbin (From the Author's Collection) .................. 21

Adjustable Easel-like Stand for Spanish Lace Pillow ................ 24

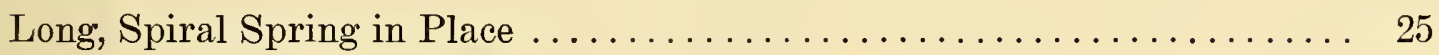

Showing Bobbins Couched Between Bands of Ribbon ............... 27

Placing One End of Skein Over the Left Thumb .............. 30

Laying the Other End of the Skein Around the Little Finger........... 31

Bobbins Can Be Easily and Quickly Wound $\ldots \ldots \ldots \ldots \ldots \ldots \ldots \ldots$

Old Rhode Island Whale-Ivory, Reel, Winder, or "Swift" (From the

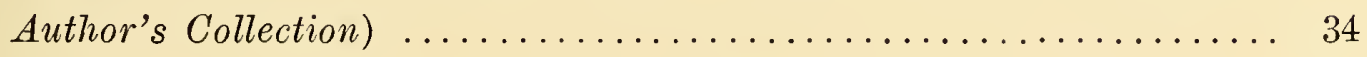





\section{A LACE GUIDE \\ for \\ MAKERS and COLLECTORS}





\section{CHAPTER I}

\section{BY WAY OF INTRODUCTION}

" 'In time of war prepare for peace.' . . . . . For there will be a future. And in that future there will be eniulation, if not rivalry, among the peoples of the earth. And the victor's wreath, as well as more substantial fruits will be given to those who can produce most cunningly the things that peaceful people desire-such as chairs, tables, beds, clothing, utensils, adornments, jewelry, and all things of use or ornament that make men comfortable and tend to to make them joyous.

"Then . . . the nations whose workers in dusty factories transform earths into clumsy dishes for common use will get... a modest or a decent living; but the nations whose skilied artisans, guided by gifted and trained artists, turn those same materials into forms of grace adorned with lines of beauty, will receive fame and fortune, and set their childen's feet on those broad plateaus where knowledge and power and enjoyment are to be had."

-Bulletin of the Metropolitan Museum of Art.

This little manual is the outcome of six summer's' work under the encouragement of the lace director of the Metropolitan Museum. Realization of the fact that in 1912 the museum had few examples of meshes except such as appeared in scattered bits throughout the delightful collection of berthas, trains, fichus, et cetera, that it was difficult to compare the effects of these stitches worked in different sized threads, in designs and spaces of varying forms, and at different ends of the rooms, and that the few mesh specimens the galleries had, were more or less scantily named, the suggestion arose that a comparative, indexed sampler of bobbin lace grounds and fillings be made. It is hoped that it may prove of use to students of stitchery in general,- or of bobbin lace in particular,- to see how certain meshes are woven; that it may aid those planning to produce lace, either by hand or machine, in comparing and judging effects, in advance, and that it may assist collectors and classifiers to identify lace: for after all, it is the actual stitch which finally determines a variety, only certain meshes being used in a lace of pure type. As different authors and localities use diverse names for the same thing, several appelations have been indicated for many of the samples. The index down the two sides of the sampler should be used as one given with a map:- tracing down from the number noted at the top, and inwards from the letter at the side: the point of junction showing the lace in question.

At first an attempt was made to grade and assort the different kinds of stitches; but this was found impracticable, for as the work grew, meshes found here and there, in the country, in the city, on a gown, in a book, were incor- 
porated. Nor were all by any means exhausted: but some limit had to be chosen, so it was decided to stop when an even gross of samples, or a half-dozen seasons' work had been completed. The two extra meshes illustrated over and above the twelve dozen, are the bobbin-made bands which frame and connect the whole, and one little sample made at the very end for fun, partly because the extra pattern was already drawn, and partly because of a dislike to show preference to one little mite, consigning the other to the waste paper basket-though many ought doubtless to be there.

Perhaps a word of explanation should be said about the twenty Trude Grounds. They are fancies of the maker's imagination, thrown in for whatever they may be worth; perhaps out of pique, just to show that, rudimentary as they may be, America has at least the beginnings of an ability to originate her own lace.

A. Penderel Moody writes, "Fillings should be to the lace-maker what a jewel is to the goldsmith. The choice of each for its particular setting will call for the exercise of equal taste and discretion. These stitches are known as 'modes,' or 'jours,' in the great outside world, of which the village worker knows so little; needless to say such terms are unknown in the West Country, where as often as not, we talk of them as 'villins.'

"The fillings enrich the work, and also by judicious arrangement break up the monotony of a repeating design.

"The individuality, if one may so express it, of a piece of lace, is enhanced by these small changes, and while the foundation lemains unaltered, each repeat is slightly different, emphasizing the fact that it is not machine-made.

"The space to be filled will often vary greatly in shape and size. Here it rests with the worker to decide which is the most suitable stitch to use, and the best point at which to hang on.

"It will often happen that by starting at one particular point, some bobbins may be cut off on the one side in time to allow their being used again for the widening of the pattern elsewhere. Naturally, this is a saving of trouble, but the worker must bear in mind when pricking her filling that if, to avoid the use of extra bobbins, she works at a wrong angle, the effect of her work is spoilt.",

The illustrations of stitches in this book are taken from the sampler, the patterns or prickings are the ones made and used in connection with it, and the text is an attempt to describe how to weave these nets and modes. Architects' tracing-cloth can be laid over the designs in the book, the cloth mover along two inches at a time until as long a pattern as desired has been traced. Black, waterproof ink is the best for this purpose. The tracing need not be mounted, but can be laid upon Bristol or press-board for greater strength, the same pins holding both board and tracing-paper in place.

At fir'st glance the mesh-making instructions will seem bewildering: but if each one is read entirely through just before using it, and then is followed step by step, the making of the lace will unfold without real difficulty. Several of the fillings are complicated and one is apt at the start to forget some detail and have to undo; but after about one inch of lace has been successfully made, these 
tricky points will have become impressed upon the mind, and thereafter cause no annoyance. The descriptions are not intended for the absolute beginner; but, on the contrary, presuppose a little knowledge of how to handle the bobbins; and of how to adapt or transfer a coveted groundwork to the lace in which it is to be used, or to make of it a plain, solid, insertion by simply adding an appropriate edge or finish. However, the privilege has been taken of adding a few general remarks and instructions that it is hoped may not be considered too irrelevant; particularly as they are the result of only limited, personal experience. The more the author studies, the deeper she inquires, the better she realizes the possibilities and complexities of her subject, and the likelihood of error and confusion. There are several books of manual instruction for bobbinlace beginners, among them :-

"The Priscilla Bobbin Lace Book."

"Pillow Lace" by Elizabeth Mincoff and Margaret S. Marriage.

"The Art of Bobbin Lace" by L. and R. Tebbs.

"La Dentelle" by Mme. Marguerite de Brieuvres.

"Manuel de Dentelles aux Fuseaux" by Mme. H. H. de Juillien.

"D. M. C. Library Encyclopedia of Needlework"' (translated into all principal languages) by Thérèse de Dillmont.

"Bibliothek D. M. C.—die Klöppelspitzen, 1te Serie."

A book giving elementary instruction, unexplained by cuts: but also advanced rules and stitches with illustrations: and one that is recommended in connection with "A Lace Guide for Makers and Collectors" is:-

"Devon Pillow Lace, Its History and How to Make It" by A. Penderel Moody.

In an article written some years ago, Mrs. Florence G. Weber says, "At Burano in the Royal Lace School under Queen Margherita's patronage, I found splendid conditions. The girls work from nine to twelve, and from two to four. The patterns are all dark colors. They wear clean cotton dresses and dark cotton aprons. Take note, feminine reader, you who put on a dazzling white apron when you sit down to fine work! It was my good fortune to see the girls come out at noon. They wear a cotton kerchief pinned over the head to keep their hair clean. Their shoes are simply a sole of wood held on by a leather strap over the instep. At every step, the wooden sole clicks on the street. As the girls poured out of the shop, the noise of their shoes reached us a block arvay, until the whole three hundred pairs of wooden soles clicking over the stone pavement produced in me much the same feeling as the musical rattle of hundreds of lace-bobbins. When I hear it blended with the soft voices of my girls, it suggests at once the combination of industry and the joy of youthful content. I was full of theories when I went to Europe: my experience with the girls in our shop had been that lace-making first of all is a joy to the worker. It is a pursuit so refined, so ennobling, that this fact alone is a plea for our industry in Boston. In Europe, my theories proved true. In the lace-making villages, the women are of superior type. They are never idle. Their manners and voices are gentle. Their work is a constant joy. Never did I find one who admitted it a strain 
upon the eyes. Do not believe all the constantly published paragraphs about lace-makers going blind in factories! The lace is no longer made under painful conditions-in damp cellars. Good lace-makers are valuable to their employers and skill is to be treasured, not abused. They do not work in dark rooms at all, but in upper stories of well-lighted and well-ventilated buildings. Personal cleanliness is essential at all times."

The following paragraph from "Lace-Making in the Midlands" by C. C. Channer and M. E. Roberts gives us another glimpse into the life of the lacemaker, showing us that in England as in Italy "there is a freemasonry between lace workers which, once formed, is very strong; a feeling of kinship which is not easily understood by those outside"-the "spell that lace seldom fails to throw over its devotees."

"There are hundreds of women between sixty and ninety years of age quite unfit for any other kind of work who keep themselves by it in independence; any lace-buyer can count up a large number who keep their husbands as wellhusbands past work, crippled, or blind, or bedridden. The old mother living in the son's or daughter's house, past being any assistance in the housework, feels the delight of not being a burden on the hard-pressed children. She can sit at her pillow part of the day and earn the four or five shillings a week which keeps her. Perhaps to the aged the occupation is almost as great a boon as the earnings, and this accounts for the intense pleasure with which the work is almost always spoken of. When sons and daughters are all grown up and gone away, the long days may be unspeakably dull to the old couple, but the wife can always make herself happy turning over the bobbins. We went to see a widow, over eighty years old, living all alone, and tried to buy some of her beautiful lace. 'When my husband was alive,' she said, 'he didn't care for me working at it, so I put it on one side; but now he's dead, I couldn't do without it, I should be so dull.' She could not sell us any of her work, she had orders that would keep her busy for months to come.

"But it is not only the aged who are glad of the work; the mother of the family finds it a great help. When the housework is done, and the children are all away at school, she can sit down and work for a couple of hours, and the week's earnings will be a comfortable addition to her man's wages, especially when there is a large family. There is no other industry so convenient for the home. It is clean work and needs cleanliness, for lace must be spotlessly white if the worker is to get her full price. It creates no litter and no untidiness. The pillow stands by the window with a cloth thrown over it and the chair ready before it. When baby is put to sleep, the mother has but to lift the cloth and begin her work: there is no getting out of material and implements, and no putting away and clearing up when the children come home to tea. Where certain other work is taken at home, the littered floor and whirring machine make an unpleasant contrast to the tidiness and quietness of the bobbins with their little subdued rattle so pleasant to the ear. Lace-making is not tiring, nor in any way trying; given suitable spectacles for the old women, it is not at all trying to the eyes-indeed, an expert worker on a lace she knows well, looks at it no more than a needlewoman looks at a long seam. 'I could do it with my eyes shut' is a phrase one often hears of lace-making, but we take that statement for 
what it is worth. It is not monotonous work, for even in the simplest lace the pattern creates a variety of motion and sufficient occupation for the mind. 'My mother always said that to sit down to her pillow was the best rest she could have after her work,' we have been told by the daughter of a famous lace-maker."

"Art gracieux, travail bienfaisant", wrote M. Engerand. "Sa nature même se concilie avec les obligations de la vie rurale; on le quitte et reprend sans dommage. C'est l'idéal d'un travail féminin, peu fatigant, presque récréatif, distingué, s'exerçant à la maison; dans la belle saison, en plein air ou sous les pommiers; procurant aux enfants un salaire presque immédiat, permettant aux vieilles de gagner quelque argent jusqu'à la mort. Est-il vraiment beaucoup d'industries plus touchantes, plus intéressantes, mieux adaptées aux nécessités de la vie des champs?" 


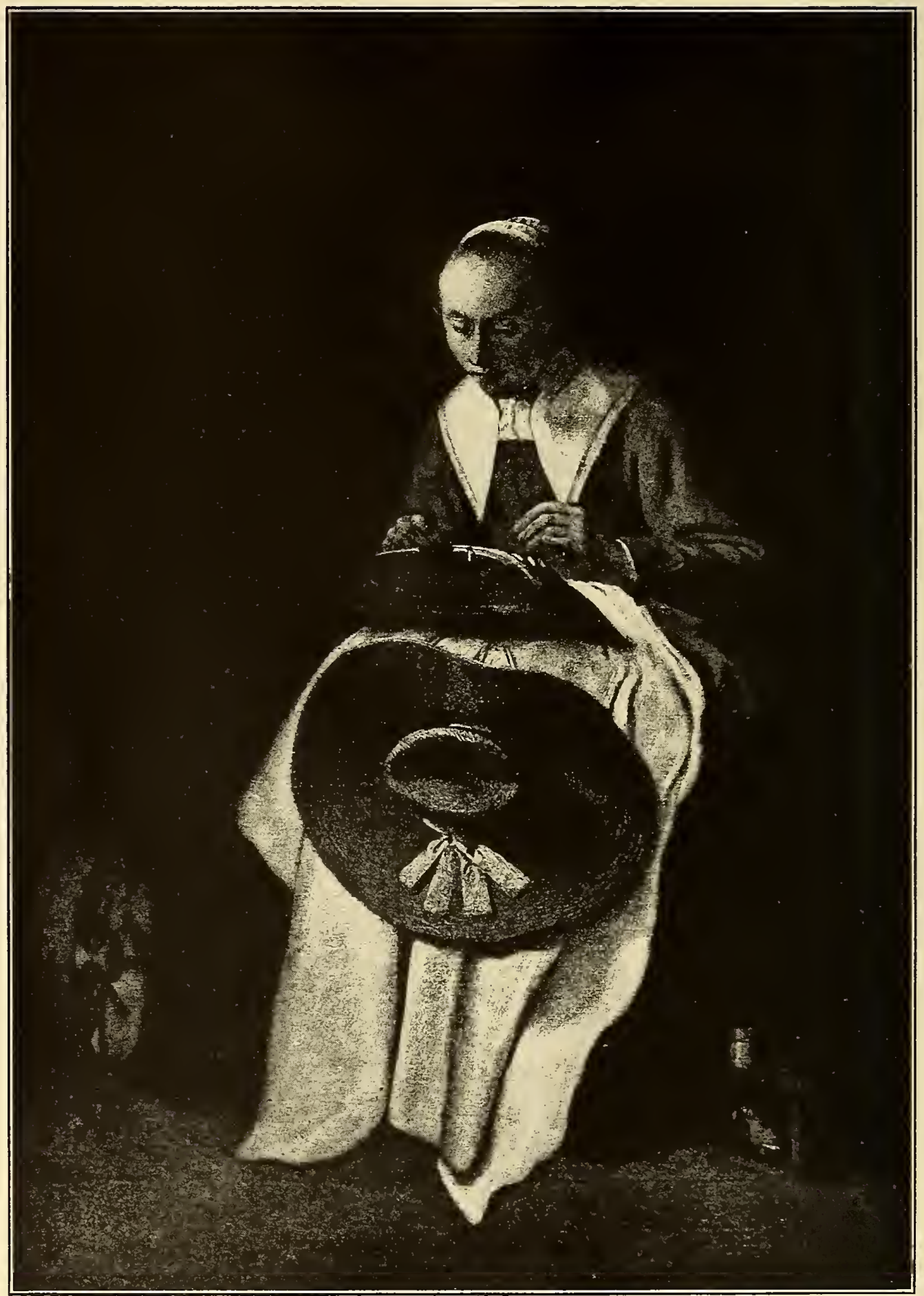

THE LACE MAKER.

By Pieter van den Bosch. 


\section{THE LACE-MAKER.}

When in doubt, when in dread, When her sky's overblown, To the plier of threadGentle artist unknownComes the blessing of work, Of her fine, quiet work.

Her poor form can relax As with pillow she sits, Deftly weaving the flax That is wound on her sticks, On her bobbins is wound,

To their spindles is bound.

Oh, such merry tools these, Quaintly carvéd and turned, Tinkling, trying to please

With the lullabies, learned As they twist, mingle, toss

In life's take, give and cross!

As the rhythmic repeat

Of their come and their go

Soon becalms by its beat,

By its cadences, so

Her resistance it smoothes,

It uplifts and it soothes.

From her fingers is shed

By the exercise light

All the nerve-poison bred

Through her worrisome plight;

It unconsciously slips,

As it were, from their tips. 
Not, perhaps, sensing how :

Yet her sore troubled mind

"By the sweat of the brow"-

The work's light though in kind-

Has ceased fretting, grown clear,

Forgot self, forgot fear.

Unpreoccupied, free

And receptive at last,

Like the heart of a wee

Little child, unharrassed,

Is the thread worker's soul,

Ay, her patient-grown soul.

She can now hear the voice-

That "still small voice" of God's-

That leads all to rejoice,

Fills their souls with the Lord's

Inexpressible peace;

Peace which never need cease

E'en midst tumult and war, If our part therein's just

And we seek nothing more

Than the duty we must

Carry out and with cheer,

Carry on without fear.

Thus her struggle so true

That her heart's very beat

Has rung upward and through

To the Heavenly Feet:

Yea, her effort sincere

To do right, persevere, 
Has brought insight and cheer, Taught her lace-maker's skill-

Skill so oft without peer-

Taught her faltering will,

To work on, not to slack,

To "look forward, not back":

That God helps us to cope

With our troubles, if we

Will keep on and but hope,

Will but lowlier be,

Not obsessed by dismay,

Not obstructing the way:

Taught her hands and her mind

Nimbly forward to fly,

Spinning each in its kind, And with patience to ply,

Weaving fabrics of worth,

Adding grace to the Earth.

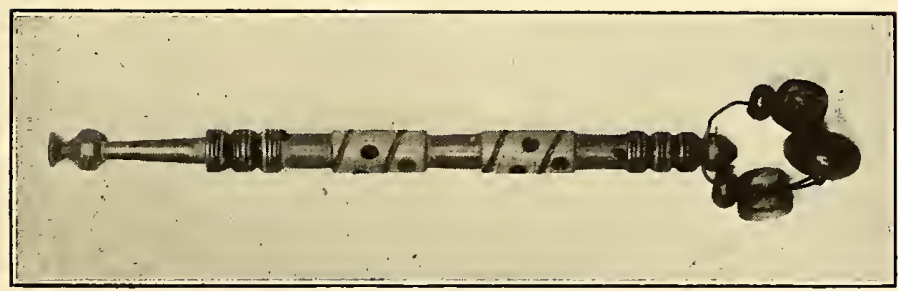

OI.D I.ACE BOBBIN.

(From the Author's collection.) 


\section{SUGGESTIONS}

"Who would believe," said the weaver of braid one day to his neighbor the lace-maker, "that 1 ell of thy lace should be worth more francs than 10 ells of 2 carat gold galloon?"

"Thou oughtest not be surprised," she answered, "that my merchandise should have a value so greatly above thine; that is because Art is worth more than Matter."

\section{-From Thomas de Yriarte, 1750. Teneriffe.}

In the chapter on Tools in "Pillow Lace" by Elizabeth Mincoff and Margaret S. Marriage, the writer says :-

"Here I should like to protest against the hide-bound conservatism that rules-sad to say-especially in women's handicrafts. Why should we so illiberally cling to some traditional way of holding the hands in our work as the only correct one? Why cannot we recognize the fact that our hands are shaped differently, the strength of our muscles balanced differently, that some are stronger in the wrist, some in the fingers, and so can never use their force to best advantage by all trying to pose themselves in some one accepted traditional way?

"In many parts it is traditionally correct to hold a great number of bobbins in the hands while working. It is possible in this way for some to economize the time they would spend in taking up and setting down the pairs in use. But that is no reason why the beginner should feel herself clumsy and amateurish because she can work better with only two pair in hand at a time. This is much less confusing, and I have known a fairly experienced worker to waste more than the time she gained in having the bobbins so close at hand, by being obliged to undo a good part of her work because she had got hold of the wrong pairs. The Flemish lace-makers, who work very fast indeed, retain no bobbins in the hands, but let them all lie in a row on a stiff card fastened across the pillow, lifting each bobbin in turn over the next.

"Work in the way that comes natural to you. There is no need to follow slavishly the rules laid down in this or in any other book, in order to become expert. If the instructions given here appear precise and dogmatic, it is because to give a choice of methods confuses and worries the beginner, not that only one road 'leads to Rome.' Later on, the worker, gaining experience, will find short cuts and ways of her own.

"Take pains to find the most comfortable pose for working, the best heights for table, stand, and chair, so that you do not have to bend over your work, nor fatigue your arms with raising them unduly. These details, un- 
noticed at first through absorption in the work, afterwards make themselves most unpleasantly apparent in stiff neck or arms.

"Do not hurry because you have heard professional workers clicking their bobbins at a great rate; remember that they mostly make one pattern day after day. The amateur has no need to turn herself into a machine, and cannot expect to work as fast as if she did so. Lace-making is a pleasant and soothing employment; if it 'excites the nerves,' as I have heard German ladies complain, it is because the worker does not take it in the right spirit, either regarding it as a task to be finished quickly, or as an opportunity of 'showing off." "'

The advantages of the Spanish, lace pillow are many. This upright, cylindrical pillow, used also by the revivors of Swiss lace-making, can be placed in an adjustable easel-like stand, or its lower end put upon the worker's knees, while the upper end leans upon a chair-back, against a table-edge or wall; or should the lace-maker be outdoors, a tape or ribbon can be secured behind the pillow by a pin, then this band can be crossed over and behind the worker's shoulders, brought forward and tied around the waist. The disadvantage of this last method is that when one leans forward to inspect a certain point, the pillow tips forward with one. Should the chair-backs available be rounded up instead of being scooped, a soft pillow, or a divided air-cushion placed between cushion and chair will keep the former from rolling or sliding. No basket, box, table or foot-stool is necessary. The work is level with the eyes, avoiding a bent-necked, stooping, hollow-chested position, making it unnecessary to hold the arms in a tiresome, spread-eagle way above the work, but allowing the elbows to fall naturally, for the bobbins hang down into the hands, making it possible to manipulate sixteen at once, instead of lifting one slowly above another; or in an effort to hurry, throwing one out of place too far beyond the other. The hanging of the bobbins keeps the threads taut and the lace smooth, without ugly loops. Suspended bobbins do not slip out of their nooses as do those lying on a horizontal pillow, nor can they roll sideways and backwards out of place, but naturally remain on the front of the cushion.

Brass pins bend and steel ones rust, so that nickel-plated tin seem to be the most all-around. The heads should be small, so as not to obstruct the view of the work beneath them, and so as not easily to catch threads when one is making a serpentine or tape-like design, when, of course, the pins are supposed to be pushed all the way into the pillow. For this reason pins should not be too long, and on account of fine laces, the shanks should be slim. The ordinary pin found in nearly all large American department stores that seems best to fulfil all these requirements, is Kirby, Beard and Company's S.W. Ne Plus Ultra, Solid Head, Smooth, Adamantine Points, $3 / 4$ of an inch long. However, special lacemakers' pins can be bought in Europe. A long fine pin is very useful in reaching in among the others to push something into place, or to assist in untying a knot.

Long, spiral, steel springs can be obtained, pinned to stand out straight horizontally against the cushion, or wrapped around it and hooked behind, at a height or level just above the heads of the bobbins, so the threads will fall between its meshes and remain in place. To prevent having to lift each thread out from 


$$
\text { it }
$$




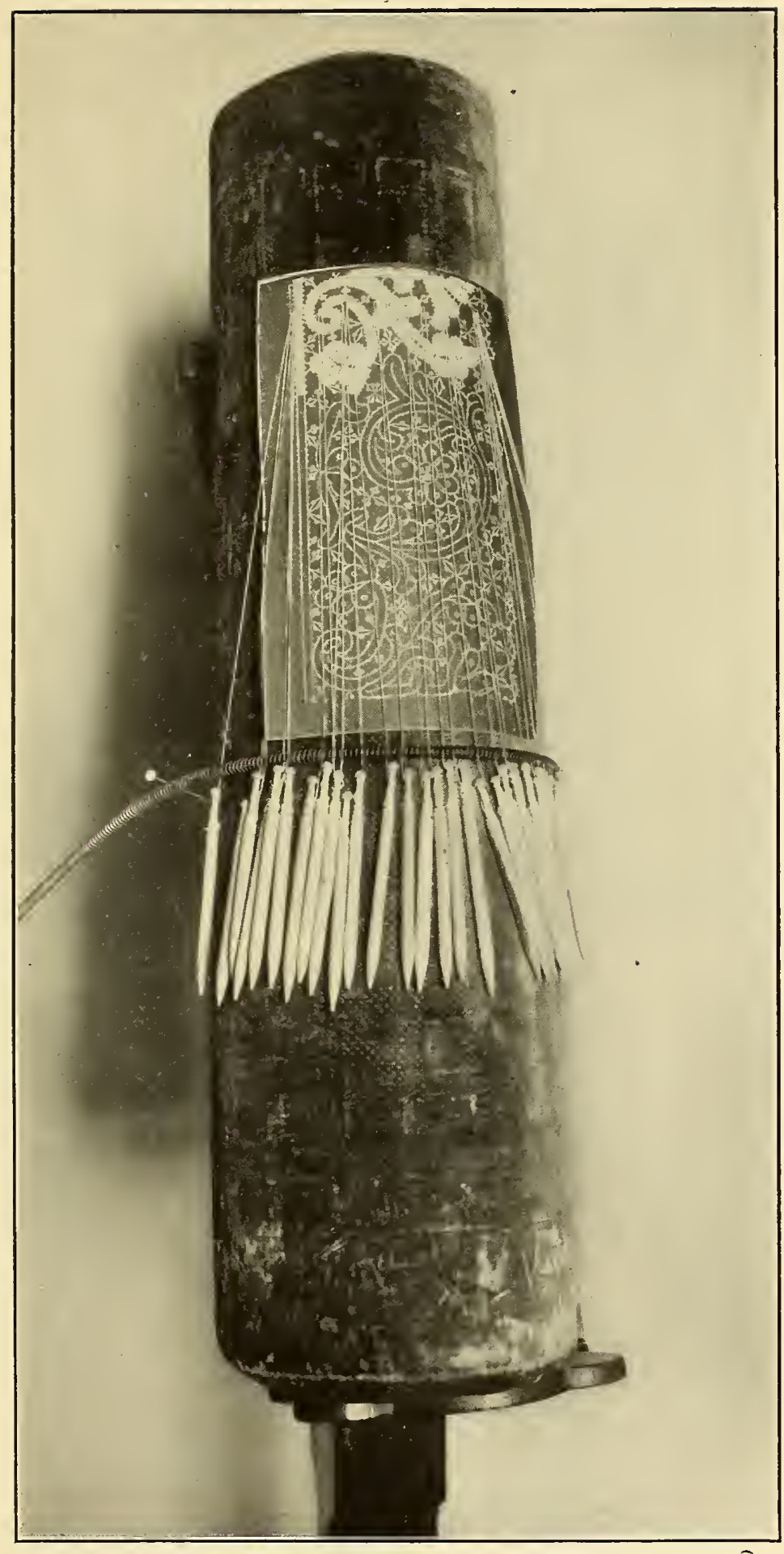

LONG, SPIRAL SPRING IN PLACE. 
a deep cleft between spirals, the spring should be of small diameter; say a quarter of an inch. If it is not brass or nickel plate, it should be kept carefully free of rust.

One can conveniently couch hundreds of bobbins or sticks in the order in which they are used by laying a broad tape or ribbon between superimposed layers of them, thus keeping an upper layer from falling into those beneath. A long tape is pinned at its centre to the middle of the pillow, and the right-hand end forms a zigzag back and forth from the centre to the right-hand edge. The left end zigzags back and forth between the left-hand layers of bobbins. Of course, a large supporting pin has to be placed in the middle and at each end to turn or wrap the tape around. The outer edge bobbins should be placed first, the left-hand ones way to the left, the right-hand ones way to the right. Then both sides are filled up to the centre pin, pair by pair. Now the tape, starting at the middle, is laid flatly over this first layer of bobbins, each end of the tape in its own direction over the big end pins. Starting at the centre from where one left off, adhering to respective sides, another layer of bobbins is couched until one reaches the two outer pins; when the tape going around these pins, returns to be folded around the centre support, so that more bobbins can be added; and so on. When the lace-maker is using the bottommost bobbins at the left of the lace, the other left edge bobbins are laid in the same orderly fashion upon the right-hand ones-with tape between, of course. Thus, first the left is laid upon the right-hand pile, then vice versa; and if done regularly, the bobbin next wanted will generally be the next to hand. Long stiff pins can be ranged fan-like to separate pairs, or to hang successive pairs upon. This avoids confusion, broken threads, knots, eye-strain and loss of time. Some schools teach that it is advisable to adhere to a fixed, orderly method of starting lace, and on account of the securing of cutworks, the left side has proved the more advantageous to begin from. Therefore, by first couching the right-hand bobbins, the left-hand ones come nearer the top. In many cases, however, it is just as easy to begin weaving at the centre without first unpiling the bobbins. To unpile, one lays the top left-hand layer of bobbins upon the top right-hand layer, doubles back the righthand tape once more, and so forth until the bottom or edge left-hand bobbins are exposed, ready for working. One then works layer by layer towards the centre. A pillow should never be put aside without first securing a ribbon firmly over even the top layer of bobbins and pinning it down tightly, so nothing can slip and no one can inadvertently upset the work. Time is not then lost in recommencing later on. And the pillow, first swathed in a roll of clean, washable linen or silk, can be safely taken about in a shawl-strap or steamer-rug roll.

This inside cover should be kept around the pillow even at home, to prevent dust or insects from settling upon the lace, and to lay under and behind the cushion when in use, to keep pins on the back of it from scratching wall or furniture. Cover and bobbins should be scrubbed before starting a new piece of work; but bobbins ought not to be soaked, as they are liable to warp. Should a creamy lace be desired, it would be better to rely upon unbleached linen, than upon the discoloration that comes from careless handling, for this of course, rots the thread and lessens the value of the product. Moreover, should the work become more tawny than intended and so require washing, there is risk of spoiling the original 


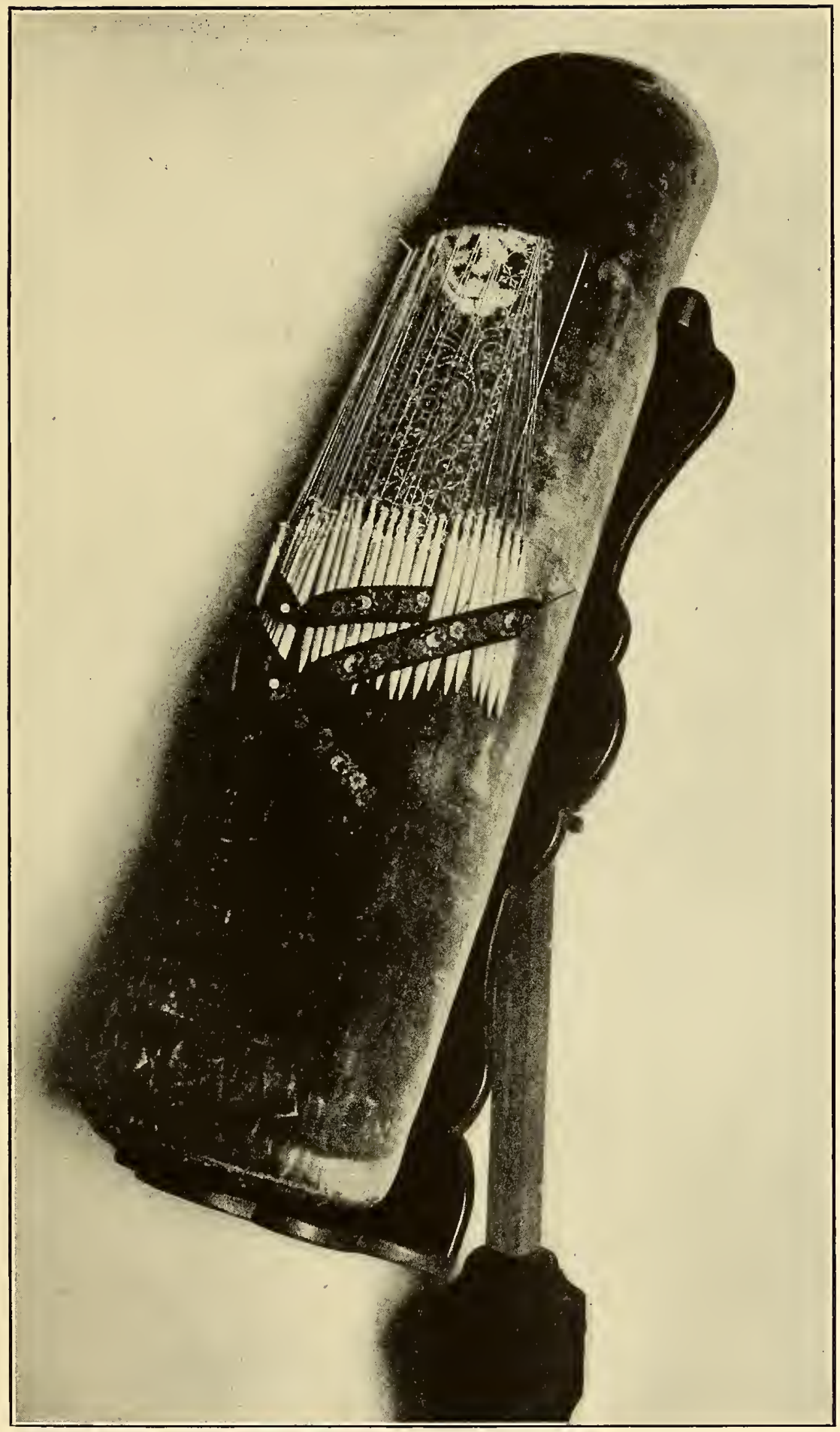

SIIOWING BOBBINS COUCHED BETWEEN BANDS OF RIBBON. 
charm of its delicate and perishable web. A damp washcloth can be kept in a rubber sponge bag or pocket at one's side and used whenever the hands feel sticky. Or those who suffer from moist hands, can use some of the various toilet preparations on the market; keeping the hands soft, nevertheless, by the use of some soothing balm or lotion.

When tape laces are made on the Spanish or Mexican pillow, a stiff felt not quite half an inch thick and about ten inches square, is attached to the pillow by one or two pins and turned or tipped from side to side as the serpentine design progresses. The bobbins therefore, always hang in the normal position and do not entangle themselves helter-skelter by catching in pins behind them in the work already completed. Such felt can be procured at a harness shop; or better still, at a felt manufacturer's.

In making long continuous strips of lace, when the lower part of the modern Swiss pillow is reached, a ribbon is laid under all the bobbins, and in tying, the outer bobbins are lifted upward and inward. This bunch is held in one hand while the last inch of work and pins are removed from the pattern. These pins should be laid over the corresponding part of the pattern on the upper part of the cushion, the bobbins so supported that the threads will not pull, and the pins pushed into their new places, thus firmly securing an inch of lace from which to work. In moving, the pins ought not to be pulled out of the lace, but only out of the pricking. The ribbon can now be removed and weaving continued.

Art needlework departments and fancy work shops keep pointed and blunt ended tweezers, which save one's nails and fingers a good deal of damage in removing pins.

The cylindrical pillow is about 26 inches long by 7 inches in diameter. Long clean straw is tightly tied together, some of the heads of the straw placed alongside some of the stalk ends to assure even thickness. If the cushion is thin and slight in diameter, there is less width of surface upon which to spread the bobbins. When the desired diameter has been obtained, the ends of the straw are chopped off to the correct length. A heavy roll of ticking or denham is sewed tightly over the straw and two circular ends are sewed on.

Short or long pattern-prickings canbe used upon this upright pillow, and two or three different pieces of lace can be in the making at once on different sides of the cushion, thus varying the work and relieving possible monotony. Two exactly similar, short patterns can be used on no matter what type of cushion, by placing one alternately below the other, and when the first one is all worked and the pins removed, placing that in turn below the one which was previously below it. It is easier to see and work on a dark pattern with light lines than on a light pricking with black lines, as white threads stand out more distinctly against a dark background.

Bahrenburg, 401 Lafayette Street, New York City, sells a soft, light green "Mytho" Bristol board No. 533, 20 by 32 inches, that is light enough to show ink marks clearly, dull enough to rest the eyes, and is interlined with muslin to prevent tearing; an excellent material for bobbin lace prickings.

If one sits with a window or lamp directly to the right or left, one side of the thread is in the light, the other in the shadow, thus showing more plainly than when the light comes over the shoulder making all the threads dead white, not 
vutlining one against the other. Splendid adjustable lamps now come, throwing their light in four directions. The three direction lamps are not fully adequate, and the addition of a movable blinder is a great help. The three directions in which many lamps move, are a sliding up and down motion, a swinging to the right and left, and a tilting to the right and left. They should also tilt or turn up and down as well as slide, just as a snake-necked lamp will; for the light should not shine downwards through the lace pins, casting shadows onto the working space, but upwards through the working place in among the pins, so the work just finished can also be observed. And the light beams should not flare out sideways into one's eyes. There is a modern theory that one should not look through a layer of darkness into a band of light, as this might cause a contradictory contraction and expansion of the pupil of the eye. But to execute lace in a diffused light is certainly very trying. The happy medium might be to place oneself in a broad, general light and then add a concentrated light directed solely upon the work. In this connection it may be interesting to note that in European lace-making communities, each worker has a bottle or jar of water tinted blue which she places in front of a candle or lamp to concentrate yet soften the light thrown upon her pillow.

In weaving wide lace, also in using fine thread, or for the so-called Italian method (that is, sewing or crochetage), slim, pointed Devonshire bobbins will be found to take up much less room, and their pointedness and lack of protruding flanges (the thread space is indented) allow them to slip easily through a loop. See the illustration in the lower right-hand corner of the sampler diagram.

A reel or yarn winder, though convenient, can be dispensed with, as a skein of thread can be held around the left hand and wound onto a spool or bit of cardboard in the right hand, by just placing one end of the skein over the left thumb, bringing the skein across the inside of the hand and around, across the back; again over the palm and around the back a second time; then across the inside of the fingers a third time, laying the other end of the skein around the little finger. The fingers and thumb should then be stretched apart to keep the thread from slipping off. Care should be taken not to twist one strand of the skein over the other, but to keep the two sides parallel.

Some people prefer to shrink each skein before using it.

A bobbin winder is an unnecessary article for a lace-maker to store or carry about with her, as the bobbins can be easily and quickly wound by tying a heavy white thread, preferably a tightly twisted or glazed one, single or doubled, to a long pin, and sticking the pin firmly into one's pillow or the upholstered arm of a convenient chair. The point of the pin in this case should be slanted towards one to anchor the work, as in hemming. Here it might be parenthetically said, that in bobbin lace-making, pins should always be placed somewhat at this angle in order that they may not give and allow threads to slip out of place; but they should, however, all slant at the same angle. The heavy white thread referred to in a previous sentence is called a cable. A cable should be, roughly speaking, about eighteen inches long: but many workers prefer a very much shorter one. The loose, lower part, not necessarily the very end, of the cable is customarily held firmly by the left tlumb twice around the forefinger of the left hand, coming up in front of it. To secure the lace thread to the bobbin, an end should 


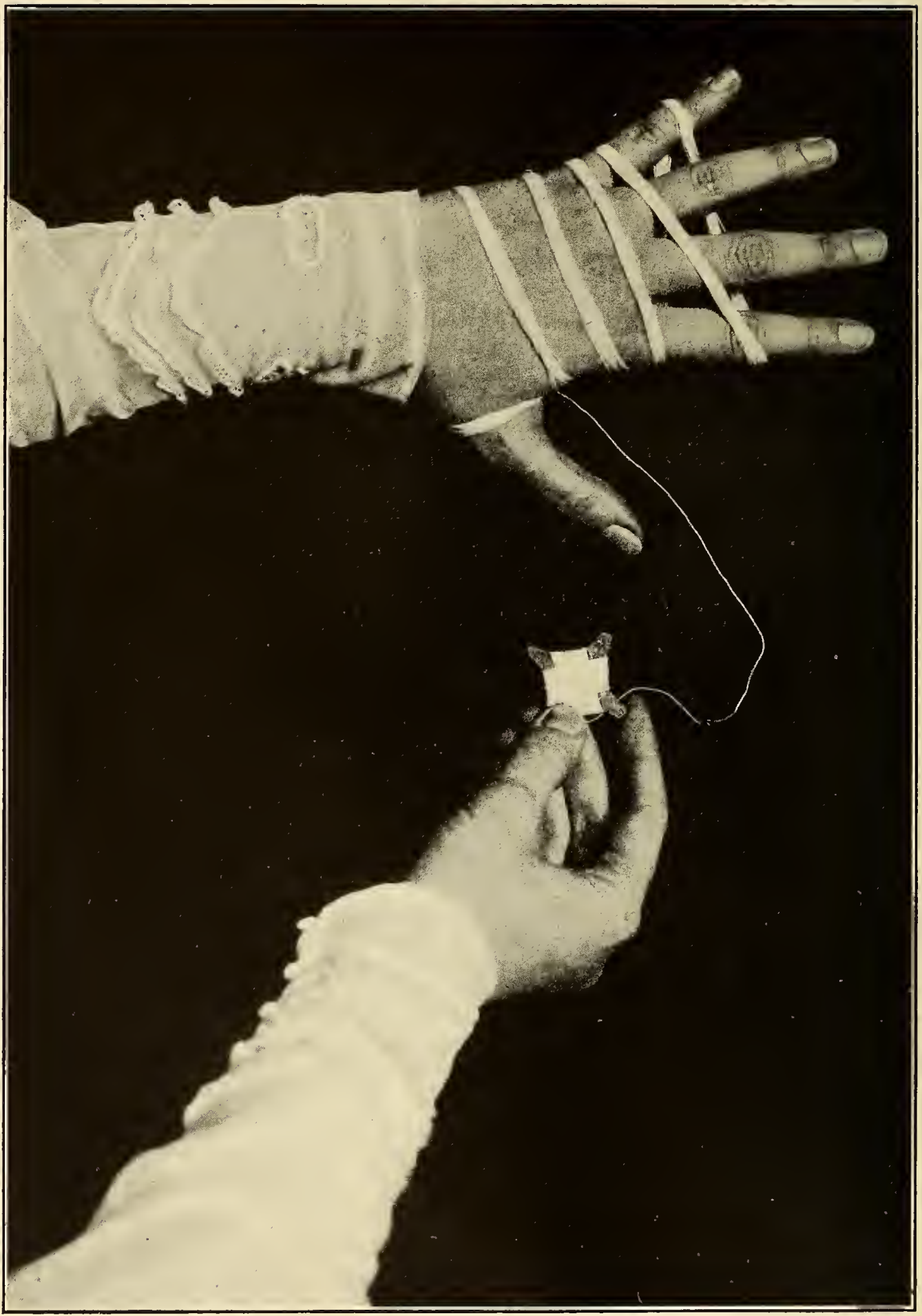

PLACING ONE END OF SKEIN OVER THE LEFT THUMB. 


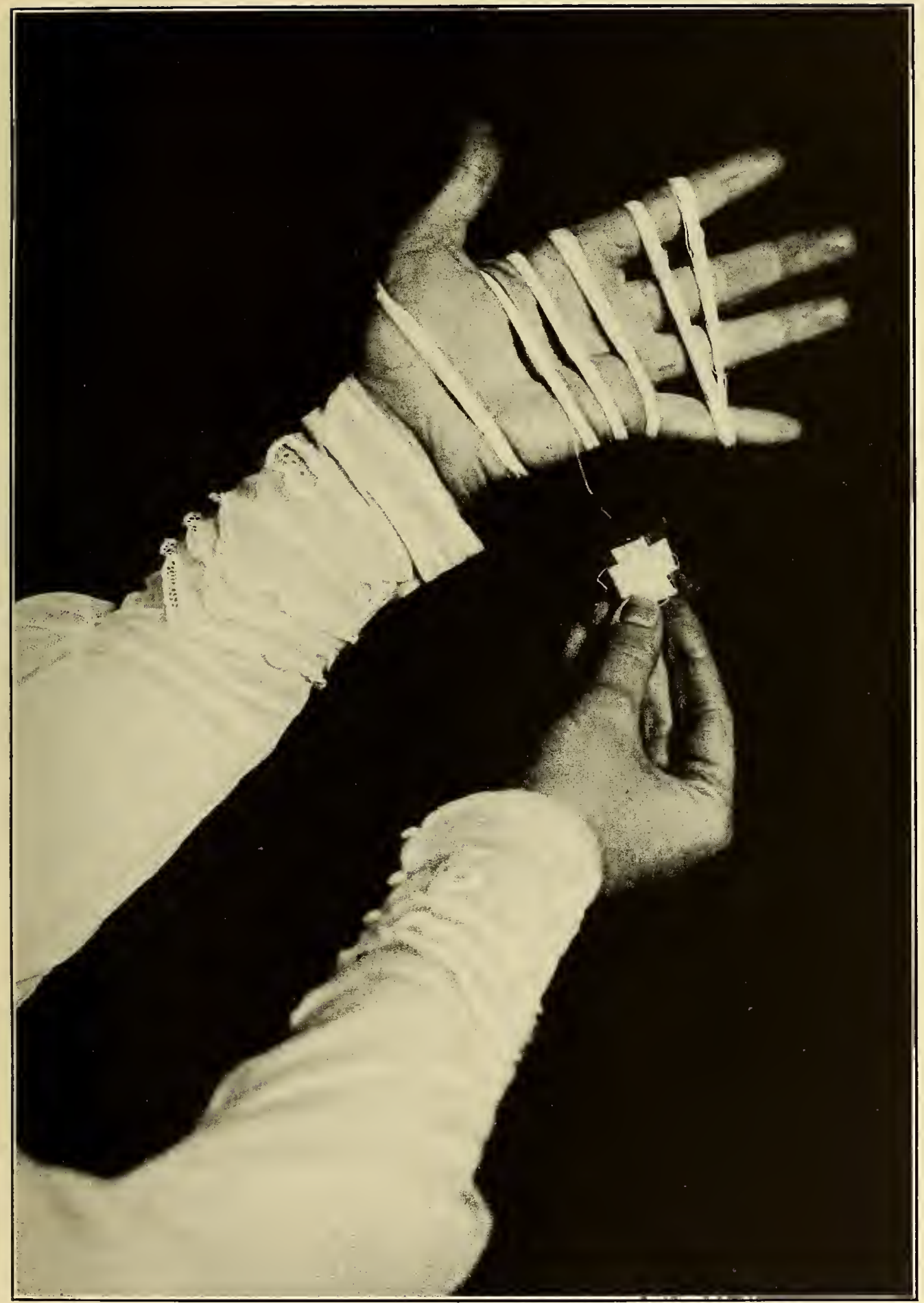

LAYING THE OTHER END OF THE SKEIN AROUND THE LITTLE FINGEI. 


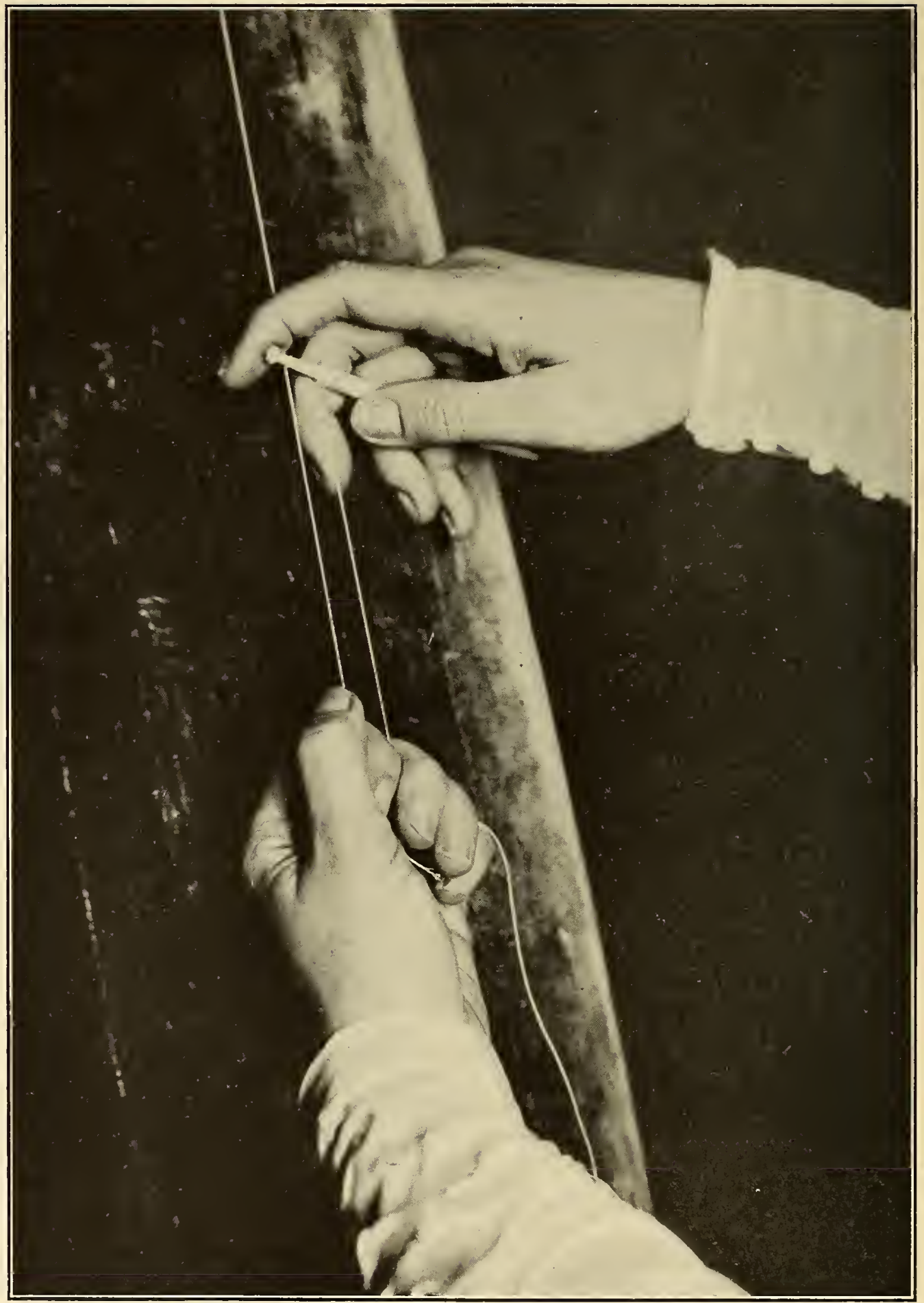

BOBBINS CAN BE EASILT AND QUICKLY WOUND. 
be placed towards the right across the handle flange at the lower end of the spindle and held there for a moment by the right forefinger. Then winding the thread twice down behind the back and up around the front of the spindle, one turns the thread end back towards the left across these two twists, using the left thumb and forefinger, replacing the right-hand finger to secure the reversed end, while one continues to wind three or four rounds of thread on top of it. The worker can then begin using the cable, in the meantime replacing the first righthand finger by the second if necessary. The lace spool or thread holder is laid in one's lap or somewhere else just below the left hand, and the lace thread comes up to the bobbin on which it is to be wound, behind the little and forefingers, in front of the two center ones of the left hand. This permits of an adjustable tension. The bobbin is held horizontally in the right hand with its head towards the left, the handle sloped slightly to the right to make the thread wind nearer the handle end than the cable end of the spindle. The thread groove around the head of the bobbin or upper end of its spindle just next to the spreading head flange, is laid in front of and against the cable. The lower end of the cable is then brought up in front of, over the bobbin, and down behind it, making one loop around-without a knot. The bobbin should slip or slide up and down in this loop, so the loop ought not to be kept too tight or the bobbin cannot move. If, however, the cable is too loose, the bobbin will slip out. Practically the whole trick lies in this tension: but that this is easily and quickly mastered, is shown by the fact that some little four-year-old, meningitis patients learned it without difficulty. The cable must be around the stick only, not in with the thread, or the bobbin cannot turn. The two first fingers of the right hand are placed above and down behind the bobbin to the left of its handle-flange, the other two righthand fingers are similarly placed: but to the right of the flange: the forefinger to the left of the cable, the other three to the right, one over the thread or spindle part, two over the handle. This keeps the bobbin properly centered, and these fingers are used to push or slide the bobbin down the cable, allowing the stick to roll. The thumb of the right hand is placed below the bobbin to the right of the cable and handle-flange, in what is the slender part of most bobbin handles, thus leaving a clear view of whether the thread is winding smoothly; and pushing the stick upwards on the return movement without the bobbin's rolling. To prevent its rolling, the thumb, of course, grips it more tightly for the moment. Once this simple trick is mastered, it seems very easy and is great fun; in fact, one feels as though one were playing a game rather than really working.

If the bobbins are wound on the two ends of the same thread, winding the first from the spool or ball, then measuring and cutting off what one wants for the second stick, no knot appears at the beginning of the lace. Knots, of course, have to be avoided in the midst of fine work, when one is adding an extra pair astride the weavers right in the middle, where there is no seam or pin. Beginners find it easier to knot two threads together around a pin at the start of a new piece: for otherwise until a little lace has been woven, securing the threads, one bobbin of a pair, when pulled, pulls up its mate on the other end of the thread. To wind sticks in advance and keep them until needed without tangling, one can 
wind each bobbin right up to the middle of the thread, there making the usual slip-noose, bringing the second stick close up to the first, with not more than a half inch of loose thread between them. Should one wish, an elastic band can then be slipped over the two handles.

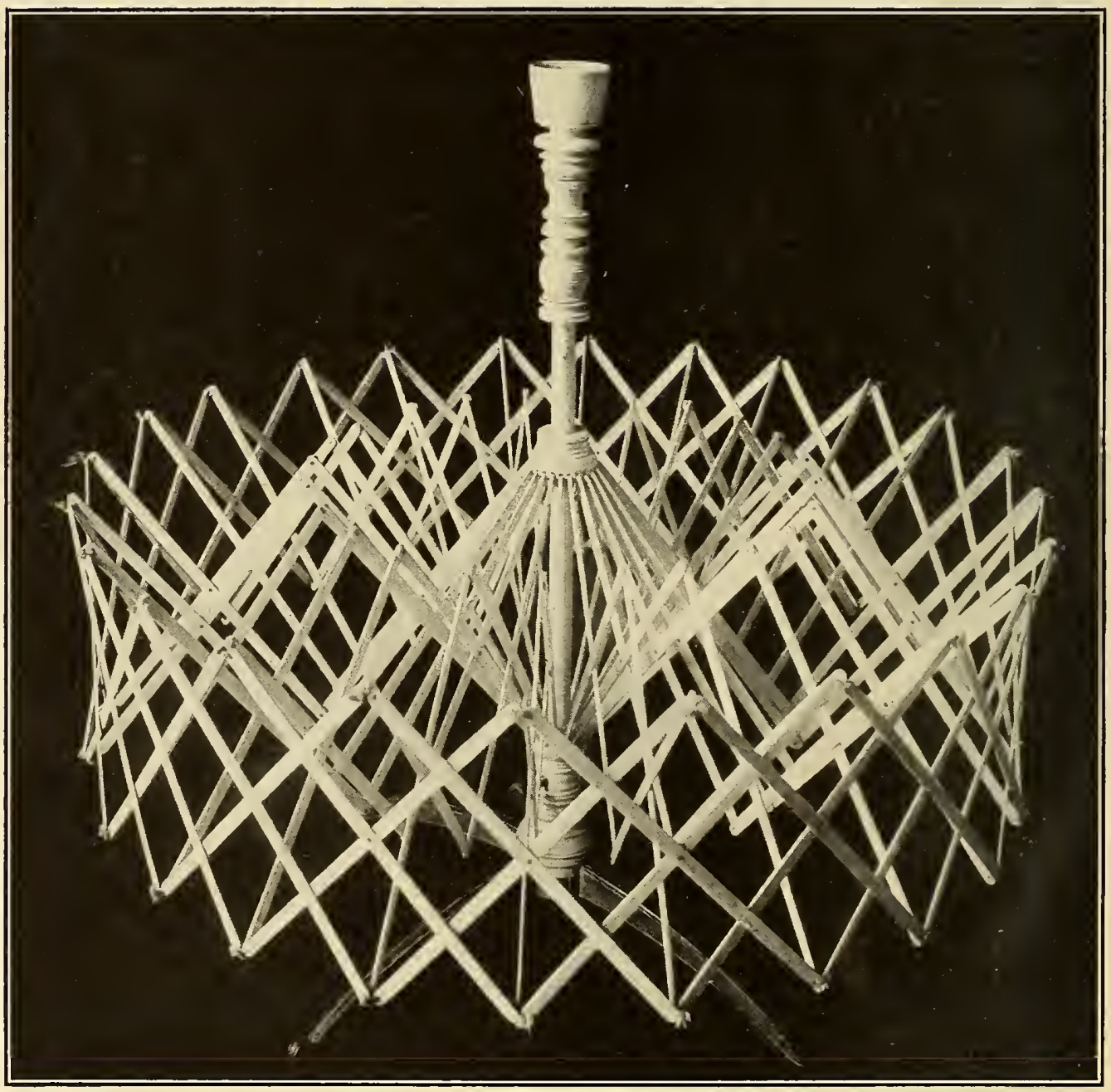

OLD RHODE ISLAND WHALE-IVORY REEL, WINDER OR "SWIFT."

(From the Author's collection.) 


\section{EXPLANATIONS AND NOMENCLÁTURE}

"The most perfect must by reason of its very perfection lack the impression of life which the very faults and irregularities of human handivort can alone produce."

There are two general definitions of lace:-one, that it is any fancy work which consists of more or about as much open space as solid part, including such products as drawn-work, reticello, cutwork, punched-work, darned net or tambour work, and Carrickmacross, which is the application of muslin onto net;the other, that lace is evolved entirely from a simple length of thread, without the foundation or addition of linen, net or any other fabric. Such laces are netting, macramé, needle-point, bobbin lace, knitting, crochet and tatting.

Carità says: "The following words of Charles Blanc very graphically convey the pleasure that will assuredly result from attempting to work out the many intricate and clever stitches handed down to us through the ages.

" "When we see these traceries so skilfully plaited in which straight lines and curves intermingle, cross, branch out, disappear and recur, we experience a high pleasure in unravelling a puzzle which at first perhaps appeared to be undecipherable, and in acknowledging that a latent arrangement may be recognized in what at first and at a distance seems an inextricable confusion.',"

\section{TERMS} pair.

By twisting is meant, placing the right-hand bobbin over the left of the same

By crossing is meant, placing the left-hand bobbin of the right-hand pair under the right-hand bobbin of the left pair.

By sewing, raccrochage or crochetage is meant, hooking one thread of a pair through a small opening, usually a pin hole, by means of a fine crochet hook or pin: then passing the other bobbin of the pair through this loop, and closing the loop by pulling up the first bobbin.

By closing is meant making the same stitch after placing a pin, as one made just prior to placing it.

By half-stitch is meant twisting, crossing.

By cloth or linen stitch is meant crossing, twisting, crossing.

By whole or double stitch is meant the half-stitch repeated.

By Winkie Pin is meant an edge where the weaver comes out (sometimes twisted, sometimes not) around a pin and returns to its former work. This edge is made up of many tiny loops.

By Bohemian Edge is meant an edge where the weaver comes out from its work and (generally after being twisted) is woven through an outside, hanging, 
waiting pair; which then becomes the new weaver, going around a pin back into the work proper, while the former weaver hangs idly awaiting the next similar edge operation. The pin is not closed. In this way an extra pair is required, as the weavers alternate in their work. The edge formed has a solid outline.

"Wincken" is the Dutch word for a quick movement, hence the English word "wink." A winkie pin edge can be made in less time and with fewer pairs than a Bohemian edge with its outside couples and extra twisting.

Just here it should perhaps be added that different authors use various terms for the same stitch or instrument, as indicated in the following five-language, lace nomenclature. Moreover, teachers vary in their instruction for forming even the elementary half, linen and whole stitches. For example:-

The "Priscilla Bobbin Lace Book"says:

Half throw-twist, cross. Whole throw-twist, cross, twist, cross.

The "D. M. C. Library Encyclopedia of Needlework" says:

Half passing-twist, cross. Double passing - twist, cross, twist, cross.

"Pillow Lace" says:

Half stitch-twist, cross. Cloth or whole stitch-cross, twist, cross.

“Die Klöppelspitzen"' says :

Halbschlag-twist, cross. Ganzschlag-twist, cross, twist, cross.

"A Text Book on Cluny and Torchon Laces"' by M. E. Woodward, says :

Half point-cross, twist. A point-repeat the preceding.

Point matte-cross, twist cross.

"The Art of Bobbin Lace" says:

Half stitch-cross, twist. Cloth stitch-cross, twist, cross.

"Devon Pillow Lace"' says:

Half stitch-cross, twist. Whole stitch-cross, twist, cross.

The Torchon Coöperative Lace Company, formerly of Chicago, says:

Half throw-cross, twist. Linen ground-cross, twist, cross. Whole throw-cross, twist, cross, twist.

The "Manuel de Dentelles aux Fuseaux" says:

Demi-point-twist, cross. Point entier-cross, twist, cross.

I have, therefore, chosen the system which appealed to me as the more logical and thorough, although either method uniformly and consistently followed, will give the same result.
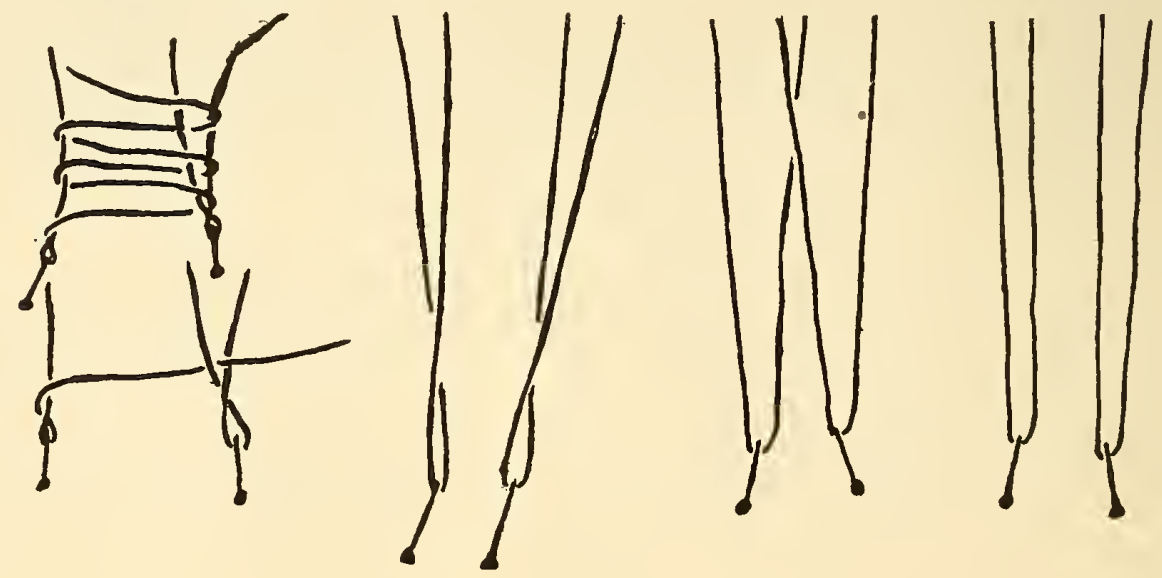
In describing the following meshes, the author has often stated that it requires so and so many bobbins for the making of a certain stitch. In this case, however, for the sake of making the explanation clear, the stitch has been isolated and described as though it were going to be woven all by itself. Should the maker wish to have several continuous lines or columns of any such mesh, not so many bobbins would be required as might at first appear. That is, if the description says that one mesh requires eight bobbins and one is about to make six such stitches side by side, it will not be necessary to use six times eight bobbins, for there is more or less give and take between pairs; that is, the strand which forms the left edge of one mesh also forms the right-hand border of an adjoining stitch.

\section{A LACE STUDENT'S NOMENCLATURE}

"A small thing may make Beauty, Yet Beauty is no small thing." - Michelangelo.

The following lace vocabulary or, more correctly speaking, nomenclature, can be largely supplemented and improved by readers who are linguists or who have studied abroad. There are spaces where missing or more appropriate words can be inserted, giving to each volume an added and individual value. In addition to the knowledge of terms gained by the author in studying lace-making and its history in different European countries, many-very many-dictionaries and technical books have been used in checking and counter-checking, and a number of foreign authorities consulted.

The names of stitches and varieties of lace are not included. See the index for a partial list of these: but the nomenclature applies to knotted, knitted, crocheted, needle, bobbin, run, applied and mixed lace: not, however, to the machinemade. Designing, laundering and historical terms also are given; as well as the names of those articles frequently made of lace or trimmed with it, and the tools, materials, et cetera, used in making it. 
ENGLISH

Ability, dexterity, deftness

Adapt, to, reconstruct, to

Admirer: see Amateur

Agate: see Puff iron

Agent, commission agent, middleman, collector, buyer, factor

Alb

Album

Aloe (tree)

Alpaca : see Mohair

Altar-cloth, cerecloth

Altar-hangings, altar-curtain

Amateur (beginner, not professionally trained)

Amateur (lover, fancier, admirer)

Amber

American (adj.)

Angel

Aniline, anilin: see Dyestuff

Antimacassar: see Tidy

Antique (adj.)
Apparatus : see
Tool
Applier (of lace)
Apply, to, onlay,
to: see Setting
Apprentice
Apprenticeship
Apron
Arabesque
Arrangement, dis-
position
Artist
Asbestos, amian-
thus, amianth
Assemblage

Attach, to: see Tie, to

Auction, sale: see Fair

\footnotetext{
Authority : see Connoisseur: see Expert
}

FRENCH

ITALIAN

SPANISH

GERMAN

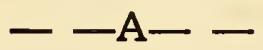

l'habileté, la dex- l'intelligente térité, l'adresse

adapter, ajuster, reconstruire

la factrice, le facteur, la koopvrouw, la factoresse, l'intermédiaire

l'aube

l'album

l'aloès

la nappe d'autel

le parement d'autel

le commençant, la commençante

l'amateur, l'amatrice

l'ambre

américain -e

l'ange

l'aniline

l'antimacassar, la pommadière, le dessus de fauteuil

antique

l'appareil, l'ustensile, l'outil

l'appliqueuse

appliquer

l'apprentie

l'apprentissage

le tablier

l'arabesque

l'arrangement,

l'agencement,

l'ordonnance

l'artiste

l'amiante

l'assemblage, le point de raccroc, le rucroc

la vente, l'enchère

l'autorité l'autorita

la desteridad, la habilitad

adaptar, ajustar

l'agente, il fattore

il camice

l'album, il libretto dei ricordi

l'aloe

l'altare

il paramento

l'incominciatore

il dilettante

l'ambra

americano

l'angelo

l'anilino

l'antimacassar

antico, vetusto, anticho

l'apparecchio

l'applicatrice

applicare

l'apprendista

il tirocinio

il grembiale

l'arabesco

l'ordine

l'artista

?

il redunamento, la commessura

la vendita die Fähigkeit, die Fertigkeit, die Geschicklichkeit anpassen el factor, el agente el alba

el album

el áloe

la sabanilla

la colgadura de altar

el aficionado

el aficionado

el ambar

americano

el ángel

la anilina

el antimacassar

antiguo

el aparato

la aplicadora

aplicar

el aprendiz

el aprendizaje

el delantal

io arabesco

la disposición

el artista

el asbestos

el conjunto

ento die Käuferin, die Kommissionärin, der Geschäftstrager

das Chorhemd das Musterbuch

die Aloe

das Altartuch, die Altardecke

der Altarbehang

der Anfänger

der Amateur

der Bernstein

amerikanisch

der Engel

die Anilin

der Schorner, die Schutzdecke, die

Sofadecke zum

Schutze gegen

Haarölflecke

alt, antik

der Apparat

die Auflegerin auflegen

der Lehrling, das Lehrmädchen

die Lehrzeit

die Schürze

die Arabeske

die Anordnung

der Künstler

der Asbest

das Zusammensetzen

la subasta pública, la almoncda

la autoridad

die Versteigerung, die Auction, die Gant

di: Autorität 


\section{ENGLISH}

FRENCH

Backed (cloth or linen) (adj.)

Background: see Ground

Back-stitch

Backwards, the wrong wa $\mathrm{g}$, against the grain

Bag

Ball, clew : see Bottom

Band: see Stripe: see Row

Band (for cap)

Bangle: see Yarnholder

Bar, rod: see Pearl-tie: see Stripe

Barker, decoy

Baste, to, tack, to

Bath - mantle, bath set

Bead

Bead edge, beading, narrow edge finish : see Edging

Beading, seaming, spacing: see Insertion

Beautiful (adj.) : see Pretty

Bedspread, counterpane, quilt

Bee

Beginner : see $A m a$ teur

Belgian (adj.)

Bertha, fall

Bias, on the bias

Bib

Binding off : see Casting off

Black (adj.)

Blade

le point arrière

à rebours

le sac

il sacco

la boule, la pelote, le peloton

la bande

la passe

la barre

le raccoleur

faufiler, bâtir

l'équipage de bain (descente de bain, sac à odeurs, serviettes, peignoirs, garnitures de bain avec volant)

il punto in dietro

in dietro

il gomitolo, la gomita

la striscia, la lista, la benda l'ala

la barra, la stanga $?$

el reclamo

imbastire

l'equipage di bagno

hilvanar

el equipo de baño

el punto-atrás, el pespunto

contra pelo, al re- rückwärts vés

el saquito, la bolsa de mano

el ovillo

la venda

el ala, la banda

la barra, la varilla der Stift la perle

la dentelle étroite

le trou-trou, l'entrelac, l'entrelas

beau, bel-le

le couvre-lit, la courte-pointe, le couvre-pied, la couverture, la couverte de parade

l'avette, l'abeille, l' apette

la perla

belge

la berthe, le godet

en biais

la bavette, le ba- il bavaglio voir

noir

la lame
Blind pin: see Fal se stitch il orlo

la passa nastri

bello

il coltre, la coperta

belgica

la ciotola, il scodellino

sbieco, sghembo

al sesgo

el abalorio

el encaje estrecho

el borde, la pestaña

bello, hermoso

la colcha, la sobrecama, el cobertor

la colmena

bélgico

la berta

el babero

nero

la lastra, la lama, la laminetta der Marktschreier, der Werber, der Schreier reihen, bastan der Bade-mantel

der Beutel, der Sack der Knäuel, der Ball das Band das Maubenband die Perle ?

der Kettenzug, der Einsatz

schön

die Bettdecke

das Nähkränzchen

belgisch der Spitzenkragen die schiefe Richtung, in schiefer Richtung, schräg das Lätzchen

schwarz die Klinge 
ENGLISH

Blonde, flaxen, silken : see Silk: see Cream colored: see Ecru

Blue (adj.)

Blunt, ob t u is e (adj.)

Blunt (needle) (sub.)

Bob: see Crown

Bobbin, stick

Bobbin lace, bobbin work, pillow lace, bonelace, pinwork

FRENOH

ITALIAN

la blonde, la biset- il merletto di seta te

oleu - $e$

émoussé, épointê, ottuso, grossolano contondant ?

le fuseau

la dentelle aux fuseaux, le plat

Bobbin winder : see Winding machine

Bodkin : see Stiletto

Bone (fish) (animal)

Bonnet: see Hood

Book

Boot-tops, kneescarfs

Borax
Border : see Edg-
ing
Bottom, foot
Bottom (of thread)
see Ball
Boudoir cap
Bout (knitting),
round
Bracelet : see Yarn-
holder
Braid: see Plait:
see Tape
Bran: see Excel-
sior
Branch, flower
Brass, latten
Bridal (adj.)
Bride: see Pearl-
tie
Bristol-board, pas-
teboard, press-
board, cartridge
paper
Bronze
Brush
Bud

Bullion le borax

le bas

le peloton

la cornette

le tour passe-lacet, l'ai-
guille à passer

l'arête, l'os

le bonnet, la calot-

le livre

de bottes

e son ceau

le cuivre jaune, l'ai- il rame, il bronzo rain, le laiton

nuptial

nuziale

le carton fin

il cartone

il bronze

?

le pinceau

le bouton

la cannetille, la frisure, la bisette, le clinquant guaine

l'osso, la spina

la berretta

il libro gi XIV

il borace

il fondo

la turna moglio pello te, la cornette

le ramage, le rin- il ramo

i piombi, il mazzette

trina a fuselli, piombini nastro, l'infila-

sorta d'ornamento a merletti che si metteva ai gambali delle

la pelot, la gomita

la cuffia da notte

la crusca, la simola

il bottone, il ger-

la canutiglia, il or-
SPANISH

GERMAN

el encaje o la blonda, hecho de seda

azul

embotado

blau

stumpf

la aguja embotada ?

los palillos

el encaje hecho con palillos

'argi p e r passe brache sotto Lui-

el salvado

la rama, el ramo

la calamina, el latón nupcial

agujeta
de jareta

la raspa 6 espina, el hueso

la gorra, el gorro

el libro

parte alta de las botas

el bórax

el fondo

el globo, la pelota

la gorra $\sigma$ el gorro de gabinete

la vuelta

der Klöppel, der Spitzenklöppel

die Klöppelspitze, die geklöppelte Spitze

die Durchzienadel

die Gräte, der Knochen die Haube

das Buch

das Spitzenbesatz am Knie, das Schenkelstrumpf, das Hosenbein

der Bor

das Ende

der Knäuel

die Morgen-haube

die Kleie

der Zweig

das Messing, das Erz hochzeitlich

die Pappe la cartulina

el bronce

el cepello

el botón, el capullo

el canutillo die Bronze, die Glockenspeise der Pinsel

die Knospe, der Keim

der gekräuselte Goldfaden, das Rauschgold 


\section{ENGLISH}

Burl, to

Burler

Burling, flattening

Burnisher : see Puff iron.

Butterfly

Buttonhole, to

Buttonhole stitch, close stitch

Buttonholing (raised,) outlining : see Gimp: see Outlining thread, see Finishing

Buy, to, purchase, to

Buyer

Cabinet

Cable

Candle-board, poleboard, candleblock

Canopy, tester, ceiling

Canvas, scrim

Cape

Cap-string

Carbon, autographic, transfer paper, colored tracing paper: see Tracing cloth

Care cloth

Carnation

Cartoon

Case: see Needlecase: see Sheath

Cas s o ck, cloak (worn over a cuirasse)

Casting off, binding off, $\mathrm{ch}$ a in of stitches

\section{FRENCH}

ébouler, rabattre, corriger les inégalités

l'ébouleuse

l'éboulage, l'affaissement

le papillon

faire le point noué, de boutonnière, de feston

le point de boutonnière, le point de feston, le point noué

la brode

acheter

l'acheteur, l'acheteuse
ITALIAN

appianare, spianare $?$

?

la parafalla

fare la festone

l'occiello, il punto a feston, il punto serrato, il punto a festone ? la desmotación to de ojales

comprare

il compratore

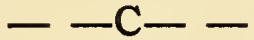

il gabinetto

la gomena, il gherlino

il candelabro

il baldacchino del letto, il baldacchino

le canevas

la pèlerine, le manteau

la bride

le papier autographique, le papier bleu de calque, le papier lombard

?

? nuziale

l'oeillet, l'oeillet-
giroflée
le carton
l'étui

il garofano

il cartone

l'astuccio, la busta, la custodia

la cotte, la casaque la casacca

la chaîne de mailles

\section{SPANISH}

desnudar

el que quita los nudos en el paño

la mariposa

ojalar, hacer ojales

el punto de ojal

el bordeado o el ribeteado con pun-

el clavel

\section{GERMAN}

noppen

die Nopperin

das Noppin

der Schmetterling

m it KnopflochStich ausbogen

der Knopflochstich

$\underset{\text { Spitze }}{\text { Art }}$ Alenconner

kaufen

die Käuferin, der Einkäufer

das Sammlungscabinet

die Schnur

der Leuchterstuhl, das Leuchtergestell

el cielo de cama

der Baldachin, der Betthimmel

die Stickgaze, die Gitterleinwand, der Kanevas

der Rad-mantel, der Kragen

das Bindeband

el calco, la copia hecha en papel transparente

el cartôn

el estuche

la cota de armas

el ribete de costura, das Abnehmen la cadena de mallas das Kopierpapier, das Kohlenpapier, das Lombardpapier

eine Decke, die der Braut während $\mathrm{d}$ e $\mathbf{r}$ Trauung gehalten wurde die Nelke

d i s Muster - Vorzeichnung das Etui

der Waffenrock über der Kopf 


\section{ENGLISH}

Casting on

Caul : see Filet

Celebration, jubilee: see Fair

Celluloid

Centre, middle

Centrepiece

Century: see Period

Chain stitch

Chalice cover, paten cover: see Pall

Chasuble

Cheap (adj.)

Chemical, chymical (adj.)

Chemise, shift

Chenille

Chest, linen chest

Chinese (adj.)

Christening, baptismal clothes, bearing eloths

Chronogram

Chronological, chronologic (adj.)

Church

Circular (adj.)

Clamp, vise, hemming-bird, clip: see Weight: see Screw

Class

Cleaning, cleansing

Clew : see Ball: see Bottom

Close, to, cover, to, shut, to, repeat, to: see Closing stitch

Closing stitch: see Close, to

Cloth stiteh, linen stitch, clothing work

Coarse (adj.)

Coffee

Coffin

Cogwheel, notched

Coif, cap

Cold (adj.)

\section{FRENCH}

le montage, monter la chaîne, ourdir

la célébration

le celluloïd, le celluloïde

el centre, le milieu

le centre de table

le siecle

le point de chaînette, la maille en l'air, la maille chaînette

la pale, la palle, la voile de bénédiction

la chasuble

bon marché

chimique

la chemise

la chenille

le coffre, le coffret

chinois - $e$

les robes de baptême

le chronogramme

chronologique

l'église

circulaire

le crampon, la clampe, le pincenotes

la classe

le nettoyage, le il nettamento nettoiement

fermer

le point final, le dernier point

le point de toile, le point matte, le mat, le toilê

gros -se, grossier -e

le café

le cercueil

la roue dentée, la roue à crans, le tournant

la calotte, la coiffe

froid -e
ITALIAN

rimontare

la festa

il cellulòide

il centro

il centro di tavola

il secolo

il punto a catenella

la patena

la pianeta

buon' mercato

chimico

la camicia, il camisciole

la ciniglia

ia cassa, la forziere chinese

la gonneletta di battesimo, la vesta di battesimo

la cronogramma

eronologico

la chiesa

circolare

il rampone

la classe

fermare, chiudere, cubrir serrare

il punto di ferma

la punta tela

grosso, grossolano

il caffe

la bara, il cataletto ?

la souffia, il cappellino, il berrettino, la scazzetta freddo

\section{SPANISH}

tramar

la celebracíon

el celuloide

el centro

el centro de mesa

la centuria, el siglo

el punto de cadena

la cubierta de plato, la cubierta de cáliz

la casulla

barato

químico

la camisa de mujer

Ia felpilla

el area

chineseo

el vestido bautismal

el cronôgrama

cronológico

la iglesia

circular

el tornillo

la clase

la limpiadura

el punto de remate

el punto de tela

grosero, basto

el café

el ataúd

la rueda dentada

la cofia

frio kalt

GERMAN

anzetteln

die Feier

das Celluloid

der Mittelpunkt

das Mittelstück

das Jahrhundert

der Kettenstich

der Kelchdeckel

das Messgewand wohlfeil, billig chymisch

das Hemd

die Chenille

die Truhe, die Lade chinesisch

die Taufkleidung

d a s Chronogram, die Zahlbuchstabeninschrift chronologisch

die Kirche kreisrund, kreisförmig

die Schraubzwinge, der Papierhalter, di e Klammer, der Schraubstock die Classe

das Reinigen

nadelschliessen

der Schlusschlag

der Leinenschlag

grob, rauh

der Kaffee

der Sarg

das Zahnrad

die Haube 
ENGLISH

Coll a r, wimple, gorget, w h i s k : see Falling collar: see Standing collar: see Yoke

Collecting (stitch)

Collection : see $M u$ seum

Colored, coloured (adj.) : see Dyestuff

Combing cloth: see Razor-cloth

Companion piece: see Mate

Company, corporation

Compass

Connoisseur: see Expert: see $\boldsymbol{A} u$ thority

Contraband

Contrast

Convent, nunnery

Conventionalized

Cope (choir)

Copper

Coptic (adj.)

Copy

Copy, to

Cord ( fancy), draw - string, band, string: see Gimp

Cork: see Excelsior

Corner

Cotta

Cottage (work)

Cotton, gossypium

Couch, to, tack, to catch down, to: see Baste, to: s e e Outlining thread

Couple, to: se e Join, to: see Tie together, to

Court

Covering cloth : see Sheath

Cravat, Steinkirk: s e e Frill: se e Jabot

Cream (colored) : see Blonde: see Ecru: see Isabel

Crease, pucker

\section{FRENCH}

le col, le collet, le il collare collier

\section{?}

la collection

colorié

le peignoir

la compagnie, la
corporation

e compas

le connaisseur, la il conoscitore, il esconnaisseuse

la contrebande

le contraste

le couvent

rendu -e, conven- ? tionnel -le

la chape

le cuivre

cophte, copte, cophtique, coptique

la copie

copier

la ganse, la corde, la corda, la stringa, le lacet

le liêge

le coin

le rochet

à domicile

le coton

coucher, bâtir

accoupler, coupler accoppiare

la corte

la cour

la housse

la cravate

couleur café au lai

la coperta

la cravatta, il fazzoletto

beige, crema

le pli, le godet, le faux-pli coricare
SPANISH

GERMAN

el cuello

der Kragen el punto de reco- ?
gida
la colección

colorado

el peinador

la compañía

el compás

el perito, el conocedor

el contrabando

el contraste

el convento

becho convencional

la capa pluvial

el cobre

cóptico

la copia

copiar

el cordón, la presilla

el corcho

el ángulo

la cota, el sobrepelliz

trabajo hecho a domicilio

el algodón

ribetear parear, juntar

zusammenkuppeln

la corte

la cobertura, la funda

la corbata

crema

die Gesellschaft

der Kirkle

der Kenner

d i e verbotenen W a a ren, die

Schmuggelwaare der Contrast

der Convent, d a s

Kiloster

stilisirt

der Chorrock

das Kupfer

Koptisch

die Copie copiren, abzeichnen die Schnur, das Schnürchen

der Kork

die Ecke

das kurze Chorhemd

das man $\mathrm{nach}$

Hause nimmt

die Baumwolle

aufnäben, $\quad \mathrm{fla} \mathrm{ch}$ nähen

der Hof

die Decke

die Halsbinde, die Kravatte

die Rahmfarbe

el pliegue, la plega- die Falte dura 
ENGLISH

Crescent

Crochet, to

Crnchet-hook,

Shepherd's Hook

Crochet - knitting,

Tunisian knit-

ting, Victorian

knitting

Crochet thimble: see Thimble for crochet work

Cross, to

Cross-section paper, point paper

Cross-stitch

Crown

Crown (of a bonnet), bob

Crowns, pin work, spines, thorns: see Rosettes

Cuff, wristband : see $R$ uffle

Curtain: see Window shade

Curve

Cushion (sofa) : see Pillow

Cut, to

Cutwork

Cutworks, le a d works, le r d works: see Tuft

Cylinder

Dalmatic

Damask

Dampen, to, moisten, to: see Wet Danish (adj.)

Darn, to

Darner (needle)

Date

Dealer, trader

Decorative

Decrease, to, intake, to, diminish, to, take in, to, narrow, to: see Reduce, to

\section{FRENCH}

le croissant

crocheter

le guipnir, le crochet

le crochet-tricot, le ? crochet tunisien

croiser

le papier quadrillé

le point croisé, le gros point

la couronne

le fond de bonnet

les couronnes

la manchette, le p a r a m e n t, le parement (turnover)

le rideau

la ligne courbe

le coussin, le carreau

couper

le point coupé

les points d'esprits

le cylindre, le rouleau, la boule tournante

la dalmatique

la toile damassée, le damassé, le damas

humecter

danois -e

broder en reprise, repriser, passefiler

l'aiguille à passer

la date

le commercant

décoratif - ve

diminuer, rétrécier

\section{ITALIAN}

la luna crescente ricamare a uncinetto

l'uncinetto

incrociare

?

il punto croceato, il punto Iungo, il punto croce

la corona

la forma

i ornamenti

il manichetto

la cortina, il coltinaggio

la linea curva

il cuscino, il guanciale

tagliare

il punto tagliato

le punta armeletta

il cilindro

el cilindro

cruzar

la corona

la curva hadón cortar

\section{?}

\section{SPANISH}

el creciente

hacer crochet

la aguja de gancho

el crochet de Túnez

el papel con líneas cruzadas

el punto cruzado

la coronilla

el ornamento

el puño, la boca-

la cortina

el cojín, el almo-

la obra de bordado

\section{$--\mathrm{D}--$}

la tonicelle, la dalmatica

il damasco

umettere

danese

rammendare, filo supra punto

l'infila cappio

il giorno

il mercante

decorativo

diminuire, scemare la dalmática

el damasco de hilo

mojar

dinamarqués, danés zurcir

la aguja de zurcir

la data

el interventor, el comerciante

decorativo

decrecer, disminuir

\section{GERMAN}

der halbe Mond häkeln

die Häkelnadel

d e r tu nis che Häkelstich

kreuzen

das rechnen Papier

der Kreuzstich

die Krone

der Boden

das Kronenwerk

die Manchette, die Handkrause

der Vorhang, die Gardine

die Krümme Linie, die Kŕrümmung

das Kissen

schneiden, abschneiden die durchbrochene Arbeit

die Karos im Formenschlag, d e $r$ getupfte Tüll der Zylinder

die Dalmatika

der Damast

befeuchten

dänisch

stopfen

die Stopfnadel

das Datum

der Händler

decorativ, zieren vermindern, abnehmen 


\section{ENGLISH}

Decree, mandate, ordinance, edict

Denim, denham

Design: s e e $S u b$ ject

Designer

Devil's Broth : see Starch, to

D ex t e r it y: see Skill: see Execution

Di a g ona l: see Oblique: see Slanting

Di a gram : see Draft

Diamond: see Lozenge

Diamond shaped

Dicky-pot

Difficult

Dilettante : $\quad$ s e e Amateur

Dimension : $\quad \mathrm{s}$ e e Size

Dip, to, soak, to

Discoloration

Disengaging, detaching, loosening, releasing

Disentangle, to, untangle, to: see Undo, to

Doilie, d'Oyley

Dollar

D o t, tear - drop, polka dot: see Drop, to

Double (adj.) : see Turn, to

Double faced: see Reversible

Dozen

Draft, plan: see Diagram: $\mathrm{s}$ e e Laying out

Drawing pin : see Thumb tack

Drawn-work

Drawn-worker, drawn-work maker

Draw out, to, pull out, to
IRENCH

ITALIAN

il mandato

le dessin

il disegno

le dessinateur, la il disegnatore dessinatrice

diagonal -e, oblique diagonale

il piano, la pianta

le plan, la figure

en carreau, en losange ?

difficile

a rombo, romboide

?

difficile

plonger, tremper

la décoloration

le dégagement

démêler

le sous-bol, le dessous de vase, la petite nappe, le napperon, la serviette de dessert

l'êcu

le pois, la larme, le point

double

à double face

la douzaine

le brouillon, l'esquisse, l'ébauche, le plan

le point tirê, à fils tirés

la tireuse de fil

tirer immergere

il scoloramento

Io scioglimento distacco

strigare

la tovagliuola, mantilette

? dollare, l'ecu

la gocciola, il punto lagrima, il pisello

doppio

doppio faccia, due visi

la dozzina

il disegno, la copia

il punto tirato, la sfilatura, il desfilato

il filatoro

tirare bagnare, tuffare, sumergir, bañar

\section{SPANISH}

el mandato, el decreto, el edicto

la tela basta $\mathrm{y}$ resistente de algodón

el dibujo, el trazo, el diseño

el dibujante, el diseñador

diagonal

el diagrama

de figura romboide difícil, dificultoso

el descoloramiento

la desatadura, la separación

desenredar, desenlazar

la servilleta pequeña

moneda de los Estados Unidos $\mathbf{J}$ el Canadá, el escudo

la gotita

doble, doblado

de doble cara, de dos caras

la docena

el diseño, el plan

\section{GERMAN}

das Decret, das Gesetz, die Verordnung

eine Art grobes

Baumwollenzeug

die Zeichnung

der Zeichner

(

schräg

das Diagram, der Abriss

rautenförmig,

rhombus

schwer, schwierig

eintauchen, e i n weichen, tunken

das Verschiessen, die Verfärbung

die Ablösung, die Trennung

entwirren

das Deckchen

der Thaler

der Tupfen, der Punkt

verdoppelt, $\quad$ weifach

mit zwei Seiten

das Dutzend

der Entwurf

los calados

die Auszieharbeit

la perfiladora, la die Fadenzieherin caladora

tirar

ausziehen 
ENGLISH

Dress
Dressed pillow
Dressing, stiffen-
ing, sizing
Drop, to (a
$\quad$ stitch): see Dot
Dry (adj.)
Dutch (adj.)
Duty, tax
Dyeing, coloring
Dyestuff: see Col-
ored: see Ani-
line

Eagle

Easy (adj.)

Ecclesiastical, ecclesiastic, sacerdotal (adj.)

Ecru, unbleached ( a d j. ) : see Blonde: see Cream

Edging, border : see Selvage: see Bead Edge

Effigy

Eighteenth (adj.)

Ell ( 45 inches, $1 \frac{1}{4}$ yards)

Ellipse
Embroiderer, em-
bellisher, em-
broidery worker
Embroidery

Emery, corundum

End, extremity

English (adj.)

Enlarge, to: see Increase, to

Enrich, to, adorn, to, embellish, to: see Light up, to

Entertainer: s e e Reader

Epoch: see Period

Est a b lis h, to, found, to

Excelsior, st u f fing: see Bran: see Sawdust: see Cork

Execution, w o r kmanship: se e Skill

Expensive, d e a r , costly (adj.): see Valuable: see Rare

\section{FRENCH}

la robe

le coussin prepare, apprêtê, disposé, dressé

l'apprêt, l'empois

lâcher, laisser tomber, laisser couler

sec, sèche

hollandais -e

le droit, l'impôt

la teinture

la $\mathrm{te}$ in t u r e, le teint, le coloris

\section{l'aigle}

facile

ecclésiastique, sacerdotale

êcru -e

la dentelle, le bord, il pizzo, il orlo le passement

l'effigie, l'image

dix-huitième

l'aune, l'avant-bras, 1.85 mètres $(7 t$ inches)

l'ellipse

la brodeuse

ia. broderie

l'émeri

le bout, l'extrémité anglais -e

agrandir

enrichir, orner, embellir, parer

établir, fonder, instituer

le papier à copeaux d'emballage, la tontisse ligneuse

la façon, l'exécution, le travail

cher, couteux
ITALIAN

la gonna

il cucino fatto per incominciare

l'apprechio

lasciar caseare

secco

olandese

il dazio, la gabella

la tinta, la tintura

la tintura

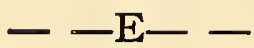

l'aquila

facile

ecclesiastico

crudo -a

l'effigie, l'immagine diciottesimo, decimotta vo

l'anna, la canna

l'ellissi

?

il ricamo, la ricamatura

il smeriglio

la fine estremita

inglese

aggrandire

fatte richo

stabilire

l'ecelsore

la fettura, l'esecuzione, il lavoro, la fattura

dispendioso, caramente, a gran prezzo

\section{SPANISH}

el vestido

la almohadilla lista para comenzar

la cola

perder (un punto)

seco

holandés

el derecho, el impuesto

la tintorería

el tinte

el águila

fácil

eclesiástico

crudo, que no ha sido lavado

la orla, el ribete

Ia efigie

décimo octavo

la ana

el elipse

la bordadora, Ia ricamadora

el bordado, la bordadura

el esmeril

el cabo, el fin

inglés

agrandar

enriquecer, adolnar, embellecer

establecer, fundar

la madera en hebras $y$ virutas delgados para empaquetar $\quad y$ rellenar colchones

el trabajo

costoso, caro
GERMAN

das Kleid

das Klöppelkissen fertig zur Arbeit

der Leim

fallen lassen, abgleiten

trocken, dürr

hollandisch

die Taxe, der Zoll

das Färben

der Farbstoff

der Adler

einfach, leicht

ecclesiastisch

ecru

das Börtchen, die Randspitze, die schmale Spitze das Bildniss achtzehnt

die Elle

die Ellipse

die Stickerei

der Schmergel

das Ende

englisch

erweitern, vergrössern

ausschmücken, bereichern

etabliren, grïnden

die Holzwolle

di e Ausführung, die Arbeit

teuer, kostspielig 


\section{ENGLISH}

Expert: see Connoisseur: see $A u$ thority

Eye (of a needle)

Eyelet

Factory: see Work-room

Fair: see Auction: see Cclebration: see Festival

Falling collar, falling band, fall : see Collar

False stitch, false pinhole, b l ind pin: see Omit: see Repeat

Fan

F a n c $y$, fanciful, ornate (adj.)

Fancy work

Fan-shaped $(\mathrm{a} \mathrm{dj.)}$ : se e Scallop

Fascinator, headwrap: see Mantilla

F a s t e $n$ off, to, make fast, to, secure, to: see Tie together, to

Felt, baize

Festival, jubilee: see Fair

Fichu: see Kerchief

Fifteenth (adj.)

Filet, netting, caul lace

Filigree

Filler in of point

\section{FRENCII}

l'expert

le chas, le trou

l'oeillet

a fabrique

la foire

le col rabattu, le il collare rabato, le rabat

?

il punto false

l'éventail

faconné -e, orné -e, de fantaisie

la tapisserie, la broderie

en éventail

la fanchon

arrêter

le feutre

la fête, le jubilé

il feltro

la festa

ventaslio

firntasia, affazwato

il ricamo

a ventaglio

la ciarpa

arrestare, fermare

quinzième

quindicesimo le filet, le lacis, le point conté, la résille

le filigrane

la remplisseuse

il lavoro di maglia, il punto a maglia quadra, il modano, il punto a maglia quadrata la filigrana

la rimendatrice

décimoquinto

la red cuadrada

\section{la filigrana}

la insertadora de
puntos

el morlo

Filling, plaiting, le mode, l'àjour, le al giorno

band work jour

Filling maker: see Maker

Fine (adj.)

Fine drawing

fin -e

la reprise perdue

fino, delicato

Finger

Finger $\left(4 \frac{1}{2}\right.$ inches) le doigt

le doigt (18 millimètres) il dito

il dito fino, delicado el punto perdido de zurcido

el dedo

la longitud del dedo, del medio

\section{GERMAN}

der sach Verständiger

das Nadelöhr, das öhr

das kleine Loch, das Schnürloch el abanico

de capricho, de gusto fantástico

la obra de fantasía

en forma de abanico

el pañuelo de cabeza

atar, asegurar

el fieltro

la fiesta

das Fabrikgebäude

die Messe der Jahrmarkt

der Umlegekragen

$?$

der Fächer

geschmückt, verziert

die weibliche Handarbeit

fächerförmig

das Kopftuch

festmachen

der Filz

das Jubileum, der Festtag, das Jubeljahr, das Jubelfest

fünfzehnte

die Netz Arbeit, das Filet, der Gitterground, das Netzwerk, das Filett

die feine Drahtarbeit

die Spitzenflickerinn, die Spitzenstecherinn, di e Spitzenausfüllerinn

die Fülle, der Eintrag, die Füllung fein

?

der Finger

der Mass von 41/2 Zoll 


\section{ENGLISH}

Finger-shield, tailor's thimble

Finisher, refiner : see Repairer: see Ironer

Finishing : see Buttonholing: see Mending of faults

Firmly, steadily

Fish-shaped (adj.)

Flange

Flat (adj.): see Smooth

Flax, linum usitatissimum, fin e Levantine flax

Flax comb: see Heckler

Flaxen: see Blonde

Flemish (adj.)

Floss-silk, sleine, sleided silk

Flounce, furbelow, robing: see Frill

Flower

Flute, to, gauffer, to, crimp, to

Fluting, goffering, quilling: see Quille

Fold, set: see Plait

Foliated (adj.) : see Scroll

Footing, bead edge, heading, beading: see Selvage

Forked (adj.)

Form, shape, contour

Foundation

Fourteenth (adj.)

Frame (embroidery) : see Hoop

Fray, to: see $R a$ vel, to

French (adj.)

Fresh, c l e a n (adj.) : see New

Fretwork : see Grille

Frill, cascade, jabot: see Flounce: see Oravat

Fringe

Fuller's earth, Whiting
FRENCH

le dé ouvert, le il ditale aperto doigtier

l'affineuse

l'achèvement

fermement

pisciform

le rebord, la saillie

plat -e

le lin, l'afioume

flamand -e

la soie plate, la floche

le volant, le godet, la tournante

la fleur

tuyauter, gaufrer, froncer, goudronner, goderonner, gaudronner, crêper

le tuyautage, le gaufrage, de s Turgaux

le pli, la pince

en feuilles, feuillé -e, à feuillages

l'engrêlure, le pied, le bord, la bisette

fourchu -e, en fourche

la forme

la fondation

quatorzième

le métier à broder

quattordicesimo -a
il telaio da ricamo

limpressione sulle stoffe

la piega

a fogliami

il merletto ordinario

biforcato, forcuto

la forma

il fondamento

français -e

frais, fraîche, propre

le jabot

la frange, l'effilé

la terre à foulon, le blanco d'Espagne

francese

fresco

la frangia

la terra da digrassare o da purgare
SPANISH

GERMAN

el apoyadedos, el dedal de sastre

der Schneider-Fingerhut

la perfeccionadora, la afinadora

la última mano, el perfeccionamiento

firmemente

pisciforme

el realce

llano, plano

el lino

ie Vollenderin

?

fest

fischförmig

die Flansche, der Rand

flach, ohne Relief

der Flachs

flamenco

flämish

der Floss

die Falbel, das Gebräme

die Blume

goffrieren

das Goffrieren, die Rüsche

la doblez, el pliegue, die Falte la plegadura

batido en hojas

el ribete

horcado

la forma, la figura, el contorno

el fundamento, la fundación

décimocuarto

el bastidor

francesa

fresco, nuevo

la gola, la digiuna la chorrera el fleco

la tierra de batán französisch frisch, rein

mit Laubwerk

der Kantensaum

gabelförmig

die Form

der Grund

vierzehnte

der Stickrahmen, der Nährahmen, das Tamburin

der gefaltete $\mathrm{Bu}$ senstreif

die Franse

die Walkererde, die Tünche 
ENGLISH

FRENCH
ITALIAN

$--\mathrm{G}-$

Galloon, Orris, Ar- l'Arras, le galon ras

Gather, to, pucker, to

Gauge: see Meshstick

Gently

Geometric (adj.)

German (adj.)

Gimp, rib, trolly, cordon: see Buttonholing: se e Outlining thread: see Raised

Gingles, jingles, beads

Glazed, shiny, glossy, lustrous $(\mathrm{a} \mathrm{dj.)}:$ s e e Smooth

Glove

Gold

Gothic (adj.)

Grille, fretwork, lattice

Groove

Ground, grounding, field, background : see $\mathrm{Net}$

Grounder, maker of grounds, groundworker

Guimpe (child's) : see Wimple

Guipure

Gum Arabic

Gusset, mitre

Hair, locks, tresses: see Horsehair

Hairpin (for crocheting)

Half stitch, half throw, half pass

Hand

Handkerchief

Handle, holder

Handmade (adj.)

Handsome: s e e Rich: see Beauti ful: see Pretty il gallone, il fregio

froncer, coulisser

la jauge, la mesure

doucement

géométrique

allemand -e

le cordonnet, la nervure, le fil de crin, le guimp, la brode, le cordon

la cliquette, la perle de verre

glacé -e, lustré -e, luisant -e, vitré $-e$

le gant

l'or

gothique

la grille, la grecque, la treillis

la ramure, l'entaille

le fond, le champ, l' entoilage, le treille, le fondement

la foneuse, la gazeuse, la gazière, la réseleuse, la fondeuse

la guimpe

la guipure

la gomme arabique la gomma arabica

le gousset, la mitre quadratelli

les cheveux, les la treccia di capeltresses

la fourche

le demi point, la passé de filet, la grillee

la main

le mouchoir

le manche, la poignée, l'anse

fait à la main

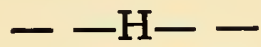

increspare, piegare, raggunzare

la misura staza

leggermente, dolcemente

geometrico

tedesco

il cordoncino

il peso che si attacca alle fuselli

lustrato, lucente

il guanto

l'oro

gotica

la rete, la reticella

l'antro profondo, la scanatura

il fondo

colui o colei che fabbrica veli

la guimpa

il ghipur, il merletto in rilievo

a treccia di capel-
li, il capello, la ciocca di capelli

la forca, il bidente

il mezzo punto

il mano

il fazzoletto, il moccichino

l'impugnatura, il manico

fatto a mano

SPANISH

GERMAN

el galón, el ribeci1lo

fruncir

la vara

dulcemente

geométrico

germániç, alemán, tudesco

el cordon

el peso que se une a los palillos

lustroso, glaseado

el guante

el oro

gótico

el calado

la ranura

el fondo

el que hace los fondos

el camisolín de mujer, el canesu

la puntilla de hilo fuerte en que los dibujos enlazados forman el tisú sin fondo

la goma arábica, el agua de goma

el escudete, el inglete

los cabellos, la trenza

la horquilla

la semi puntada

la mano

el pañuelo

el mango, el puño

hecho a mano die Tresse

falten, in Falten

legen

das Mass

sanft

geometrisch

deutsch

die Gimpe, der Umrissfaden, dasi Bändchen

die Glasperlen

glänzend, schimmernd

der Handschuh

das Gold

gothisch

das Gitterwerk

die Rinne

der Grund, der Spitzengrund

die Spitzengrundmacherin

das Lätzchen

die Guipure

das Gummi Arabicum der Zwickel, die Inful, die Mitra

die Haar-Locke

die Haarnadel

der Halbschlag, der Gympenschlag, der Netzschlag

die Hand

das Taschentuch

der Griff

mit der Hand gemacht 
ENGLISH

FRENCH

ITALIAN

SPANISH

GERMAN

Hangers: see Passive pairs

Hang up, to

Hank

Head

Head-dress, tower, head, Fladdal, fallals

Heading : see Footing

Head worker, supervisor

Heart
Heaviness, dull-
ness: see Showy
Heckler, flax comb,
hatchel
Hem
Hemp

Heraldic (adj.)

Hexagonal (adj.)

Holder : see Handle

Hole

Honeycomb

Hood: see Bonnet

Hook

Hoop, tambour: see Frame

Horizontal (adj.)

Horn (adj.)

Horsehair : see Hair

Hot (adj.) : see
Warm

Housewife, kit

Hunting

Imbricated : see Overlapping

Imitation

Inch

Increase, to, add, to; see Enlarge, to

Index finger

India ink

\begin{tabular}{|c|c|c|}
\hline $\begin{array}{l}\text { Indian (adj.) } \\
\text { Initial }\end{array}$ & & $\begin{array}{l}\text { indien -ne } \\
\text { l'initiale }\end{array}$ \\
\hline ak & & l'encre \\
\hline $\begin{array}{r}\text { Insertion : } \\
\text { Beading }\end{array}$ & see & $\begin{array}{l}\text { l'entredeux, } \\
\text { bande }\end{array}$ \\
\hline
\end{tabular}

le trou capeline croche bour

horizontal -e

de corne

le crin

chaud -e

le nécessaire

de chasse

l'imitation

le pouce

augmenter

l'index

bande pendre, suspendre

la botte, la poignée, la pantine

la tête
sospendere
la matassa
la testa, il capo
l'acconciatura di capo
colgar
la madeja
la cabeza
el tocado

a fontan
commode

la maitresse-ouvrière, le chef d'atelier

le coeur
la matité
le seran, la seran-
coie, l'affinoir
l'ourlet
le chanvre
héraldique
hexagonal -e, hexa-
gone

le gâteau de miel, la rayon de miel

le capuchon, la

le crochet, le guipoir, le croc, la

le cercle, le tam-

il cuore

il cattivo

il pettine da lino

l'orlo

la canapa, il canape

araldico

esagonale, esagono

il forame, il buco, il pertugio, la bucca

il faxo, il fiale

la bauta, il cappuccio

l'uncine, l'uncinetto

il tamburo, l'ordigno da ricamare orizzontale

di corno

il crine di cavallo

caldo

la cassetta da viaggio

di caccia

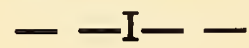

l'encre de Chine cargada

el corazón tolidez

el ribete

el cañamo

heráldico

hexágono jerito

el panal

la toca

el gancho

horizontal

de cuerno la crin

caliente

de caza

l'imitazione

il pollice

aumentar, ampliare

l'indice

l'inchiostro China

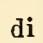
China

indiano

l'iniziale

indio

la inicial

l'inchiostro

la

la trina, l'inserzione, l'entemel-

la tinta la primera oficiala de un taller de mujeres, la en-

la pesadez, la es-

el rastrillo

el agujero, el agu-

el bastidor, el aro

la crin de caballo,

el costurerito

die Vorsteherin, die erste Arbeiterin

das Herz

die Schwerfälligkeit

die Hechel

der Saum

der Hanf

heraldisch

sechseckig

das Loch

die Wachsscheibe, die Honigwabe

die Haube

der Haken, das Häkchen, das Häkelhaken

der Reif, das Tamburin

horizontal

aus Horn, hornen

das Rosshaar

heiss

das Nähkästchen

Jagd (spitzen)

la imitación

la pulgada

acrecentar, alargar, aumentar

el dedo indice

la tinta de la China, la tinta

el entredós die Nachahmung

der Zoll

vermehren, vergrössern

der Zeigefinger

die Tusche

indisch, indianisch der Anfangsbuchstabe

die Tinte

der Einsatz 
WNGLISH

FRENCH

Instrument : see Tool

Insular (adj.)

Interlace, to, entwine, to

Interline, to

Intersect, to

Introduce, to

Inventory

Irish (adj.)

Iron, to

Ironer: see Finisher

Isabel (adj.) : see Cream colored: see Ecru

Italian (adj.)

Ivory

Jabot: see Cravat Japanese (adj.)

Join, to: see Couple, to

Joiner of lace (person)

Joining-stitch : see Sewing

Jubilee: see Celebration: see Festival

Kerchief, fichu : see Fascinator

King

Knee-scarfs : s e e Boot-tops

Knife

Knit, to

Knitter

Knitting-needle

Knitting pin, needle end, knittingsheath, support, knitting shield

Knot: see Noose: le noeud see Tie, to

Knotted work : see Macramé

en tredoubler

le jabot

japonais -e couvre-chef

le roi tricoteuse la broche aiguille insulaire

entrelacer, accoler

entrecouper

introduire

l'inventaire

irlandais -e

l'affiqueuse

isabelle, de couleur isabella, sauro isabelle

italien -ne

l'ivoire

raccorder

la raccrocheuse

isolano ? versare

introdurre

l'inventar

irlandese

la stiratrice

italiano

l'avorio

la gola

giapponese

accordare

l'accordatrice repasser

collegare, intrecciare, intralciare, frammettere

intersecare, attra-

stirare, soppressare
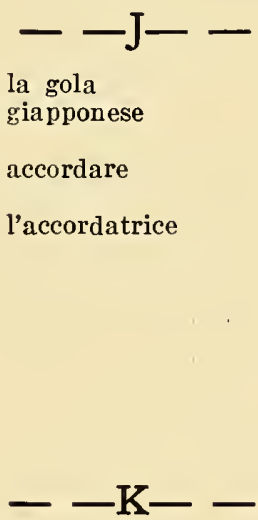

le fichu, la fanchon, la marmotte, le

il fisciu, il fazzoletto di capo da donna

il re

il cotello

lavorare all'ago, lavorare a maglia

le tricoteur, la il calzettago

l'aiguille à tricoter,

l'affiquet, le porte-

il ferro da calza, il ferro da calzetta

il cannello pei ferri da calza

il nodo, il groppo, el nudo il gruppo a gola

japonés

enganchar

el enganchador

insular, isleño entrelazar, entremezclar

entretelar

entrecortar

establecer, presen$\operatorname{tar}$

el inventario

irlandés

planchar

la planchadora

de color isabelino, amarillo parduz-

italiano

el marfil

el pañuelo

el rey

el cuchillo, el cortaplumas

hacer media, tejer

el calcetero, el tejedor

la aguja de hacer medias $\delta$ de malla

el palillo sujeto a la cintura para apoyar la aguja de hacer calceta

GERMAN

insularisch

d u r c h f l e c hten, durchweben

zwischenfütten

durchschneiden, durchkreuzen

vorstellen, bekannt machen, einführen

die Inventur, das Inventarium, das Bestandsverzeichniss

irisch, irländisch

plätten, bügeln

die Plätterin, die Bügelerin

isabellenfarbig, isabellfarbig, misfarbig

italienisch

das Elfenbein

?

japanisch, japanesisch

zusammenstücken

der Aufhänger, der Anhänger, der Verbinder

das Brusttuch

der König

das Messer

stricken

der Stricker, die Strickerin

die Stricknadel, der Strickstock die Strickscheide, die Stricknadelhalter, das Stricknadelrohr, das Nadelholz

der Knoten 
ENGLISH

FRENCH

ITALIAN

SPANISH

GERMAN

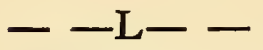

Lace, pearlin, la dentelle, le paspearling

sement

il merletto, la trina (narrow) (cuts, le bois dentelle, le

$$
\text { laget }
$$

la dentellière

vegetable lace)

Lace-maker, laceworker

Lace turn: see Winding machine Lace up, to

Lacing, string, cord: see Capstring

Lamb

Lambrequin, mantle-cloth: see Tidy

Lapel, revers

Lappet, tab, pinner

Layette

Laying out: see Outlining: see Setting: see Lay out, to: see Draft

Lay out, to; block out, to; stake out, to; mark out, to ; apportion, to: see Laying out

Leaf, paddle, seed, grain, wheat ear, lozenge: see Tuft

Leaf-stitch, matting-stitch : see Tuft

Learn, to

Left (adj.)

Length

Lesson

Letter

Light, illumination

Light, fluffy (adj.)

Light up, to ; lighten, to ; increase the high lights, to ; set off, to ; enhance, to: see Enrich, to le cordon

l'agneau

le dessus de cheminée, le manteau de cheminée

le revers

la barbe

la layette

le trace

jalonner

le pétale

?

apprendre

gauch -e

la longueur

la lecon

la lettre

la lumière

léger -ère

éclairer, décharger pinkings, pinchings) il pizzo (tips, peaks), il passamano, il fimboice, gli merli (little turrets, battlements), il tarnete

?

la lavoranta in la encajera merletti

lacer $\quad$ allacciare

l'entrelac, la ficelle, il groppo

il agnello

il fregi d'intaglio

rego

el emantelete caje

lacear

la mostra d'un abite la solapa la falda, la bandella

le fasce, i pannollini

la traccia, la mostra

los pañales

la traza

abbozzare, indicare, piantar delle biffe

nos

l'armelletta, il foglio

aprender

la longitud

la lección

la lunghezza

il lezione

la lettera

la luce, la lume

leggero

balenare las puntillas, el en-

die Spitze

el cordón de enlace

schnüren

die Schnur

das I.amm

die Kaminbekleidung, das Zacken oder Bogen Behänge, die Bekleidung als Zimmerschmuck.

las caídas de toca

reas los contor-

la punta armeletta el empalletado

izquierda siniestra la carta

la luz

ligero

alumbrar, aligerar der Aufschlag

der Zipfel, der Haubenflügel

die Ausstattung für ein kleines Kind das zur Schau legen, das Herauslegen

verteilen, die Richtpunkte aufstellen, auszeichnen, abstecken

das Blatt

der Formenschlag

lernen

linke

die länge

die Aufgabe, die Lehrstunde der Buchstabe das Licht

leicht laden erleichtern, aus- 
ENGLISH

Line: see Row

Linen apparel, lingerie

Linen chest: see Chest

Linen closet

Linen cloth: se e Napery

Linen house, white goods house

Linen press: see Press

Linen-stitch : see Cloth-stitch

Linen thread

Linen trade

Lint

Little finger

Livery

Lobster claw : see Puff iron

Long (adj.)

Long, column or treble stitch

Loom

Loop : see Pearl

Loop-maker, ringlet-maker

Loop row, first row

Loose, slack (adj.)

Lozenge, diamond

lache

le losange

le fil de lin

la toilerie

la charpie

le petit doigt, l'auriculaire

la livrée

long -ue

la bride

le métier à tisser

la bride, la boucle, la ganse, la bouclette

la boucleuse

?

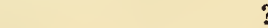

lento, allentato

il rombo

il refe

il commercio di biancheria

il flaticcio

il dito mignolo, il dito auriculare

la livrea

lungo

il punto lungho

il telaio da tessere

la maglia

la cordoncinatrice

$?$

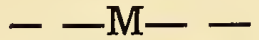

Machine net

Macrame, knotted work, filet de Carnasière

Maker of modes or jours, filling maker

Making, working

Making of : see Pricking of

Maltese (adj.)

Mantilla: see Fascinator

Mantle

\section{Manufacturer}

Mark

Mark out, to: see

Lay out, to

SPANISH

el armario lienzo

la lencería

la prensa

il tulle, il tulle meccanico

le machine

le macramé, l'entrelacs, le filet de Carnasière

la modeuse

il punto a groppo

la giornotrice

l'exécution, la con- il costruzione fection

maltais -e, de Mal- malteze

te

la mantilla

la faille, la mantille

le manteau, la mante

il sopreveste, il soprebito, il mantello

le fabricant, le manufacturier

la marque fabbricante, il
fabbricatore, manifatturiere

la marca

\section{GERMAN}

die Linie

die weisse Wäsche

der Leinenschrank

la tela de lino, el

die Leinwand, das

Leinen

die Weisswarenhändel

die Leinenpresse aros

suelto, destado el rombo

el hilo de lino

el comercio de lien-

zos

el lino

el dedo meñique

la librea

largo

el punto largo

el telar

el lazo, el rizo

el que hace el rizo

la primera línea de

el mecánico

el encaje Moresco

der Leinenfaden

der Leinwandhan-

del

die Charpie

der kleine Finger

die Livree

lang

das Stäbchen

der Webstuhl

die Schlinge, die

Oesen, die ösen

der Oesenmacher

das Aufschlag

$\operatorname{los}$

die Rhomboide, der Rhombus

$\underset{\text { Netz }}{\text { Maschinen }}$

die Knüpfarbeit

el hacedor de puntos de fantasía

la hechura, el trabajo, la ejecución

d i e Füllungmacherin

die Vollziehung, die Ausführung

maltés

malthesisch

die Mantille

el manto, la capa

der Mantel

el fabricante

der Fabrikant

la marca

die Marke, das Mal, das Merkmal la mantilla 
ENGLISH

Marking out, dividing, laying out, indicating, staking, staking out Mask

Mate, companionpiece

Materials, furnishings

Matting-stitch : see Leaf-stitch

Measure: see Tape measure: $\mathrm{s}$ e $\mathrm{e}$ Mesh stick: see Ruler

Medallion, inset : see Square

Mediaeval, medieval (adj.)

Mend, to

Mending of faults : see Repairing: see Finishing

Mercerised (adj.)

Mesh

Mesh-stick, mold: see Gauge: see Measure: see Ruler

Metallic (adj.)

Mexican (adj.)

Middle: see Centre

Middle finger

Mirror: see Penelope

Mitre: see Gusset

Model

Modern (adj.) : see New

Modesty piece: see Tucker

Modify, to

Mohair, alpaca

Moisten, to: see

Dampen, to

Monogram

Moon

Mosaic, tesselated (adj.)

Mother-of-pearl

Mount, to: see Transfer, to

Mummy wrappings

Museum: see Collection

Mythological (adj.)

\section{FRENCH}

ITALIAN

la jalonnement, la il divisione division

le masque, le loup

le pendant

les matériaux, les fournitures, l'outillage

la mesure

la mesura

la maschera, il lupo

il riscontro

le forniture, li materiali

l'incrustation, l'applique

du moyen age

raccomoder

le régalage

mercerisé -e

la maille

le moule, l'ais a faire des filets, la planche à faire les filets

metallique

mexicain -e

le doigt majeur, le médius

le modèle

moderne

la garniture de corsage

modifier le mohair, l'alpaga

modificare

l'alpaca

il monogramo

le monogramme

la lune

en mosaïque

la nacre

monter, entoiler

les draps de momie

le musée

my thologique

l'incrostatura, l'incrostamento, gli pezzi da incastare, gli pezzi da intarsiare

il medio evo

raccomodare ?

lucido

la maglia, la maglia di rete

il asse, la tavola di legno

metallico

messicano

il medio, il dito medio

il modello, il esemplo

moderno

la garnitura di corsagio

la Iuna

mosaico

la madre perla

montare un lavoro

?

il museo

mitologico
SPANISH

GERMAN

el señalado

la máscara

el compañero

die Maske

los avios, los materiales

das Gegenstück

die Materialien, das

Arbeitsmaterial la medida

el embutido, el medallón

das Linead zum gleichmässigen Einstecken der Stecknadel

das Spitzen-Medallion, der SpitzenEinsatz

de la edad media

remendar, reparar el corregido de faltas

la malla

el molde

metálico

mejicano

el dedo del medio

lla, una blonda que se pone a los vestidos en la parte superior del pecho

modificar

la alpaca

el monograma

la luna

mosaico

el nacar, la madre perla

montar

la ropa de momia

el museo

mitologico mexikanisch

der Mittelfinger

das Muster

modern

der Streifen an einer Schnür

mittelalterlich

ausbessern, flicken

die Ausbesserung mangelhafter

Spitzen

ercerisiert, merceiert

der Strickstab, der Strickstock

abändern

das Haartuch, der Mohr

der Namenzug

der Mond mosaikartig

die Perlmutter

aufziehen

das Mumiengewand das Museum

my thologisch lustroso 


\section{ENGLISH}

FRENCH

\begin{abstract}
Nail: see Tack: le clou see Thumb tack

Nail $(21 / 4$ inches $)$ ?
\end{abstract}

ITALIAN

- - N- -

il chiodo, il chiovo, il aguto, il chiavello

il ottavo (misura)

Name
Napery, linengoods : see Linen cloth Napkin

Narrow (adj.)

Naturalistic (adj.)

Needle

Needlecase, needle book: see Case

Needle ends, protectors

Needleful, a

Needlepoint lace

Needle threader, threader (instrument)

Needle-work

Net: see Ground

Netting-needle

Network, darned netting, spider work: see Spider

New (adj.): see Fresh: see Modern

Nighteap

Nineteenth (adj.)

Noose, slip-knot: see $K$ not

Norwegian (adj.)

\footnotetext{
Oblique (adj.) : see Diagonal

Oblong (adj.)
}

Ochre, ocher

Oil

Oil cloth, wax

Olive (adj.) la dénomination, le nom

la napperie, la nappe

la serviette

étroit -e

naturaliste

l'aiguille

l'étui à aiguilles, le porte - aiguille, l' aiguillier

?

une aiguillée el agugliato

la dentelle à l'ai- il trino ad ago guille

?

l'ouvrage à l'aiguille, la tapisserie, l'ouvrage de dames

le rếseau, ? droschel, le rézel, le rézeuil. le razzeuil, le tulle

la navette

le lacis, le filet brodê, le point conté

neuf, neuve, nou- nuovo veau, nouvelle

le toquet

dix-neuvième

le noeud coulant

norvégien -ne, de Norvége

il nome

la biancheria da tavola

la salvietta, la tovagliuola

stretto

naturalista

el ago, il aco

il agoraio, il agaioulo, il buzzo

?

il lavoro ad ago

il rete, il redexelo

il spillo di fare rete

il lavoro di maglia, il punto a magliata

il berrettino diciannovesimo, decimonono

il nodo scorsoio

norvegio

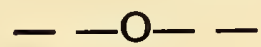

oblique

de forme oblongue, de figure oblongue

l'ocre, l'ochre

l'huile

la toile cirée

d'olivier

obliquo

il octa, l'ocria

l'olio

la tela incerata

d'oliva
SPANISH

GERMAN

el clavo

la medida de dos pulgadas $\mathrm{y}$ cuarto, $\delta$ la dieciseisava parte de una vara

el nombre

la mantelería

la servilleta

estrecho, angosto

naturalista

la aguja

el alfiletero

el porta-agujas

la hebra

la punta

el ensartador de agujas

la labor de aguja, la costura

el rete

das Netz, der Netzgrund

la aguja de tejer

die Netz-Nadel

la obra de malla

das Netzwerk

nuevo, nuevecito

neu

el gorro de dormir décimonono

el lazo

die Nachtmutze neunzehnte

die Fadenschlinge

noruego

norwegisch

oblícuo

schräg, schief

oblongo

länglich, oblong

el ocre el $61 \mathrm{eo}$, el aceite

el encerado, la tela encerada

de oliva der Ocher, der Oker

das Oel

das Wachstuch, die

Wachsleinwand

oliven 
ENGLISH

Omit, to, skip, to : see False stitch

Open (adj.)

Openwork

Organdie, organdimuslin

Ornament

Orphrey, clavi

Outer pairs

Outline, to: see Outlining: see Wheel

Outlining : see Outlining thread: see Buttonholing: see Laying out: see Setting: see Gimp: see Outline, to

Outlining thread, outline: see Gimp: see Buttonholing

Over, above, upon

Overcast, to, whip, to, over-sew, to

Overlapping, imbricated (adj.)

Overs

Padding

Pair

Pall, cloak

Pall, covering: see Chalice covering

Panel

Parallel (adj.)

Parasol, sunshade

Parchment, vellum : see Pattern

Passementerie

Passive pairs, passives, hangers

Paten-cover: s e e Chalice cover

Patronage

Pattern, diagram: le patron, le tracé see Parchment

\section{FRENCH}

passer, omettre sauter

ouvert -e voie dis

l'ornement

\section{l'orphroi} res ner, bâtir

l'entourage bâti

au-dessus, sur surjet à ché -e

le jeté

la paire

le pallium mortuaire

le panneau

parallèle

le parasol chemin passementerie chaîne

le patronage l'ouvrage à jour, l'ouvrage à claire-

l'organdi, l'organ-

les paires extérieu-

cerner, scilloner, border, échelon-

le fil de trace, le fil de contour, le

surjeter, faire un

imbriqué -e, imbricê -e, enchevau-

ITALIAN

SPANISH

GERMAN

omettre, trascurare pasar por alto, omi- überspringen

aperto abierto

il lavoro a giorno calado

l'organdi

el organdí

il ornamento, il adornamento, il fregio

?

?

bastimentare

l'orditura

il filo di traccia

sopra, di sopra, ol- sobre tre, sulla

cucire a sopraggit- hilvanar

to

imbricato

imbricado

el punto por encima

\section{$--\mathrm{P}-$}

le poêle, le drap

la cartisane, le par-

le passement, la

les paires pendantes, les paires de pione la borra

il paio

il pallio

il patronezgo

la mostra, il cam-

la guata, la borra

el par

el palio de arzobispo

il coltre, il panno da morti

el assicello

parallelo, equidistante

il parasole

la pergamena, la cartapecora

il passamano

?

l paño de ataúd, el paño mortuorio

el cuarterôn

paralelo

el quitasol, el parasol

el pergamino, la vitela

la pasamanería

el par pasivo

el patrocinio, el patronato

el modelo das Unterlegen

das Paar

der Bischofsmantel, der Talar, das Pallium

das Pallium, das Leichentuch

das $l a ̈ n g l i s c h$ e Stück

parâllel, gleichlaufend

der Sonnenschirm

das feine Kalbsleder, das Pergament, das Velin die Passementerie

die Risspaare das Patronat, die Begünstigung

das Muster, das Spitzenmuster, der Spitzenmodel 


\section{ENGLISH}

FRENCH

Pattern maker

Pearl: see Loop

Pearl-maker

Pe a $\mathbf{r}$ - $t$ i e, b a $r$, strand, bridge, coxcomb, $\quad \mathrm{leg}$, pearl, half-wheel, tie, bride: see Bar

\section{Pearl-tier}

Peasant

Peddler, hawker

Peg, plug

Pen

Pencil

Penelope mirror

Period, epoch : see Century

Petticoat

Pewter

Photograph

Pick up (a stitch), to

Pillow (lace) : see Cushion (sofa)

Pillow lace: see Bobbin lace

Pillow sham

Pillow slip, pillow case, pillow-bier, pillow-beer, pillowebere

Pin

Pin, to: see Stick in, to

Pincushion

Pinhole

Pink, to patronneur

la picoteuse

la bride

la patronneuse, le la zoccolaja

le picot, la boucle

la brideuse

la paysanne, le paysan

le colporteur, le camelote

la cheville, l'épingle de bois

la plume

la crayon

le mirroir Pénélope

l'époque

le jupon

l'étain

la photographie

relever, reprendre

le coussin, le carreau, le métier

la manche de parade ?, le cache oreiller

la taie d'oreiller

l'êpingle

mettre une épingle, piquer une épingle, poser une épingle

la pelote à épingles

le trou d'épingle, la porte

faire des oeillets, trouer, percer un etoffe, découper suivant un dessin, chequéter

\section{ITALIAN}

la zoccolaje

la smerlatura, il dentello, l'orlatura di ricamo

la smerlatrice la bride
SPANISH

\section{GERMAN}

la bridetrice ?, la la aseguradora legatrice

il paesano, il contadino

il merciaiuolo

la caviglia, la cavicchia, il piulo, il brocco

la penna

il pennello

lo specchio di Penelope

l'epoca

la gonnella, la gonnellina

il peltro, il stagno

la fotografia

rialzare

il tombolo, il cuscino, il guancialino

?

la fodera, la foderetta

la spilla

pungere

il guanciallino da spilli, il torsello

la bocea da spilli

foracchiare, bucacchiare una stoffa a disegno el hacedor de modelos

la puntilla, el piquillo

la picadora

la ligadura, los hilos que conectan las varias partes sólidas del encaje, hecho de dos o más cabos que son o bien como cordones o cubiertos con puntos de remate 0 bordes

die Musterzeichnerin

das Picot

die Oesermacherin

das Bindeband, das Schlösschen

die Festigmacherin von Alençonner Spitze

der Bauer, der Landmann labriego, el campesino

el buhonero, el baratillero

la estaquilla, la clavija

la pluma

el lápiz

el espejo de Penélope

la época, el período

la falda bajera o de barros

el peltre

la fotografía

recoger (un punto)

la almohadilla para hacer encajes

la cubierta de adorno para almohada

la funda de almohada

der Hausirer

der Pflock

die Schreibfeder

der Pinsel

der Penelope Spiegel

der Zeitraum, die

Periode

der Unterrock

das vermischte Zinn

die Photographie, das Lichtbild

wieder aufnehmen

das Kissen, das Köppelkissen, der Klöppelsack

die Kissendecke

der Kissenüberzug

el alfiler

prender con alfile-

die Stecknadel stecken

res, asegurar

el acerico

el agujero

ojetear, picar das Nadelkissen

der Stecknadel Punkt

auszacken, a us. schneiden 
ENGLISH

FRENCH

I'TALIAN

SPANISH

GERMAN

Pinner: see Lappet

Plain: see Simple

Plait, braid, tresse : see Fold

Plait, to, braid, to

Plaiting: see Filling

Platform of pillow

Plume, tuft, panache

Ply (single) strand

Point, vandyke : see Scallop

\section{P'oking stick (iron), setting- stick, strut (wood or bone) : see Puff iron}

Polish, to

Polychrome (adj.)

Position

Pound sterling

Press: see Puff iron: see Linen press

Pretty (adj.) : see Beautiful

Price

Pricker, marker (instru ment) : see Stiletto

Pricker, marker (person)

Pricking, parchment, down, each

Pricking or making of

Professional (adj.) see Expert: see Authority

Prong

Pucker : see Crease : see Gather, to

Puff iron, lace awl, polishing iron, agate, raiser, lobster claw, bur-. nisher: see Poking stick: see Press

Pull, to

Pull over, to: see Slip off, to

Pupil

Puppet, doll, manikin la tresse, la natte la treccia

tresser, natter

la planche, la plateforme

le panache

le pli

la crête

la broche, le bàton à plisser les fraises ou les manchettes, le composteur, le potelet

polir

polychrome

la position, la pose

la livre ( 25 francs)

le lissoir

joli -e

le prix

la pointe, l'aiguille à piqueter

la pointeuse, la piqueuse

le piqué, le cartonguide, le passement

le piquage, la piqûre, le picage, le piquetage

professionel -le, professionale professionale

la dent de fourchon

l'oeuf, le fer à cannonier, le fer a coque, l'alésoir, la pince, l'aficôt

il frastaglo

tirer, serrer

rabattre, rabattre les mailles

l'êlève

la marionnette, le Courrier de la Mode, la poupée il pizzicore, li pizzilli, il cartone

la picadura

professional

la punta

el esponjador

il puffiture, le branche dei gamberi

la trenza, el cordoncillo

trenzar

la plataforma

el penacho

la doblez

el cuello de encaje Van Dyke

el instrumento de hueso 0 madera que se usa ajustando los pliegues de una lechuguil-

$$
\text { la }
$$

policromo

la positura, la pos tura, la posicion

la libra esterlina

el satinador, el lustrador

el precio

el punzôn

el que pica, el marcador

la picadura

il rebbio

tirare

abbassare, scemare

il scolare

(ivar

el discípulo

il manichino

el maniquí der Flechtenschlag, die Flechte flechten

das Klöppelbrett

der Federbusch, der Helmfederbusch einfach

die ausgezackte Spitzen, das Zäckchen, die Spitze

das Stäbchen

oliren, glätten

bunt

die Lage, die Stellung

das Pfund Sterling

? Weisshölzer, die Glattmaschine

hübsch

der Preis

die Pickiernadel

die Punktierin, die Musterdurchpauserin, der Löcherstecher

der Klöppelbrief, das Muster, "die Aufwinde"

d a s Durchstechen, des Musters auf Pergament

berufsmässig

die Zinke

der Puffer, das Bügel, ? Kobben, der Glättstahl, der Glätter, die Hummerschere

ziehen

verschränken

der Schüler, die Schülerin

die Puppe, die Marionette 


\section{ENGLISH}

Purl, to ; seam, to, tricoter à l'envers reverse, to

\section{Quality \\ Quatrefoil \\ Queen \\ Quick (adj.)}

Quille: see Fluting

Quilling: see Fluting

Quilter: see Stitcher

Quilting: Wadding

Quincunx

Quiver, sheath

Raised, embossed (adj.) : see Gimp

Raiser: see Puff iron

Rare (adj.): see Expensive: see Valuable

Ravel, to ; fray, to; unravel, to : reave, to ; reeve, to ; unweave, to

Ravellings

Razor-cloth : see Combing cloth

Reader, lay-sister, entertainer, nonworker

Realistic (adj.)

Reduce, to ; lessen, to ; diminish, to : see Decrease, to

Reel, to ; wind, to

Refiner: see Finisher

Removing, loosening, detaching: see Rip, to

Renascence, rebirth

Repairer of breaks and faults: see Finisher

Repairing, reparation: see Strengthening: see Mending

Repeat, to ; see False stitch

Reticular, retiform (adj.)

Reversible (adj.) : see Double faced

la qualité

les quatre-feuilles

la reine

leste, vite la ruche

effiler, effiloquer filure, l'effilure

le linge à barbe

la béate

réaliste

reduire

dévider

l'enlevage

la renaissance

la régaleuse

l'épéter

rétiforme

à deux endroits
ITALIAN

far la calza a mag- perfilar lia a volta

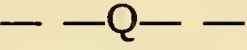

la campane, la houppe, la touffe,

la qualita

le quatro foglio

Ia regina

lesto, snello, spedito

la frangia, il merletto piegato en forma di arnia

la stoffa cosi detta

l'imbottir. trapunto

la quinconce

la faretra

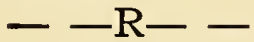

en relief, bombé -e

in reli e vo, rose rilevato

raro

sfilare, sfilacciare

le parfilage, la par-

le ravaudage, le remaillage gli filacce

il cencio da barba

il leggitore, il mantenitore

realista

ridurre

addipanare

il levare

il risorgimento, il rimascimento

la regalatrice

il racconciamento

race

ripetere, ricomin- repetir ciare

rete

reticular bador

realista

reducir rivocabile
SPANISH

la calidad

el cuadrifolio

la reina

veloz, acelerado, ligero

el pliegue en forma cilíndrica

la cajera, el picado

el quincunce

el carcaj

en relieve

raro

deshilar, desenlazer

GERMAN

links stricken

das Vier-blatt

die Königin

schnell

die 'Troddel, die Quaste

das Steppen

das Quincunx der Köcher

erhaben

selten

auftrennen, aufziehen

la hilacha

el babadero, el ba-

Ia lectora

Ausgezuptes, ausgezogene Fäden das Bart-Tuch ?

realistisch vermindern

haspeln, aufwinden

das Wegnehmen

die Renaissance

el reparador, el apisonador

la reparación

die Ausbesserung, das Ausbessern

wiederholen

netzförmig

que admite posición umkehrbar o direccion opuesta 
ENGLISH

Rib: see Raised: see Gimp

Ribbon: see Stirrup

Rice

Rich, handsome (adj.) : see Beautiful: see Pretty

Right hand side

Right side, front

Ring

Ring finger

Rinse, to

Rip, to

Rococo (adj.)

Rod: see Bar

Rolling, whipping

Rose

Rosette (general use), rose threadworks) : see Crowns

Rough (adj.)

Row: see Line: see Band

Royal (adj.)

Rubbing: see Tracing

Ruff

Ruffle, hand ruff, parte: see Cuff

Ruler: see Tape measure: $\mathrm{s} \mathrm{e}$ Mesh-stick: see Measure

Runner: see $T a$ blecover

Russian (adj.)

Rust, to
FRENCH

ITALIAN

il nastro

il riso

ricca

droit -e

I'endroit

destro le cercle

le doigt annulaire rincer

découdre

Rocaille, Barocco, Roccoco, rococo

le point roulé

la rose

la rosette, le noeud

les couronnes, les fleurs volantes, les rosaces rude, ébouriffé -e

le rang, le tour

royal -e

l'impression

la fraise, la rotonde

la manchette, l'engagéante, la pagode

le tire-ligne, le règle, le réglet, la réglette

le chemin de table russe rouiller, se rouiller

la rosa

le cornoa ruffato

l'ordine, la fila

reale, regio pronto nuola manichetto

il stecche

la striscia

russo
Rosettes (minute

la rosetta, la gala

rozzo, rude, abba-

l'impressione, l'im-

il collare alla spag-

il manichino, il

arrugginire, a rrugginirsi, irrugginire

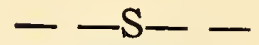

Sacramental (adj.)

Saint Ann

Salary

Sample

Sampler, sam cloth

Sand

Sawdust: see $E x-$ celsior

Scale, proportion de bénédiction

la Sainte Anne

les appointements, le traitement, les honoraires

l'écbantillon

l'exemplaire

le sable

la sciure, la sciure de bois

l'écbelle de benedizione

Sabbia Anna

l'onorari, la sportu-

la, la ricompensa

il campione

l'esemplare
SPANISH

GERMAN

derecha

el lado derecho

el círculo, la cera el anillo

el dedo anular

enjuagar

rasgar, hender

churriguersco

der Reis

reich

rechts

die Rechterseite

der Ring, der Kreis

der Ring Finger

auswaschen, aus-

spulen

auftrennen

rococo

der Rollsaum

enrollado, el rollamiento, el arrollado, el arollamiento

la rosa

die Rose

la rosa, la roseta

die Rosette

la rosa, la roseta, el rosetón

die Rosetten, die Rosette

erizado, encrespado

raub, roh, uneben

la fila, la línea, la hilera

real

el frotamiento

la lechuguilla

la vuelta, el puño

la regla

die Reihe

königlich

der Abdruck

die Krause

die Manschette, die Handkrause

das Lineal

el tablero

der Tischläufer, der Läufer

ruso

enmohecerse

russisch

rosten, verrosten

sacramental

Santa Ana

el salario

la muestra

el ejemplar

$\begin{array}{ll}\text { la lazanta } & \text { la arena } \\ \text { la segatura } & \text { el serrín } \\ \text { la scala, il propor- } & \text { la escala }\end{array}$

sacrementlich, sacrementarisch

die Heilige Anna

die Besoldung, das Gebalt

das Muster

das Modelltuch, das Musterblatt, das Sticktuch der Sand

das Sägemehl

der Masstab 
ENGLISH

FRENCH

Scallop : see Point : see Shell: see Fan-shaped

Scalloped (adj.)

Scarf : see Tidy

School

Scissors

Scraps, remnants

Screen

Screw: see Clamp

Scroll (spiral) : see Foliated

Seal

Secular,lay (adj.) : see $R$ eader

Sell, to

Selvage, selvedge : see Edging: see Footing

Serpentine, vermiculate (adj.)

Set

Setting: see outlining: see Laying out: see $A p$ ply, to

Setting-stick: see Poking-stick

Setting up (of loose petals)

Seventeenth (adj.)

Sew, to

Sewing, joining (lucky stroke?), accroaching

Shade: see Window shade

Shaded (adj.)

Shape: see Form

Sharpen, to ; grind, to ; whet, to

Sharps

le feston

ITALIAN

SI'ANISH

GERMAN

il festone

Ia recortadura

dentelé -e, festonné -e, en êcailles

l'écharpe

l'école

les ciseaux

les restes

le paravent

la vis

l'enroulement, l'enjolivement, le rinceau

le cachet, le plomb

séculier -e, laïque

vendre

la lisière

serpentin -e, en serpent, tortueux -se, vermiculeux -se

la parure, l'assortiment, la garnitu$\mathrm{re}$

la sertissure, le sertissage

Shawl

Sheath: see Covering cloth: see Case

Sheet

Shell: see Scallop a festoni, scaglia di
pesce

la sciarpa, la ciarpa

la scuola

gli forbici

il paravento

il vite luta, il incartocciarsi

il piombo, la marca secolare, laico

vendere

la cimossa

serpentina

il assetto

la incastonatura

la incastonatura engaste, la mon- tadura.

la engastadura, el

festoneado

la banda

la escuela

las tijeras

los restos

la pantalla, el biombo

el encaracolado, el adorno en espiral

el sello

secular

vender

la orilla

serpentino

el juego

die Einfassung er Abfall, die il avanzo, il resto

il avvolgersi, la vo-

el tornillo
$?$

dix-septième

coudre

l e crochetage, I e raccrochage, $1 \mathrm{e}$ point de raccord, le point de raccroc, le point de rucroc

ombré -e, nuancé -e

aiguiser

?

?

diciassettesimo, decimosettime

cucire, cusire

la cucitura, il cucito

\section{la montadura}

décimo séptimo

coser

el cosido, el enganche

\author{
digradato \\ affilare, aguzzare
}

?

Io sciallo

le châle

l'étui, la gaîne, le fourreau, la noquette, la feuille trousse

le drap

la coquille de St. Jacques
il astuccio, la cus- todia, Ia busta

il lenzuolo

la chiocciola, la lumaca sombreado

amolar, afilar

la aguja de coser de forma mâs larga y más delgada

el chal, el pañolón, el pañuelo grande

la vaina, la cubierta

la sábana

la concha de corne, la häkeln die Garnitur

das Siegel

weltlich

verkaufen

das Salbende, die Kante

schlangen-artig

der Bogen, die Zack-

ausgezackt, ausgedie Schärpe

die Schere

Kleinen Stücke

die Schraube

der Schnörkel

das Aufsetzen

siebzehnte

nähen

das Heften, die $\mathrm{Zu}$ sammenhäkelei, das Zusammen-

schattiert

schärfen

$?$

der Shawl, der Schal

das Besteck, das Futteral, di e Scheide

das Bettuch die Muschel 
ENGLISH

Shift, to

Short (adj.) : see Squat

Showy, for display, os tentatious (adj.) :see Heaviness

Shrink, to

Shuttle

Sicilian (adj.)
Silk: see Blonde
Silver
S i mp l e, p l a i n
(adj.) : see Easy
Single (adj.)
Single faced (adj.)
Single stitch, small
close stitch
Sitza
Sixteenth (adj.)
Size, dimension

Sizing, stiffening:
see Dressing
Skein
Skill, dexterity : see
Execution
Skirt

Skirt

Slab

Slanting (adj.) : see Diagonal

$\mathrm{Sl}$ a sh ed, paned (adj.)

Sleeve

Slider

Slip, to

Slip off, to: see Pull over, to

Slit, opening, line, band

Slow (adj)

Smock, shift, shirt

Smooth (adj.): see Flat: see Glazed

Smuggling
FRENCH

changer

court -e

d'apparat

se rétrécir, se rapetisser, rétrécir

la navette

sicilien -ne, de Sicile

la soie

l'argent

simple

seul -e, simple

à simple face

la petite maille serrée, la chaîne serrée

? sitza

seizième

la grosseur, la grandeur

l'écheveau

l'habileté, la dextêrité

la jupe

Ia plaque

de biais, en biais, incliné -e

crevé -e, à crevés, fendu -e

la manche

le glissoir de corne

glisser, passer, une maille -un point pour le reprendre le tour suivant

g li s s e r, couler, lâcher, retourner la livière

lent, lente

le sarrau

lisse, uni -e

la contrebande
ITALIAN

cambiare

corto

di pompa, ostentazione

scolciare, ritirarsi, diminuire

la spola, la spuola

siciliano

la seta

il denaro

semplice, senzo ornamenti, senza fasto

solo, sola, semplice, unico

semplice

il semplice piccolo pun to

? sitza

sedicesimo

l'estenzione, la grossezza, la grandez$\mathrm{za}$

la matassa

la destrezza, la desterita

il gonne, la gonnella

la tavola

a sghembo, a sbieco, a schiancio

staffilato, tagliato, sfregiare, (apertura nelle maniche per mostrare la stoffa al disoto)

la manica

che sdrucciola, la passante

sdrucciolare, scivolare

colare, lasciare

l'aperto

lento

il pastrano, il gabbano

liscio, piano, unito

il contrabbando
SPANISH

cambiar

corto

ostentoso

encogerse, acortarse, disminuir

la lanzadera

siciliano

la seda

la plata

sencillo -lla, simple

funico, solo

de una cara

el punto sencillo

? sitza

décimo sexto

el tamaño, la dimensión

la madeja

la habilidad

la falda, la saya

la plancha

inclinado, sesgado

acuchillado

la plancha corrediza transparente

perder un punto para volver a cogerlo

deslizar

la abertura

lento, tardio

la blusa de obrero

liso, llano, iguel

el contrabando
GERMAN

wechseln

kurz

prunkhaft

sich zusammenziehe $n$, einschrumpfen, zusammentrocknen

das Weberschiffchen, der Schütze

sizilianisch

die Seide

das Silber

einfach

einfach

einseitig

das einfache Stäbchen

? sitza

sechzehnte

der Dicke, die Grösse, Stärke

die Strähne, die Fitze

die Geschicklichkeit

der Rock

die Platte

schief

geschlitzt

der Aermel

der Schieber

gleiten

rerschr:̈inken

der Schlitz

langsam

der Kittel

eben, glatt

der Schleichhandel, des Smuggeln 


\section{ENGLISH}

Soak, to

Soap

Soda

Soft (adj.)

Soil, to

Song, verse, tell

Spanish (adj.)

Spider: see $\mathrm{Net}$ work

Spin, to

Spindle

Splice, to

Spool

Spray, shoot, tendril, sprig: see Tack

Sprinkled, s o w n, powdered, strewn (adj.)

Square: see Medallion

Squat, d u m p y, truncated (adj.) see Short

Stake out, to: see Lay out, to

Stamp ou t, to ; round $o u t$, to: see Puff iron

FRENCH

tremper

le savon

la soude

mou, mol -le, délicat

souiller

la chanson, le chant

espagnol -e, d'Espagne

l'araignée

filer

la broche, la bobine, la casse

épisser

la bobine

la vrille, le brin, la brandille, le rinceau

semé -e, moucheté $-e$

le carré

trapu -e

\section{ITALIAN}

SPANISH

bagnare, animol- remojar lare

il sapone

la soda

molle

imbrattare, ingrozzare, macchiare

il canto, il canzone, la canzonetta

spagnuolo

il ragno, il aragno

filare

il fuso, la bobine, il contraforte, l'infornapana ?

il rocchetto

il viticcio, il capreolo

seminato, spargerato

il quadrado

atticciato

affiquer, bosseler, refouler, fa i r e ressortir

le collet montant Medici c oll a r, standing $r$ uff : see Collar

Star

Starch, to (Devil's Broth - e a r l y name for starch)

Steel

Steeping, maceration

Stencil

Steps, in $(\operatorname{adj}$.$) :$ see Zigzag

Stick in, to; put up, to: see Pin, to

Stiff (adj.)

Stiffening: s e e Dressing

Stiletto, punch : see Pricker

Stirrup : see Loop: see Ribbon

Stitch

l'étoile

amidonner, goudronner, empesser

l'acier

le rouissage

le patron, le poncif, il modello le poncis

en échelons

enfoncer, mettre, affondare, fissare planter

raide, empesé -e

le poinçon

?

le point, la passée

Stitcher, quilter, la piqueuse coucher per iscaglionli

la stella

insaldare

il acciaio

il macerazione

escalonado

picar, punzar

tieso

el punzôn

el estribo

la $\mathrm{punt}$ a da, el punto tura, la maglia

la piatrice, il ma- el colchonero terassaijo
GERMAN

durchnassen, in der Weiche liegen, einweichen

die Seife

die Soda

zart

beschmutzen, besudeln

das Lied

spanisch

die Spinne

spinnen

d e r Strickstock, der Stengel, die Spindel, ? Spille splissen die Spule

das Reis

sprenkelich, sprenkelig, fecken

das Viereck, d a s Quadrat untersetzt

aufstechen

der Medicikragen

der Stern

stärken

der Stahl

das Tunken, d a s

Tauchen

die Schablone

staffelweise, $\mathrm{s} t$ a $\mathrm{f}$ felförmig

cinstecken

steif

die Pfrieme

der Bügel

die Masche, d e r Spitzenstich, der Schlag, der Stich die Stepperin 
ENGLISH

Stomacher

Straight (adj.)

Strand

Straw

Streaked, striped, scored, striated $(\operatorname{adj}$.$) : see$ Stripe

Strengthening, reinforcing, backing: see Repairing

Stretch, to ; give, to (intr.)

Stretch, to ; pull, to (trans.)

Stripe: see Band: see Line: see Streaked: s e e Bar

Stroke, to ; dispose, to

FRENCH

ITALIAN

SPANISH

GERMAN

Stroke

Studio: see Workroom

Study, to

Stuffed (adj.)

Style, fashion

Style, ma n n e r, taste

Subject: see $D e$ - le motif, le sujet sign

Sumptuary laws, les lois somptuaires Office of Pomp

Sun

Surplice, stole

Swaddling band

Swiss (adj.)

Symbol

Symmetrical (adj.)

Tablecloth

Tablecover: s e e Runner

T a ck, sprig, flat nail: see $N$ ail

Tailor's thimble : see Finger shield

T a I i t h, tallith, praying $\mathrm{s}$ c a $\mathrm{r}$, mantel

Tambor: see Hoop

Tambor-work

Tangle, to; snarl, to

Tape, braid le corsage lacé

droit -e

la mèche, le cordon

la paille

strié -e, rayê -e

le rentoilage, le renforcement,

l'action de fortifier

prêter, s'élargir, s'étendre

étendre, tendre

la raie, la rayure

striquer riser

régula-

trait

il corpetto, il busto, la pettiera, il gustacuore dritto

il cordone, il cordoncello, il cordoncino

la paglia

strisciato

il rinforzamento

cedere

stendere

la riga

rendere, regolare

il tratto

lo studia

studiare

imbottirato

il modo, la voga

il tuono, il stile, il gusto

il soggetto, il motivo

le legge suntuaria

le soleil

le surplis

il sole

?

la bande d'emmaillottement

suisse

le symbole

symétrique

la fascia

svizzero

il simbolo

simmetrico

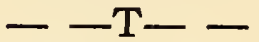

la nappe

le dessus de table, le tapis

la semence, la broquette

le taled

la broderie au tambour

emmêler, entortiller

le ruban de fil, la rivière de toile

il nastro di filo, di il taled

il tambur

la tovaglia

la tavolina

la bullettina

el talid

el tambor

scompigliare, imbrogliare lino, di cotone

el mantel

el tapete beza

enredar algodón el peto, el corpiño

derecho

el cabo, la hebra

la paja

estriado

la ribeteadora, la cosedora

estirar

extender, estirar

la raya pliegues con la aguja

el toque

el taller

estudiar

llenado, relleno

la moda

la manera, el gusto, el tono

el motivo, el sujeto

el arreglo suntuario

el sol

el sobrepelliz

la mantilla, el pañel

suizo

el símbolo

simétrico

la tachuele sin ca-

la cinta de lino o alisar, igualar los der Latz

gerade

die Ducht, die Kardesle, die Schnur eines Strickes

das Stroh

streifig

das Verstärken

sich dehnen lassen

spannen

der Streifen

ausrauhen

der Strich

das Atelier

studiren

gestopft, v o ll gepfropft

die Mode

der Styl, die Man-

i e $r$, d e $r$ Geschmack

das Motiv

die Aufwandsgesetze

die Sonne

die Stola

das Wickelband

schweizerisch

der Sinnbild

symmetrisch, ebenmässig, gleichmässig

das Tischtuch

die Tischdecke

der Stift

d e r Gebetmantel, der Talar

die tamburirte Arbeit

verwirren

das Zwirnband, das Bänđchen 


\section{ENGLISH}

Tape measure line: see Ruler: see Measure

Tassel: see Tuft

Tatting

Tatting pin and ring

Tawdry, trashy, p o o r, ordinary, common (adj.)

Tea

FRENCH

ITALIAN

SPANISH

GERMAN

la misura

la nappa

le gland

la frivolité

l'occhi

?

Teach, to

Teacher, instructor

Thick (adj.)

Thickness

Thimble, thummel, thumb-bell, fingerling

Thimble for crochet wor k, crochet thimble

Thin (adj.)

Thread

Threader : see Needle threader

Thumb

Thumb tack, drawing pin: see Tack: see Nail

Ticking

Tidy, chair-back : see Scarf: see Antimacassar: see Lambrequin

Tie together, to ; attach, to: see Couple, to: see Fasten off, to: see $K n o t$

Tight, taut (adj.)

Tighten, to

Tin, white metal

Tippet

Token, coin

Tool, instrument: see Apparatus

Top

Torn, rent (adj.)

Tow

Towel

Towel sham, throw- le cache linge over vilain -e, ordinaire, comunaio pauvre, maigre, misérable

le the

enseigner

l'inștitutrice, l'instituteur

épais -se

l'épaisseur

le dé

le dé pour le crochet sur métier

mince

le fil

le pouce

la punaise

il pollice

?

il te

ammaestrare, istruire, insegnare

l'istitutore, l'istitutrice

grosso, fitto

la grossezza

l'anello da cucire, il ditale, il ditali chiuso

la toile à matelas, il traliccio le coutil

le dossier pour fau- l'antimacassar teuils, etc.

attacher, lier

serrê -e, tendu -e stringato, teso

serrer stringare

l'étain, le ferblanc il stagno, la latta, il ferro stagnato

la pèlerine

la pellegrina

le jeton, le gage

la fiscia, il gettone, il pegno

l'istrumento, l'ordigno

le haut

déchiré -e

la filasse

l'essuie-main

l'alto

squarciato, lacerato

la stoppa di canapa

l'asciumano, la salvietta

il ciocche spende sopra la cinta para medir

la borla, el borlón

el encaje de hilo hecho a mano con lanzadera

el alfiler $\boldsymbol{y}$ anillo usado para hacer encaje de hilo con lanzadera

sin elegancia

el té

enseñar

el maestro, el preceptor

espeso

el espesor

el dedal

el dedal para hacer crochet

delgado

el hilo

el pulgar

la tachuela

el terlíz

la funda para muebles

atar, ligar, unir

ieso, bien cerrado estirar

el estaño, la lata

la esclavina

la medalla

la herramienta, el instrumento

el encabezamiento

rasgado

la estopa

la toalla

la cubierta de adorno para toalla das Werkzeug das Bandmass, das Rollmetermass

die Quasta

das Occhi, die Frivolitäten

?

geschmacklos geputzt, flitterhaft, wertlos, unnütz

der Tee

lehren, unterrichten

die Lehrerin, der Lehrer

dick

die Dicke

der Fingerhut

$\underset{\text { der hükel Finger- }}{\text { dut }}$

dünn

der Faden, der Spitzenzwirn, der Zwirnfaden

de1 Daumen der Reissnagel, der Reisszwecken

der Zwillich

das Schutzdeckchen, der Schoner

zusammenbinden

straff, gespannt

f ester machen, spannen, anzieh. en

das Zinn

d e r Halskragen, der Palatin

das Zeichen

das Obereteil

zerissen

der Werg

das Handtuch

das Überhandtuch 


\section{ENGLISH}

'Trace, to ; calk, to ; rub, to; pounce, to

Trace through, to

Tracer

Tracing: see $R u b-$ bing

'Tracing cloth, paper: see Carbon paper

Transfer', to: see Mount, to: see Carbon paper

Transfer paper : see Carbon paper: see Tracing cloth

'Trash, camlet

Tray

Trefoil

Tresse: see Hair: see Plait

Triangle

Triangular (adj.)

'Trimming', guarding

Triple, treble (adj.)

Trousseau

Truck system, payment in kind

T-square

Tucker: see Modesty piece

Tuft (raised), Byzantine, Medici or Florentine cutwork, overstitches: see Tassel: se e Cutworks: see Leaf: see Leaf stitch

Tulip

Turn around or back, to ; reverse, to: see Double

Tweezers

Twist, to ; simple twist, to

Twisted (adj.)

Twister (machine)

\section{FRENCH}

tracer, calquer, faire une impression

tracer, buriner, calquer

la traceuse, le traceur

\section{?}

le papier de calque, le papier transparent, 1 a toile à calquer, le papier végétal, le papier gelatine, la toile d'architecte

transférer, remonter

le camelote

le casier

le trèfle

le triangle

triangulaire

la garniture, la passementerie

triple

le trousseau

le paiement en nature

l'équerre

la collerette, le tour de gorge

le point d'esprit dessus, la touffe la mouche, la houppe

la tulipe

tourner, retourner

les pincettes

tordre, tortiller

cordé -e, tordu -e

le croise-fils
ITALIAN

calcare, punteggiare un disegno, copiar un disegno passando una punta sui tratti

tracciare, calcare, copiare

il tracciatore

il punteggiare un disegno

la tela d'architetto rasferire, rimontare, reprovsedere

transferi tar

la cattiva mercanzia, l'opera di poca entita

lo scompartimento

il trifoglio

il triangolo

triangolare

il guarnizione

triplo, triplice

il corredo

il pagare in natura

la squadra, la norma

il collaretto, la gala

la macchia, il fiori$\mathrm{ni}$, il fiocco, la nappa

il tulipano

girare, volgere

el tulipán

girar, volver

il pinzette, le mol- las tenacillas lette torcere

torcer

retorcido, torcido

la maquinilla pal'a

retorcer hilos

el triángulo

la guarnición

tríplice, triplo

el equipo

pago en la mis-

-

el escote

el copete

attorto
GERMAN

Irachzeichnen, kalkiren, durchpausen

pausen

die Vorzeichnerin der Umrisse

die Pause

die Pausleipwand, das Pauspapier

übertragen

der Fachkasten

der Klee

der Dreieck

dreieckig

der Besatz, die Verzierung

dreifach

die Aussteuer

der Lohnzahlung in Waren

das Winkelmass, das Winkeleisen, das Winkelholz

der Bruststreifen, der Halsstreifen die Musche die Tulpe umkehren

das Züngelchen

drehen

rerschlungen 


\section{ENGLISH}

FRENCH

Under, beneath, below

Undo, to

Unravel, to: see Ravel, to

Untie, to

défaire mage
Unemployment le chômage, le chan-

dénouer, détacher, sciogliete

$-\mathrm{V}-$ feriormente

disfare vorare au-dessous, sous

$-\mathrm{U}-$

sotto, di sotto, in-

il sciopero, il sciopro, il tempo che se passa senza la-

la balza, il pendaglio, il drappelone

di gran valore, prezioso

la specie, la variete

vegetale

il velo

il velo, la bandinella

venato

(fol" the Host)

reined (adj.) (raised)

Vertical (adj.)

Vestment

Victorian (adj.)

Virgin

Wadding: see Quilt-

Waist

Warm, tepid (adj.) see $H o t$

Warp, chain

IV ash, to

Water

Watering place, spa, summer resort

Waves, undulations, overlapping loops, ripples, folds

Wax

Wax-cloth : see Oitcloth

Wearer, worker, le trameur, le conrunner ducteur, la pai-

Web

Weight: see Clamp re de remplissage

le tissu, la toile

l'ouate

la blouse, le corsaciède

la chaîne (fils tendus)

laver

I'eau

la ville d'eau

des flots

Ia cire

la cera

il tessitore

il vestimento, l'abbigliamento

Vittoria

la Virgine

\section{- -W- -}

l'ovatta, la bambasia, l'imbottitura

la blusa

tiepido, tepido

l'ordito, la catena

lavare

l'acqua

l'acque, i båni

l'anella

el entreforro

la blusa

cálido, tibio

la urdimbre, la tela, la cadena lavar"

el agua

el balneario la onda, la ondula-
ción

la cera

el tejedor, el trabajador

el tegido, la tela

il tessuto, la tessitura

il peso, el piombo

\section{GERMAN}

unter

auflösen

die Feierzeit

der Bettkranz

wertvoll, kostbar

die Gattung, die Art

pflanzenartig, vegetabilisch

der Schleier

der Vorhang

geadert

senkrecht, vertikal das Gewand, das

Kleid

victorisch

die Jungfrau

die Wattierung, die Baumwollwatte, die Füllung die Taille

warm

der Weberzettel, die Kette waschen das Wasser das Spaa

die Kräusel

der Wachs

das Schusspaar, der Weber

das Gewebe

das Gewicht la pelote lourde 


\section{UNGLISH}

Wet (adj.) : see Dampen, to

Wheel: see Out-

line, to: see

Winding ma-

chine

Whip, to : see Overcast, to

White (adj.)

Whole stitch, double pass, whole throw, ginip, mat, math

width

Wimple (nun's), gorget : see Guimpe

Wind, to ; hank, to

IVinder, reel

\section{Winding \\ Winding machine, bobbin winder, lace turn, wheel \\ Window shade: see Curtain}

IVood

Woof, weft (shuttle thread)

Wool

Work, opus

Work bag

Work basket

Work box

Worker: see Weaver

Workroom: se e $F$ a ctory: see Studio

Worsted, yarn

Wrongside, back

Yak

Yard

Yarn-holder, bangle, bracelet

Yoke, chemisette, dickey, gorgias: see Collar

\section{FRENCII}

mouillé -e

la roue

blanc, blanche

le point entier, le point matte, le toilé, la double passée

lit largeur

la guimpe, la barbette

pelotonuer

le dévidoir

l'enroulage

le dévidoir, le bobinoir.

le store

le bois

la trame

la laine

l'ouvrage

le sac à ouvrage

la corbeille à ouvrage

la boite à ouvrage

l'atelier, l'ouvroir

le fil de laine, la laine filée

l'enver's

Ia yack

le mètre (39 Eng-

lish inches)

le bracelet

l'empiècement

Zigzag: see Steps, le zigzag in
I'TALIAN

bagnato, umido

la ruota

bianco

il punto finito

la larghezza

il soggolo, la gorgiera, la benda

aggomitolare

l'arcolaio, il guindolo

l'aggomitolare

il guindolo, il arcolaio, il avolajo di fuselli

la persiane, il parasole, il legno

il legno

la trama

la lana

il Iavoro

il sacco

la paniera de lavoro

l'astuccio da lavoro

il lavoratorio, la el taller bottega da lavoro, l'officina

la lana filata

il rovescio

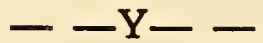

l'iaco

la jarda

il $s \mathrm{~m}$ a $\mathrm{n}$ ig l i 0 , il braccialetto, il anello da polse

l'empiecement, il devanti d'u n e blusa

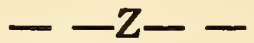

il zigzag blanco

el punto completo

el ovillar

la enrrolladora para palillos

el transparente

la madera

la trama

la lana

la obra, el trabajo

el saco de labor

la cesta, la canasta

el costurero, la caja de labor

el hilo de lana

el revés

GERMAN

nass

das Rad

weiss

der Ganzschlag, der

Doppelschlag, (2

Halbschläge)

die Weite

der Brustschleier, der Wimple, das

Brusttuch

knäuelenbjlden,

wickeln, aufwickeln

die Garnwinde, die Garnhaspel, del H a s p e l, d i e Zwirnwinde

das Wickeln

die Wickelmaschine

der Fensterschirm

das Holz

das Gewebe, der Einschlag, der

Eintrag der Warf die Wolle

die Arbeit

der Arbeitsbeutel

der Arbeitskorb

die Arbeitsschachtel, d a $\mathbf{Z}$ Zwirnkästchen

die Werkstatt

das wollene Garn

die Rückseite

el yak

la yarda

el brazelete pa $\mathrm{r}^{*}$ hilo de lana

? Yack die englische Elle

die S p a n g e, der Garn Haspel

el peto de blusa, el das Achselstïck frente de blusa

el ziszás, el zigzag der Zickzack 


\section{Chapter IV RULES FOR MAKING}

"The whole value of lace as a possession depends on the fact of its having a beauty which has been the reward of industry and attention. That the thing is itself a price-a thing everybody cannot have. That it proves, by the look of it, the ability of the maker; that it proves, by the rarity of it, the dignity of its wearer. . . If they all chose to have lace, too, if it ceases to be a price, it becomes, does it not, only a cobweb? The real good of a piece of lace, then you will find, is that it should show, first, that the designer of it hath a pretty fancy; next, that the maker of it had fine fingers; lastly, that the wearer of it has worthiness or dignity enough to obtain what is difficult to obtain, and common sense enough not to wear it on all occasions."--Ruskin.

\section{LINEN OR CLOTH STITCH JOINING BANDS.}

The rule for making linen stitch or cloth stitch is:-cross, twist, cross.

The quarter inch bands in this sampler are made of six hanging pairs and a weaver.

The half-inch bands are made of twelve pendant pairs and a weaver.

The one inch bands are made of twenty-four pairs and a weaver. 
LINE A, COL. 1,

Net Stitch, Lattice Ground, Demi-Point, Toilé Ouverte, Point Réseau.
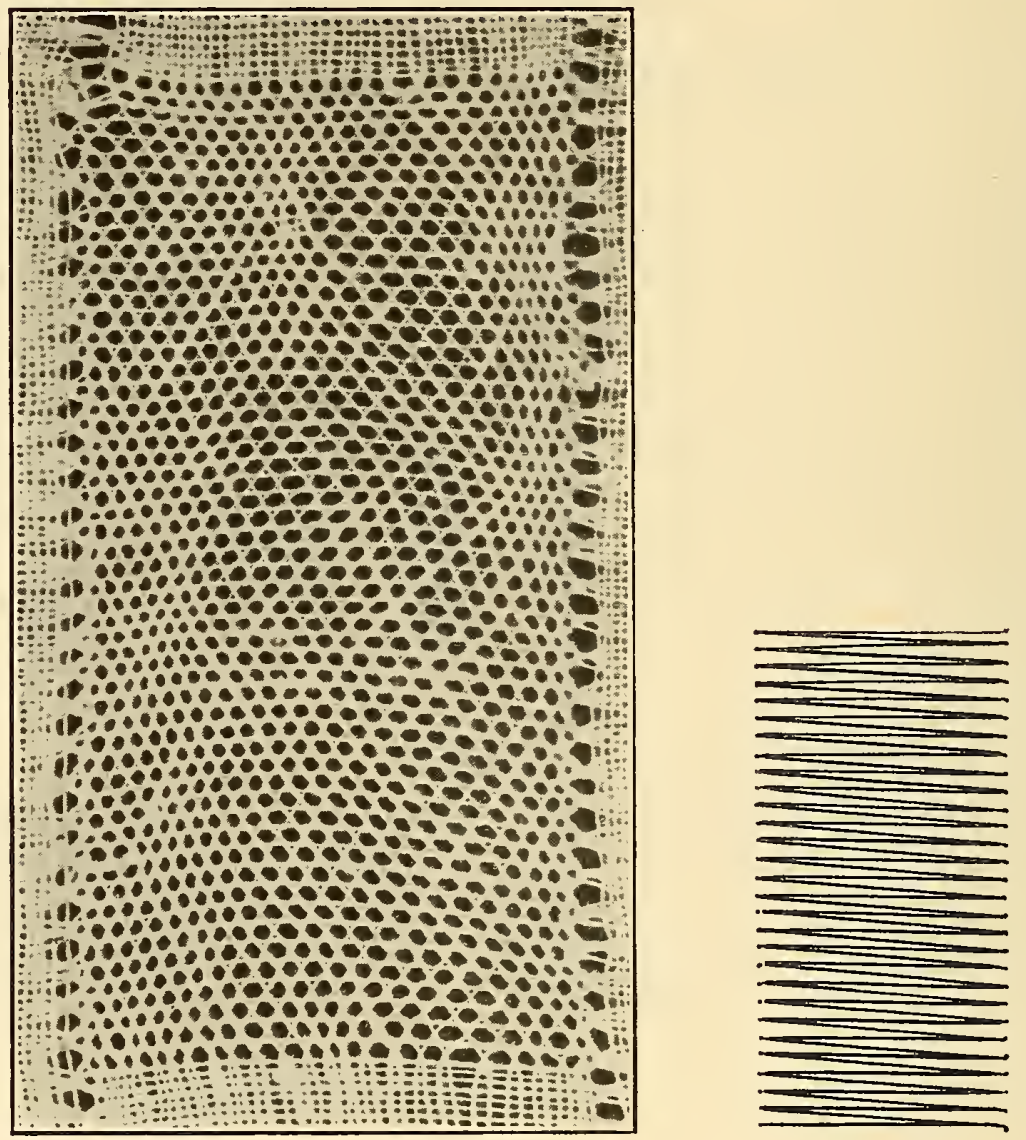

For this first sample twenty-four pendant bobbins and a weaving pair are needed. It is made entirely of simple half-stitch, for which the rule is twist, eross. This operation is repeated from left to right across the top row, then from right to left across the one below, and so on until one reaches the bottom. By making the same stitch a second time at each edge; that is, by repeating it after placing the edge pin, before starting the next row below, the edge can be made firmer. 
LINE A, COL. 2,

Virgin Ground, Pin Check, Pink Check, Ornamental Ground, Binche, Cinq Trous, Point Carré.
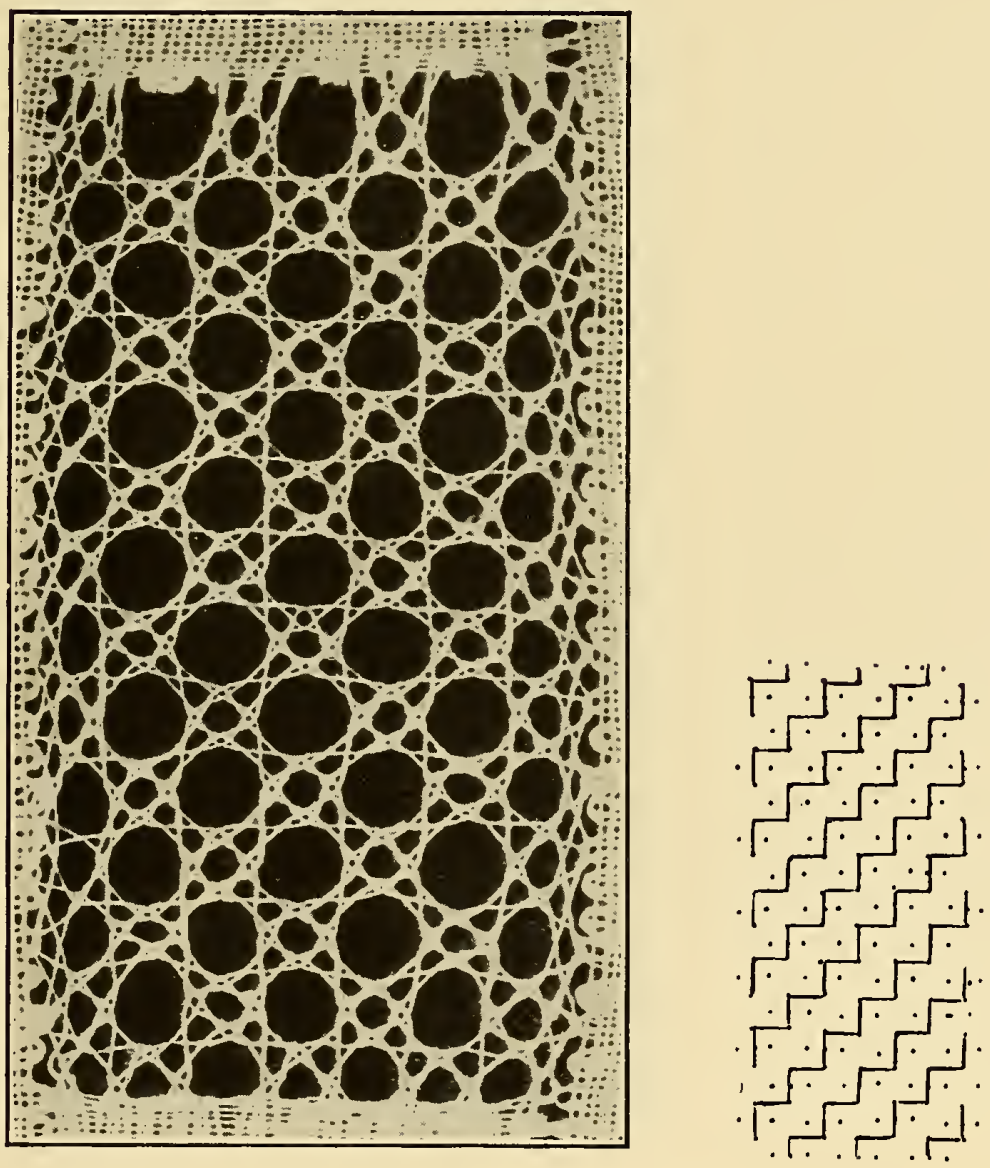

This is the Variation of Virgin Ground, generally known as Cinq Trous, belonging originally to Binche Lace. Each motif or block requires four pairs, two of which enter at the upper left-hand corner, two at the upper right. To make the upper left-hand ornament, twist and cross. The upper right-hand ormament is made in the same way. Two center pairs, one coming from the left and one from the right, are twisted and crossed. A pin is placed at the 


\section{LINE A, COL. 2-Continued,}

\section{Virgin Ground, Pin Check, Pink Check, Ornamental Ground, Binche, Cinq Trous, Point Carré.}

center top and is closed by twisting and crossing. This is repeated at the center left, center right and center bottom. The ornaments at the lower left and lower right are now made as they were above by twisting and crossing without pins. At the edge of the lace, the ornament is made before tying the threads or entering a cloth-stitch band, and is again made after coming out from the clothstitch band. If the above instructions are followed, every pair will have been twisted once before it intersects another pair.

The essential difference between Cinq Trous and Virgin Ground is that the ornaments of the former are more open, making the corner holes more prominent, as they are only twisted and crossed, while the Virgin Point ornaments are twisted, crossed, then again twisted and crossed.

Another method of making Cinq Trous is that of following a zigzag line running downwards from right to left, the points of which occur at the middle top and center base of each little solid block of Cinq Trous filling, the maker using only two instead of four pins; that is, omitting the two side ones. At the beginning of each zigzag, after having twisted the threads and made the cloth-stitch, one places a pin without closing it. To descend one step of the zigzag stairway, one makes a half-stitch with the two left-hand pairs, a similar half-stitch with the two right-hand pairs, next twisting the threads and making a linen-stitch with the two pairs now lying nearest the center. At this point one places the next or second pin without closing it. To remount a step, one puts aside the two pairs at the right of the pin, taking up two new pairs at the left, and with these two new ones and the two directly left of the pin, one repeats what one did in descending the stair. One leaves two pairs aside only at the foot of a step. At the base of the whole stairway, after having finished the stitch and having placed a pin, one again makes a complete stitch without removing the pin or using another, to finish off; exactly as though one were about to redescend; and it is well to see that the big bars or bands of solid and open Cinq Trous are parallel in both directions. 
LINE A, COL. 3,

Malines, Mechlin, Ijsgrond, Fond de Glace, Eisgrond.

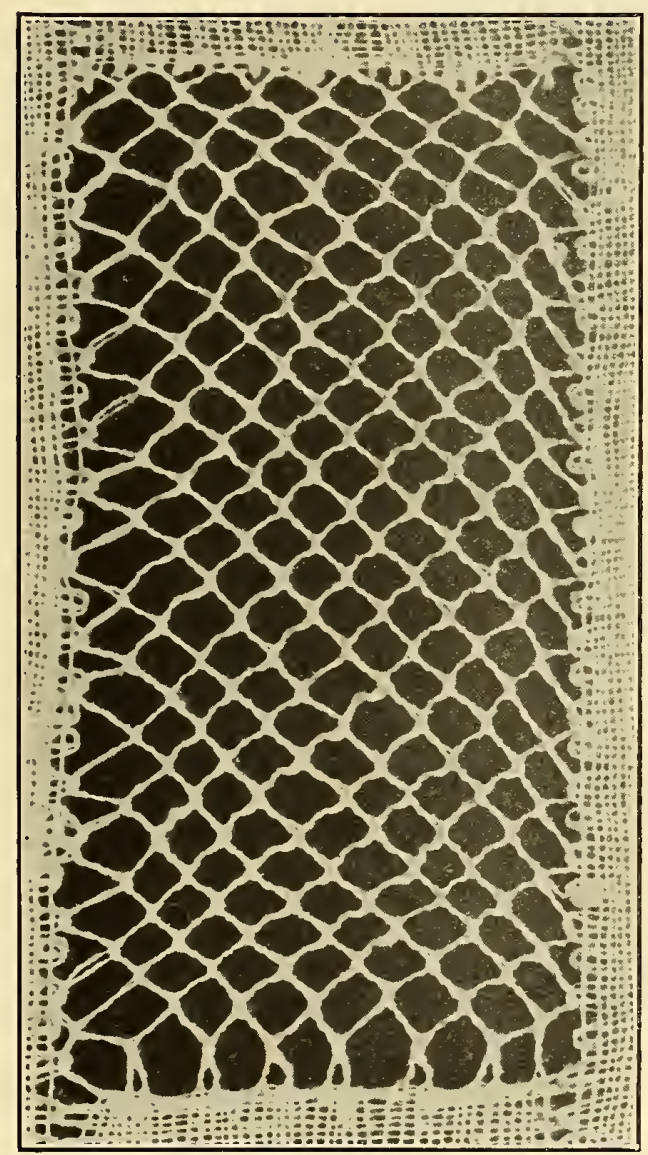

It requires eight pairs to make a Malines mesh, two pairs on each vertical side of the mesh braided three times. The two innermost pairs, one from each braid, are now twisted twice each and coming together, form a new braid for a lower or succeeding mesh. The meshes thus formed are six-sided, having two braided sides and four twisted ones. 


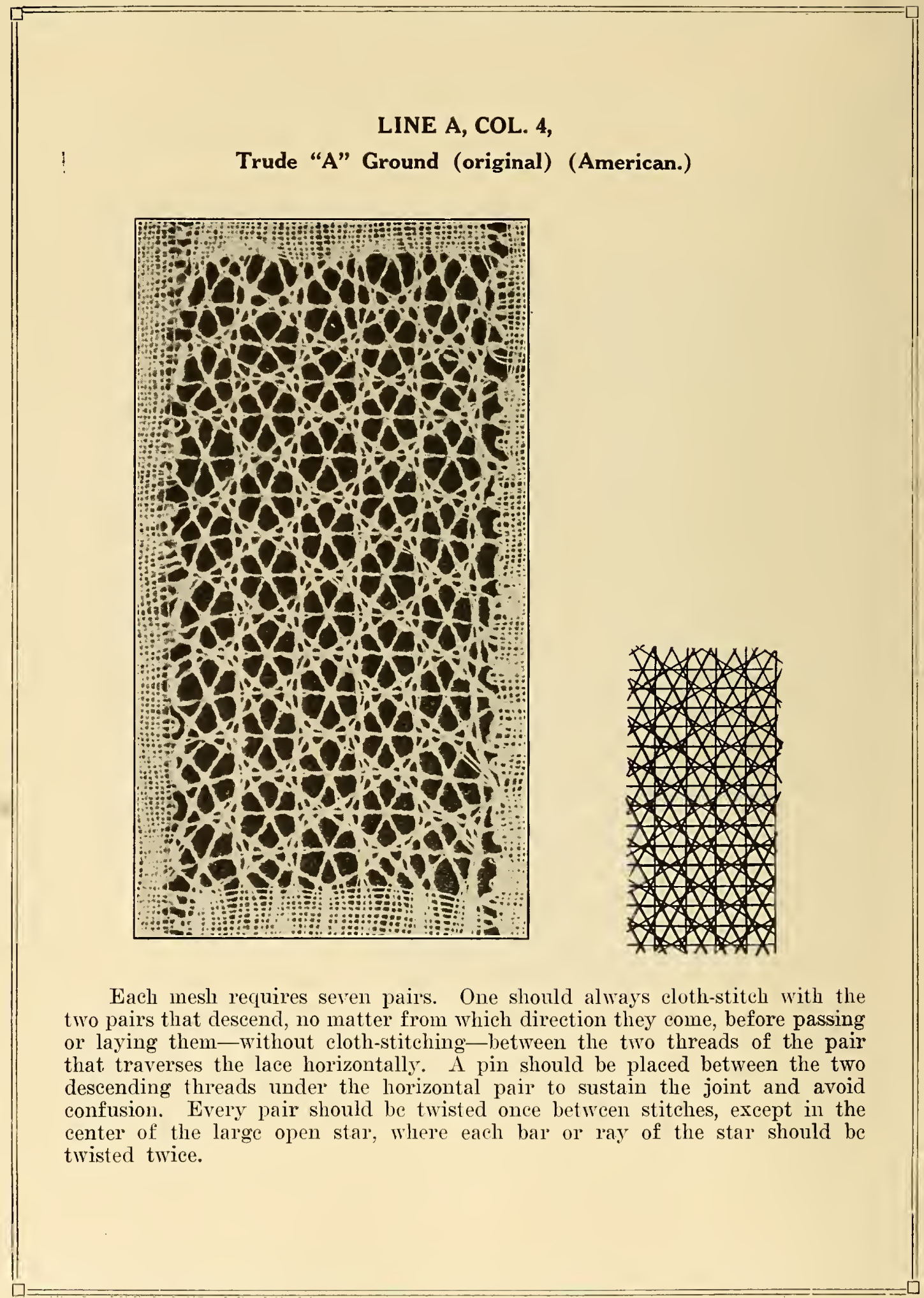


LINE A, COL. 5,

Star Mesh, Double Ground, Point de Paris, Point de Six, Eternelle, Point Double, Trenne, Chantilly, Fond Chant, Engelsche Grond, Dentelle de Grammont.
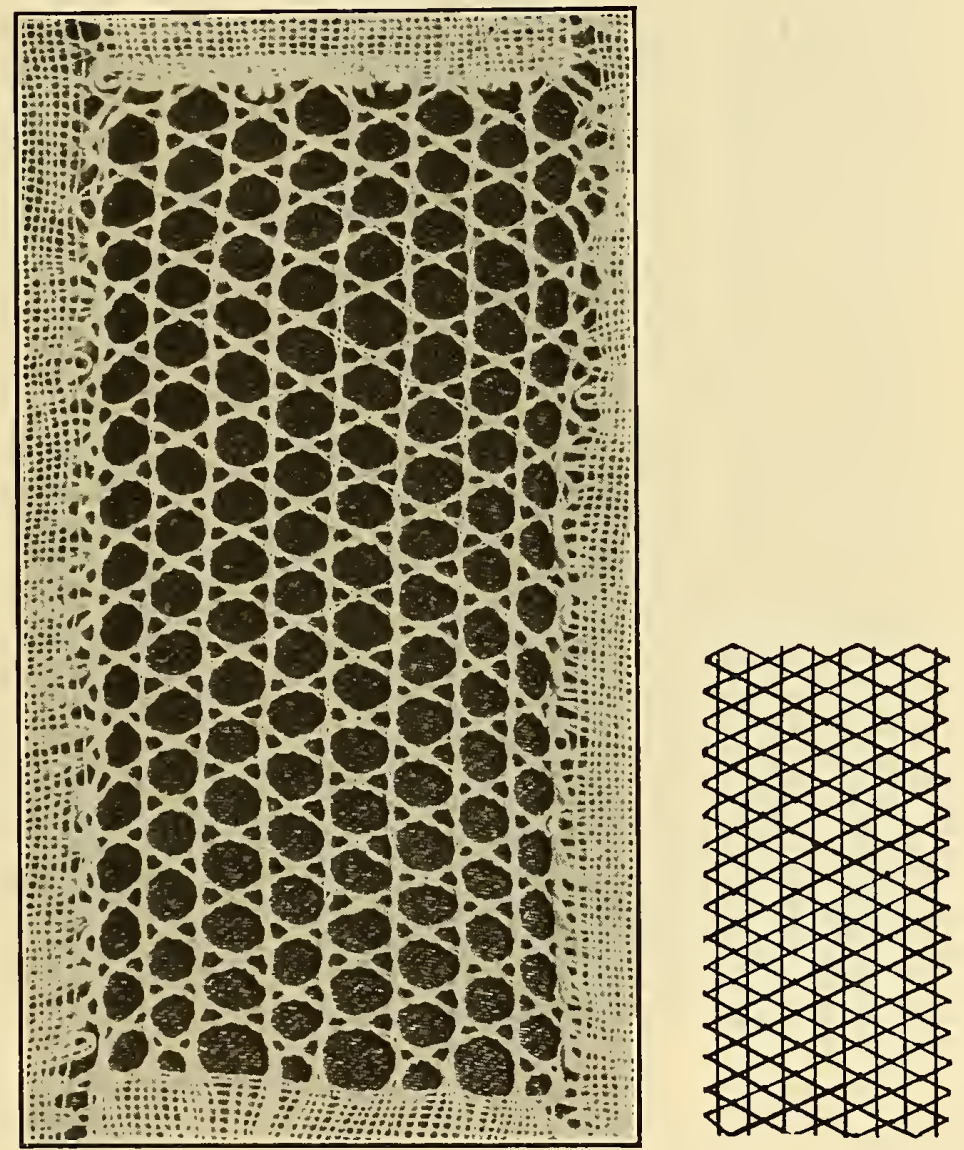

This pretty and durable stitch is made in the same way as that described under Line C. Column 5, except that each pair is twisted once before every encounter, and a pin is placed beneath each cross to support it. The actual stitch is a linen-stitch. 
LINE A, COL. 6,

\section{Point du Mariage fait à la Torchon au Demi-Point.}
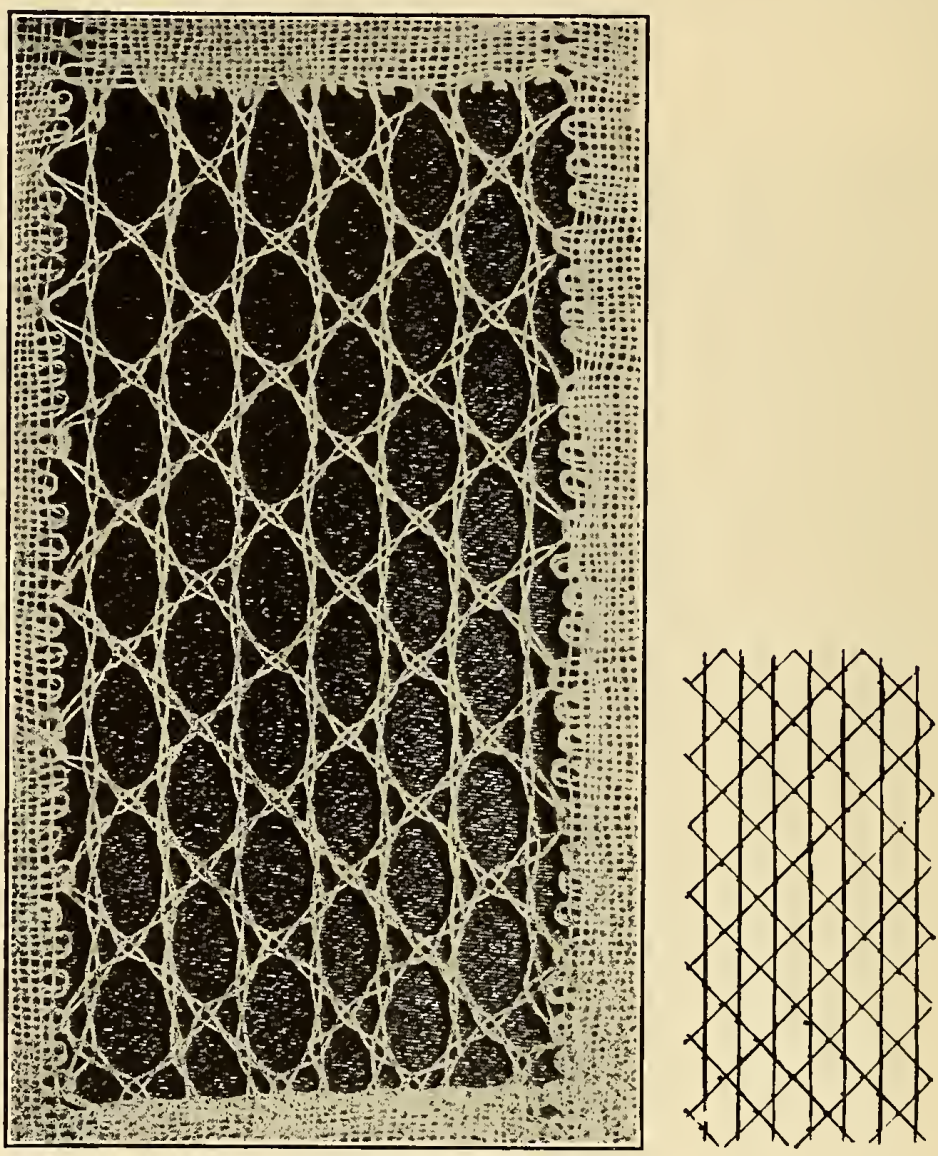

Each motif in this case requires two parallel, vertical pairs and two intersecting, diagonal pairs. The point of their intersection comes between the two parallel, vertical lines. Each time that the worker, coming from the upper lefthand, traverses another pair, whether a vertical or another diagonal, it and its mate are twisted and crossed once. A pin is placed and they are twisted and crossed to close it. The weaver coming from the upper right-hand, and the two parallel pairs, do likewise wherever they encounter other pairs. The pins should not be removed until the work is finished, as the threads pull easily.

This mesh is quickly made; but does not wash well. See Line A, Column 5. 
LINE A, COL. 7,

Square-meshed Valenciennes of Honfleur (braided 1 or $1 \frac{1 / 2}{2}$ times).
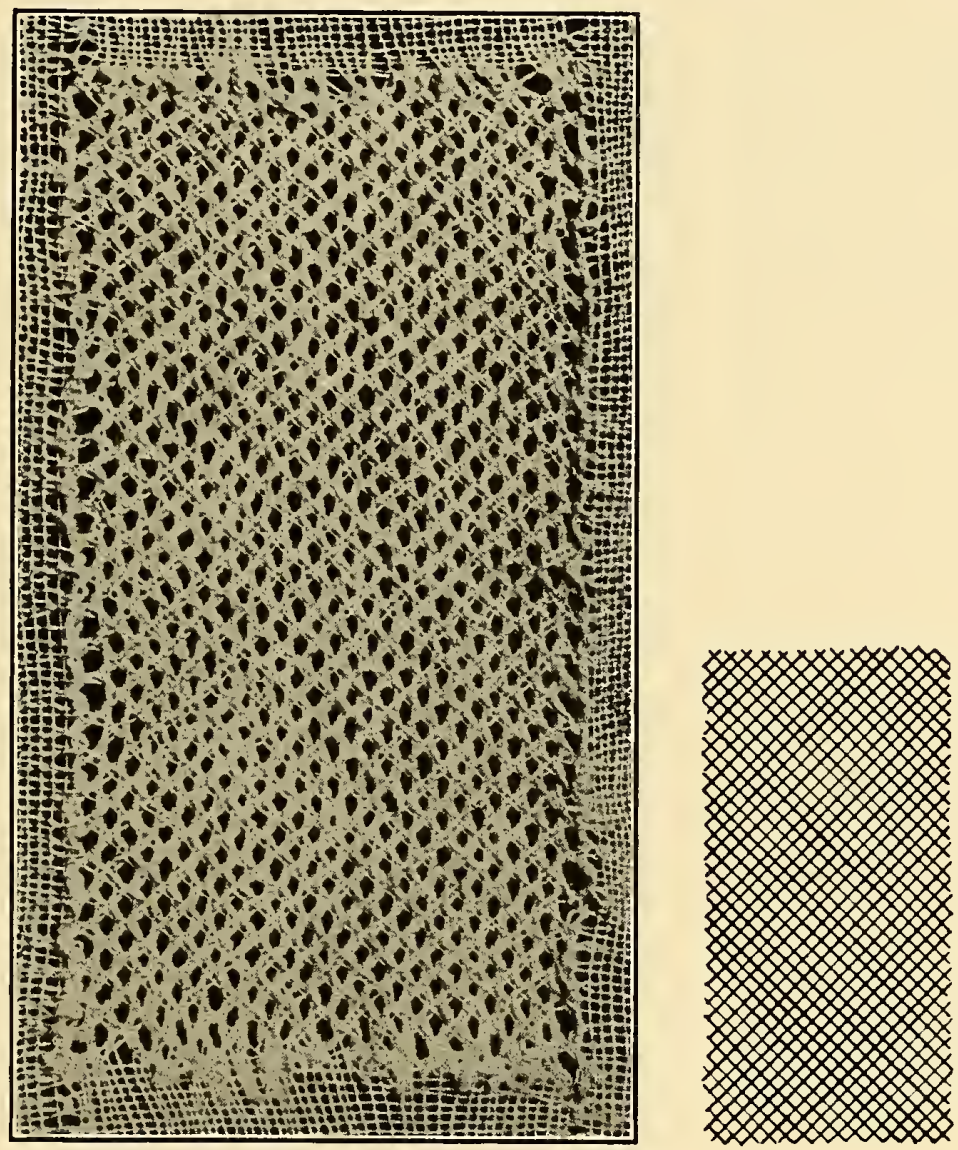

Each mesh requires four threads to a side. These threads are braided once between joints. The two pairs which, after the tressing, are at the inside next each other, now cloth-stitch and the joint is supported by a pin. The right-hand one of the pairs is twisted once after the joint, but the pair going towards the left remains untwisted before entering the new plait. The two outside, hanging pairs of the braid are, however, twisted once before they enter into the new braid below, which is the beginning of a new mesh. Thus only the interior pairs linen-stitch, and the two outside pairs, which are twisted once, hang idly while the cloth-stitch is made. This joint is spoken of by some writers as being braided once, and by others as being braided one and a half times; the discrepancy of description being caused by an extra cross in the braiding, for 


\section{LINE A, COL. 7-Continued,}

\section{Square-meshed Valenciennes of Honfleur (braided 1 or $1 \frac{1}{2}$ times).}

immediately after and immediately before each joint, there must, in square Valenciennes, be a cross. If one braids by crossing, twisting: then the cross must be added at the end. If one plaits by twisting, crossing: then a cross must be made at the beginning, after the joint is finished. It is less confusing to work across the lace in a horizontal line. One can make the right-hand braid which is about to enter into the joint, placing the right-hand pair astride a pin to keep the plait from coming undone: then making the left-hand tress, and with these bobbins in the hand, finish the joint. This method can be reversed when one is working in the opposite direction. Then holding the two center pairs firmly in hand, one can detach the right-liand pair, pull all into shape and place a pin.

This Valenciennes is strong, clumsy and very slow to make. 
LINE A, COL. 8,

Devonshire Pin Filling.
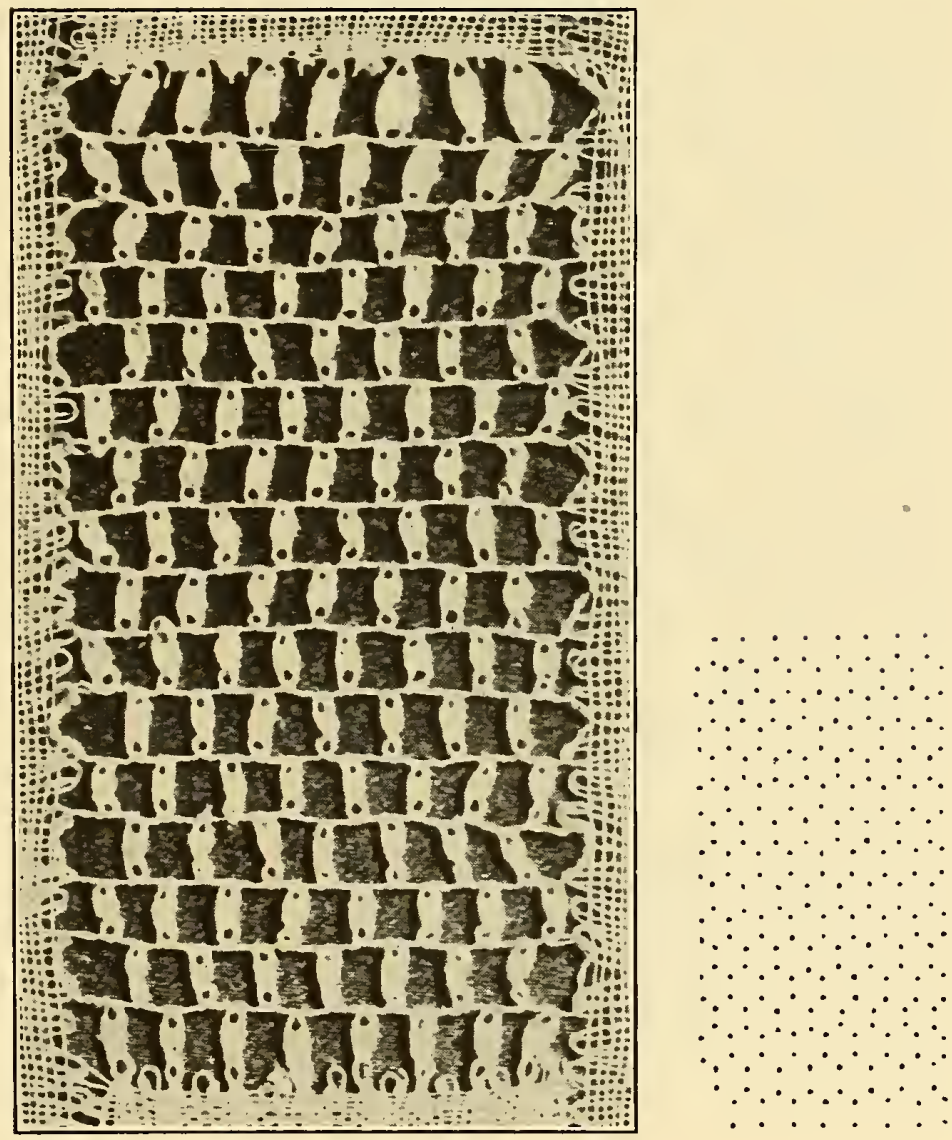

This is an easy, pretty jour. The cutworks are placed alternately below each other. At the bottom of a cutwork a pin is placed, when the pairs are twisted three times, cloth-stitched through each other, and again twisted three times going in opposite directions, but horizontally, towards the tops of other points d'esprit or leadworks. At the top of a new cutwork, the pairs entering it cloth-stitch. Here a pin is placed and the pairs, after being twisted three times, are ready to form the new leadwork, which must be made long enough to reach the pin hole below. 


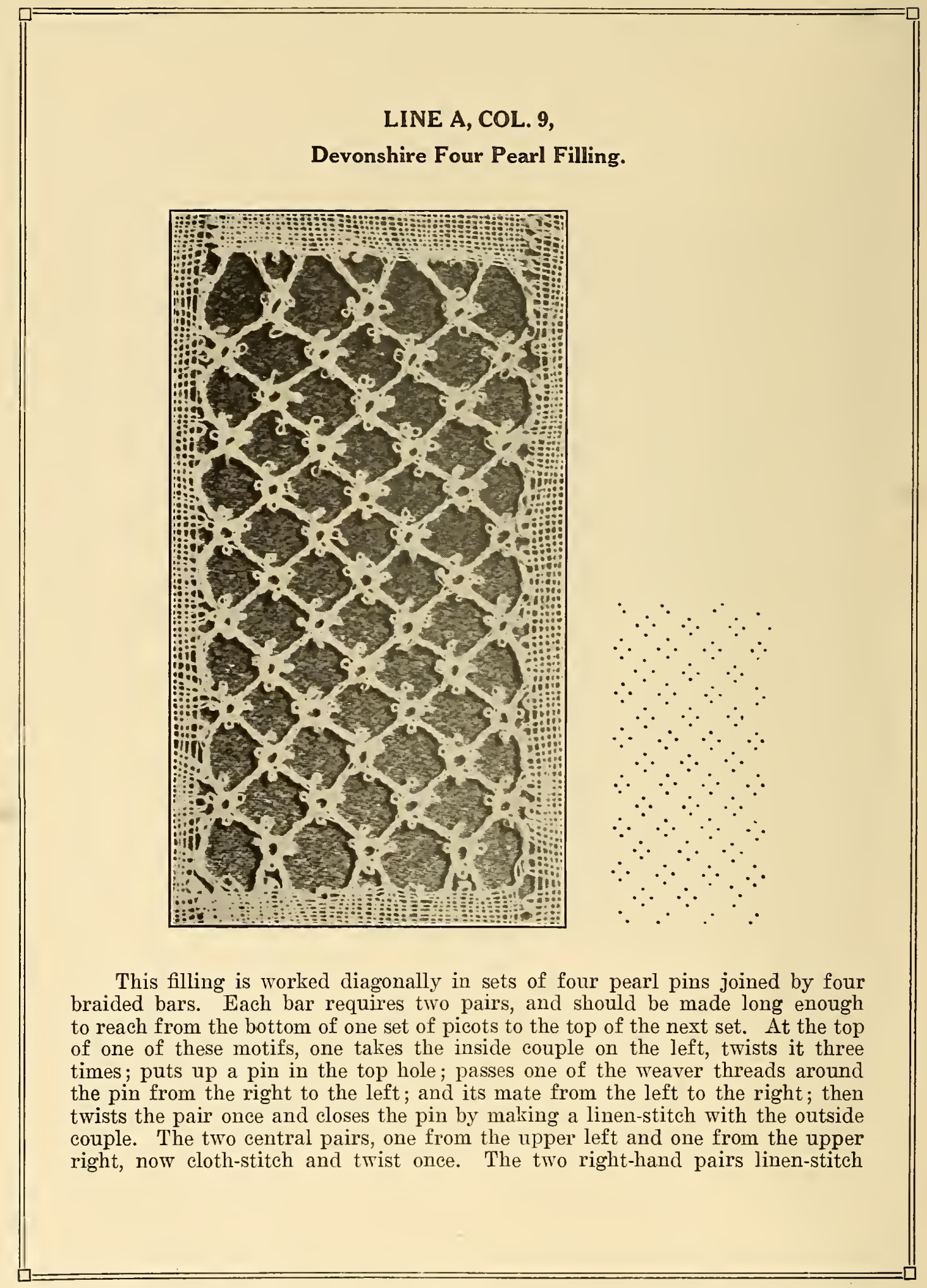




\section{LINE A, COL. 9-Continued, \\ Devonshire Four Pearl Filling.}

and another picot is made at the right-hand pin hole in the same way as at the top, and the pin is closed by cloth-stitching the picot pair with its mate and twisting them once. The left-hand pearl pin is made in the same way. Then the two center, bottom pairs, each one already twisted once, linen-stitch. Next the two right-hand pairs cloth-stitch and the inner pair of these two makes the fourth picot. These two pairs continue downwards toward the right, braiding until they meet the next motif. The two left-hand pairs are also plaited until they meet another set of pearl pins at the lower left. 
LINE A, COL. 10,

\section{Devonshire Diamond Filling.}

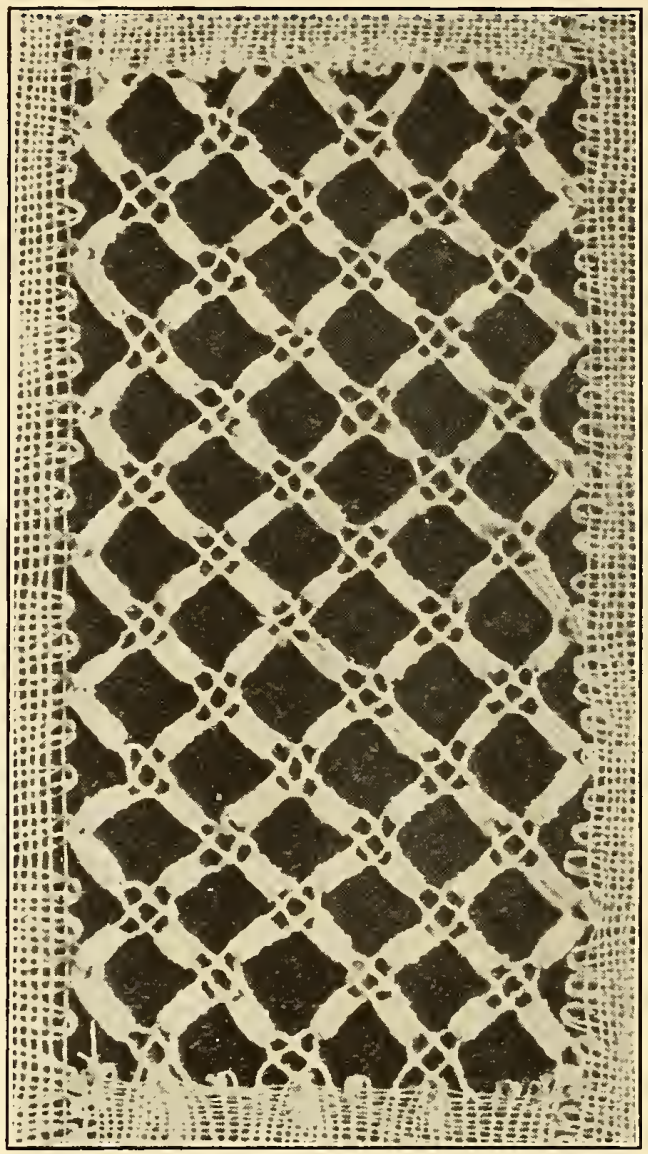

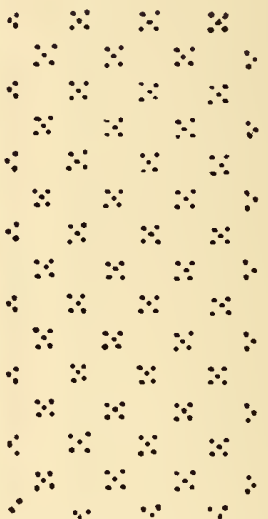

After finishing the oblong cutwork, each pair is twisted three times and each cutwork is supported by a pin placed in the two upper of the four holes. This division leaves a pair of bobbins outside of each pin with two couples together in the center. These two upper, inside pairs linen-stitch through each other, and a pin is placed between them to support the joint, when they are twisted three times. They then continue downwards in their respective directions; one to the right and one to the left; and here each one linen-stitches through the pair it meets coming from the cutwork above, when each pair is again twisted three times. The two pairs now at the center, cloth-stitch through each other and are twisted three times. Here the two lower side pins are placed.

One is now ready to make the long, rectangular point d'esprit, diagonal bands between the attractive, middle five hole, diamond openings. These cutworks are made in the usual way: but are about twice as long as the standard square point d'esprit. 
LINE A, COL. 11, Trude "D" Ground (original) (American).
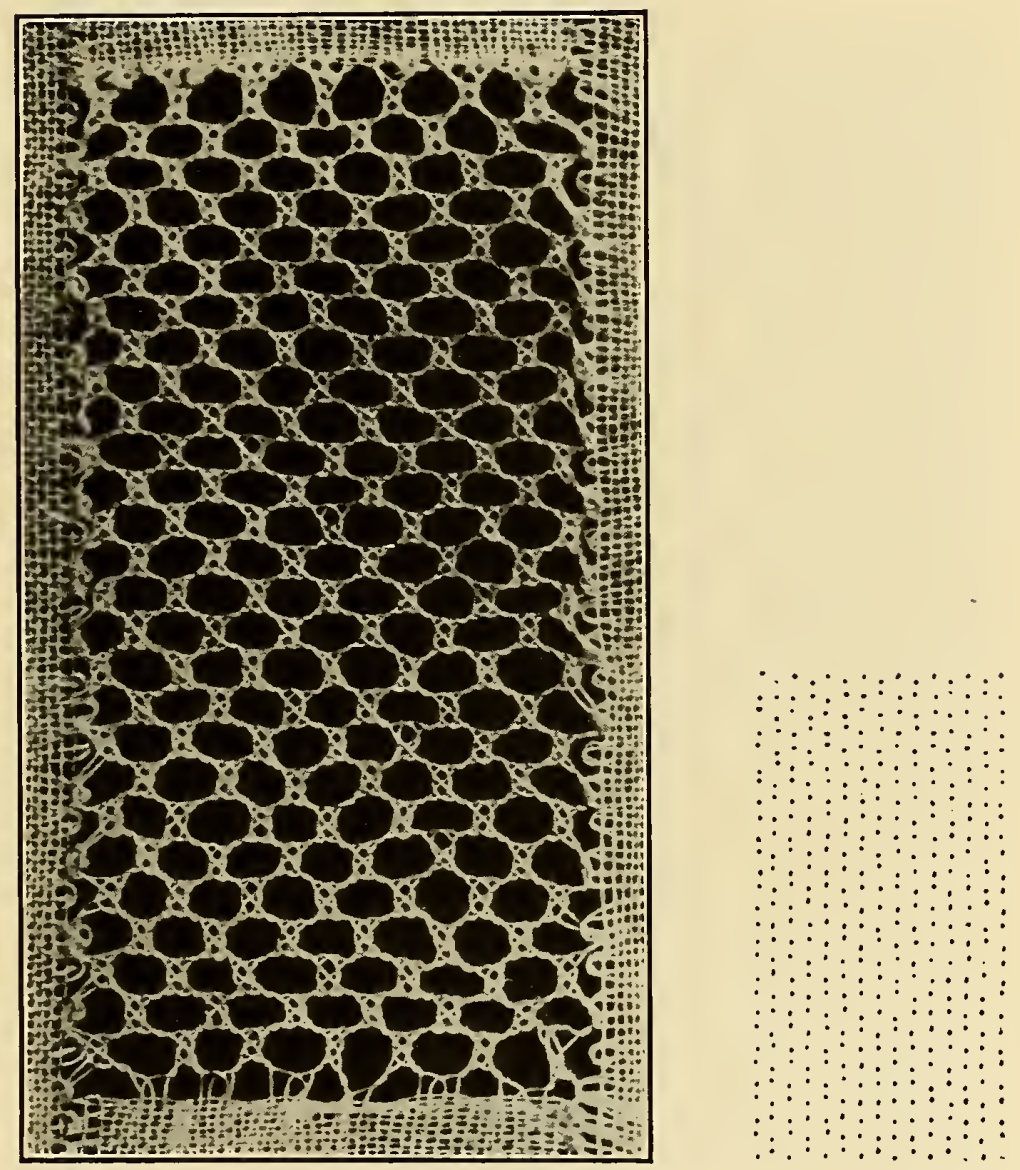

Two pairs to a joint are required for this pattern, which is made on the diagonal, with two pins placed right below each other forming a double joint. The two threads coming from the upper left-hand are twisted twice and those coming from the upper right-hand are twisted twice. The two center bobbins are crossed and a pin placed below. The pairs are again twisted and crossed, and another pin placed, which is closed by twisting and crossing. 
LINE A, COL. 12, Trude "G" Ground (original) (American).

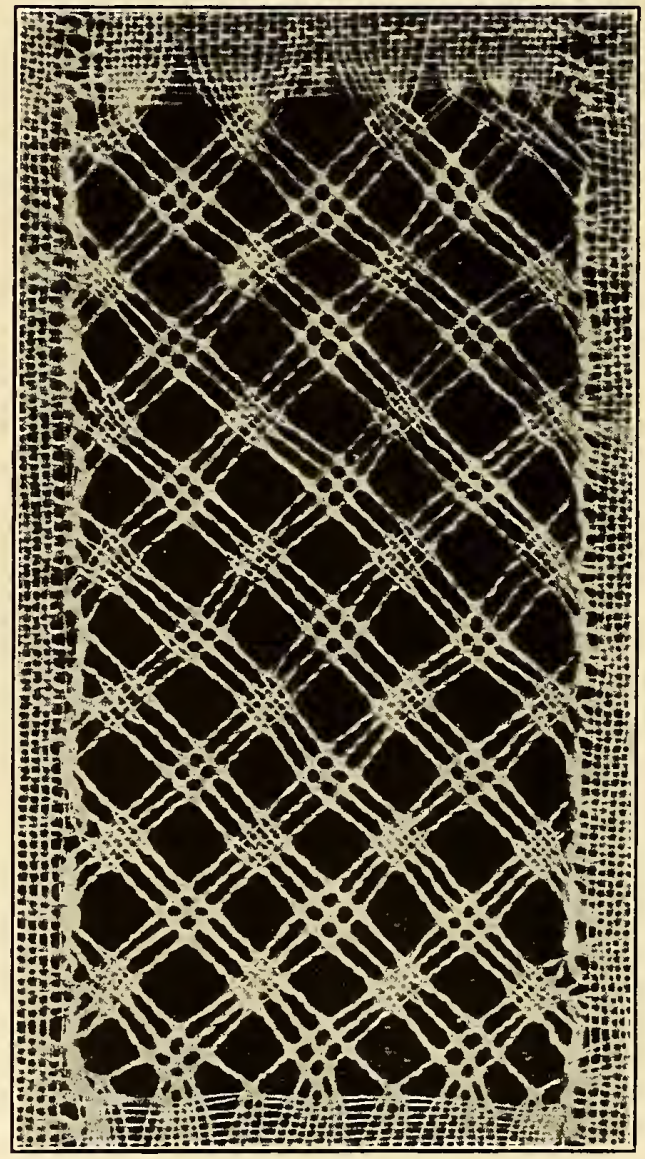

Three pairs or bars enter at each upper side of the diagonally tipped squares. Each of these six bars is twisted three times between squares. Every other square is made of cloth-stitch, and every other one is grilled instead of being solid, each pair twisted once between the linen-stitches. The squares are thus alternated. A pin is placed below each one to sustain it: but no others are used. 
LINE A, COL. 13,

Trude "I" Ground (original) (American).
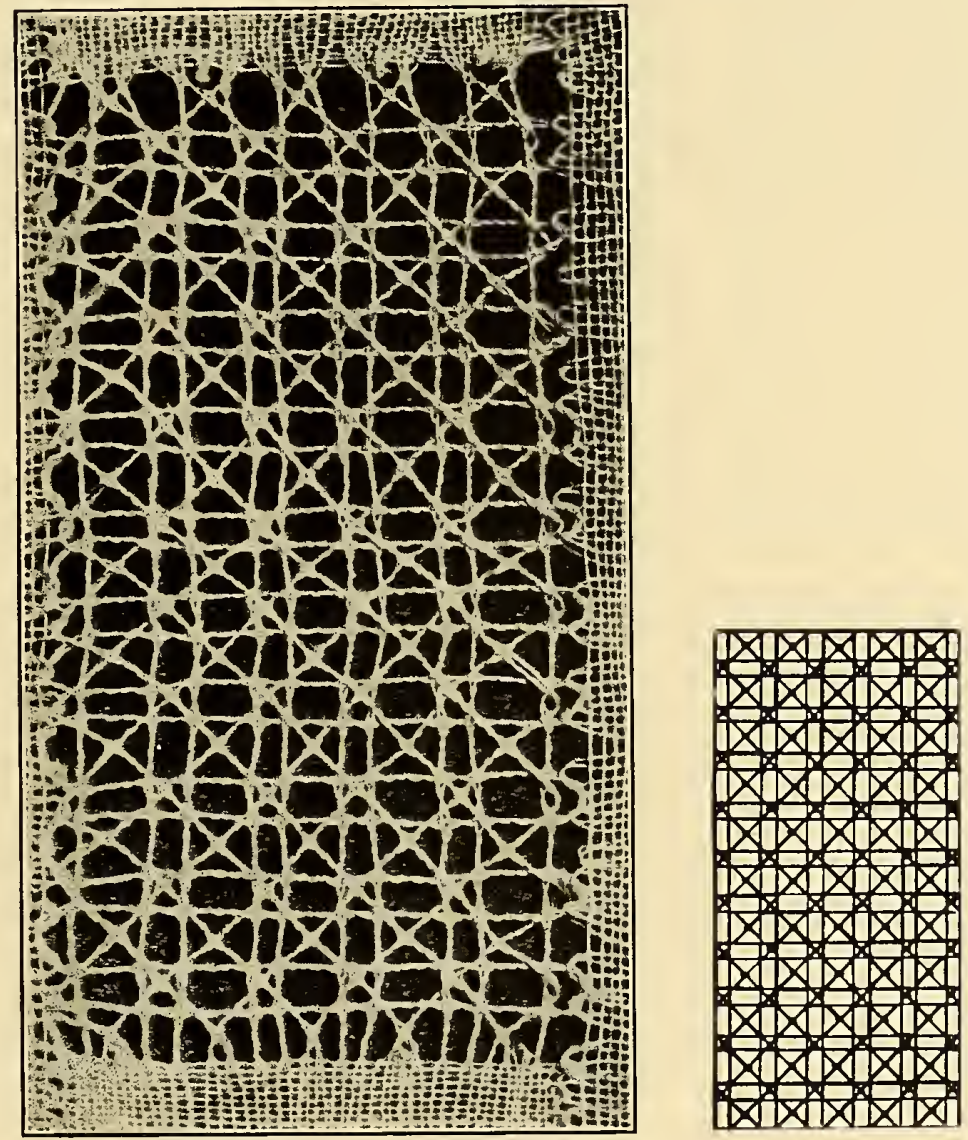

Twenty-one pairs were used in making this sample, the horizontal pair going from left to right, then back, and so on, as a weaver. Each line on the pricking represents two threads twisted. The long diagonal, vertical and horizontal pairs are twisted four times; the short vertical and horizontal pairs are twisted once. The vertical and horizontal threads weave through each other with a linen stitch each time they intersect.

The diagonals in the small squares are not twisted, as the former twisting holds over. The diagonal threads entering the small squares at their righthand upper corners are placed under the vertical and horizontal pairs withnut a stitch. The diagonal threads entering the small squares at their left-hand upper corners are placed over the vertical and horizontal pairs without a stitch. 


\section{LINE A, COL. 13-Continued, \\ Trude "I" Ground (original) (American).}

At the bottoms of these tiny squares, the diagonal threads that enter at the left, leave at the right by passing under the other threads. The diagonals that come from the right go out over the vertical and horizontal ones without a stitch, so as to prevent their slipping either up or down or from left to right. At the centers of both the large and small squares, the two diagonal pairs intersect and weave through each other with a linen stitch. These intersections should be supported with a pin. 


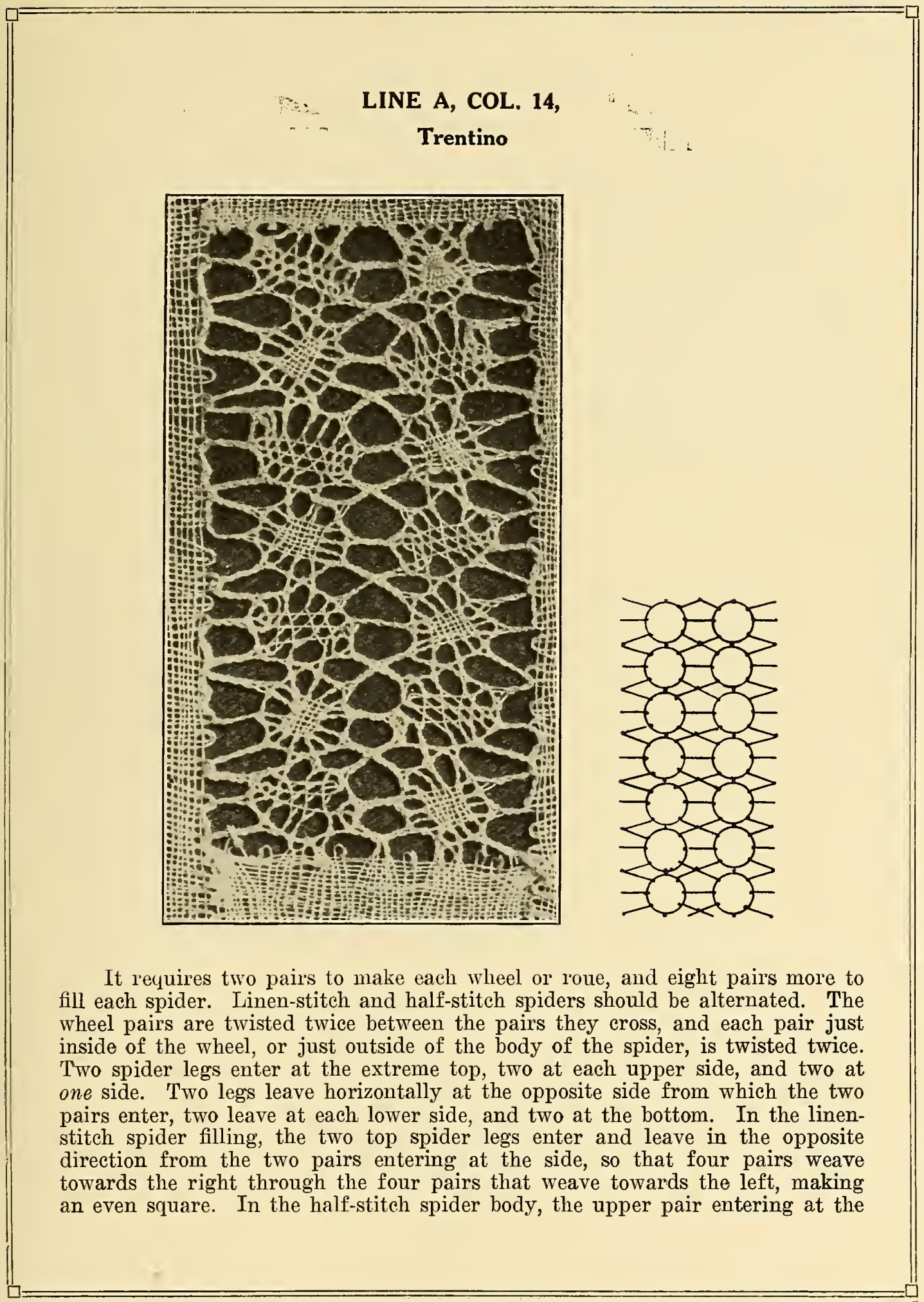




\section{LINE A, COL. 14-Continued, \\ Trentino.}

upper side is used as a weaver, and crosses to the center of the opposite side, taking in the two legs entering there. It then returns to the center of the first side, taking in the remaining upper side pair; then it weaves to the lower part of the opposite side. This makes three eross threads. One must be sure that it is really the two wheel or encircling pairs that meet at the bottom. One braid stitch is made at the bottom after the wheel is finished, between the left wheel pair and the spider leg pair to the left of it, and between the right-hand wheel pair and the leg to the right of that. One is then ready to start the spider right below. The entrance and exit of the horizontal side legs make it necessary to make one row of spiders from the left to the right and the row below from the right to the left. A short, horizontal braid is made between spiders; also a diagonal braid connections of lower legs from one spider crossing over downwards through a reverse braid to become the upper legs of the spider one row diagonally below. 
LINE A, COL. 15, Triangular, Fan-Shaped Points d'Esprits or Cut Works.
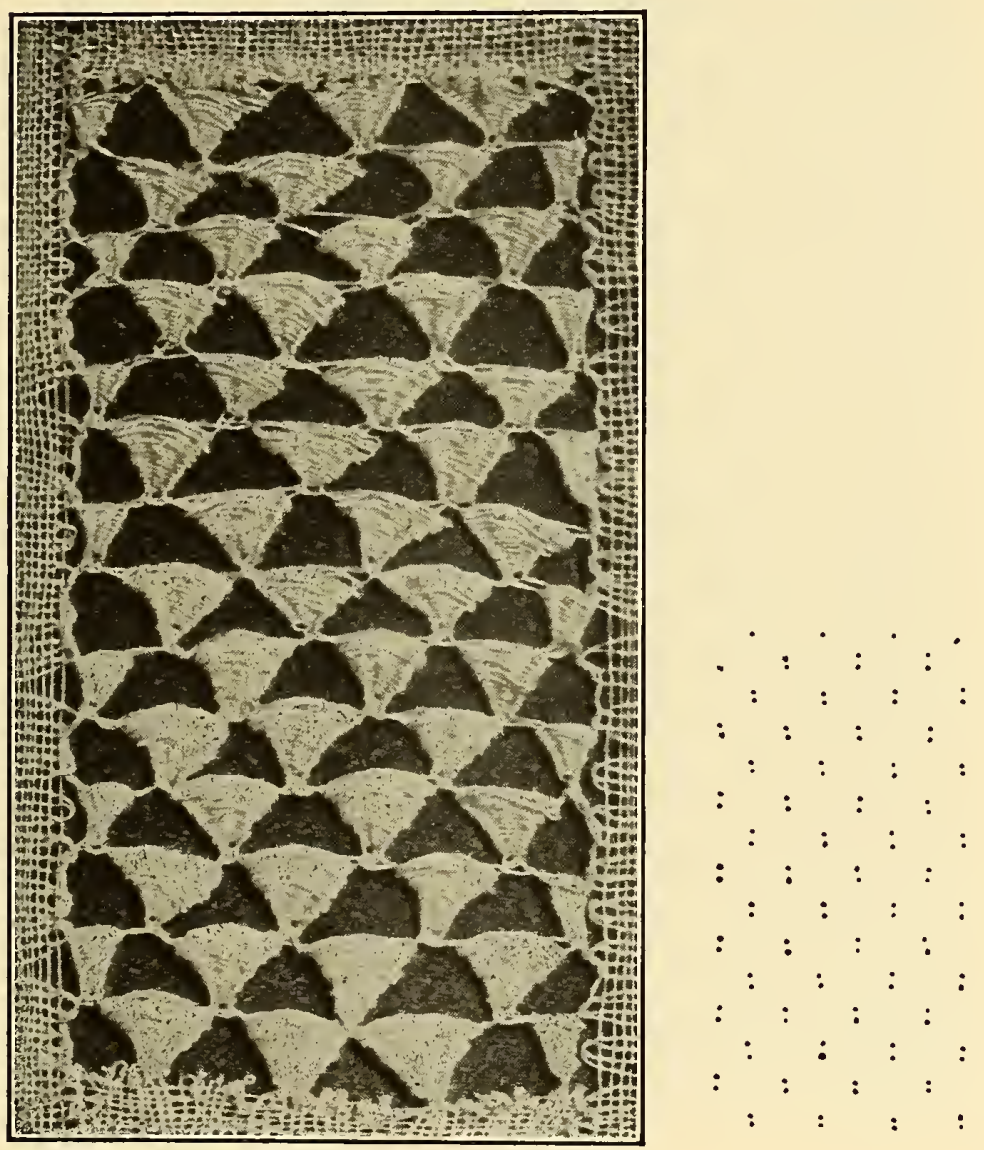

It requires four threads to make one fan, and the fans are woven exactly as cutworks or leaves are, but started wide at the top and gradually tapered to a point at the bottom. At the foot of one fan and the top of another, one should make sure that the two entering threads at the right and at the left are twisted round each other, so that two independent threads will not be seen bridging between triangles. The top of the new fan should be supported by two pins spread as far apart as the triangle is to be made wide. Another pin should be placed under the finished apex at the bottom of the triangle. 
LINE A, COL. 16, Abruzzian Mezza Cambruccia.
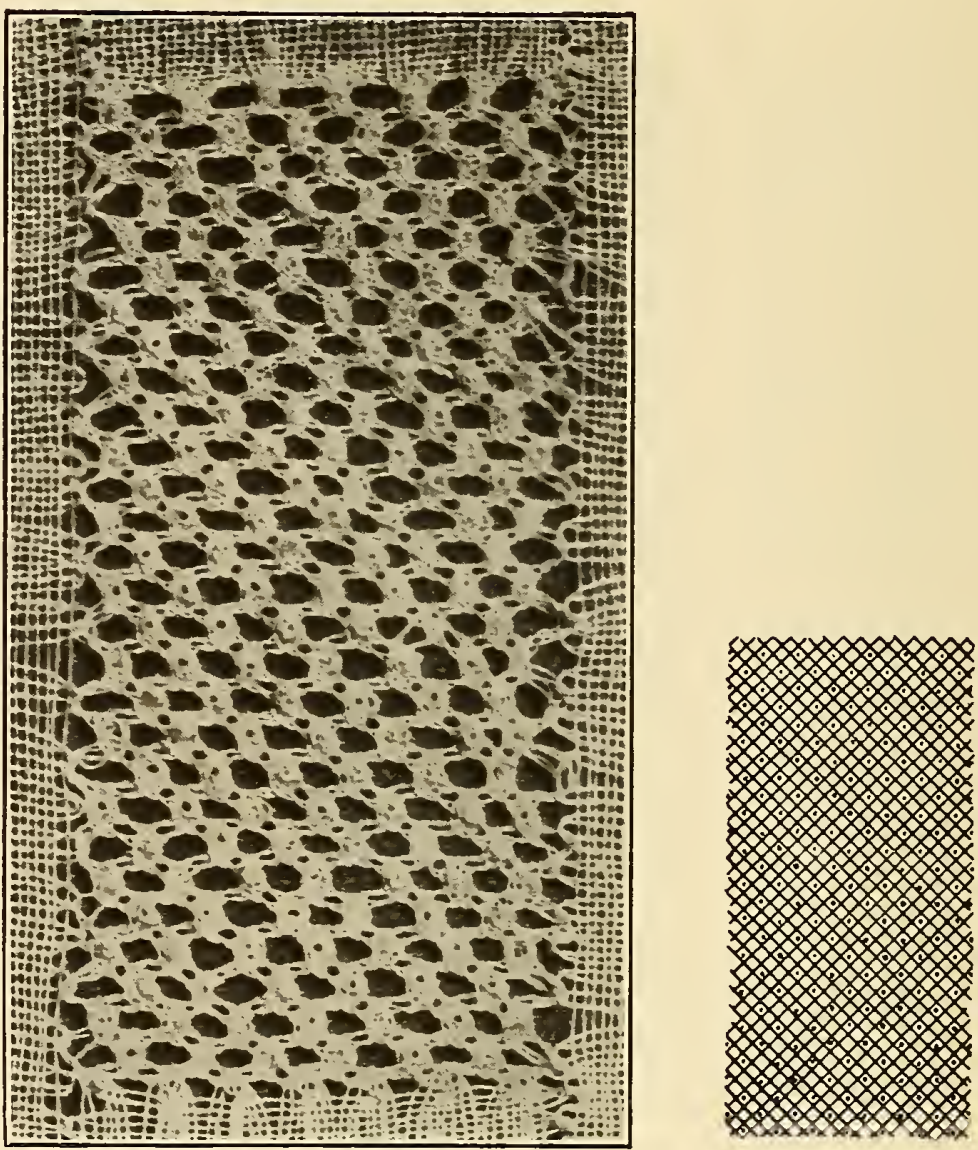

It requires four threads to make each one of these spiders. Two pairs twisted once entel at the left-hand top of the spider and two pairs twisted once enter at the right-hand top of the spider. This spider is made as the ordinary spider is: but the centers should be arched by pulling the outside threads tighter than the inside ones, and holding the inside ones up in the air while working around the pin. This arched shape can be better preserved by placing a support pin just at the base of the spider. The two pairs that leave the spider going towards the left are twisted once and enter the spider next below towards the left. The two threads leaving at the right are twisted once and enter the spider just below on that side. 
LINE A, COL. 17,

Trude "N" Ground (original) (American).
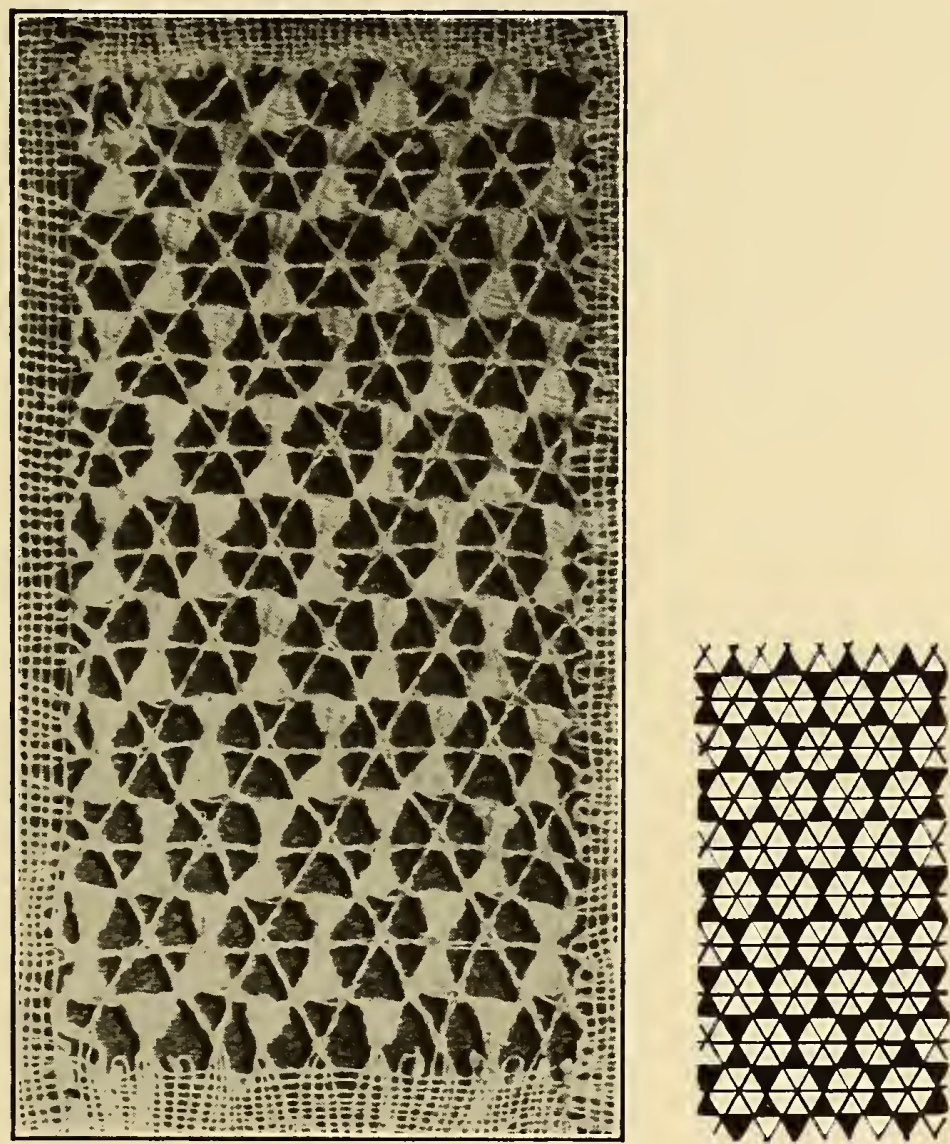

Each tiny triangle requires four threads. In making these, one completes a whole line from left to right, then the succeeding line from left to right, as this secures the two suspension or scaffold threads of the triangle before pulling and again using the weaver. At the top of each triangle, whether at its broad or its pointed end, one should give two twists to the two framework threads that are about to enter into the cutwork to prevent their stringing out and later appearings as loops. The worker and its mate should be twisted once or twice as is convenient before beginning a new point d'esprit. At the small end of the cutwork, between an upper and a lower triangular spot, the twice-twisted, horizontal band pair, cloth-stitches through the cutwork pairs, each of these latter pairs being considered as one thread so as not to spread the point of the 


\section{LINE A, COL. 17-Continued,}

\section{Trude "N" Ground (original) (American).}

triangle. This passage should be supported by a pin. When the cutwork below is begun, the pin should be removed as soon as possible, otherwise the weaver will leave a loop around it. When starting the broad end of a triangle, one should place pins at the top of it to hold apart the threads. When finishing at the broad end, pins should be placed inside the two pairs to hold them apart and support the work. These pins have to be replaced when the line below is worked, but after all they are only supports and helpers. No knotting of the cutwork is necessary, as the next triangle follows so closely that it holds the joint in place. At the open centers of the stars between the cutworks, where the three twice-twisted pairs meet, the weaver or worker cloth-stitches through one to hold in its twists, and is then just laid between the other two threads coming from the opposite direction, each of these threads just passing around it, elasping it, but not working through it, to avoid making a bulky joint. 
LINE A, COL. 18,

Fond de Neige, Punto di Néve.
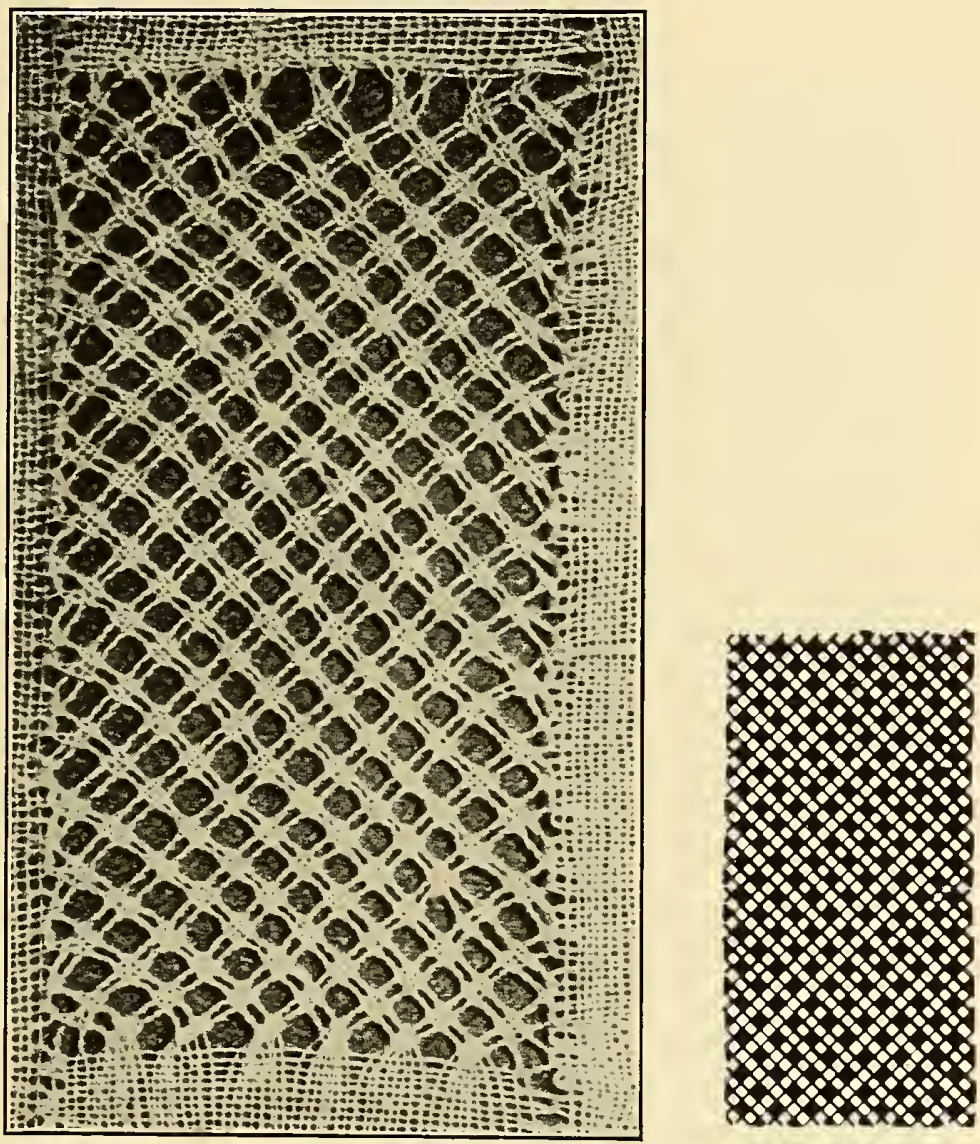

This pleasing little ground requires only four pairs to each mesh, two coming from the upper left, and two from the upper right-hand. Each pair is twisted twice. They are then ready to cloth-stitch through each other to form the little solid squares, which, when finished, can be supported at the base by pins. For example, using the inner, upper left-hand pair as a weaver, one should linen-stitch through the two pairs coming from the upper right. One should then do likewise with the remaining upper left-hand pair, which finishes the dot.

See Line B, Column 18. 
LINE B, COL. 1, Tulle Du Puy.

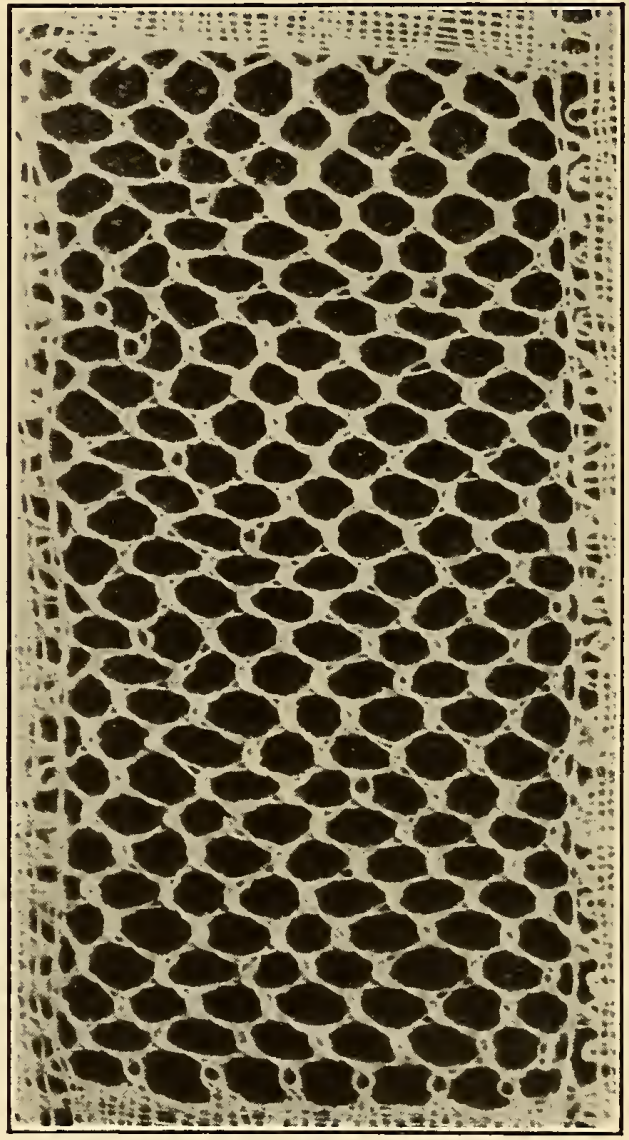

'This net is made by twisting once, then crossing, twisting and crossing, placing a pin and closing it by crossing, twisting and crossing. This mesh is made on the diagonal; is very simple, and as the strands are interlocked, it is much firmer and less apt to shift than Torchon Ground, for which it can generally be substituted. 
LINE B, COL. 2,

Virgin Ground, Ornamental Ground, Fond de la Vierge, Point Carré.

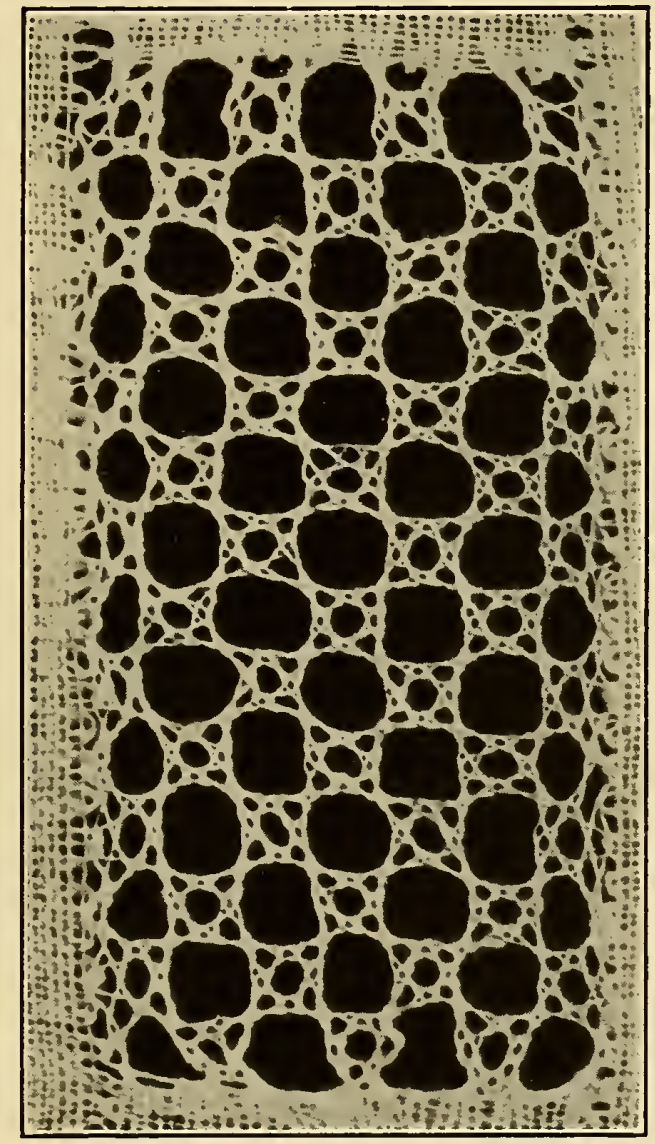

This is the plain, ordinarily used Virgin Ground. Four pairs and four pins are required for the making of each square; two pairs enter at the upper left to form the upper left-hand ornament, which is made by twisting once and crossing, and twisting once and crossing without pinning. The same is done at the upper right-hand cormer. The two center pairs, one from the right and one from the left, now twist and cross : a pin is placed at the center top, and is closed by twisting once and crossing. This stitch is repeated at the center left, the center right and the bottom; then the two lower ornaments are made, just as the two top ones were, without pinning. These lower ornaments serve as the upper ones for succeeding squares below. 


\author{
LINE B, COL. 3, \\ Brussels, Droschel, Vrai Réseau (fait sans épingles), Drochel.
}

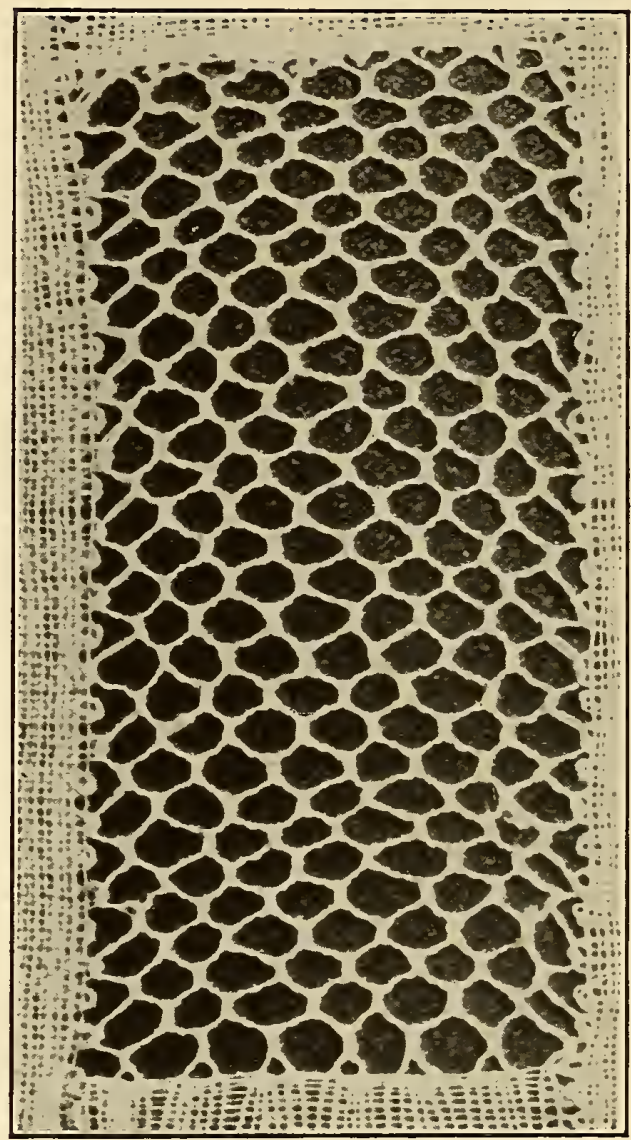

See Line C, Column 3.

Brussels hexagonal ground requires four pairs to each stitch, the two vertical sides of the stitch being braided four times. The braided pair of each plait, now towards the center, is twisted twice; and the two pairs being brought together, form a new vertical plait. Thus each mesh is six-sided, having two braided and four twisted sides.

This ground, having one braid more than Mechlin, is slightly more open. 
LINE B, COL. 4, Trude "B" Ground (original) (American).
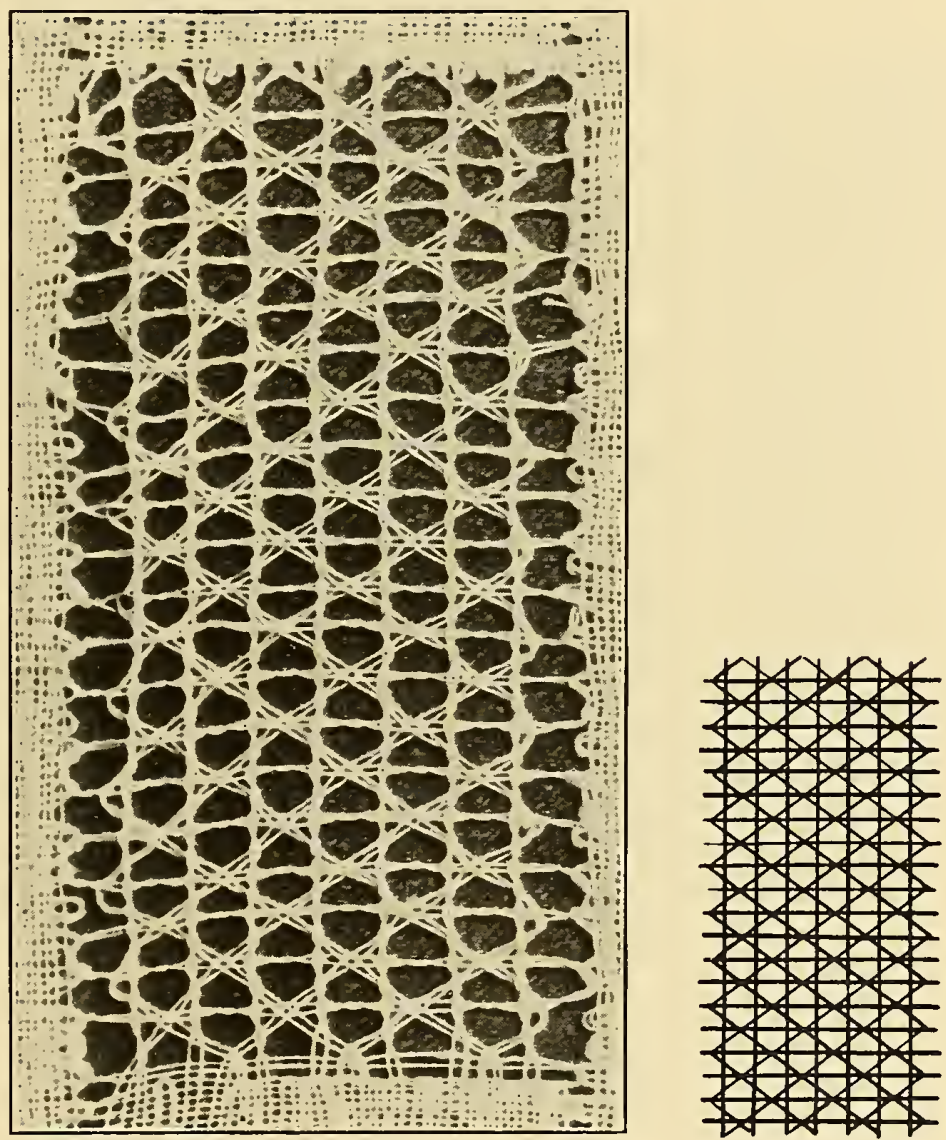

This ground requires five pairs to each mesh. The pendent pair is twisted once between stitches. At the star-center where the three pairs traverse each other, none of them are twisted, but the two diagonal pairs should linen-stitch and be placed or laid between the two threads of the horizontal pair. Here one should place a pin between the diagonal pairs, under the horizontal one, to support the joint and serve as a guide. The horizontal pair should be twisted twice in the long space that occurs above and below the star-centers, between vertical pairs. 
LINE B, COL. 5,

Lattice Ground, Gekreuzter Gittergrund (3 twists).
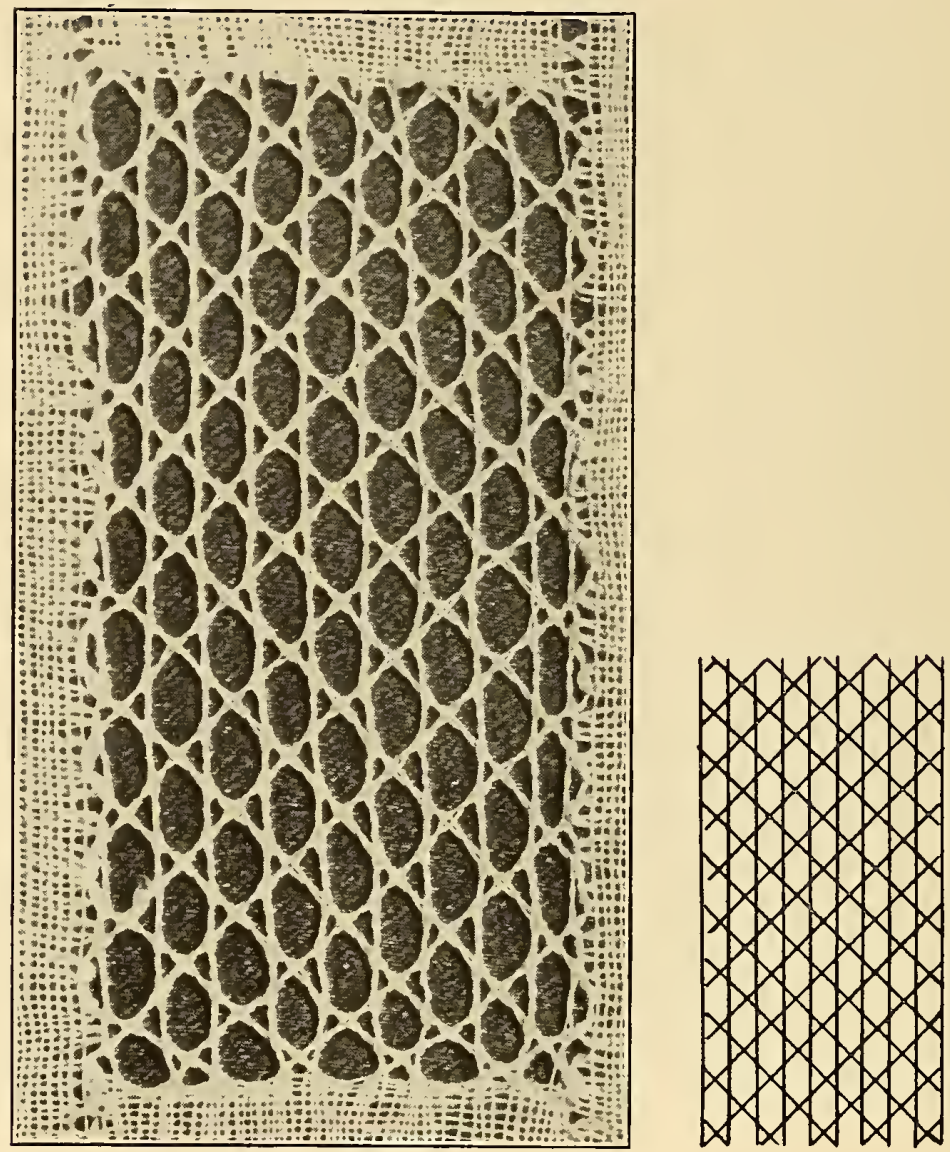

Four pairs are required in making this stitch, two that fall vertically and two which run diagonally. The joints formed by the weaving of the oblique pairs through each other should be supported by pins. The vertical pairs are twisted three times between intersections; the diagonal pairs once. All joints are formed by cloth-stitching. 


\section{LINE B, COL. 6,}

Twice-twisted Virgin Point-mit zweimal gedrehtem Schlusschlag.

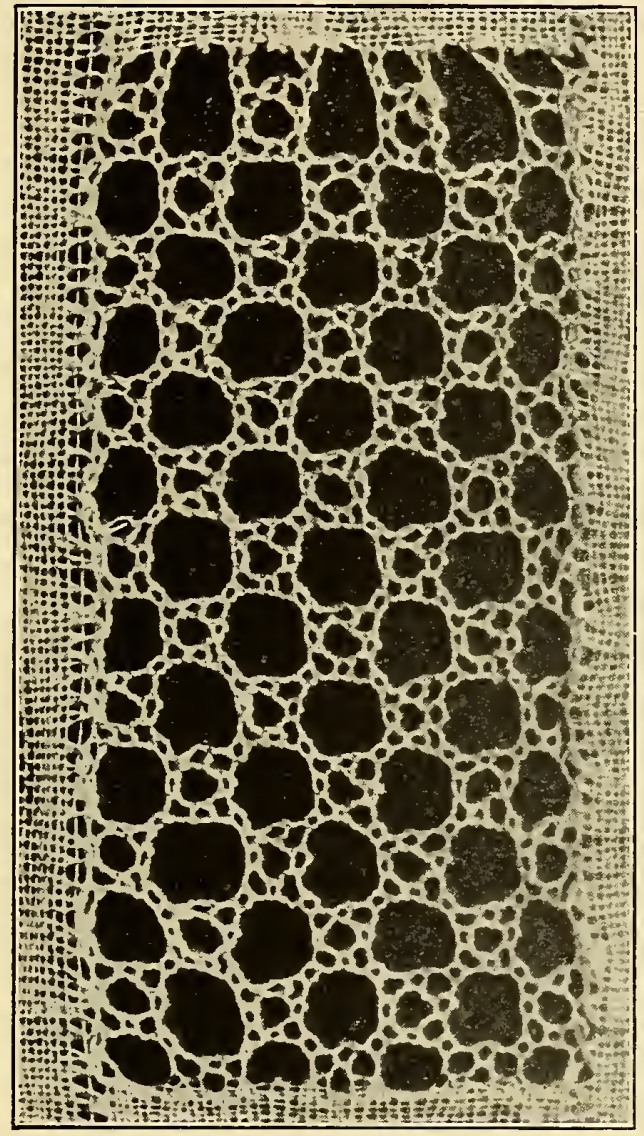

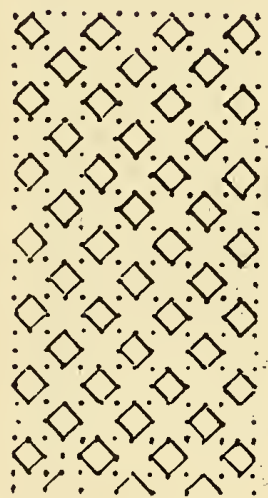

Two pairs enter each motive or block at the upper left-hand and two at the upper right-hand. Each square requires eight pins. The four ornament, or corner pins, are placed thus! ; then the central stitches inside of

the ornaments are held in place by pins placed thus

The two pairs entering at the upper left-hand are twisted twice and crossed. Here a pin is placed and closed by twisting twice and crossing. This is the upper left-hand ornament. The same process is repeated for the upper righthand ornament. Now the two center pairs, one from the left and one from the right, are twisted twice and crossed. A pin is placed at the center top and closed by twisting twice and crossing. This stitch is repeated at the center left; that is, twisting twice, crossing, placing a pin and closing it by twisting twice and crossing. The same is done at the center right and again at the center bottom with the two middle pairs. One is now ready to make the lower, left- and righthand ornaments. These done, one has only to twist the pairs twice in order to make the centers of the squares below; for the lower ornaments of one square serve as upper ornaments to succeeding squares. 
LINE B, COL. 7,

Square-meshed Valenciennes of Ghent or Gand and Menin (braided 2 or 21/2 times).

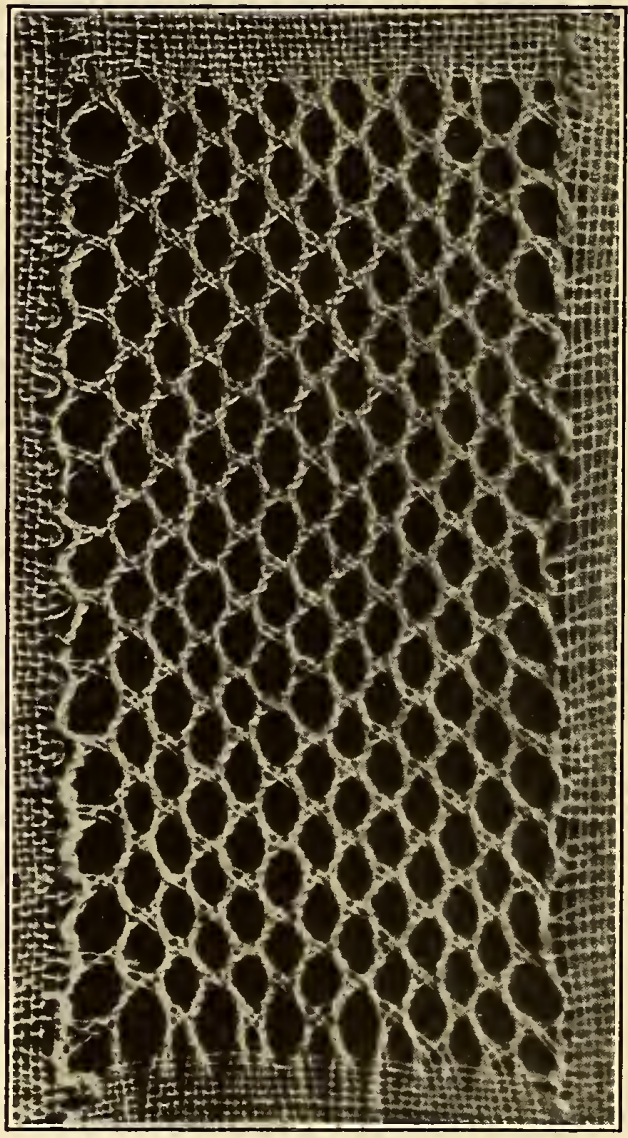

See Line A, Column 7. This Valenciennes is made in the same way, except that the sides of the meshes are braided two or two and a half times, the joints being made in the same way as those of Honfleur. 


\section{LINE B, COL. 8,}

Devonshire Cushion.
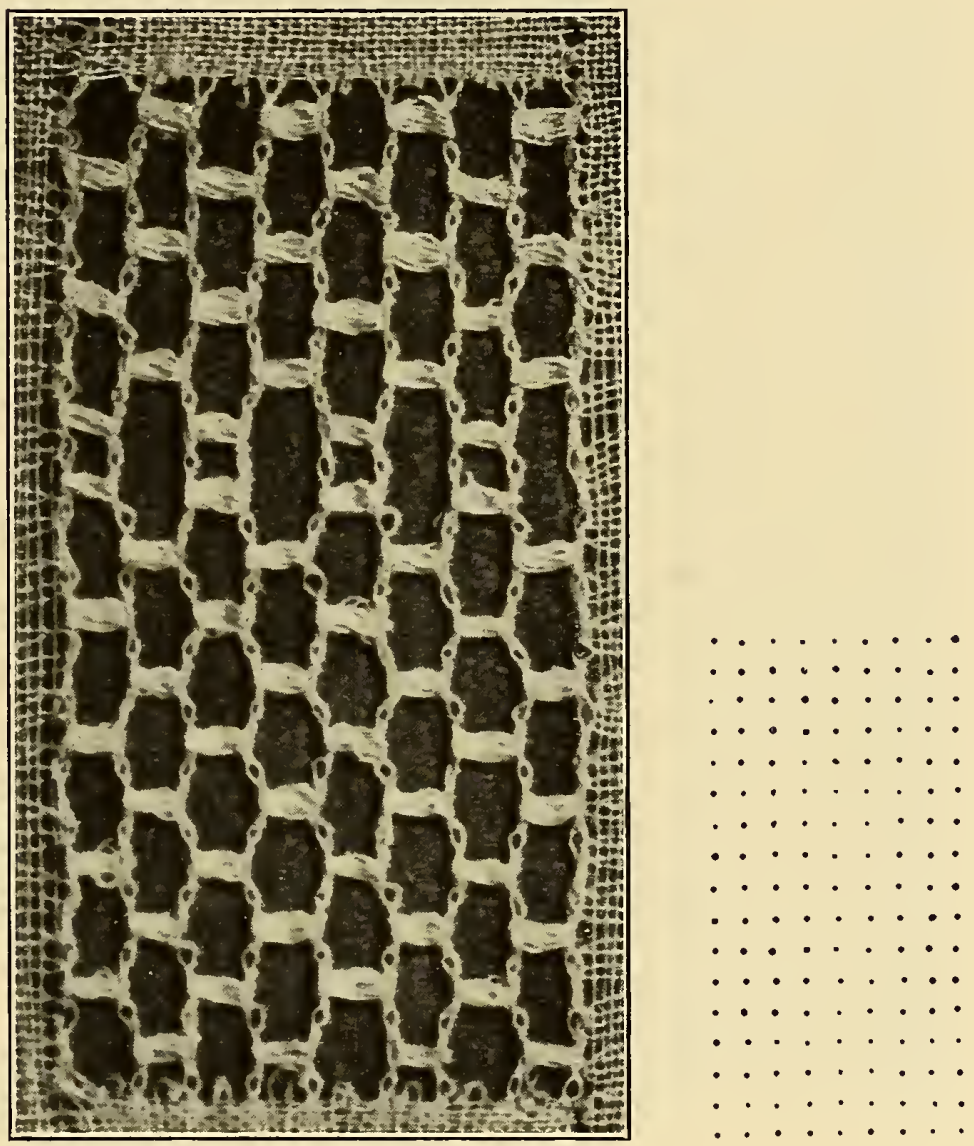

Four pairs are required for each motif: two pairs at the upper left and two pairs at the upper right cloth-stitch, are twisted three times, pinned and closed with a linen-stitch. When all four couples have been worked up to this point, the two outside ones are twisted three times and hang idly while the leadwork is being made, waiting to join in again below it. The two inside pairs are each twisted once and proceed to make the cutwork. After it is finished, they are again each twisted once and cloth-stitched through the two outside couples which have been awaiting them. A pin is placed below each of these joints and the pairs are twisted three times and closed, ready to continue. 


\section{LINE B, COL. 9,}

\section{Devonshire Hexagonal Bar Filling.}
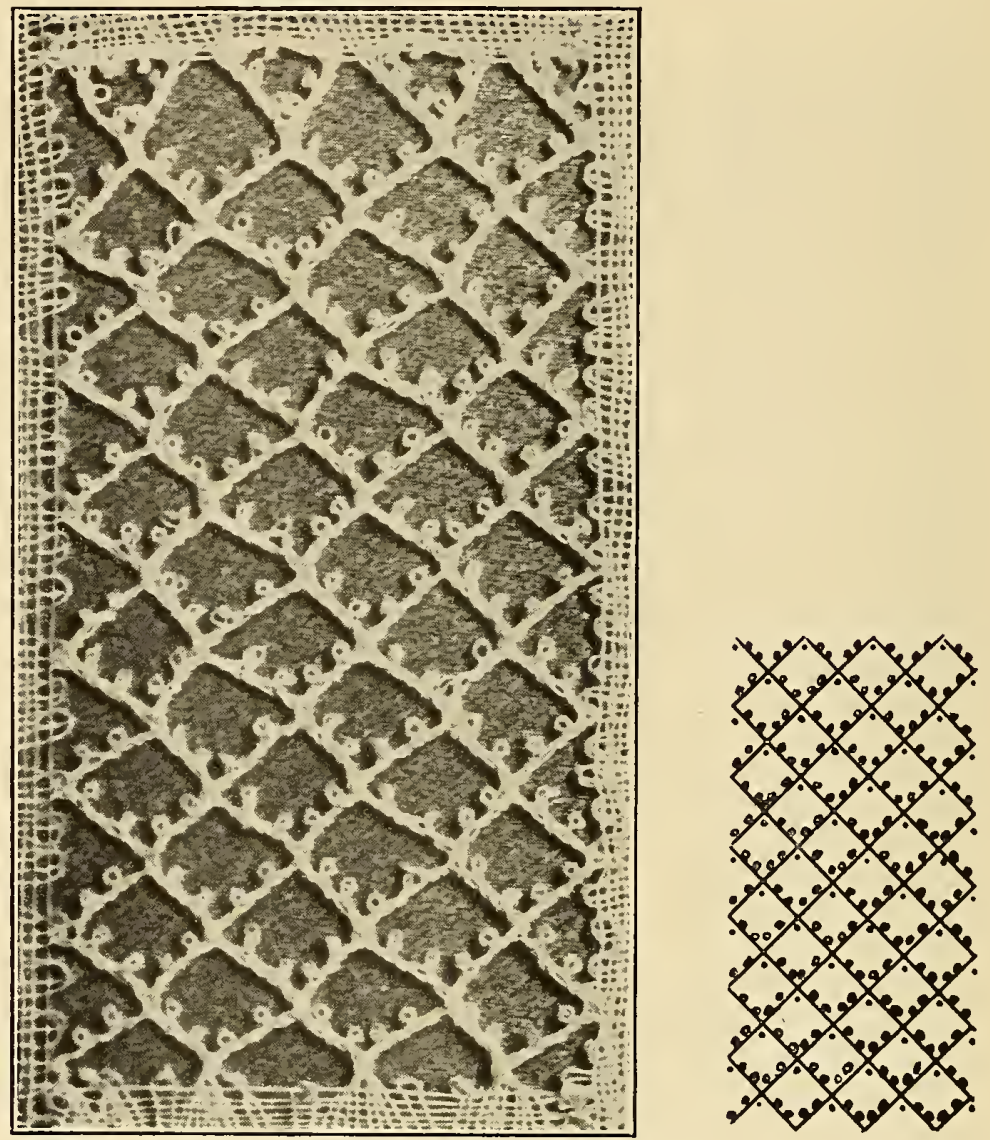

Each bar requires two pairs, but at the joint four pairs are worked together. Here the threads are used double, two bobbins being passed over two others, so that the stitch made is identical to that made by only half the number. At this intersection the pairs should be crossed and twisted and again crossed and twisted. Now the couples divide, two working to the right and two to the left. Each one is now twisted and crossed three successive times. The pairs nearest the pin holes are twisted three times. One thread is put around the pin from right to left and its mate from left to right, when the pair is twisted once and re-enters the braid. The braid is made by twisting and crossing three successive times. Then a second pearl pin is put up; and the braid again twisted and crossed three times. 
LINE B, COL. 10, ?
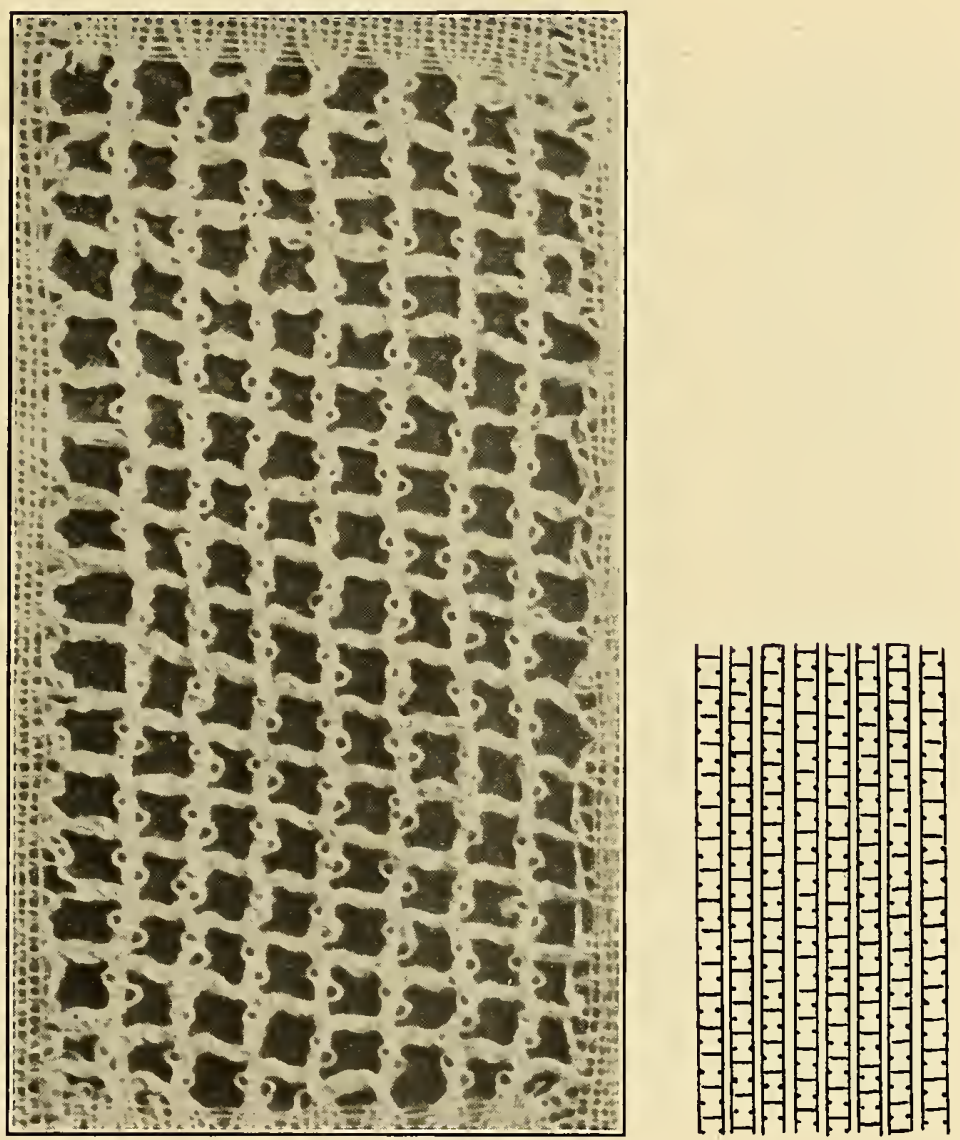

'There are two pairs in these vertical bands, besides the weaver. 'The latter' is twisted three times around each winkie pin. Each pair that enters into the cutwork (the weavers from the two sides) is twisted once before entering the points d'esprit. But the cutwork weaver should be twisted twice after the leadwork is finished before cloth-stitching through the band to the other side. This filling is worked from the left to the right, as the left-hand cutwork must be finished before the one slightly below it to the right can be begun. 
LINE B, COL. 11, Trude "E" Ground (original) (American).

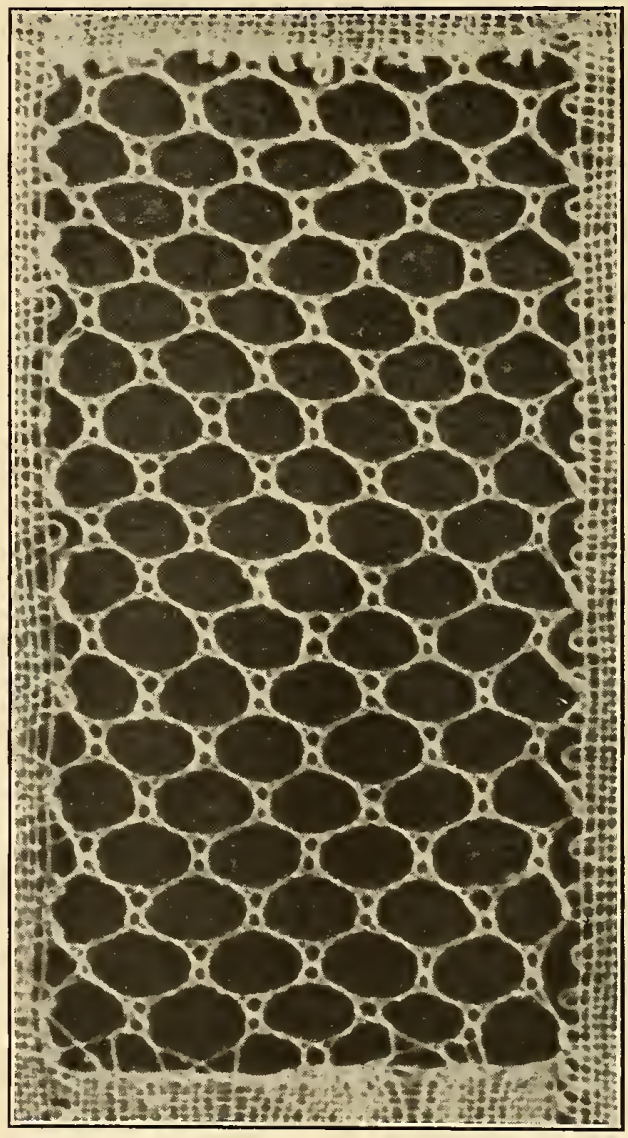

Two pairs to a joint are required for this pattern, which is made on the diagonal, with two pins placed right below each other forming a double joint. The two threads coming from the upper left-hand are twisted twice and those coming from the upper right-hand are twisted twice. The two center bobbins are crossed and a pin placed below. The pairs are twisted twice and crossed and another pin placed, which is closed by twisting twice and crossing. 


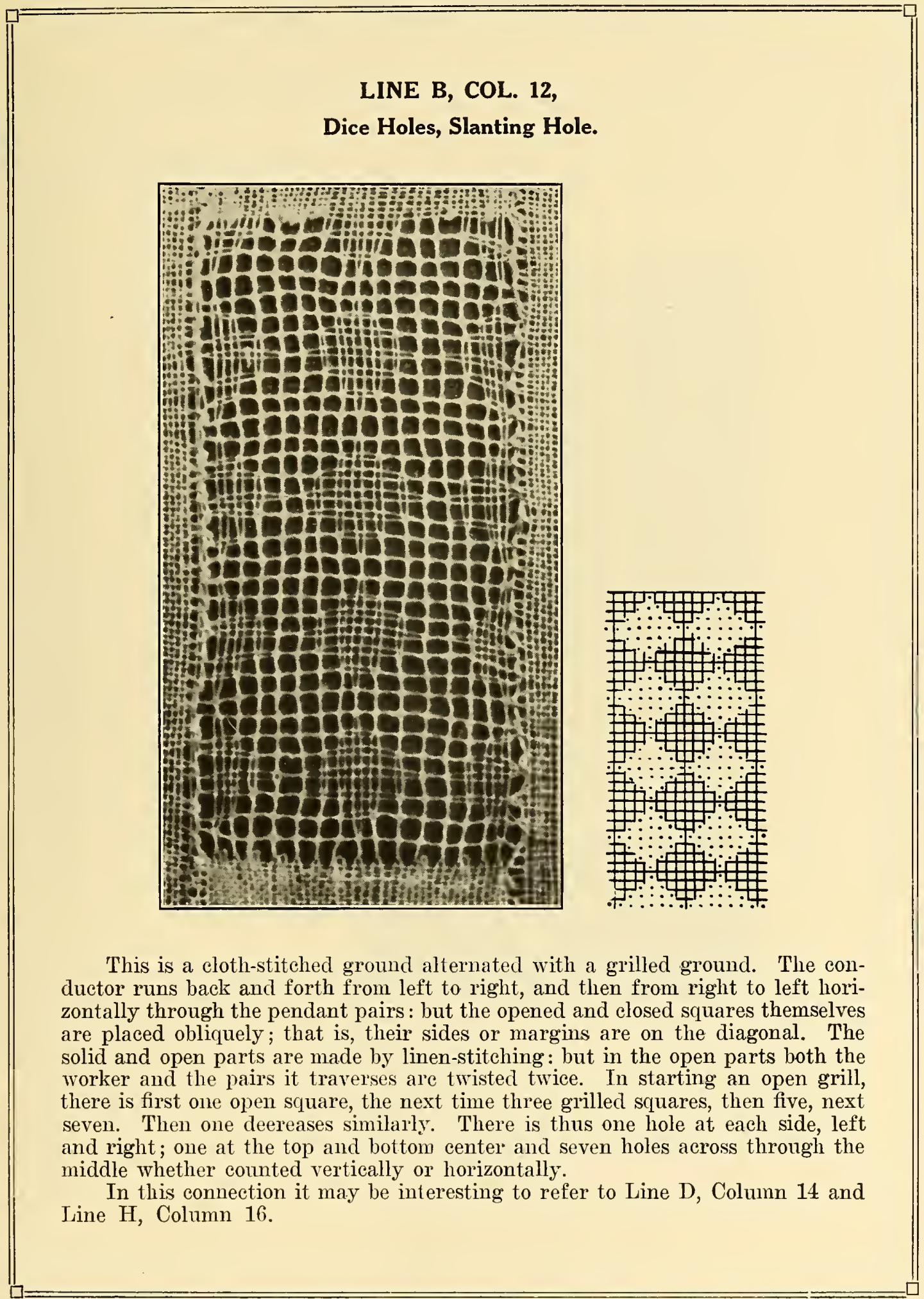


LINE B, COL. 13,

Point de Tresse with Plain Picots in Lower Joints.

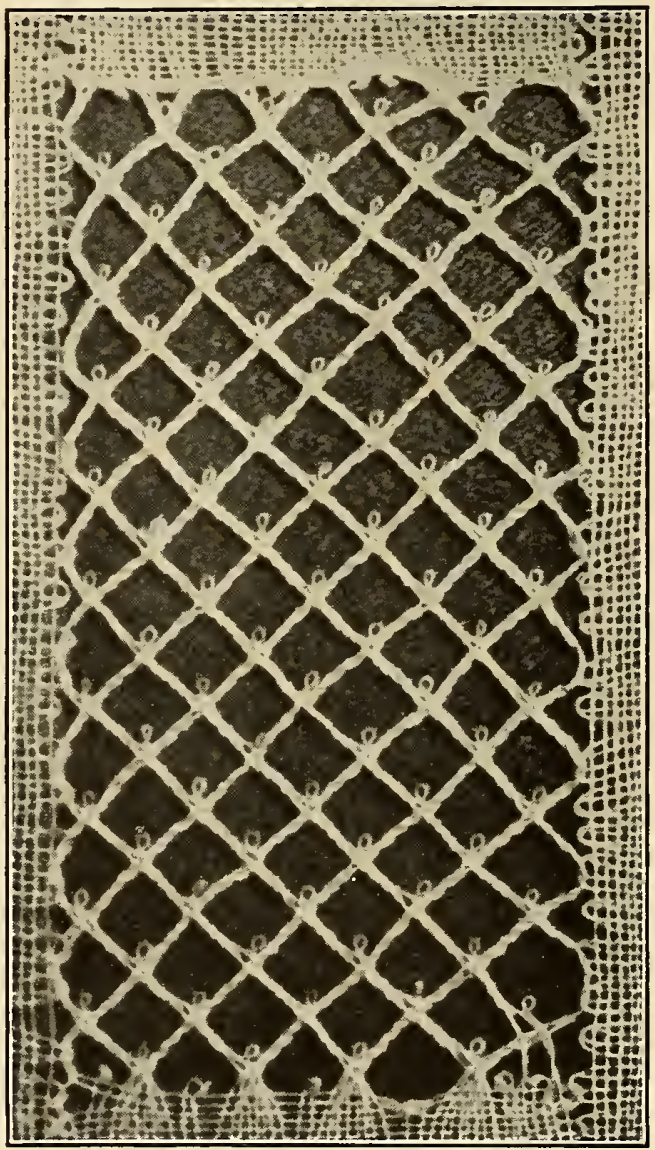

This sample requires twenty pairs, four to each braid.

The picot just below the lower joining of each two braids, is made with the left-hand thread in the same manner as usual. The threads should be twisted before they are crossed, as crossing would push the picot up the side of the braid. The braids then intersect each other with a linen-stitch. 
LINE B, COL. 14,

\section{A Spotted Italian Ground.}
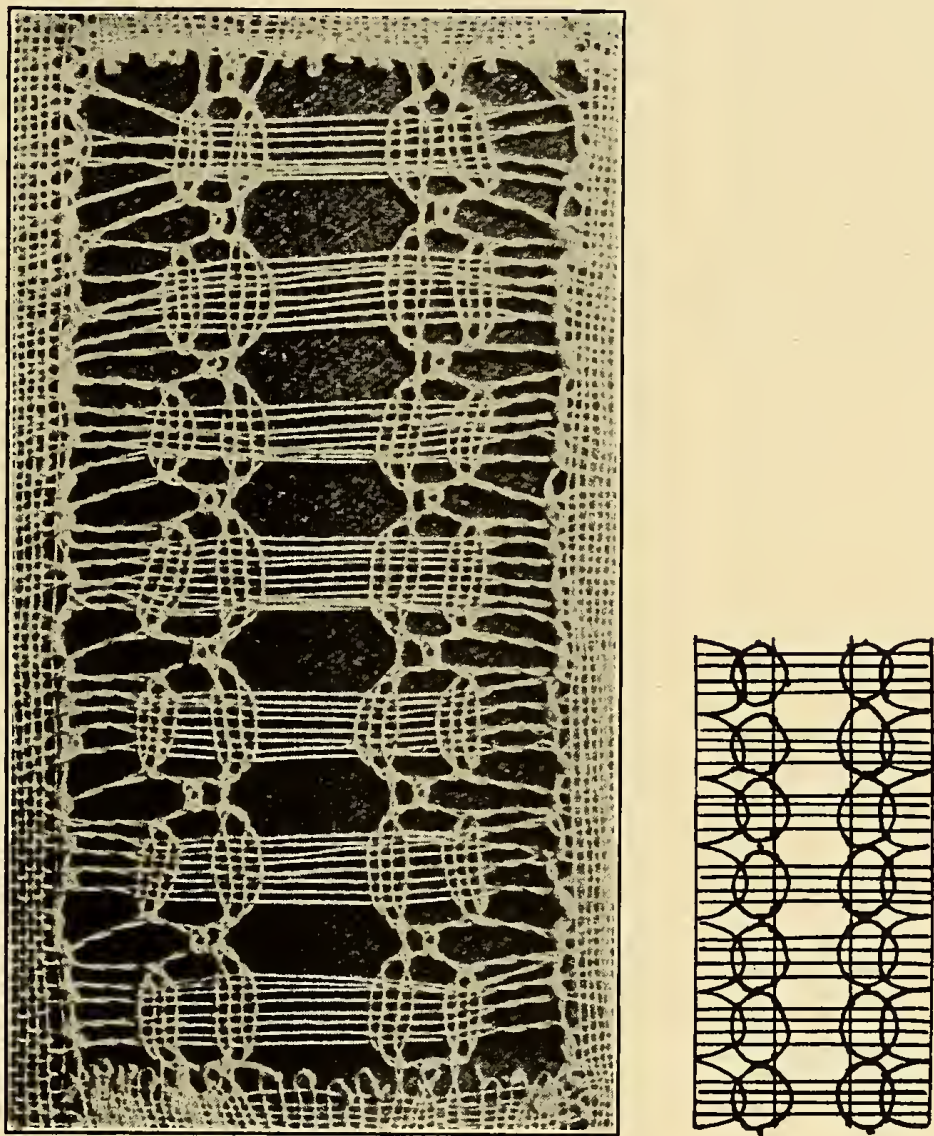

'This pretty ground is very quickly and easily unade.

Four passive or vertical pairs besides the weaver are required in the making of each spot. These four pairs are each twisted once. The two center ones then cloth-stitch and are twisted once: a pin is placed and closed by linen-stitching; and these two central pairs are again twisted once. One pair now works towards the left and one towards the right, each cloth-stitching with a remaining vertical pair. A pin is here placed between the two left-hand pairs, and another pin between the two right-hand ones, all four are again twisted once, and are now ready to be cloth-stitched four times by the working pair. The spot or dot pairs are not twisted again until the weaver has woven through them four times. 


\section{LINE B, COL. 14-Continued,}

\section{A Spotted Italian Ground.}

The weaver works all the way across the lace from one side to the opposite edge, then back; without being twisted either between dots or in traversing them: but the conductor can be twisted twice, if one wishes, at the edge of the lace beyond the outermost columns of spots.

The bottom or end of the circle is completed in the same way only reversed, that it is begun-by placing a pin below the last line of the weaver between the two left-hand pairs of the dot, and another pin between its two right-hand pairs; then by twisting each pair once, cloth-stitching the two left-hand ones and clothstitching the two right-hand ones; then twisting each pair once more, linen-stitching the two that are now in the center, twisting them once, placing a pin, closing it by a linen-stitch, again twisting these central pairs once, so that they may be ready to linen-stitch through the other two pendent pairs. 


\section{LINE B, COL. 15,}

Fat, Maltese Petals, Leaves, Seeds, Grains, Wheat Ears, Paddles

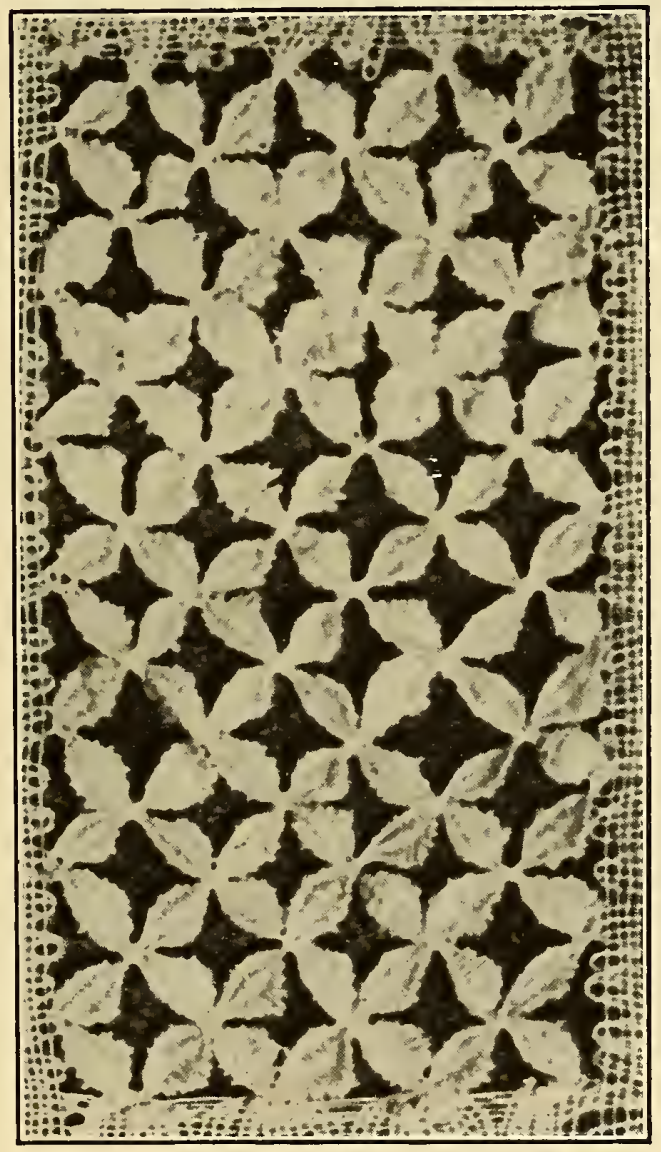

Each leaf is made of four threads woven as are the ordinary Cluny petals; but made very fat or wide, even though one leaf overlaps another. A little practise enables one to produce even edges. 
LINE B, COL. 16, Abruzzian or Pescolane Cross Pattern.
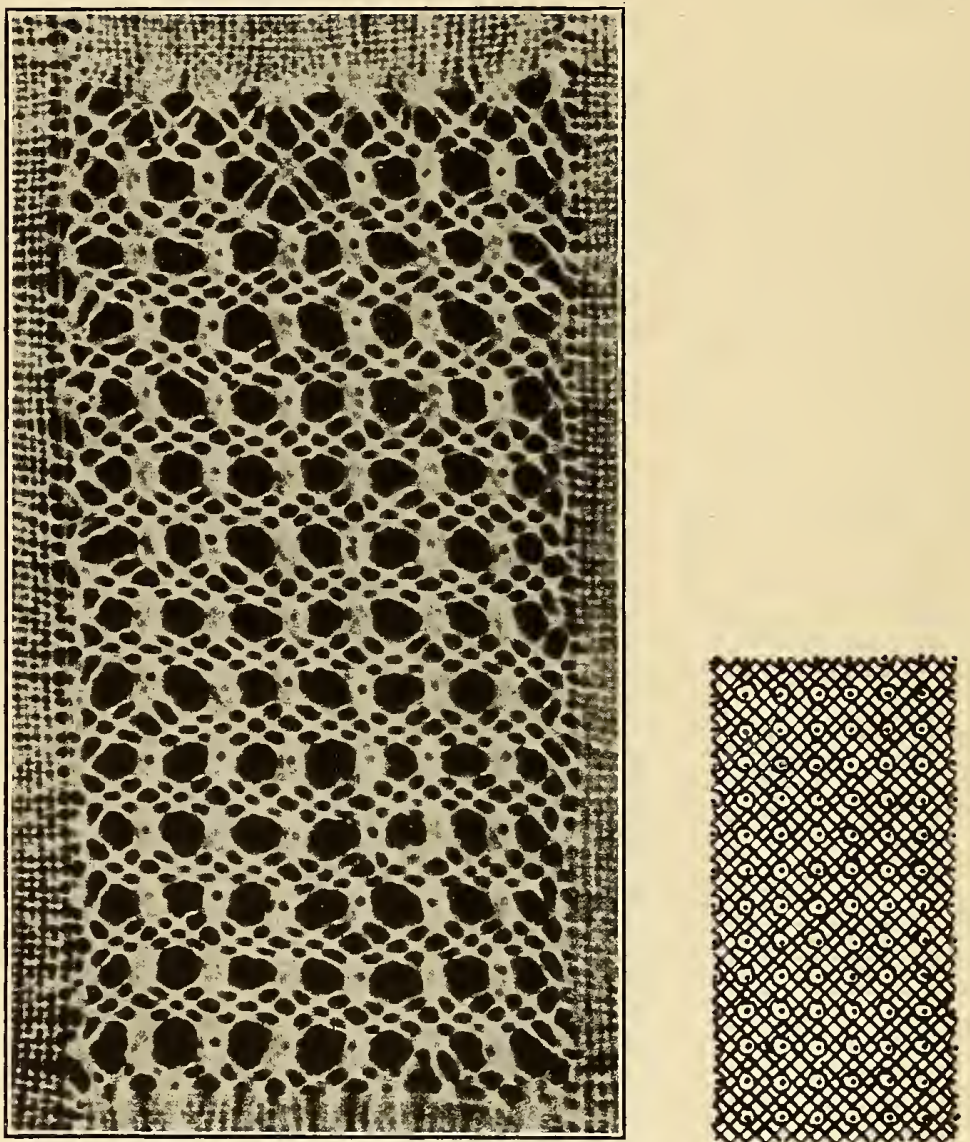

This pattern is the same as Line A, Col. 16-Mezza Cambruccia-except that between an upper row of spiders and the row beneath it, each pair of threads leaving one spider passes obliquely through two other sets of threads before entering a lower spider. Thus little, hollow, diagonal squares or double crosses are formed between spiders. The two pairs of threads that leave the lower righthand end of an upper spider pass obliquely to the right into the left-hand upper end of the next spider just below to the right, and vice versa. Each of these pairs of threads is twisted once between intersections with other pairs of threads. 
LINE B, COL. 17,

Trude "O" Ground (original) (American).
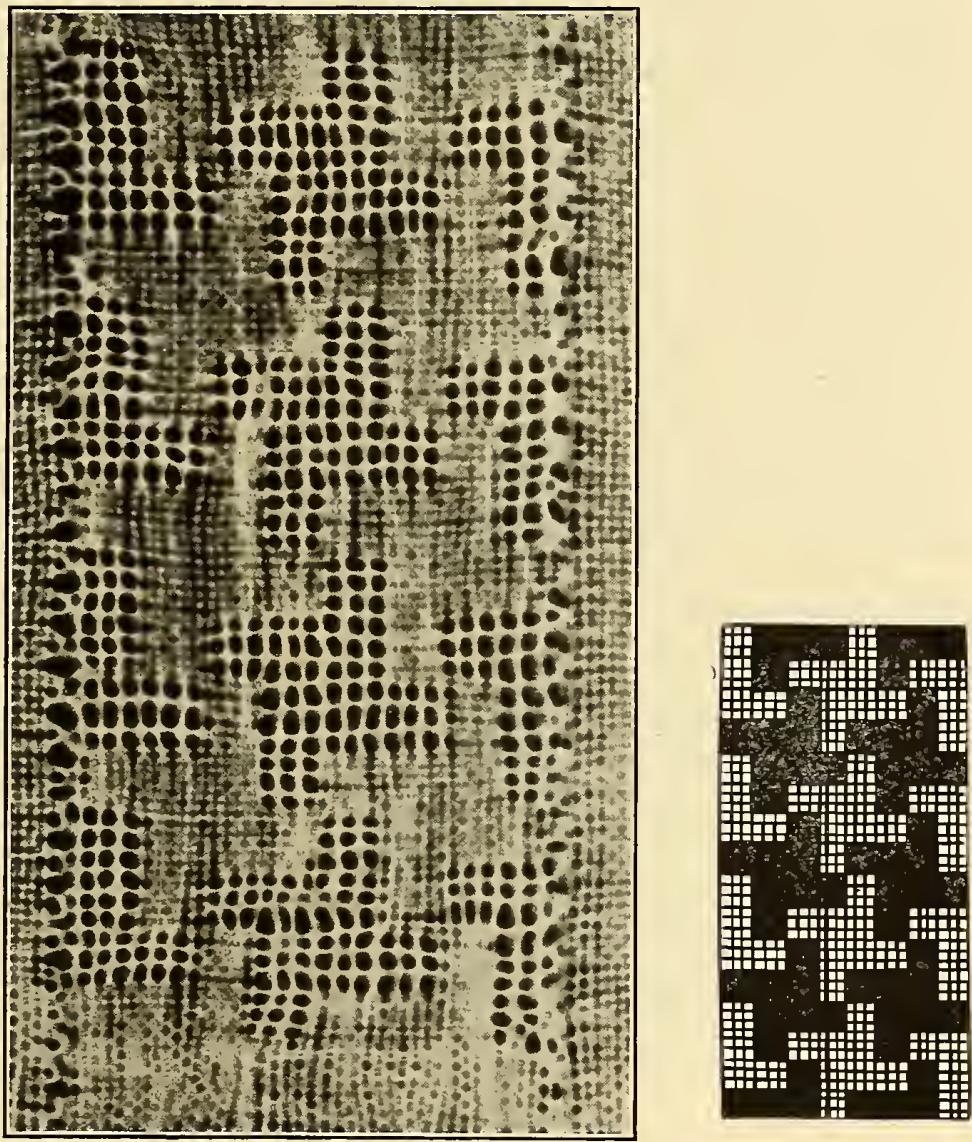

The linen is four pairs wide; the grille only two. Each pair is twisted once in the grille work. A supporting pin should be placed between threads at important junctions to help one find the place, and to keep the line straight; but should not be left in place more than one line back, or one cannot pull up the loose, spread threads which the pins leave. The twisted pairs spread or push the cloth-work away from them, and this pushing inward of the linen must be specially guarded against on the long sides. Where the grille and cloth edges meet, the margin pair always belongs to the linen. 


\section{LINE B, COL. 18, \\ Moulinet.}
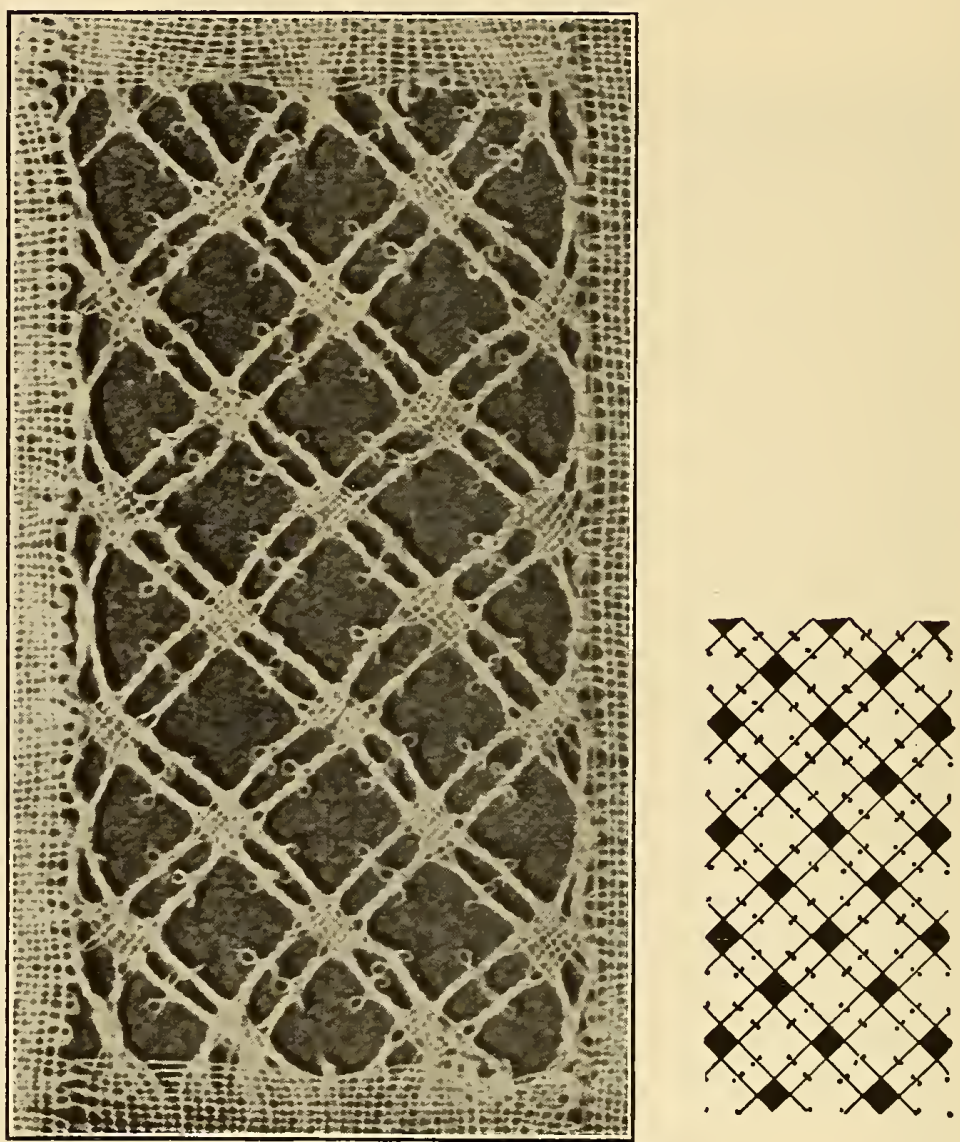

This ground was originated by MIme. H. H. de Juillien and took a prize at one of the leading expositions in Milan.

Sixteen pairs are required for the making of each mesh, as two braids enter at the upper left and two at the upper right of each little solid square. In making these squares, one must be careful to spread out one's threads in order to prevent the appearance of a hollow streak in the center of the square. In weaving this solid dot, one cloth-stitches the innermost pair of the inner, upper, left-hand braid through the pairs of the two right-hand braids. Then one uses the other pair of the inner, upper, left hand plait and again linen-stitches down through the right-hand pairs. One can now reassemble the two pairs of the upper, inner left-hand tress and begin a new one sloping towards the right below the solid square. Returning to the upper left-hand, one uses first the inner and then the 


\section{LINE B, COL. 18-Continued, \\ Moulinet.}

outer pairs of the remaining braid as weavers, cloth-stitching them successively through the four pairs coming from the upper right. This done, the solid square is completed and can be supported at its base by a pin.

The braids should not be made too long or they will buckle up or out. Loops or picots occur at each side of the center of every plait to relieve the straightness and stiffness of the lattice background. The picots here shown are the plain, ordinary ones, but knotted picots can be used instead should one prefer.

Those picots used in this sample, which fall to the right of a braid, are made by using the rightmost thread of that plait, placing a pin under it with the point towards the left, raising the point downwards towards the right over the thread, and sticking the pin into the indicated dot on the pricking. To prevent a gap in the braid, one should make the picot immediately after twisting, and should recommence the tress by twisting, pulling the threads up tight. The picot on the left of the braid is made by using the leftmost thread, holding the pin in the left hand, placing its point downwards towards the right under the thread, bringing it downwards, up over the thread, towards the left and into the indicated pinhole. 


\section{LINE C, COL. 1,}

\section{Plain Hole Ground, Torchon, Réseau Stitch, Einfacher Löcherschlag}

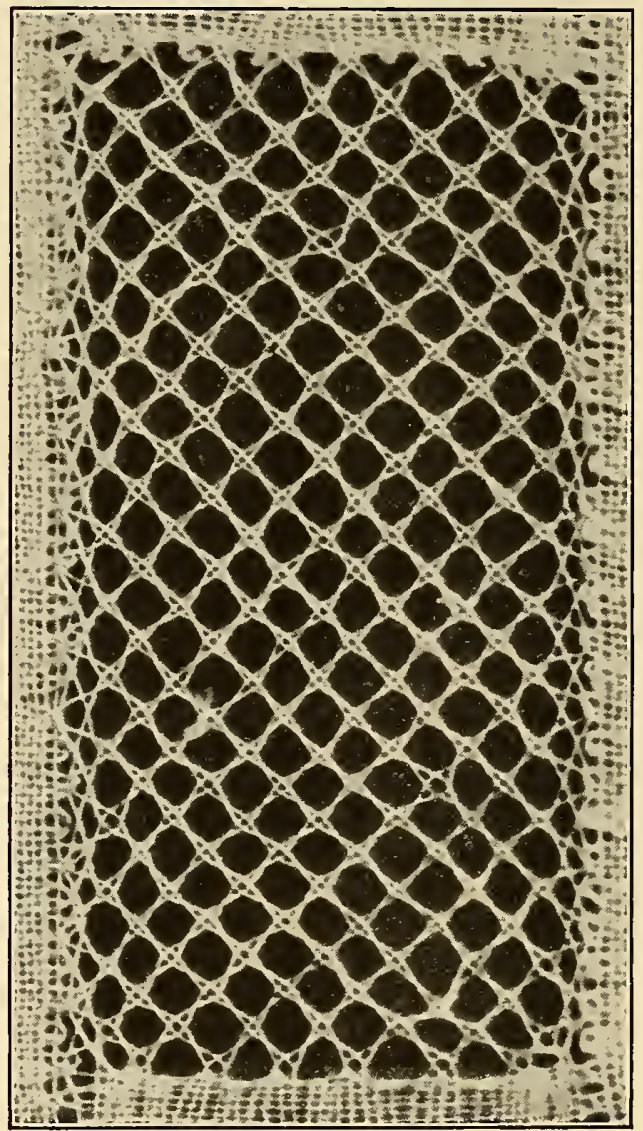

This very simple net ground is made by twisting and crossing, and placing a pin. The pin is closed by twisting and crossing. The mesh runs obliquely. 


\section{LINE C, COL 2,}

Scotch Broom Stitch, Point Jeumet ou Genêt, Ziergrund mit Schrägstreifen-Musterung.
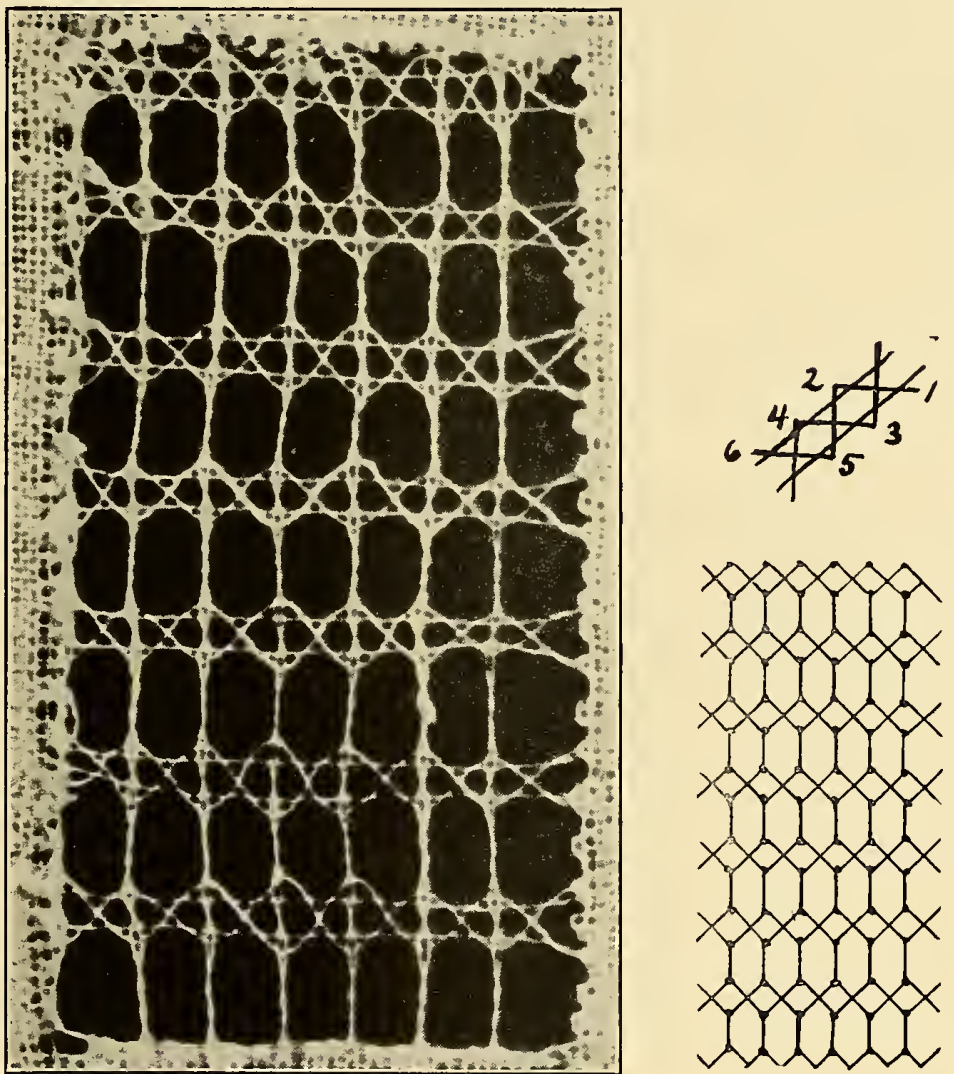

This requires three pairs. One enters, divides, and becomes one of the two, long, parallel lines. A second pair divides, and forms the other of the two, parallel lines. Then a third pair enters at the upper left. This stitch is made from right to left by twisting and crossing once each time. The little bars or barrettes between the two, double bands of parallel lines are made by twisting three times. When one reaches the edge of the lace on the left, the pairs have to be knotted and cut off unless they form part of a long, continuous pattern made by the French 


\section{LINE C, COL. 2-Continued}

Scotch Broom Stitch, Point Jeunet ou Genêt, Ziergrund mit Schrägstreifen-Musterung.

method. The worker entering at " 1 " intersects a parallel line by twisting and crossing, and continues towards the left, twisting and crossing through the second, parallel line, then twisting and crossing with the barrette that enters at "2." Here a pin is placed and closed by twisting and crossing. As one descends towards the right, one intersects by twisting and crossing; a pin is placed at " 3 " and closed by twisting and crossing, which leaves a barrette pair hanging towards the right; this is twisted three times and is now ready to enter the set of lines in the band below. Then one works to the left towards " $t$," where another barrette enters from above. 
LINE C, COL. 3,

Brussels, Droschel, Vrai Réseau, Point d'Angleterre Net, Drochel.

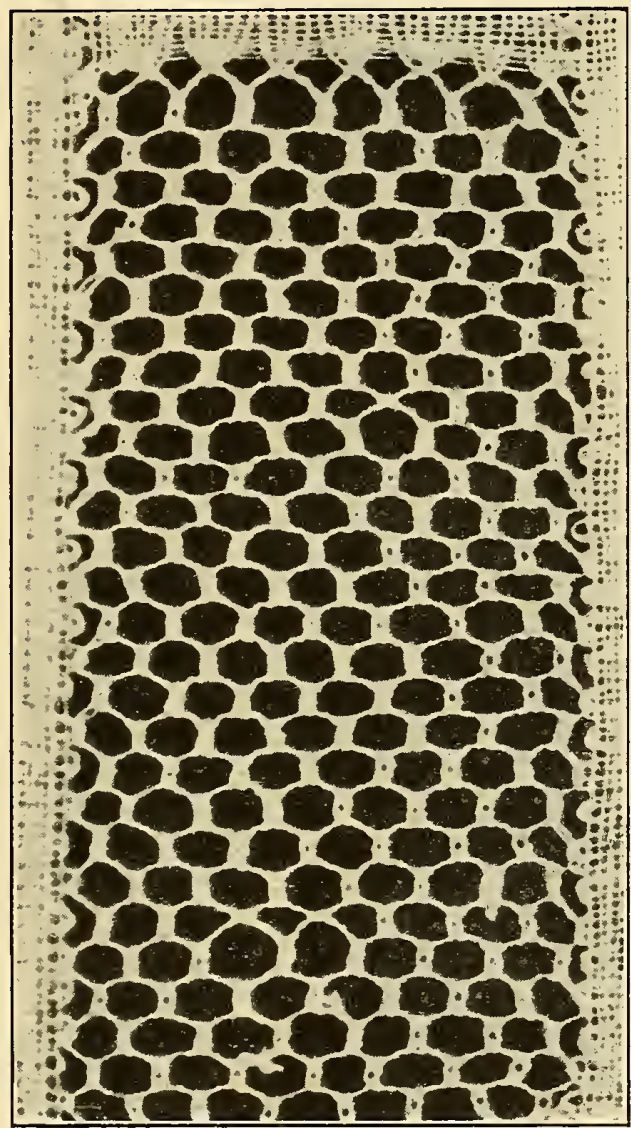

See Line B, Column 3.

This mesh made with the support of pins is, in the hands of an amateur at least, much more regular and pleasing than when pins are not employed. The ground requires four pairs to each stitch. Commencing with the vertical side, one braids twice-thus making a whole-stitch. A pin is then placed and closed by the repetition of the two plaits or whole-stitch. This finishes one vertical side. The other vertical side is made in the same way. After these two are finished, one can begin the two lower oblique sides. One pair should be taken from each braid - the pairs which lie nearer the center. These should each be twisted twice, and should then be brought together in position for forming the next vertical braid. One thus produces a six-sided mesh with two braided and four twisted sides, the latter coming at the top and bottom of the mesh; the plaited edges, at the two sides. 
LINE C, COL. 4,

Rose Ground, Scandinavian Ground, Point du Mariage, Gelosia, Tulle Double.
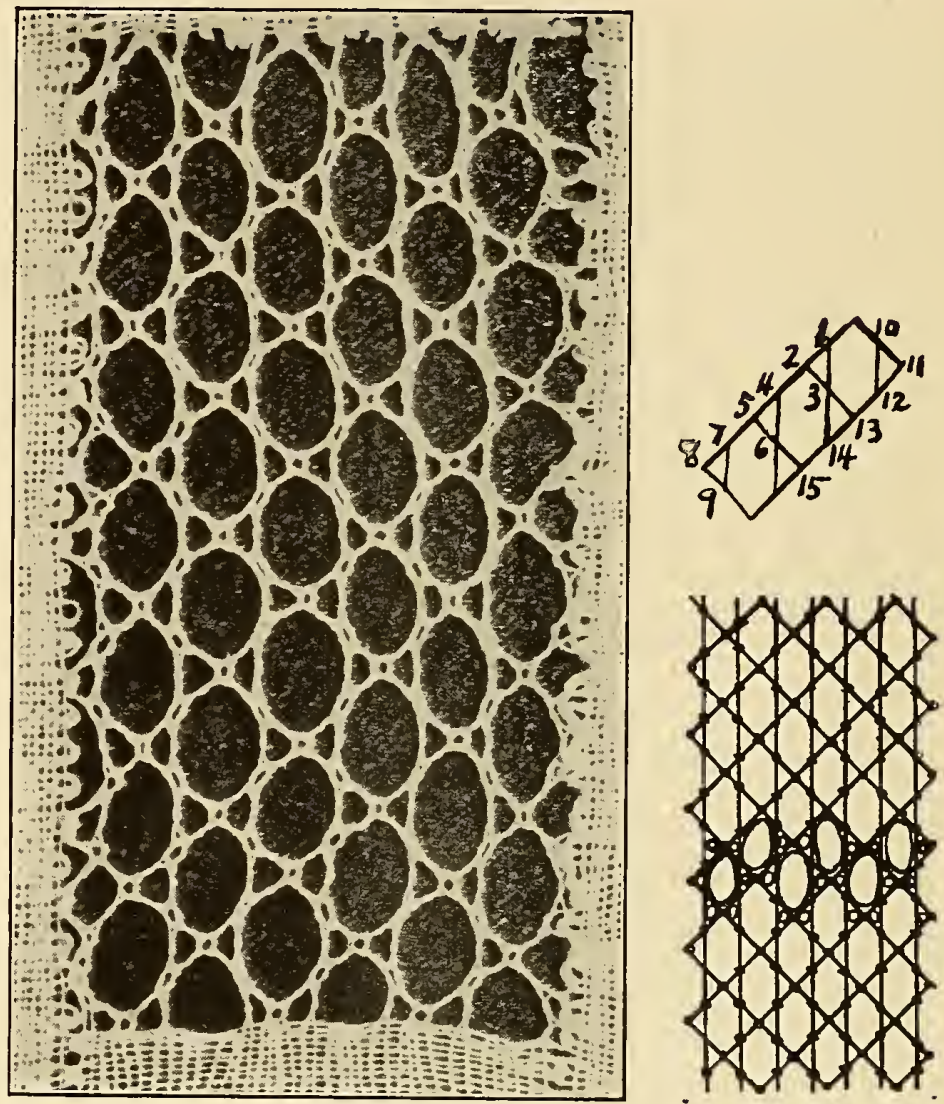

Rose Ground is practically the same as the small-meshed Tulle Double, except that the pins are differently arranged so as to make a more open mesh.

The pairs are twisted twice and crossed, then pinned, again twisted twice, and crossed to close the pin.

A stitch is made between the pairs one and two, and a pin placed at three. Then a stitch is made with the pairs four and five and a pin placed at six, then a stitch is made between the pairs seven and eight, and a pin placed at nine, et cetera. When one has reached the end of this row, one starts again at the upper right, using the pairs ten and eleven, placing a pin at twelve. Then using ten and twelve, placing a pin at thirteen; then using three and thirteen, placing a pin at fourteen; then using three and fourteen, placing a pin at fifteen, et cetera; Jeaving one pair hanging after each stitch. Every pin is closed without exception. 
LINE C, COL. 5,

Old Buckingham, Fond de Milan.
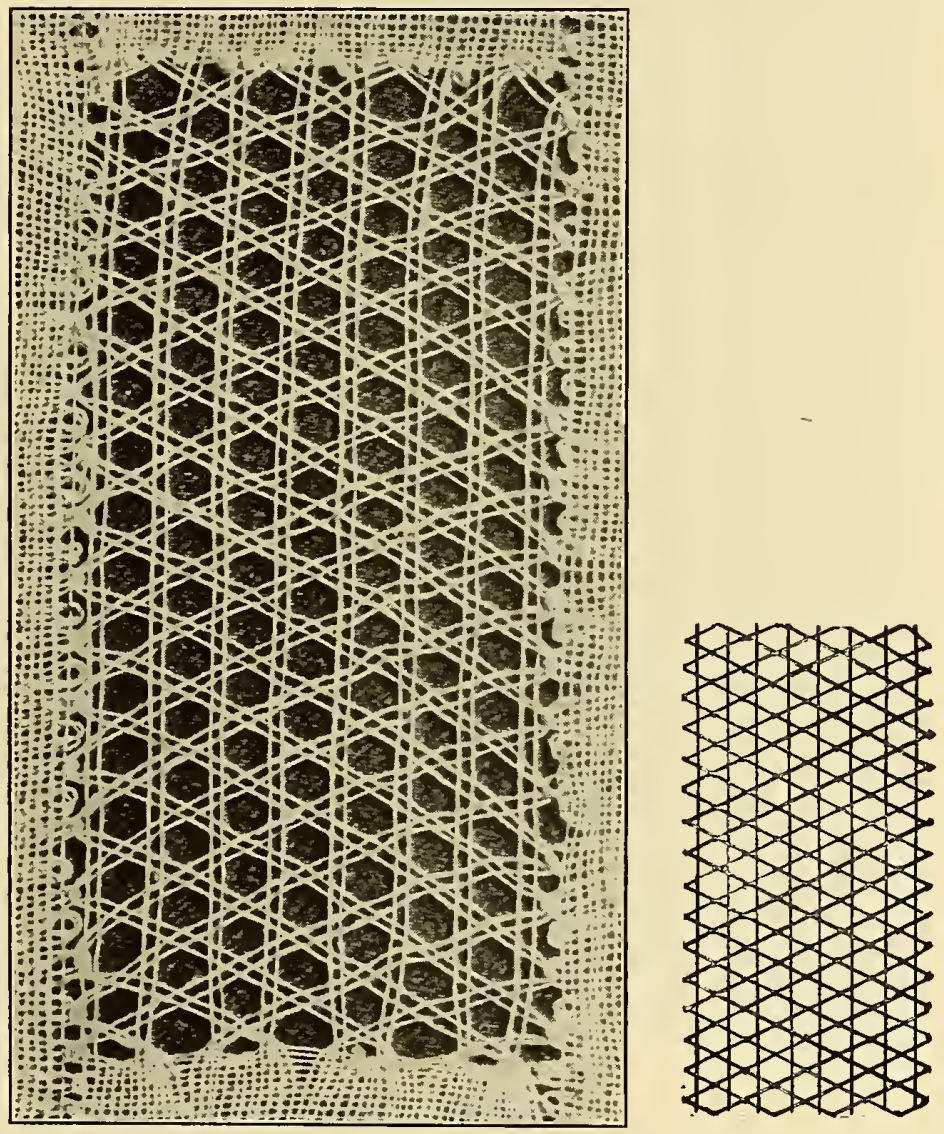

Each stitch requires four pairs, and none of them should be twisted. One should work from the right to the left all the way across the piece, cloth-stitching each pair as one encounters it, working the cross and the passive pairs in a diagonal line descending towards the left, momentarily considering the pair that comes from the right as a weaver. A pin should be put through the center of each cross. Then one should return in the other direction, weaving the pears that should now be hanging ready. 
LINE C, COL. 6,

Slavonian Style Virgin Point, "Point à la Vierge" nach Slavischer Art.
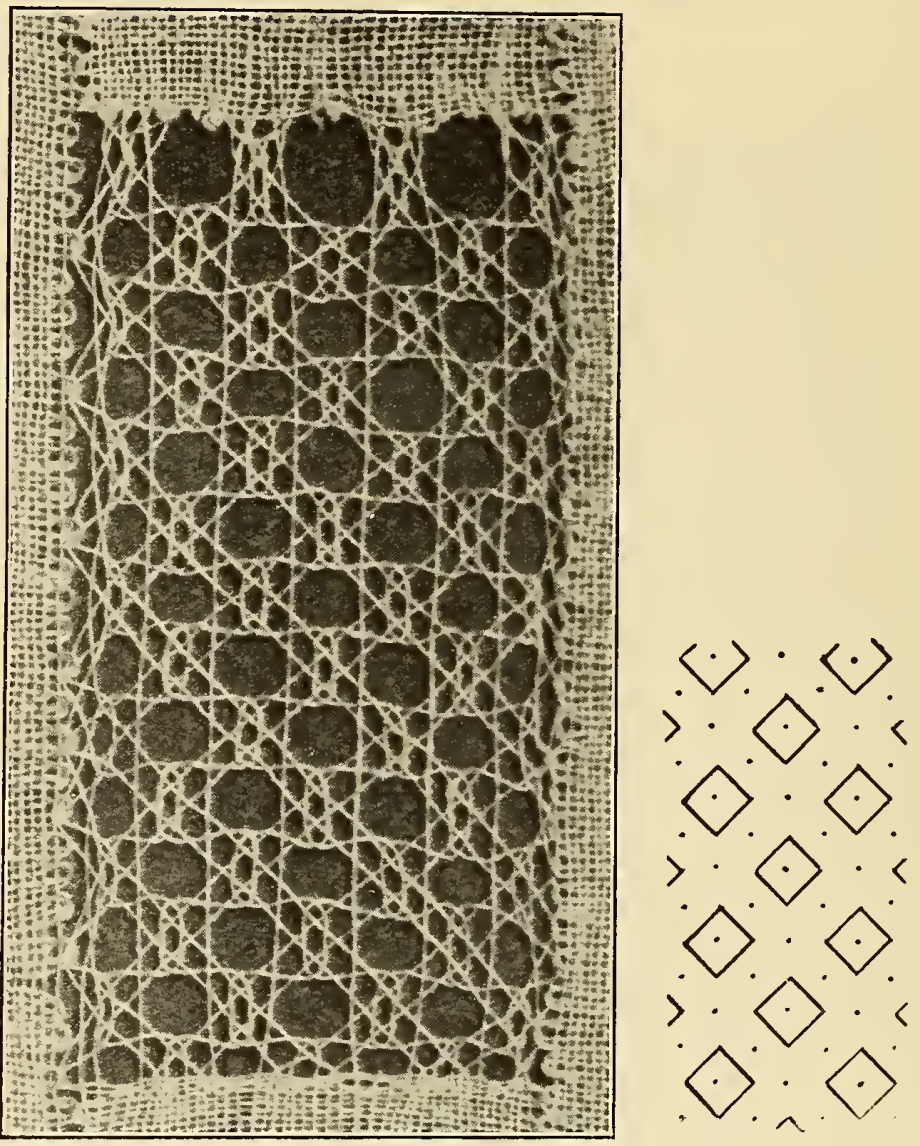

This form of Virgin Point requires four pairs and two pins to each motif or block. One pin is placed at the center top ; the other at the center bottom. The upper, left-hand ornament should be made with the two pairs that enter at the upper, left-hand; twisting once, crossing, twisting. The same is repeated at the upper, right-hand corner. Then the two center pairs are taken, one from each ornament, twisted once and crossed. Here a pin is placed and closed by twisting and crossing once. The two pairs, which are now at the left, are twisted and crossed once. The same is done with the two pairs at the right. The same is repeated with the two pairs now at the center, that is, one from each side. Here another pin is placed and closed by twisting and crossing once. The two, lower ornaments, one at the right and one at the left, are now made by twisting, crossing and twisting once. These two lower ormaments serve, of course, as upper ones for squares that are to follow. 


\section{LINE C, COL. 7,}

Square-meshed Valenciennes of Courtrai and Menin (braided 3 or $31 / 2$ times).

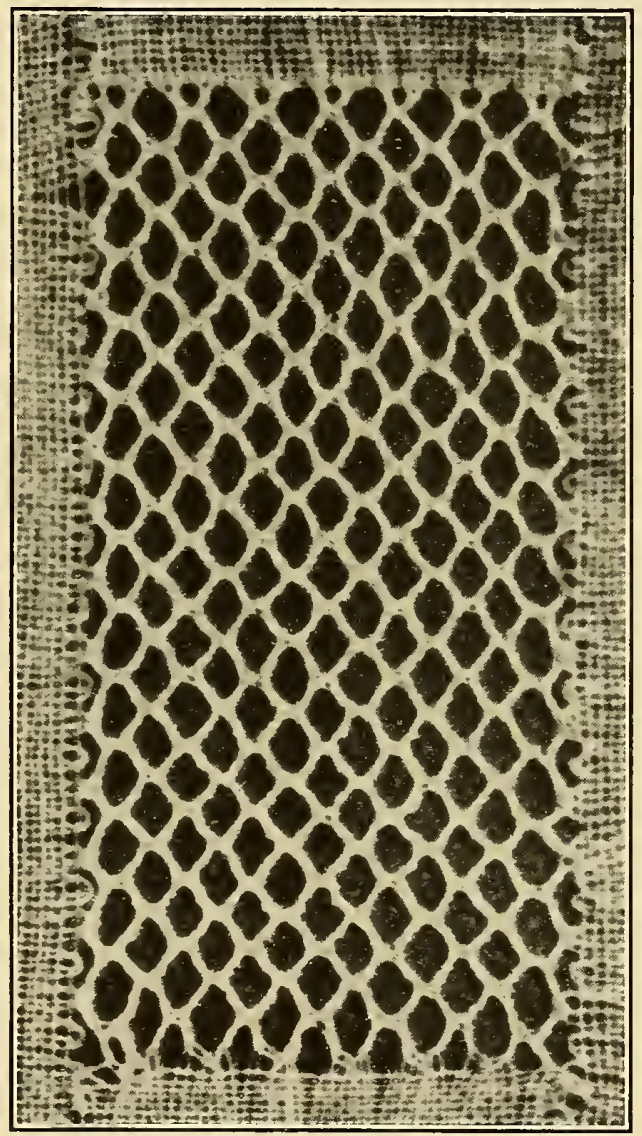

See Line A, Column 7 and Line B, Column 7. The Valenciennes of Courtrai and Menin is made in the same way as that of Honfleur, except that the sides are braided three or three and a half times. 
LINE C, COL. 8.

Devonshire Brick, Mignonnette.

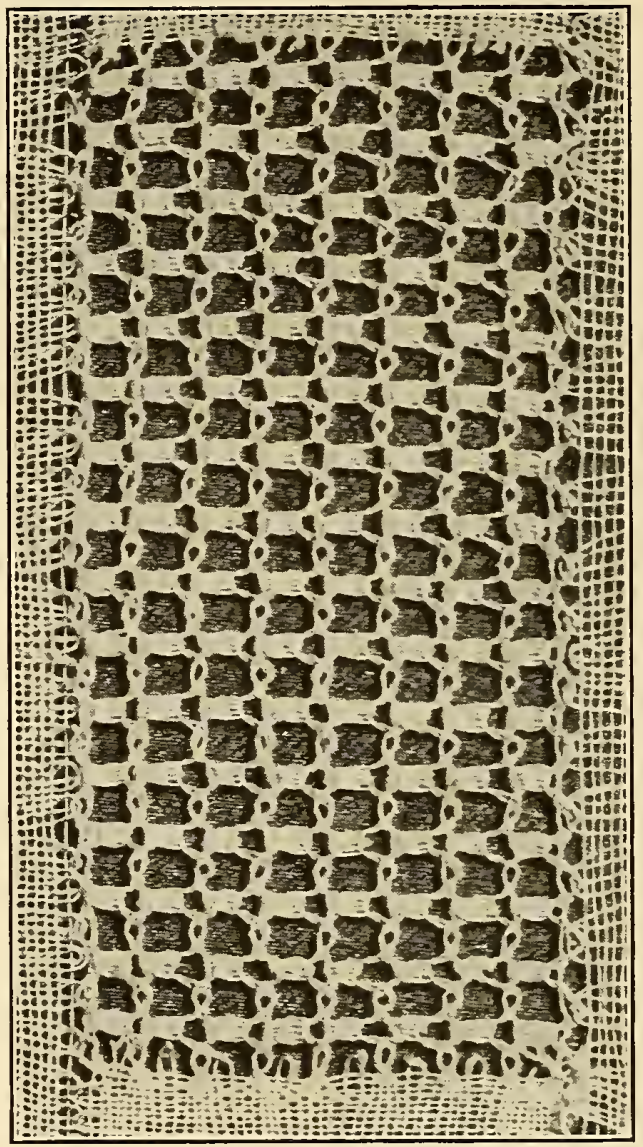

The pricking for this is the same as that for the Devonshire Cushion Filling, Line B, Col. 8, but instead of every alternate square having a point d'esprit, each one is filled, which makes a closer and more elaborate mode. That is, the pairs which lie idly in Cushion Filling, are here employed to make other points d'esprit, side by side to the others. Below cutworks at each end of them, the pairs are twisted once; cloth-stitch; a pin is placed; the pairs are twisted three times; are closed by linen-stitching and are twisted once ready to form the eutworks directly below them. 
LINE C, COL. 9,

Devonshire Double Ground Pin.
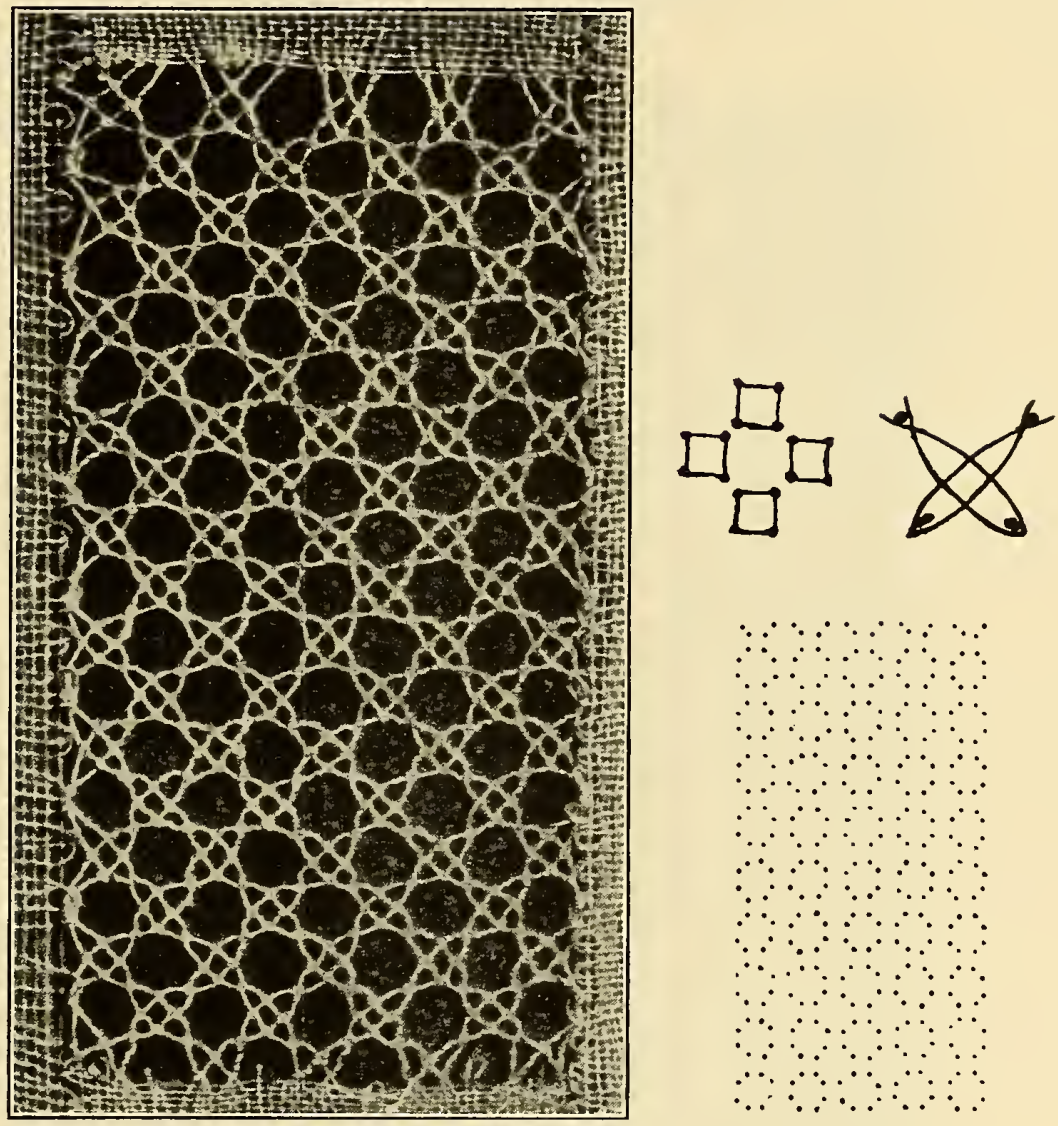

This easy, dainty, net-like filling is made by twisting every pair three times between encounters. Two pairs at the upper left and two at the upper right cloth-stitch and are twisted three times. A pin is placed under each joint. The two couples now at the center, cloth-stitch and are twisted three-times. No pins are put up here. Then one pair to the left and one to the right, linen-stitch through the pairs they meet at the left and right respectively, and are twisted three times, but no pins are placed under these two joints. The two center pairs now linen-stitch and are twisted three times, when they recommence the stitch and are supported by pins. Thus four pins are used to a complete motif, placed under the joints of the four outer arms. The pricking shows four little squares, each corner of which is marked by a pin-prick. 


\section{LINE C, COL. 10.}

Devonshire Winkie Pin Bars and Cutworks.
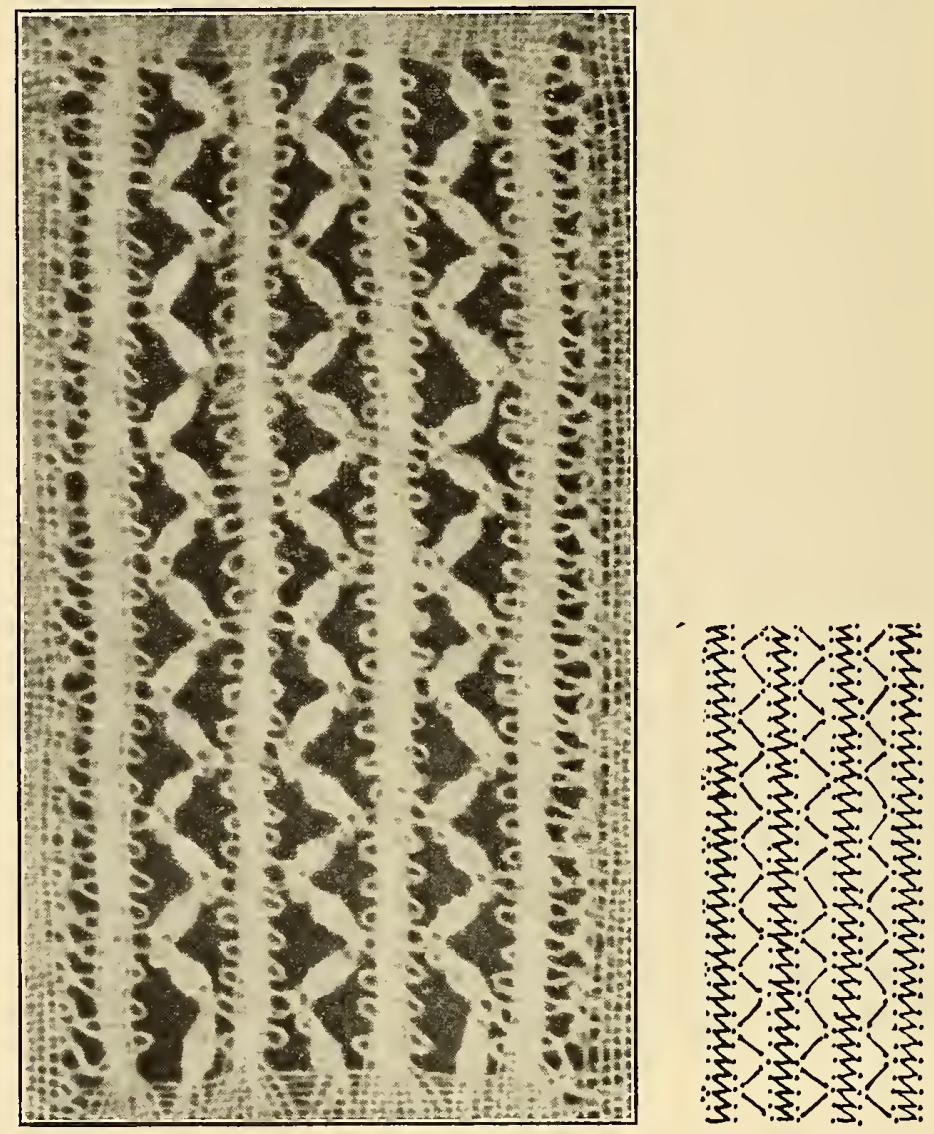

This ground is made in almost the same way as the Bohemian Edged Devonshire Bars and Cutworks, Line D, Col. 10. There are two differences; one lying in the edge of the bar and one in the direction of the leaf zig-zags. In Line D, Col. 10 , the different bands of petals have been made in parallel lines. In this ground the zigzags have been made to wave in opposite directions. The edges of the vertical bars in this sample require only five pairs, as the same weaver continues throughout, being twisted twice around the winkie pin. 


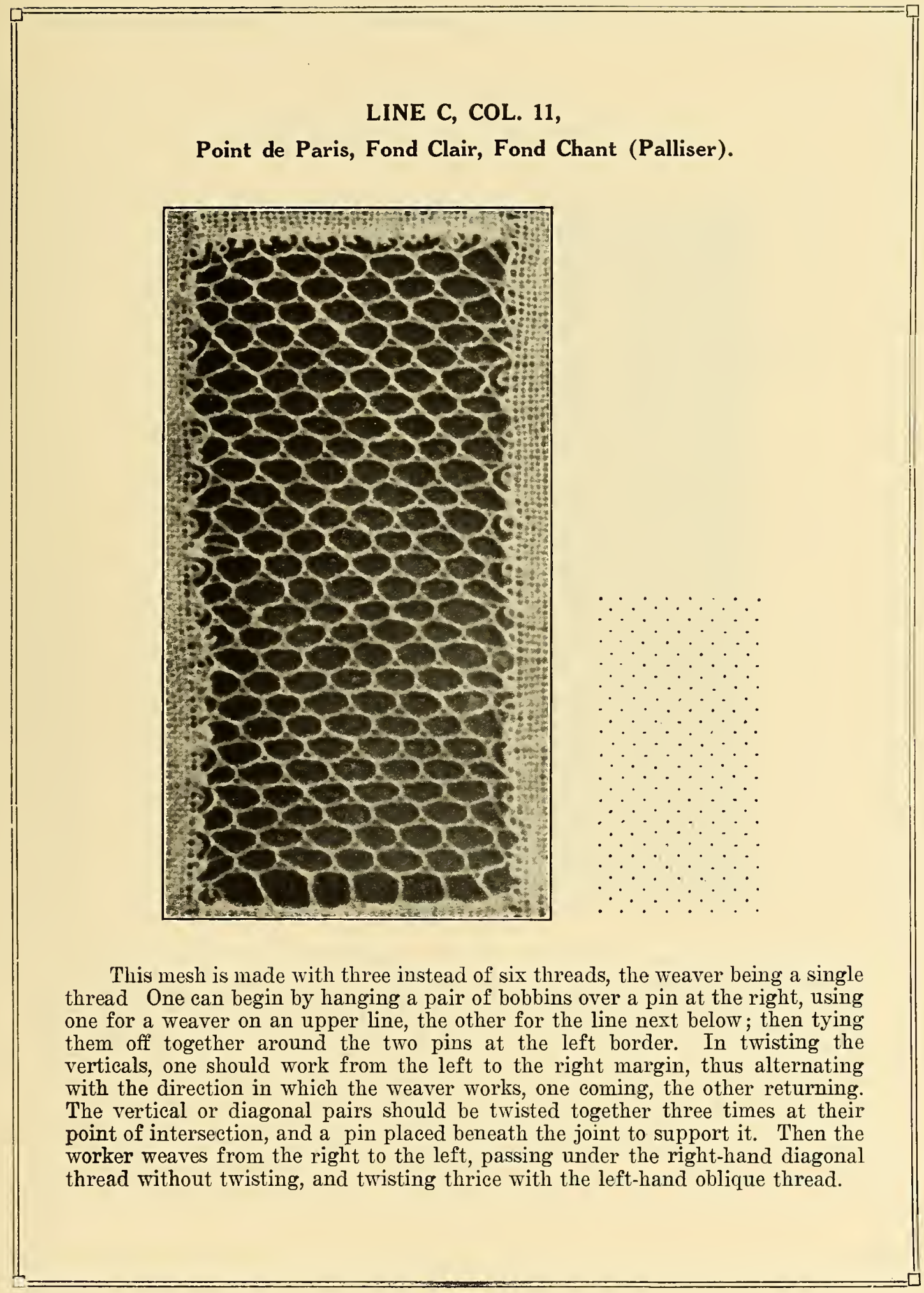


LINE C, COL. 12,

Trude "H" Ground (original) (American).
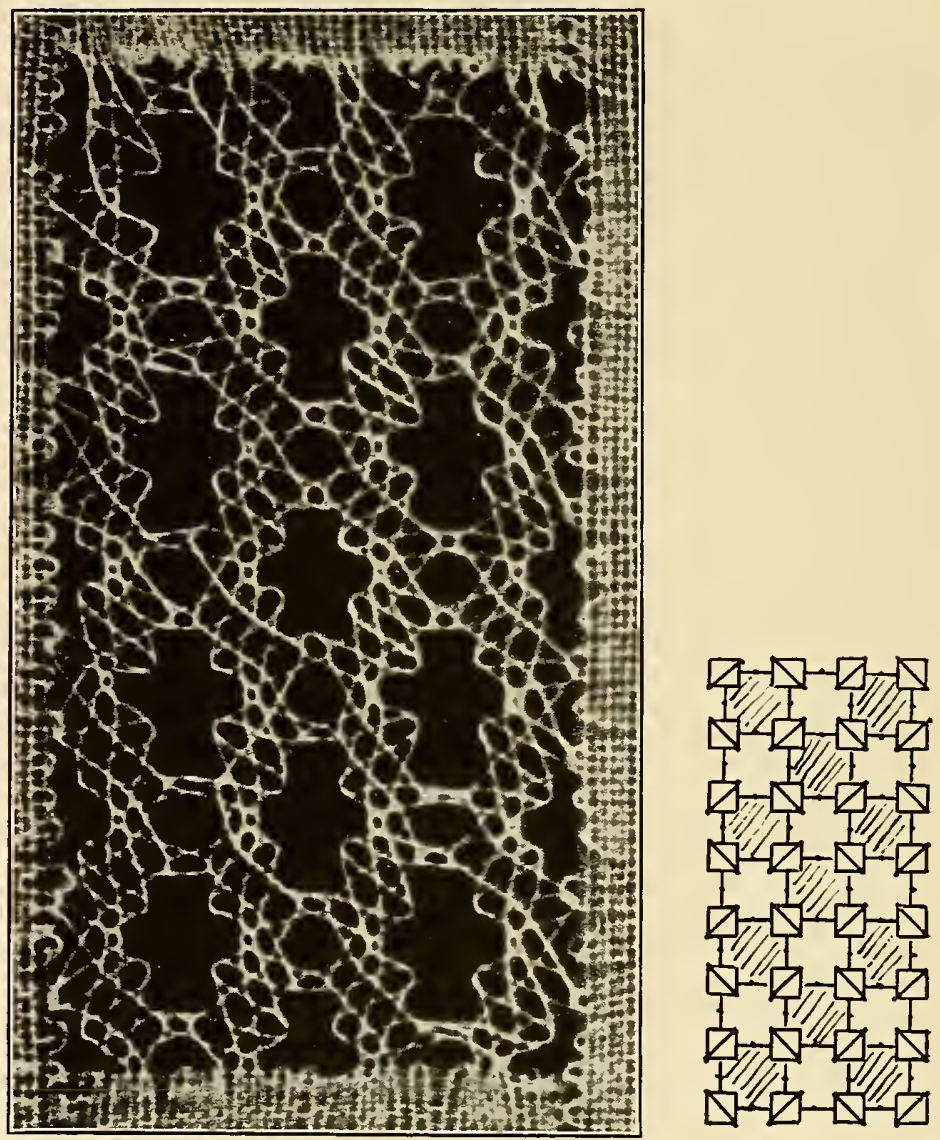

Three pairs enter at the upper left-hand corner, and three at the upper righthand corner. The ground is entirely made of half-stitch : but it is twisted twice outside of every pin to reinforce it. Beginning at the upper left-hand corner, with the left pair as conductor, one weaves through the middle and right-hand pairs, pins, closes, works to the lower left of the little, corner ornament Then works toward the right again, entering the big square. The upper righthand ornament is made in just the reverse way, starting thus $\rightarrow$ from the right, and working towards the left to meet the weaver of the opposite ornament. They meet at the center top of the large square. Here a pin is placed, each 


\section{LINE C, COL. 12-Continued}

\section{Trude " $\mathrm{H}$ " Ground (original) (American).}

pair twisted twice, and the pin closed. Each weaver works back towards its own side, through two, pendant pairs and is pinned and closed at its side of the large square. Then the weavers work towards the center bottom; meet and go out into the two little square ornaments: the right-hand weaver now becoming the upper left of the succeeding, large square and therefore doing what was before done to make the upper left ornament. It leaves the large square, works towards the right is pinned and closed, Z works towards the left, is again pinned and closed, and proceeds into the next large square. The oppositc, corresponding weaver does just the reverse.

This ground would not wash well. 


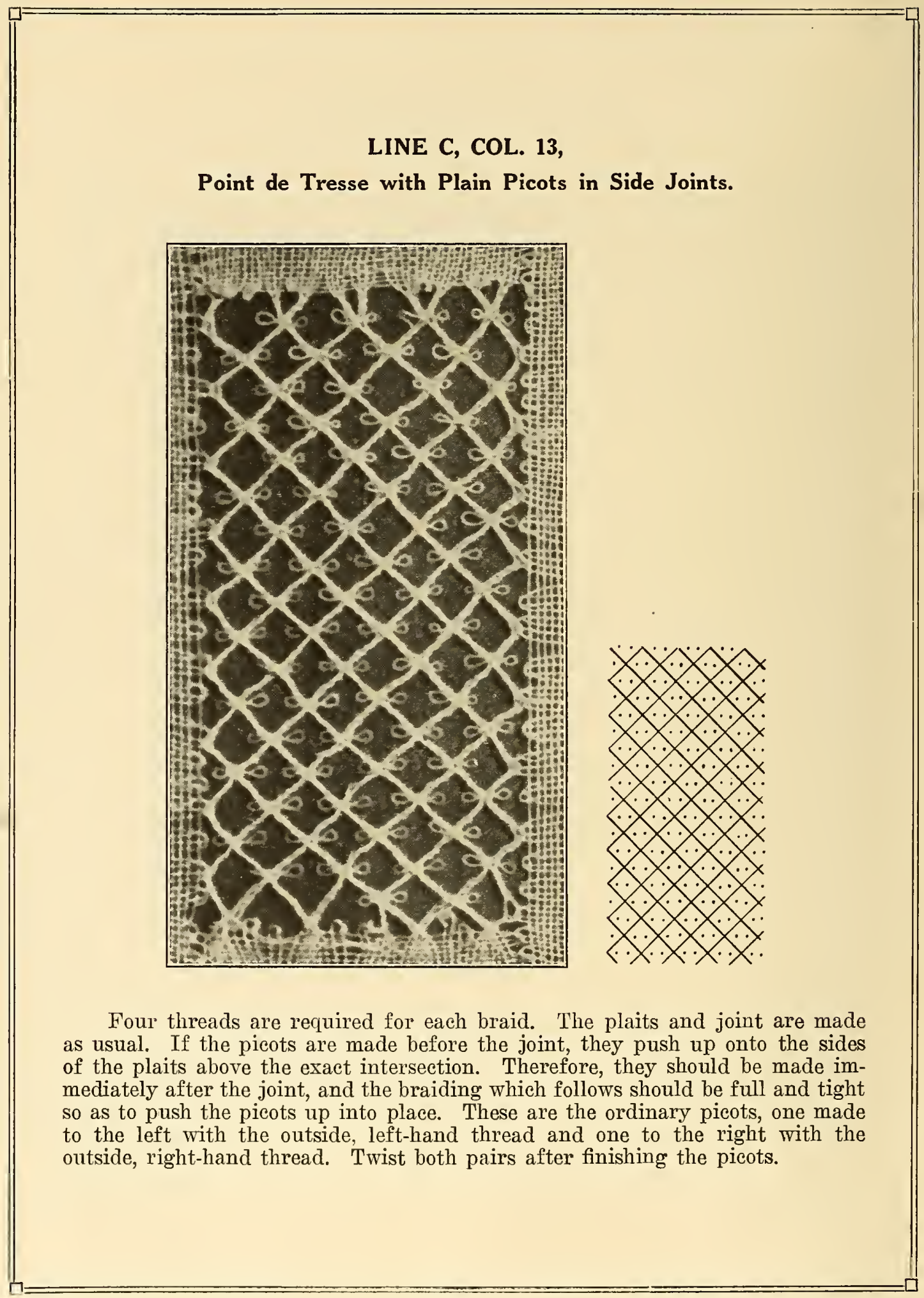




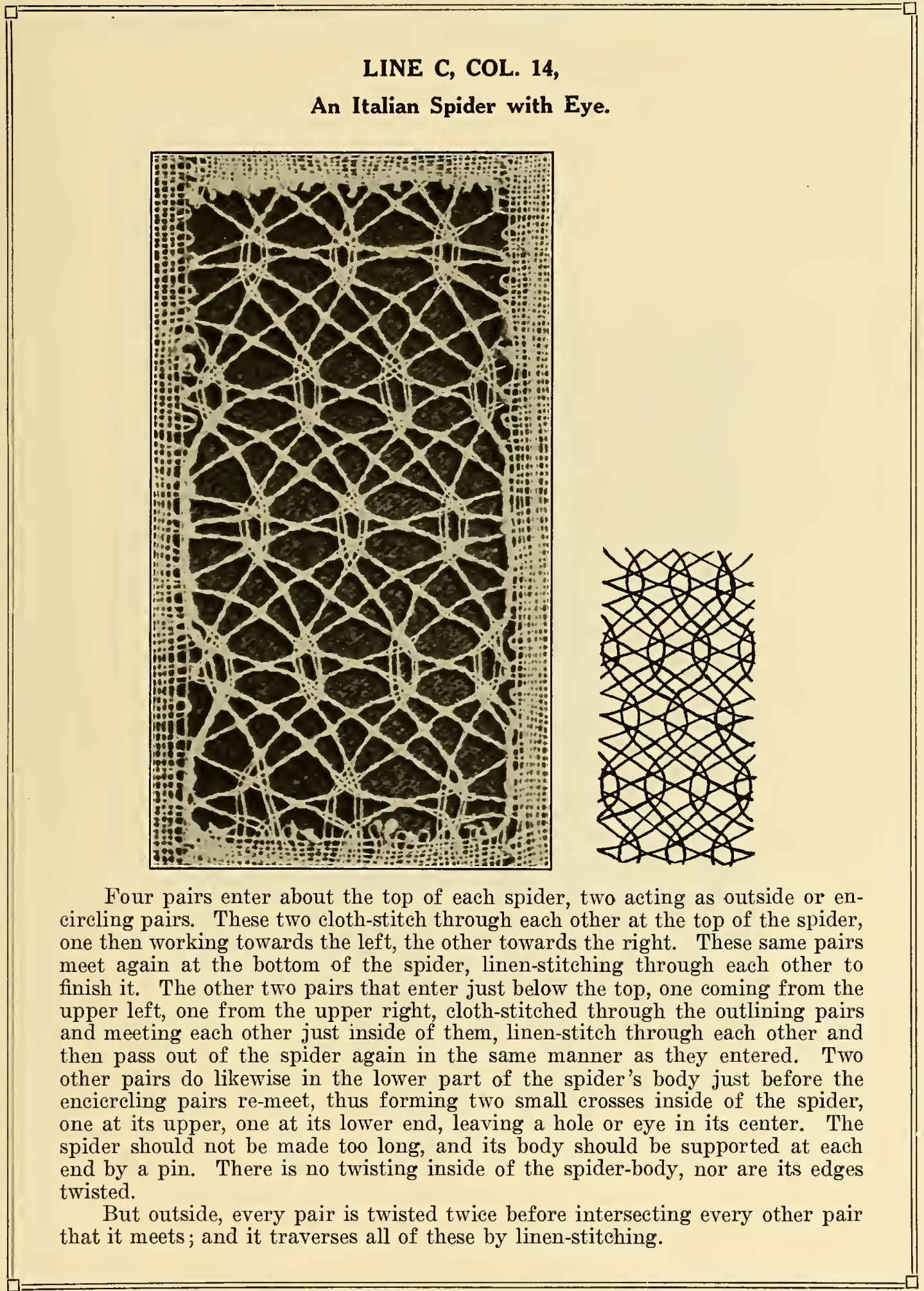


LINE C, COL. 15,

Thin Cluny Petals, Leaves, Armelle, Armeletta, Grains, Seeds, Wheat Ears, Paddles.

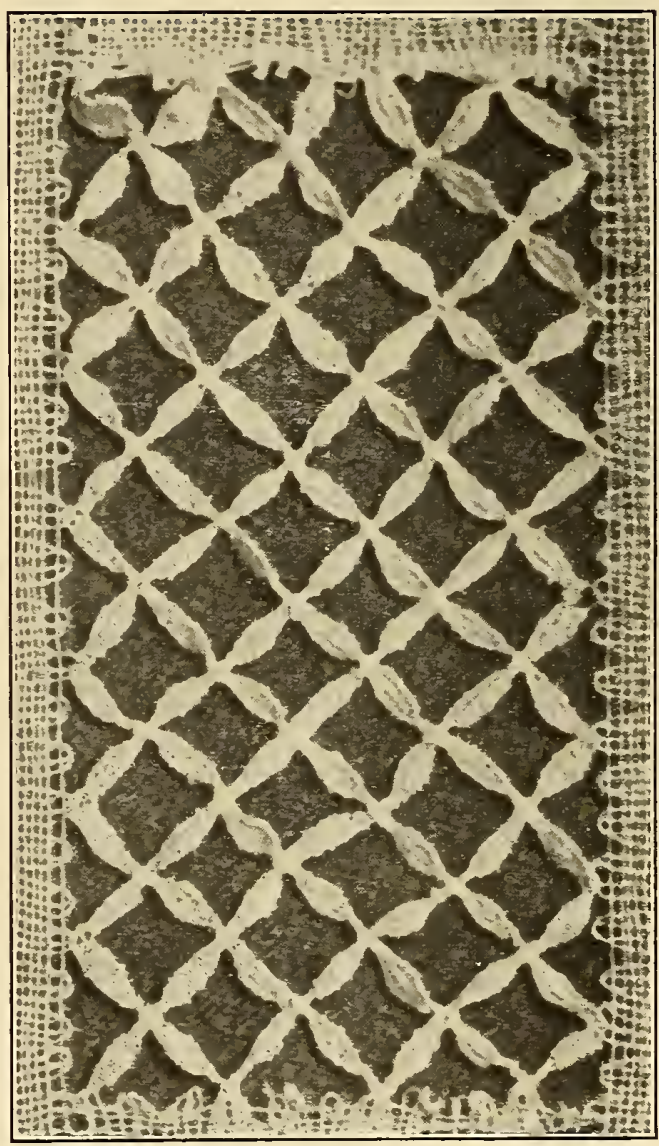

These petals are made like those of Line B, Col. 15, except that they are attenuated in form. 
LINE C, COL. 16,

Abruzzian Lescatelle.
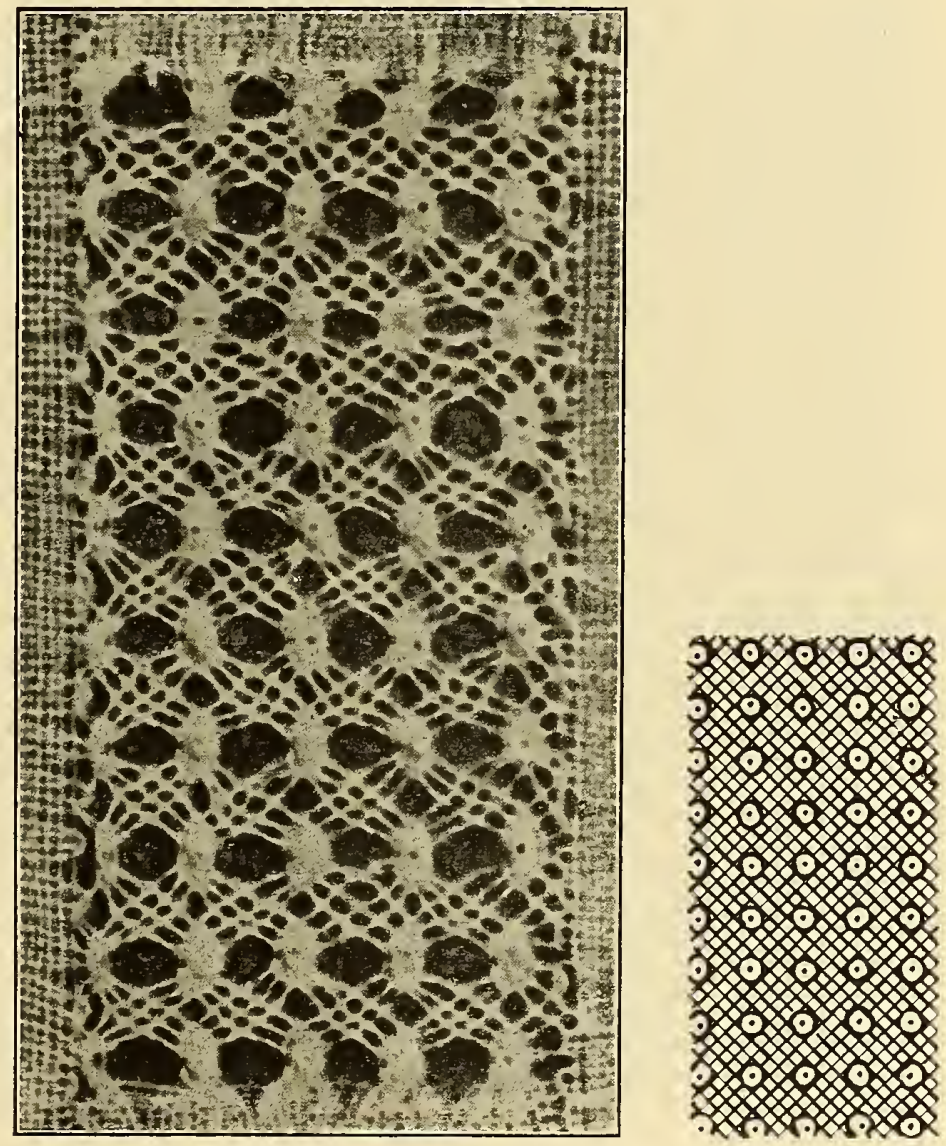

This is the same as line B, Col. 16, or Abruzzian Cross Pattern, except that it requires six pairs to make each spider, and that between spiders the three pairs leaving an upper left-hand spider cross diagonally through the three pairs of threads leaving the next nearest right-hand spider. 


\section{LINE C, COL. 17,}

Trude "P" Ground (original) (American).
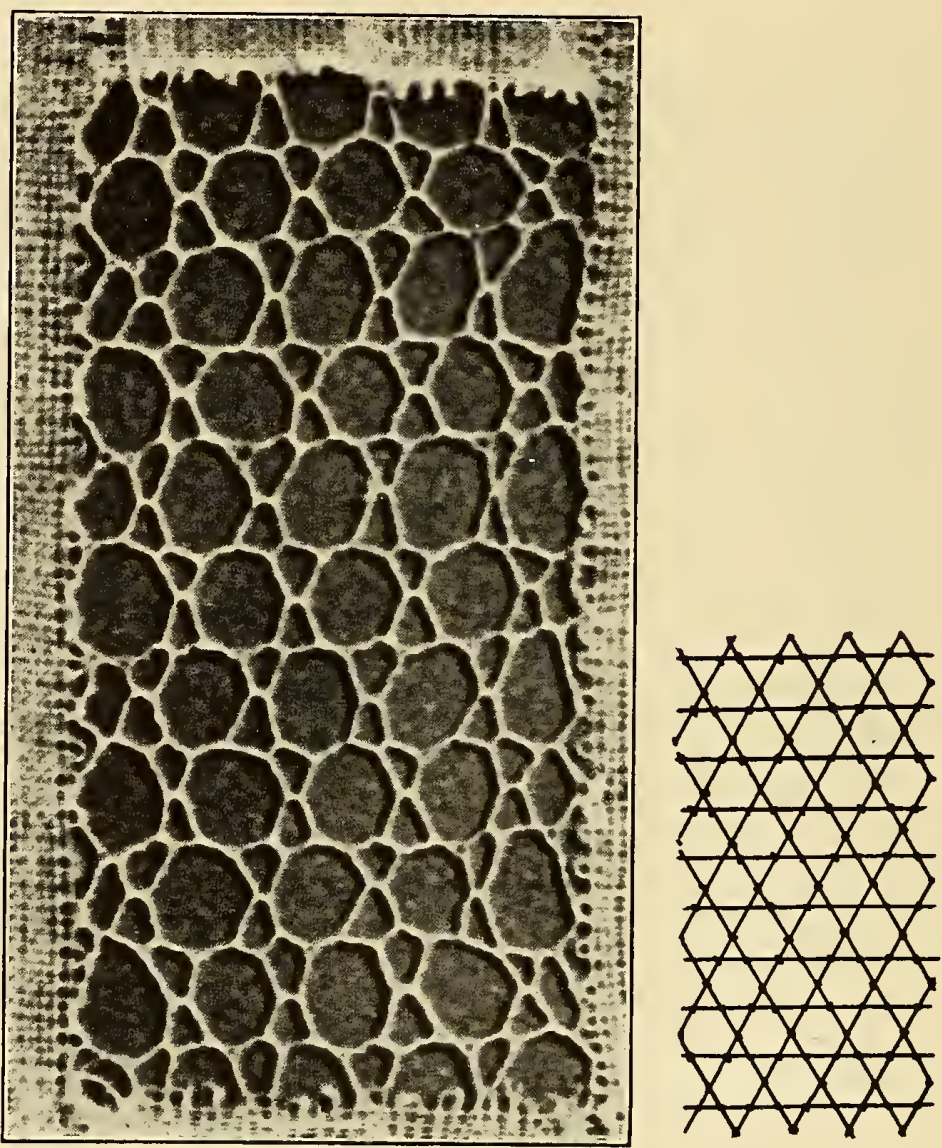

The pairs are twisted four times and crossed and one must be careful to take up the correct pairs. The pins are not closed. On one horizontal line a pair works across towards the right, twisting four times and crossing as it goes. When it returns, it weaves from the right towards the left. This reverse action tilts the circles slightly first to one side, then to the other. The horizontal pair always works with the very next hanging pair it encounters. Between the horizontal lines, wherever two pendant pairs meet each other, they are interwoven with the same four-twist-and-cross stitch. 
LINE C, COL. 18,

\section{Genoese Grilled Six-leaved Marguerite.}
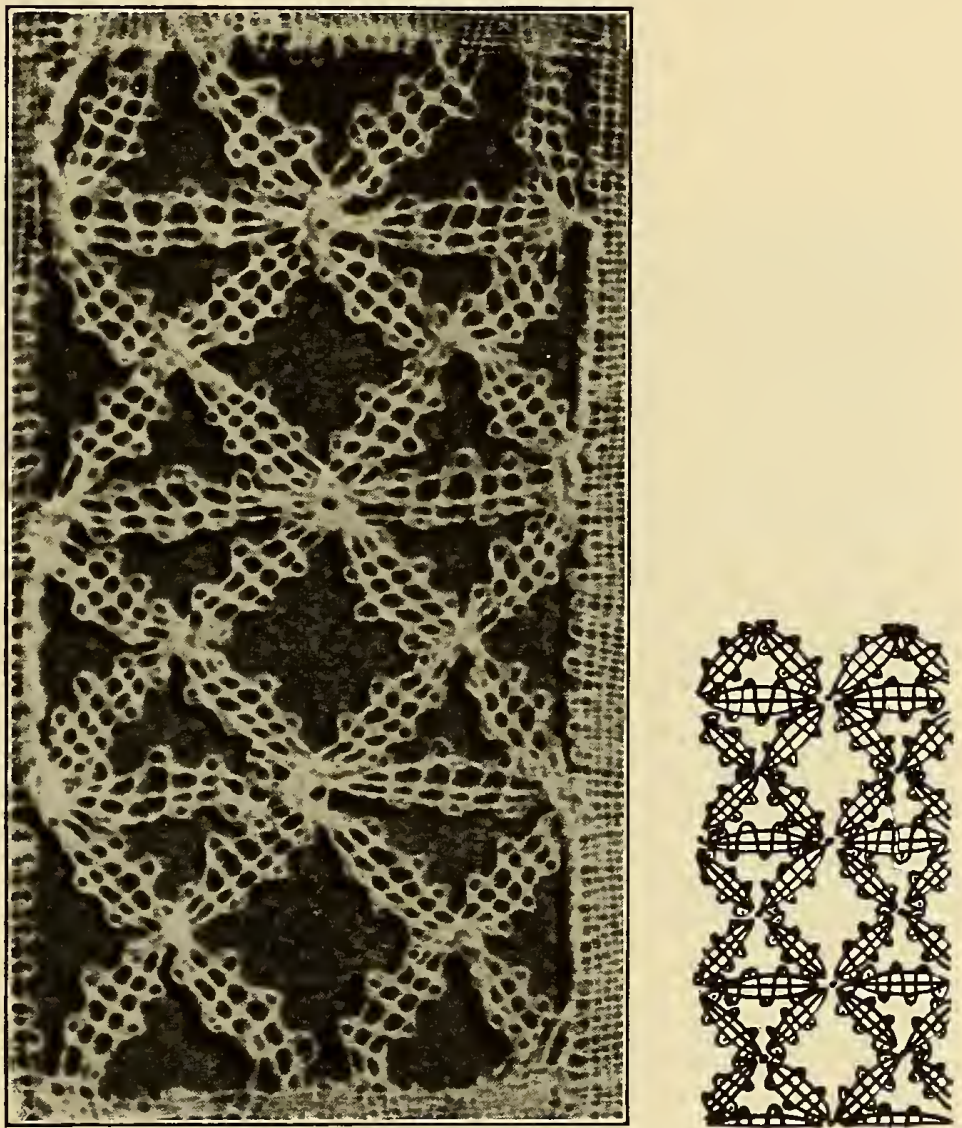

Each leaf or pétale requires four pairs. Every pair is twisted once between intersections. One pair serves as a weaver and is fastened Winkie Pin fashion - that is, outside the leaf around a pin, the same pair continuing as weaver. There are three pins on each side of every leaf. After the last passage or interweaving of the conductor nearest the center of the "Marguerite," each pair including the weaver, is twisted once ready to make the "Marguerite" or daisy center. Here, if two leaves intersect, they do so like two Cluny braids, two pairs used as one single thread. If three intersect, the two top diagonal ones cloth-stitch like two Cluny braids, and a pin is placed; then the third horizontal leaf, cloth-stitches through these upper two, each two upper pairs being used as one single thread. The pin is now removed and replaced below the triple intersection, and is closed by again cloth-stitching the eight diagonal pairs, using two pairs as one thread. 


\section{LINE D, COL. 1,}

Twisted Hole Ground, Tulle Double, Maglia di Spagna.

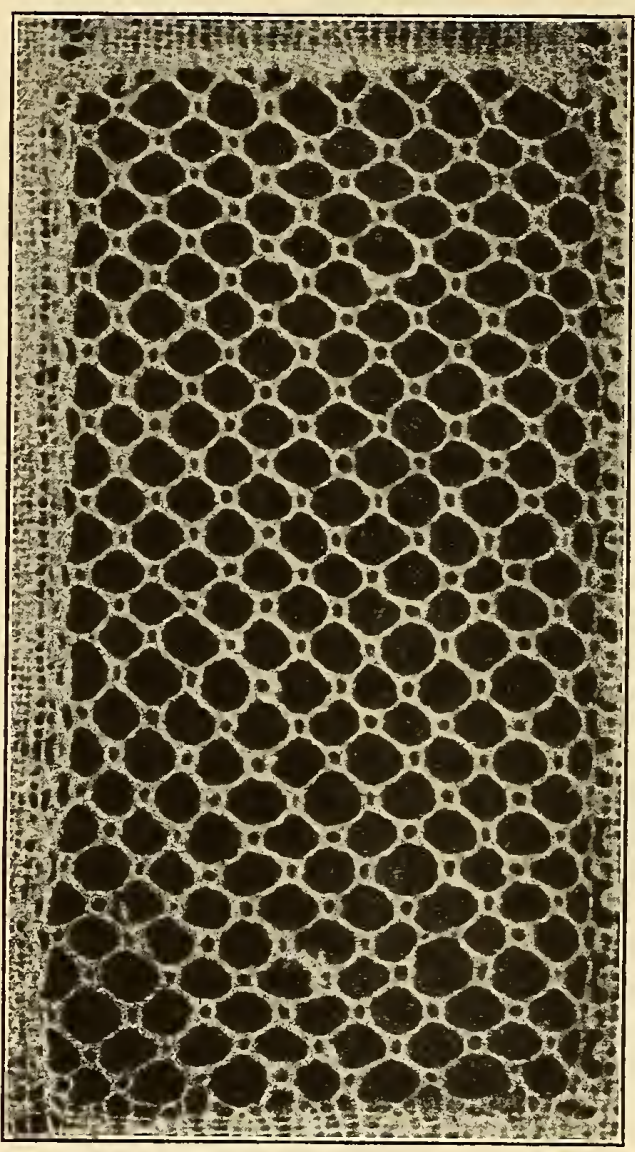

This net is easy, strong and dainty. Is made by twisting twice and crossing, placing a pin, and twisting twice and crossing to close it. 
LINE D, COL. 2,

Flemish, Trolle Kant, Fond Armure, Spinnekop.
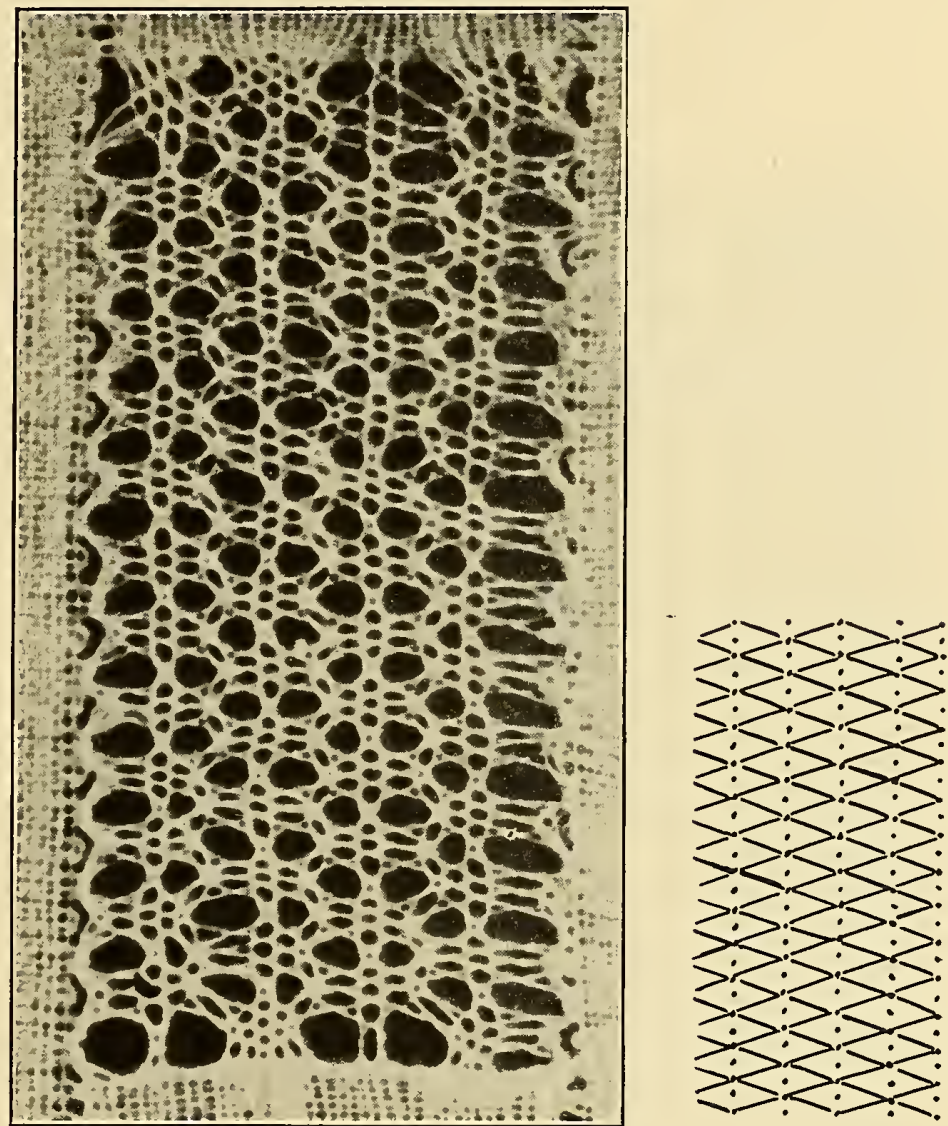

One of these meshes requires six pairs like the six legs of a spider, two at the left, two at the top, and two at the right. The body is made by means of half-stitch. A pin should be placed at the top and the bottom of each spider between the central legs. One begins below the top pin by making a half-stitch. Then the right-hand leg traverses with a half-stitch all the right-hand pairs, and the other leg all the left-hand pairs. Then one returns to the two central pairs making another half-stitch, and again traversing for the second time all the right-hand and all the left-hand pairs. One then returns to the center and does this a third time. Then to finish the body one half-stitches with the two pairs now at the center and places a pin below them. Now one uncrosses the two legs at the left and the two at the right, which should be twisted only and not crossed between one spider and the following one. Only the central legs begin and end with a full half-stitch. 
LINE D, COL. 3,

Droschel de Bruxelles, Drochel.
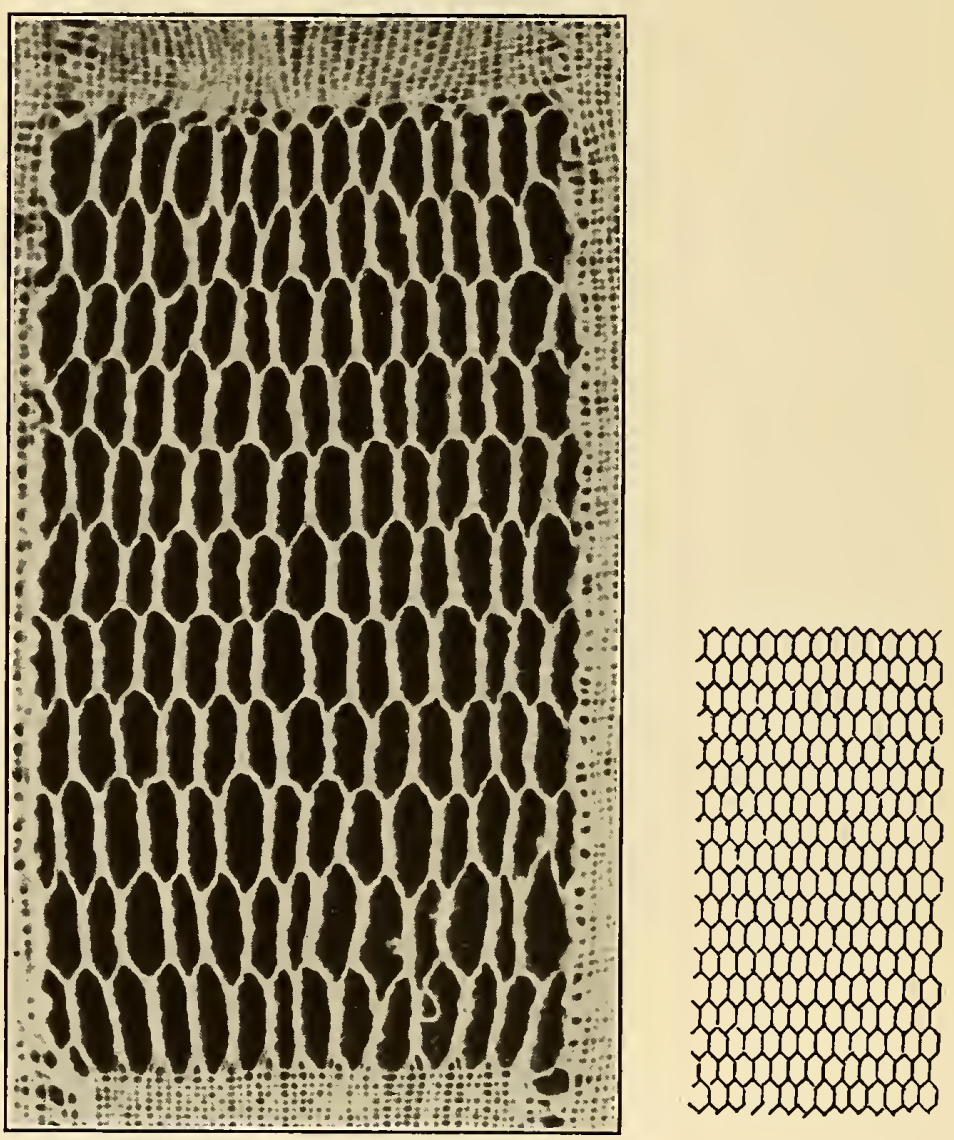

The principle of this mesh is the same as that described under Lines B and C, Column 3; except that at the top and bottom there is only one twist, and that the sides are twisted and crossed six times.

This is not the usual Drochel de Bruxelles. 


\section{LINE D, COL. 4,}

\section{A Flemish Filling, a Lille Mode.}
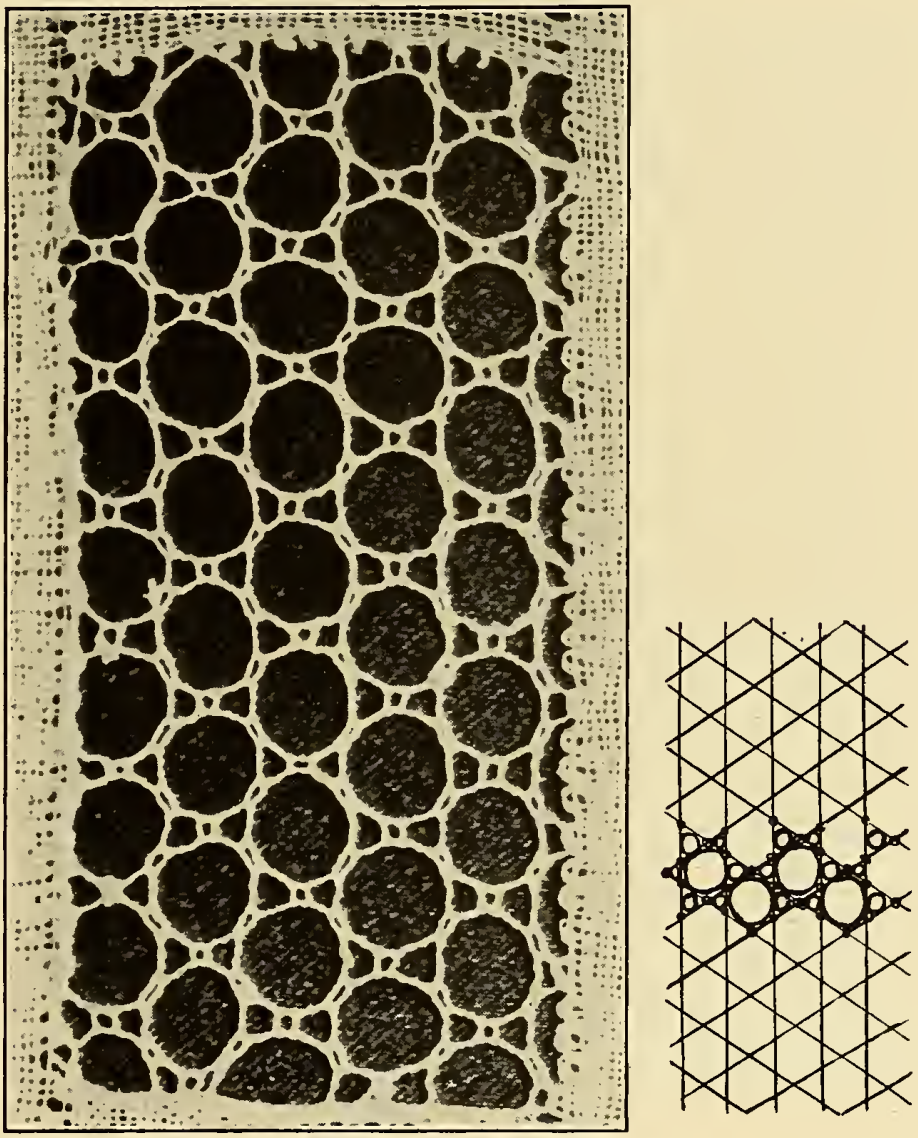

This is made in almost the same way as Line C, Col. 4, "Rose Ground, Scandinavian Ground, Point du Mariage, Gelosia, Tulle Double," except that the pins are so arranged as to make the mesh more circular, less elliptical; and that the pairs are twisted three times before each crossing instead of being twisted only twice. 
LINE D, COL. 5,

Plain Lattice Ground, Filet, Einfacher Gittergrund.
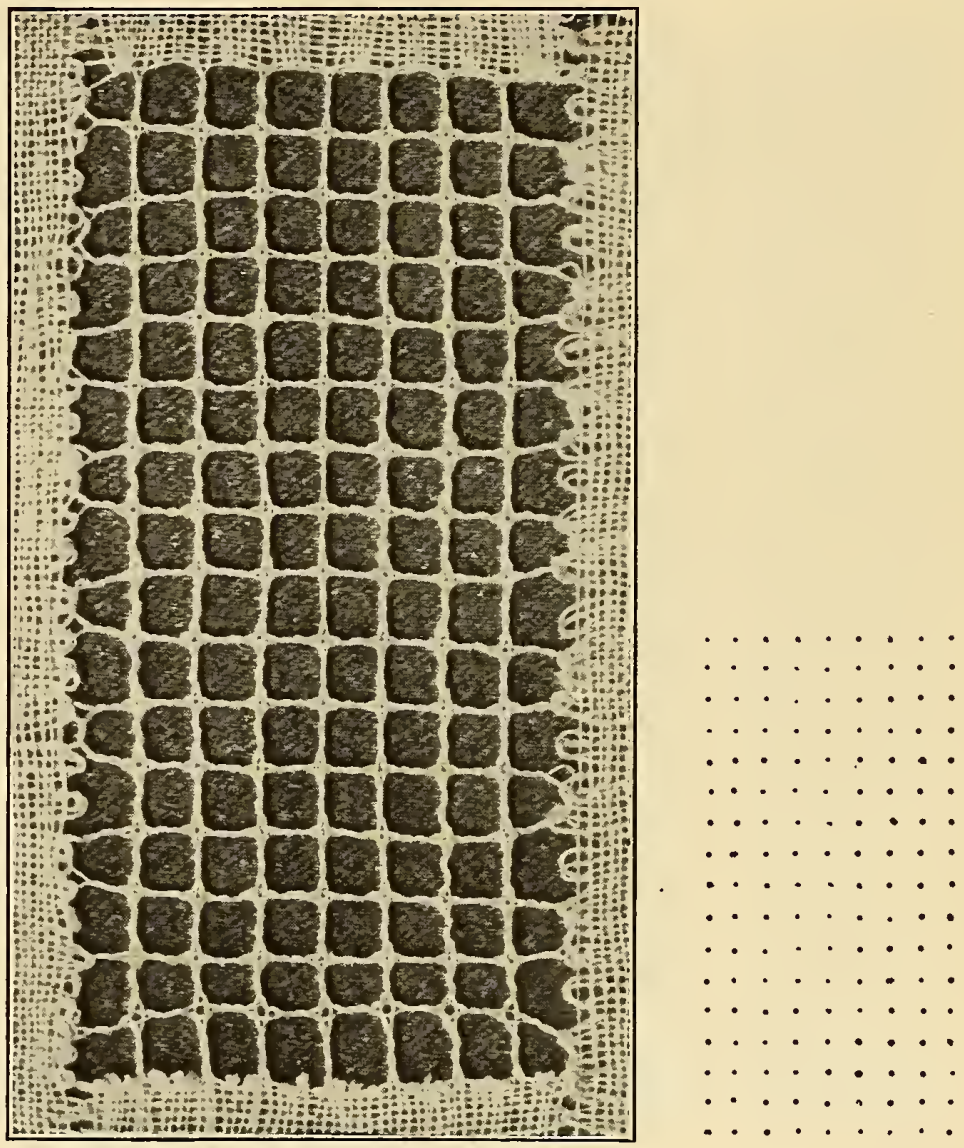

Every pair is twisted three times between intersections. The joints are made by linen-stitching. A pin should be placed in the center of each joint and left there until the corresponding joint on the line below is ready to be pinned. The upper pin should then be removed in order to prevent leaving a hole; but it is necessary to use pins in order to preserve the alignment of the threads, which must be pulled well into place. 
LINE D, COL. 6,

Ornamental Ground with Striped Effect in Diagonal Squares. Ziergrund mit Streifen-Musterung in Karo-Einteilung.
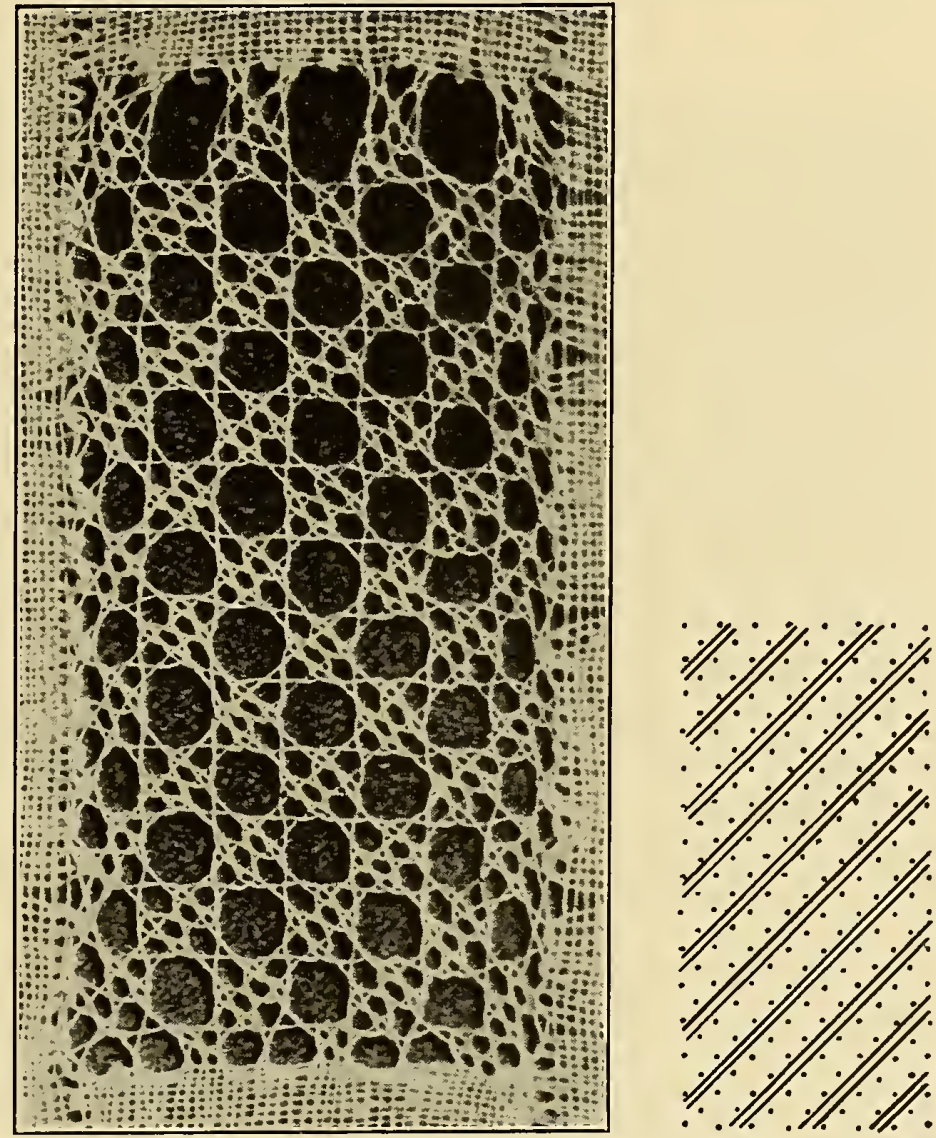

The two pairs entering the upper, left-hand ornament are twisted once, crossed and twisted once. The two pairs entering the upper, right-hand ornament are treated in the same way. The two pairs now at the center, one from the left and one from the right, are twisted once and crossed. Here at the center top a pin is placed and closed by twisting once and crossing. The pairs lying upon the pillow may now be considered in their order from left to right as first, second, third and fourth. The third and fourth pairs are twisted once and crossed. A pin is placed at the center right and closed by twisting and crossing. Then the third and second pairs are twisted and crossed without pinning. Then the second and first pairs are twisted once and crossed; a pin is placed at the center left and closed. Then the second and third pairs are twisted once and crossed; a pin is placed at the center bottom and closed, and one is ready to make the lower ornaments as they were made above. 
LINE D, COL. 7,

Square-meshed Valenciennes of Bruges, Ypres and Alost (braided 4 or $4 \frac{1}{2}$ times).
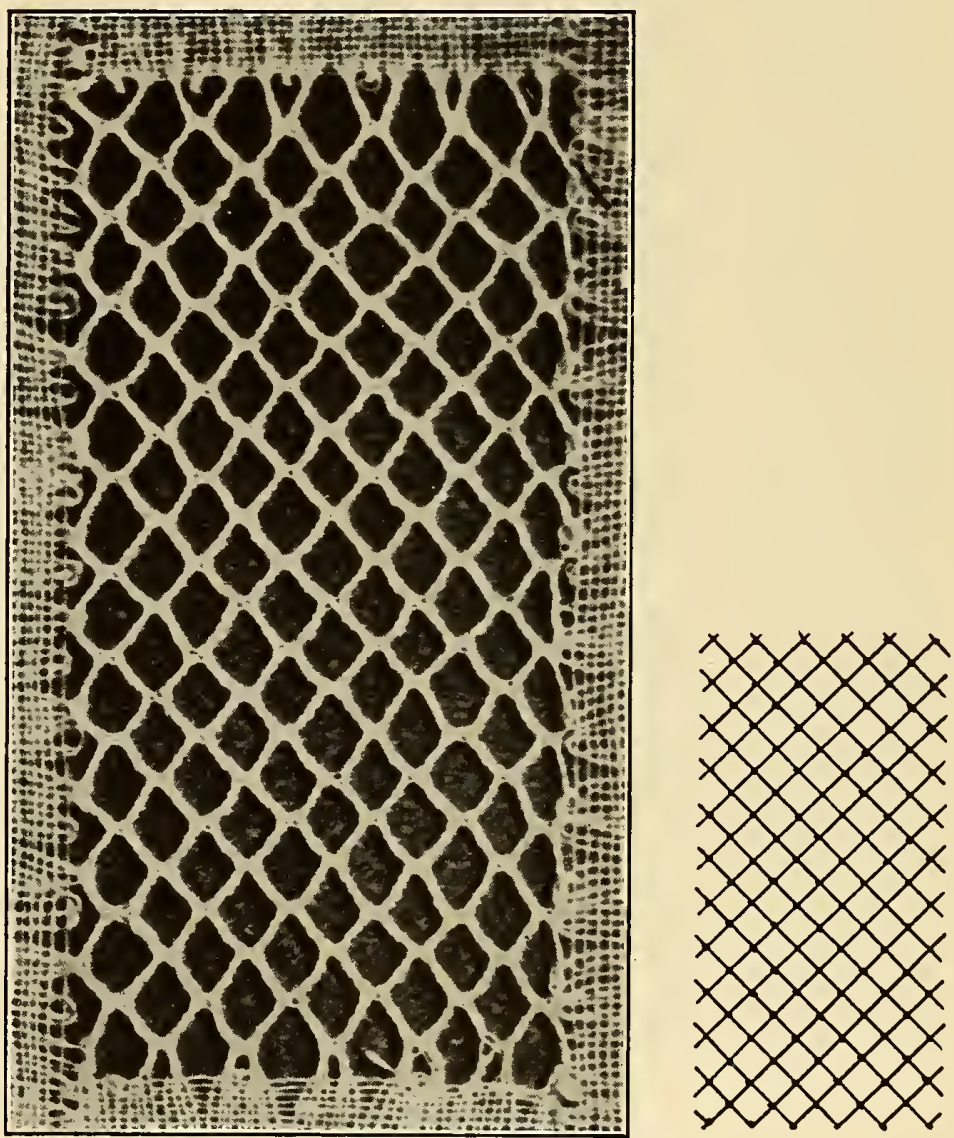

See Line A, Column 7, line B, Column 7 and Line C, Column 7. The square-meshed Valenciennes of Bruges, Ypres and Alost is made in the same way as that of Honfleur, except that the sides of the meshes are braided four or four and a half times instead of one or one and a half times. This "Val" ground is more open and clear than the three mentioned above, throwing any pattern worked upon it into greater contrast and distinction. The mesh described under Line E, Column 7 forms an even clearer background. 


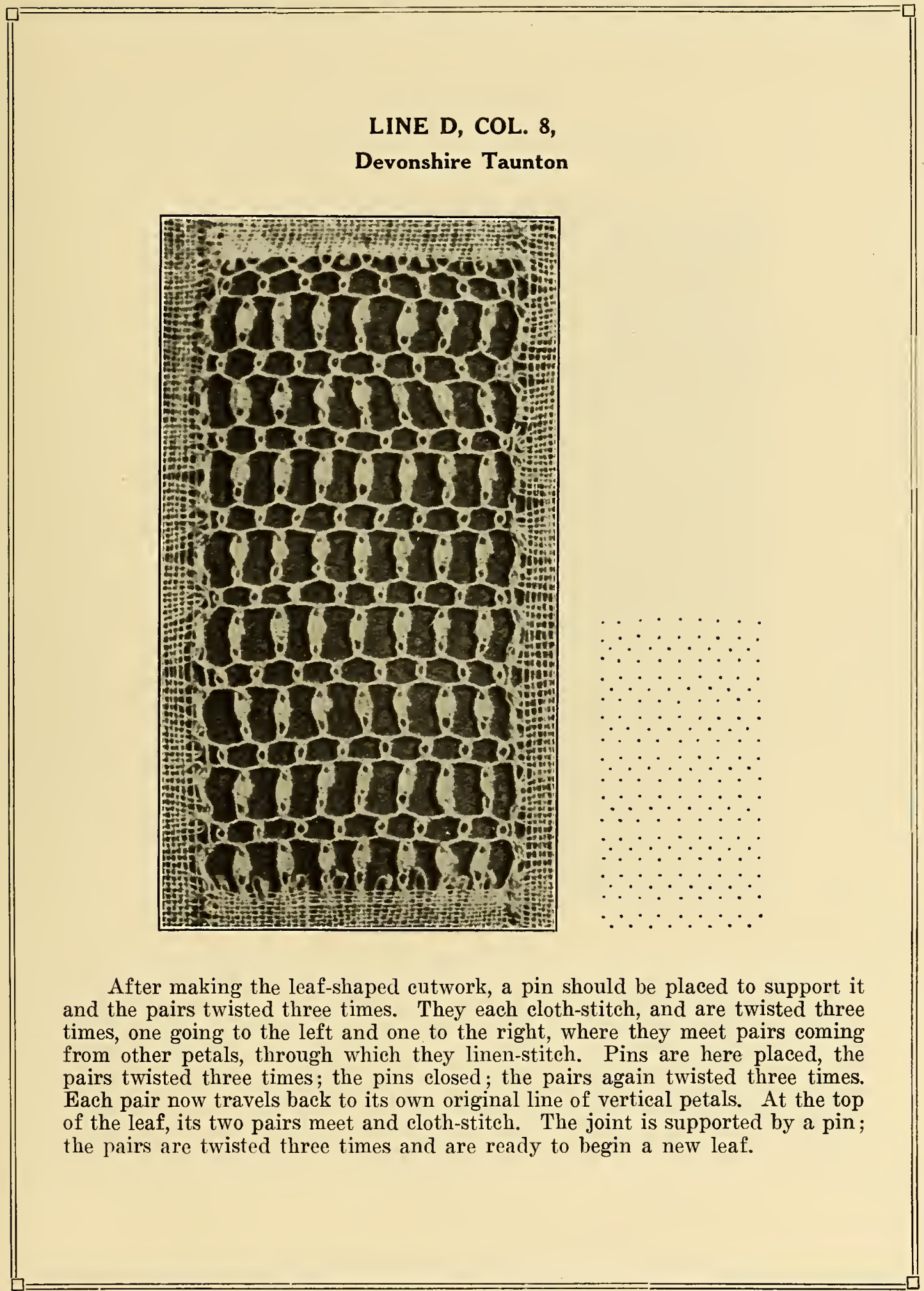




\section{LINE D, COL. 9,}

\section{Trude "C" Ground (original) (American).}
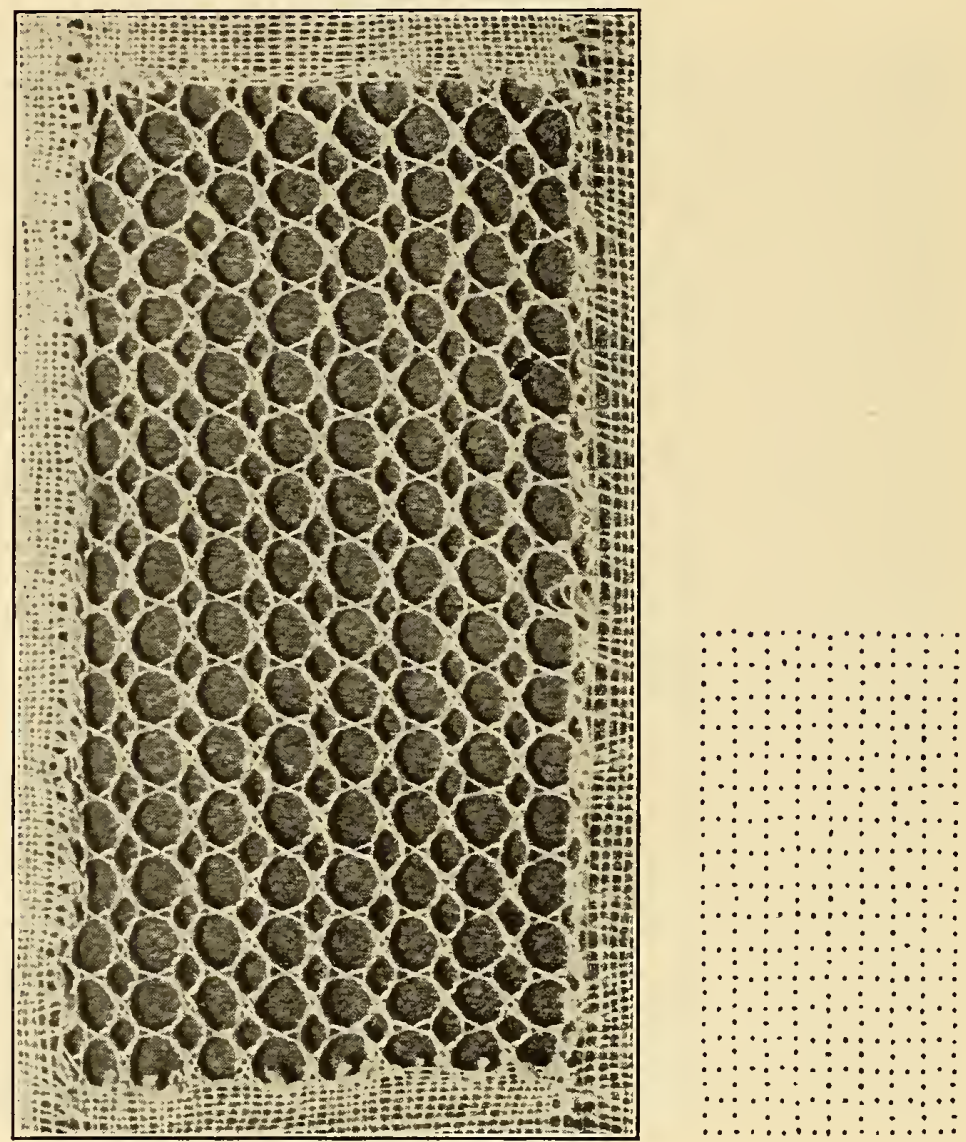

Three pins are placed, one directly above the other, through the centers of the squares, and one pin to each side. The first three support three small crosses; the fourth and fifth, that is, the two to the side, support large crosses. Beginning directly above the top center pin; that is, the uppermost of the three, the pairs are twisted twice and crossed; a pin is placed. The pairs are then twisted once and crossed; a second pin is placed and the pairs are twisted twice. Crossings are then made with the pairs at each side; pins are placed under these long crossings to support them, and one is now ready to twist twice and begin over, the third pin at the bottom and the first pin at the top of a motif being the same. 
LINE D, COL. 10,

"Bohemian Edged" Devonshire Bars and Cutworks.
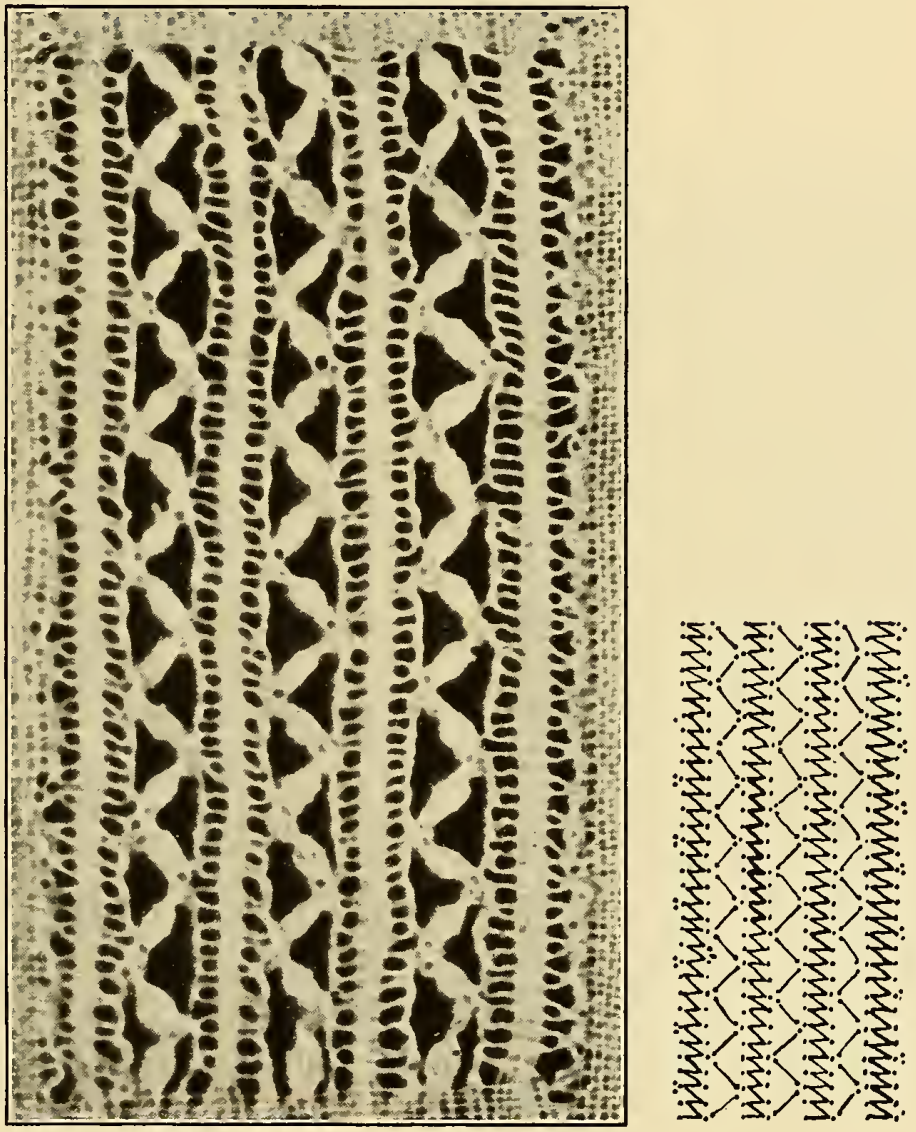

Six pairs are required for each bar, and two couples for each band or zigzag of cutworks. The center or solid part of the bars is made by linen-stitching. At their edges the weaver is twisted twice, cloth-stitched through the outside or edge, pendant pair, which has already been twisted twice, and hung outside of the pin : the former, pendant pair turning inwards and becoming the new weaver, is twisted twice before it enters the solid part of the braid. The leaves or petals are made in the usual way. At the point where they touch the braid, the leaf pair next to it, cloth-stitches in and out of the braid, a pin being placed in the center of the stitch to hold both the braid weaver and the leaf. 
LINE D, COL. 11,

Tulle Double or Redina Point de Paris Variation.
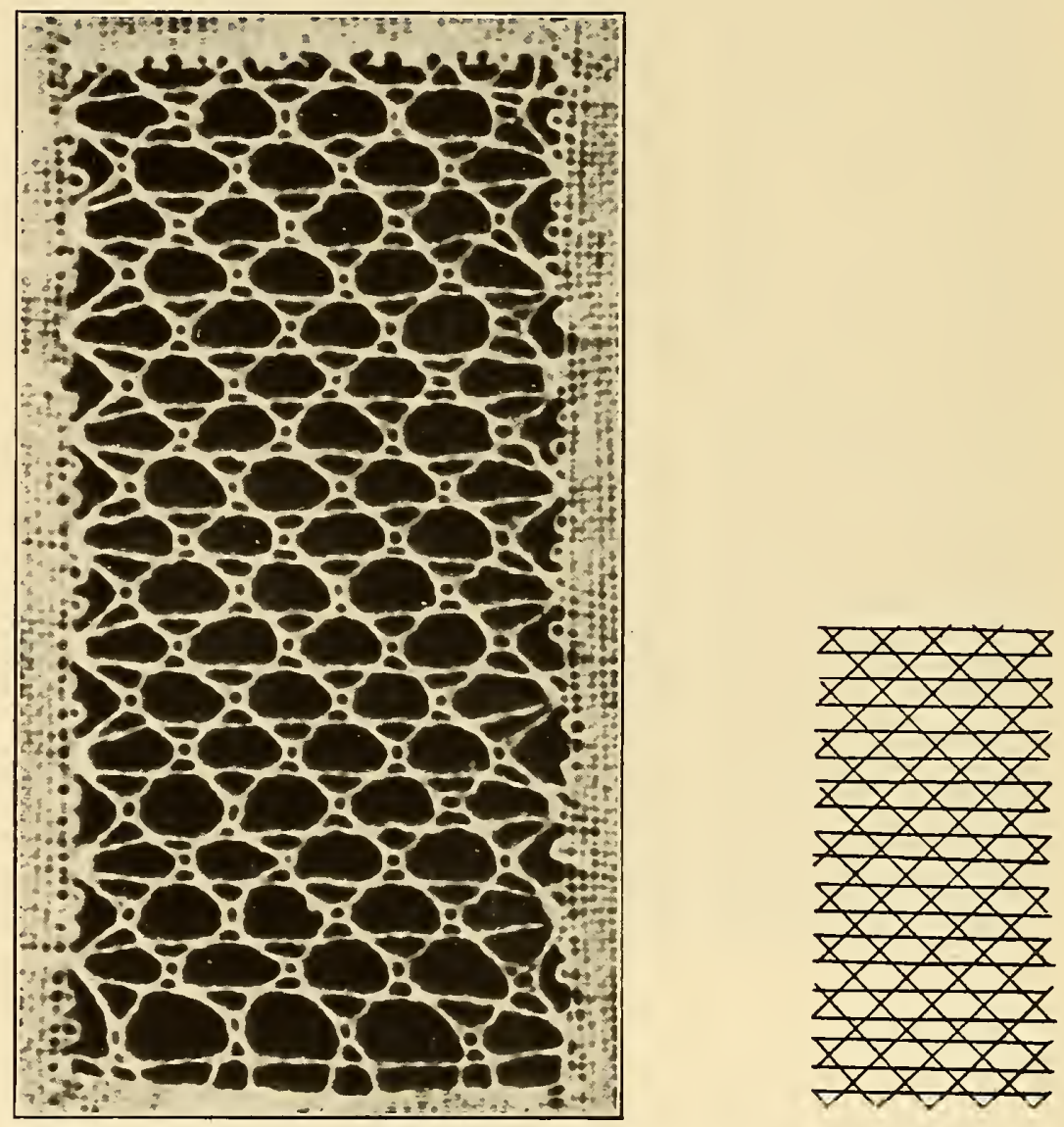

All the threads should be twisted twice between stitches. Where the diagonal threads meet after having been twisted twice, the two inner ones should be crossed, a pin placed, the pairs twisted twice, closed by crossing, and again twisted twice, ready to cloth-stitch through the horizontal threads, which should also be twisted twice. 


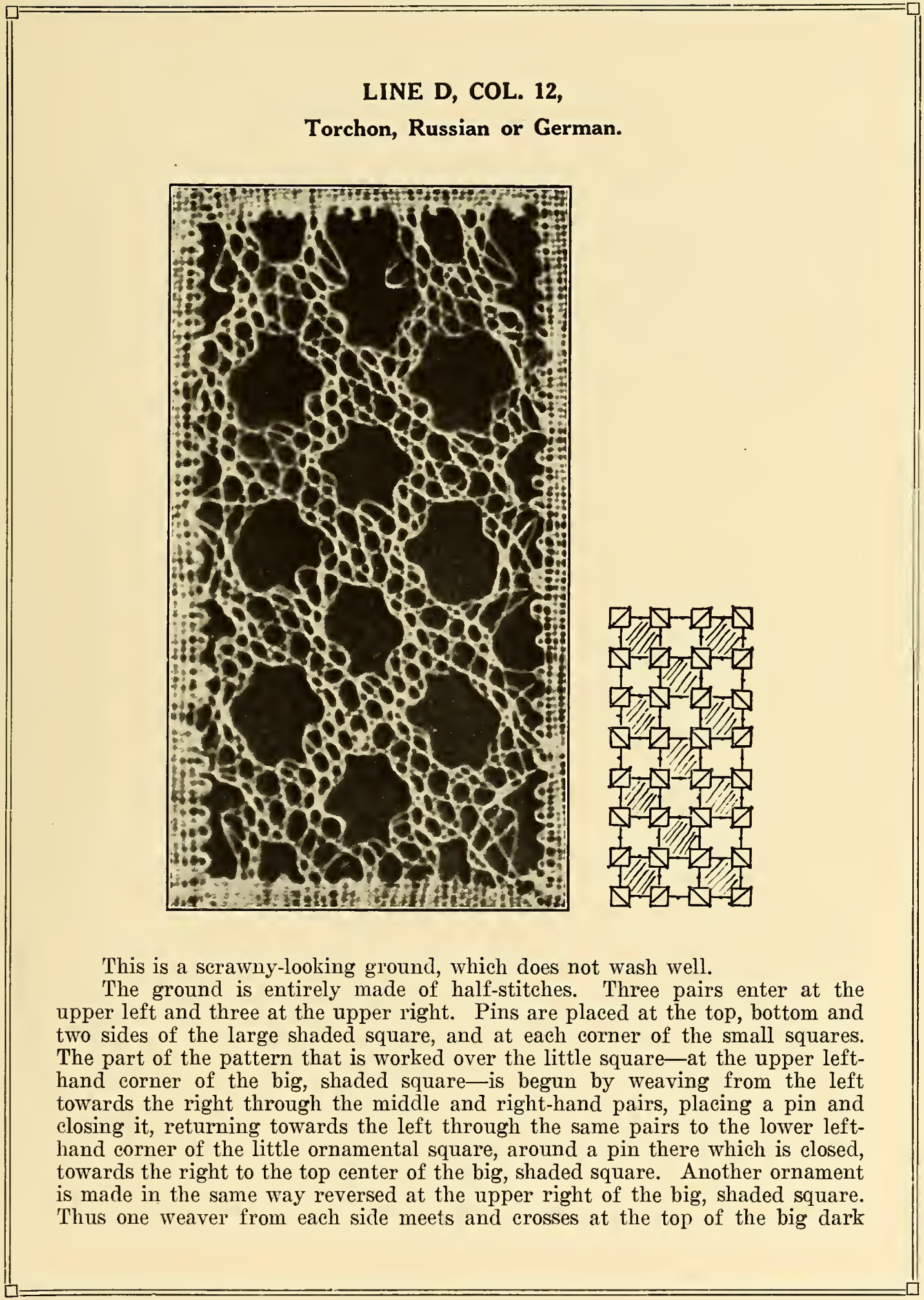




\section{LINE D, COL. 12-Continued \\ Torchon, Russian or German.}

square. Here a pin is placed and closed. After passing this pin, one weaver hangs at the left, the other goes to the right, half-stitching through the remaining pairs until it reaches the right-hand center pinhole, which is closed. One now works through the pairs hanging at the left, straight across to the left hand center where a pin is placed and closed. Then one works back towards the right to the center pin at the base of the large, shaded square. The pairs are now ready to make the little ornaments, which, though they are below the particular large, dark square upon which one has been working, are above large squares which are to follow; so that from here on the rule duplicates.

See Line C, Column 12. 


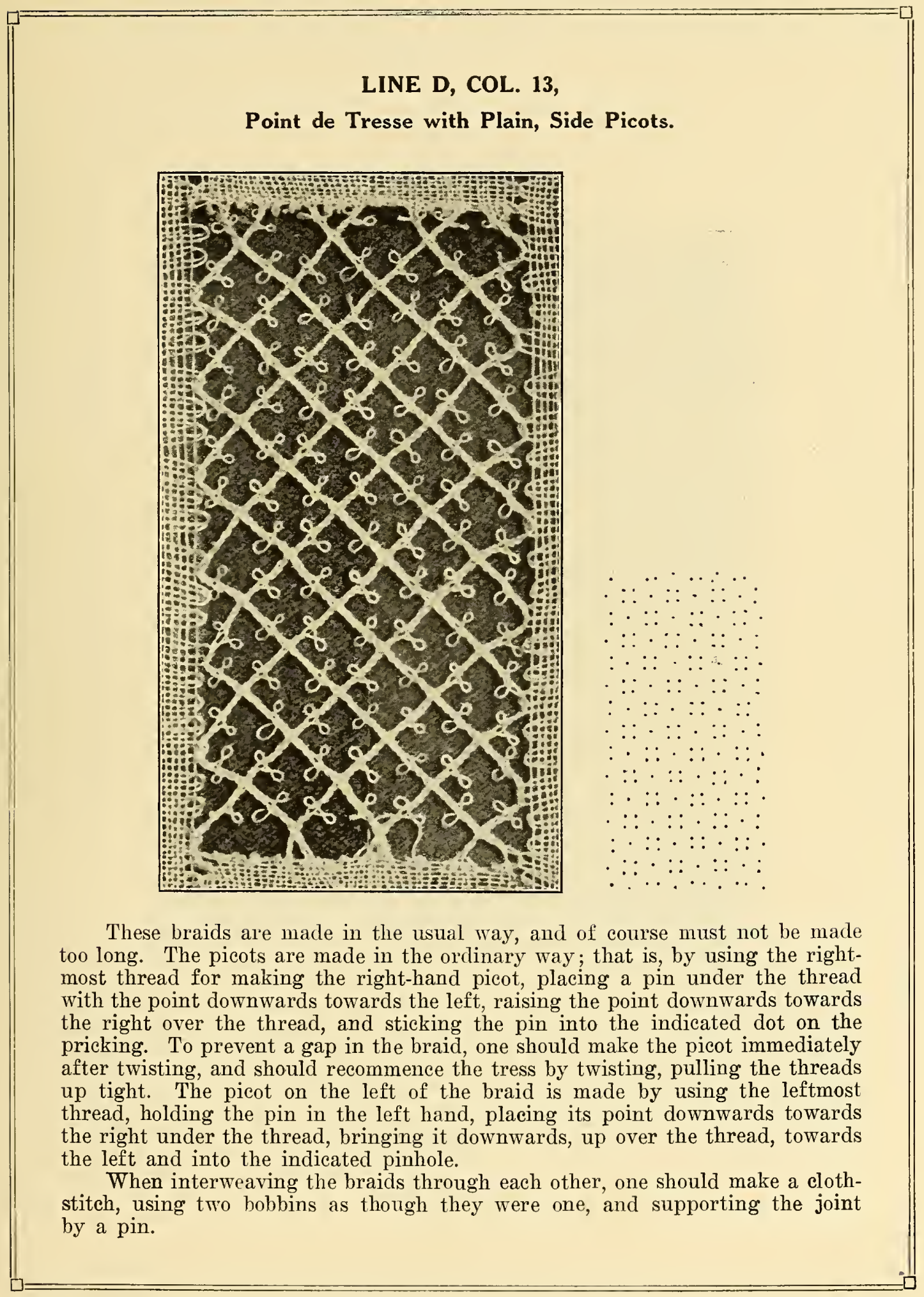


LINE D, COL. 14,

An Italian Filet with Toile Dots.
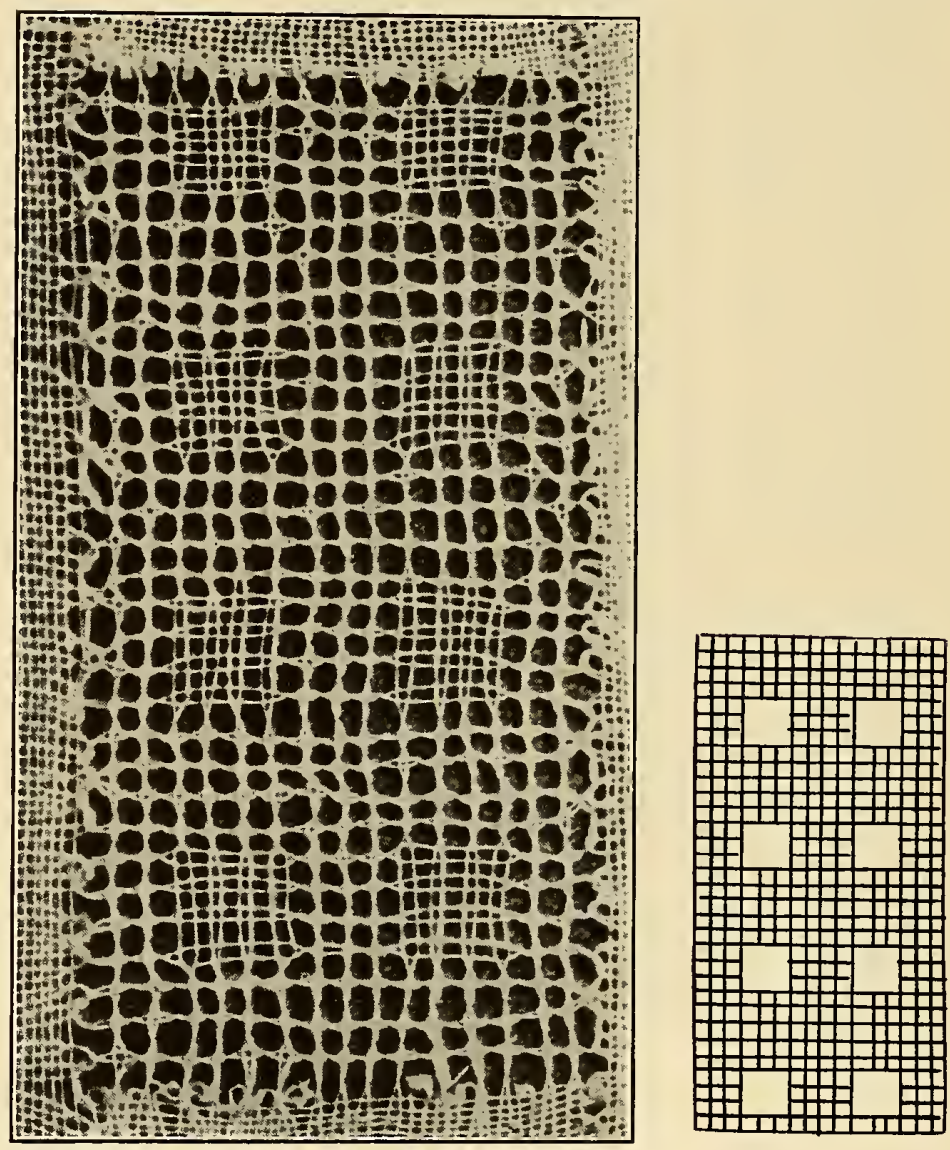

Four pairs enter at the top of the dot and the weaver traverses it in clothstitch twice from the right and twice from the left alternately, working all the way from one side of the lace to the other through both twisted grille and linenstitch dots. Each pair should be twisted once in making the grille. Pins are used only at the encountering edges as supports, or to guide one so as to avoid confusion. They should be placed in the middle of the cloth-stitch-that is, one thread above, one below, and one each side of the pin. 
LINE D, COL. 15,

\section{Double Picots.}

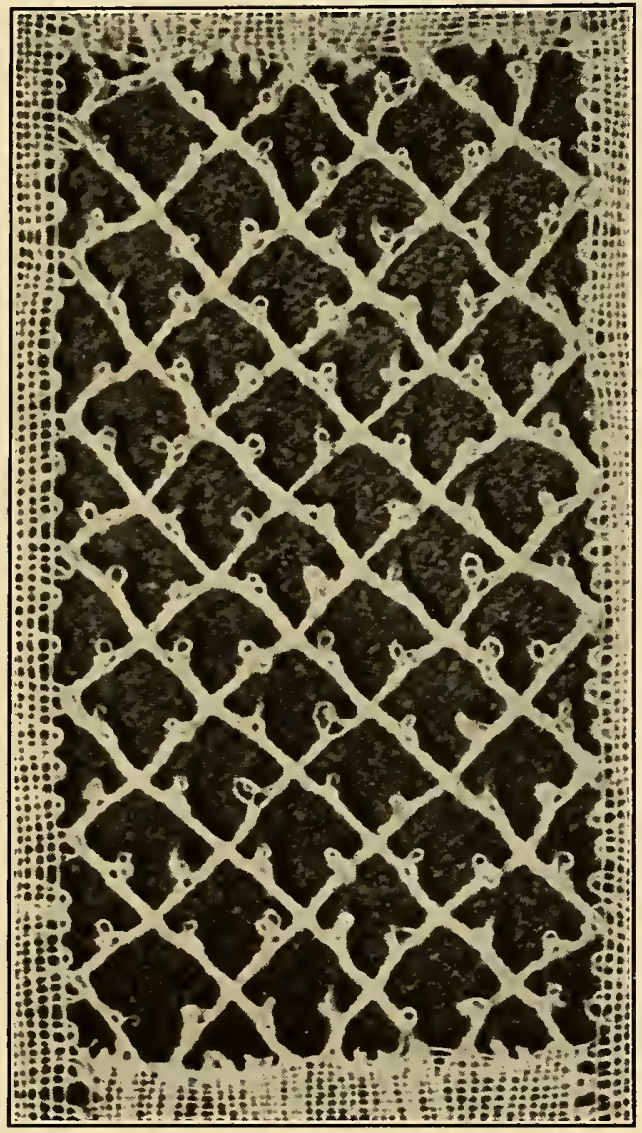

These cannot be made on both sides of a braid at the same spot, as that would leave an ugly hole in the plait, so one must make all the picots either towards the upper or towards the lower side of the tress. In this sample they are made downwards, towards the lower side. The pins holding the picots should be pricked right into the line of the braid, not to one side, as that would pull the plait to one side, out of plumb. Two of the braid threads are used for making the picots-the two that fall conveniently towards the lower side. The right-hand thread is wrapped first under, then over the pin; the left-hand one first over, then under the pin. The pin can be placed in the hole, and first one thread, then the other wrapped around it. 


\section{LINE D, COL. 16,}

Abruzzian Piscitelli.
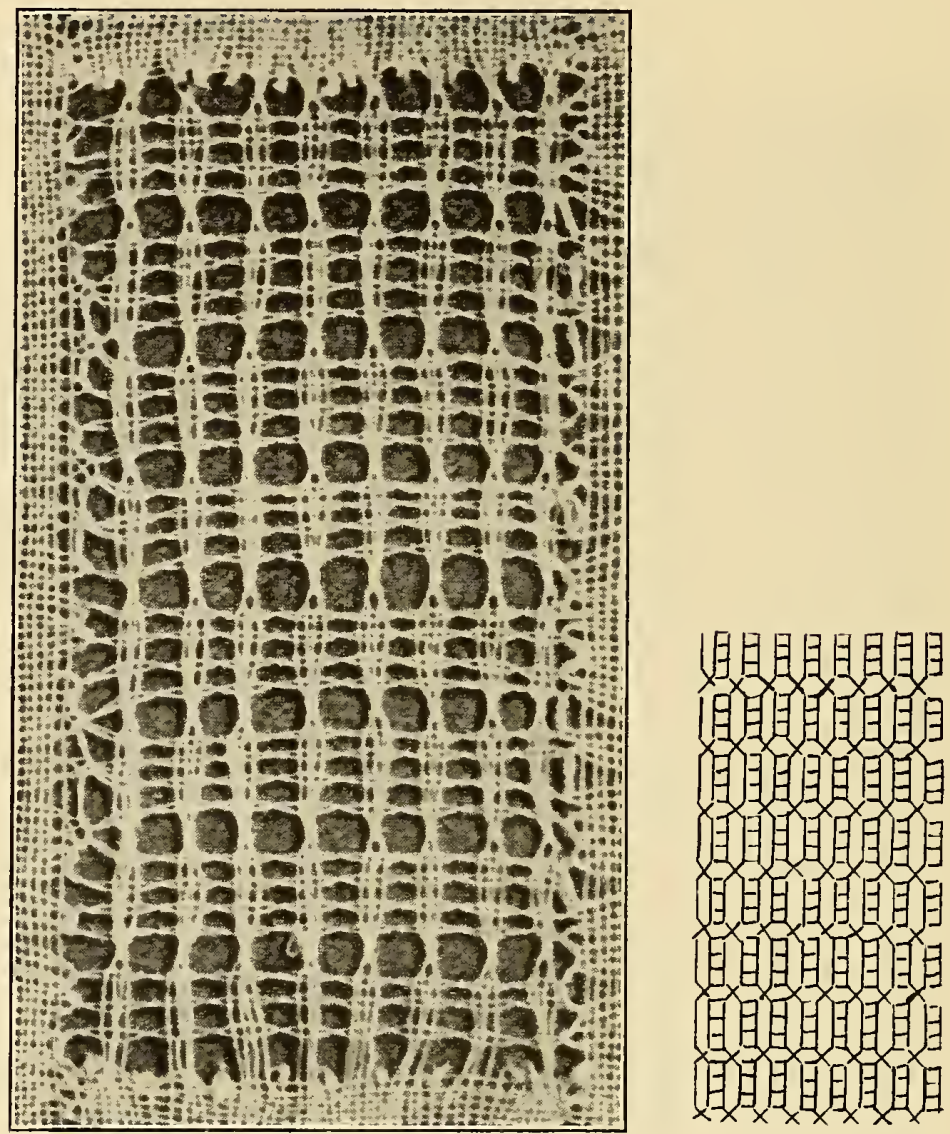

Two pairs wake the long, vertical spider or fish (as the name indicates) body, which is not twisted except at the two ends. It is made of cloth-stitches like a spider, but is not pulled up around a central pin as is that animal. The weaver or horizontal pair cloth-stitches all the way across the lace in one direction, returning in the other, passing four times altogether through the bodies of each parallel band of fish. The fish come directly below one another. The working pair is twisted once between fish, but is not twisted while passing through their bodies. At the top and bottom of the band, above and between the passings of the weavers, at the heads and tails of the fish, the two fish pairs are each twisted once, cloth-stitched through each other and again twisted once, in readiness to enter and form the fish directly below. It is well to hold these bodies in line by supporting the cloth-stitches above the fish by pins, which are not, however, closed, but which should be removed when the next crossing is made, so that the threads may be pulled up tight, leaving no conspicuous openings. 
LINE D, COL. 17, Trude "Q" Ground (original) (American).
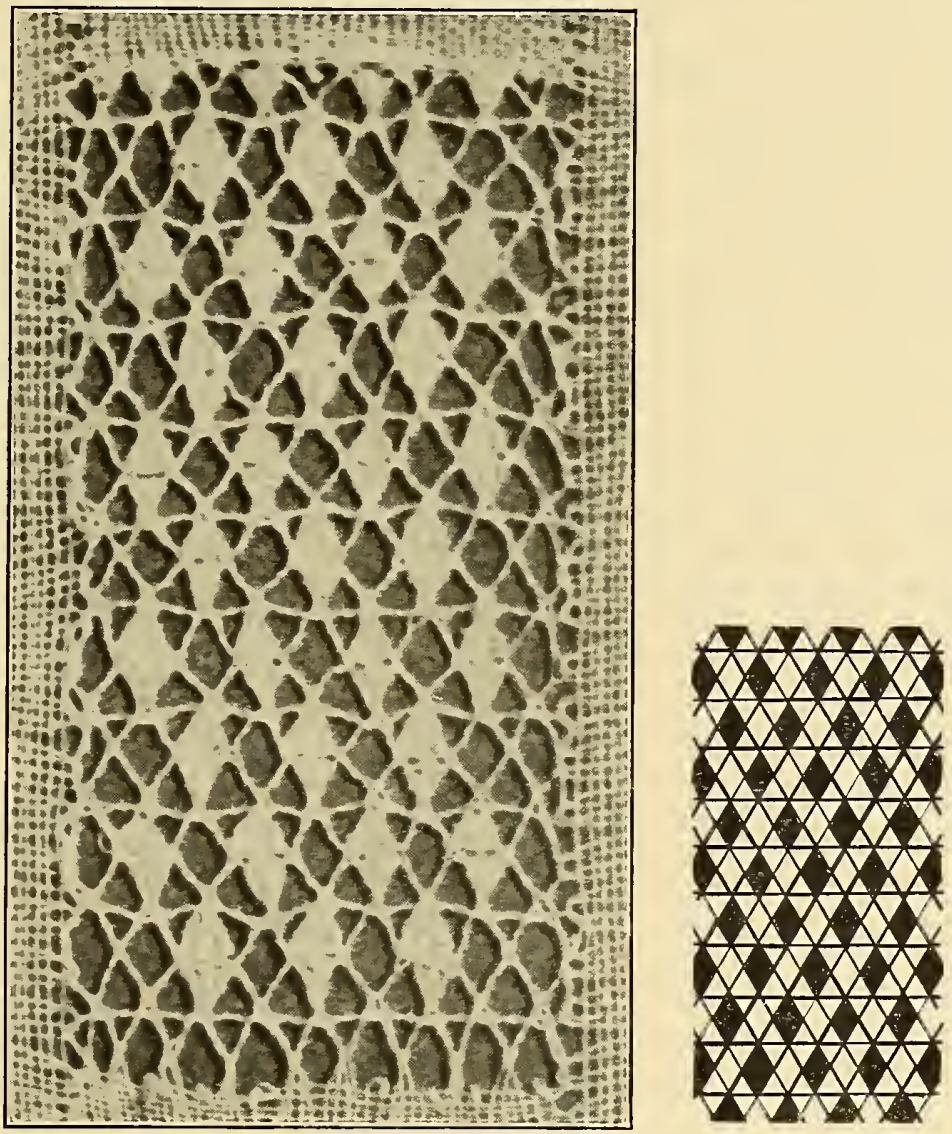

Each pair is twisted twice between cutworks. Pins are used only for support. The horizontal line which traverses the ground between the cutworksthat is, the one touching the point d'esprit diamonds at their lower and upper tips-is cloth-stitched with the pair, which in the cutwork just finished was the weaving thread and its mate, thus securing the weaver; but is only laid between the two threads of the pendant or scaffold pair, in order to keep the joint as small as possible. At the foot of each open diamond, the two hanging pairs cloth-stitch through each other before meeting the horizontal pair. The cutwork weaver should be left unmistakably longer than the other threads for at least several stitches after the lerdwork is finished, or it may be inadvertently pulled and ruin a point d'esprit made some way back. 


\section{LINE D, COL. 17-Continued Trude "Q" Ground (original) (American).}

Four threads are required for each cutwork. In starting at the top of a solid diamond, one proceeds in the usual way to make a triangular or fan-shaped point d'esprit. See Line A, Column 15. When the center side is reached, however, one exchanges the two left scaffolding threads for the two outside ones -which have first been twisted twice-that are found hanging directly to the left. A pin is placed between the two pairs to support their linen-stitch joint, and the two outgoing pairs are twisted twice to help keep the formation firm. At the center of the right side of the solid diamond, the weaving thread and its mate should be twisted once before cloth-stitching to avoid showing a long, loose thread. This pair is then exchanged by linen-stitching through its right-hand neighbor from the outside, and a pin is placed beneath the stitch. When making the exchange at the center of the sides, the two left-hand threads of the cutwork must be woven and secured before the two right-hand threads, laying the weaver meanwhile across some pins above, and taking it down only when ready to exchange it. The two new pairs now entering at the right side, now make the lower half or triangle of the diamond. Here at the bottom of the solid form, one can pull and wind all the bobbins evenly; not so at the sides. After working the weaving pair through the bottom of an open diamond to the right of its former position, the threads should be very gingerly pulled into a smooth twist, not touching or coaxing the weaver until the other threads are right, then using this pair again as the weaver for the next cutwork below at the right. 
LINE D, COL. 18,

Trude "S" Ground (original) (American).
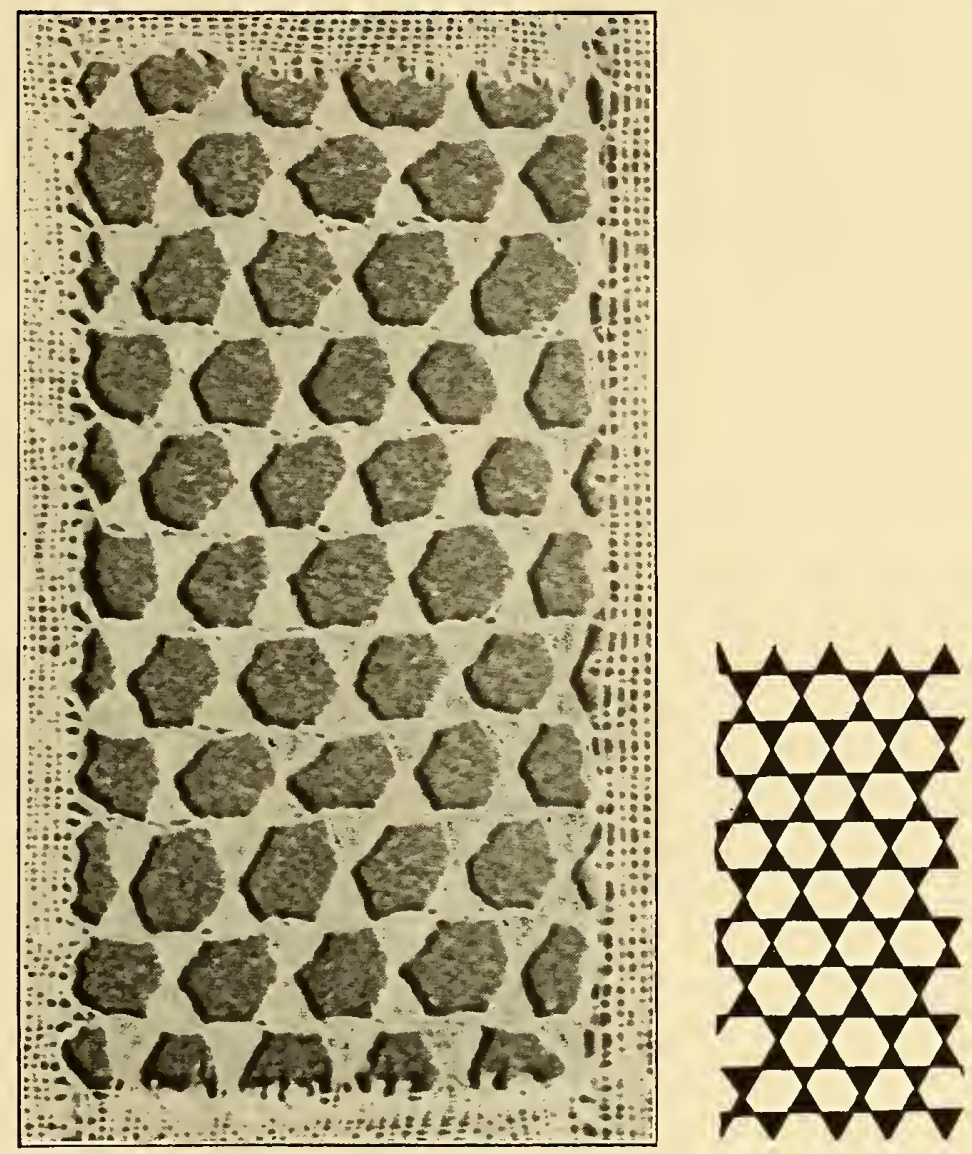

Each of these star formations consists of six equilateral triangular points d'esprits or cutworks, which are held in place by a pair of twisted, horizontal threads that pass first to one side, then back to the other along and between the horizontal tops and bases of these cutworks, never through their apeces. The horizontal pair is twisted three times between intersections or encounters, and cloth-stitches through the points d'esprits pairs. Under the horizontal, twisted pair and between the left-hand pendant threads of the cutwork at its broad base, a pin is temporarily placed. Another one is put inside but not between the two right-hand threads. After the three scaffolding threads have been pulled into place, any loop or irregularily left by the weaver should be carefully drawn out. 


\section{LINE D, COL. 18-Continued \\ Trude "S" Ground (original) (American).}

In finishing a cutwork, whether at its bottom or at its apex, the weaver and its mate should be tied once with a granny knot; first, to prevent slipping, and second, to make the point sharp and small. Keep the weaving thread long to distinguish it and to avoid aceidental pulling. Pins must be used between the upper and lower apeces, where they meet, to hold the upper triangle until the one just below is made. The three framework threads should then be pulled until the pin hole is closed.

It may be found helpful to lay the weaver across two pins up out of the way of the work until one is again ready to use it. 
LINE E, COL. 1,

Tulle de Dieppe.

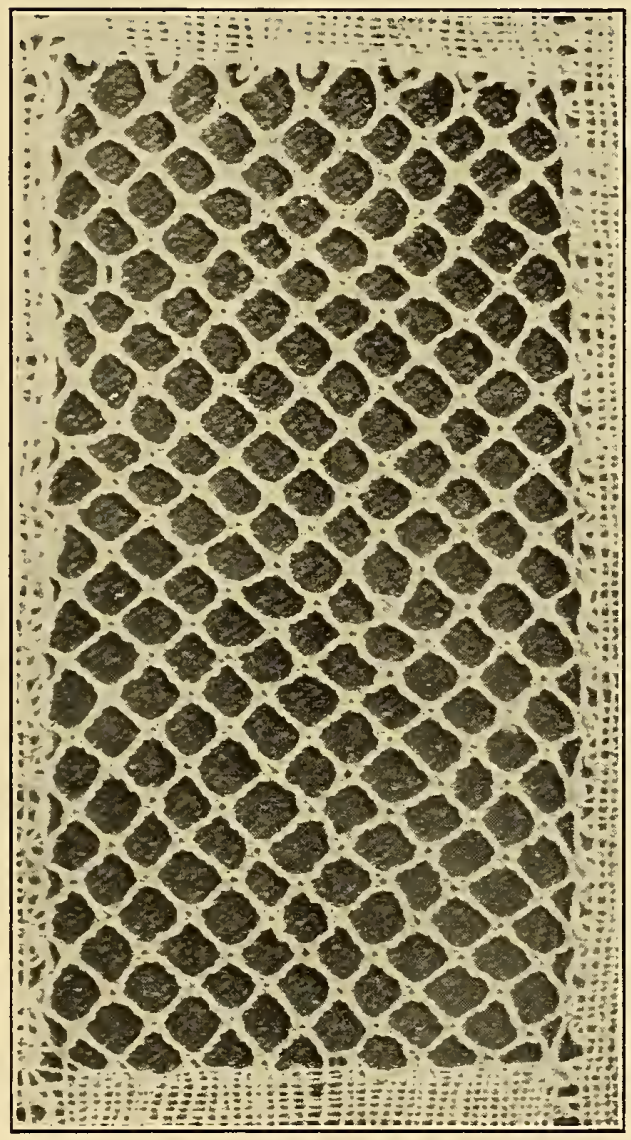

This net is obtained by twisting the pairs three times, crossing, placing a pin and closing it by crossing. It is made on the oblique. 
LINE E, COL. 2,

Petits Pois de Dieppe
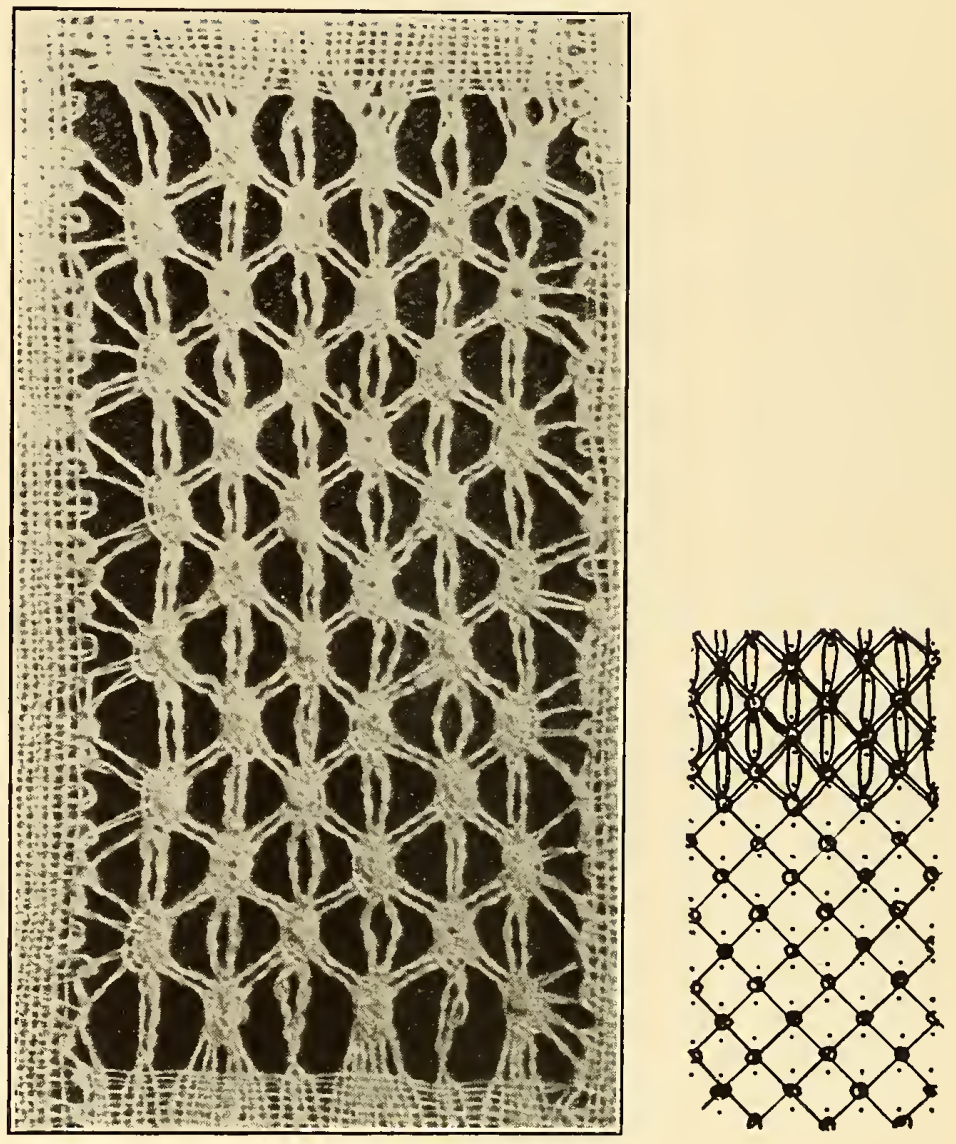

These spiders are made in the usual way; see Line II, Column 2 ; the two center top pairs, however, are twisted three times and then cloth-stitch, having a pin placed above the joint before entering the spider. At the bottom of the spider the two center pairs, after making the joint, have a pin placed directly below. Thus there are two pins between spiders vertically above each other. The side spider legs are also twisted three times. 


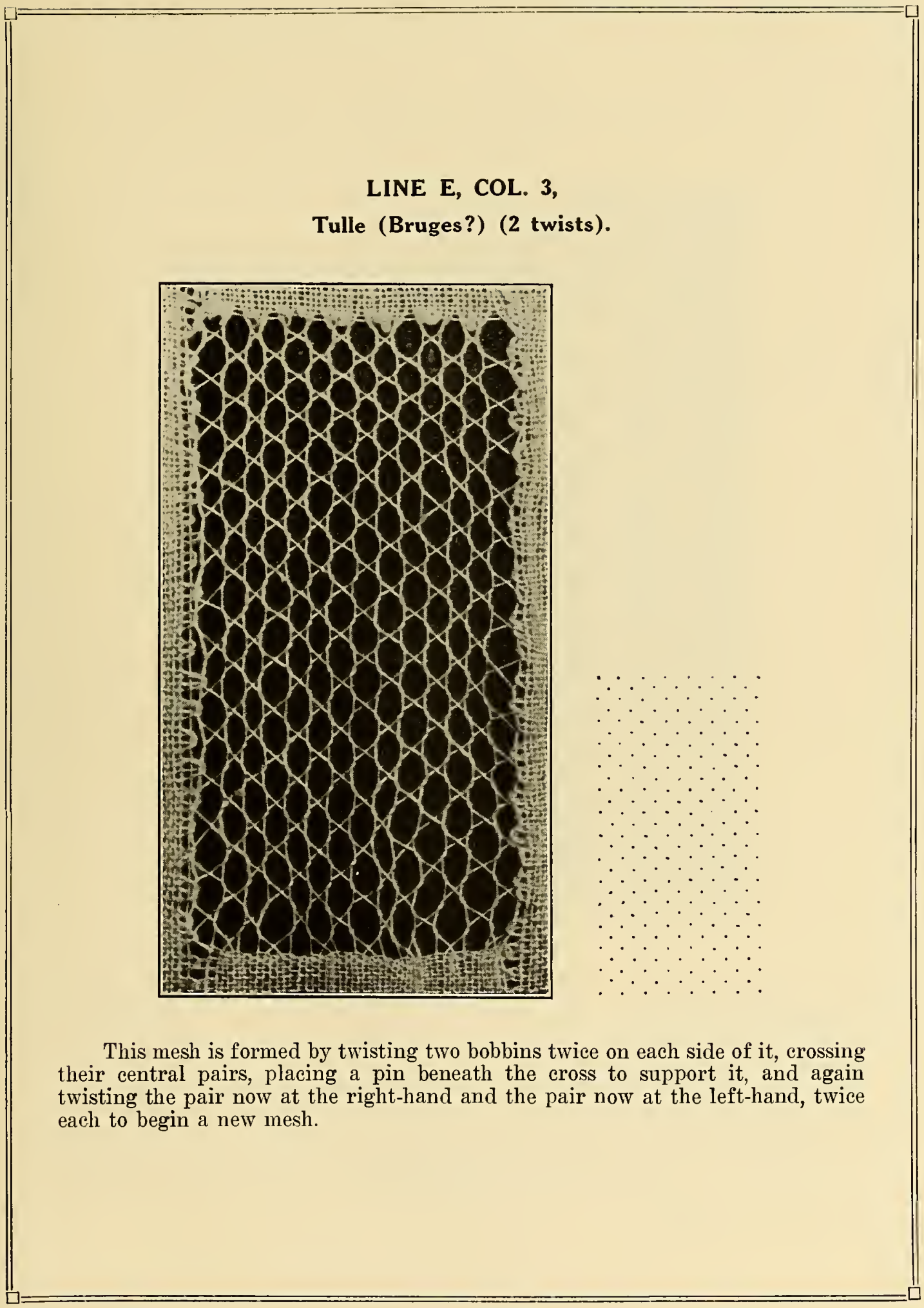




\section{LINE E, COL. 4,}

\section{Plain Torchon Spiders.}
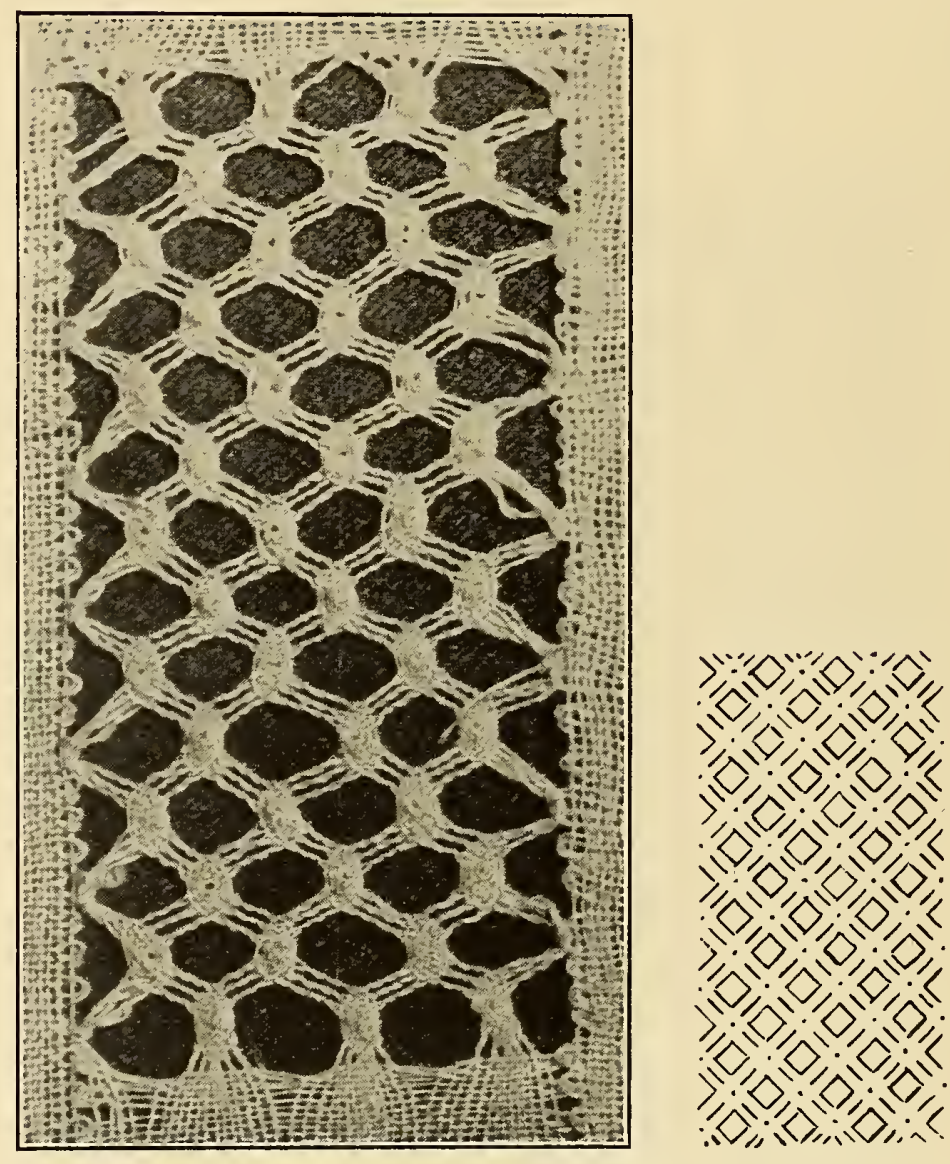

Each spider requires six pairs. In this sample each pair has been twisted three times between spiders. Pins are used in the center of the spider bodies only. These centers should be raised to give an arched effect. This is done after the first half of the spider body is woven, by holding the pairs nearest the pin up high and tight against it while closing it, closing the other, outer pairs lower down and close to the pricking, and pulling the outer pairs up tight, so that the inner ones cannot sink down into them. The spider is made by cloth-stitching the three left-hand pairs in consecutive order through the three right-hand pairs, putting up a pin, and closing it by cloth-stitching all the pairs through each other in the reverse direction. The three legs that came in at the upper right of the spider go out at the lower right and form the three upper left-hand legs of another spider. 
LINE E, COL. 5,

Buratto, Filet.

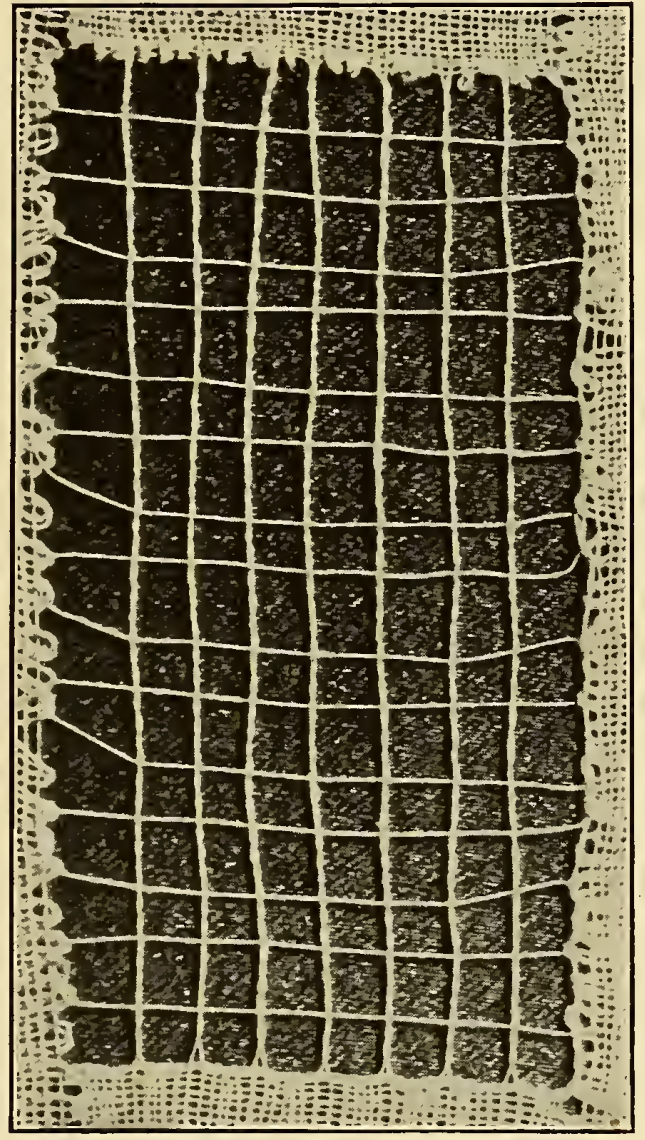

This ground has been much used as a network upon which to embroider. It is usually woven, but directions are here given for making it with bobbins on a lace pillow, should one wish to.

The vertical pairs are twisted three times between intersections. The single horizontal thread is simply laid between them at regular distances and supported, at least at every other crossing, by pins, which keep the whole from pulling out of alignment. These pins should not be left in long or they will spread the twisted threads, leaving holes behind. 


\section{LINE E, COL. 6,}

Ornamental Ground with Zigzag Diagonal Stripes, Ziergrund mit Streifen-Musterung in Zacken-Einteilung.
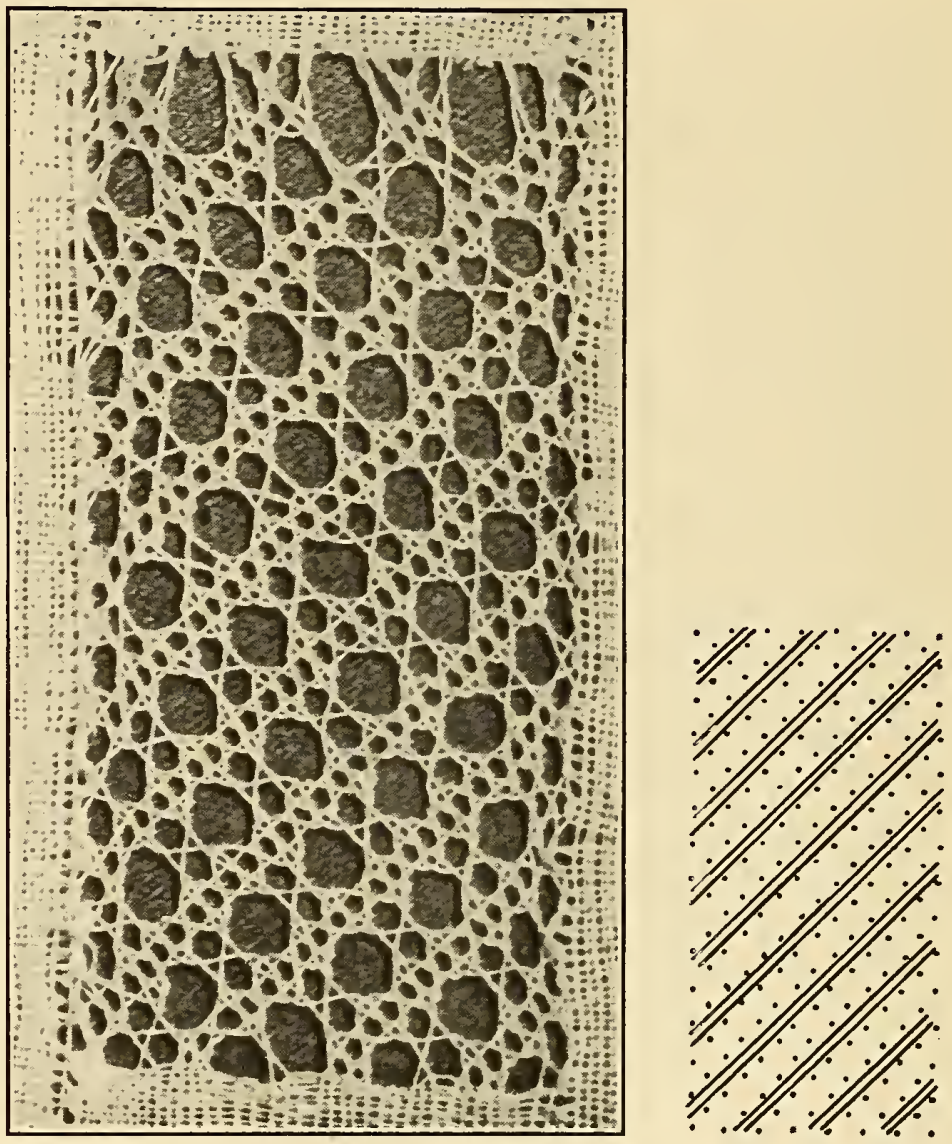

This Virgin Point is made fundamentally the same as the Ornamental Ground with Striped Effect in Diagonal Squares, Line D. Column 6, only the two pairs leaving the bottom of the square or block instead of intersecting each other, are separated. The upper pair, working upwards to join by a half-stitch the lower pair of the block above; and the lower pair, intersecting by means of a half-point, the uppermost pair of the square below. Thus the block is pulled apart into a zigzag. It is best to make the squares as one works downwards from right to left, and then make the ornaments as one reascends from left to right. At the edges, where certain pairs are lacking, the stitches should be made as much as possible like the others, proceeding in the same way. 


\section{LINE E, COL. 7,}

Square-meshed Valenciennes of Alost and Ypres (braided 5 or $51 / 2$ times).
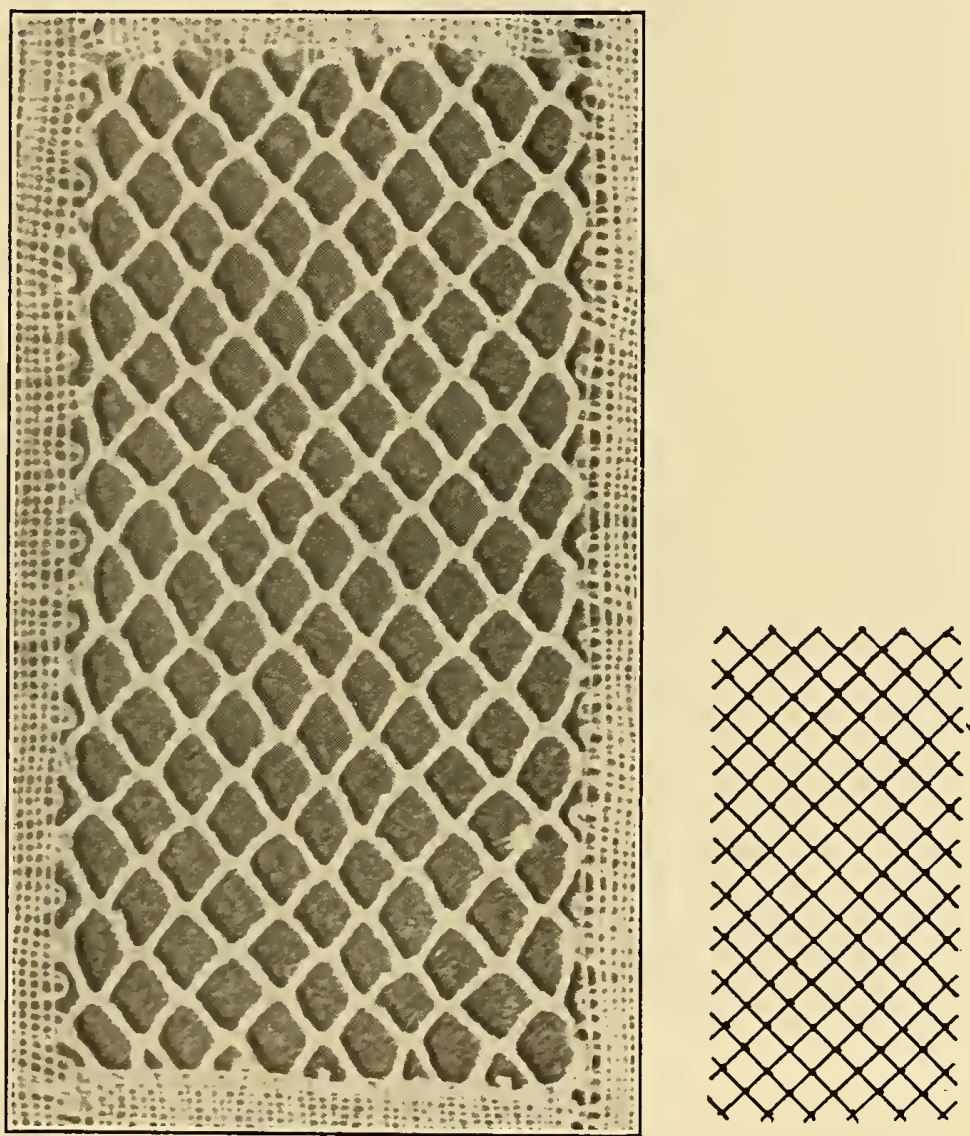

See Column 7, Lines A. B, C and D. The mesh of Alost and Ypres is made in the same way as those described above, except that the sides of the mesh are braided five or five and a half times, producing a peculiarly distinctive and clear-cut ground. 
LINE E, COL. 8,

Devonshire Second Swing Filling.
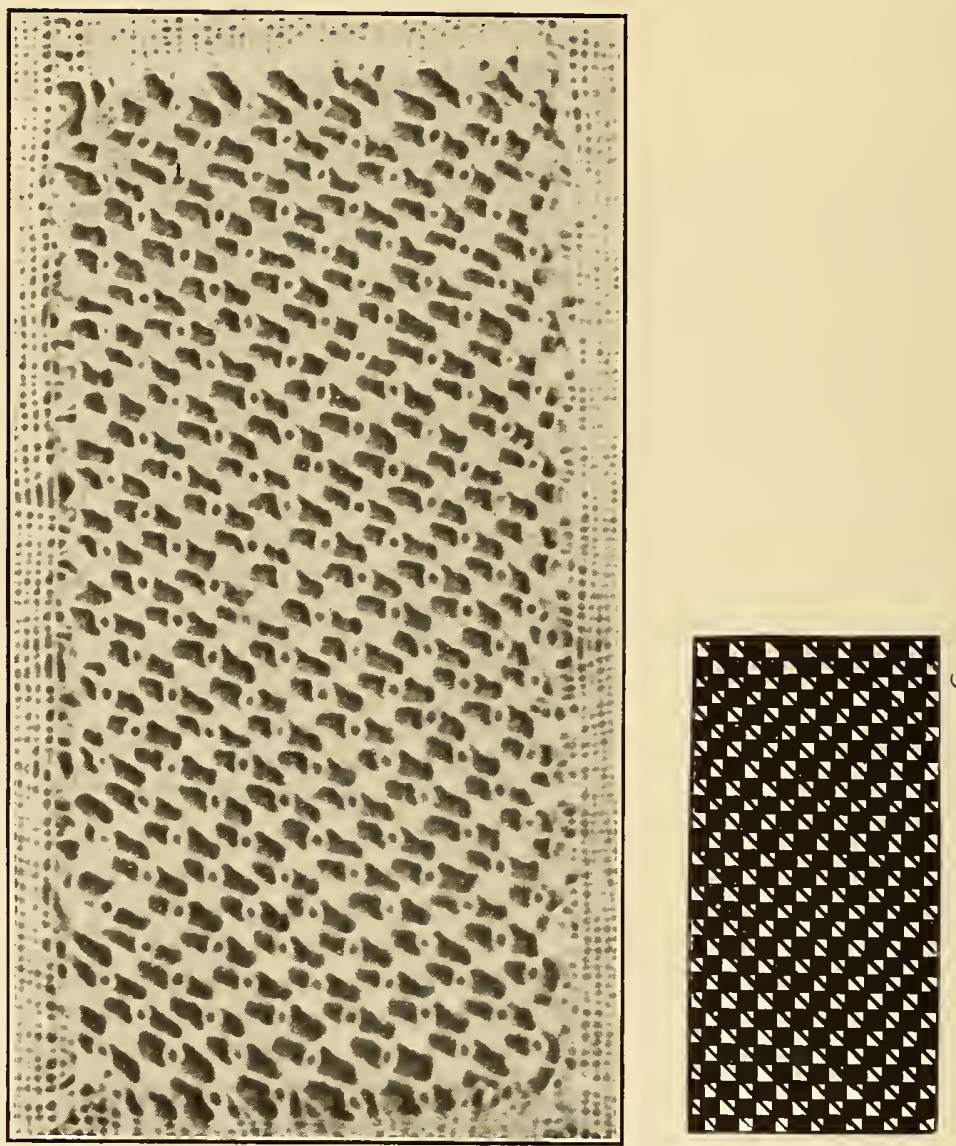

This stitch is apt to look slovenly unless it is carefully made.

After a cutwork has been finished, a pair from the left, twisted three times, cloth-stitches through the lower, left-hand pair of the cutwork, also twisted three times; the pairs are again twisted three times; a pin is placed and closed by linen-stitching. Here the pairs are once more twisted three times. The left-hand pair enters the lower cutwork; the right-hand pair works towards a new circle on the lower right. This filling is made from the upper left to the lower right: first a whole row of cutworks, then a whole row of circles, et cetera, alternately. No pins are used for the cutworks themselves, but only in the circles. The cutwork weaver enters at its upper left and leaves at the lower right. 


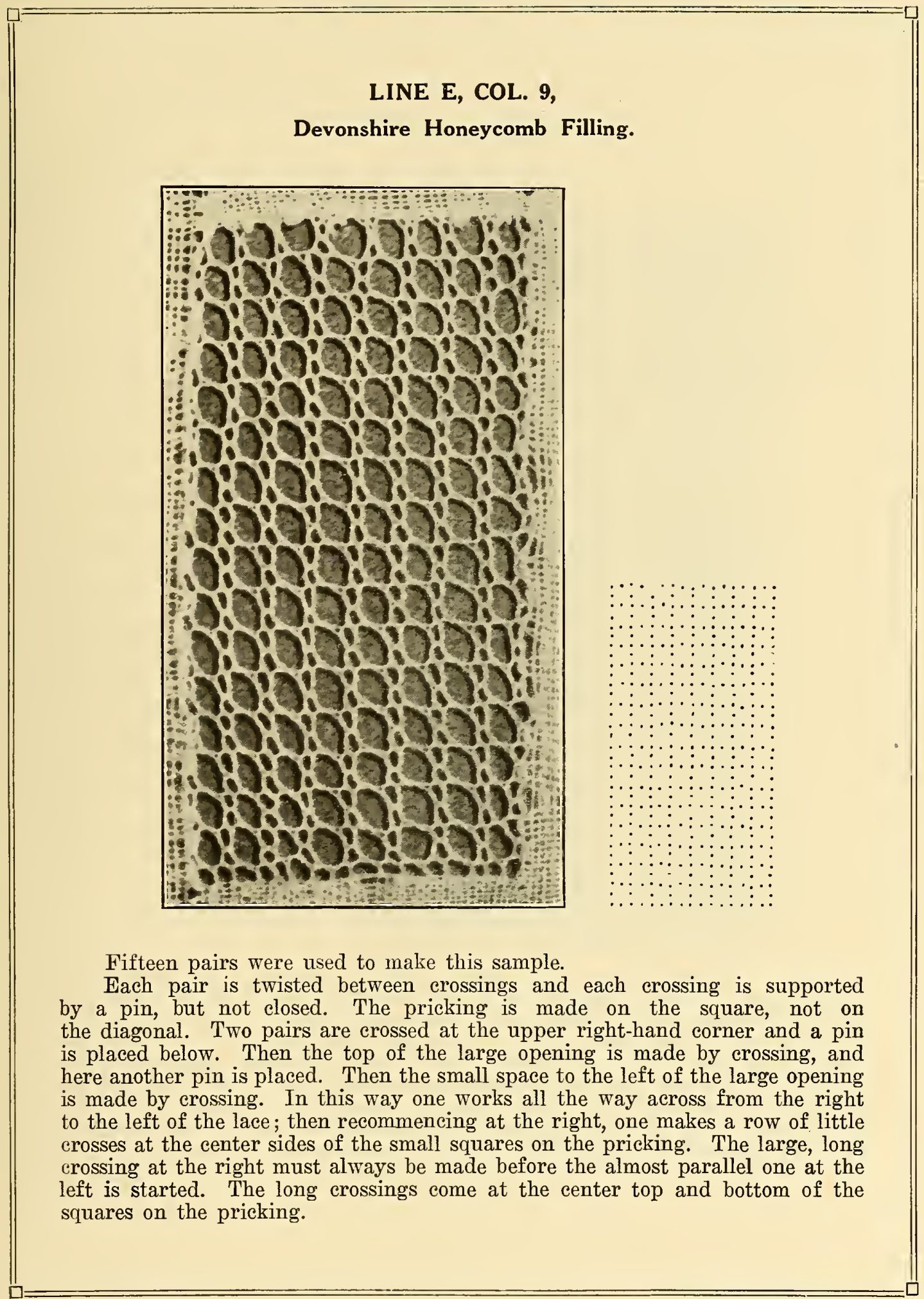




\section{LINE E, COL. 10, \\ Binche Mode.}
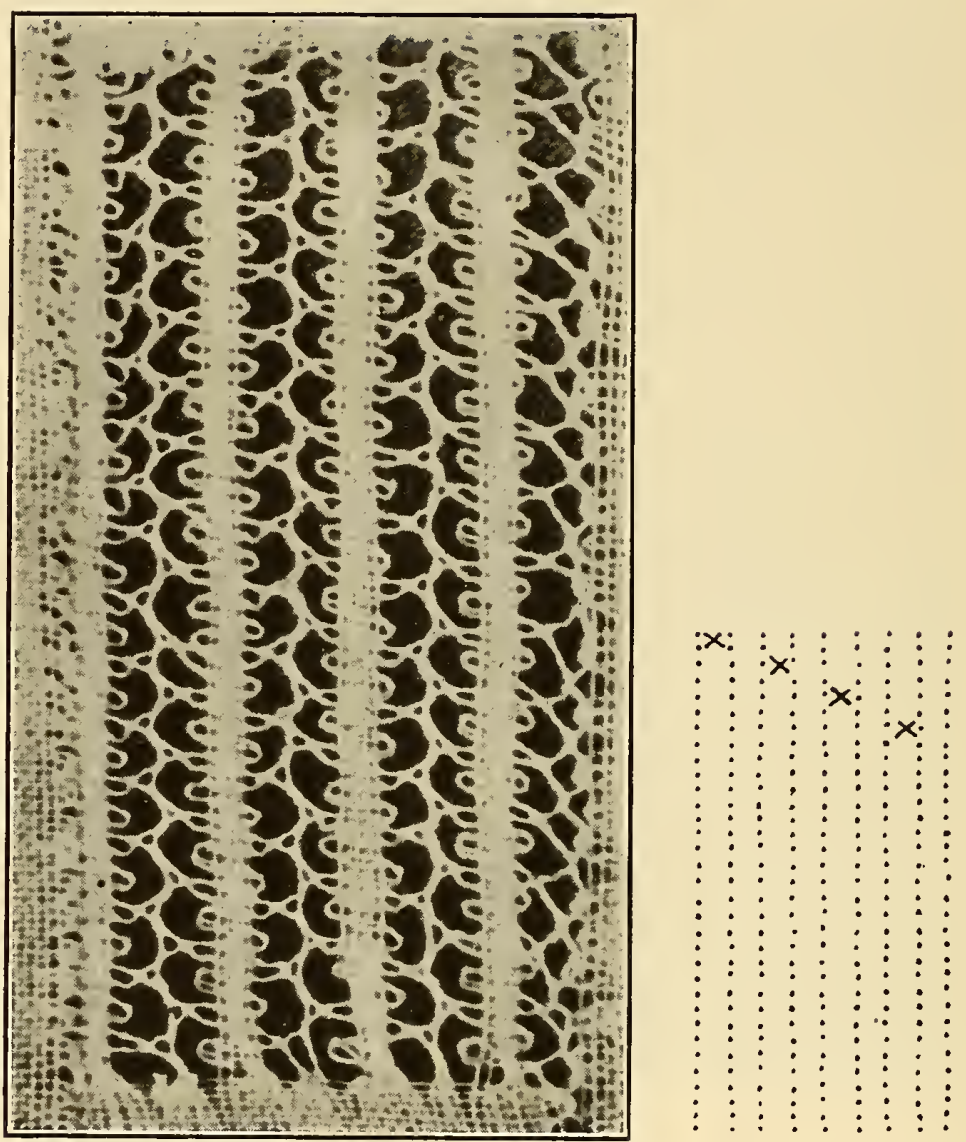

Six vertical threads and a weaving pair are required for each bar, one to the right and one to the left of the zig-zag, and one pair is needed for the zig-zag itself; the braid part of which is made in conjunction with a borrowed worker, which the zigzag transfers to the bar opposite the one from which it was borrowed: borrowing a new worker from the second bar, et cetera. After exchanging weavers, one should make two pins' length only of the vertical, cloth band before beginning a zig-zag braid, as this furnishes a firm foundation against which to pull. The conductors are twisted twice around the winkie pins at the 


\section{LINE E, COL. 10-Continued}

\section{Binche Mode.}

side of the upright bars; also before and after crossing in and out of the zig-zags. The zig-zag makes three braid stitches with its newly borrowed weaver.

Though this stitch is simple, it is confusing, so the bar should not be completed more than two pin holes ahead of any of the rest of the work. The uppermost conductors must be exchanged and braided in before the next lower pin hole of the opposite cloth bar can be worked. The zig-zag spine always hangs between the bars, and two weavers cannot enter two, opposite, cloth bands at the same time. The zig-zag pair itself must not be used by mistake for a weaver, although the braid pair nearest the bar is always used as the exit conductor. One must be sure to twist both pairs twice before uniting a new weaver and the spine. 
LINE E, COL. 11.

Point de Paris Variation with Tressed Sides.
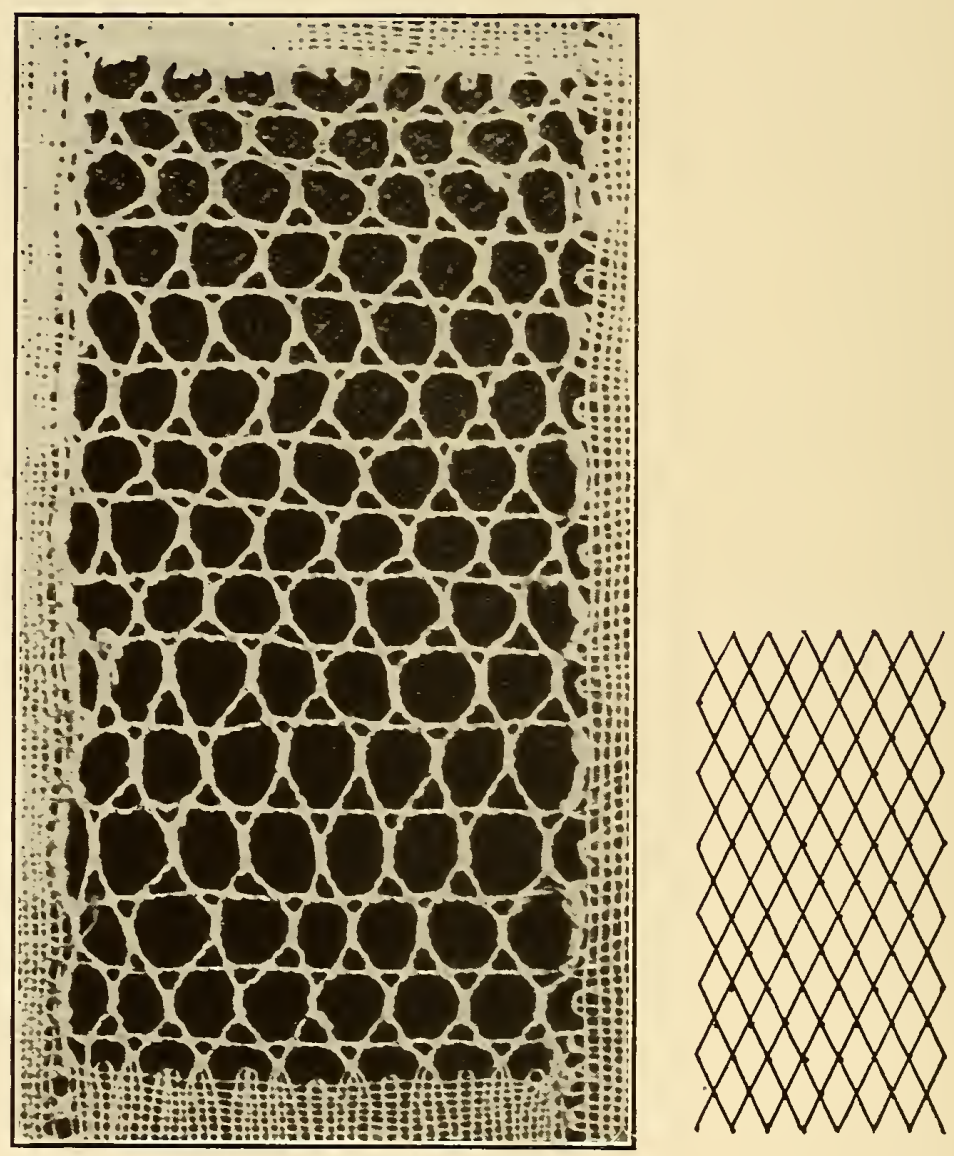

The sides of the four vertical pairs should be braided four times; the diagonals twisted twice below the horizontal line and twice above it. The weaver or horizontal pair is twisted twice between stitches, and linen-stitches through the diagonals. 
LINE E, COL. 12,

Torchon.
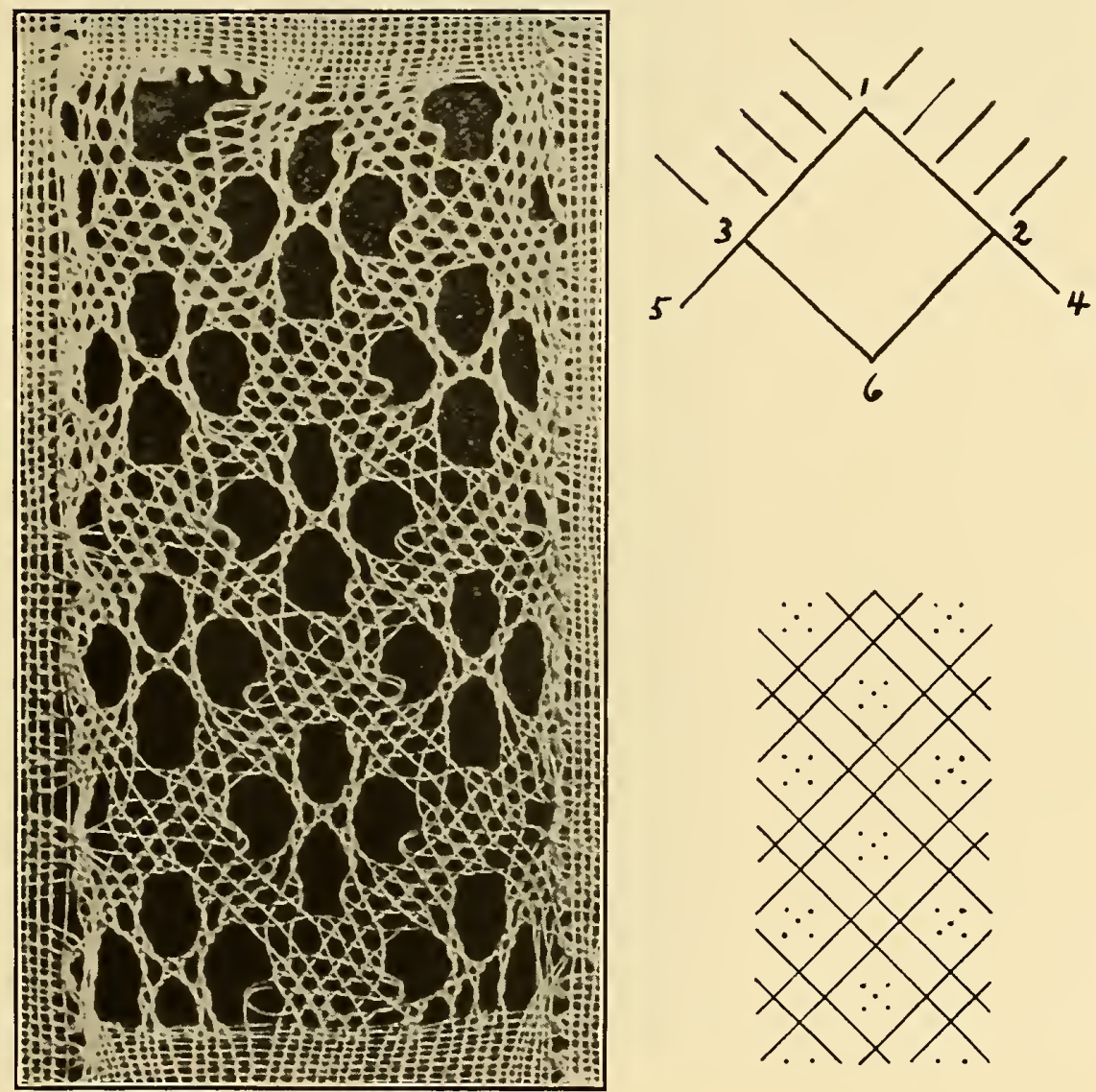

This requires the entrance of five pairs at each upper side of the small, solid junction-square formed by the crossing of the oblique bands of the design. Half-stitch should be used, and the weaver must not be confused, as using the wrong pair leaves an ugly hole. The two weavers, one from the left and one from the right, meet at " 1 ," the topmost, central, point of the small, solid, diagonal junction-square. The right weaver closes the pin, returns towards the right and continues as general weaver, going from points 1 to $2,3,4,5$ and 6 , where it closes with the third pair, which again becomes a worker, each weaver continuing in its own direction; " 4 " and " 5 " are the only pin holes in the big, outer, open square that do not connect with something. They are above the 


\section{LINE E, COL. 12-Continued}

\section{Torchon.}

lower, central point of the solid junction-square that is formed by the crossing of the diagonal bands of the design.

The ornament in the center of the large, open square is formed by dropping a pair out of the oblique bands after closing each pin, two coming out of each upper side and re-entering the lower sides of the big square after having made the ornament. The ornament requires five pins, elosed by half-stitches, each pair twisted twice between pins, but not in closing. 


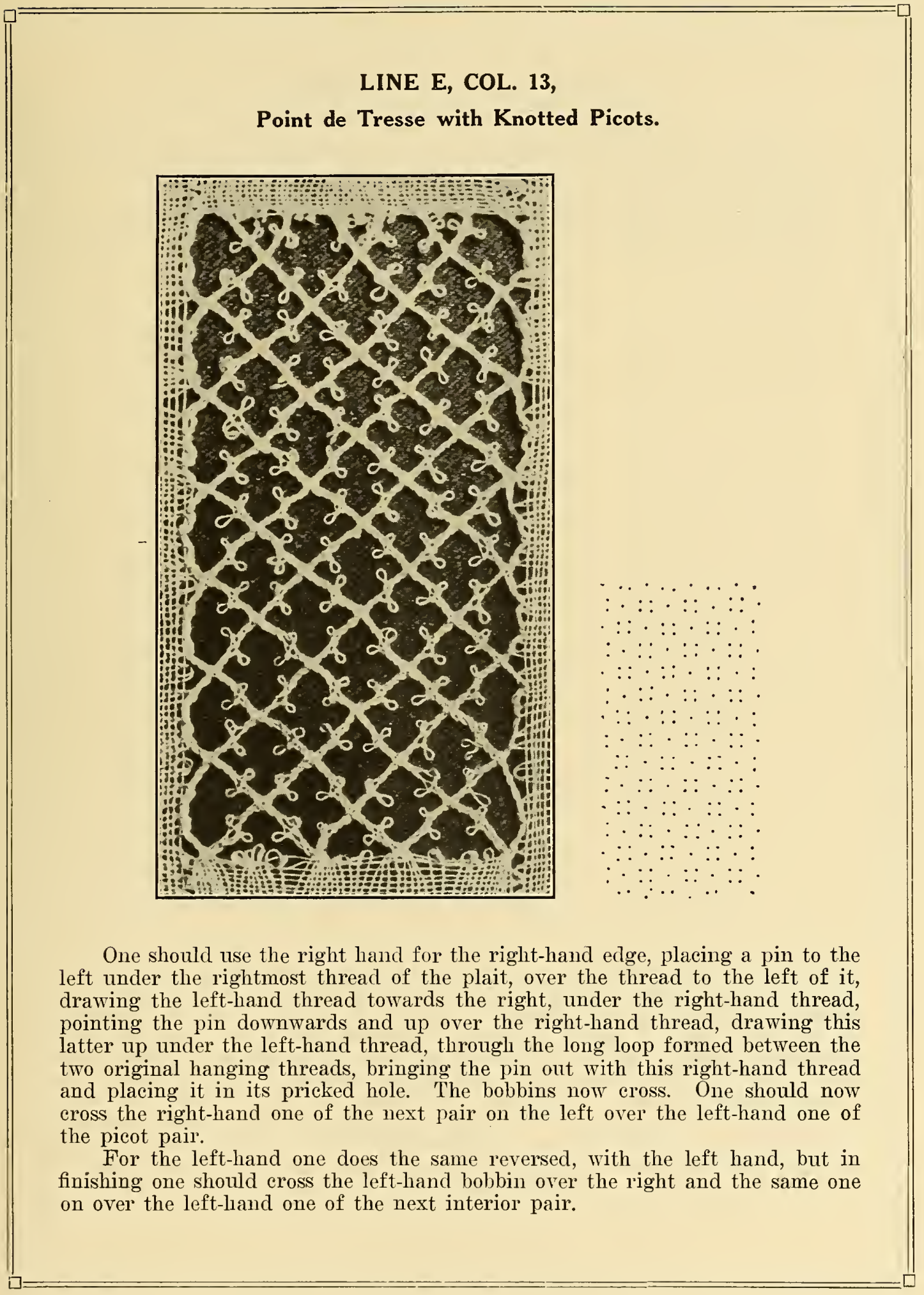




\section{LINE E, COL. 13-Continued \\ Point de Tresse with Knotted Picots.}

Another rule is, just to twist and cross after making the left and right picots the same as for an ordinary one, and to twist before making a picot. The author prefers this method.

When interweaving the braids through each other, one should make a clothstitch, using two bobbins as though they were one and supporting the joint by a pin. 


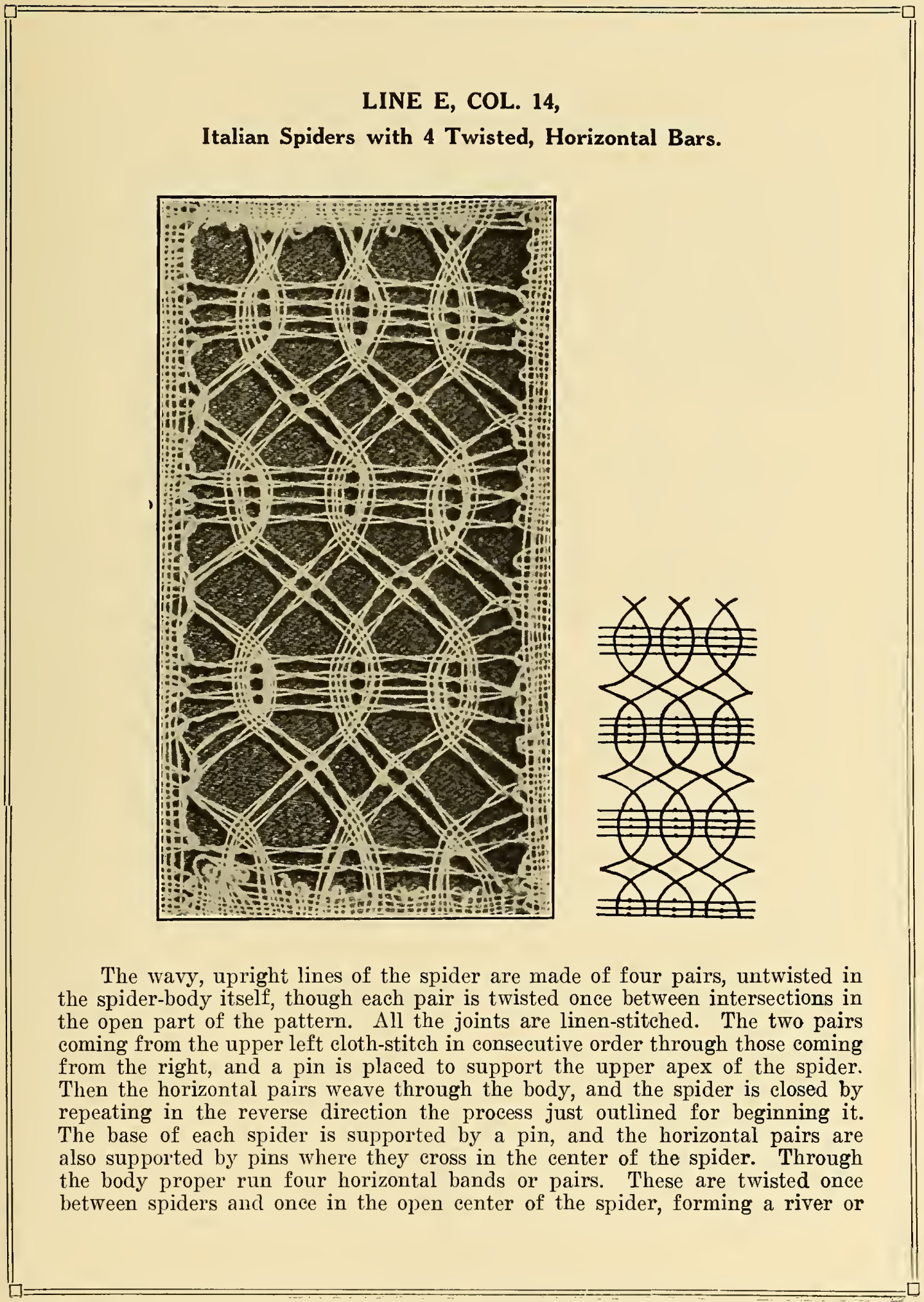




\section{LINE E, COL. 14-Continued}

\section{Italian Spiders with 4 Twisted, Horizontal Bars.}

open eye. They are not, however, twisted as they weave through the upright, wavy pairs.

The open part of the pattern between upper and lower rows of spiders is formed by each of the lower right-hand legs of an upper left-hand spider being twisted once and linen-stitched in consecutive order through the lower left-hand legs of an upper right-hand spider, which should also have been twisted once. But one must not forget to twist those legs again after they have completed one linen-stitch and before they begin another, so that each side of the little square is twisted once. After this square is completed, each leg is twisted once before beginning new spiders. 
LINE E, COL. 15, Marguerites à Six Pétales (one sided joint).

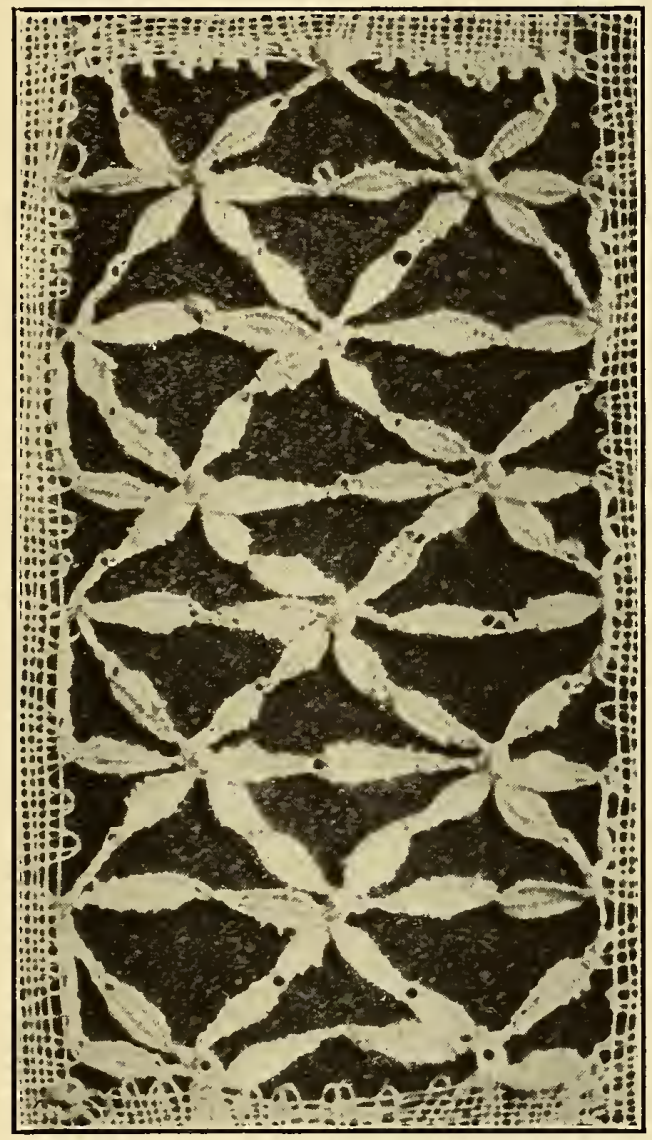

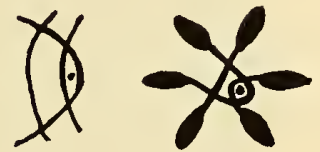

No, 1

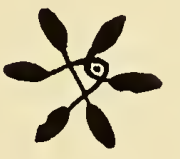

No. 2
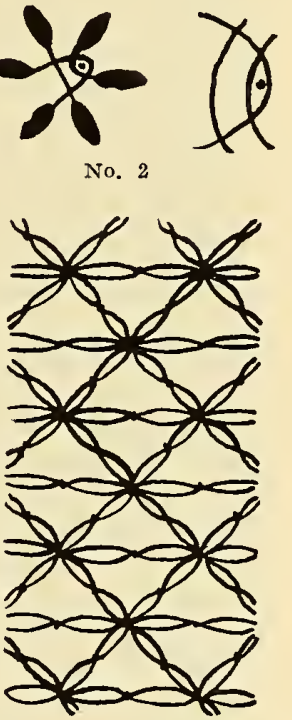

Each leaf is made of four threads; - six radiating leaves making one "Marguerite." These may be supported by pins here and there at the end of one petal and before commencing the next or wherever else it is found convenient.

These six-leaf joints are necessarily one-sided. The two upper petals being finished, cloth-stitch through each other, each pair being used as a single thread. Here, if the horizontal petal comes from the left, it cloth-stitches through the left-hand four threads which come from the right-hand upper petal. Then a pin is placed. The four horizontal threads now cross-stitch again through the same four threads they intersected before, which closes the pin. The horizontal pairs now form the left-hand lower leaf. The other two pairs which come from the right-hand upper leaf, linen-stitch through the remaining two pairs which come from the upper left-hand leaf and which now form the lower right-hand leaf. When the horizontal leaf comes from the right-hand side, the method of procedure is exactly reversed, as shown in this diagram. The centers of these daisies should be raised by holding the pairs next the pin higher than the outer ones and by pulling these latter tighter than the inside ones. 
LINE E, COL. 16,

Trude "K" Ground (original) (American).
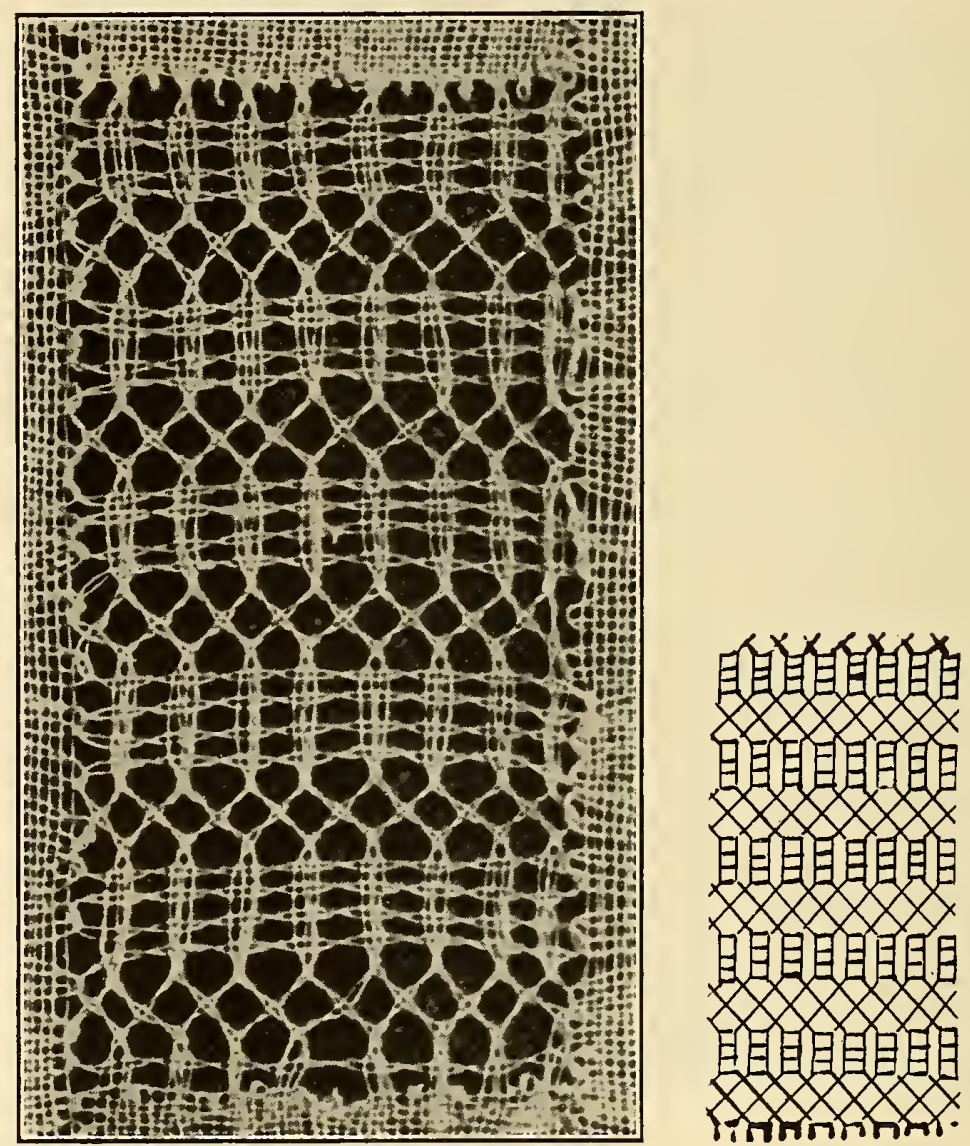

This ground is similar to those illustrated and explained under Column 16, Line D; Column 16, Line G; and Column 16, Line F. The working pair clothstitches all the way through each band of fish from the right to the left, then back, making four trips altogether. The workers are twisted once between bodies, as are also the oblique, passive pairs between linen-stitches: but the weavers are not twisted in passing through the actual fish. Not counting the heads and tails of the fish, the oblique pairs cloth-stitch through each other once between fish, forming one open square below the tail of one fish and the head of another. The fish are placed directly below one another. Where the diagonal pairs meet to form a fish-that is, at their heads-they linen-stitch and are twisted once, the stitch being supported by a pin. The same procedure reversed is used to form the tails; that is, the pairs are twisted, a pin is placed and a linen-stitch made. 


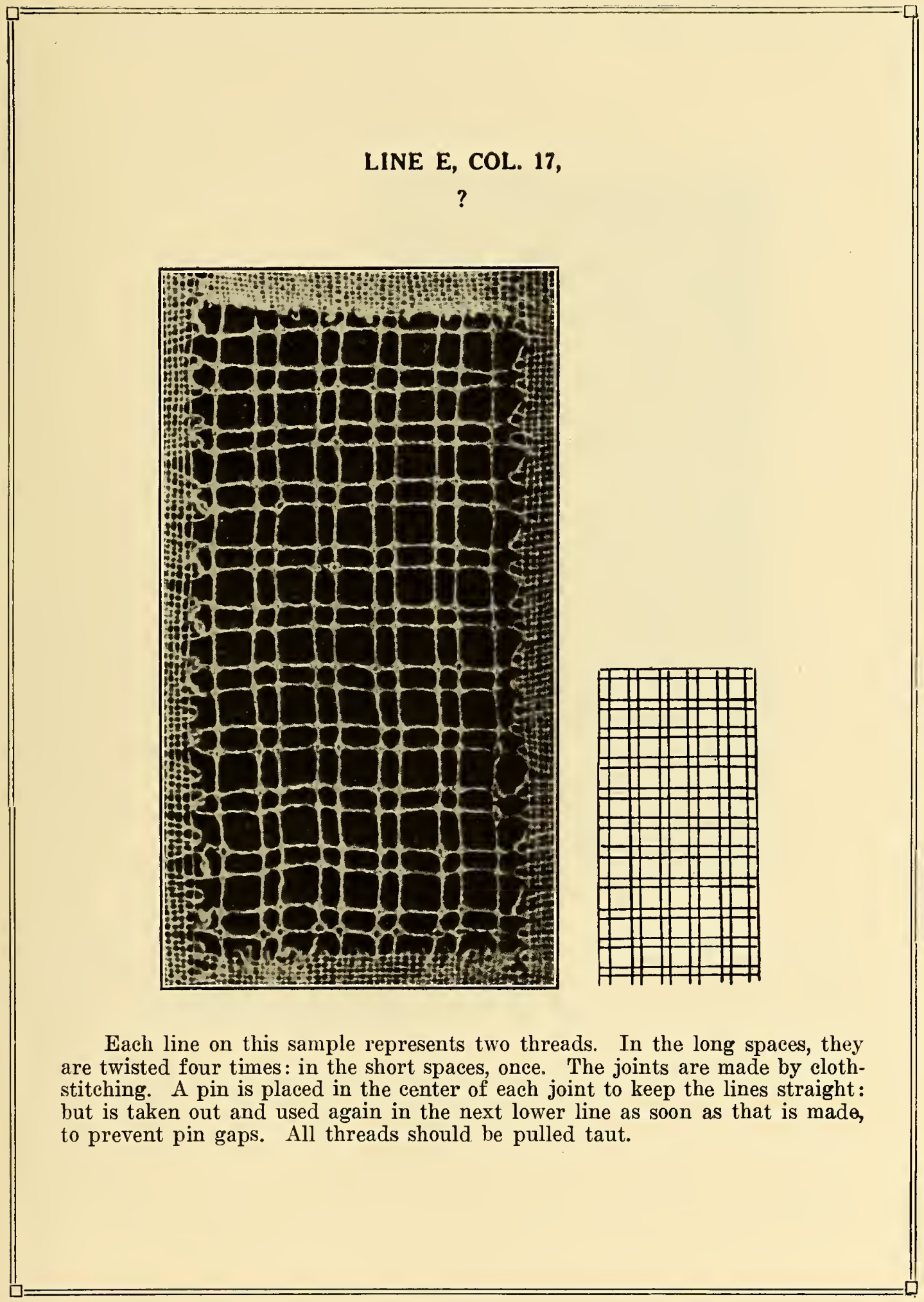




\section{LINE E, COL. 18,}

Marguerites à Centre de Toile.
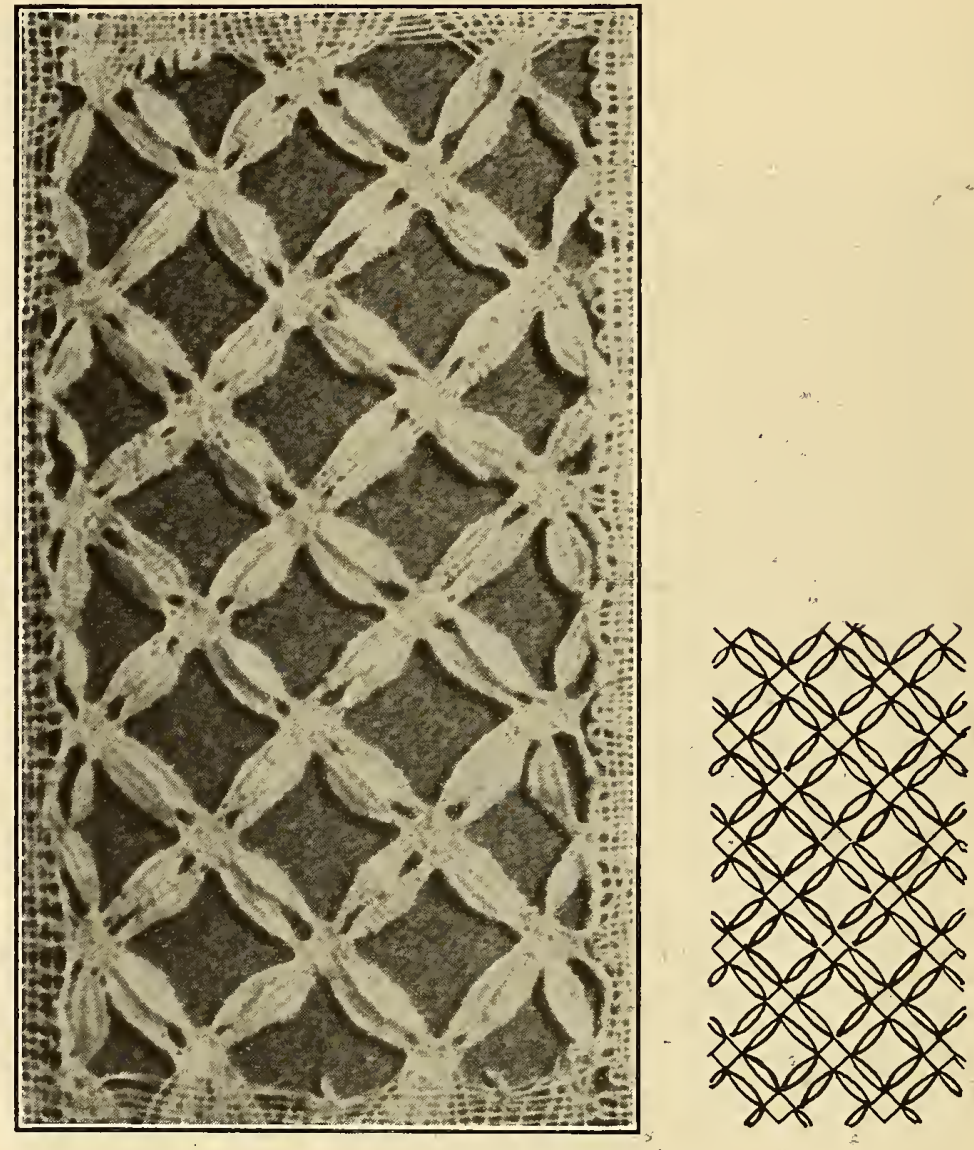

Four threads are required for each leaf, and four leaves enter each "Marguerite" or daisy at the top, two at the left and two at the right. After making the long, slim petals, the eight left-hand threads cloth-stitch through the eight right-hand threads, forming a small square placed on the diagonal. The four threads making their exit at the lower right-hand side of the square become the two lower right-hand leaves of this particular linen square, and at the same time the two upper left-liand leaves of the square obliquely below. The remaining eight threads are woven into two lower left-hand petals, becoming in turn the upper right-hand petals of a square diagonally below. Pins should be placed at the lower ends of the leaves to keep them from unravelling until the little square dots are finished. IIowever, when these pins are removed, all holes and loops must be carefully pulled out before new petals are commenced. A supporting pin should be placed below the lower corner of the square to hold it in place. None of these pins are closed. 


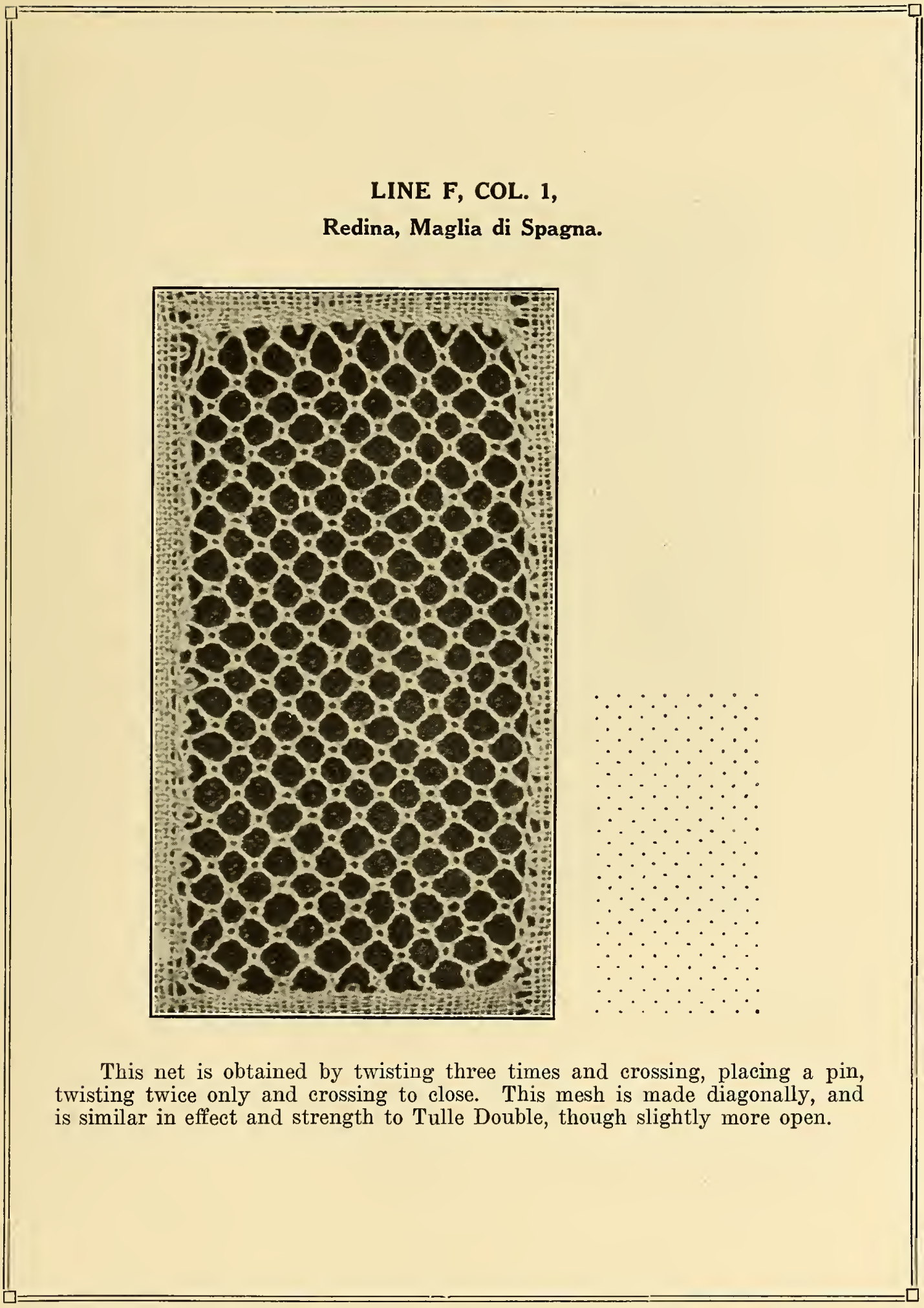




\section{LINE F, COL. 2,}

\section{Les Mille Pattes.}

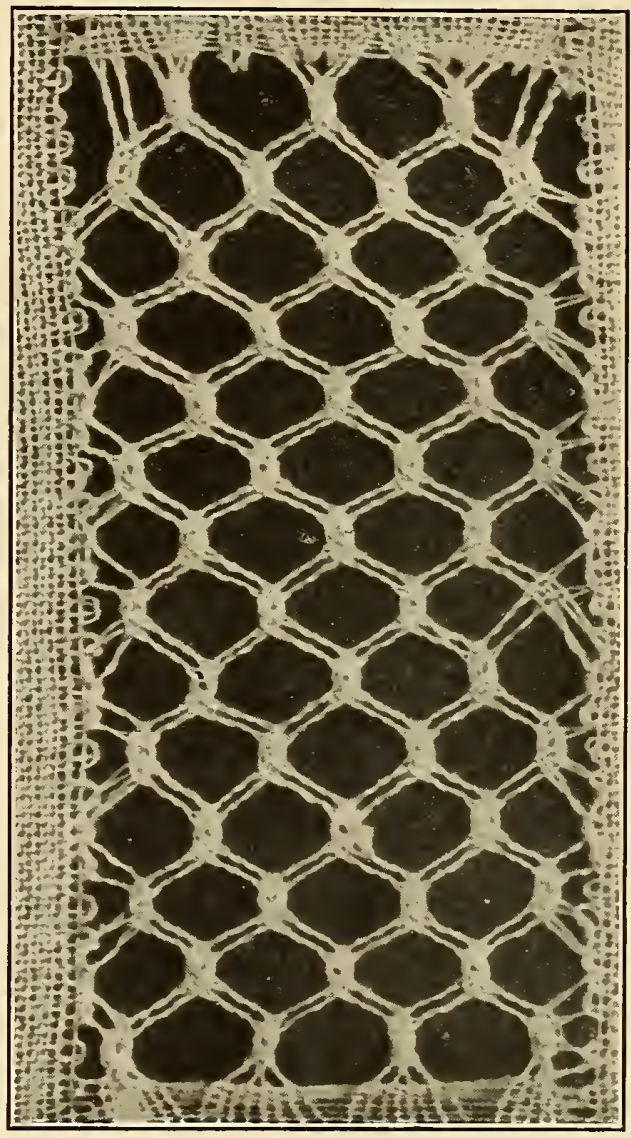

This is a series of spiders made with four pairs of bobbins, each pair twisted three times. The pairs coming from the upper left linen-stitch in consecutive order through those coming from the upper right. A pin is placed and closed by repeating this process in the reverse direction: so that the upper left-hand legs of the spider are also its lower left-hand legs, becoming the upper righthand legs of a new spider on a lower line. To raise the centers of the spiders one should hold the innermost pairs of the joint somewhat up in the air against the center pin, pulling the outer pairs especially tight in closing them, so tlat the inner pairs cannot sink down into them.

See Line E, Columns 4 and 2. 


\section{LINE F, COL. 3,}

Tulle Ground, Lille, Filoche, Fond Clair, Fond Simple, Point de Brabant, Trolly Net, Töndern, Arras, Marche, Point de Hollande, Dutsche Slag.

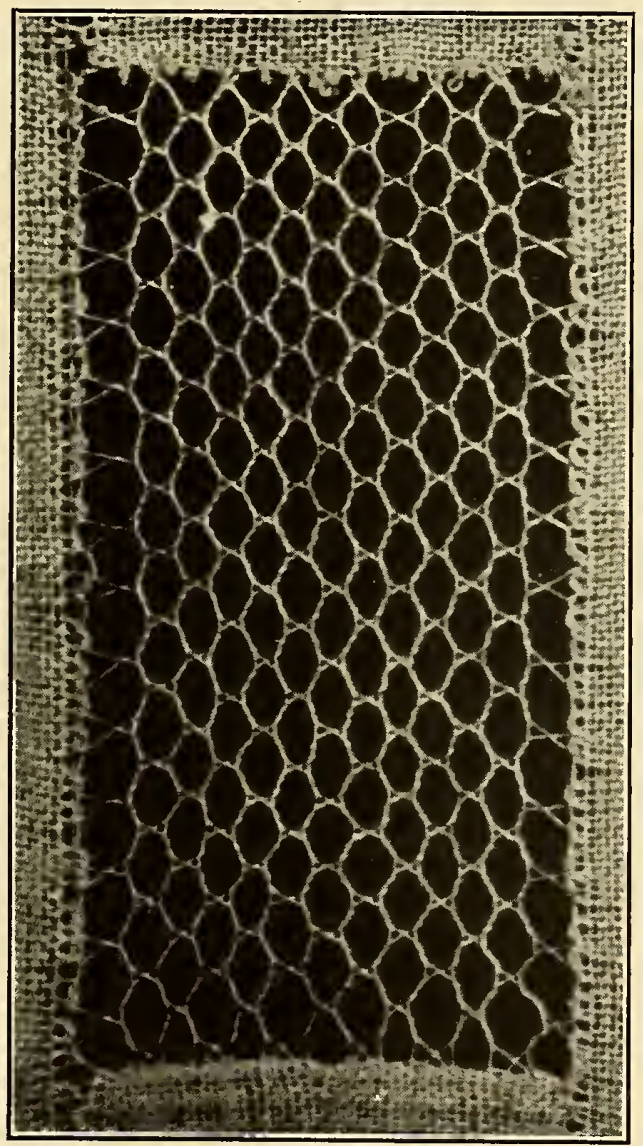

See Line E, Column 3.

This ground is made by twisting the sides of the meshes three times each; then erossing the inner thread of each pair, placing a pin beneath this joint to support it, and again twisting three times the pairs formed at the right and left. 


\section{LINE F, COL. 4,}

Potten Kant, Flemish, Antwerp.
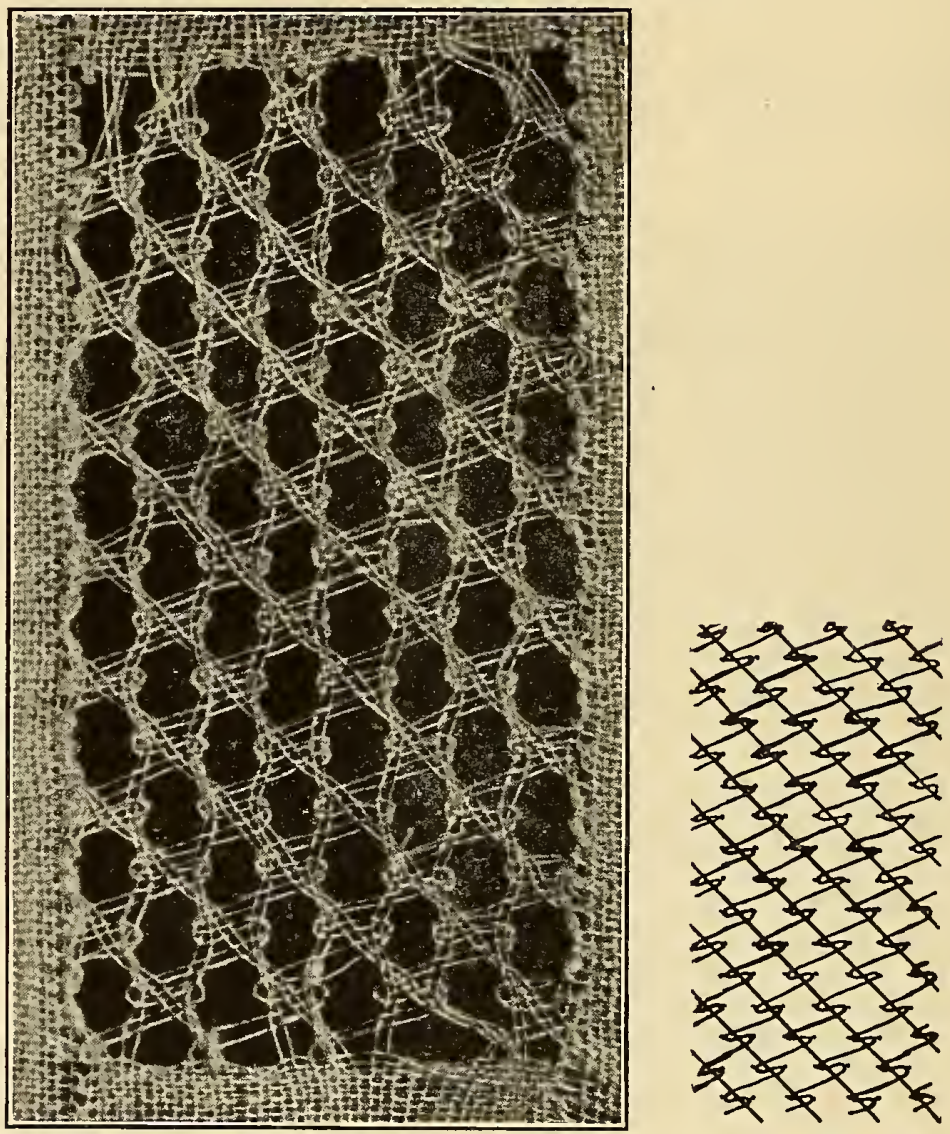

This ground requires four pairs to each mesh, two entering at the left and two at the right, and two correspondingly leaving at the lower left and two at the lower right. The two upper left-hand ones cloth-stitch through each other before entering the main square of the design: but those at the right have already linen-stitched in finishing the preceding square. The conductor or weaver comes from the right-hand, cloth-stitching through the two left-hand pairs. A pin is placed here at the left of the middle of the side of the solid square. The weaver should be twisted once around the pin and cloth-stitch back through the two pairs that came from the left; but in addition, through the one waiting at the right. Another pin is placed at the right of the square opposite the first pin. The conductor is twisted, returns towards the left without pinning and finishes the square. Each square requires two pins directly opposite each other, causing the weaver to run a little uphill in returning from the left toward the right. The solid squares follow each other diagonally, the workers always travelling from the right towards the left, and one pair always working from the left towards the right, cloth-stitching through the vertical pair at the beginning of each solid square. 
LINE F, COL. 5,

Un Fond Hollandais, Filet.
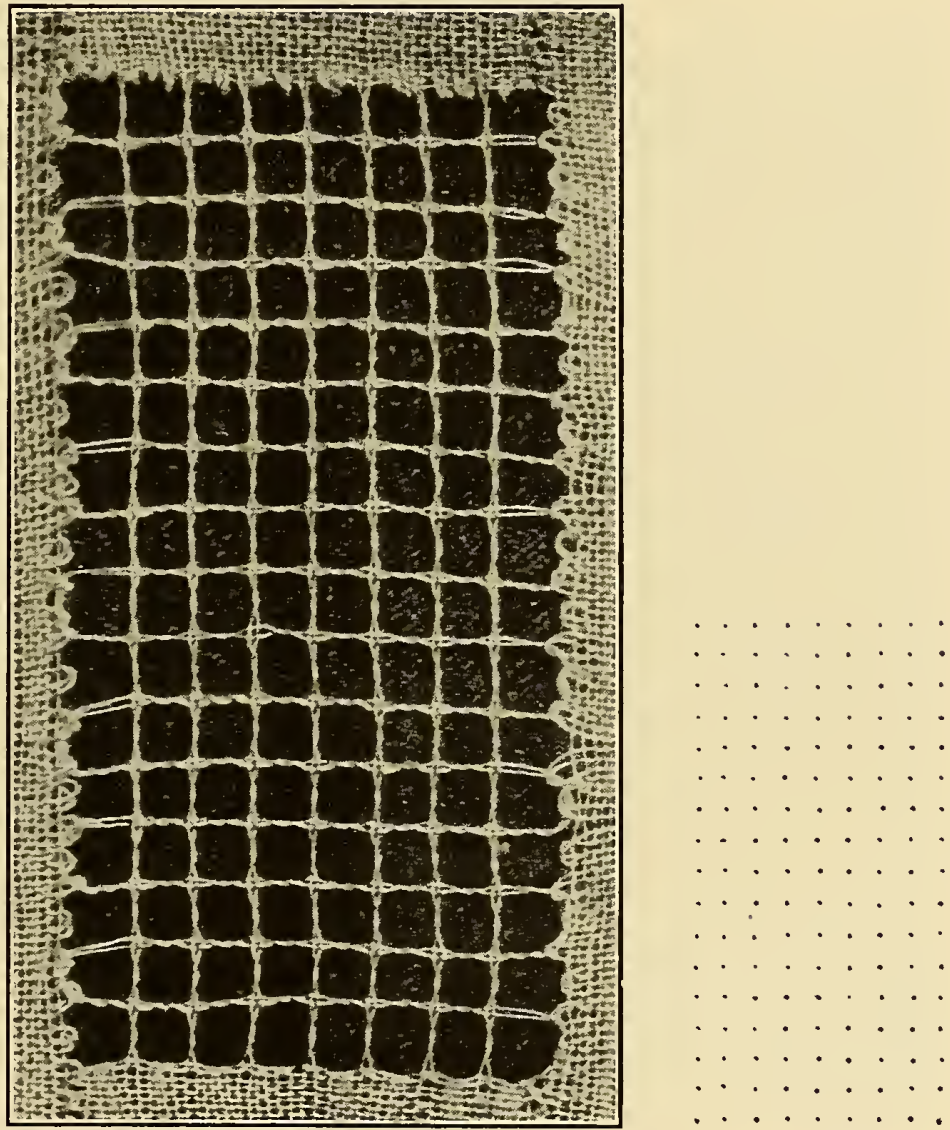

This filet was made with seven, hanging pairs and a working pair. Each pair is twisted twice between joints. The joints are made by cloth-stitching. Pins are placed under the joints to keep them in place; but an upper line of pins is removed as soon as a lower line is reached in order that no gaping holes may be left. 


\section{LINE F, COL. 6,}

\section{Lëcherschlag.}

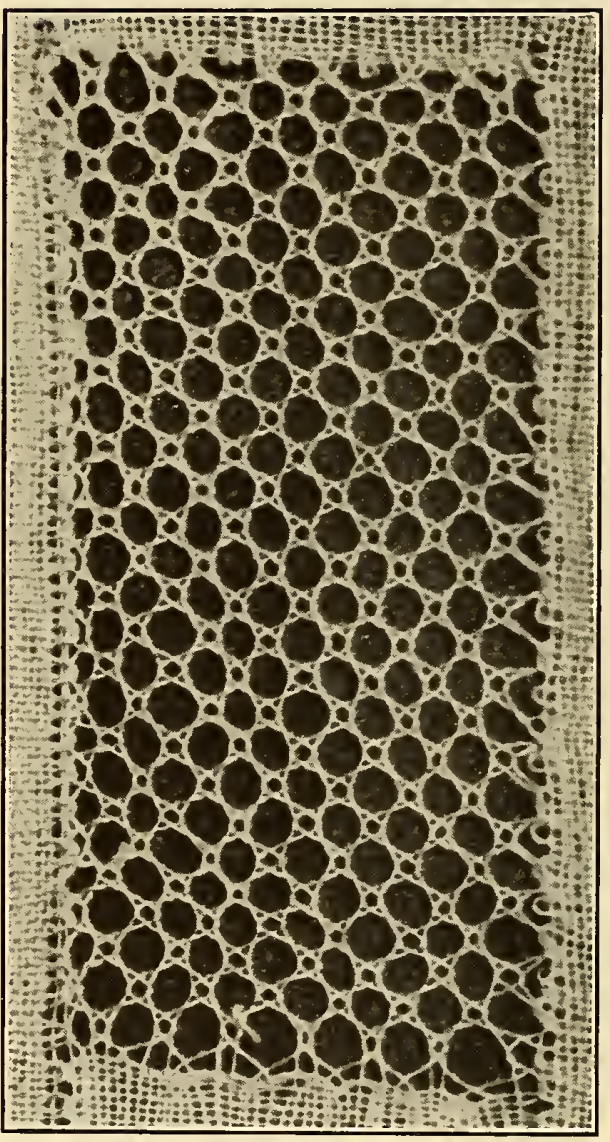

This plain, but pretty ground, is procured by twisting once, crossing, pinning, twisting twice, and then crossing to close. It is made on the oblique. 


\section{LINE F, COL. 7,}

Valenciennes Mixte.
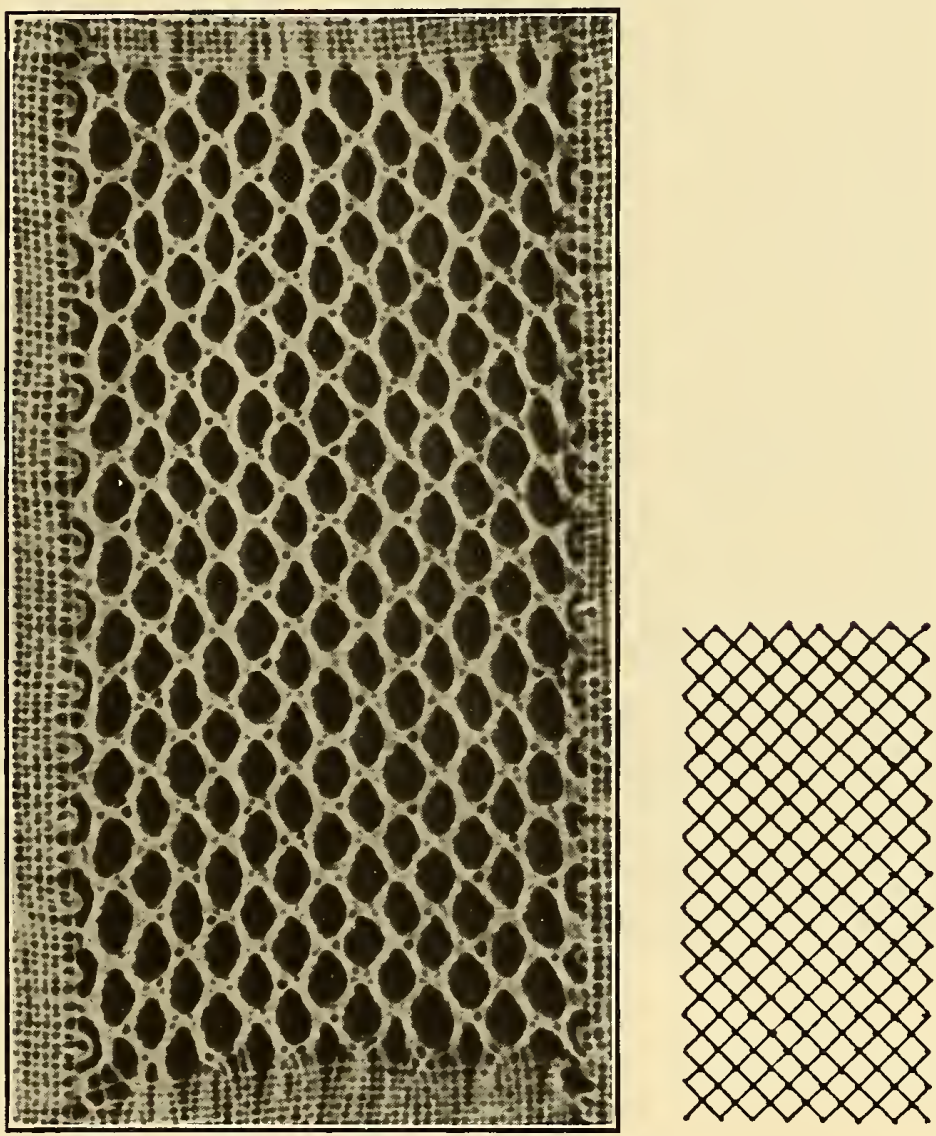

The making of this ground is similar to that of the square-meshed "Vals": see Line A, Column 7. After the braided sides have been made, one should weave the linen-stitch as in the square-meshed "Val," not twisting these two pairs before cloth-stitching; but twisting them both once after the linen-stitch is made, before beginning the new braid. The outside, or pendent pairs, are twisted once as in the square-meshed Valenciennes. 


\section{LINE F, COL. 8,}

\section{Devonshire Swing Filling, Spot Stitch, and no Pin.}
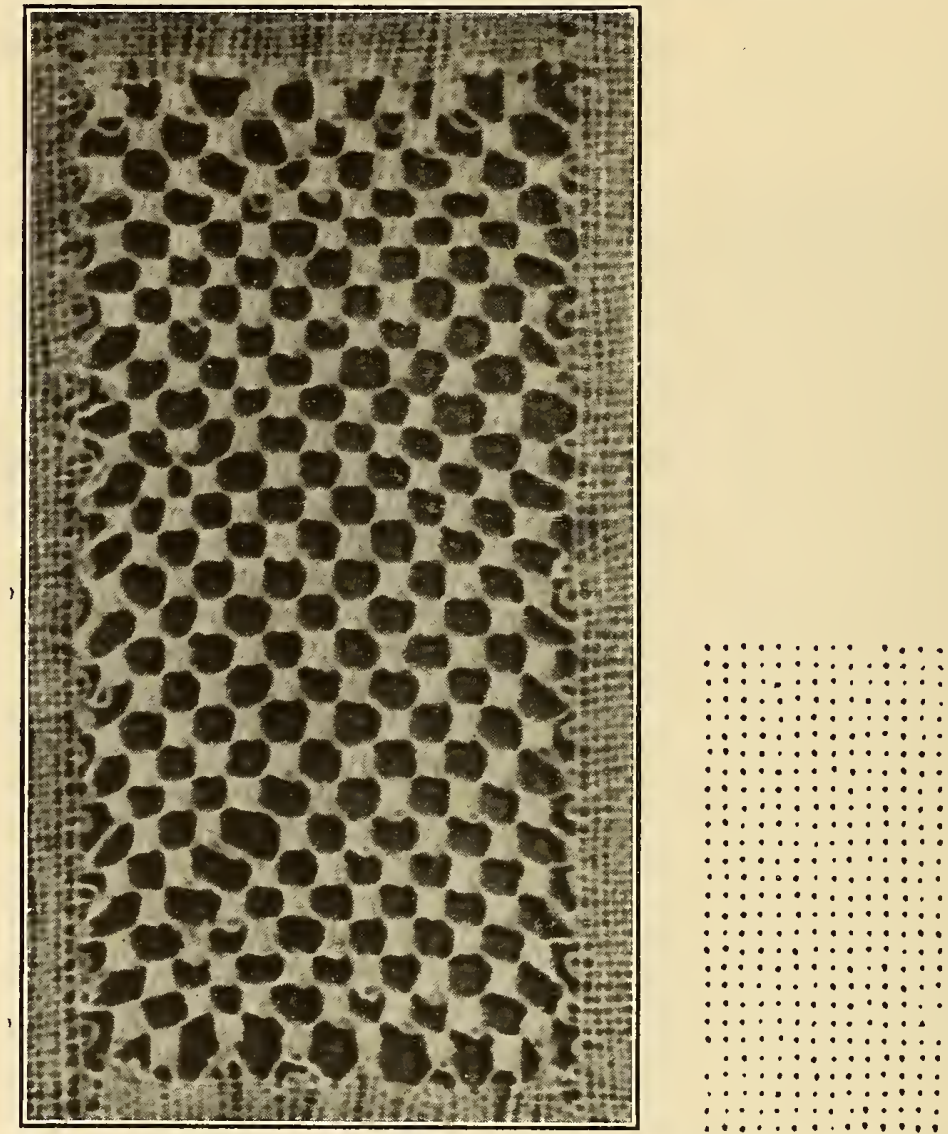

As A. Penderel Moody says, "Either name refers to the working of the stitch, no pins are necessary, and the same worker is swung from each cutwork to the one below." Although Moody's book on "Devon Pillow Lace" suggests making this stitch from the right to the left, it seems perfectly easy to follow the general rule of making it from the left to the right, except, perhaps, in some peculiarly formed space. The weaver would then always come between the lower right of an upper cutwork and the upper left of a lower cutwork. In working from the left, the two left-hand or skeleton threads of a cutwork are secured with the following stitch below or to the left of it in order to give a firm foundation against which to pull, for one cannot pull the weaver of a working pair without misshaping the cutwork. This is, perhaps, what Penderel Moody means by working from the right to the left, as the work would progress in a diagonal line slanting that way. The weaver itself should always be left long to distinguish it, and the same one should be used in each successive cutwork to avoid ever pulling it unduly. The pairs should be twisted three times between points d'esprit. 
LINE F, COL: 9,

\section{A Lille Jour.}
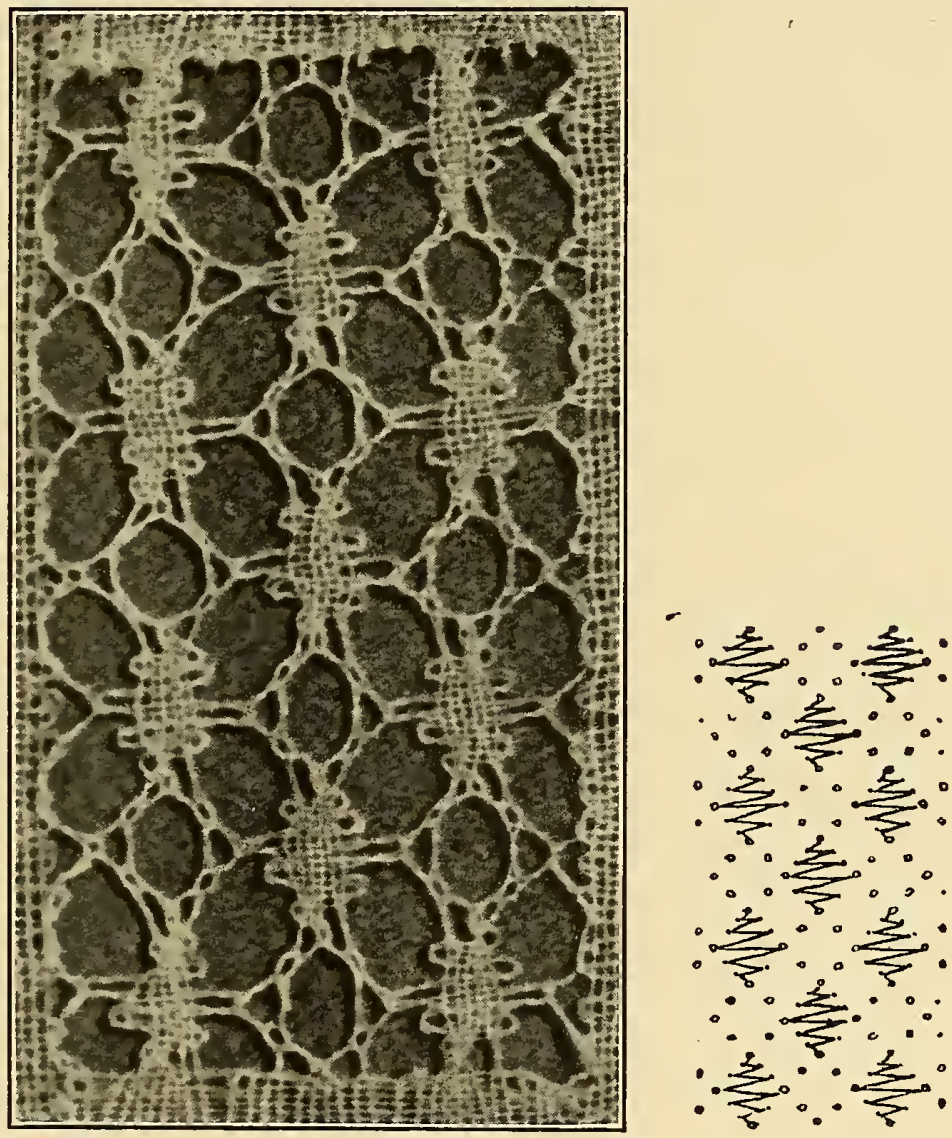

This is made on the basis of Point du Mariage, but each second motif alternates and is eloth-stitched. The pricking is on the diagonal. At the bottom of the Point du Mariage motif where the solid part begins, the two center pairs linen-stitch; a pin is placed, the pairs are twisted twice and the pin is closed. The weaver then works towards the right, working through the righthand mariage pair, which should first be twisted twice; here the pairs again cloth-stitch; another pin is placed; the pairs around it are twisted twice and weave towards the left. Here at the left, the pair hanging from out the mariage 


\section{LINE F, COL. 9-Continued}

\section{A Lille Jour.}

motif, must also be twisted twice. At the center left and right of the solid motif, the weaver cloth-stitches through the mariage motif at its side; pins are placed and closed. The worker here in the space between the two motifs, is twisted only once, in order that the solid part may not be pushed back, but remain as wide as possible. At the bottom of the solid motif, the two center pairs cloth-stitch; a pin is placed : but here one recommences the mariage stitch.

Point du Mariage or Tulle Double is described under Line C, Column 4. At the sides where the mariage motif meets the weaver of the solid spot, the mariage pair should be twisted twice before and twice after the intersection. 
LINE F, COL. 10,

Devonshire Toad-in-the-Hole.
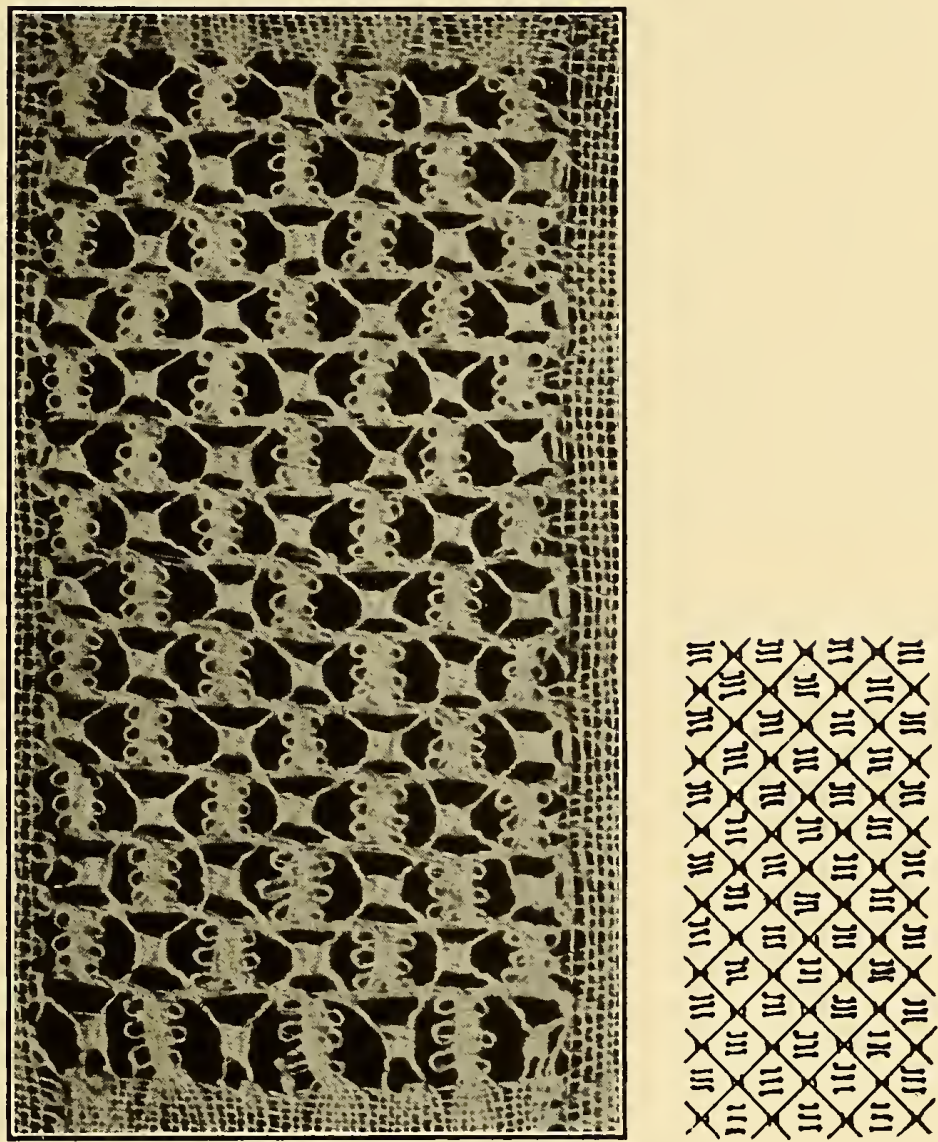

The little cutwork toad is guarded by four cloth-stitch walls; each wall requires four pairs, and each cutwork two. This pricking is made on the diagonal. Each cutwork pair is twisted three times; then the cutwork is made and the weaver and its mate are looped together once to avoid unnecessary pullings. The weaver should be left longer than all the other threads, that it may always be distinguished and not inadvertently pulled. In all cutwork fillings, one should work from the left to the right; then starting again at the left, so as to secure the two left scaffold or foundation threads of the cutwork with the next stitch before weaving the point d'esprit worker into its succeeding stitch. After the cutwork and the looping are finished, a supporting pin is placed below the leadwork and both cutwork threads are again twisted three times. These leadworks should come exactly in the middle of each square. The cutwork pairs are 


\section{LINE F, COL. 10-Continued \\ Devonshire Toad-in-the-Hole.}

now ready to eloth-stitch downwards, each couple on its respective side through the four threads on each side that are going to make the wall directly below. This done, the cutwork pairs are again twisted three times and are ready to make new points d'esprit, the same weaving threads being used throughout from upper row to lower row as workers.

Before starting a wall one must eloth-stitch the two upper left-hand pairs and the two upper right-hand pairs; when the right-hand inside couple becomes the weaver, working through the remaining pairs at the left, so that the first pin is placed at the upper left. At the edge of the wall, the workers are twisted three times around the winkie pin and woven back into the wall. When the last of these wall holes lhas been reached, the bobbins are again divided into two sets; the two wall pairs at the lower right, after having been intersected by the weaver, cloth-stitch through each other and pass towards the right; the weaver and the remaining left-hand pair linen-stitch together towards the left. These two sets are now ready to intersect the descending, diagonal, eutwork pairs. When the wall sets thus divide, they run horizontally. 
LINE F, COL. 11,

Trude "F" Ground (original) (American).
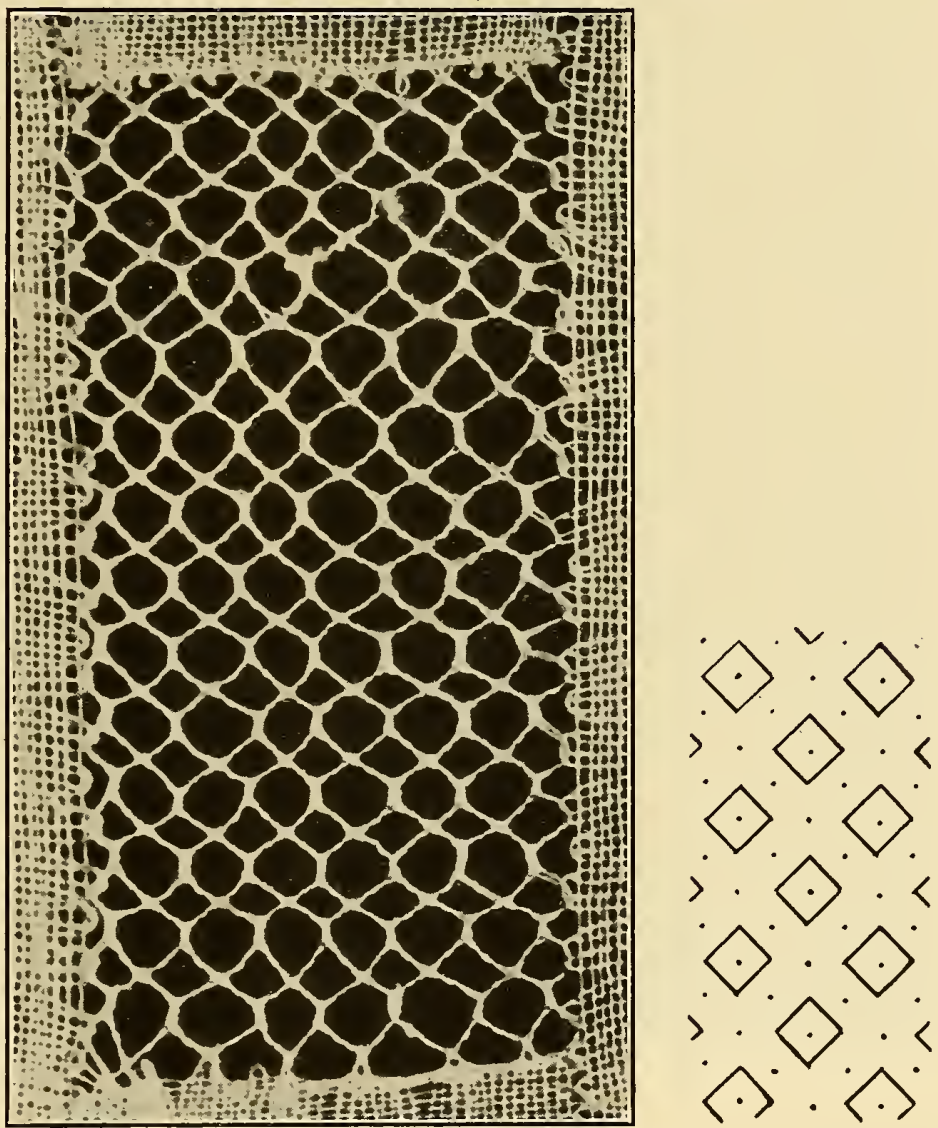

Each shield in this design is made of four threads; two coming from the left and two from the right. The pins are placed directly below each other and the pricking is on the square; that is, vertical and horizontal. The pins are placed above the joint to hold it down. The sides are braided four times and the tops and bottoms are twisted twice, crossed and twisted twice. This mesh loses its shape in washing. 
LINE F, COL. 12,

A Fancy Zeccatello.
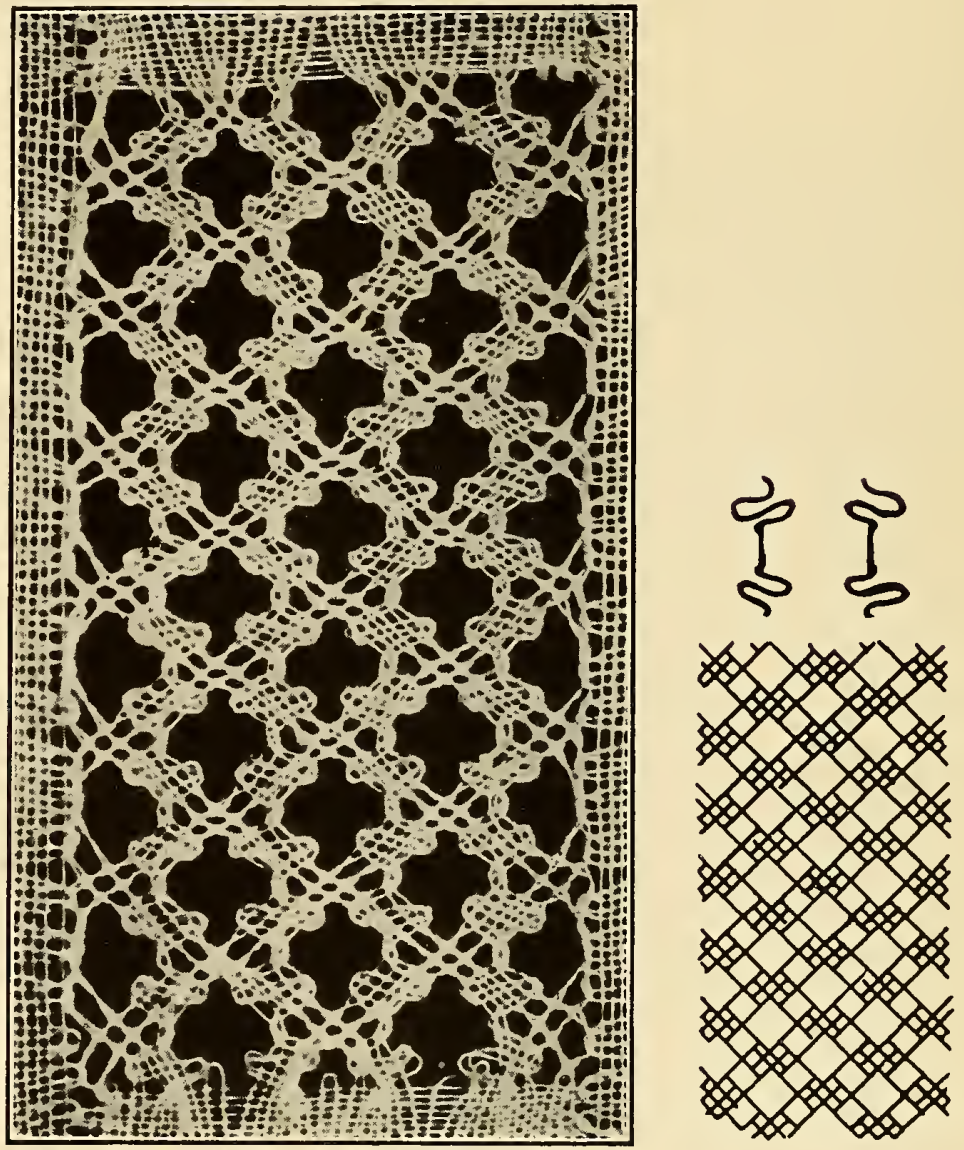

Each linen-stitch spot is made up of eight threads, and each complete motif requires four linen-stitch spots with an open, twisted cross between. All joints are made by cloth-stitching. A weaver and a pendant pair enter at the top of the linen; left-hand, upper square. Here a pin is placed and closed. Then one weaves towards the left corner of the square, places a pin and closes it. Then to the right-hand lower corner of the same square, where another pin is placed and closed, then to the bottom, where a pin is placed and closed, the threads then entering the square directly below. The upper, right-hand, linen square of the motif is made in the same way, but reversed; that is, a pin is placed first at the top, then at the right-hand corner, then at the left, then at the bottom. The other two pairs, which enter at the tops of these two linen spots, after cloth-stitching through their centers, emerge below, coming towards each other, 


\section{LINE F, COL. 12-Continued}

\section{A Fancy Zeccatello.}

ready to intersect and form the open cross in the center of the motif. Eacl pair is twisted once, cloth-stitched, twisted again, cloth-stitched through the second, opposite pair and again twisted once. In finishing the two lower blocks, one is really starting new ones below to the right and left; the right-hand lower square becoming the left-hand upper square of a succeeding motif. The grilllike, twisted, center threads are now cloth-stitched into the lower blocks to form their bodies. It should be remarked that these squares are not exactly opposite: - the uppermost pair in leaving a higher square, crosses through the grilled center and enters the middle of the lower square to the other side: the pair coming from the middle of the upper block crosses and enters at the lovver part of the side of the square below. 
LINE F, COL. 13,

Valenciennes Picots.
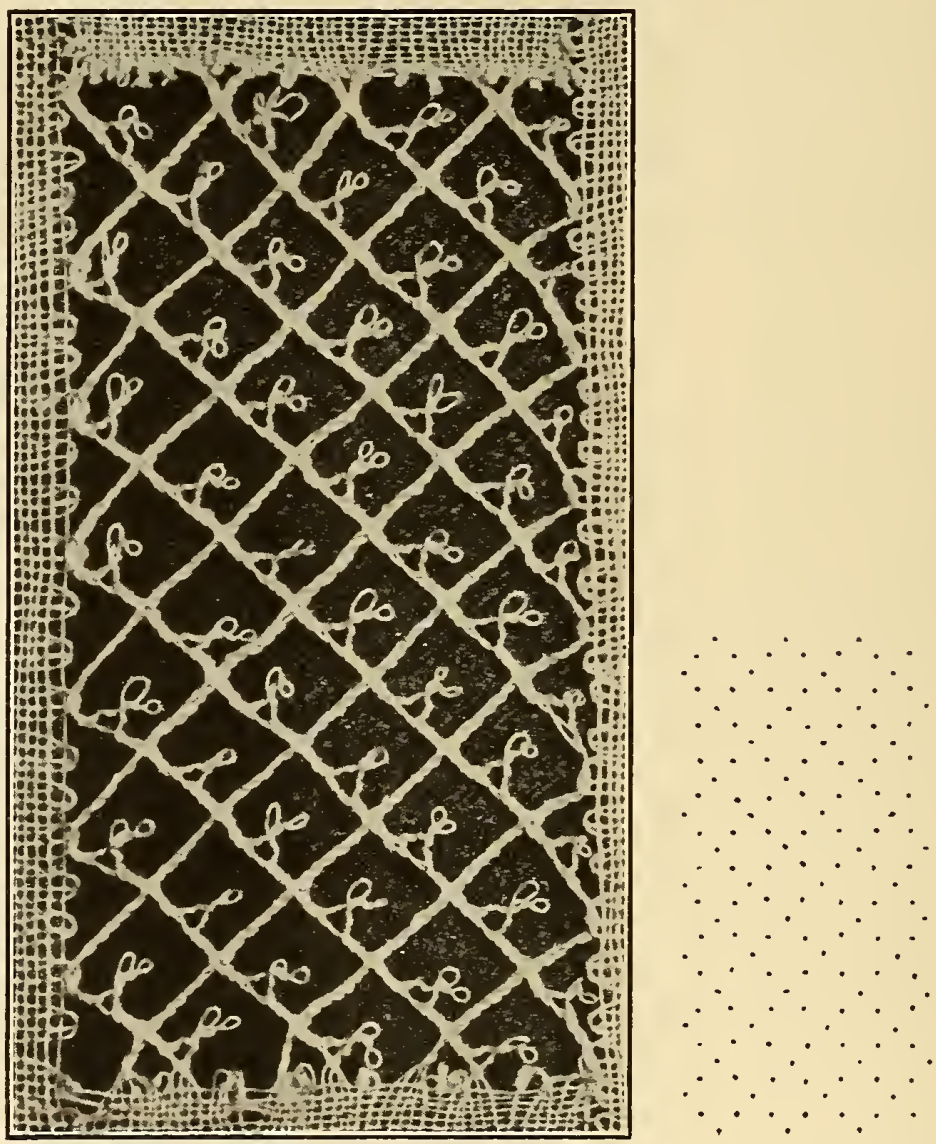

These plaits are braided in the usual manner, and the linen-stitch joints are made as in Lines D and E, Column 13.

The right-hand pair is here used to make the picot. It is twisted three times and followed by an ordinary picot as explained under Line E, Column 13. To complete it, one crosses the two threads of the pair, takes the exterior thread alone and places it in the reverse direction over and around the pin. One then twists the pair three times, and having twisted the waiting, mnused pair of the braid, recommences plaiting. 
LINE F, COL. 14,

Italian Open-eyed, Cable-like Spiders.
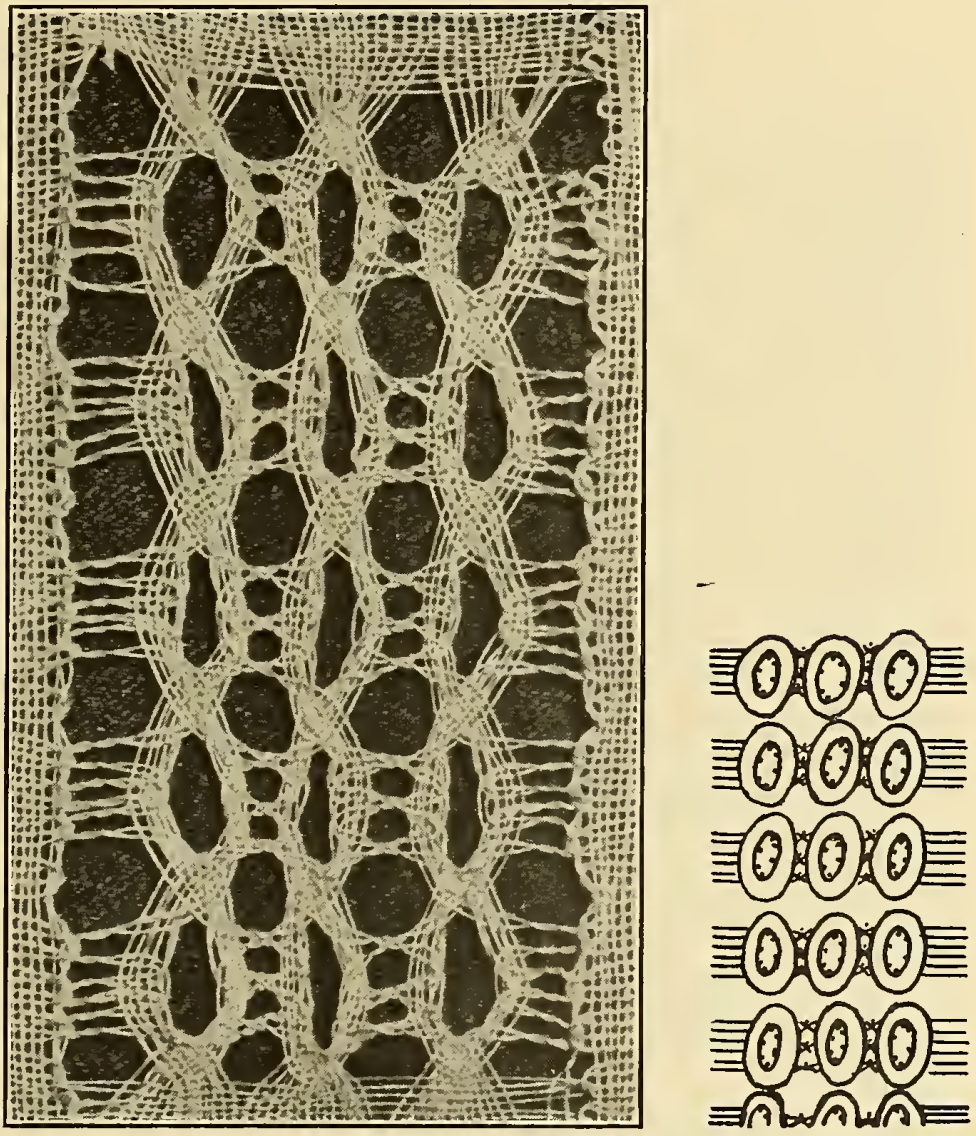

Eight threads enter at each side of the top of every spider, cloth-stitching in consecutive order through each other. Each spider is closed in the same way, but reversed, at its base. At the upper left of the spider inside the innermost pair, a pin is placed and then this pair linen-stitches through its mates towards the left. Once outside the spider, this pair is twisted once. Here it meets a corresponding pair-also twisted once-coming in the opposite direction from the spider next to the left. These two now eloth-stitch and the joint is supported by a pin, each pair being twisted once after the joint. These pairs therefore exchange, each one working towards the opposite spider, linen-stitching through it till it reaches the inside, where in the same way that a Bohemian edge is made, the newly-entered pair becomes the inside spider pair and the former inside spider pair exits around a pin by linen-stitching outwards through the other pairs and doing as was done before, just above. In all, there are three such exchanges on each side of every spider, so that three pins are placed between spiders and three pins on the inside of each side of every spider. 


\section{LINE F, COL. 15,}

\section{Demi-Marguerites.}
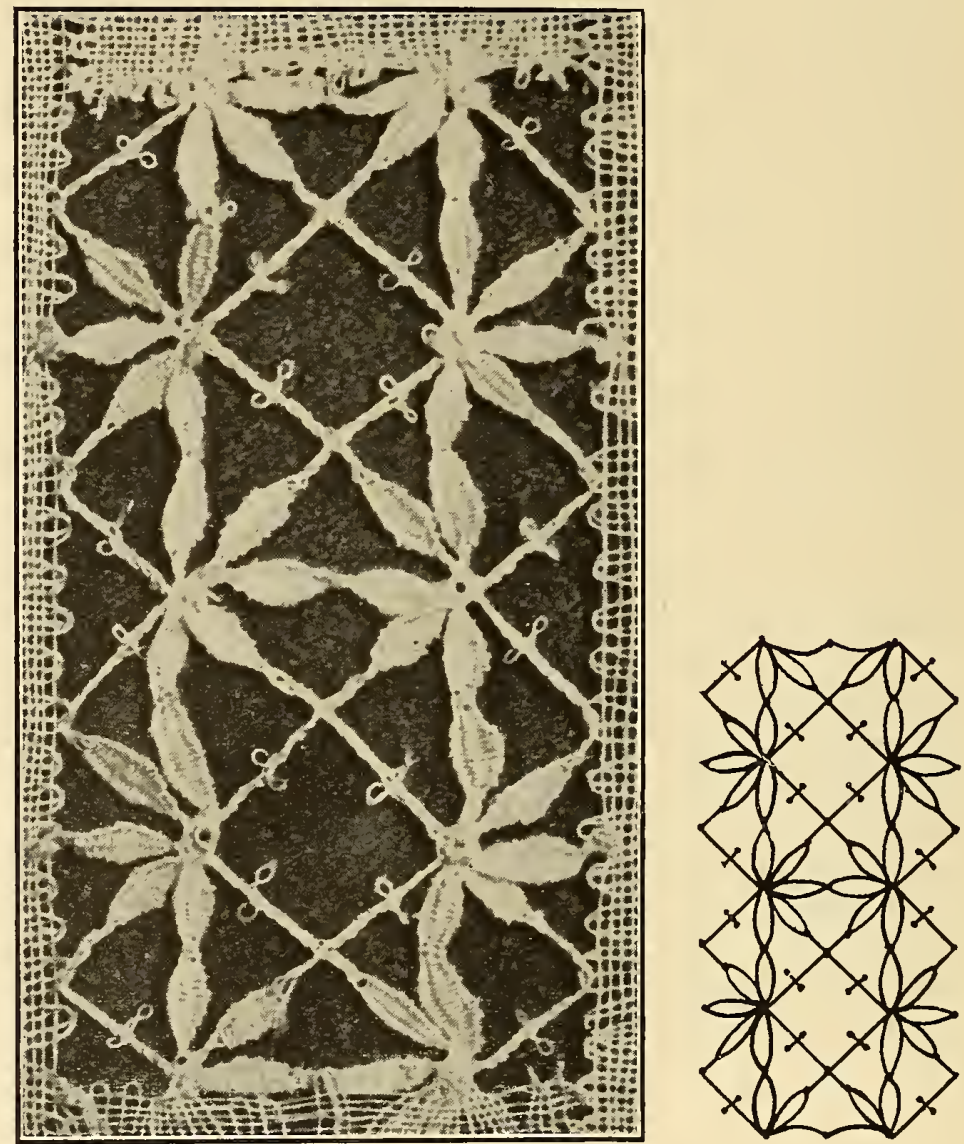

These half-daisies alternate with braids that are ornamented with a picot on each side of the middle of their long sides. The centers of the marguerites should stand up as has been described elsewhere under Line F, Column 2. Pins are placed at the beginning or end, as it may be, of each petal, at the point where it joins a braid. The horizontal leaves have to be added at either the left or the right, according to which marguerite is ready first or according to one's preference of direction in weaving: have to be added in the air; that is, cloth-stitched through an incoming braid, using two threads of the braid as one thread, before the center of the daisy is made, in order that the new pairs may be well anchored. The centers should be made in this case the same as in an eight-leaved daisy. See Line G, Column 15. 
LINE F, COL. 16,

\section{Trude "L" Ground (original) (American).}
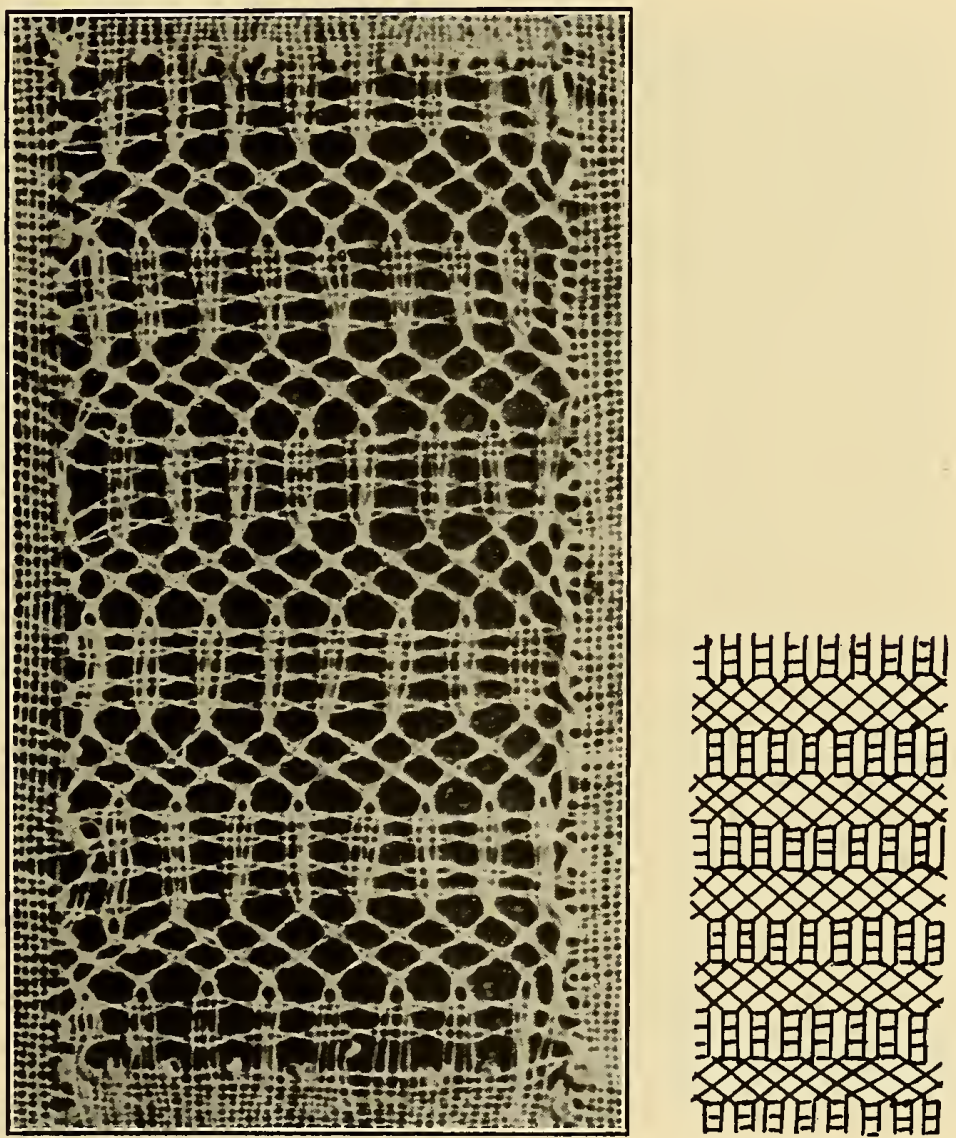

See Column 16, Line E, and Column 16, Line G. The method of working is similar to that of Trude " $\mathrm{K}$ " Ground, but the bodies of the fish are placed alternately below one another instead of directly below each other as in Trude " $\mathrm{K}$ " Ground; and instead of the diagonal pairs passing through each other only once-not counting their exits and entrances into fish-they, in this case, cloth-stitch through each other twice between tails and heads; and are twisted once between stitches. The horizontal workers are also twisted once between fish, but not while working through the bodies; and the fish pairs themselves are twisted once at the head and tail, where pins are placed before finishing each body with a cloth-stitch. 
LINE F, COL. 17,

Dieppe Three-Thread Valenciennes.
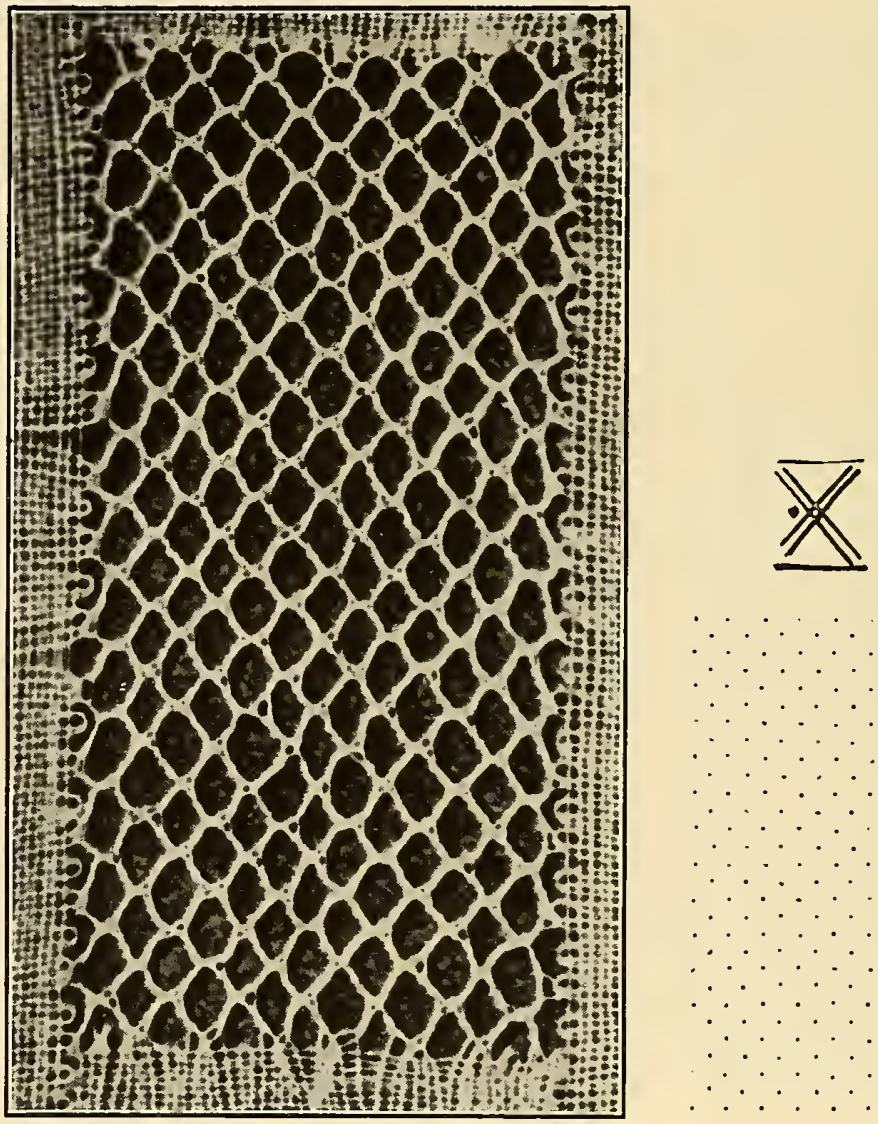

Each braid requires three threads and should be made by placing the righthand thread over the center thread; then the left one over the center one. This should be done three times with each braid between intersections. The joint is made by cloth-stitching the four threads nearest the center, placing a pin below the linen-stitch to support it and avoid confusion. Meanwhile one thread should be left idly dangling each side of the joint. These idle, side threads are again taken up and braided after the joint is finished. The braiding is recommenced in the same way as before, by placing the right thread over the center, then the left one over the center. 
LINE F, COL. 18.

Tulle Double Done on the Square.
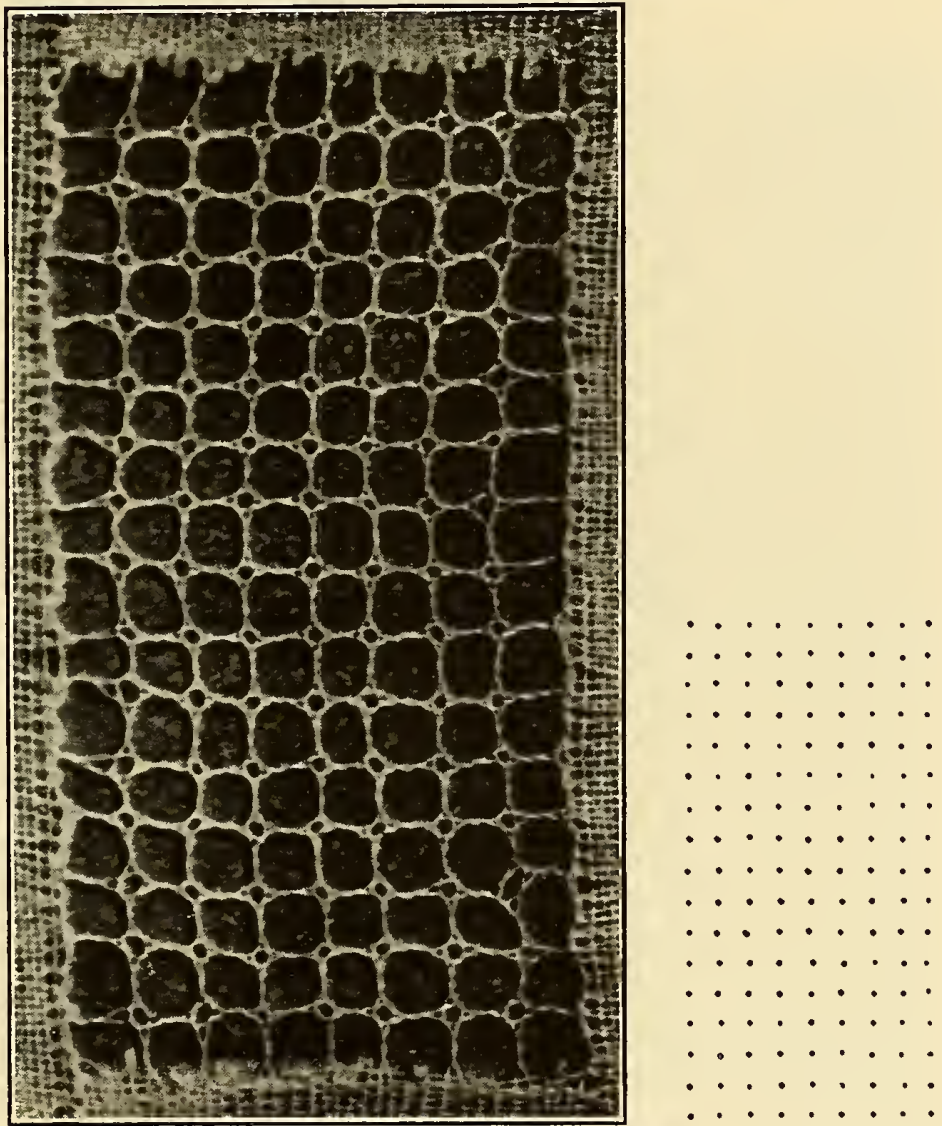

This ground is made in the same way as that described under Line D, Column 1, except that the pricking is not on the diagonal, and the threads run vertically and horizontally instead of obliquely: the horizontal threads being used as the weavers, working from left to right on one line and from right to left on the succeeding one; in other words, alternately. 


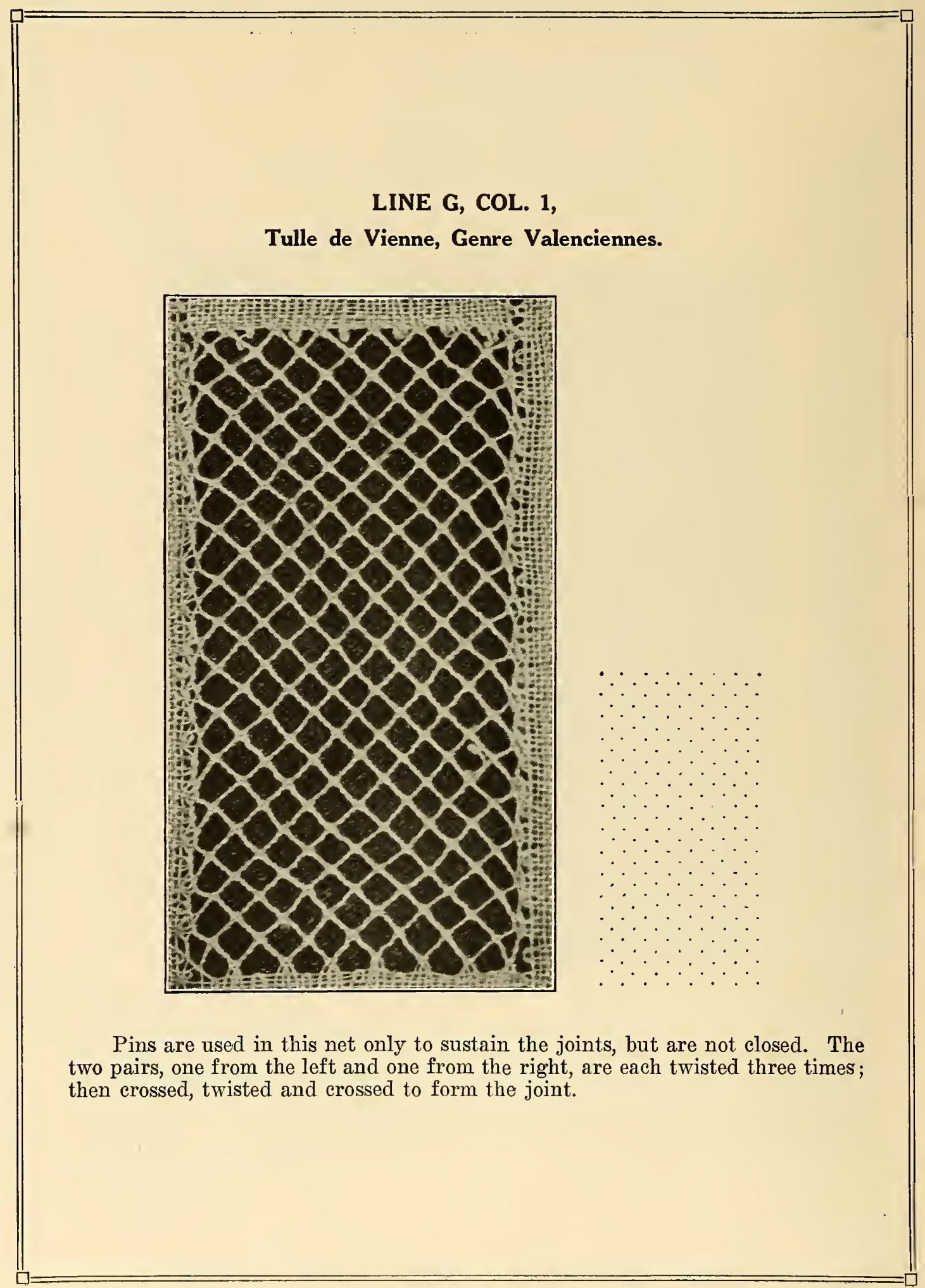


LINE G, COL. 2,

Round Spiders in Twice-twisted Hole Ground, les Arraignées Rondes.
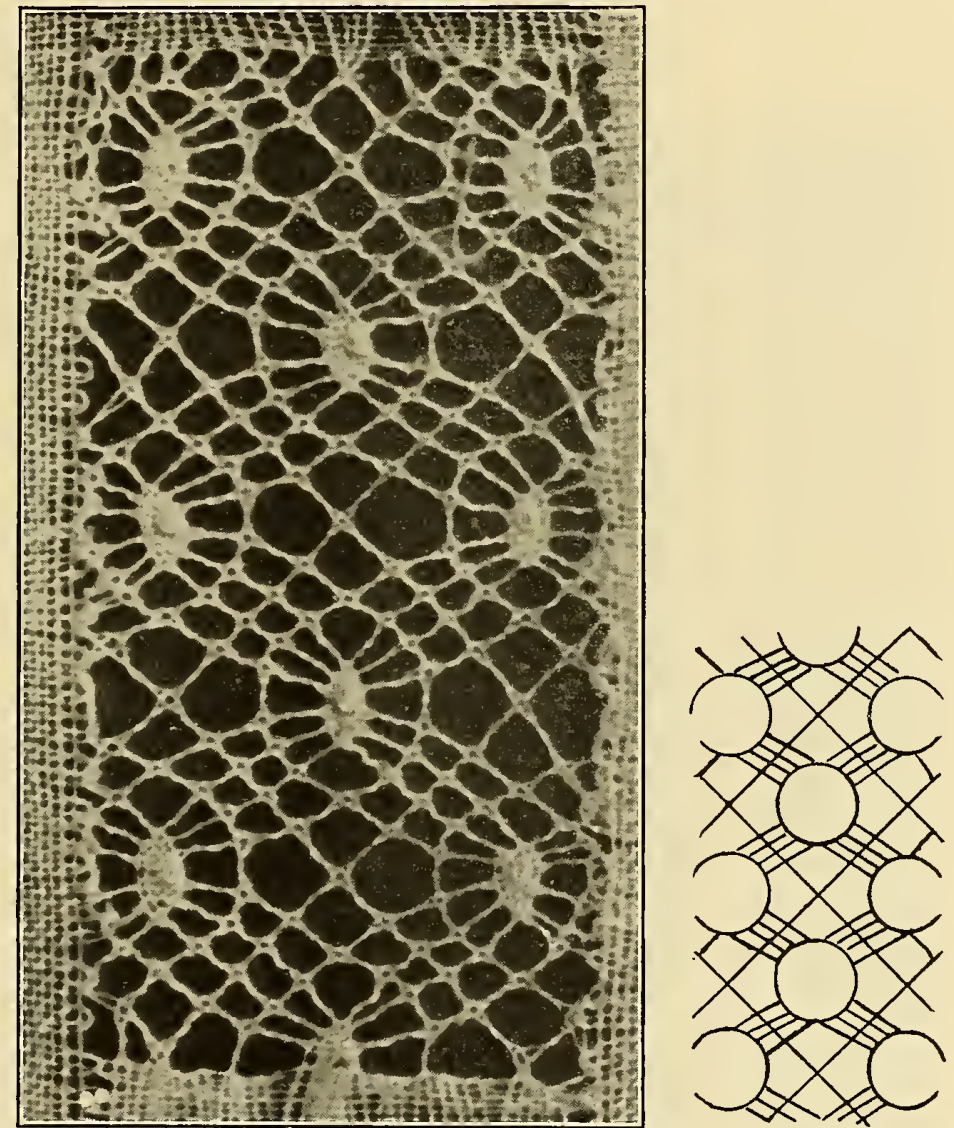

Each of these spiders requires six pairs to form the legs, three at the upper right and three at the upper left. Two more pairs are needed to form the circle around the spider, and another two pairs to form the square around the circle. The spiders themselves are made in the usual way; as, for example, in line $\mathrm{H}$, Col. 2; the legs twisted three times: but the circle around the spider is made, if the pairs have not already been twisted, by twisting them twice and crossing, placing a pin, and crossing to close it. The square outside of the circle is made in the same way. 


\section{LINE G, COL. 3, \\ Tulle (5 twists).}
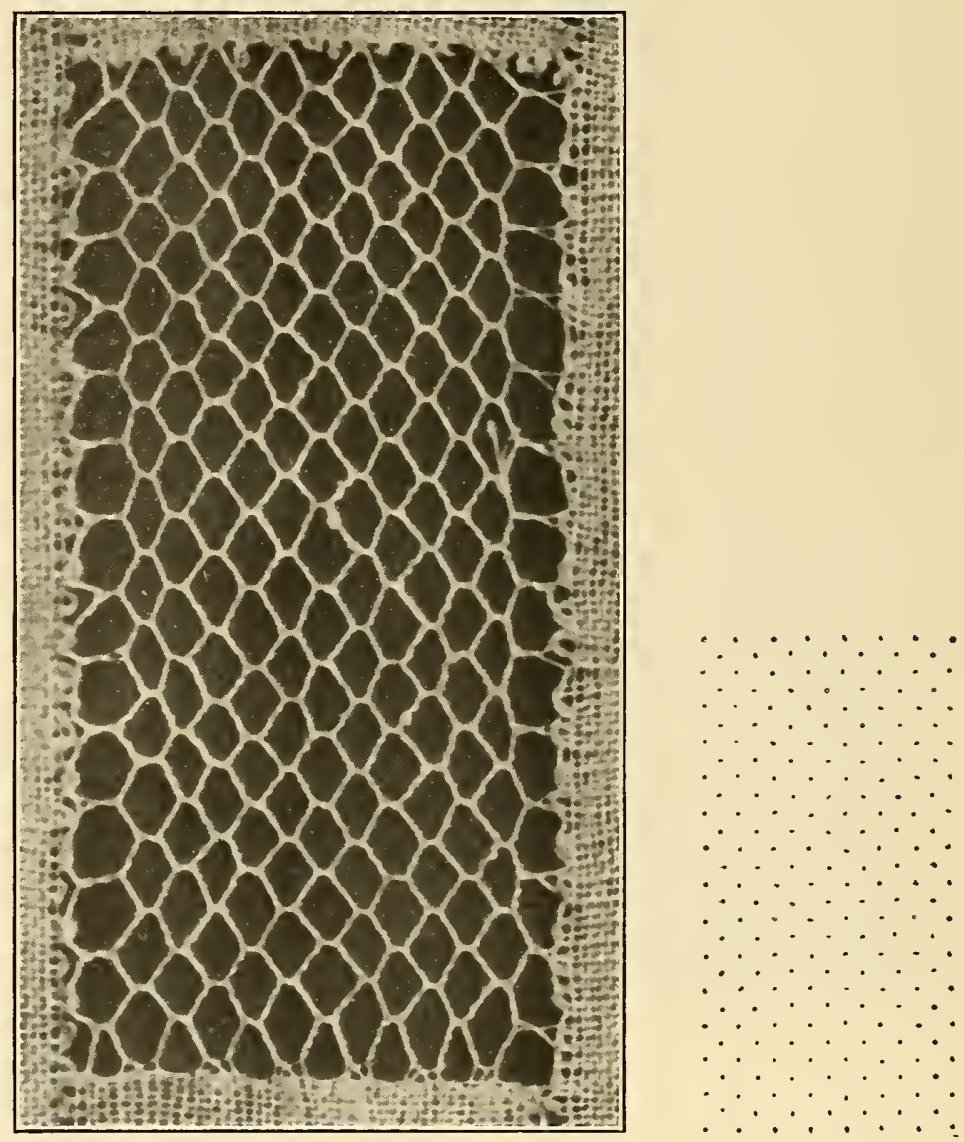

The principle of this mesh is the same as that described under Lines $\mathbf{E}$ and $\mathrm{F}$, Column 3; except that the sides are twisted five times, making it appear less even and well-balanced than the ground of Line F, Column 3. 
LINE G, COL. 4,

Round, Open-eyed, Brabant, Binche Spiders, Oeil de Perdrix, Réseau Rosacé, Point de Flandre.
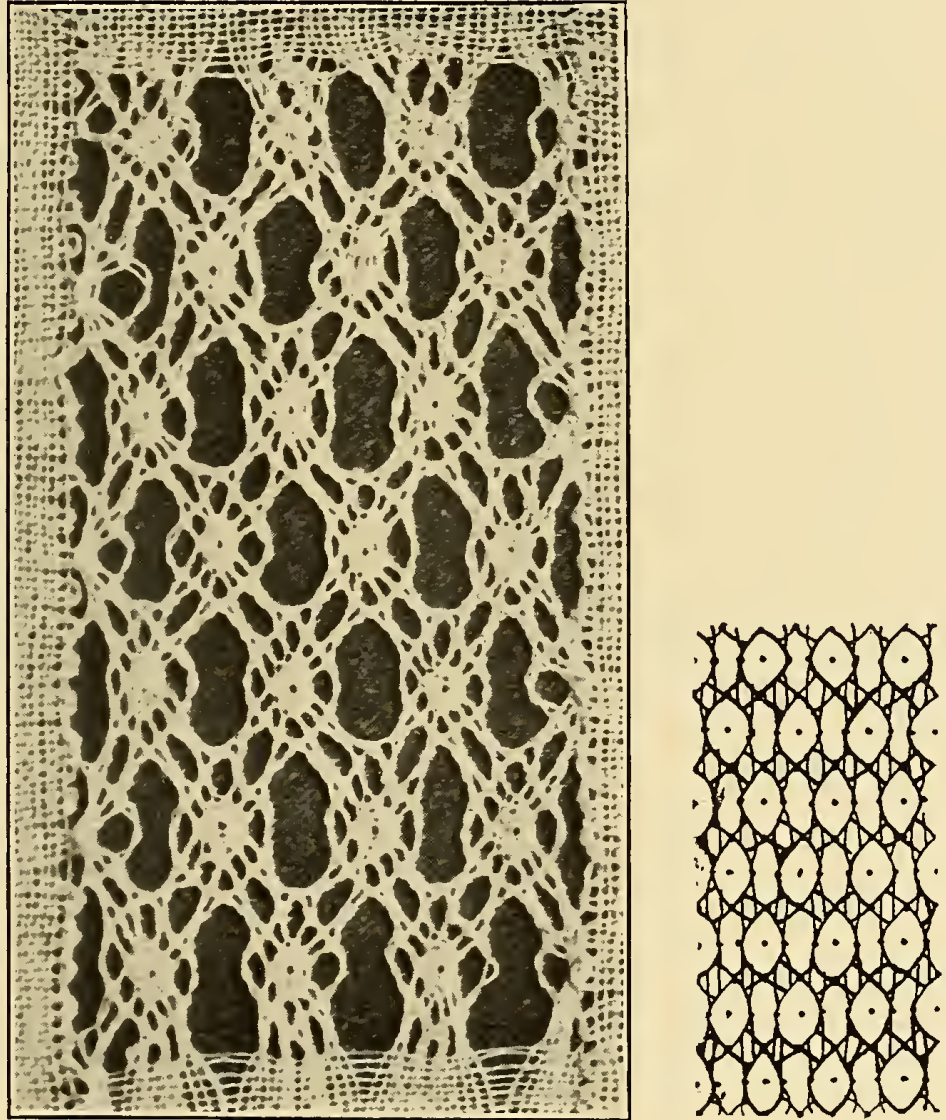

Eight pairs are needed to make this very pretty, but somewhat complicated spider. Six pairs for the body proper; three entering at the upper left, inside of the circle; and three at the upper right, inside of the circle. At the top of the circle, the inside, or first two pairs which meet, are cloth-stitched through each other, the joints supported by a pin, partly to avoid confusion. These two encircling pairs then cloth-stitch through the spider legs, being twisted once between stitches. At the bottom of the spider they meet again and once more cloth-stitch through each other, the joint being supported as before by a pin. Each spider leg is twisted twice. In order to make this body, the prominent part 


\section{LINE G, COL. 4-Continued}

\section{Round, Open-eyed, Brabant, Binche Spiders, Oeil de Perdrix, Réseau Rosacé, Point de Flandre.}

of which is the open eye at the center, so made that it cannot close, because the pairs pull away from each other, some of the pairs have to be split or separated, one thread from its mate. The top, center or first, upper, right-hand pair passes continuously from the top to the bottom of the spider, cloth-stitching through whatever pairs it meets: but keeping to the right of the pin. The second, upper, right-hand leg does likewise; the third, upper, right-hand leg cloth-stitches through whatever pairs it meets; but keeps above the pin and passes from the upper, right-hand side of the spider to the lower, left-hand side of the spider. The first, upper, inside, left-hand leg separates, its left-hand thread lying idle until there is another separate thread to take for its mate, when it cloth-stitches through the pairs it meets, keeping to the left of the pin. Its right-hand thread does likewise, but passes to the right of the pin, around it, below it, and back to its original mate. The second, upper, left-hand pair splits in the same way. In fact, its two threads become respectively the mates of the two preceding threads. After passing around and under the pin, the original pairs rejoin each other. The third, or lowest, left-hand, upper leg does not separate; but keeps on the underside of the pin, passing from the upper left to the lower right of the spider. In this way, there are six threads to the left of the central pin and six to the right. Each spider leg is twisted twice just inside of the circle, outside of the spider body, as noted above. The pairs outside of the circle are each twisted once and in couples cloth-stitch through each other, making crosses; are again twisted once, and are then ready to pass into another circle. The top and bottom center legs combine with the wheel or circle: the other two legs crossing each other.

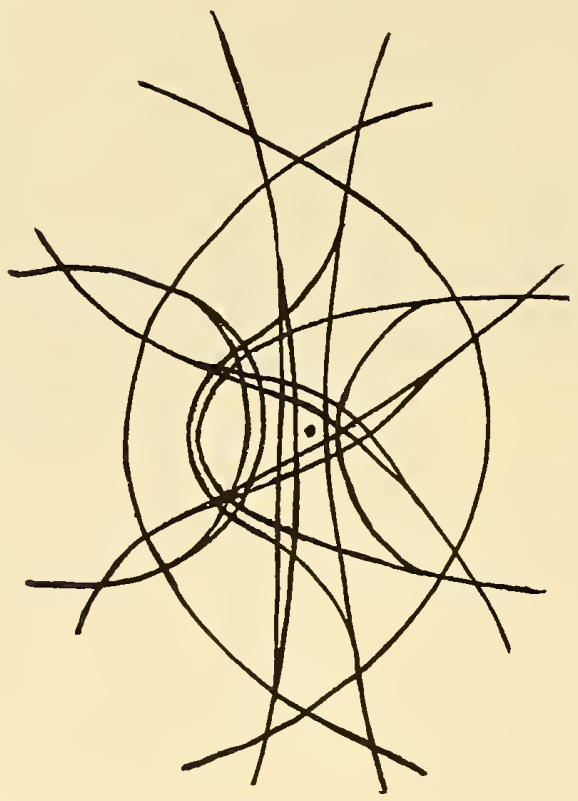




\section{LINE G, COL. 5,}

Bohemian Ground.
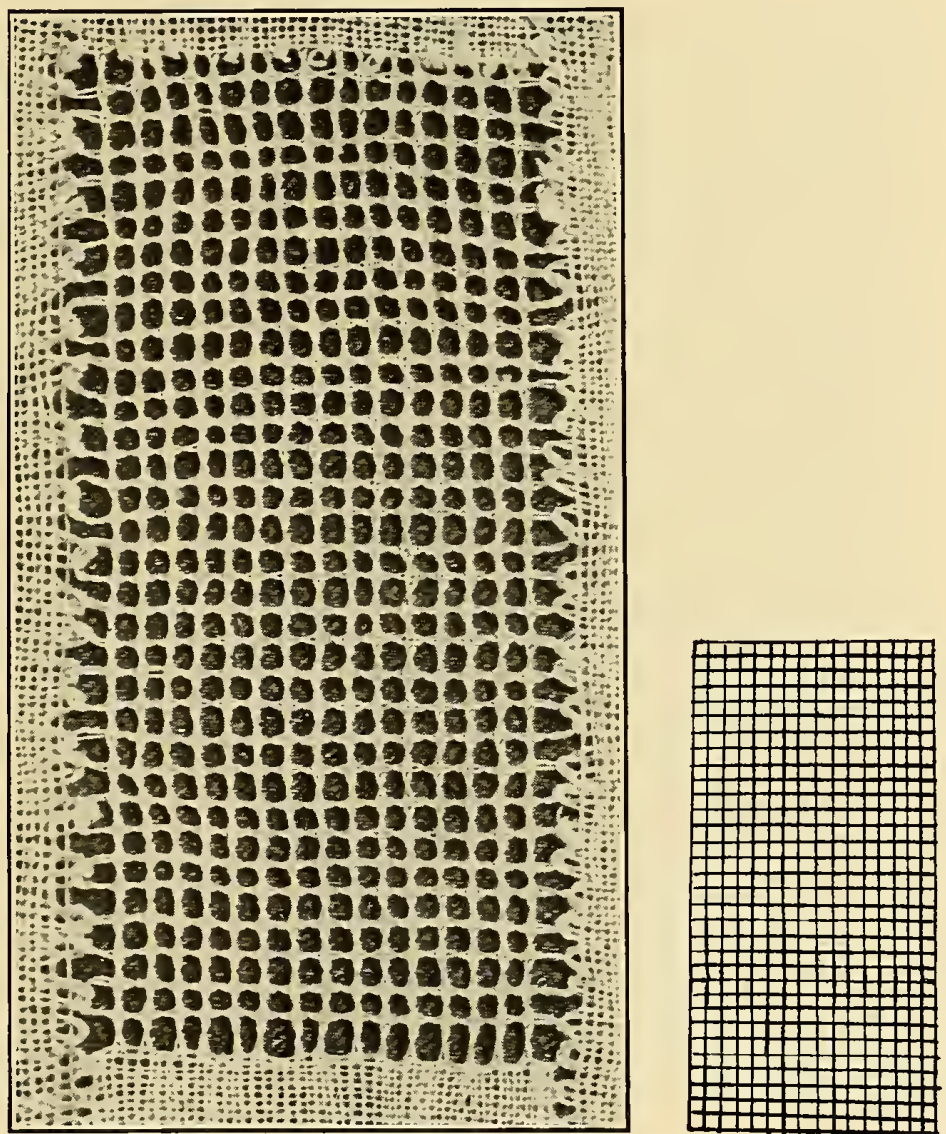

This is a very simple filet mesh, every pair being twisted once between joints, the joints being made by linen-stitching, and the horizontal pair being used as weaver, working from left to right on one line and from right to left on the next lower one. The joints should be supported here and there by pins in order to retain the alignment: but the pins should not be left in long or they will spread the threads and so leave ugly gaps. 


\section{LINE G, COL. 6,}

Réseau Simple, Analogue à Celui de Lille, d'Arras, de Marche, de Töndern, de Buckingham.

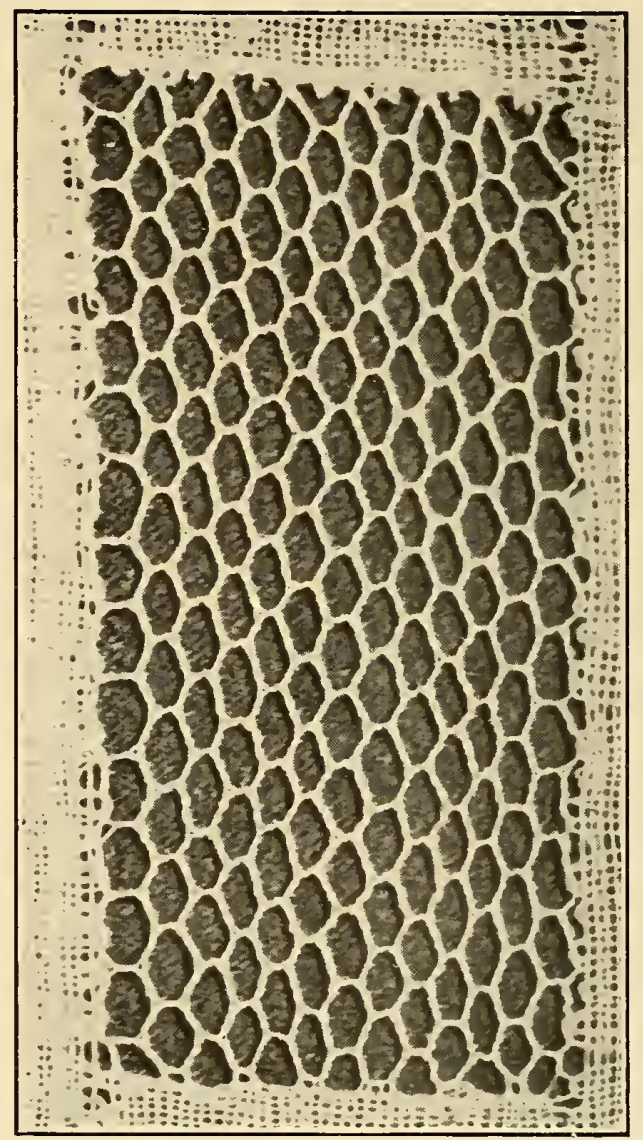

Two pairs are required to make this stitch and they should be twisted three times between joints. In making the joint, the left-land thread of the right-hand pair passes under the right-hand thread of the left-hand pair, coming out above it and falling forward and downward, now forming a new lefthand pair. The other joint-thread passes forward and downward towards the right, forming a new right-hand pair. A pin should be placed below this knot to sustain it. This is an exceptional stitch in bobbin lace making, as the passing of the bobbin througlı the loop really forms a loose knot. 
LINE G, COL. 7,

Round-meshed Valenciennes (singly twisted joint, centuple braid)

(Bruges has triple braid).
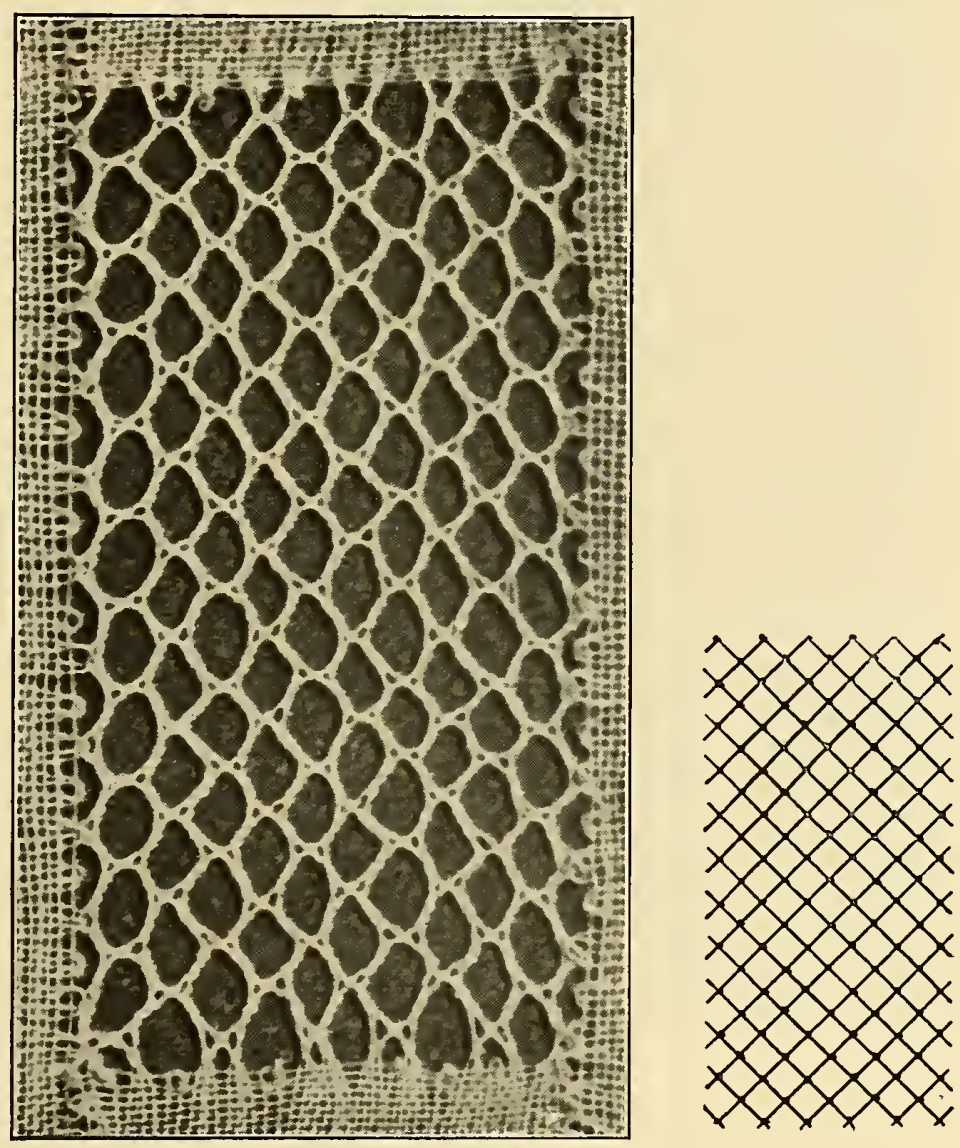

See Line A, Column 7 and Line F. Column 7. The sides of the meshes in round Valenciennes are made in the same way as those of square or mixed Valenciennes, but the joints are more open and weaker. The sides of this particular ground are braided five times. The joint is made by twisting each of the two inner pairs once after finishing the braid and before cloth-stitching, and twisting once the pair coming towards the left after linen-stitching: but not the pair going towards the right, before beginning the new plait below. The outside hanging pairs should be twisted once between braids. 


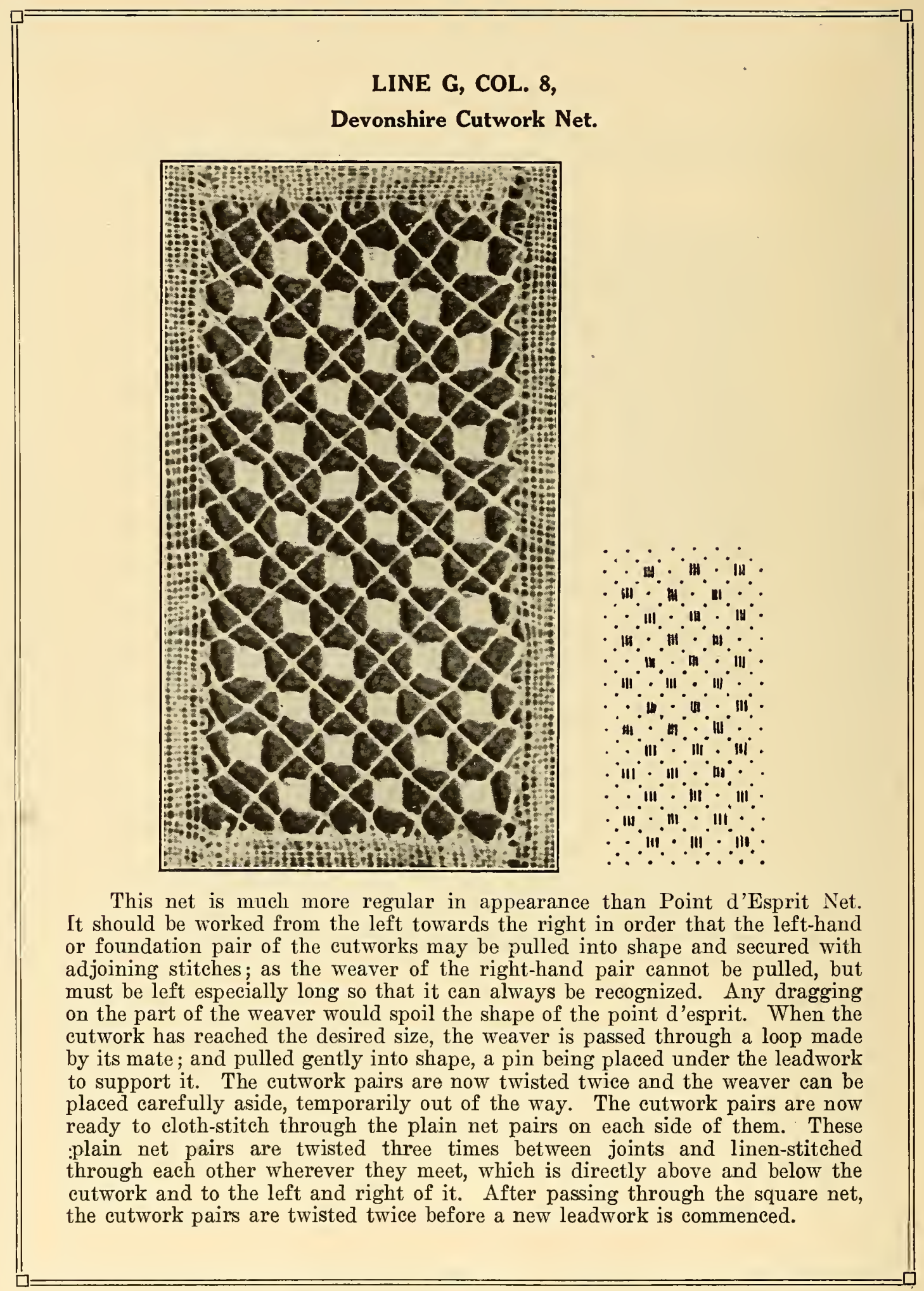




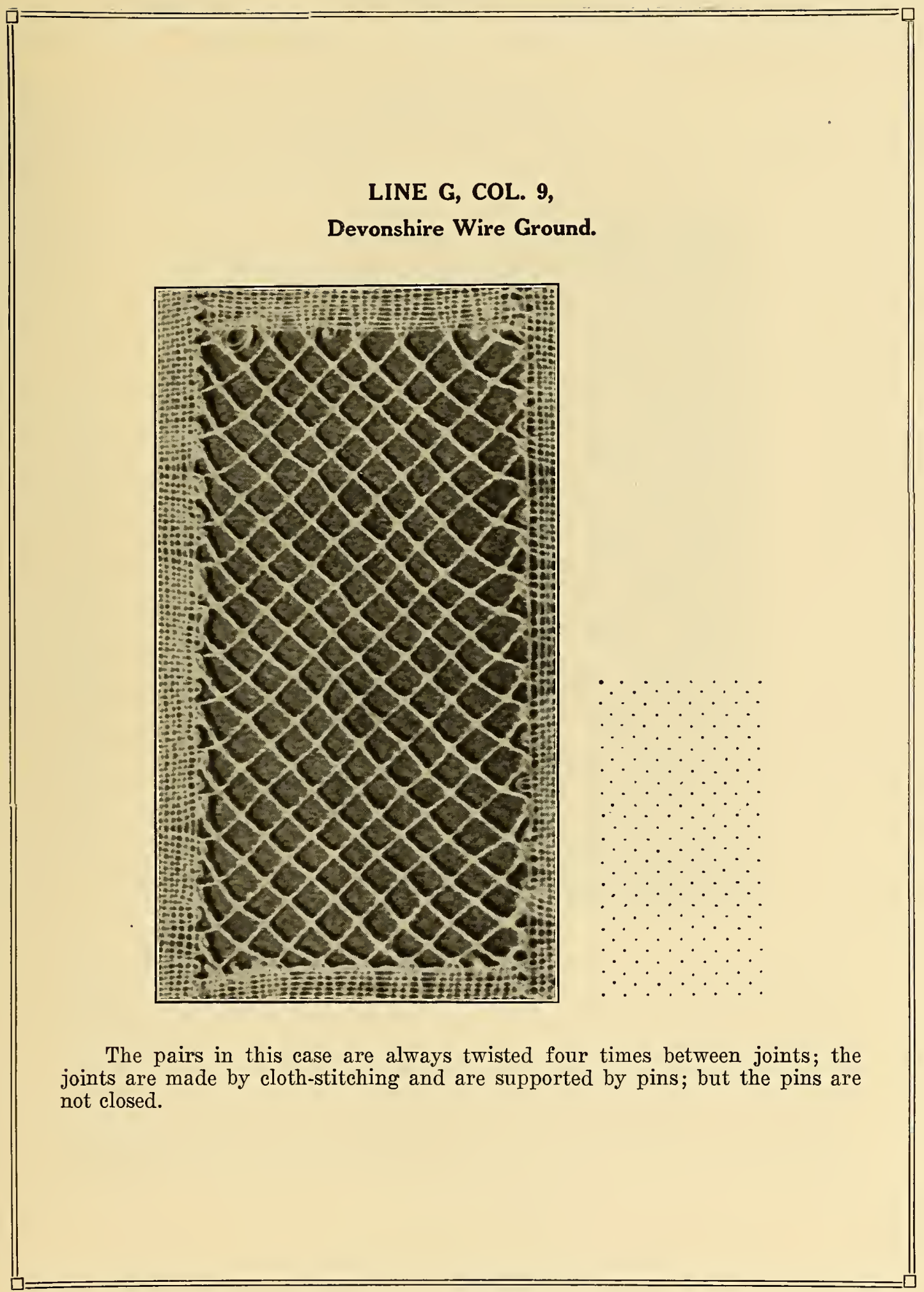


LINE G, COL. 10,

\section{Devonshire Wall Filling.}

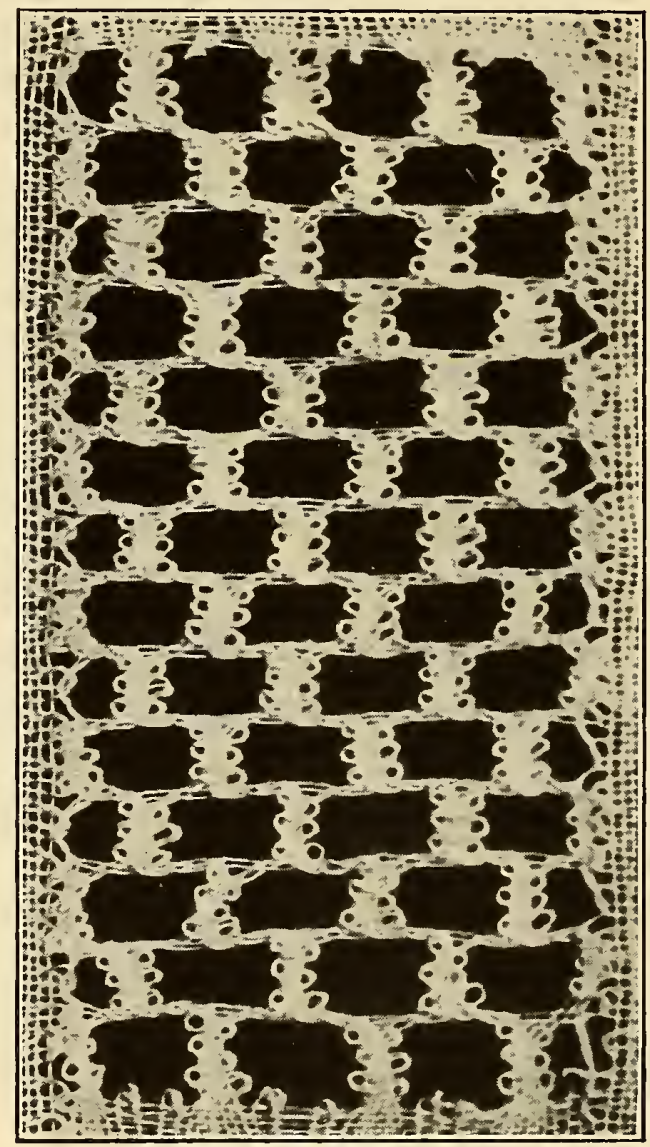

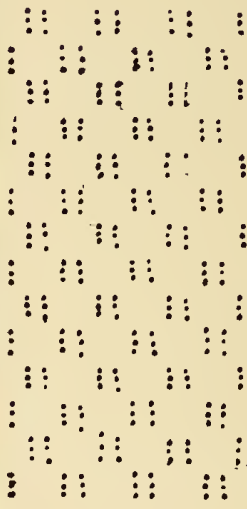

Eight threads are required for each wall. The weaver starts at the upper right, cloth-stitching to the upper left, and is twisted three times around the winkie pin. There are three pin holes to each side of the wall. At the bottom of the wall, after the lowest right-hand pin has been placed, the weaver clothstitches again to the left and with the left-hand lianging pair, passes over into the top of the left-hand, lower wall, cloth-stitching once en route through the pair it picked up. The two, right-hand pairs coming out of the upper wall at its base now cloth-stitch through each other and pass into a lower wall at the right. The weaver for this lower wall is the weaver that came from the wall above it, to its right. 
LINE G, COL. 11,

Round-meshed Valenciennes of Harlebeke, Bruges, Courtrai, Bailleul (braided 4 times) (often twice, Dentelle épiscopale).

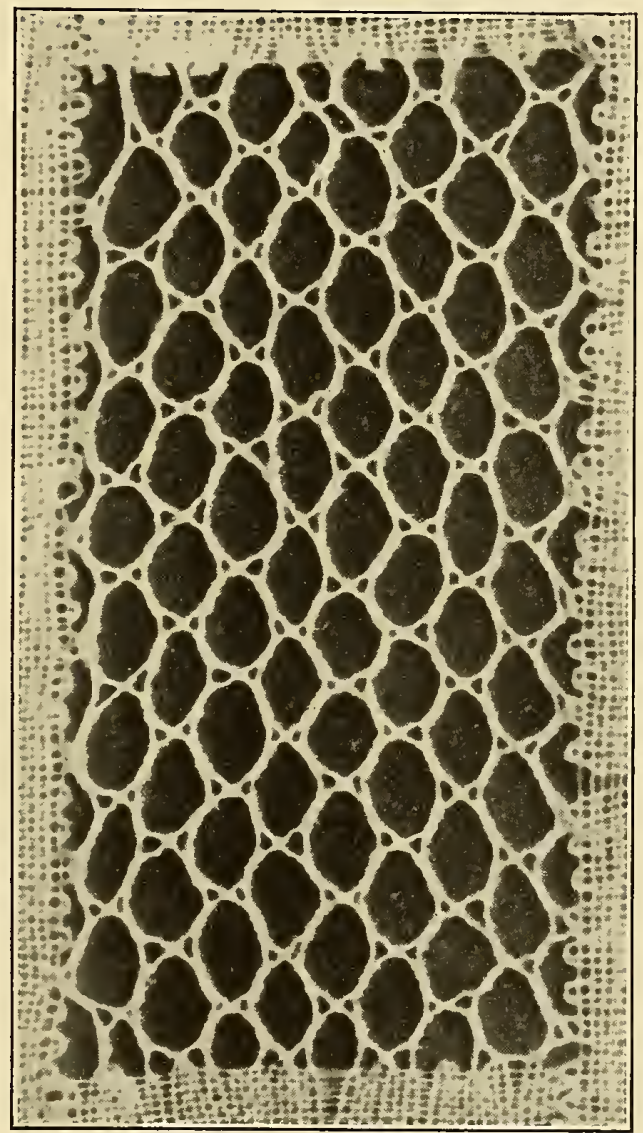

The sides of this Valenciennes each require four threads and are braided four times. When the sides are braided only twice, the lace is called Dentelle épiscopale.

The joints are quite open, giving the effect of a round Val with two little open dots between the larger holes. The vertical, pendant pairs which hang outside of the joint, are each twisted twice between upper and lower braids, and the interior pairs of the braids which cross each other by means of a linen-stitch between braids, are each twisted twice both before and after the eloth-stitch. See Line A, Column 7. 


\section{LINE G, COL. 12, \\ Zeccatello.}
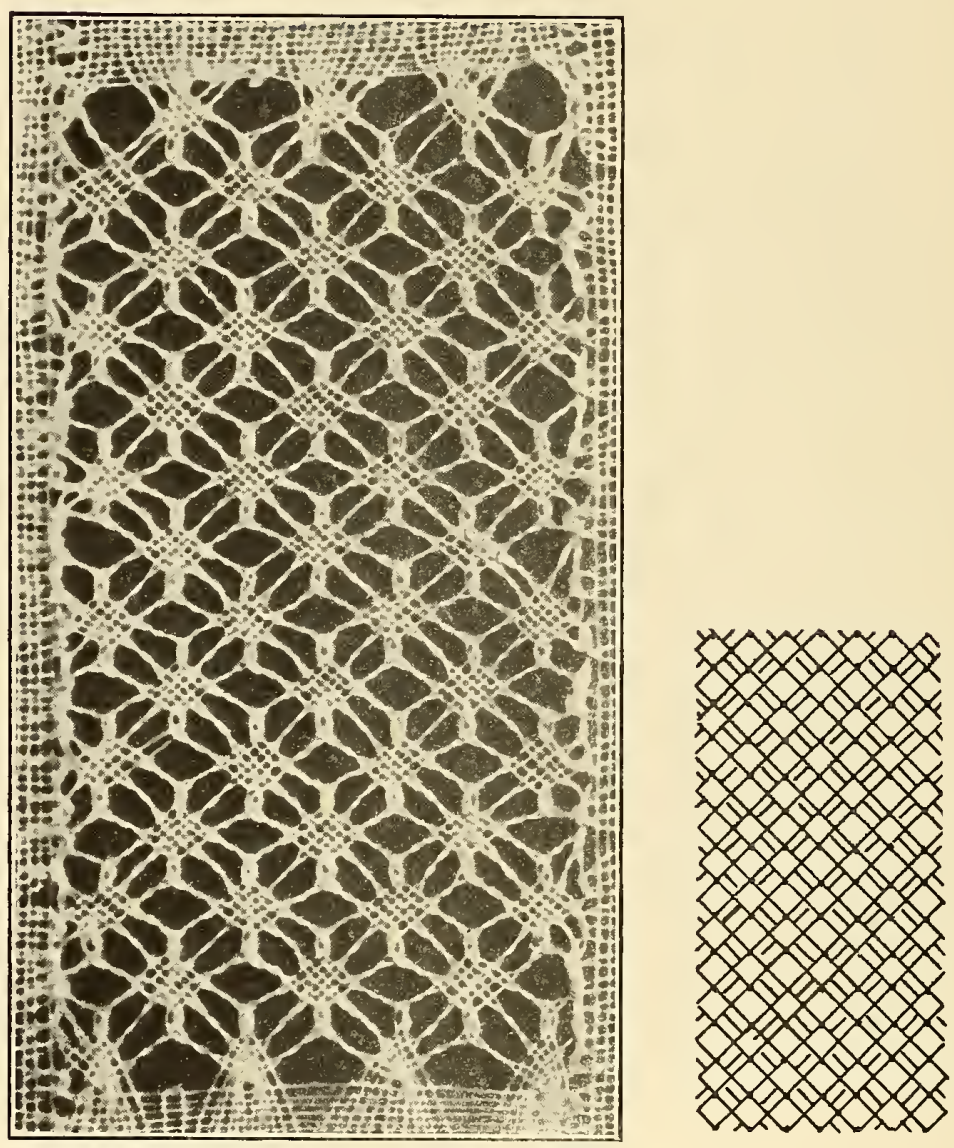

Three pairs twisted twice, enter each solid spot at the upper left; and three pairs twisted twice, at the upper right. The two central pairs of each of these sets, intersect with a linen-stitch, and after a pin is placed at the top of the little, linen-stitch square, are closed. A similar stitch is made at the bottom of the little square. No pins are used elsewhere. 


\section{LINE G, COL. 13,}

\section{Irish Ground.}

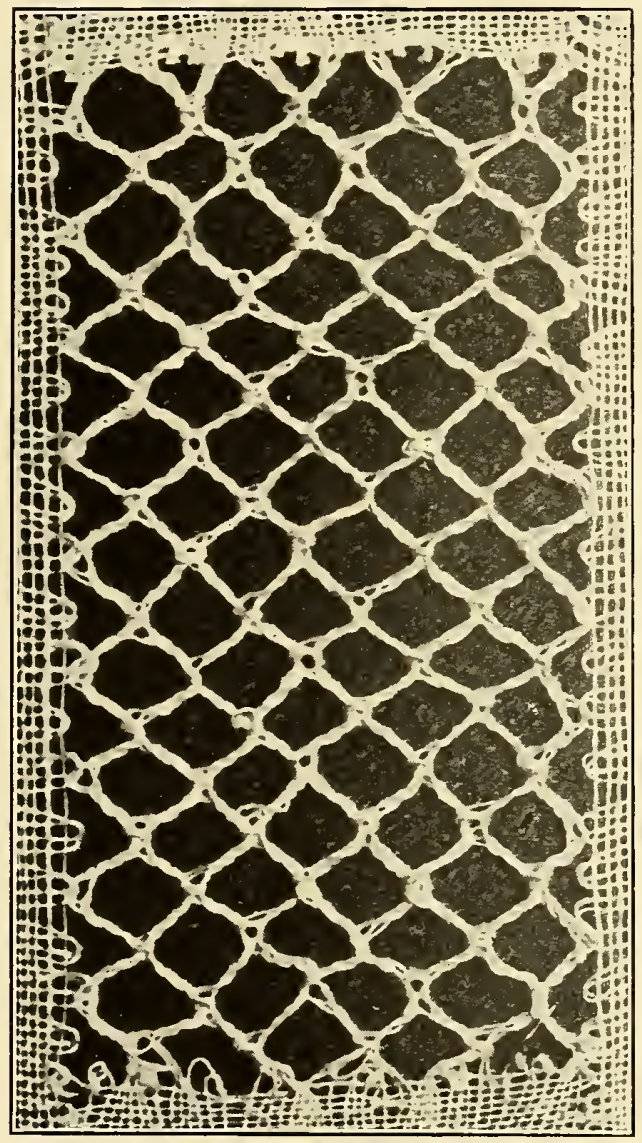

The braids are made in a horizontal zigzag, the downward points held down by pins until a lower line joins and holds them. The braids should not be made too long. When one reaches the second line or lower row, one should pull one pair of the second line bobbins by means of a crochet-hook under and around the downward point of a preceding line; passing the other pair of the second or lower line into the loop of the two hooked-up threads, pulling the knot thus made well on top of the joint into plain sight. One is then ready to braid again.

This ground is supposed to look slightly rough and clumsy, giving to the mesh a rustic appearance. 
LINE G, COL. 14,

Italian Spiders with 2 Hcrizontal Bars.
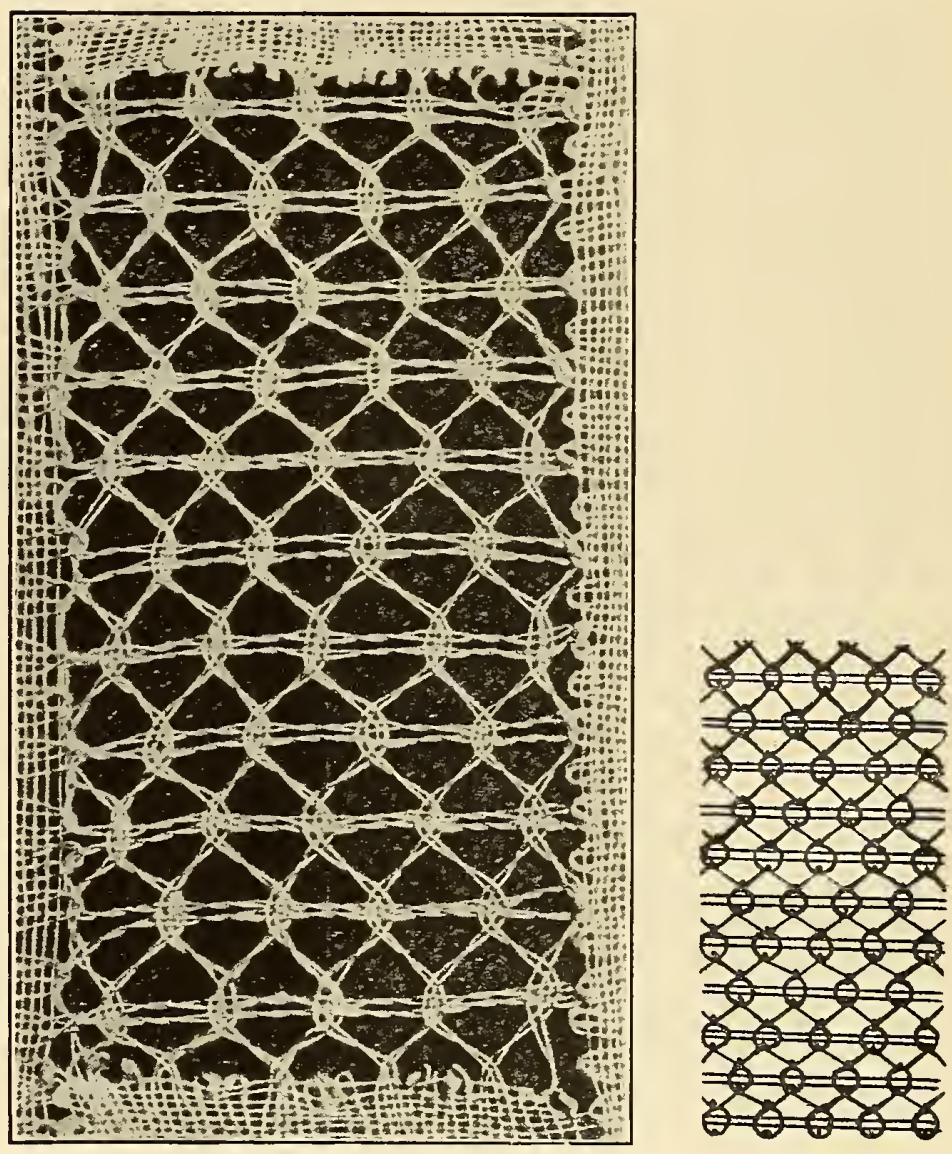

This easy ground requires a horizontal weaving pair and two pairs for each spider. The upper left-hand spider pair cloth-stitches through the upper righthand spider pair, the joint being supported by a pin. Then the working pair runs from left to right, cloth-stitching through the two spider pairs, being twisted twice between spiders, and immediately returns from right to left through the same spiders in the same way. Each spider pair is twisted once between spider bodies. The spiders are terminated in the same way that they are begun, only by the reverse process. 
LINE G, COL. 15,

Marguerites Centres à Huit.
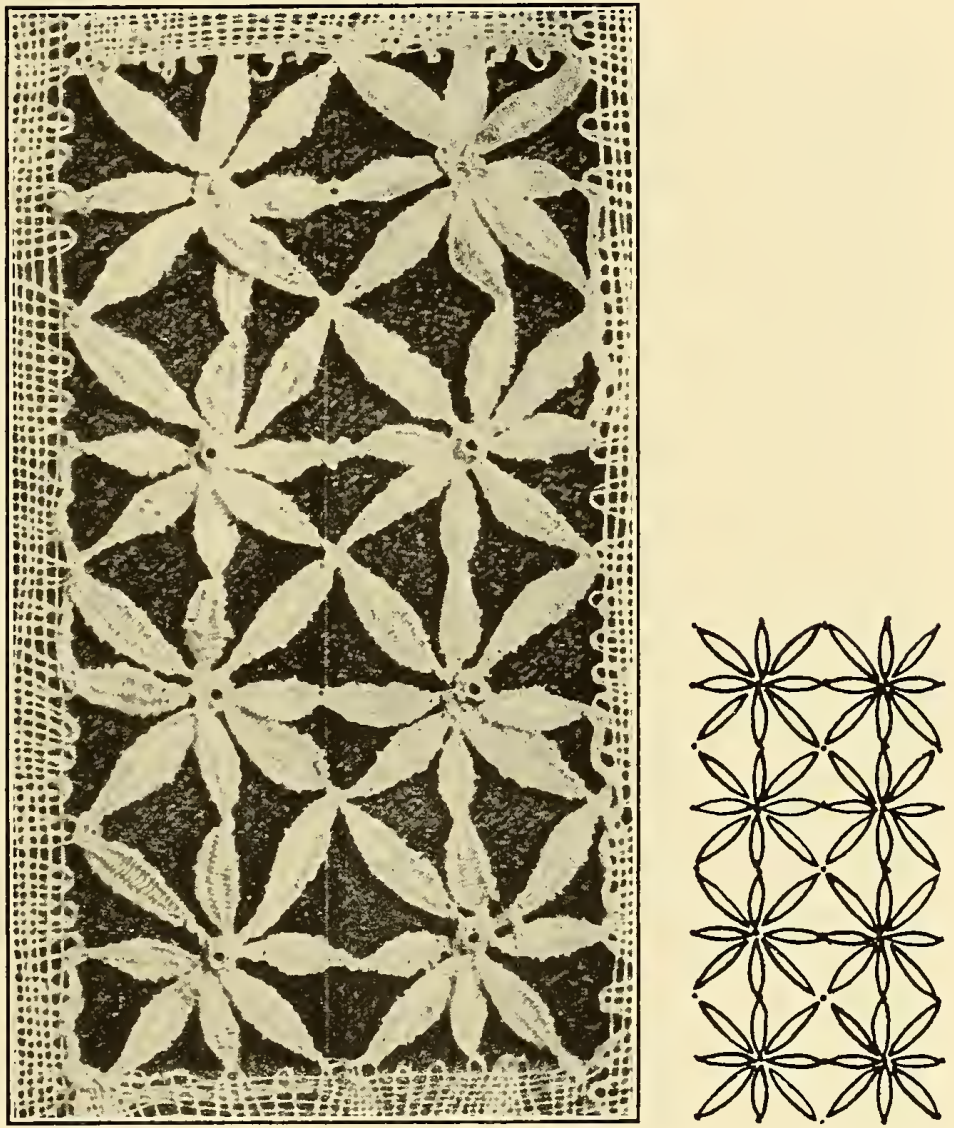

This firm, attractive ground is easy to execute-provided one enjoys the making of leaves. Each pair can be considered as one thread or each thread can be worked individually. The two left-hand petals cloth-stitch consecutively through the top and upper right-hand petals. Here a pin is placed and closed, the center being arched in the way described under Line E, Column 4. Should one prefer, one can work from right to left instead of from left to right: the idea in either case being to linen-stitch the two, upper petals through two, other, upper petals. Where the horizontal petals meet each other, a pin should temporarily be placed, but removed before the second petal is entirely woven in order that the threads may slip up and fill the hole left by the pin. Between daisies, where the petals form a cross, they linen-stitch through each other and the joint is supported by a pin. 
LINE G, COL. 16,

Fish with 2 Horizontal Bars.
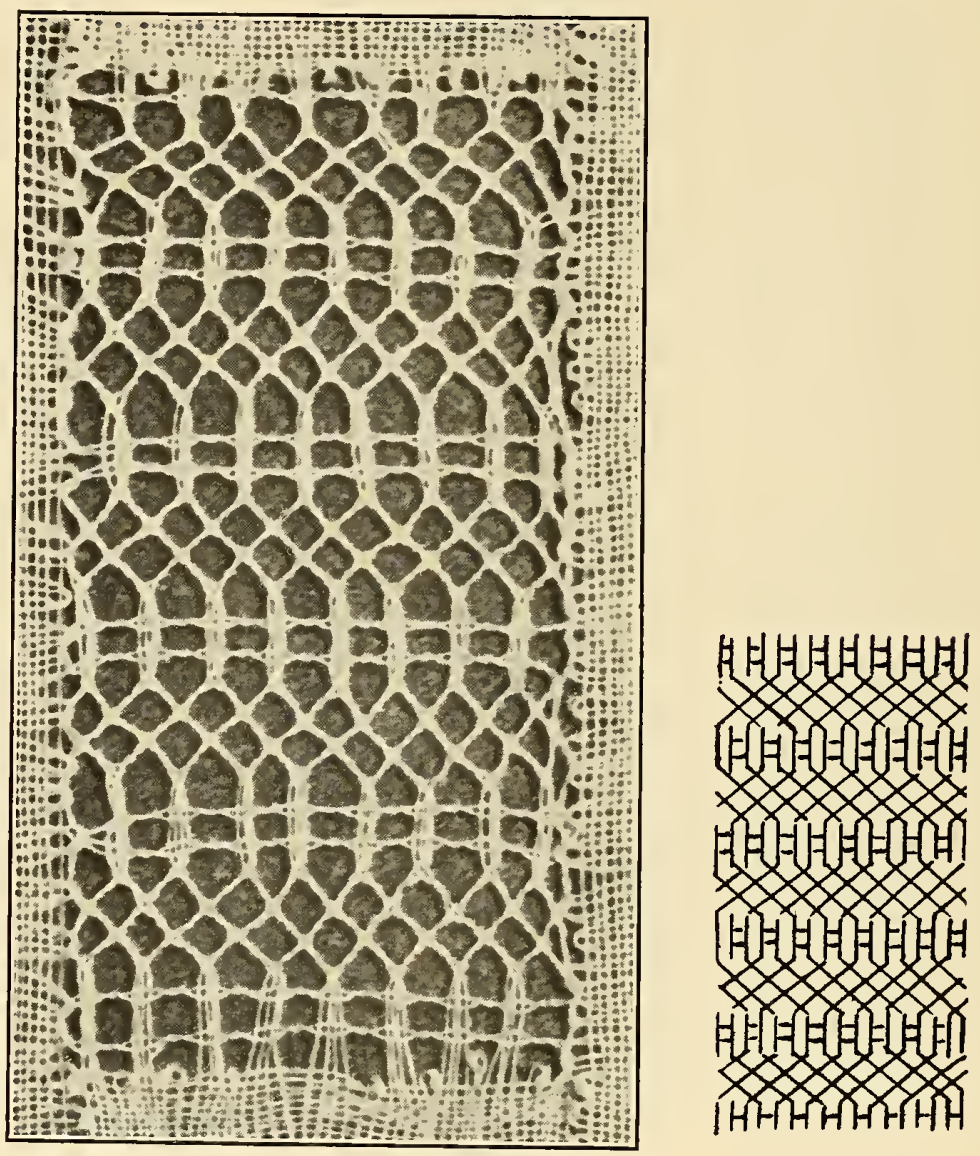

The weaver or horizontal bar passes twice through each so-called fish. The weavers and all other threads are twisted twice between fish and between other stitches, but the body of the fish is not twisted after the two pairs which form it, have cloth-stitched together at the top, nor until after they have cloth-stitched together at the tail. The fish are placed alternately below one another. Between bands of fish-that is, below one band and above the next-the passive or oblique pairs cloth-stitch through each other twice, not counting the exit and entrance into the fish bodies. Any pins used as supports, should soon be removed to avoid leaving unsightly gaps behind. 
LINE G, COL. 17,

Trude "R" Ground (original) (American).
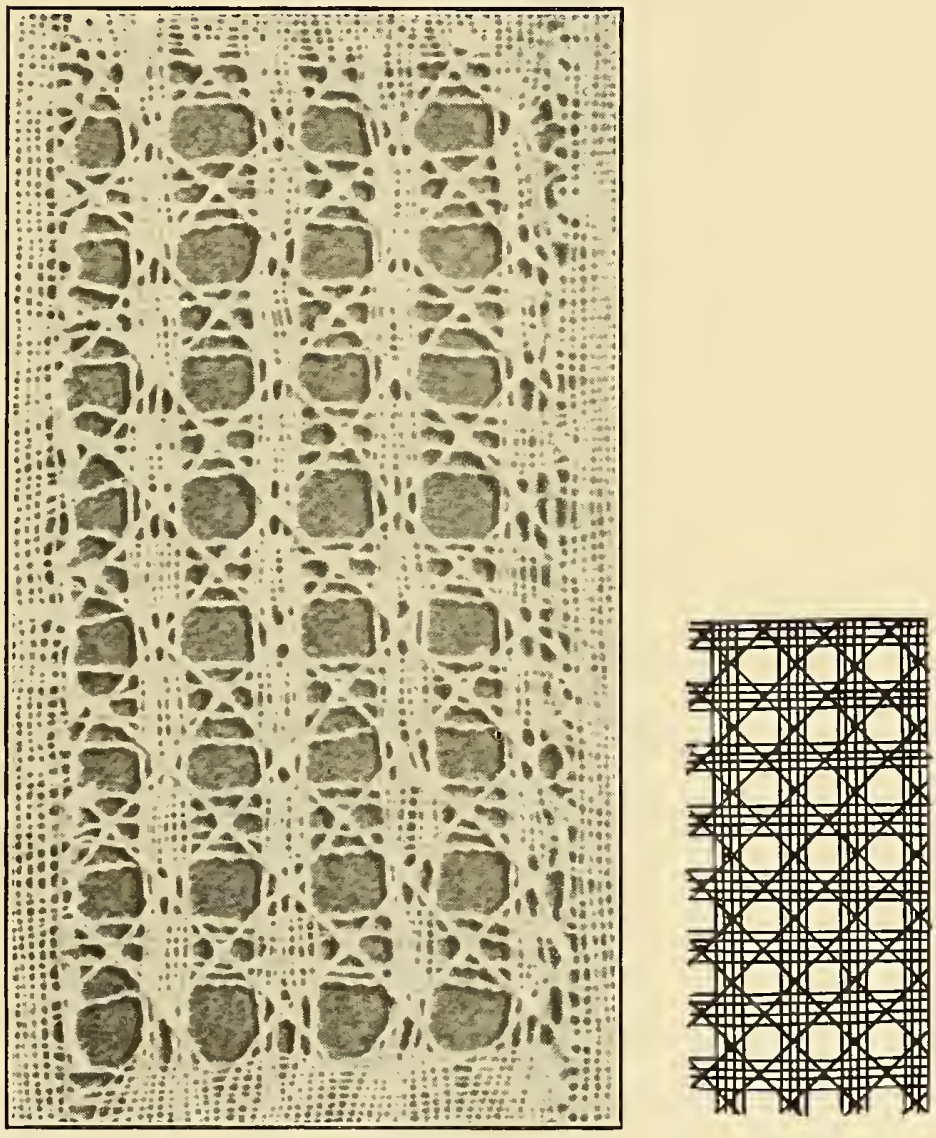

This mesh is strong, but rather confusing to make. The under or lower ground runs vertically and horizontally, each band having four pairs, twisted four times between the line-stitch squares. No pins are used in this part of the work except to hold up the weaver, which working back and forth from one side of the lace to the other, forms the horizontal lines.

The superimposed design runs diagonally, two pairs twisted four times between intersections, weaving through each other by means of a cloth-stitch, made just over or above the twisted parts of the under-ground.

To connect the two grounds, one should lay one thread of the diagonal overmesh between two threads of the under-mesh, following the direction in which both are travelling, taking care to keep the diagonal threads on top. One ought 
always to connect the first, two appropriate pairs which meet, so, when travelling

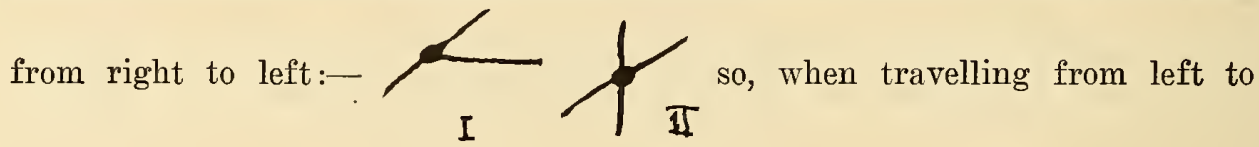

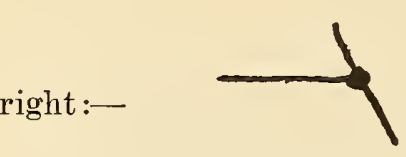

111

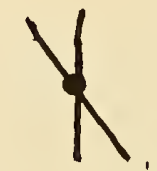

iy
When working over

the horizontal bars,

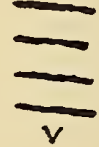

the top or next to the top horizontal weaver is twisted once before it connects with a diagonal super-band, then it is twisted three times. The diagonal strand is twisted three times before and once after its comnection when it meets the top or next to the top weaver-band of the under-mesh, here for example:-

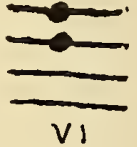

Then one eloth-stitches this diagonal pair with its mate, placing a pin below the cross-joint in the center of the linen-stitch to support the joint. This pin should be removed before much work has been done, so as not to leave a hole behind it. When the horizontal weaver returns to this spot on the rext lower line

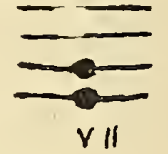
the first diagonal pair it meets should have one thread passed through it to steady the structure, thus:- $\frac{25}{V I I}$ or, thus:direction in which the weaver is travelling. This prevents the super-structure from slipping up or down. Over the vertical twists, \|\| the diagonals are $x$ similarly attached to prevent their slipping sideways, thus:thus:These black dots indicate connections, or slipped-in threads, XII

not pin holes. The pins used are placed at the center of the diagonal joints

thus :-
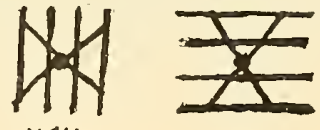

$\times 111$

$x / V$ 
LINE G, COL. 18,

Trude "T" Ground (original) (American).
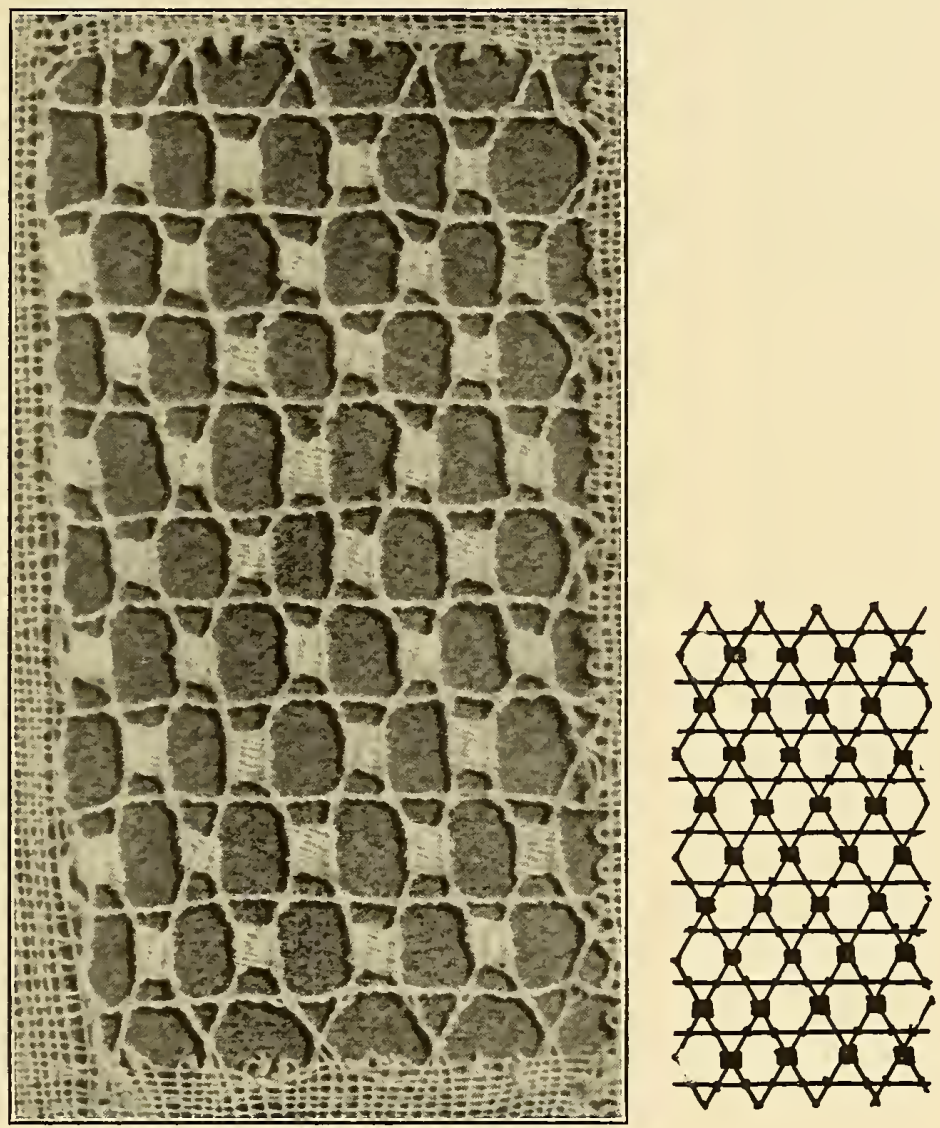

This sample requires ten pairs, four for each cutwork, and a weaver. The cutwork should be separated by a horizontal weaver bar running from left to right and vice versa, fastened at each end to afford a little firmness. The same design worked with several vertical bars is less satisfactory on account of less stability while working, besides its requiring more threads.

Each pair is twisted three times between encounters or intersections. Pins should be temporarily placed below the cutwork weaver, and between the other cutwork threads while pulling these gently into position. The left-hand cutwork pair should be adjusted first, and the weaving pair knotted once before 


\section{LINE G, COL. 18-Continued}

\section{Trude "T" Ground (original) (American).}

twisting it three times. The weaving pair should be kept on the right hand, and the weaver itself longer than its mate. This same weaver must be used as the conductor on the cutworks below, so as never to use it as a side thread and thereby pull it too hard. After the three other threads are pulled out smooth, the weaver is pulled, and if necessary its knot is slightly lifted up into place close under the cutwork or point d'esprit with the help of a long sharp pin, the weaver's mate being firmly held meanwhile. The pins should be left in place until ready to start a new cutwork. Then the two right above the point d'esprit should be removed to prevent leaving loops behind. Other pins that are in one's way, may be pushed down, but not quite all the way in, that they may be easier to grasp and later remove by means of fine embroidery tweezers. 
LINE H, COL. 1,

Twice-twisted Hole Ground, Dieppe Ground, Hole Stitch with Twice-twisted Thread, Löcherschlag mit Zweimal gedrehten Fäden.

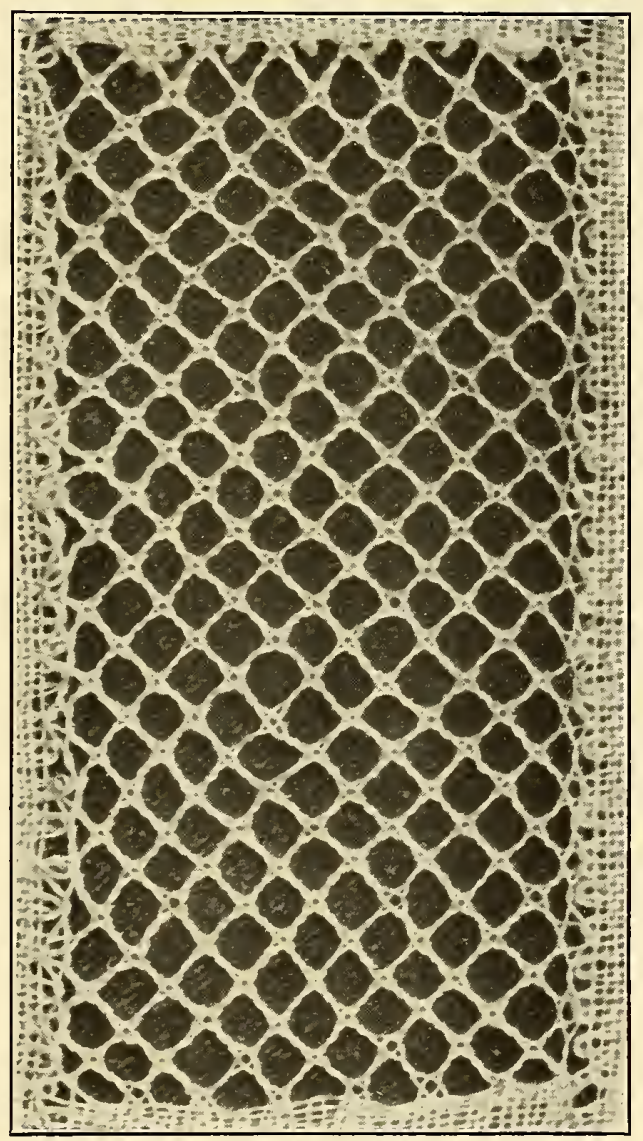

This Twice-twisted Dieppe Ground is slightly easier than the regular, French Tulle de Dieppe, as it is twisted twice instead of three times between joints. The joint itself is made in the same way; that is, by crossing, twisting and crossing, placing a pin and closing it by crossing, twisting and crossing. 


\section{LINE H, COL. 2,}

\section{Les Arraignées Carées en Tulle Double.}
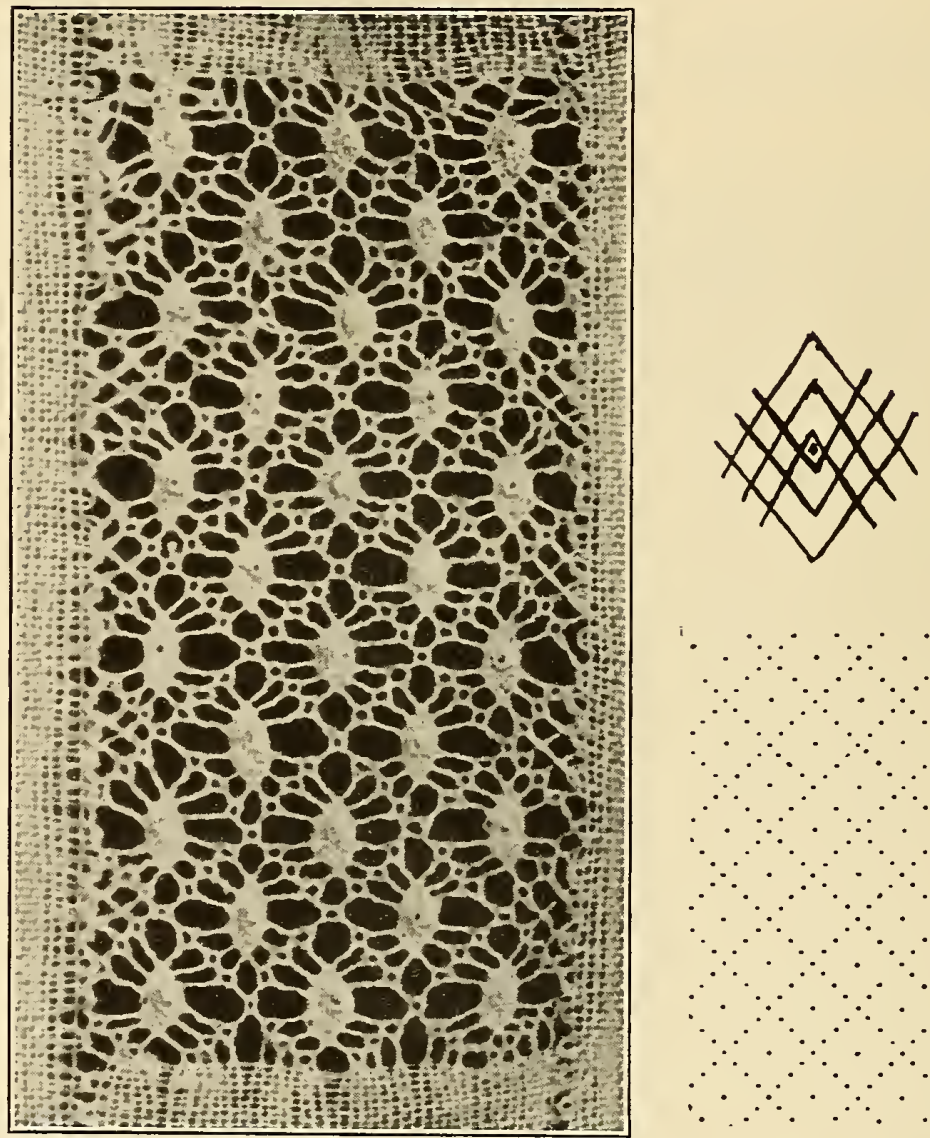

Each spider requires six pairs, three entering at the upper left and three at the upper right; these pairs or legs are each twisted three times, above and below the spiders. The spider bodies are made in the usual way. That is, the three upper, left-hand legs cloth-stitch through the three upper, right-hand legs. A pin is placed in the center; the inside pairs are held high in the hand and the outside pairs are pulled specially tight in closing this spider, so as to make a little prominence at the center of the body, and the pairs on the left are cloth-stitched through those on the right to close the pin. The little row of open squares between spiders is made at the points of encounter between three righthand legs of an upper spider, coming down to meet three, upper, left-hand legs of a lower spider; and at the center, top, bottom, left and right of the square, which frames the spider. At these points, the pairs which meet, if not already twisted, are twisted twice and crossed. Here a pin is placed and closed by twisting twice and closing. This is Tulle Double. 
LINE H, COL. 3 ,

Fond de Brides.

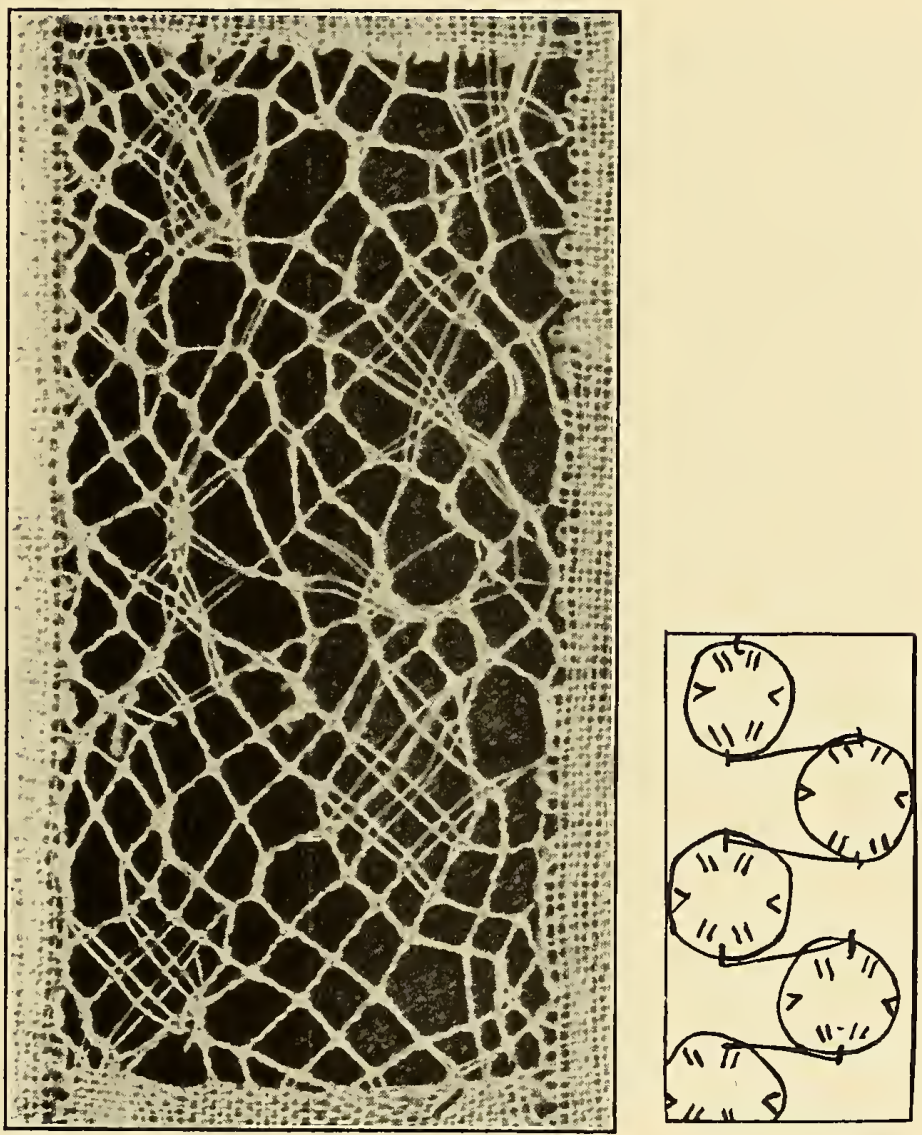

The scrolls and figures of bobbin lace were at first made to touch or overlap in order to hold together. Later they were held in place by twisted, braided or fancily worked cross-bars of thread, known as "brides." The throwing across or arrangement of these "bridges" became more and more regular as lace-making advanced, until they suggested network and led to the making of established and recognized grounds.

There is no real rule for the making of Fond de Brides, except that it should be so twisted, braided, or otherwise entwined as to form a more or less equal and evenly spread out amount of open and solid, of light and dark, of evenly arranged, equally large pseudo meshes. 
LINE H, COL. 4, Eyeless Spiders, Fond de Neige.
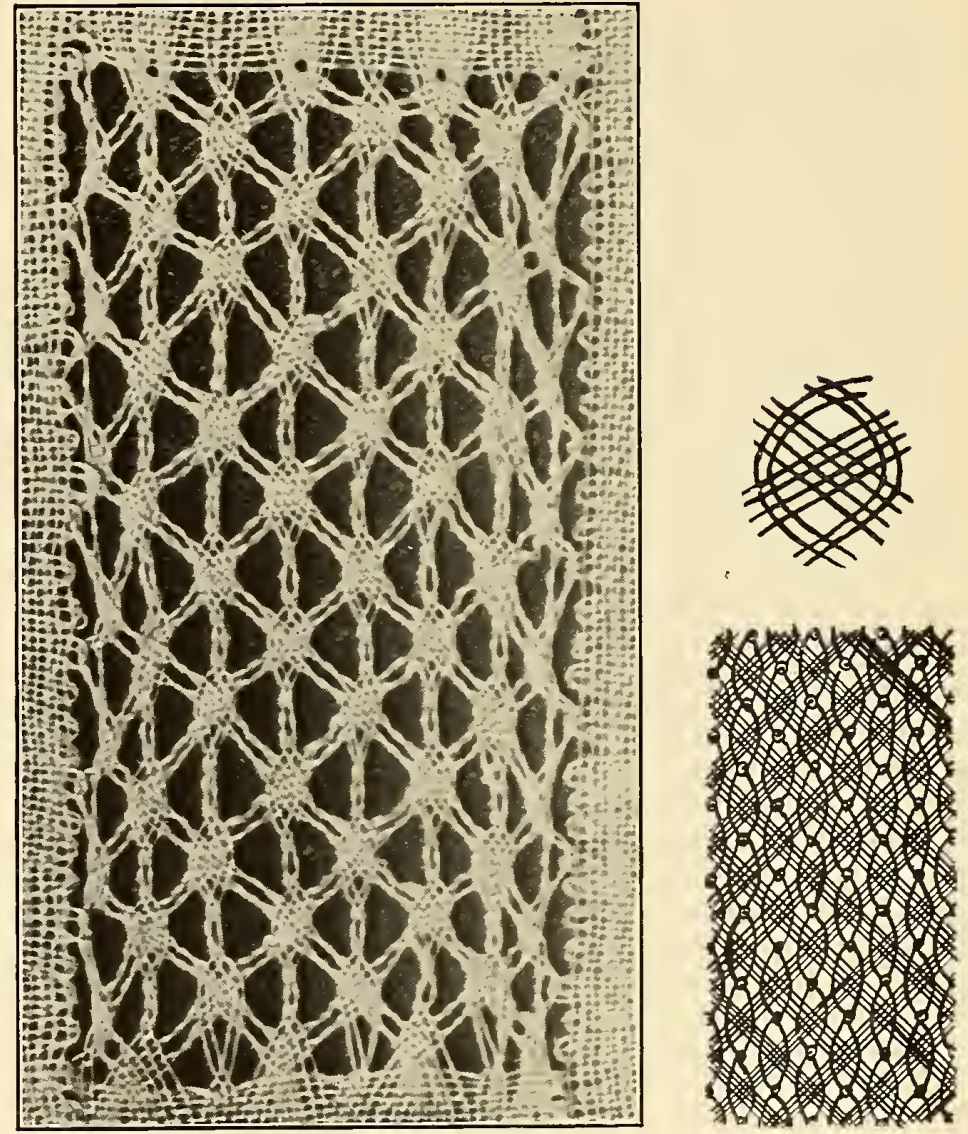

These eyeless spiders; that is, spider bodies without pin or other holes in the centers, are made with six pairs to each spider. The pairs or legs, entering at the upper left and upper right and leaving at the lower left and lower right, are twisted twice each between spiders; also the two legs entering at the top and leaving at the bottom. But these last, vertical pairs cloth-stitch through each other at the top of the spider having a pin placed above; and then spread out, cloth-stitching through the legs entering at the upper and lower left and upper and lower right, so as to form a circlet or wheel around the body of the spider, thereby squeezing the center of the body more compactly together. At the bottom of the spider, these encircling pairs eloth-stitch again through each 


\section{LINE H, COL. 4-Continued \\ Eyeless Spiders, Fond de Neige.}

other, have a pin placed below the joint and are twisted twice. They are then ready to cloth-stitch again and enter the top of a lower spider. Inside of this wheel, the two, upper, left-hand legs cloth-stitch obliquely through the two, upper, right-hand legs and become the two lower, right-hand legs and are twisted twice and are ready to enter a spider below at the right. The upper, right-hand legs become the two, lower, left-hand legs, are then ready to enter another spider below to the left. No pin is placed in the centers of these spiders. 
LINE H, COL. 5, Genoese, or Reticella Mode.
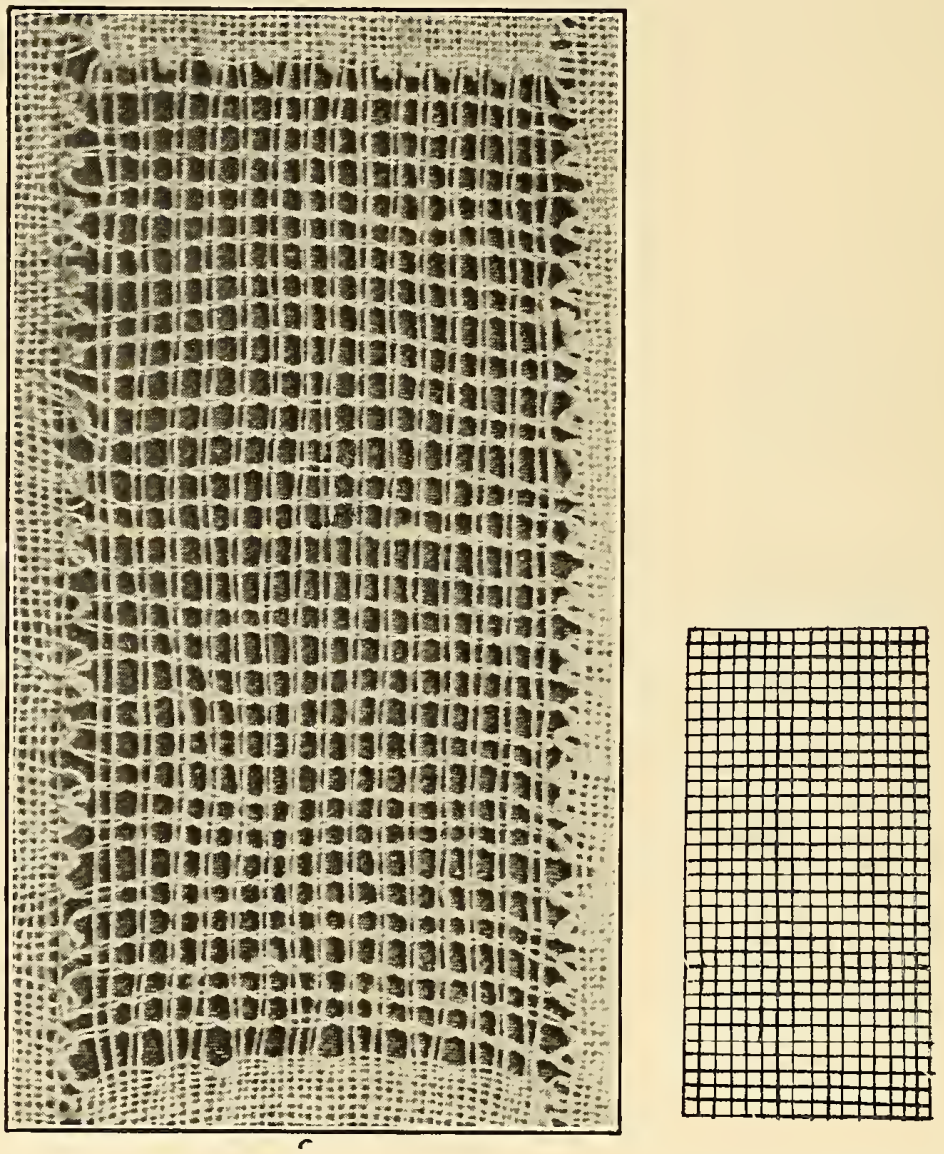

This ground somewhat resembles Buratto, a textile ground usually woven on a loom and embroidered similarly to the usual filet. The mode here described has a horizontal weaver, twisted once between pairs, which works from left to right and then back, et cetera; eloth-stitching through untwisted, vertical pairs. These joints should be supported by pins in order to preserve a true alignment. 
LINE H, COL. 6,

Lock Stitch or Du Puy Point de Paris Variation, Torchon Mode.
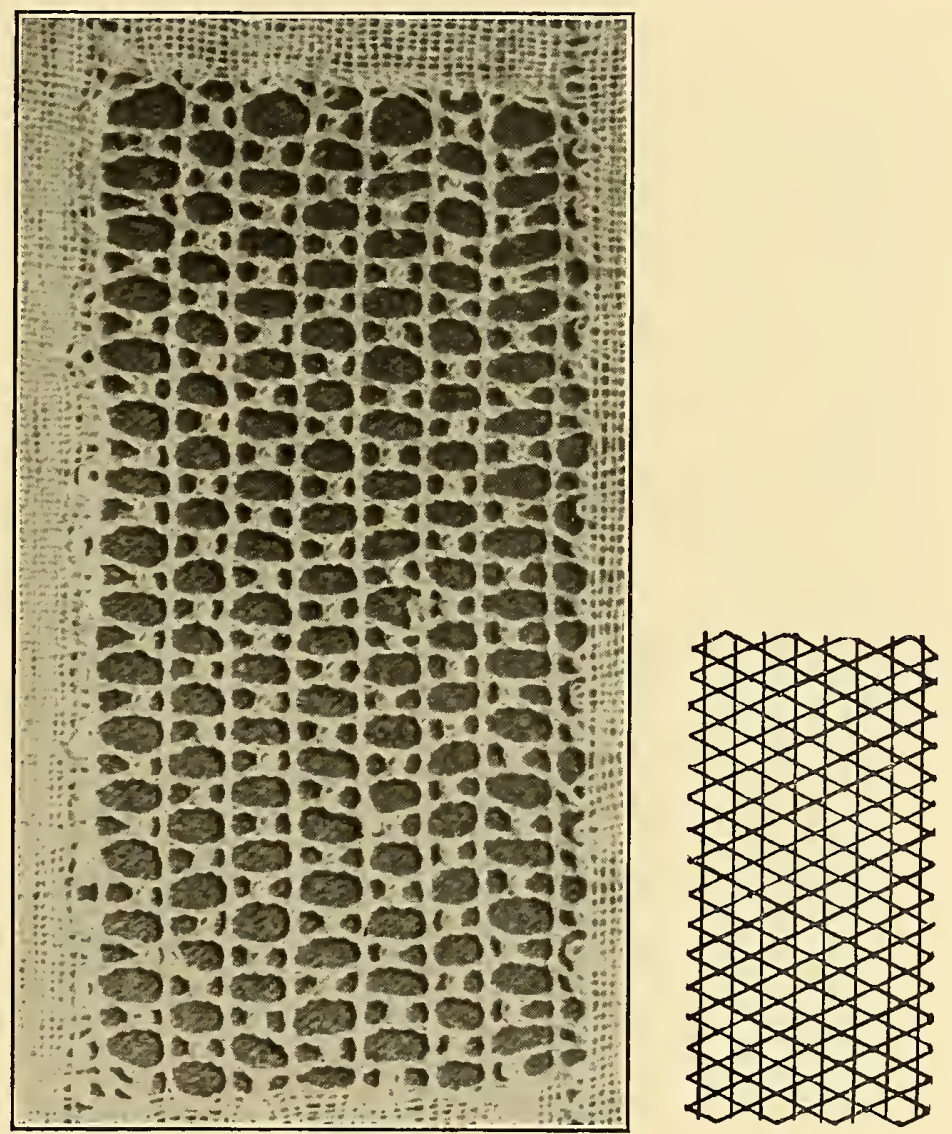

See Line C, Column 5 and Line A, Column 5. Four pairs are required for each stitch, two of them hang vertically, the other two work back and forth obliquely. Every pair is twisted once between stitches. At the point where the two verticals meet each other, a cloth-stitch should be made, and a pin placed and closed by another cloth-stitch. Where the diagonal pairs traverse the vertical ones, a linen-stitch should be made without pin or closure. 


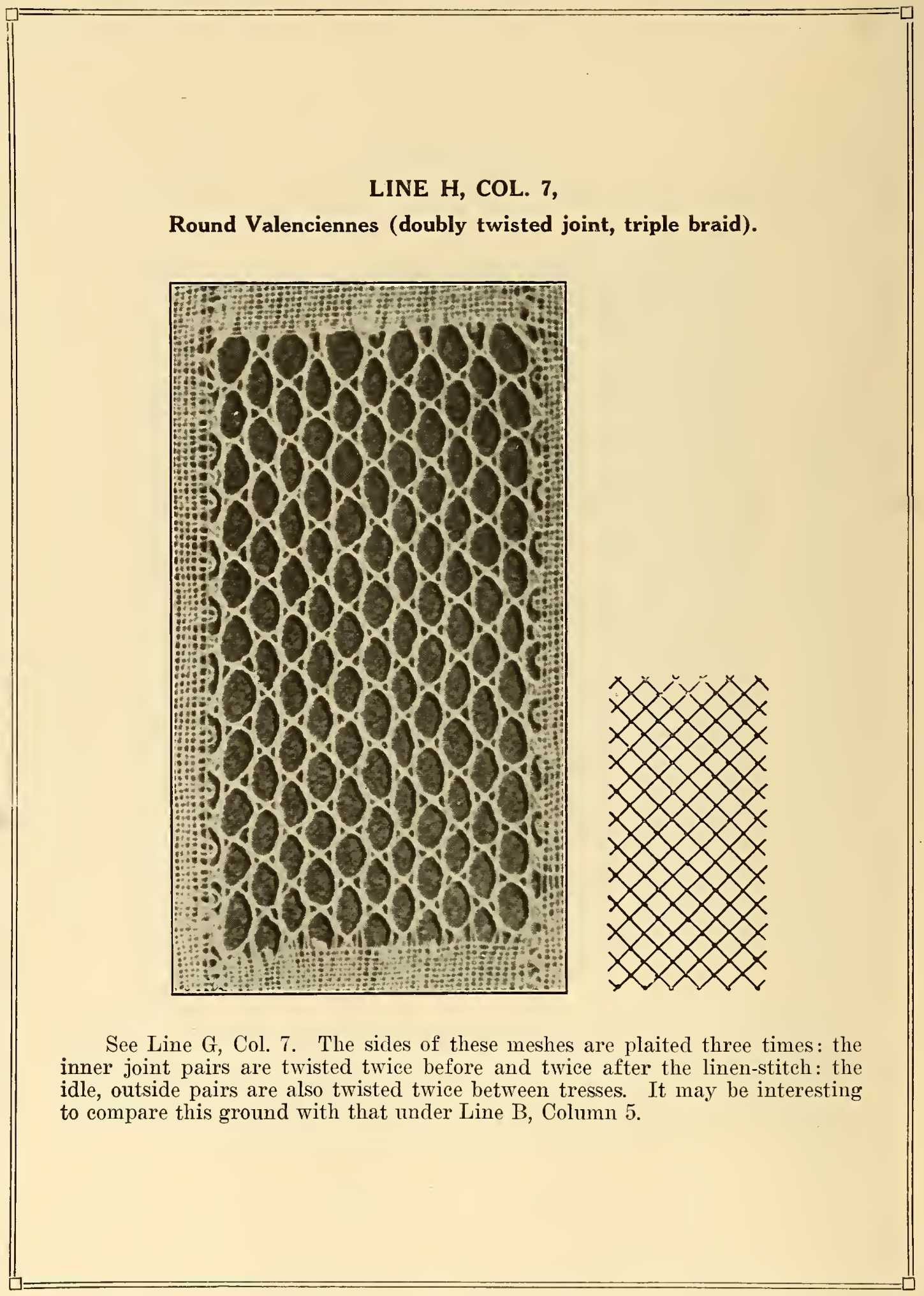


LINE H, COL. 8,

Devonshire Point d'Esprit Net.
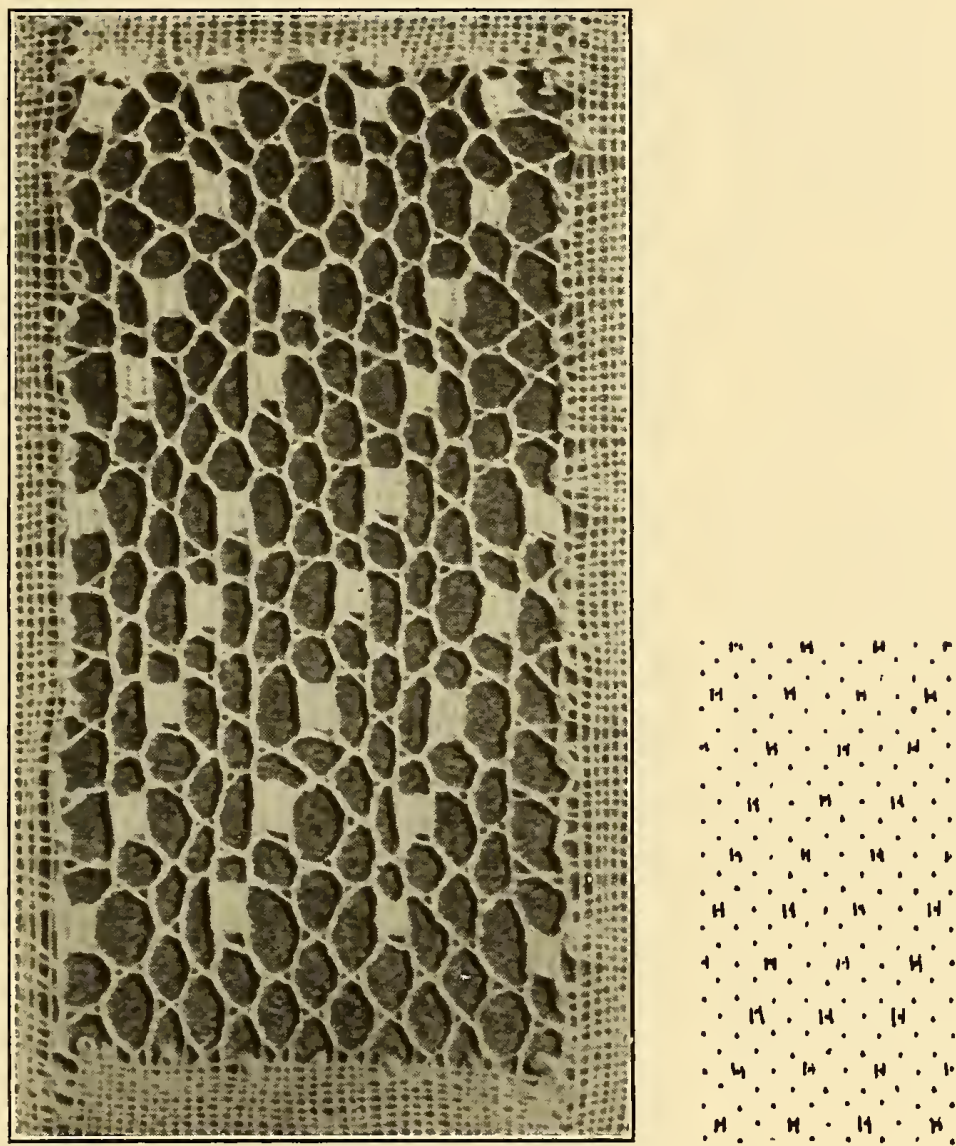

This higgledy-piggledy net requires very little explanation for the making and must be left partly to the eye of the maker regarding the distribution of the spots. One suggestion is to work the first row alternately with net stiteh and spot; the next row all net, and the third again alternated, placing the lower cutworks a little to one side of those above them. The net is made by twisting three times and crossing. Pins should be used to support these crosses. When the maker wishes to form a cutwork, instead of an open, net mesh, the pairs should be twisted twice before beginning the spot. Otherwise there will be an ugly gap at the top of the leadwork, showing an isolated, bridging thread. At the end of the cutwork it is imperative to loop the weaver and its mate before proceeding.

A simple designing method called Spot Repeat presents an easy way of 


\section{LINE H, COL. 8-Continued \\ Devonshire Point d'Esprit Net.}
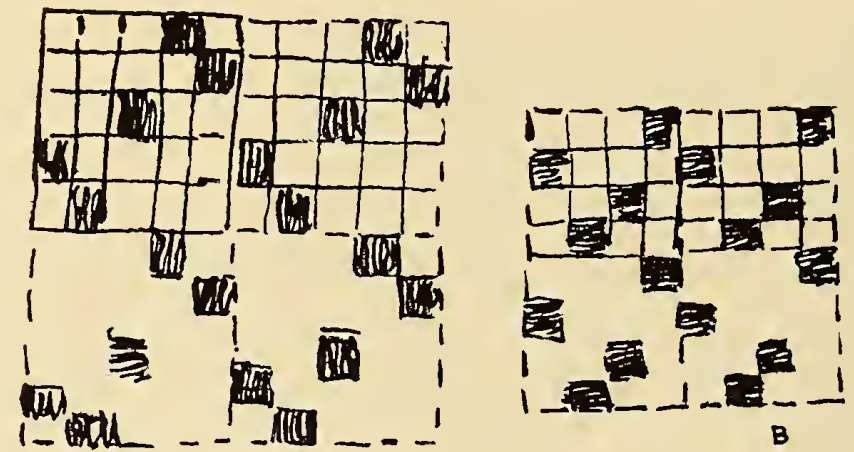

distributing the cutworks in Point d'Esprit Net. One draws a square and divides it vertically and horizontally into four, five, six or seven equal sections or smaller squares. If the original square be divided into four, there will be sixteen little sections, and upon these one places four dots-representing cutworks. No two of these dots should be in a vertical or horizontal line from each other, but always to the right or the left, above or below, so that only one spot appears in each vertical and horizontal space. Arranging them is as much fun as playing a game. When one large square is finished, one places a duplicatedots and all-adjoining one side of it; and two others, one below each of these, thus forming a still larger square unit. One can now get the effect of their sprinkling of dots, and see whether these chance to form unexpected and objectionable bands or zigzags. When one cuts a square into five sections each way, one places upon it five spots; if into six divisions, then six dots, and so on. As the prickings for circular nets in bobbin lace are founded upon squares placed diagonally instead of vertically and horizontally, one should turn the cross section or quadrille paper upon which one has distributed one's dots, in an oblique position. 


\section{LINE H, COL. 9,}

\section{Flemish Filling.}
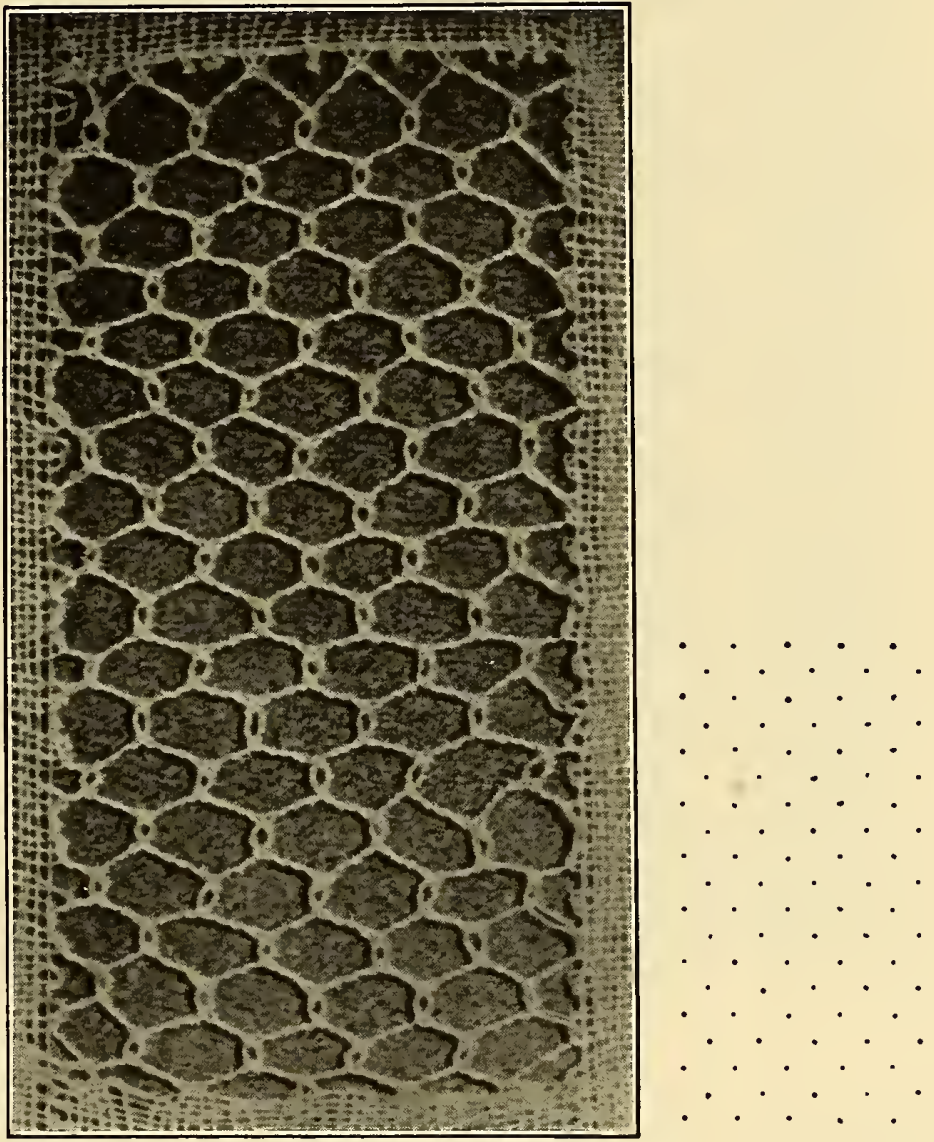

This is an easily made, strong ground. Each pair is twisted three times. One coming from the upper left and one from the upper right, cloth-stitch. A pin is placed, the pairs are again twisted three times and the pin closed by cloth-stitching. 
LINE H, COL. 10.

?
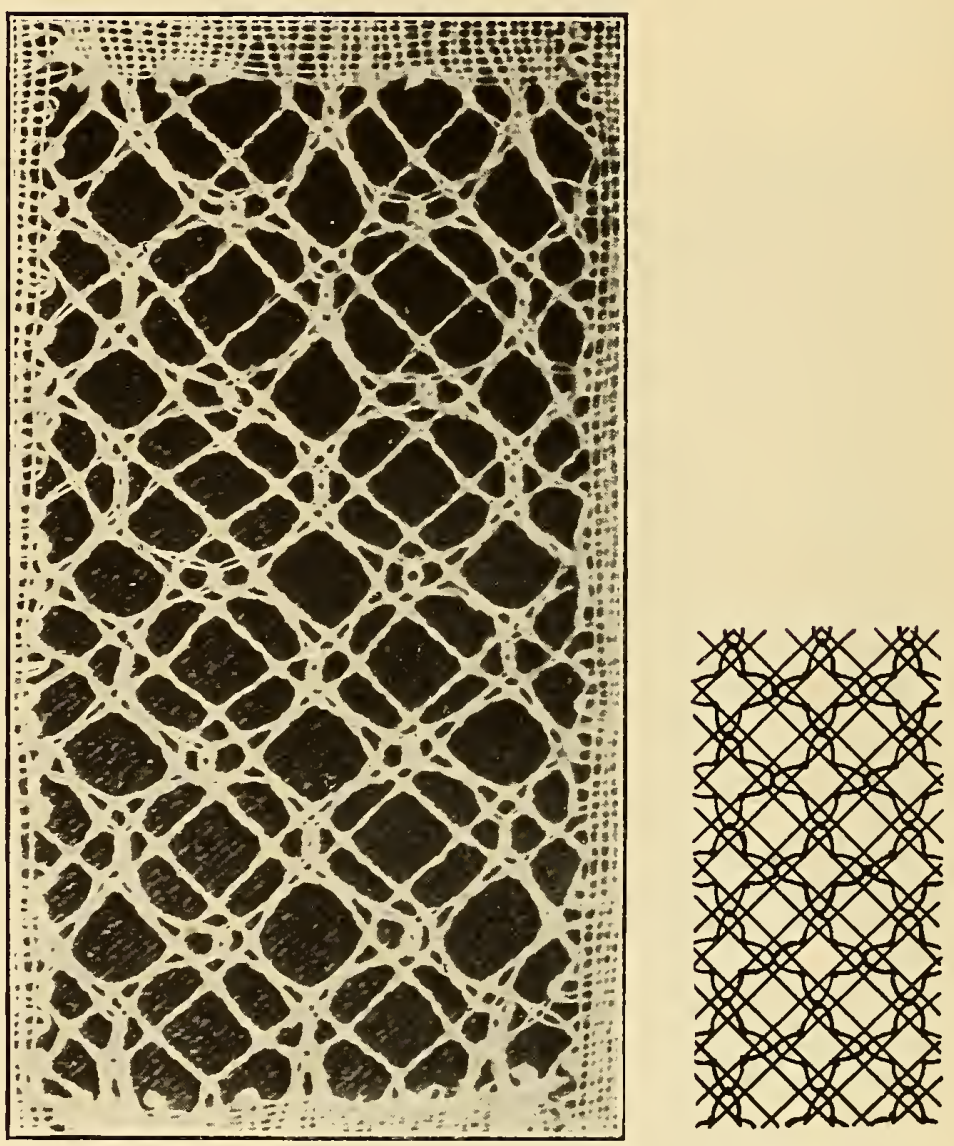

This ground has a sort of donble-lattice background, each pair of which is twisted three times on its long, uninterrupted sides and twice on its short sides, where the little squares are formed. Interwoven through this is a fancier mesh which meets in the center of the little squares, cloth-stitching and closing around the central pin. The pairs that make this joint are twisted once around the pin, but are not twisted afterwards until they have cloth-stitched out through the center of the sides of the little square (between its two twists). Now being ont, they are twisted once and then cloth-stitch through the once-twisted side of the big square just encountered, which here exchanges to form the fancy mesh in the center of the succeeding little square, each pair being twisted once after the cloth-stitch, which is supported by a pin. Thus the centers of the big squares are empty. 
LINE H, COL. 11,

Five or Six Sided Milanese Mesh.
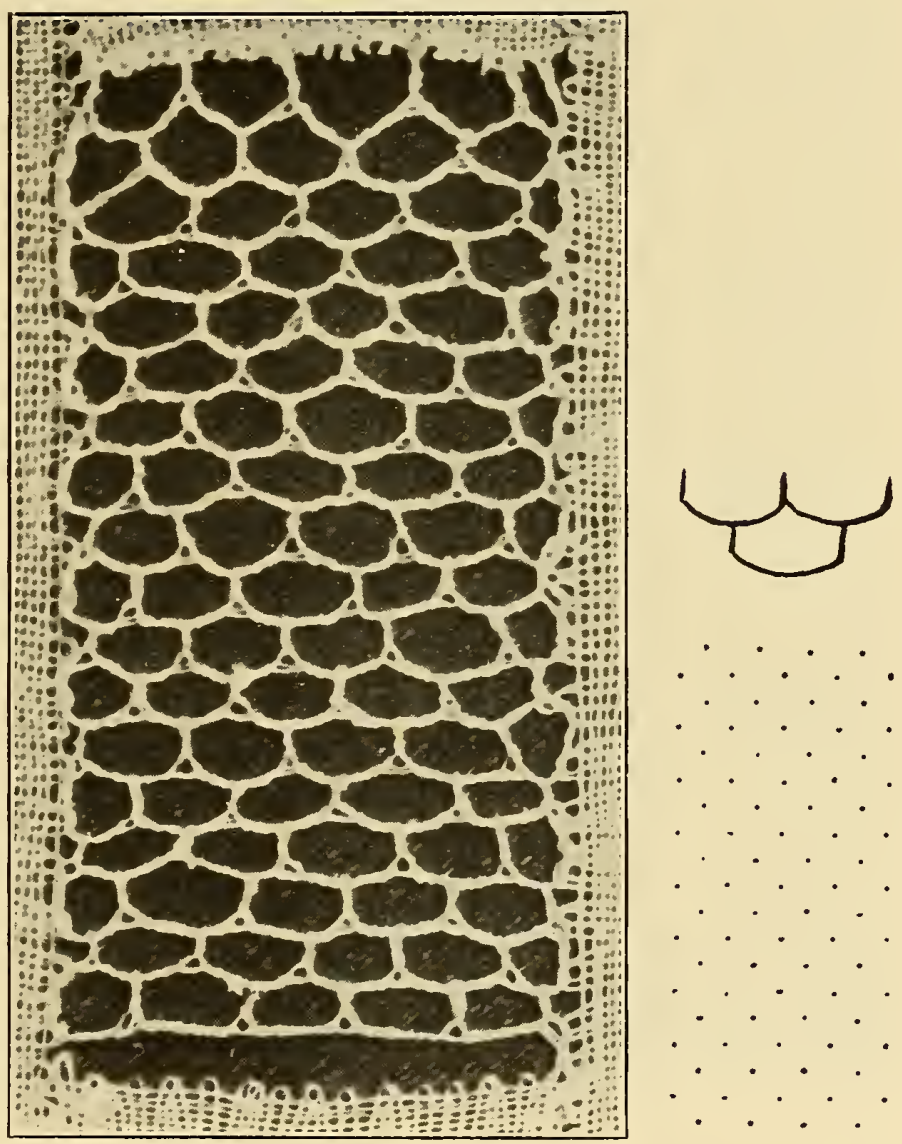

This sample requires only four bobbins altogether, and is worked from one side to the other; the lower row sewing or crocheting into the one above. The pricking is made on the diagonal. A pair should be braided twelve times between joints. Here the two lower pairs are left untwisted; one of the upper threads is hooked over and above the preceding row, and its mate put through the loop, when one twist is made and these two threads looped or sewed once around each other. A pin is placed below this joint between the two pairs, and braiding is recommenced. 


\section{LINE H, COL. 12, \\ "Sunspots."}
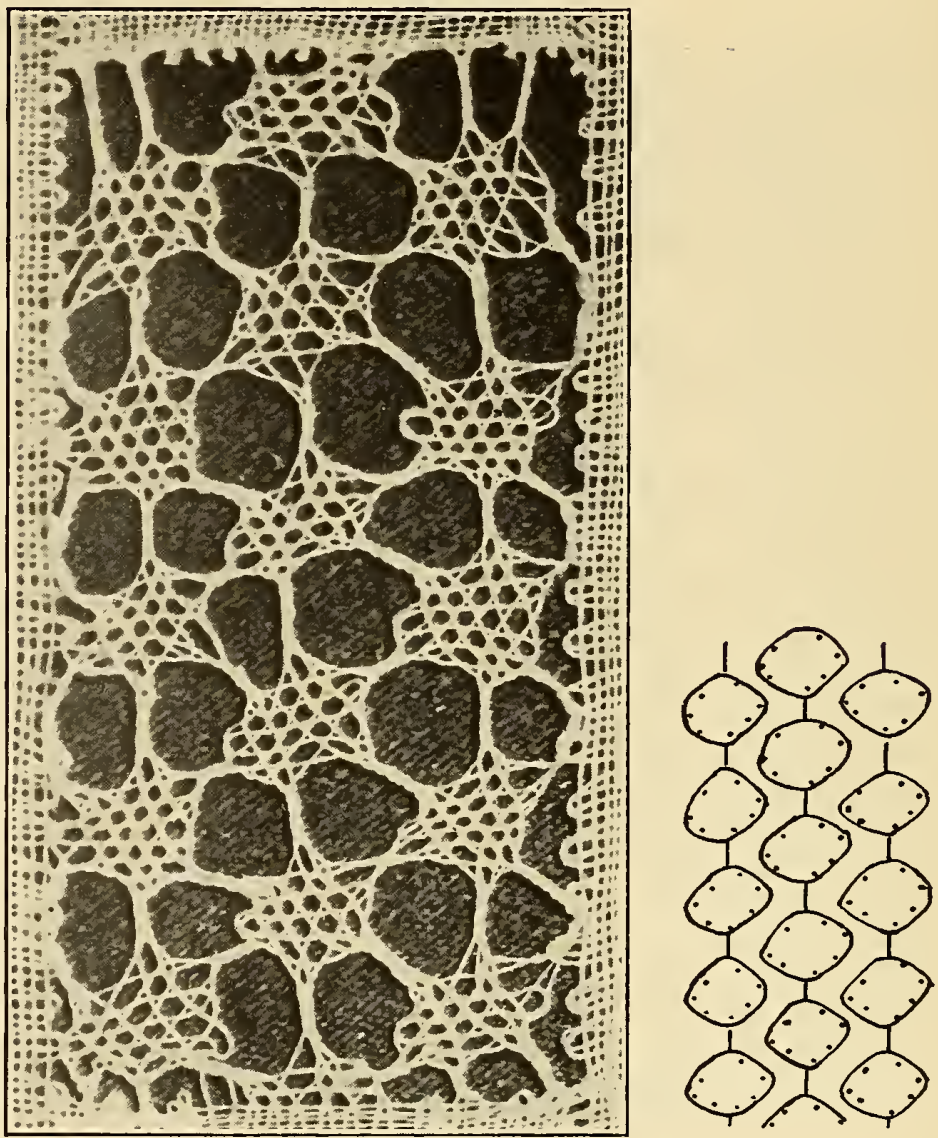

Twelve threads grouped into three braids enter near the top of each "Sunspot" and leave towards its base. "The left-hand pair of the right-hand braid becomes the weaver. It half-stitches through the right-hand pair of the center braid. A pin is then placed and closed. The work is continued towards the left, taking in the two pairs of the left tress. Another pin is placed and closed, the work now going towards the right, taking in the last right-hand pair. Here it pins, closes, and works to the left. After closing here, one pair makes its exit. One then works again to the right, pins and closes, where another pair makes its exit. Again towards the left. Here, after closing, one pair exits. These two left-hand pairs are now braided and enter at the right of the "Sun- 


\section{LINE H, COL. 12-Continued \\ "Sunspots."}

spot" to the lower left. One then works back towards the right and here, after closing, makes a plait that will enter the lower right-hand "Sunspot." The two remaining pairs at the bottom are then braided without closing and enter the top of the "Spot" almost directly below. These "Spots" are intended to be a trifle irregular in shape, and the tresses to slope a bit. The spots should be a little smaller than the ink lines on this pricking indicate. A cordonnet or gimp outline can be used and worked through the vertical top and bottom braids. 
LINE H, COL. 13,

Medici, Florentine, Byzantine Knots.

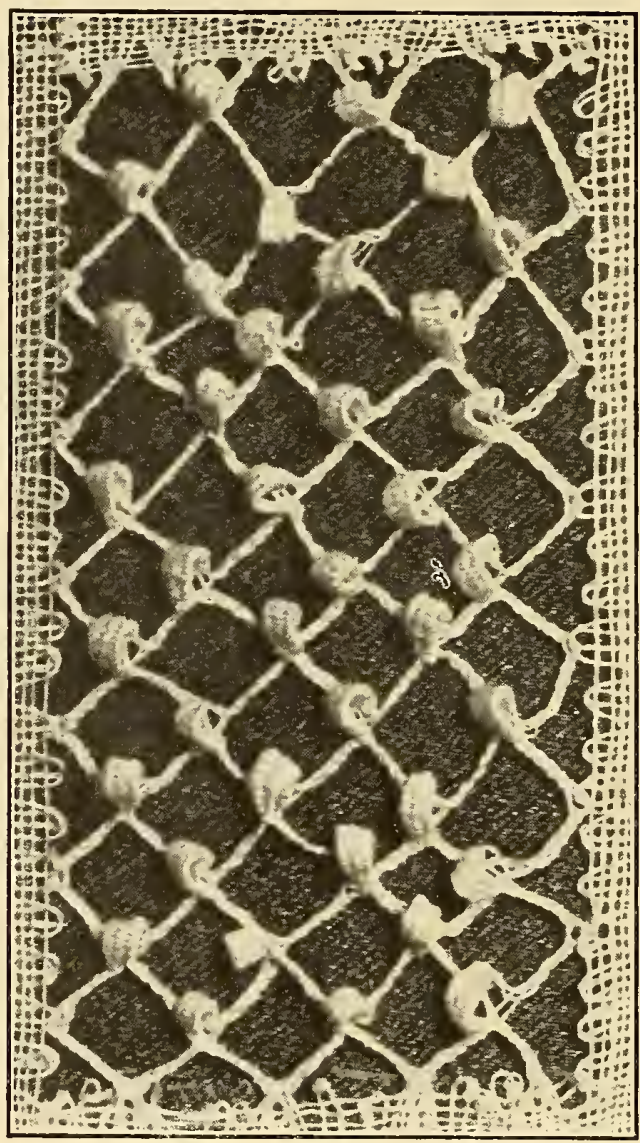

T'wo pairs are used on each side to make the braids, and the two center ones used after the braid joint is made, to make a small leaf or petal (the size of the petal should be in proportion to the size of the mesh made by the braids). Before a petal is started, a pin should be placed above the joint to hold it downwards. After the petal is finished, a simple granny knot is tied with the weaver and its mate- the right-hand, leaf thread. Then a pin is placed below the joint to hold the petal up, and the braiding is continued, plaited especially tight just around the joint. 


\section{LINE H, COL. 14, Italian 6 Legged Spiders with Ribbons.}
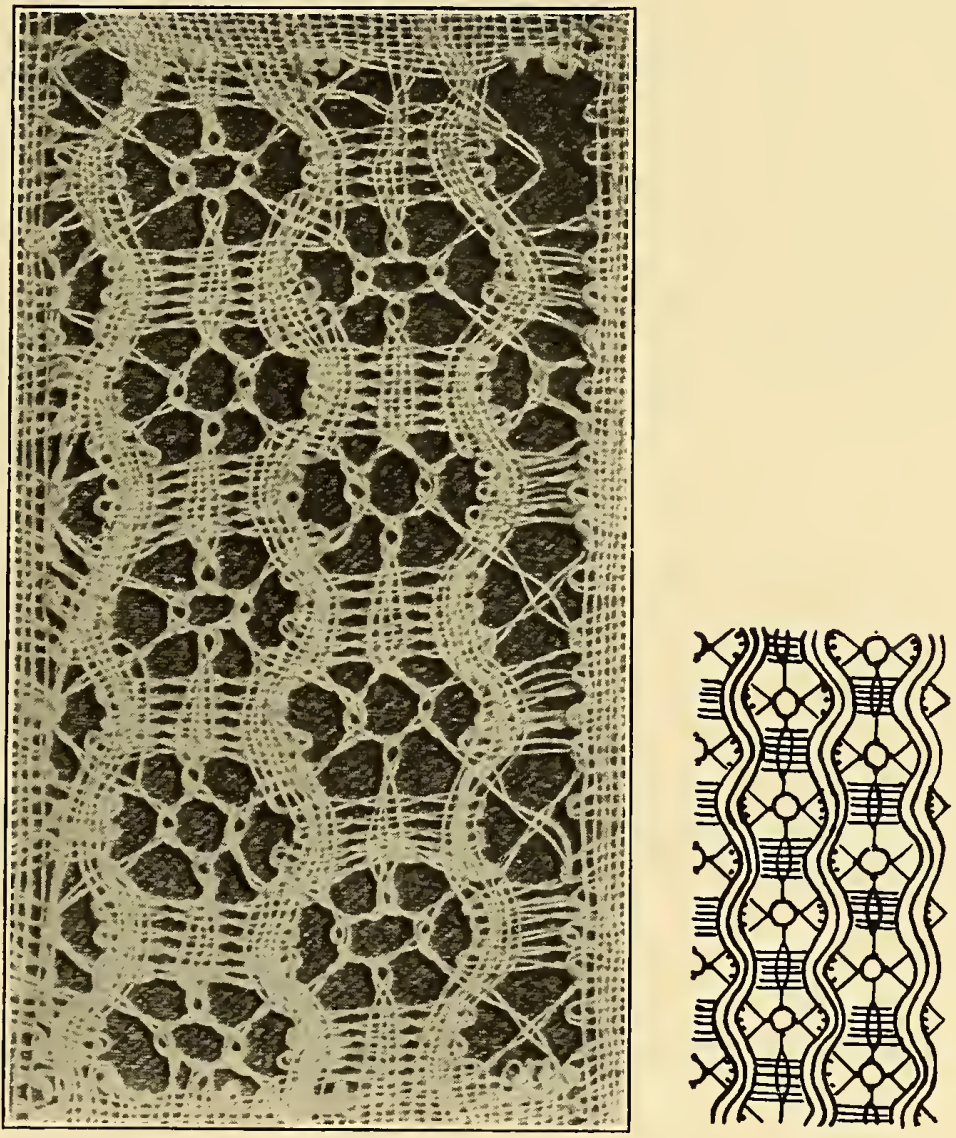

Starting at the apex of the little open square, one twists two pairs, makes a cloth-stitch with them, places a pin, twists, closes and twists. One of these pairs now works towards the left and one towards the right. The left-hand pair cloth-stitches with the once-twisted pair now entering at the upper left-that is with the upper left-hand leg of this little, open, spider square. A pin is placed here and the pairs twist, elose, twist. One should do likewise at the right-hand with the right pair and right leg. Again the same at the bottom with the two remaining central pairs, for the two legs that enter at the upper left and right exit at the lower left and right. The two center pairs now cloth-stitch six times untwisted down through a twisted weaver and then commence another spider similar to the one just described. But it is well to be careful that the weaver 


\section{LINE H, COL. 14-Continued}

\section{Italian 6 Legged Spiders with Ribbons.}

really does make six horizontal trips. This worker is twisted once each side of the pendant legs of the spider, between them and the wavy ribbons, but is not twisted in weaving through the legs.

A wavy, cloth-stitch, three-pair band or ribbon separates one column of spiders from another. Opposite a spider on one side of the upright, wavy border, come six weaver crossings on the opposite side, then another vertical, waving ribbon; then again a spider.

Where the weaving pair of the ribbon meets the diagonal leg of the spider, it should be noted that it weaves through the ribbon once above the leg and downward through the leg and then drops to the position of a passive pair. The inside, passive pair on the other margin of the ribbon now becomes the new worker, cloth-stitching once through the descending leg, and linenstitching through to the other side of the ribbon. 


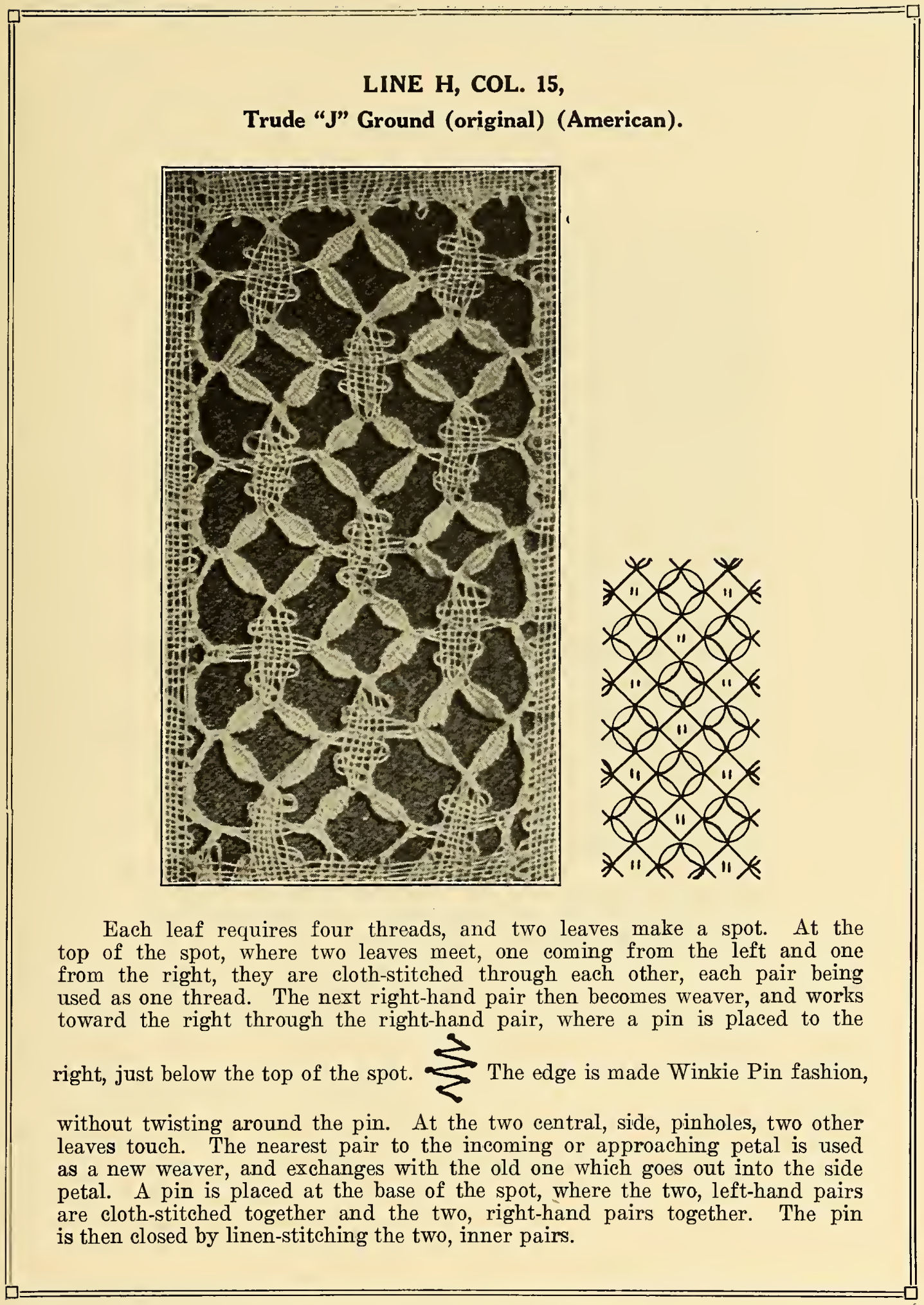




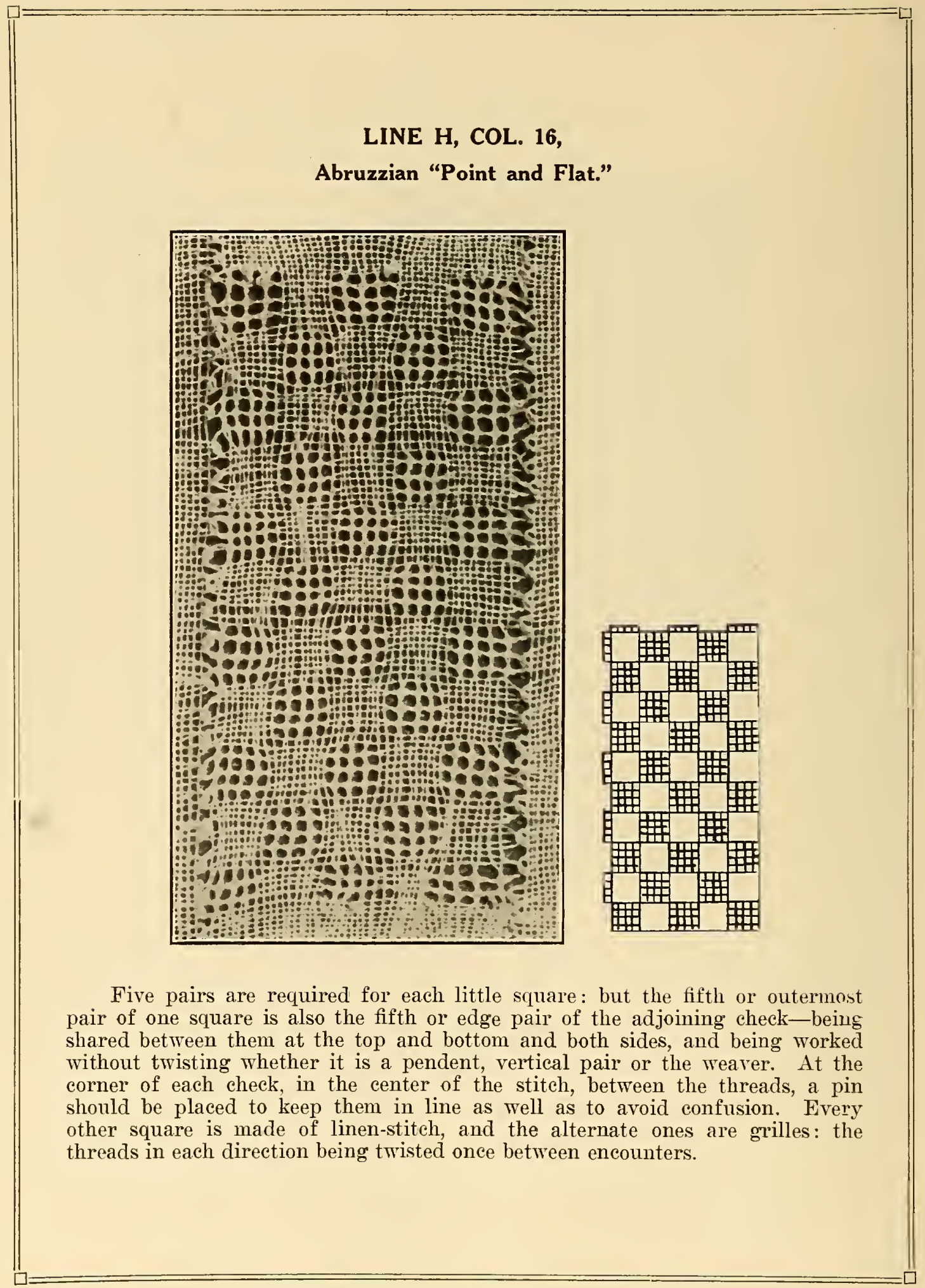


LINE H, COL. 17,

Tresses with Open Hooked Joints.
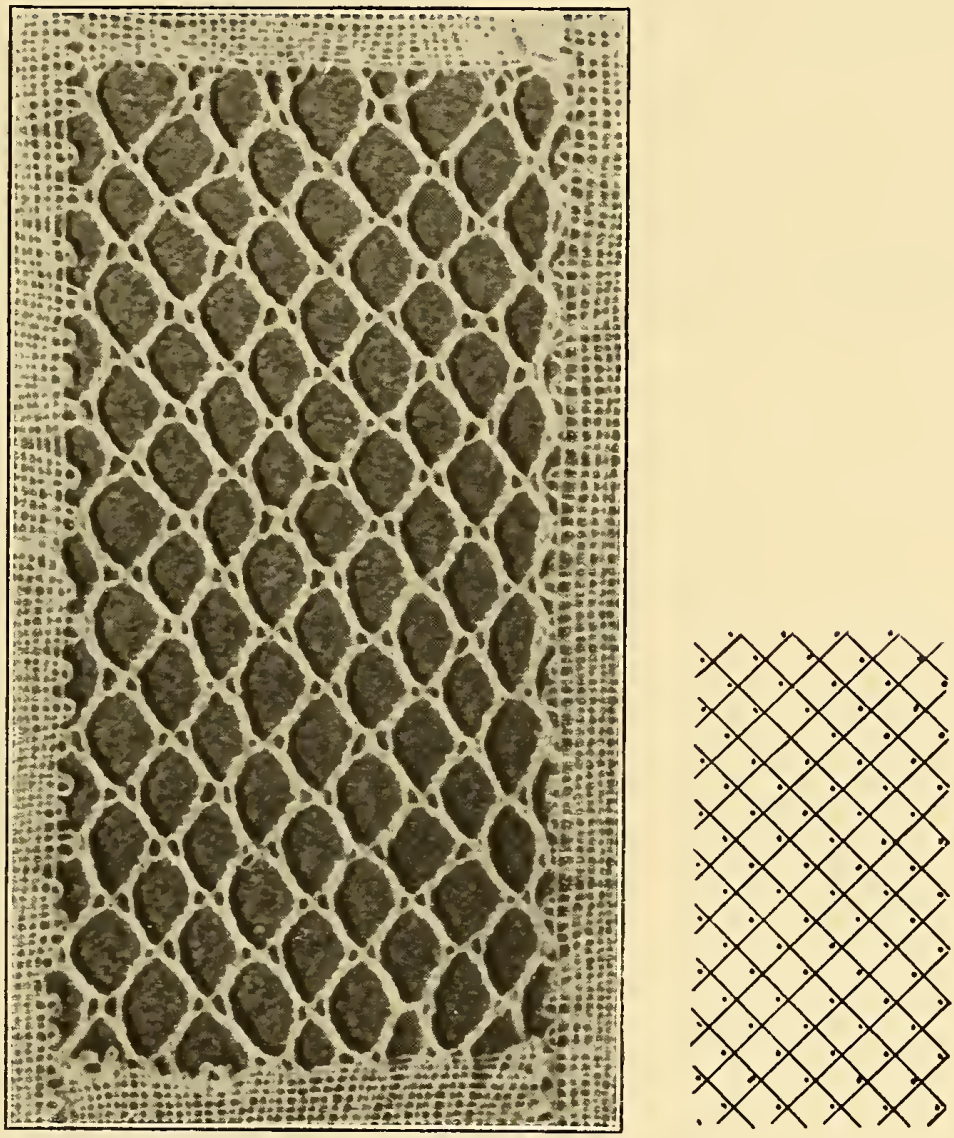

A quickly, easily made stitch. This sample can be done in either of two ways :- by weaving several parallel, upright braids, or by making one horizontal plait, running first in one direction, then returning below in the opposite direction. This sample was made by the first of these two methods, which places the two holes of the joint side by side between the upper and lower braids:- the second method would place these two, little holes one above the other. There should be four threads to the braid and four braid stitches tightly done between joints. The actual joint will pull a little to one side of the pin hole, as the pin of the preceding plait or braid is removed when the joint is made, and the second braid of the joint pulls the first one towards it. No pin is needed to hold the joint in position.

The first braid is plaited four times, then each of its pairs is twisted 


\section{LINE H, COL. 17-Continued \\ Tresses with Open Hooked Joints.}

twice and a pin is placed in the opening between the two twists, and the braiding is continued another four times, when this braid makes a joint with the one preceding it,-unless it happens, of course, to be the first braid, either topmost or farthest to the left. A joint is made where a later braid in its zigzags meet a preceding one. Then the pair in the second braid nearest the first plait, is twisted once, and one thread is hooked into the former pin space while the mate is passed into this crochetage loop. The threads are pulled up smoothly, the working pair twisted once, and the idle, hanging pair twice. Then regular braiding is recommenced. In making the first two, tress stitches after the joint, the braid should be held in a line continuous to its direction before the joint was made, as this helps to pull out the preceding braid more smoothly. 
LINE H, COL. 18,

? ?

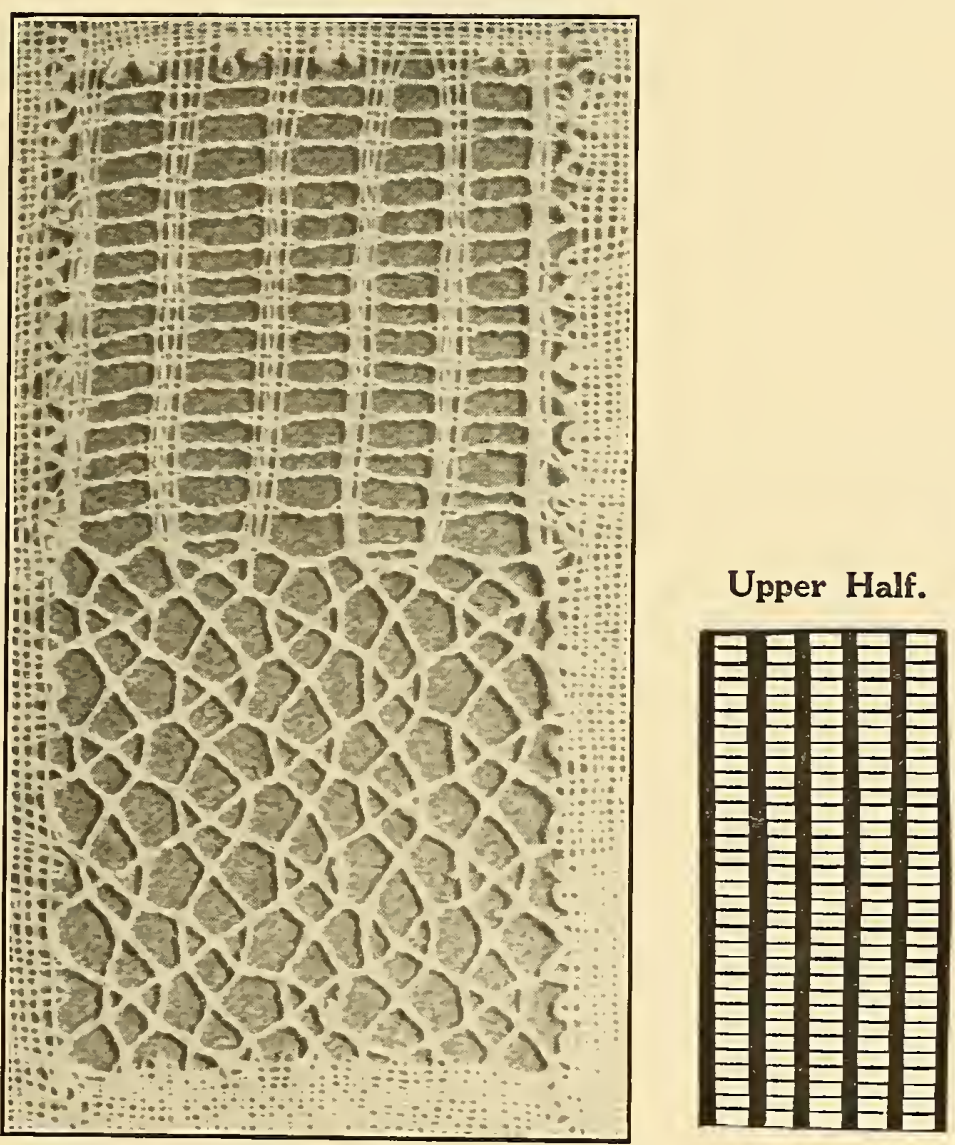

This sample requires twelve, vertical pairs and a weaver.

Two horizontal threads, twisted four times between the flat, spread-out, vertical bands, act as a conductor, weaving from one side of the lace to the other and back, cloth-stitching through the four, untwisted, vertical threads. No pins are necessary, except as occasional supports to keep the lines straight and in plumb. 


\title{
LINE H, COL. 18,
}

\author{
Lower Half.
}

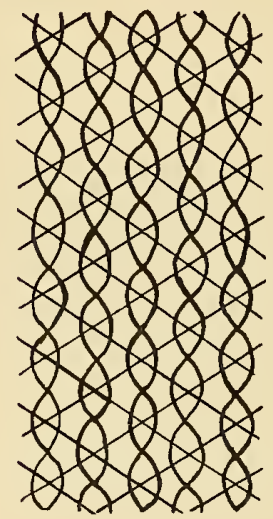

This sample requires fourteen, twisted pairs.

The sides of the ellipses are twisted three times between stitches to keep them open, and each section of the cross inside of the ellipse is twisted three times to round out the ellipse. Supporting pins are placed under, but not inside of the joints to support these crosses. The bars between one ellipse and another should be twisted only once. 


\section{BIBLIOGRAPHY}

This list was started soon after the author left school. Unfortunately, she then had no definite object in keeping it: but did so simply because anything to do with lace, appealed to her. She therefore noted books and articles so connected when she saw them in museums, public libraries, private collections, catalogues, books, magazines, newspapers or at sales: but she did not always keep an account of where she had come across the works. The descriptions of the many different editions of the Vinciolo and Vecellio pattern books, are largely quoted from Mrs. Bury Palliser, whose splendid "History of Lace" is well worth perusal or consultation. Although the following bibliography has been compiled from many sources, thanks are particularly due to the Needle and Bobbin Club for kindly allowing its list to be reprinted; to the author's friend and schoolmate, Miss Ruth S. Granniss, Librarian of the Grolier Club; to Miss Frances Morris, Assistant Curator at the Metropolitan Museum and Vice-President of the Needle and Bobbin Club; and to Mr. William M. Ivins, Junior, Curator of Prints at the Metropolitan Museum. As it is practically impossible to see personally every book described in a list of this sort: but it is nevertheless desirable to make such a bibliography as nearly complete as possible in order that it may be of the greatest service, the author has included books which she, not having already come across herself, found listed elsewhere; or she added to her own nucleus of information, items that seemed desirable. But feeling that the compilers of such matter, should have the credit for the fine detailed work they have done, the author has used only such parts of their descriptions as are essential to the identification of the different volumes. It has also seemed more accurate not to translate the descriptions given by others. In cases where the differences between the two books are very slight, both volumes are noted, as without in each instance seeing the actual work, it is impossible to decide which annotation is the more exact. Readers are referred especially to the catalogues of the South Kensington Museum, Mrs. Bury Palliser, Mr. E. F. Strange, Mr. Emmanuel Bocher, and Professor Eugene van Overloop.

Mr. Edward F. Strange in the VIIth Volume of the Transactions of the Bibliographical Society gives the following interesting and enlightening account:

The earliest known Lace-book now appears to be that of Jörg Castel, of Zwickau, Ein New Modelbuch, etc., 1525, a copy of which has recently been added to the collection in the Königliche Kunstgewerbe Bibliothek, Dresden. This furnishes the originals, of which six plates in the book of Pierre de Sancte Lucie, Dict Le Prince, successor to Claude Nourry, of Lyons (1530-1533) are copies. Its title page shows it, however, to have had at least one earlier edition; and others followed in 1527 and 1529.

Next in order of date seems to come the publication of Peter Quentell, of Cologne, Eyn ney Kunstlich boich ... Gedruckt tzu Collen up dem 
Doemhoff dwrch Peter Quentell. Anno MDXXVII. ${ }^{1}$ In the same year, and at the same town, appeared Liure noveau et subtil touchant lart et sciēce tant de brouderie fronssures, tapisseries . . . En primere a culoge [Cologne] par matrepiere quinty deupre leglie de iii roies. Then come two rare volumes, of which copies, said to be unique and hitherto undescribed, were offered for sale by Rosenthal, of Munich, a short time since: Ein new Furm büchlein (c. 1528-29, with 32 plates, said to be entirely original) and Ein new getruckt model Büchli; auff nehen vnnd bortten wircken ynn der laden vnnd lanngenn gestell. Ganntz gerecht nach abteilung der Feden tzal. (1529. Forty-five cuts of needlework and lace.) It appears, however, to be an edition of Gastel's book. [The last two are now (1918) in the Metro. Mus., N. Y. Gertrude Whiting.]

The earliest Italian book of which a record exists is A. Paganino's De rechami . . . (Venice, 1527). Then comes an edition dated 1528 (noted by Brunet and Merli), of Giovanni Antonio Taglienti's Opera nuova che insegna a le Dōne a cuscire, the edition of 1530 being printed at Venice "per Giovan Antonio Tagliente \& i Fratelli de Sabbio." Tagliente was the compiler of one of the earliest and best of the writingbooks (1524). This publication has a title in red gothic letters; four woodcuts, with women at work. Its contents are of a somewhat fanciful nature, and include several symbols, such as hearts transfixed with arrow and sword, several pages of examples of lettering, designs of animals and vases, a good border of angels on the reverse of Aiiii, and six pages of instructions; from which we see that the patterns were intended to be executed in various coloured and black silks, gold and silver thread, etc., for embroidery, for the use of both men and women. The next is Esemplario di lavori dove le tenere, etc.: Venice, "per Nicolo D'Aristotile detto Zoppino MDXXIX," of which a copy is in the Bodleian Library; and in 1531 appears G. A. Vavassore's Esemplario di lavori che insegna alle donne, etc. Of this a copy is in the Kunstgewerbe Museum, Berlin. The earliest edition described by Mrs. Palliser, is only dated 1546, but Dr. Jessen has doubtless had good reasons for dating his copy as above, and Professor Kumsch agrees with him. An interesting point in it is, that a design of Orpheus charming the Beasts, which in Tagliente's volume appears in simple line only, is in that of Vavassore shown in squares for making "lacis."

Of the French books, the honour of being the first belongs to a Florentine who published in 1530 la fleur de la science de pourtraicture et patrons de broderie. Facon arabicque et ytalique.... Ce present livre a este imprime a paris par jaques nyverd. Le IV jour daoust. Lan de grace mil cinq cēs XXX. Pour noble hōme messire Francisque Pelegrin de florence. It is of value as showing how wide was the diffusion of patterns, though these contain neither animals nor other natural objects, and are confined to moresques. Of about the same date is that published by Claude Nourry at Lyons. 
So far as the beginnings of our subject in other countries are concerned, we may note $A$ neawe treatys: as coernynge the excellency of the nedle worcke so playnli made \& set tout in portrature, the whiche is difficyll; and natôly for crafts mē but also for gentlewomé \& iôge damosels that therein may obtayne greater conynge delyte and pleasure. These books be to sell at Andwarp in the golden Unycorne at Willm Vorstermans. As W. Vorsterman worked from 1514 to 1542, we have here limiting dates which show the work to have been quite early, and the fact that it was worth while to produce it with an English title is interesting evidence of the closeness of the commercial intercourse between this country and the Netherlands. The first genuinely British pattern-book I have been able to trace was printed at London by J. Wolfe and Edward White for Adrian Poyntz in 1591: New and singular patternes and workes of Linnen, etc. It has an interesting "Epistle to the Reader," and dedication:- "To the Right Worshipful Gentlewoman, Mistress Susan Saltonstall, wife to the right Worshipfull Mr. Richard Saltonstall, Alderman of the City of London," both given at full length by Mrs. Palliser. In the latter the author alludes to "certaine paternes of cut-worke and others brought out of Foreign Countries which have been greatly accepted of by divers Ladies and Gentlewomen of sundrie nations and consequently of the common people," and states his hope "to increase and augment with more paternes of work."

It is a surprising fact that no one, so far as I am aware, has yet noted the existence of any Spanish book of the kind, though, as Mrs. Palliser says, "Dominique de Sera, in his Livre de Lingerie, published in 1584, especially mentions that many of the patterns of point couppé and passement given were collected by him during his travels in Spain." The Spanish writing-books, though few in number, are among the finest of their class; and one would have expected at least some sets of patterns to have been published in that country, though they would have probably been devoted to gold and silver thread-work rather than lace, the use of which was restricted by ordinances and heavy duties, and the supply derived from the Low Countries and France. The 1597 edition of Parasole's Studio delle Virtuose Dame has a dedication in Spanish, to Doña Joana de Aragon y Cardona, a member of the family of the Dukes of Segorbe. Her arms appear on the title-page; and one of its quarterings- the "Moorish King"" of the Cordova shield-forms the central ornament of the first cut, with other heraldic devices; and the inscription Nichil sine ipso factum est.

ABBREVIATIONS

B. K. M.

Berlin Kunstgewerbe Museum.

D. K. S. .

B. M.

Metro Mus.

Dresden Kunstgewerbe Schule.

British Museum.

S. K. M. . . . . . . South Kensington Museum.

V. \& A. M.

Victoria and Albert Museum. 
Fuller descriptions of the following early pattern books can be found in the "Manuel des Travaux à l'Aiguille," 1911, by Emmanuel Bocher, in "A History of Lace," 1902, by Mrs. Bury Palliser, or in "Early Pattern Books of Lace, Embroidery and Needlework" by Edward F. Strange in the Transactions of the Bibliographical Society, December, 1904,London :-

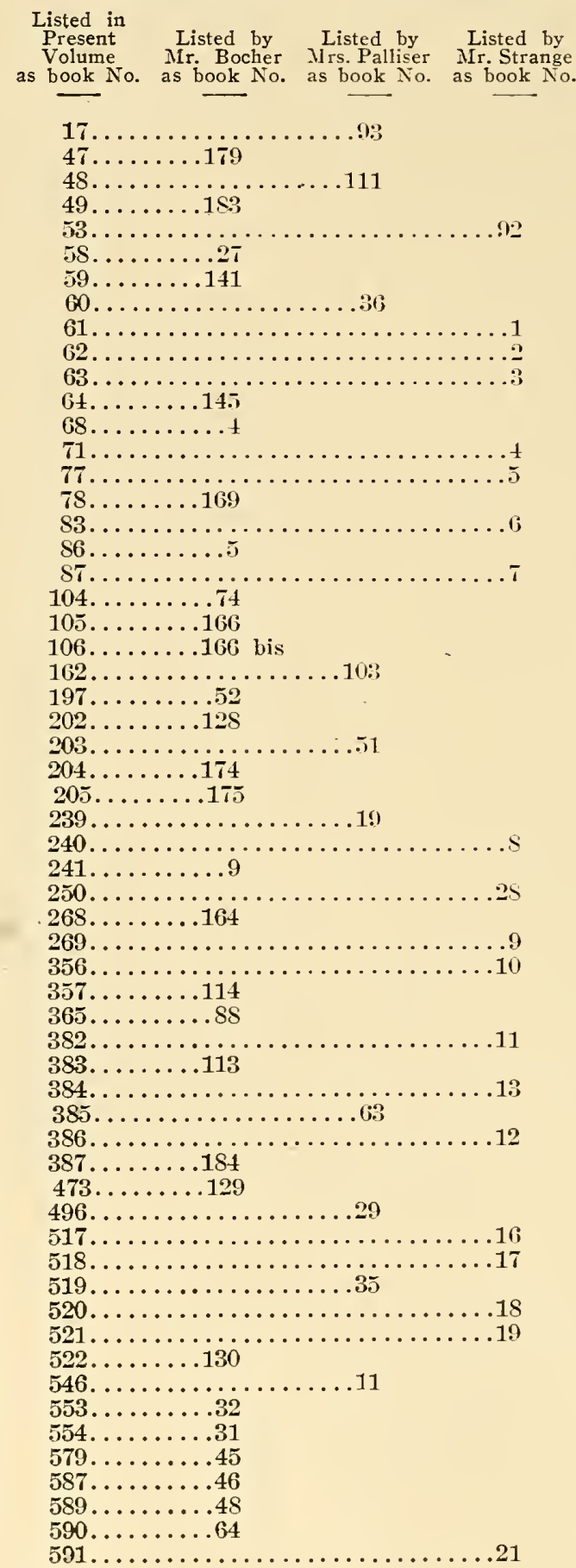

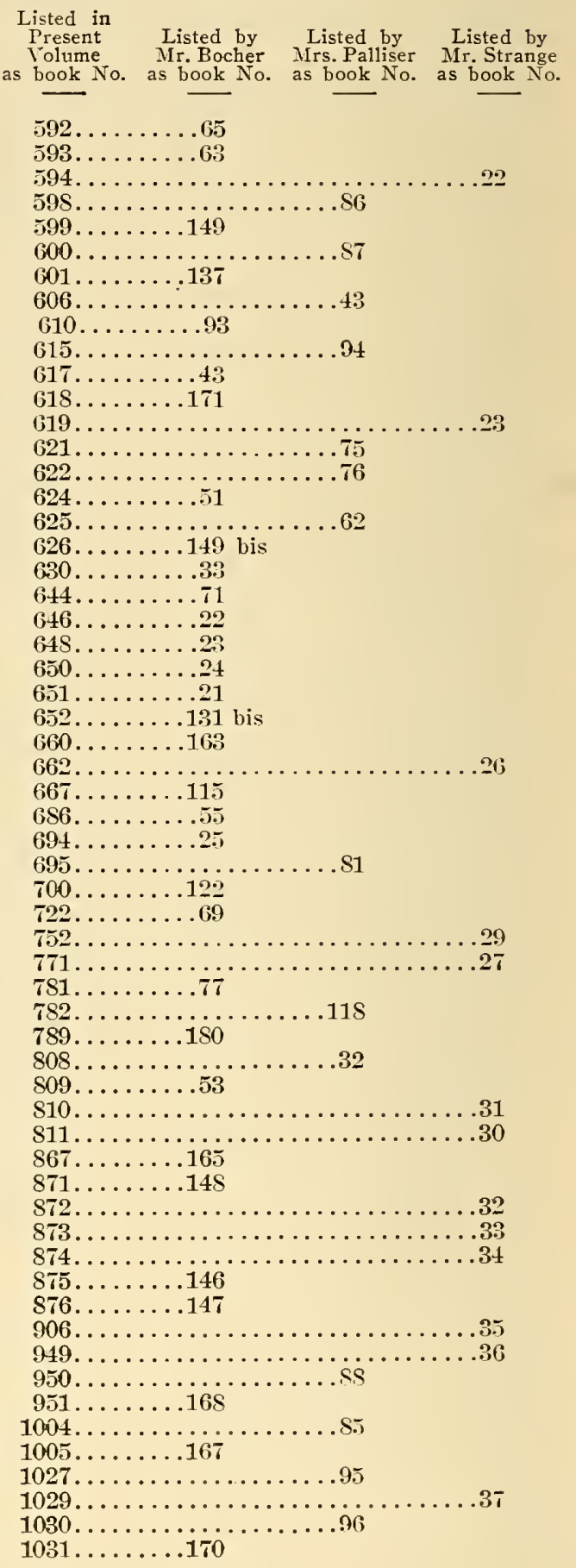


Listed in

Present Listed by Listed by Listed by

as book No. Mr. Bocher Mrs. Palliser Mr. Strange

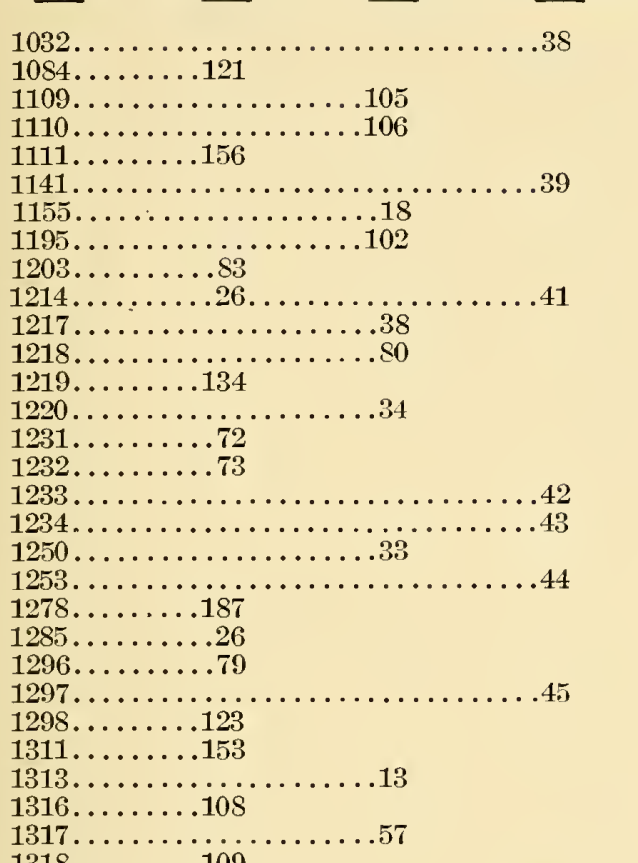

$1318 \ldots \ldots \ldots \ldots \ldots \ldots \ldots+\cdots \cdots$

$1319 \ldots \ldots \ldots \ldots \ldots \ldots \ldots \ldots \ldots \ldots$

$1320 \ldots \ldots . .84$

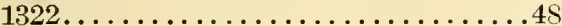

$1323 \ldots \ldots \ldots \ldots \ldots \ldots \ldots \ldots \ldots \ldots$

$1341 \ldots \ldots .56$

$1342 \ldots \ldots \ldots 57$

$1343 \ldots \ldots \ldots 5$

$1344 \ldots \ldots \ldots \ldots \ldots \ldots$.

$1345 \ldots \ldots 60$

$1346 \ldots \ldots \ldots 61$

$1347 \ldots \ldots \ldots 60$ bis

$1348 \ldots \ldots .81$

$1349 \ldots \ldots .81$ bis

$1350 \ldots \ldots \ldots \ldots \ldots \ldots \ldots$

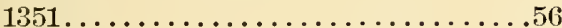

$1352 \ldots \ldots \ldots \ldots \ldots \ldots \ldots 27$

$1354 \ldots \ldots \ldots 110$

$1355 \ldots \ldots .111$

$1356 \ldots \ldots \ldots 151$ bis

$1358 \ldots \ldots \ldots 154$

$1359 \ldots \ldots \ldots 155$

$1360 \ldots \ldots \ldots 75$

$1361 \ldots \ldots 76$

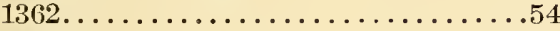

$1363 \ldots \ldots \ldots .7$

$1364 a \ldots \ldots 66$

$1365 \ldots \ldots \ldots 116$

$1366 \ldots \ldots 117$

$1367 \ldots \ldots \ldots 118$

$1368 \ldots \ldots \ldots 119$

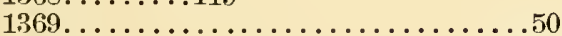

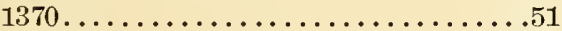

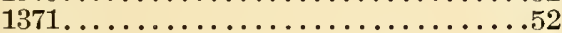

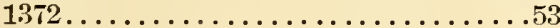

$1374 \ldots \ldots \ldots \ldots \ldots \ldots \ldots \ldots \ldots \ldots$ $1398 \ldots \ldots \ldots 49$

1400 .
Listed in Listed by Listed by Listed by Nolume Mr. Bocher Mrs. Palliser Mr. Strange

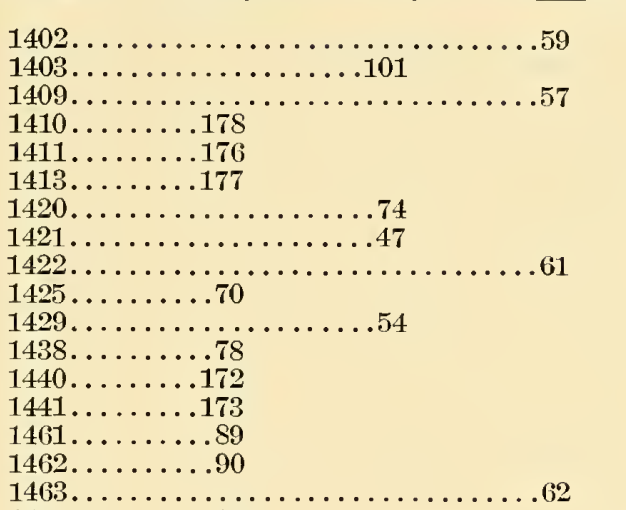

$1465 \ldots \ldots \ldots 91$

$1466 \ldots \ldots .92$

$1490 \ldots \ldots \ldots 28$

$1491 \ldots \ldots \ldots 29$

$1492 \ldots \ldots \ldots \ldots \ldots \ldots \ldots \ldots \ldots \ldots . \ldots \ldots$

$1493 \ldots \ldots \ldots 30$

$1498 \ldots \ldots \ldots 126$

$1523 \ldots \ldots \ldots 181$

$1537 \ldots \ldots \ldots 62$

$1566 \ldots \ldots \ldots 162$

$1567 \ldots \ldots \ldots 161$

$1575 \ldots \ldots 144$

$1580 \ldots \ldots \ldots 80$

$1581 \ldots \ldots \ldots 125$

$1582 \ldots \ldots \ldots 124$

$1583 \ldots \ldots .159$

$1584 \ldots \ldots \ldots 160$

$1586 \ldots \ldots . . .88$

$1596 \ldots \ldots \ldots 1$

$1624 \ldots \ldots \ldots 112$

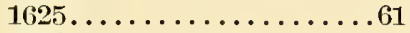

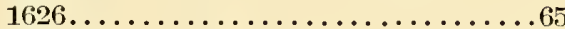

$1628 \ldots \ldots \ldots 42$

$1636 \ldots \ldots \ldots \ldots \ldots \ldots \ldots . \ldots . \ldots 94$

$1637 \ldots \ldots \ldots \ldots \ldots \ldots \ldots$

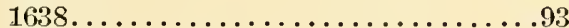

$1639 \ldots \ldots \ldots \ldots \ldots \ldots$

$1642 \ldots \ldots \ldots 133$

$1644 \ldots \ldots \ldots \ldots \ldots \ldots$

$1645 \ldots \ldots \ldots 139$

$1646 \ldots \ldots 140$

$1649 \ldots \ldots \ldots \ldots \ldots \ldots \ldots \ldots \ldots \ldots \ldots \ldots \ldots$

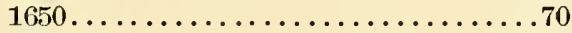

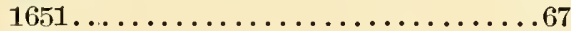

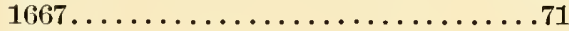

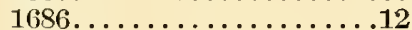

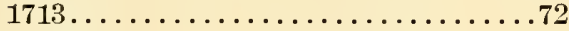

$1722 \ldots \ldots \ldots \ldots \ldots \ldots \ldots \ldots \ldots \ldots$

$1730 \ldots \ldots 142$

$1731 \ldots \ldots \ldots 143$

$1734 \ldots \ldots \ldots \ldots \ldots \ldots \ldots \ldots \ldots \ldots$

$1736 \ldots \ldots 150$

$1737 \ldots \ldots \ldots 151$

$1755 \ldots \ldots \ldots 127$

$1758 \ldots \ldots \ldots 54$

$1759 \ldots \ldots \ldots 63$

$1767 \ldots \ldots .182$

$1769 \ldots \ldots . .158$

$1791 \ldots \ldots \ldots 50$

$1795 \ldots \ldots \ldots 46$ 

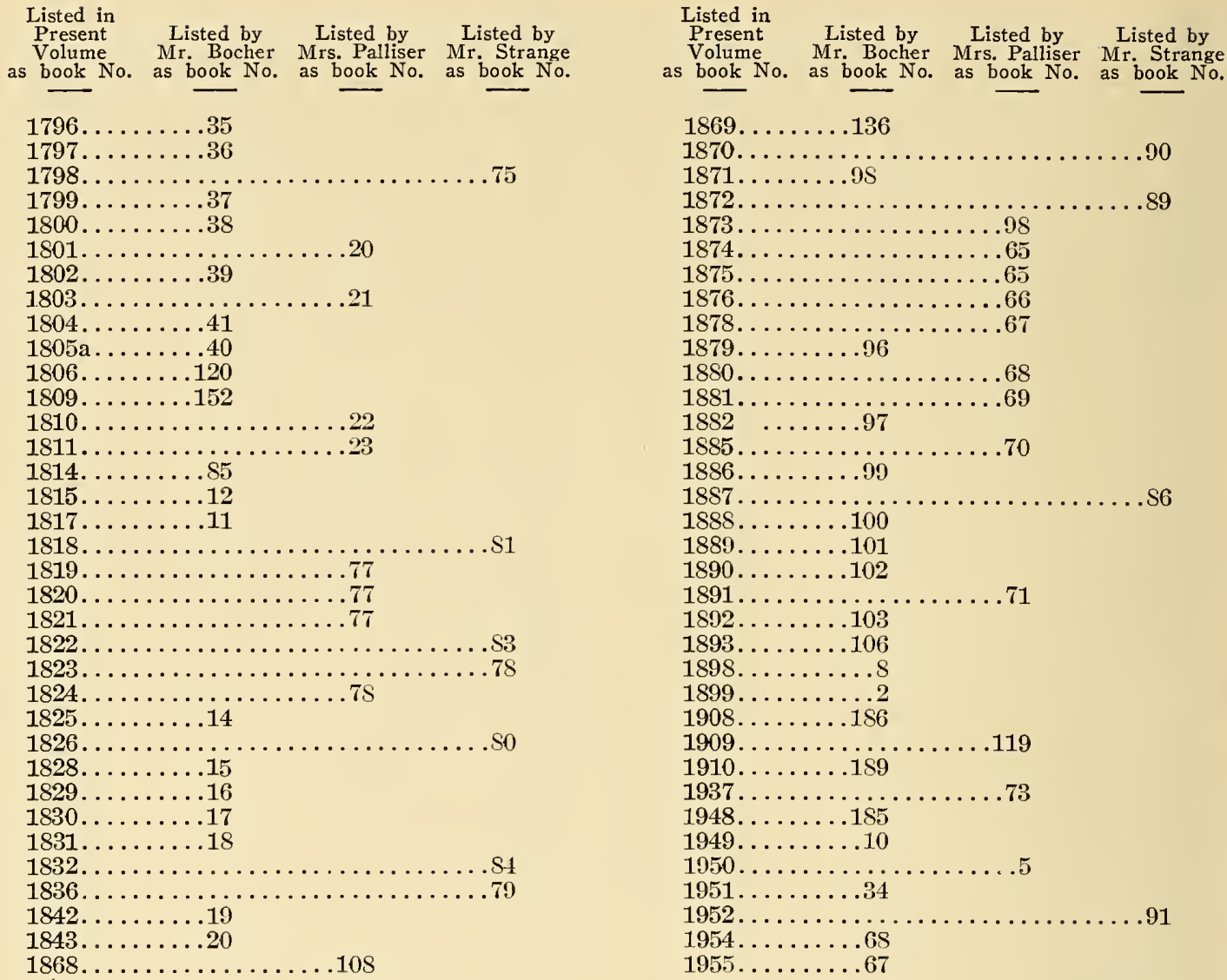

For the facsimiles here noted of early pattern books, see: Amand-Durand, Cocheris, Munster, Ongania, Quaritch, Ricci, Seemann, Wasmuth.

\section{NOTE}

Owing to a re-arrangement made necessary by the inclusion of several new titles, the following numbers have been omitted from the Bibliography:--794, 1055, 1307, 1424, 1456, 1464, 1478, 1479, 1576, 1658, 1883.

For the same reason the following interstitial ones have been added:-747a, 881a, 902a, 1516a, 1756a, 1805a, 1889a, 1949a. 
1.-Acker, M. E.-Crocheted Doilies. Harper's Bazaar, V. 36, pp. 275-277, March, 1902.

2-Adda, Girolamo d'-L'Art et l'Industrie aux XVIe et XVIIe siècles. Essai bibliographique sur les anciens modèles de lingerie, et de dentelles et de tapisseries, etc., en Italie. Paris, 1863.

3-Adda, Marquis Girolamo d'-Essai bibliographique sur les anciens Modèles de Lingerie, Dentelles, etc. Gazette des Beaux Arts, 1863, V. 15, pp. 342$359 ; 1864$, V. 17 , pp. 421-429; 1864, V. 17, pp. 430-436.

4 -Adda, Girolamo d'-Essai bibliographique sur les anciens modèles de lingerie, de dentelles et de tapisseries, gravés et publiés en France, en Allemagne et en Flandre. Paris, 1864.

5-Adda, Girolamo d'-Le Lit de Castellazzo. Gazette des Beaux Arts, 1863, V. 14, p. 97.

6-Agnew, Lilly, at Dublin-Projets de dentelles modernes. Paris, Art appliqué, $2 \mathrm{e}$ année.

7-Aktion zur Hebung der Spitzenhausindustrie in Österreich, Die. Kunst und Kunsthandwerk, 1905, Vienna.

8-Album de l'Elégance Française (Exposition Internationale de Liège, 1905). Couture, Dentelle, Broderie, Passementerie. Numéro spécial de Dentelle et Broderie, Paris, 1905.

9-Album de l'Exposition de l'art ancien Brux. 1884. La Dentelle. 30 photogr. avec notice par Reusens. Paris gr. in-fol.

10-Album of 2241 original, pricked, pen and ink patterns for bobbin lace (Lille type), Couvet (Canton de Neuchâtel, Switzerland), April 6. 1796, Chev. Amy (see pricking No. 322). On pattern No. 310 is written "Justicier Besancent": on pattern No. 311- "Justicier Besancenet": on pattern No. 347-"pour Léonard": on pattern No. 606-"fait par Petitpierre": and several are marked "Henriod Nre." Owned by Miss Gertrude Whiting.

11-Album russischer Leinenstickereien. 2 Lieferungen. 21 Blatt sehr fein in Farben ausgeführt. 4to. St. Petersburg, 1882.

12-Alco, Madam Louise D'-Traité de la dentelle aux fuseaux. Paris.

13-Aldisio, Nicolas de-Les Tissus et les Dentelles de Pérouse. Art décoratif, Paris, 1912. Tome 14, pp. 343-350.

14-Alexandre, A.-Les Reines de l'Aiguille, Modistes et Couturières. With about 50 charming etchings (several full-page) by François Courboin, Paris, 1902. Collection of upwards of 200 original drawings of designs for Lace of various and elegant patterns.

15-Alexander, Mrs. Hirst-Art Handicrafts for Gentlewomen. The Lady's Realm, London, 1901.

16-Allen, M. E.-Handicrafts in Old Deerfield. Outlook, V. 69, pp. 592-597, Nov. 2, 1901.

17-Allerhand Model zum Stricken un Nähen. Cat. Evans, Strand. Obl. 4to, 64 plates. No date.

18-Alphabets for Samplers, etc.-Pott, A.-Nene Zierschiften für Weissund Kunst-Steckerei. Obl. fol. Hamburg, 1869. S. K. M. 
19-Alq, L. d'-Traité de la dentelle au fuseau. Dentelles de Mirecourt, Valenciennes, Malines, Flandre, etc. 112 engravings. Paris, 1879.

20-Alvin, L.-Les anciens patrons de broderie, de dentelle et de guipure. Brussels, 1863.

21-Ambrosiani, Vincent-L'Exposition romaine de tapisseries, tissus, dentelles, etc. Revue de l'Art chrétien, 1887.

22-American Revival of an ancient craft; Italian embroidery. Outlook, V. 96, pp. 800-801, Dec. 10, 1910.

23-Anker, E.-Muster-Album für Haekel-Arbeiten. (18 double plates, containing 137 examples). 4to. Leipzig, 1887. S. K. M.

24-Antonelli, Dott. Nicola-Dell'Arte dei Merletti. Letto a Pisoniano il 30 settembre, 1901-Annexe: Genoveffa Frigerio in Borzacchini. Como ebbi idea di istituire la Scouola di Merletti a fuselli. Enrico Boretti, Rome, 1902.

25-Archives de la ville de Gand. Registre G. G. Fo. 123V.-Voorgeboden, série 108 bis, No. 184.

26.-Arendt-Rechercher les origines de la fabrication des dentelles. Spécialement dans les Flanders, spécifier leurs diverses espèces, etc.

27-Aristotle, Nicolo d'-Gli universali de i belle ricami-antichi e moderni. Anno, 1530, Venice.

28-Aristotile, Nicolo d'-Esemplario di lavori done le tenere fanciulle et altre donne nobili potranno facilmente imparare il modo et ordine di lavorare, cusire, etc. 1878, facsimile of edition of 1530. [See Zoppino (Aristotile detto.) ]

29-Armand-Durand-Livres á Dentelles. Paris, 1887.

30-Armand-Durand-Reproductions and prints of laces. Vol 1-5. (Collection of Kursheedt Manufacturing Co.)

Armand-Durand. See No. 623.

31-Arts de la Vie et du Foyer, Les. La Dentelle. Revue Univ., March, 1901, Paris.

32-Aubert, Félix-Dentelles, etc.: Col en dentelle polychrome: volants et éventail, etc. L'Art décoratif. Paris, 1901.

33-Aubert, Félix-Entwürfe für Spitzen und Stickereien.

34 -Aubert, Félix-Nouveaux éventails et chale en dentelle polychrome. L'Art décoratif, Paris, 1899.

35-Aubert, Félix-Projets de Dentelles et de Broderies. Paris, Librairie centrale, 1904. 30 plates, folio.

36-Aubrey, Félix-Dentelles de l'Exposition Universelle de 1867. Rapport du Jury International.

37-Aubrey, F.-Rapport sur les Dentelles, etc. fait à la Comm. Française du Jury International de l'Exposition Universelle de Londres. 8vo. Paris, 1854. S. K. M.

38-Aubrey, F:-Dentelles, tulles, broderies, et passementeries. Paris Exhib. 1867, Reports, vol. IV., p. 233. 13 vols. 8vo. Paris, 1868. S. K. M.

39-Aufseeser, Ernst and Kathleen-Ganze Embroideries. International Studio, V. 46, pp. 153-154. April, 1912. 
40-Austin, Ern. J. at Norwood-Projets de dentelles modernes. Art appliqué, 2e année, Paris.

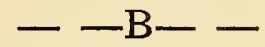

41-Babbitt, Florence S.-Samplers I Have Read About, Seen and Owned. Michigan Pioneer and Historical Society, Collections and Researches. V. 38, pp. 351-355, 1912.

42-Bahrfeldt, E.-Die Ausstellung von Stickereien, Hakel und Knupfarbeiten des Museums schlesischer Alterthumer zu Breslau. "Kunst und Gewerbe," Vol. XVII., p. 368, 4to. Nurnberg, 1883. S. K. M.

43-Bainbridge, Mabel F.-A Beginner's Lace Collection. House and Garden, Dec., 1918.

44-Bainbridge, Mabel F.-Early Lace Making in America. House and Garden, April, 1916.

45-Balachoff, L. L.-Recueil d'Ornement. 55 plates. P. Ducher. (Collection of Kursheedt Manufacturing Co., N. Y.)

46-Baldwin, E. F.-Woman's Work for Women in Italy. Outlook, V. 81, pp. 185-189, Sept. 23, 1905.

47-Baler, James-The Needles Excellency, a new Booke wherein are divers admirable Workes with the Needle. Newly inuented and cut in Copper for the pleasure and profit of the industrious. Le frontispice représente trois dames, Sagesse, Industrie, Folie, au milieu d'un jardin. Puis viennent plusieurs pièces de vers composées par John Taylor à la louange de l'aiguille et aussi en l'honneur de quelques dames industrieuses telles que la reine Elisabeth et la comtesse de Pembroque. Au-dessous de cette gravure: Printed for James Baler and are to be sold at the signe of the Marigold in Paules Church yard. The 12th Edition in larged Wth divers newe workes as needle workes, purles et others neuer be fore printed, 1640 . Pièce de vers intitulée The Fraise of the Needle. Puis commencent les broderies qui ne sont imprimées qu'au recto et qui sont toutes numérotées en chiffres arabes en bas à la pointe, à gauche de la planche. Ces broderies jusqu'à la planche 23, paraissent être des copies de l'ouvrage allemand de Siebmacker. Les autres sont d'un caractère différent. Elles sont au nombre de 29. Donc en tout: le Frontispice, 4 feuillets préliminaires et 29 planches de broderies. In $-4^{\circ}$ oblong. [See No. 48.] B. M. L.

48-Baler, James-The needles excellency, a new booke wherein are divers admirable workes wrought with the needle. Newly invented and cut in copper for the pleasure and profit of the industrious. Printed for James Boler, \&c., 1640. Beneath this title is a neat engraving of three ladies in a flower garden, under the names of Wisdom, Industrie, and Follie. It appears the work had gone through twelve impressions. . . From the costume of a lady and gentleman in one of the patterns, it appears to have been originally published in the reign of James I.-(Douce.) From this description of the frontispiece, it seems to be copied from Sibmacher. The Needle's Excellency, or a new Book of Patterns, with a poem by John Taylor, in Praise of the Needle. London, 1640. Obl. 4to, engraved title, and 28 plates of patterns. Another copy of the same date, marked 12th edition, 
is in the Library of King's College, Cambridge. It consists of title, four leaves with the poem, subscribed John Taylor, and 31 leaves of copper cuts of patterns. [See No. 47.]

-Balthazar, Sylvius-see DuBois.

49-Balthaazar, Sylvius-Variarum protractionum (1) quas Vulgo Maurusias vocant (2) omnium antehac excusarum, libellus longe copiosissimus pictoribus, aurifabris, polymitariis (3), barbaricariis (4), variis que id genus artificibus, etiam acu operantibus, utilissimus, nuncque primun in lucem editus, anno 1554. Balthazar Sylvius (5) fecit. Io Theodor, et Io. Israel de Bry, excud (6). 24 feuilles gravées sur cuivre y compris le titre. Les feuilles sont toutes imprimées d'un seul côté. (1) Entrelacs, méandres, arabesques. (2) Moresques. Voyez Ducange, Glossarium mediœ et infimœ latinitatis, qui cite ce livre à propos du mot Maurusias. (3) Tisserands. (4) Damasquineurs. Azzimistes. (5) Il est ainsi nommé à la page 104 de l'ouvrage de Firmin Didot. Essai sur l'histoire de la gravure sur bois. Paris, 1863. (6) Plusieurs pièces parmi les faïences dites de Henri II, sont ornées d'entrelacs dont le dessin se trouve dans cet ouvrage de Balthazar Sylvius. In-4 $4^{\circ}$ oblong. Bibliothèque Nationale.-Cabinet des Estampes.

50-Barber, Bernard, at Nottingham-Projets de rideaux de dentelles. Art appliqué, lre année, Paris.

51-Barbour Bros. Imperial Macramé Lace Book. New York, 1882.

52-Barcelò G.-La Barcelò tecnia ossia l'arte di ritesser'e e di restaurare ogni specie di stoffa di imitare e restaurare qualunque sorta di merletti e di costruire delle tappezzerie in figure, fiori e rabeschi in mosaico di panno. 1 vol. de texte et 1 vol. de 47 planches grav. Roma, 1859 .

53-Barley, William-A Booke of Curious and strange Inuentions, called the first part of Needleworkes, containing many singuler and fine sortes of Cutworkes, Raisde-workes, Stiches, and open Cutworke, verie easie to be learned by the diligent practisers, that shall follow the directions herein contained. Newlie augmented. First imprinted in Venice and now againe neawly printed in more exquisite sort for the profit and delight of the Gentlewomen of England. For William Barley, 1596. B. M.

54-Barrett, L.-New Ideas in Lace-making. Ladies Home Journal, V. 19, p. 23, February, 1902.

55-Bartko, Kurt-Blumen und praktische Muster für Spitzen. Plauen. C. Stoll, 1910.

56-Bartko, Kurt-Irish Lace. Plauen, K. Bartko, 1910.

57-Baseus, Nicholas-Pattern Book, 4 editions. Frankfort, 1568. 4to, 40 pp.

58-Basset, Nicholas-Ein new getruckt model Buchli, auff ausz nehen unnd bortten wircken ynn der laden, unnd lanngenn gestell. Ganntz gerecht nach abteilung der feden tzal. Sans lieu. In $4^{\circ}$ gothique. Titre à clairevoie, sans encadrement. En résumé 24 feuillets dont 45 pages de dentelles et de broderies à deux ou plusieurs modèles à la page. La plupart de ces patrons se retrouvent dans les volumes publiés par Claude Nourry. Ils ont de nouveau vu le jour dans le New Modelbuch, publié à Francfort en 1569, par Nicolas Basset. Vente Destailleurs, 1895. 
59-Basset (Baseus), Nicolas-New Modelbüch, von allerhandt Art Nehens und Stickens jetz mit viellerley welshe arbeyt, model und stahlen allen steinmetzen, seidenstickern, und Naterin, sehr nietzlich ünd Künstlich von newen zugericht. Getruckt zu Franefurt am Meyn. Anno 1569. En dessous du titre et au-dessus de l'adresse de l'imprimeur et du millésime, un médaillon circulaire dans lequel se détache sur' un fond noir, un profil d'homme regardant vers la droite. C'est le portrait de l'imprimeur Nicolas Basset. Ce médaillon est encastré dans le haut d'un ovale entouré de cuir's roulés, de rinceaux et porte en haut au milieu, un petit vase aux deux côtés duquel est un oiseau. Au-dessus du médaillon dans l'intérieur de l'ovale, N. B. In $-4^{\circ}$. Page non cotée. Au verso de cette page, la marque de Nicolas Basset. 52 feuillets. Le marquis d'Adda dans sa bibliographie en signale une édition de 1568. Vente Destailleurs, 1895.

60-Baseus, N.-New modeibüch. Von allerhandt Art, Nehens und Stickens, jetzt mit viellerley Welscher Arbeyt, Mödel und Stahlen, allen Steinmetzen, Seidenstickern und Neterin, sehr nützlich und kunstlich, von newen zugericht. Getruckt zu Frankfurt arn Mayn, 1571. Device and motto of Nicolas Baseus on title-page. Sm. 4to. 153 woodcut patterns. Library $\mathrm{V}$. and $\mathrm{A}$. Museum.

61--Basset, N.-New modelbuch von Allerhandt Art, Nehens und Stickens . . . Getruckt zu Franckfurt am Mayn, M. D. LXXI. [Mark of Nicolaus Baseus, dated 1570, on titlepage.] $4^{\circ}$. Title and 39 cuts. On sheet I-4 is a design of the Wounds of Christ, dated 1564 . V. \& A. M.

62-Basset, N.-[45 leaves of similar patterns, printed on both sides. On last page:] Getruckt zu Franckfurt am Mayn, in dem Rosen Eck, by Niclas Bassee. V. \& A. M. [See No. 61.]

63-Basset, N.-[Another edition.] Gedruckt zu Franckfurt am Mayn. M.D.LXXXVIII . . . durch Nicolaun Basseum. B. K. M. [See No. 61.]

64-Baseus, N-New Medelbuch von allerhandt art Nehens, Wirckens, und Strickens, ietz mit vielerley welscher arbeyt modelvnd stahlen allen steinmetzen Gei denstickern und naterin sehr nützlich und Künstlich von neuwen zugericht. Gedrückt zu Francfurt am Mayn, MDLXXXX (1590). Sur ce titre, un fleuron composé d'un ovale encastré dans un cartouche ornementé de rinceaux sur lesquels on voit en bas debout à gauche Adam, à droite Eve. En haut assis tous les deux, à gauche Aaron, à droite Moïse. Dans l'intérieur de l'ovale, un personnage agenouillé de profil à droite, les deux mains jointes devant lui. En haut le bon Dieu sur un nuage. Au fond deux collines sur le haut desquelles on voit des villes et leurs murailles. Sur la bordure qui entoure la composition on lit: Nicolaus Baseus excelsus. Dominus \& humilia respicit et alta. A. Loge Considerat. P. S. 138, 1590. Gedruckt zu Franchfurt am Mayn durch Nicolaum Bassacum MDLXXXX (1590). En tout 40 feuillets, 77 planches de broderies imprimées au recto et au verso. Il existe de ce livre une édition datée 1569 . Voir vente Destailleurs. In- $8^{\circ}$ Oblong. Bibliothèque Nationale.

65-Battenberg Manual (Renaissance, Flemish, Arabian Lace). Henry Frankenberg, New York, 1901. (Collection of Kursheedt Manufacturing Co., N. Y.) 
66-Battey, E. V.-Love of Lace. Harper, V. 53, p. 679.

67-Bayard, Emile-L'Art de Reconnaître les Dentelles, Guipures, etc. Paris, 1914. R. Roger et F. Chernoriz.

68-Bé, Pierre Le-Bèle Prerie, contenant divers caractères et différentes sortes de lettres alphabétiques, à sçavoir letteres Romaines, de formes, lettres pour appliquer sur le reseuil, ou lassis et autres pour marquer sur toile et linges, par Pierre Le Bé, Paris, 1601. In- $4^{\circ}$, oblong. Cité dans le catalogue de monsieur Picard, 1780.

69-Béal, J.-Les Dentelles anciennes-nouveau Choix de Specimens de tout Styles, Reproductions d'après les Originaux. Paris, A. Calavas, 1887. 28 plates.

70-Béal, J.-Dentelles, Guipures et Broderies de différents Styles. Paris, A. Calavas, 1892. 47 plates, folio.

71-Beatus, M. Georgius-[Dedication to] Der Durchleuchtigen Hochgebornen Fürstin und Frawen Loysen Julianen, Ehur Furstin unnd Psalbgräffin bey Rhein, Herzogin in Obern, und Nidern Bayern, $\bar{u}$. Gebornen Princessin zu Oranien, \& unser Grädigen Furstin und Frawen [by] M. Georgious Beatus und Johannes Ludovicus Bitchius als Romani Beati Seligen Erben daselbst. Gedruckt zu Franckfurt am Mayn bey Romani Beati Seligen Erben M. Georgii Beati und Joham Ludwig Bitchen. Im Jar 1601. 77 plates. Hamburg Mus.

72-Becker, B. H.-Lace-Making at Nottingham. Blackwood, V. 132, p. 477.

73-Becker, B. H.-Lace-Making at Nottingham. Eclectic Magazine, V. 99, p. 755 .

74-Becker, B. H.-Lace-Making at Nottingham. English Illustrated Magazine, May 1884, London. V. 1, p. 467.

75-Becker, Marie-Renaissance-Spitzen. Velhagen \& Klasings Monatshefte, March, 1898, Leipzig.

76-Becker, M.-Schön newes Modelbuch, von hundert und achtzig schönen kunstreichen und gerechten Mödeln, Teutsche und Welsche, welsche auff mancherly Art Können geneet werden, als mit Zopffnath, Creutz und Können Judenstich, auch auff Laden zu wirken, etc. 12 plates, sm. obl. Franckfurt am Mayn, Matthes Becker, 1601, (Bound with it, the ornamental title and two leaves of a Basel pattern book of 1599). S. K. M.

77-Becker, M.-Schon newes modelbuch Von hundert vnd achtzig schorren kunstreichen vnd gerechten Modeln Teutsche vnd Welsche, welche auff mancherly Art kônnen genoet werden, als mit Zopffnath Creutz vnd Judenstich auch auff Laden zu Wircken-Dessgleichen von ausserlesenen Zinnigen oder Spitzen. Allen Seydenstickern Modelwůrckerin Nåderin, vnd solcher Arbeit geslissenen Weibsbildern sehrn dienstlich, vnd zu andern Mustern anleytlich vnd verstandig. Franchfurt am Mayn, In Verlegung Matthes Beckers. M.D.C.L. $4^{\circ} .4$ pp. text. Copy of Vecellio. V. \& A. M.

78-Beckers, Matthes-Schon Newes Modelbuch von hundert vnd achtzig schonen Kunstreichen vnd gerechten Modeln, Teutsche vnd Welsche auff Mancherley art Konnen genut werden, als mit Zopffnath, Creutz vnd Judenstich, auch auff Laden zu wircken. Defsgleichen von auserlesenen Zinnigen oder 
Spitzen. Allen Seydenstickern, Modelwurckerin, naderin, und solcher arbeit geflissenen Weibsbildern sehr dienstlich vnd zu andern Mustern, anleytlich vnd vesrtandig. Franckfurt am Mayn, In Verlegung Matthes, Beckers, MDCI (1601). In-4 ${ }^{\circ}$ oblong. Titre et 2 feuillets. 57 feuillets. Cet ouvrage n'est mentionné dans aucune bibliographie et est complètement inconnu. Le titre imprimé en rouge et noir est entouré d'un large dessin représentant des femmes qui travaillent. Mme. Bury-Palliser dans sa bibliographie en mentionne une édition de 1605 .

79-Beebe, Mrs. C. D.-Lace, ancient and modern. New York, Sharps Publishing Co., 1880.

80-Belgian Lace-Makers. International Magazine, V. 1, p. 123.

81-Belin, A.-Sensuyent lis patrons de Messire Ant. Belin, etc. sm. 4to. (imperfect copy; 28 designs on 14 leaves of lace patterns, 16th cent.) Pierre de Saicte Lucie, called le Prince, Lyon, n.d. S. K. M.

82-Belin, A.-Sensuyent les Patrons de Messire A. Belin, etc. Sm. 4to, mounted imperfect copy, ornamental title, and 22 patterns. Lyon, P. de S. Lucie, called Le Prince, n.d. S. K. M.

83-Belin, A.-Sensuyuent les Patrons de messire Antoine Belin, Reclus de sainct Marcial de Lyon. Item plusieurs aultres beaulx Patrons nouueaulx, qui ont este inuentez par frere Jehan mayol, carme de Lyon. $4^{\circ} .11$ leaves of cuts. V.\& A. M.

84 -Belin, A., see Saincte Lucie. Also Jehan Troulon.

85-Bell, Mrs. A.-Breton Caps. Connoisseur, V. 23, pp. 44-48, Jan. 1909.

86-Belleze de Recami et Dessegni, opera nuova, nella quale si ritrovano varie et diverse sorti di mostre, di punti tagliati, et punti in aiere a fogliami, punti in stuora et altra sorte. In venetia. MDLVIII. In- $8^{\circ}$ oblong. 1 feuillet préliminaire, 19 feuillets, 37 planches de broderies imprimées au recto et au verso sauf la dernière qui n'est imprimée qu'au recto. Vente Riva, 1856, Vente Yemenitz, 1867, Catalogue Cicognara.

87-Bellezze.-Bellezze de Recami, et Dessegni. Opera noua, nella quale si ritrovano, uarie, \& diuerse sorti di mostre, di punti tagliati, et punti in aiere, à fogliami, punti in stuora, et altre sorte, come nella presente uedrai. Doue le belle, et virtuose donne potrano fare ogni sorte di lauori, sopra Colari Maneghetti, \& sopra tutte quelle cose, doue uanno simil lauori. Opera non men bella, che vtile, \& necessaria. Et non piu ueduta in luce. In Venetia. L'Anno MDLVIII. Sm. Ob. 4to. 20 plates of patterns. V.\& A. M.

88-Belleze de recami et dessegni, etc.Venice, 1558. Facsimile edition.

89-Беловић, J.-Српски Народни Вес и текстилна орнаментика. . Са 14 оригиналних слика. pp 254. 1907 Академија Новисад. Матица Српска. Књиге. Број 21.

90-Belovic-Vezilacka unjetnost u Hrvata i Srba. 1906. Zborink za narodni zivot i obicaje iuznih slavena kn. 11. 1.

91-Bérain, Oeuvres complètes de-Library of the Musée des Arts Décoratifs, Paris. Manueli Hoepli, Milan.

92-Bernhard and Ellen. Puntas and Passamenterie. Connoisseur, V. 24, pp. 82-88, June, 1909. 
93-Berry, Marguerite du-La Dentelle. Paris, Garnier, Frères, 1906. B. M.

94-Bert, F.-Musée de Fabrique de F. B. Professeur de Théorie de Tissage, à Lyon. (Cat.) fol. Lyon, 1855. S. K. M.

95-Bertling, Richard-Anton Moeller's Danziger Frauentrachtenbuch, 1601. Facsimile, mit Text von A Bertling. Danzig, Rich. Bertling, 1886.

96-Bertrand, Jules-Le Livre d'or de St. Pierre lès Calais. Histoire des dentelles, des tulles et de leur fabrication. Calais, Imp. Tartar-Crespin, 1885.

97-Béthune, Bon Joseph-Pour le commerce de Dentelles. Cercle historique et archéologique de Courtrai, 1903-1904.

98-Bezon-Dictionnaire général des tissus anciens et modernes. Lyon, 1836.

99-Biais, Th.-Étude sur les Broderies, Dentelles et Étoffes à l'Éxposition d'Anvers, en 1885. Paris, Impr. A. Lahure, n.d.

100-Biddle, C. H.-Mansion house exhibition, 1883. Irish lace : a history of the industry with illustrations and a map. (Signed at the end by Ben Lindsey and C. H. Biddle.) London. (1883.) $8^{\circ}$.

101 Biéchy, Élise-Spitzenmuster. Zeitschrift des Kunstgewerbevereins in München, 1881.

102-Bille, Jacques-Carton de dentelles. L'Art décoratif. March, 1902, Paris. 103-Binding or Overcast Stitch. Ladies Home Journal, V. 24, p. 39, March, 1907.

104-Bindoni, Giov. ant.-Il monte (Libro secondo). Opera nuova di recami, di punto tagliato a fogliami, dove ogni bella donna potra fare ogni sorte di lavori cioe colari, fazzoletti, maneghetti, avertadure. In Venetia, 1560. $\mathrm{Au}$ verso du titre une dédicace: Giov. ant. Bindoni, alla signora Vittoria da Cordova dans laquelle il faut noter les mots suivants. . . . Ho presso ardimento di presentavi questo secondo monte, il quale. . . ., \&. The dedication dates 1559 . Suivent 15 feuillets chiffrés avec 25 planches de broderies. Vente Santarelli, Chez M. Bigazzi à Florence.

105-Bindoni, G. Antonio-Ricchezze, Opera di Recami intitulata le Richezze. Delle bellissime et virtuosissime donne, Nella quale si ritrova varie sorti di punti tagliati, et di punti in aire, dove facilissimamente, et senza fatica alcuna, ogni virtuosa donna, potra lavorare cavezzi di varie sorti, colari, merli, da cavezzi, avertadure da huomo et da donna, manegheti, merli da mele da cusini, over forete, maneg he da camise et da vesture, et altre varie sorte di frisi, et mostre, si come veder potrai, ridotte alla vera grandezza, forma et misura che debbono essere, ne mai più pu l'adietro vedute da niuno. Opera non meno utilissima che necessaria. A la fin. In Venetia l'anno MDLVII (1557) à la Libreria de la Gatta. Des exemplaires portent MDLVIII. Première édition d'un ouvrage très rare et non cité. Elle comprend en tout 10 feuillets et 13 planches de broderies, dont 5 sont de doubles grandeurs. Le recto du premier feuillet contient le titre donné ci-dessus, et une dédicace, de G. Antonio Bindoni, datée du 3 avril 1557. La souscription occupe seule le verso du dernier feuillet. Vente Benedetto Maglione, 1894.

106-Bindoni, Gio. Antonio-Ricchezze, Opera nova di Recami intitulata le Richezze delle bellissime et virtuosissime donne nella quale si ritroza varie 
sorti di punti tagliati et punti in aiere, dove facilissimamente et senza fatica alcuna ogni virtuosa donna potra la vorare cavezzi. . . .

A la fin, In Venetia l'anno MDLVIIII (1559.) A la libreria de la Gatta. 3 parties en un volume in-folio. Libro primo. $12 \mathrm{ff}$. avec planches de broderies gravées sur bois, dont plusieurs sont de double grandeur. La primière page contient le titre et au-dessous un avis de Gio-Antonio di Bernandino Bindoni alle virtuose donne, daté de Venise, 3 avril 1557. Libro secondo, $12 \mathrm{ff}$. avec broderies, titre et dédicace de Bindoni à Lucretia Soncina gentil donna Paduana sur la première page. La dernière page est blanche. La $3^{\circ}$ partie a pour titre: Richezze. Opera di Recami intitulata: Le Richezze. Elle a $22 \mathrm{ff}$. Le premier feuillet contient le titre et au-dessous une dédicace de Bindoni. Au-dessous de la planche au recto du dernier feuillet, se trouve la mention: Il fine. Plusieurs planches sont de double grandeur. Vente Piot, 1891.

107-Binetti-Vertua, Caterina-Trine e Donne Siciliane. Ulrico Hoepli, Milan, 1911.

108-Birdwood, Sir G. C. M.-Industrial arts of India. (Lace and Needlework, Vol. 2, p. 68.) S. Kensington Mus. Art Handbook, 2 vols. 8vo. London, 1880. S. K. M.

109--Black, C.-Lace Industry. Living Age, V. 237, pp. 415-425, May 16, 1903. 110-Black, C.-The Lace Industry. Monthly Review, 11, No. 1, p. 92. Eclectic Magazine, $141: 65$.

111-Blackborne, Arthur-Catalogue of the famous Blackborne Collection of Laces. New York, American Art Association, 1908. See "Lace Collection of Arthur Blackborne."

112-Blackburn, Miss G.-Volant de berthe en dentelles. L'Art décoratif, November 1899 , Paris.

113-Blais, T.-Exposition universelle, 1878. Les Tisus et les Broderies. Extr. de la Gaz. de Beaux Arts, Dec. 1878. 8 vo. Paris, 1879. S. K. M.

114-Blais, T.-Les Industries d'Art au Champ de Mars. Les Tissus et les Broderies. "Gaz de Beaux Arts" 2nd ser., Vol. XVIII, p. 931. 8vo. Paris. 1878. S. K. M.

115-Blanc, C.-L'Art dans la Parure et dans le Vêtement. 8vo. Paris, 1875. Another ed. (Dentelles, p. 188. 8vo. Paris, 1887.)

116-Blanc, C.-Art in Ornament and Dress. (Translation of the above.) 8vo. Lond. 1877.

117-Blanc, Charles-Grammaire des Arts décoratifs. Dentelles. Gazette des Beaux-Arts. 1874, Paris. 2nd Series, Vol. IX, p. 211, 8vo.

118-Blanchon, H. L. Alph.-Au pays des dentellières (Le Puy). Le Monde moderne, October 1902, Paris.

119-Bland, Mrs.-Malacea Lace. (Royal Asiatic Society--Straits Branch.) Journal No. 45, 1906, pp. 273-277.

120-Blau, Josef-Die Spitzenklöppelei in Neuern (Böhmerwald). Extr. Zeitschrift für österrcichische Volkskunde, 1904. Vienna, 1905.

121-Blaufuss, Frl. H.-Spitzeneinsatz. Zeitschrift des Kungstgewerbe-Vereins in München, 1881, Munich.

122-Bloch, Sol. M.-On vogue for laces. N. Y. Times, July 15,11:4. 
123-Bocher, Emmanuel-Livres à dentelles reproduits pur Amand-Durand sous la direction d'Emmanuel Bocher, Paris, Amand-Durand, 1883 and 1887.

124-Bocher, Emmanuel-Manuel des Travaux à l'Aiguille. 3 vols., Le Filet Brodé, La Frivolité, Les Glands, etc. Paris, Librairie Damascène Morgand, 1911.

125-Bock (Dr. F.) - Beschrebender Katalog einer Sammlung von Spitzen und Kanten, etc. (Coll. purchased by the Museum at Dresden.) 8 vo. Aix, n.d. S. K. M.

126-Bock, Dr. Franz-Die textilen Byssus. Aachen, 1895.

127-Bock, (Dr. F.) - Geschichte der Liturgischen Gewander des Mittelalters, etc. Plates. 3 vols. 8vo. Bonn, 1859-71. S. K. M.

128-Bock, Dr. Fr.-Les Dentelles religieuses d'après les modèles du Moyen Age. Le Beffroi. Vol. III, 1866-1870, Bruges.

129-Bodli, J.-Magyar ezipesz szakismertclö könyv. 111 pp. Budapest, 1892. 8vo. B. M.

130-Boehn, Max von-Die Mode, Menschen und Moden im 17., 18. und 19. Jahrhundert. Nach Bildern und Kupfern der Zeit, ausgewählt von Ostr. Finkel, mit Text von Max von Boehn. 5 vols.

131-Bofarull, Carles de-Encajes a Mano. Museum Barcelona, 1912.

132-Boisseree (S)-Ueber die Kaiser-Dalmatika in der St. Peterskirche zu Rom. Plates. 4to. n.p., n.d. S. K. M.

133-Bonnand, Étienne-Autour d'une loi (sur la Dentelle). La Dentelle, 1905, Paris.

134-Bonnand, Étienne-Comment on crée un dessin de dentelle. La Dentelle, 1904, Paris.

135-Bonnand, Étienne-La dentelle et dessin dans nos éstablissements d'éducation. La Dentelle, 1904, Paris.

136-Book of Patterns for Point Lace. Paris 1623. 4to. Walpole's sale, 1842. 137-Borchgrave, E. de-Histoire des colonies belges en Allemagne et en Autriche.

138-Börner, Bruno-Colored Patterns for Cross Stitch Work. 25 patterns. (Collection of Kursheedt Manufacturing Co., New York).

139-Börner, Bruno-Colored Patterns for Cross-stitch. 51 plates. (Collection of Kursheedt Manufacturing Co., N. Y.)

140-Bottomley, H. T.-How to make the fashionable filet lace. Harper's Bazaar, v. 47, p. 241, May 1913.

141-Bowdoin, W. G.-Point and Pillow Lace. Artist, v. 27, pp. 257-262, 312316.

142-Brackett, A. M.-Italian Lace. The Art Workers Quarterly, July, 1902, London.

143-Branchardière, Mlle. R. de la-The Book of Greek and Roman Lace. Illus. London, 1859 . obl. 240.

144-Branchardière, Mlle. R. de la-The crochet book. London, 1847. 80.

145-Branchardière, Mlle. R. de la-The Crotchet Book of Emblem Antimaeassars, ete. obl. 4to. Lond. 1874. S. K. M. 
146-Branchardière, Mlle. R. de la-The Irish Lace Instructor: containing original designs for Spanish Point, ete. (Illus.) obl. 4to. Lond. 1886, Simpkin, Marshall \& Co. S. K. M.

147-Branchardière, Mlle. R. de la-Lacework, etc. Selected. Vol. 2. 1905.

148-Branchardière, Mll. Riego de la-Modern Orris Lace. 20 pp. London, 1885. obl. 8o. B. M.

149-Branchardiere, Mlle. Riego de la-The Netting Book for Guipure d'Art, etc. London, $1868.16 \mathrm{mo}$.

150-Branchardière, Mlle. Riego de la--The Point Lace Sampler, 1871.

151-Branchardière, Mlle. R. de la-Royal Jubilee Crochet Book. 1887.

152-Branchardière, Mlle. Riego de la-The Royal Point Lace Instructor, 1870.

153-Braun, Jos.-Winke für die Anfertigung und Verzierung der Paramente. Fribourg in Brisgau, Libr. Herder, 1904.

154-Braunmühl, C. von-Das Kunstgewerbe in Frauenhand. 4to. Leipzig (1885). S. K. M.

155-Braunmühl (C. von)-Uber Technik und Entwickelung der Spitzen. "Kunst und Gewerbe," Vol. XVI., pp. 33, 65. 4to. Nürnberg, 1882. S. K. M.

156-Brazza, Cora A., Slocomb di-A Guide to old and new Lace in Italy, exhibited at Chicago in 1893. Chicago, W. B. Conkey \& Co., 1893. B. M.

157-Brenan, James-Marketing of Irish Lace. See: Ireland Industrial and Agricultural, Dublin, 1902.

158-Brenan, James-The Modern Irish Lace Industry. Journal and Proceedings of the Arts and Crafts Society of Ireland, 1898.

159-Brenan, James-The Modern Irish Lace Industry. See: Ireland Industrial and Agricultural, Dublin, 1902.

160-Brenan (J.)-Report on a visit to Paris and Belgium respecting the manufacture of needlepoint lace. By J. B. School of Art, Cork, 1887. Sm. 4to. ph. S. K. M.

161-Breton, Gaston le-La Tissuterie Ancienne. Gazette des Beaux Arts, Paris, 1883. Tome 27, pp. 61-76, pp. 170-175.

162-Bretschneider, A.-New Modelbuch Darinnen allerley kunstliche Virsirung und Müster artiger Zûege und schöner Blummen zu zierlichen Ueberschlagen, Haupt Schurtz Schnûptüchern Hauben Handschuhen, Uhren (?) gehenzen, Kampfü tern und dergleichen auf Muhler nalıt und Seidenstûcker arbeit gantz Kunstlich gemahlt und vorgerissen, dergleichen sie bevor'n noch nie in Druck ausgegangen. 16 Leipzicht 19. Inn Verlegûng Henning Grosseren, de Jûngeren Andreas Bretschneider Mahller. Small folio, 53 plates, and half a sheet of text. Bibliothèque publique de Cassel. Leipzig, 1619.

163-Brieuves, De-La Dentelle-Historique de la Dentelle à travers les âges et les pays. Modèles et dessins de Songy. Un volume lin-12 de 196 pages, illustré de 83 figures et planches dans le texte.

164 -Brockhaus-Kunst Klöppeln. Conversations Lexicon.

165-Brooks, Beatrice, at Comberwell-Plastron en dentelle de Carrickmacross. Art appliqué, 1re année, Paris. 
166-Brown, Margaret-Duogate, at Dover-C'ouverture en dentelle pour calice. Art appliqué, 1re année, Paris.

167-Brown, N. C.-Arabian Lace. Harper's Bazaar, V. 41, pp. 886-888, September, 1907.

168-Brown, Nellie Clark-How to Make Battenberg and Point Lace. Boston, Priscilla Publishing Co., 1900.

169-Brown, N. C.-Tace Table Set. Harper's Bazaar, V. 41, pp. 1116-1119, November 1907.

170-Brown, M. M.-How lace-making industry in Belgium was subsidized by Commission for Belgian Relief. N. Y. Times, Mar. 3, V. 2:1.

171-Browning, H. Ellen-Some beautiful Lace at Nottingham Castle. The Lady's Realm. June 1903, London.

172-Bruges, Musée de Gruntlıuus. Anciennes Dentelles belges. Anvers, 1889. B. M.

173-Brunot, H. S.-Lace Industry of France. Scientific American Supplement, V. 57, p. 23817, June 25, 1904.

174-Brüssel--Historische Spitzenausstellung. Kungstgewerbeblatt, 1893-1894, Leipzig.

175-Brussels, Expos. Nationale de 1880._Cat. Officiel. (Sect. IV., Classe C., Dentelles et Broderies.) 16 mo. Bruxelles, 1880. S. K. M.

176-Brussels Lace-All the Year, V. 36, pp. 296, 353.

177-Brussels-Musées des Arts décoratifs. Catalogue des ouvrages se rapportant à l'industrie de la dentelle. 433 pp. Bruxelles, 1906. B. M.

178-Buckinghamslire, Countess of-The Buckinghamshire Lace Industry and its Revival. The Givl's Own Paper, 1876, London.

179-Buckinghamshire, Countess of-Revival of Lace. Argosy, V. 63, p. 156. 180-Buckley, Agnes, at Limmerick-Composition pour berthe en dentelle. Art appliqué, 1re année, Paris.

181-Buhring, W.-Schulen für kunstlerische Nadelspitzen in Hirschberg. Schleisen, In die Kunst, 1910, v. 22, pp. 412, 413.

182-Bulletin commercial, organe hebdomadaire du Musée commercial de Bruxelles, 1902, Nos. 33-50, about exporting lace to out-of-way places and about possible agents.

183-Bulletin mensuel de l'Association générale du commerce et de l'industrie des tissues et des matières textiles. Paris, 14e Année, 25 mars 1898. Séance de la Cliambre syndicale des dentelles et broderies.

184-Bulletin of the Needle and Bobbin Club. Pub. semi-anulually beginning Dec. 1916, New York.

185-Bunner, K.-Lace-makers of Aspley Guise. Craftsman, V. 17, pp. 85-89, October 1909.

186-Bunsen, Marie von and Heiden, Max-Berliner Spitzen-Ausstellung, 1905. Plauen, C. Stoll.

187-Burando (?), Lace-making" at- "A rt \& Letter's," Vol. I., pp. 12, 42. 4 to. Lond. 1881.

188-Burando (?)-Patterns of Lace made at. 100 Photos. Fol. Burando, 1884. S. K. M. 
189-Burato-Libri ii, iii, et iv, De Rechami per le quale se impara in diversi modi l'ordine e il modo de recamare, etc. Venice, 1527. The whole containing over 150 plates of designs. Venezia, 1878-80. Only a small number reprinted in facsimile of the originals. Metro. Mus.

190-Burrell, Mrs. J. Knitted Lace Edgings. 3 pt. Wisbech, London 1845-6. In British Museum.

191-Burrowes, M. E. B.-Buckingham shire Lace. Art Workers' Quarterly, v. 3, (No. 9), pp. 15, 16.

192_Busse, G. F.-Die Schatzkanmer der Marienkirche zu Danzig. (Photos. of Needlework). 2 vols. 8vo. Danzig, 1870. S. K. M.

193-Butterick Publishing Co.-The Art of Crocheting. Butterick, New York, 1891. (Collection of Kursheedt Manufacturing Co.)

194-Butterick Publishing Co.-The Art of Drawn Work. Butterick, N. Y., 1897. (Collection of Kursheedt Manufacturing Co., N. Y.)

195-Butterick Publishing Co.-Art of Drawn Work. 1901. (Collection of Kursheedt Manufacturing Co., N. Y.)

196-Butterick Publishing Co.-The Art of Modern Lace-making. Butterick, 1891. (Collection of Kursheedt Manufacturing Co.)

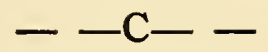

197-C., A.-Furm oder Modelbüchlein darin zu lernen vnnd gantz Lentlich zu begreyffen die recht und war Kunst auch die ausz teylung aller hand gewirck in der ram in der lade und mit der Kand ausz zu Nehen ganntz Neygemarcht. Gedruckt zu Augspurg, D. H. S. Sans date, vers 1550. Titre et 12 feuillets signés: A. C. 24 planches sur bois. Modèles de tapisserie. Catalogue Tross, 1867.

198-C., E. M.-The Lady's Crochet-book, 3rd series. London, 1877. $8^{\circ}$.

199-C., E. M.-The Lady's Knitting-book. Series I-IV. 4 vols. 16 mo. London, 1875. S. K. M.

200-Calais Lace Trade. Board of Trade Journal, May 16, 1901, London.

201-Calavas, A.-(Dentelles diverses). Portef., Paris, A. Calavas, n.d.

202-Calepino, Francesco-Lucidario di Recami nel qval si contengono molte et varie sorti di dissegni a pvnti in aere et pvnti tagliati et a fogliami et con figure et di piu altre maniere, come al presente si vsano, non piu venute in luce per leqvli ogni devato ingegno potra in diuersi modi comme dissimamamente seruirsi. In Venetia appresso Jeronimo Calepino, 1563. An-dessus de l'adresse de l'éditeur, un fleuron rectangulaire, composé de rinceaux des deux côtés d'un vase, et an-dessous un autre fleuron à clairevoie. Verso. Dédicace: Alla molto Honorata M. Anzola, ingegniera suocera mia digniss. Francesco Calepino. S. Puis une lettre ornée V. entre les branches de laquelle on voit une femme tenant dans chacune de ses mains levée en l'air une couronne. Cette lettre ornée est en tête de 21 lignes de texte finissant par les mots: Div. vara et singular virtu. Francesco Calepino affettionatiss. Puis les broderies. Page non cotée, verso. Au verso de cette page une marque d'imprimeur consistant en rinceanx avec un écusson au milieu, dans lequel on voit un animal de profil à gauche. En résumé 16 fenillets contenant 27 planches de broderies seulement, à 
cause des planches doubles. C'est pour ne pas avoir observé ce détail que dans sa bibliographie Mme Bury-Palliser indique cet ouvrage comme contenant 29 planches de broderies. Bibliothèque Nationale. Bibliothèque de l'Arsenal.

203-Calepino, Jeronimo-Splendore delle virtuose giovani dove si contengono molte, \& varie mostre a fogliami cio è punti in aere, et punti tagliati, bellissimi, \& con tale arteficio, che li punti tagliati serveno alli punti in aere. Et da quella ch' è sopragasi far si possono, medesimamente molte altre. In Venetia Appresso Jeronimo Calepino, 1563. 8vo, 20 ff., 35 plates of scroll patterns in the style of "Il Monte." Venice, 1563. Dedication "Alla molto honorata M. Anzola ingegniera suocera mia digniss." Francesco Calipino wishing, he says, to "ristampar"e la presente opera," he dedicates it to her. Bib. Nat. Bib. de l'Arsenal. Cat. d'Estrées.

204 -Calepino, Francesco-Splendore delle virtuose Giovani dove si contengono molte et varie mostre a fogliami. Cioè punti in aere et punti tagliati bellissimi \& con tale artificio che li punti tagliati serueno alli punti in aere et da qvelle che sopragasi far si possono medesimamente molte altre. In Venetia appresso Jeronimo Calepino, 1563. Ce titre est inscrit sur une draperie encadrée dans deux colonnes sur socle et surmontées en haut d'un fronton surbaissé portant au milieu un gros anneau. Au verso une dédicace: Alla molto honorata, M. Anzola Ingegniera suocera mia digniss Francesco Calepino S. Une lettre ornée, c'est un V entre les branches duquel on voit une femme tenaut dans cluacune de ses mains, levées en l'air, une couronne. Vingt et une lignes de dédicace se terminant par les mots : Div. rara \& singular virtu Francesco Calepino affectionatiss. Au verso d'une page deux gravures sur bois, l'une au-dessus de l'autre. En haut, c'est un ornement rectangulaire, formé, d'un motif central et de deux rinceaux. Au-dessous c'est une marque d'imprimeur au milieu de laquelle on voit dans une sorte d'écusson, un animal de profil à gauche. En résumé, 16 feuillets dont un titre et 29 planches de broderies. Vente Santarelli. Bibliothèque Nationale. Biblothèque de l'Arsenal.

205-Calepino, Jeronimo-Splendore delle Virtuose Giovanni dove si contengono molte et varie mostre di fogliami, cioe punti in aere et punti tagliati bellissimi et con tale artificio che li punti tagliati serueno alli punti in aere et de qvelle che so pragasi far" si possono medesimamente molte altre. In Vinegia appresso Jeronimo Calepino del 1567. In $4^{\circ}$. Frontispice, gravures, 20 feuillets, 35 planches. Bibliothèque Melzi, à Milan.

206-Calmettes, Fernand-L'Exposition Universelle (1900). Les tissus d'art, III, Dentelles. Revue de l'Art ancien et moderne, 1900.

207 - Calmettes, Pierre-Dentelles et Dentellières. Grande Revue, March, 1904, Paris.

208-Calori, E.-Travaux en guipures, études. Arte Italiana, 1901, Milan. 209-Camerino, J. G.-Collection J. G. Camerino, Paris. Les Points de Venise. Paris, Librairie des Arts Décoratifs, 1907.

210-Campbell, Mrs.-Care of Lace. Chamber's Journal, V. 80, p. 743.

211-Cardevaque, M. de-Histoire de la Dentelle à Arras. 
212_Carità-Lacis (Filet Brodé): practical instructions in Filet Brodé or darning on net. Diagrams for working old designs of Lacis. Sampson Low, 1909 ete. B. M.

3 ser., Sampson Low, 1910. B. M.

213-Carlier, Antoine-La Belgique Dentellière. Brussels, 1898. B. M.

214 - Carlier, Antoine-Les crises dentellières en Belgique. Musée social, December 1901, Paris.

215-Carlier, Antoine-Les Dentelles à l'aiguille. Extr. Bulletin des Métiers d'Art, 1903-1904. Brussels, Vromant et Cie., 1904.

216-Carlier, Antoine-Les Dentelles au Fuseau (Malines, Lille, Chantilly, Blondes.) Technique evolution des formes. 1 vol., 4 to, 100 plates. J. Poisson, Paris. Also edition de luxe with 450 engravings. Vromant \& Co.

217-Carlier, Antoine-Les Dentelles à l'aiguille, leur technique. Bull. Métiers d'Art, 1904, Brussels.

218-Carlier, Antoine-Les dentelles à l'aiguille, origine, luxe, histoire. Bull. Métiers d'Art, 1903, Brussels.

219_Carlier, Antoine-Les Dentelles à l'aiguille. Petit brochure in 4to, 50 engravings.

220-Carlier, Antoine-Les dentelles à l'aiguille, "points," technique. Bull. Métiers d'Art, 1904, Brussels.

221-Carlier, Antoine-Les Dentelles à la Main, Dentelles au Fuseau, à l'Aiguille, Points melangés. Plauen.

222-Carlier, Antoine-Dentelles des Temps passés. Illustration Européene, October 1901, Brussels.

223-Carlier, Antoine-Les Duchesses anciennes et modernes. 61 engravings, 2 plates. Petit brochure.

224-Carlier, Antoine-Le jeu des fuseaux. -Patriote illustré, March 1901, Brussels.

225-Carlier, Antoine-De Kantveraardiging in Nederland en België. Elsevier's Geillustreerd Maandschrift, April, 1904. The Hague.

226-Carlier, Antoine-Le Point de Venise. 1 f., n.p., n.d.

227-Carlier. Antoine-Les Valenciennes. Brussels, 1902. 64 pages. 8vo. 42 figs. and plates. B. M.

228-Carlile, Blanche-Lace and the North Buck Lace Association. Empire Review, January, 1903, London.

229-Carter, Miss Sybil-Brochure without title, New York, n.d.

230-Carter, Miss Sybil, and Miss Margaret A. Tomes-Lace made by North American Indians. New York, 1904.

231-Caster, G. Van-La Dentelle de Maline. Acad. Roy. d'Archéol. de Belgique Annales, V. 62, pp. 5-51.

232-Caster, G. van-Etude sur la Dentelle de Malines. Malines, L. and A. Godenne, 1909.

233-Catalogue, Daily Mail Exhibition of British Lace, March, 1908.

234 -Catalogue des objets d'art . . . dentelles . . . ayant appartens à Mme. la Comtesse Gatterburg Morosini, à Venise. Venice, 1904. 
235-Cau, James L.-The Mortons of Darvel. Art Journal, n.s. 1900. London. Pp. 7-11, 78-82.

236-Caulfeild, S. F. A., and Saward, B. C.,-Dictionary of Needlework. An encyclopaedia of plain and fancy needlework. History of the various works, etc. (Illus.) 4to. London, 1881, L. Upcott Gill. S. K. M.

237-Caulfeild, S. F. A. and Blanche C. Saward-Supplement to the Dictionary of Needlework. London, 1902.

238-Caulfeild, S. F. A.-Papers on Needlework in The Queen, The Girl's Own Paper, and Cassell's Domestic Dictionary. S. K. M.

239 - Celle, D.- "Ce livre est plaisant et utile. A gens qui besongnent de leguille," etc. 28 ff., 27 plates. Title in Gothic Letters. Dedication to the Reader, in which it states the book is for the profit of "tant hommes que femmes." Patterns medirval. At the end of the Preface, "Finis coronat opus."Lyons, N. D. Bib. de l'Arsenal. No. 11,953. Cat. d'Estrées. No. 8,843. 1. Bib. Ste. Genevieve. V. 634.

240-Celle, D.-Ce liure est plaisant et vtile \&c. . . . Corrige est nouuellement ... par ... Dominicque celle ... Taille il est totallement Par Jehan coste .. A Lyon ... Quatre vingtz fassons a vrayement Tous de differente maniere. Imprime à Lyon par Jehan coste. Lan de grace mil cinq cens trente vng. Le premier jour du moys de Decembre. Dominicus de celle fecit. $4^{\circ}$. B. K. M.

241-Celle Dominique-Ce livre est plaisant et utile

A gens qui besongnent de l'eguille.

Pour comprendre légèrement

Damoyselle bourgoyse ou fille.

Femmes qui ont l'esperit agille

Ne scauroient fallir nullement.

Corrigé est nouvellement.

Dung honneste homme par bon zelle

Son nom est Dominique Celle.

Qui à tous lecteurs s' humilye

Domicille a en Italie.

En Thoulouse a prins sa naissance.

Mise il a son intelligence

A lamander subtillement.

Taillé il est totalement.

Par Jehan Coste de rue Mercière.

A Lyon est consequemment.

Quatre vingtz fassons a vrayment.

Tous de différente manière.

Sans date. In-4. Livre de toute rareté, non mentionné par Brunet. Le titre indiqué ci-dessus est dans un encadrement. Au verso on lit un avis au lecteur, imprimé en gothique. Suivent: 27 feuillets contenant 54 planches de patrons de lingerie ou de broderie. Vente Pichon, 1869.

242 - Celnart, Madame-Manuel des Demoiselles, ou Arts et Métiers qui leur conviennent, etc. (Illus.) 12mo. Paris, 1830. S. K. M.

243- Ceresole, V.-Les Origines de la Dentelle de Venise et l'Ecole du Point de Burano à Exposition Universe lle de Paris en 1878. "L'Art," Vol. XIII., pp. 80, 105. Fol. Paris, 1878. S. K. M. 
244-Cesares, G. A.-Arazzi, Tessuti e Merletti. La Rassegna degli Interessi Femminiti. March 15, 1887, Rome.

245-Chambre de Commerce d'Alost-Rapport général sur la situation commerciale et industrielle, en 1874.

246-Chambre de Commerce de Bruges-Rapport général sur la situation du commerce et de l'industrie, en 1864.

247-Chambre de Commerce de Roulers-Rapport général sur la situation de l'industrie et du commerce pendant l'année 1864.

248-Chambre des Représentants de Belgique-Écoles dentellières, avril 1884.

249-Chambre des Représentants de Belgique-Patentibilité des Écoles dentellières, 1859.

250-C., H. N. D.-Winter und Sommer-Wårtlein, aller wol-könnenden Jungfrauen; aus welchen unterschiedliche Frücht und Blumen alzubrocken, auch zu einem Dåntzerl gegenwartiges als Musicalische Noten allen embsigen Frau-und Jungfrauen zu sonderlichem Lieb und Nutzen gegen hundert neue Arien, Sarabanden, Ballet und Capricien composirt und herausgegeben Durch H. N. D. C. $1691 . \quad 8^{\circ}, 16$ pp., 36 engravings. B. K. M.

251-Champeaux, A. de-Les Arts du Tissu. Etoffes. Tapisseries. Broderies. Dentelles. Reliures. Paris, J. Rouan et Cie., 1892. 144 pages. In B. M. 252-Champeux, M. A.-Dessins et Modèles. Les Arts du Tissu.

253-Chandler, Mabel S., at London-Projets de dentelles modernes. Art appliqué, 2e année, Paris.

254 -Channer, C. C., and Roberts, M. E.-Lace Making in the Midlands, past and present. London, Methuen \& Co., 1900. B. M.

255-Chapman, J. J.-St. Anne's Embroidery School, Nara. Spirit of Missions, V. 74, pp. 418-422, May, 1909.

256-Charles, Marguerite-La Dentelle à l'Exposition de Liége. Paris, A. Rosseau, 1905.

257-Charles, Mlle. M. and Pagès, Laurent - Les broderies et les dentelles. Cours en quarante lecons? Première série. Broderie. Origine, instruments et materiaux. Exposé des points. Histoire. Fils tirés. Les jours sur toile. Point coupé. Broderie de Nancy, Anglaise, piquée, Colbert, Richelieu, Vénitienne, au Passé, Application, (à la main). Dentelles à l'aiguille, les filets, les lacis. Points de Venise France, Argentan, Sedan, Espagne, Flandres, Dentelles au fuseau. Les principaux points. Origines. Etc. Un volume grand in- $8^{\circ}$ de 240 pages, illustré de 200 figures documentaires dans le texte et 16 belles planches phototypiées. F. Juven, Paris (1905). B. M.

258—Charles, Mlle. M., and Pagès, Laurent-Seconde Série Dentelles françaises et étrangères. Les broderies au point sur toile. Tapisserie. Crochet. Perles. Jais. Soutache Lacet, Galons d'or, en ruban, en relief, mécanique, mélangée, etc. Dentelles sur tulle, Renaissance, Guipure d'Irlande, Chantilly, Valenciennes, Flandre. Point d'Angleterre, Bruxelles, etc. Un beau volume de 240 pages illustré de 200 figures documentaires dans le texte et 16 belles planches phototypiées. F. Juven, Paris (1905). B. M.

259-Chayelé, Joannés-Le Puy Spitzen, Plauen, C. F. Schulz \& Co., 1910. 30 plates. 
260-Chayllery, Gabrielle, at Paris-Projet de col en dentelle. Art appliqué, 2e année, Paris.

261-Cherbuliez, Mlle. Emilie-Musée d'Art et d'Histoire, Genève. Les Dentelles de la Salle Amelie Piot. Genéve.

262-Chevalier de Wouters de Malines-_"Une Industrie que se meurt, la dentelle de Malines." Bulletin du Cercle archéologique, artistique et littéraire de Malines, 1901.

263-Chinesische Spitzen-Illustrirte Z eitung, June, 1845, Leipzig.

264-Choix de dentelles faisant partie de la collection du Musée Historique des Tissus de Lyon. Paris, A. Calavas. (1904.)

265-Christian, Princess-Article in Murray's Magazine, 1883.

266-Church, A. H.-Some Italian Embroideries. (Illus.) "The Portfolio." Vol. XII., pp. 32, 50, 111. 4to. London, 1881. S. K. M.

267-Church Needlework,-Book of symbols for, Plates. 2nd edit. 4to. London, n.d. S. K. M.

268-Ciotti, Giovan Battista-Prima parte de Fiori è disegni di Varie sorti di Ricami, Moderni come Merli, Bavari Manichetti, \& altri nobili Lauori che al presente sono in vso. In Venetia appresso Francesco di Franceschi, senese all'insegna diella Pace, 1591. Sur le titre un cartouche dans lequel on voit une femme, de face, tenant d'une main levée en l'air un rameau d'olivier, de l'autre une torche allumée dont la flamme est dirigée vers le sol. In $-4^{\circ}$ oblong. Dédicace: Alla Clarissima Signora et Padronna mia Colendissima la Signora Gabriella Zeno Michele. Au verso de cette page, fin de la dédicace par les mots: Di Venetia, alli 19 di Marzo 1591. Div. s. Clarissima, humilissimo et diustissimo servitore giouan battista Ciotti. Titre, dédicace et 14 feuillets, en tout 16 feuillets, dont 14 planches de broderies. Vente Yemenitz, Vente Labitte, 1877. Bibliothèque Nationale. Bibliothèque de l'Arsenal.

269-Ciotti, Giouanbattista-Prima parte de' Fiori, E Disegni Di varie sorti di Ricami Moderni. Come Merli, Bavari, Manichetti, \& altri nobili lauori, che al presente sons in vso. In Venetia. Appresso Francesco di Franceschi Senese all' insegna della Pace, 1591. [At end:] Appresso Nicolo Moretti, ad instantia di Francesco di Franceschi. $4^{\circ} .2$ pp. 15 cuts. Reproduced by Wasmuth, Berlin, 1891.) B. K. M.

270-Claesen, Josepl_-La Dentelle (Album de l'Exposition de l'Art ancien, Bruxelles, 1884). Paris, C. Clae sen, 1884.

271-Clark, Will. Alex. S.-Lace Industry in England and France.

272_Clark, Will. Alex. S.-Swiss Embroidery and Lace-making.

273-Clarke, Effie B.-Amateur Lace of Olden Times. Art Journal, 1899. Pp. 366-370.

274-Clarke, E. B.-Amateur's in Lace. Art Journal, V. 54, p. 381.

275-Clarke, E. B.-Design in a Dead Century. Art Journal, 1900, pp. 208-212.

276-Clarke, E. B.-English Lace in 1896. Art Journal, 1899, V. 48, p. 297.

277-Clarke, E. B.-Irish Lace. The Art Journal, December, 1897, London, V. 49, p. 358.

278-Clarke, E. B.-“Of 'Kerchiefs.' Art Journal, 1900, pp. 361,365.

279-Clarke, E. B.-Lace Amateur of Olden Days. Art Journal, V. 51, p. 141. 
280-Clarke, E. B.-Lace Designs of 1899. Art Journal, V. 52, p. 208.

281-Clarke, E. B.-The Laces of Queen Margerita of Italy. Art Journal, 1895. pp. 296-300. V. 47.

282-Clarke, E. B.-Modern Amateur in Lace. Art Journal, 1902, pp. 381-384.

283-Clarke, E. B.-Old Masters in British Lace. Art Journal, 1899, pp. 141145.

284 -Clay, M. S.-Design Applied to Needlework. Manual Training, V. 15, pp. 110-113, December, 1913.

285-Clerget, D. E.-Tracings by, filled in as in fac-similes, of the following lace pattern books:-La fleur de la Science de Pourtraicture, et patrons de Broderie, ete. (69 pp. of designs.) Sm. fol. Paris. F. Pelegrin, 1530. S. K. M.

286-Clerget, D. E.-Tracings by, filled in as in fac-similes. Patrons de divers manières, etc. (11 tracings.) Sm. obl. 4to. Lyons, Pierre de Ste. Lucie, 1590. S. K. M.

287-Clerget, D. E.-Tracings by, filled in as in fac-similes. Patrons pour Brodeurs, Lingères, Massons, Verriers, et autres gens d'esprit. (6 tracings.) Sm. obl. 4to. Paris, Vve. Jean Ruelle. n. d. S. K. M.

288-Clerget, D. E.-Tracings by, filled in as in fac-similes. Splendora del virtuose giovane. (42 pp. of designs.) Sm. obl. 4to. Venise, Francesco Calepino, 1563. S. K. M.

289-Clerget, D. E.-Tracings by, filled in as in fac-similes. Triompho di Lavori, etc. (9 designs.) Sm. obl. 4to. Padoue, Fra Hieronimo de Cividad di Friuli. (1555). S. K. M.

290.-Clerget, D. E.-Tracings by, filled in as in fac-similes. La vera perfezione del Disegna, ete. (23 tracings.) Sm. obl. 4to. Venice, Francesco Senese, 1591. S. K. M.

291.-Clermont Tonnerre, Cesse. Gédéon de-Histoire de la Dentelle (Translation).

292-Clever Copy, A.-The Connoisseur, III, No. II, London.

293-Clifford, Chandler Robbins-Chart of Handmade Laces. Lace and Embroidery Review, Sept. 1915, New York.

294-Clifford, Chandler Robbins-The Lace Dictionary. New York, Clifford \& Lawton, 1913.

295-Clowes, Ronald.-Lace and Needlework. The collection of Mons. G. Seligman, The Connoisseur, Jan., 1912, V. 32, pp. 27-36.

296-Cocheris, H.-Patrons de Broderie et de Lingerie du XVI e Siècle. (Reproductions of Lace books in the Mazarine Library, Paris.) 8vo. Paris, 1872. 2nd ed. 8vo. Paris, 1873. S. K. M.

297-Cocheris, Hippolyte-Recueil de documents graphiques pour servir à l'histoire des arts industriels. Paris, 1872. Cocheris Reprint-See No. 1297. 298-Colaert-Discours prononcé à la Chambre des Représentants, le 8 avril, 1884.

299-Cole, A. S.-Ancient Needlepoint and Pillow Lace. (20 Photographic illus.) fol. Lond. 1875. S. K. M.

300-Cole, Alan S.-Cantor Lectures on Neans for Verifying Ancient Enbroideries and Laces. March, 1893, London, Wil Trounce, 1895. 
301-Cole, Alan S.-Cantor Lectures on the Art of Lace-making, delivered before the Society of Arts, April and May, 1881. London, 1881. B.M. S.K.M. 302_Cole, Alan S.-Cantor Lectures. The Art of Lace-making. Journal of the Society of Arts, Sept., 1881, London.

303-Cole, Alan S.-Catalogue of Antique Lace. Cork School of Art, 1884.

304 Cole, A. S.-Catalogue of Lace. 23 pp., 1899. Dublin Science and Art Museum. General Guide. pt. 4. 1908.

305-Cole, Alan S.-Catalogue of Special Loan Exhibition of Lace at the Midland Counties Fine Art Museum, 1878.

306-Cole, Alan S.-Copy of Report on the Honiton Lace Industry, etc. Vol. LXXX. Ordered by the House of Commons to be Printed, April 19, 1888. 307-Cole, Alan S.-Les dentelles anciennes, traduit par Ch. Haussonilier, 1878, Paris.

308-Cole, Alan S.-Irish Lace and Embroidery. Great Britain Science and Art Department, 45th Annual Report, 1897, pp. 93-104.

309-Cole, Alan S.-The Irish Lace Industry. Journal of the Society of Arts, March, 1889, London.

310-Cole, A. S.-Irish Lace-Making. Journal of the Society of Arts, V. 37, p. 317.

311-Cole, Alan S.-Irish Lace, Report upon visits to Convents, Classes and Schools, etc. London, 1887. 7 photos, 4 to.

312-Cole, Alan S.-Irish Papal Jubilee Lace. Magazine of Art, 1888, V. 11, pp. 200-204.

313-Cole, Alan S.--Irische Spitzen-translation. Plauen, C. Stoll. 30 plates. 314-Cole, Alan S.-Lace at the South Kensington Museum. The Magazine of Art, Sept. 1895, London. V. 18, p. 419.

315-Cole, Alan S.-Lace (Encyclopaedia Britannica). London, A. C. Black, 1902.

316-Cole, Alan S.-Lace-making in Ireland. The English Illustrated Magazine, June 1890, Londoll. V. 7, p. 655.

317-Cole, Alan S.-Lace-making in Treland. Art Workers' Quarterly, V. 3 (No. 9), pp. 4-7.

318-Cole, A. S.-Lace-Making. Journal of the Society of Arts, V. 29, pp. 769799.

319-Cole, Alan S.-Lace. The Magazine of Art, Sept. 1879, London. V. 2, p. 249.

320-Cole, Alan S.-Means for Verifying Ancient Embroideries and Laces (Cantor Lectures). Journal of the Society of Arts, July 1895, London. V. 43 , pp. $757,769,781$.

321-Cole, Alan S.--Needlework and Lace. Pattern Books XVIth Century. The Bibliographer, March, 1882, London.

322-Cole, Alan S.-A Renascence of the Irish Art of Lace Making. London, Chapman \& Hall, 1888. B. M.

323-Cole, Alan S.-Recent Developments in Devonshire Lace-making. Journal of the Soc. of Arts, April, 1904, Luondon. V. 49, p. 192.

324 -Cole, Alan S.-Recent Honiton Lace. Magazine of Art, 1892, V. 15, pp. 30-33. 
325 -Cole, Alan S.-Report by Mr. Alan Cole upon his visits to Irish Lace-making and Embroidery Schools, in 1897. London, 1897.

326-Cole, Alan S.-Report on Northampton Bucks and Beds Lace-making. November, 1891, London, Eyre \& Spottiswoode, 1892.

327 -Cole, A. S.-Report on the visits to convents, classes, etc., where lacemaking and designing for lace are taught . . . in Ireland. 8vo. (Lond.) 1885. S. K. M.

328-Cole, Alan S.-Report upon the "Exposition Rétrospective" of the "Union Centrale des Arts Décoratifs" exhibited in the "Palais de l'Industrie,' 1882. London, G. E. B. Eyre \& W. Spottiswoode, 1883.

329-Cole, Alan S.-Science and Art Museum, Leinster House, Dublin. Catalogue of Lace, with an Introduction by Alan S. Cole. Dublin, Alex. Thorn, 1878.

330-Cole, Alan S.-Some Recent Irish Laces. The Magazine of Art, April, 1891. London. V. 14, p. 211.

331-Cole, Alan S.-A Supplemental Descriptive Catalogue of Specimens of Lace Acquired for the South Kensington Museum Between 1880 and June, 1890. 46 pages, 14 plates. 1 portfolio. London, Eyre and Spottiswoode. 332-Cole, Alan S.-A Supplemental Descriptive Catalogue of Specimens of Lace acquired for the South Kensington Museum between June, 1890 and June, 1895. London, 1895, Eyre \& Spottiswoode. 48 pages. B. M.

333-Cole, Alan S.-Studies from the Museums. Hand-made Laces from the South Kensington Museum, London. R. Sutton \& Co., 1890. B. M.

334 Cole, Alan S.-Two Lectures on the Art of Lace-making. Dublin, Alex. Thorn Co., 1884. B. M.

335-Cole, Alan S.-A Word on the Outlook of Lace-making in Ireland. The Magazine of Art, April, 1888, London. V. 11, p. 202.

336-Cole, H. H.-Cat. of the objects of Indian Art in the South Kensington Museum. Tllus. (Embroidery, p. 216.) 8vo. London, 1874. S. K. M. 337-Coles, Fred R., of the Scottish Museum of Antiquities.-Two articles in The Reliquary for Jan. and April, 1899, on spindles and distaffs.

338-Collection de dentelles au musée des tissus de Lyon, La.-114 plates. Paris, 1909. En portefeuille.

339-Collection de Dentelles du Musée de Cluny à Paris. Plauen, Chr. Stoll, n.d.

340-Collezione Arrigoni, La. Emporium, 1902, Bergamo.

341-Collier, Louis C., at Nottingham-Dessin pour rideau de dentelle. Art appliqué 1re et 2 e année, Paris.

342-Colored Italian Patterns for Cross-stitch Work. 23 photographs. (Collection of Kursheedt Manufacturing Co., N. Y.)

343-Colored Lace. Review of Reviews, v. 21, pp. 732-733, June, 1900.

344 Comment discerner' les Styles enseignés par l'Tmage-La Dentelle. Transformations progressives, XVI et XVII siècles. Paris, Ed. Rouveyre, n.d. 345-Commission d'Enquète sur la Condition des Ouvrier's et sur le Travail des Femmes et des Enfants. Brussels, 1843.

346-Commission du Travail. Brussels, 1886 and 1887.

347-Condé, Mme. de-The art of making Valenciennes lace. London, $1844.8^{\circ}$. 
348-Contributions toward Bibliography. J. P. Briscoe \& S. J. Kirk, 1896.

349-Cook, C.-Making of Macramé Lace. Scribner's, V. 15, p. 844.

350-Cook, C.-Making of Macramé Lace. Living Age. V. 112, p. 541.

351-Cook, M. E.-History of Lace. Palliser's Dial. V. 33, p. 13.

352-Cork; School of Art-Cat. of coll. of antique lace, by A. S. Cole. 10 plates. 8vo. Cork, 1884. S. K. M.

353-Cornaro, C.-Revival of Burano Lace. Century. V. 1, p. 333.

354-Cornu, P.-Le Concours de dessins de la Dentelle de France. Art et Décoration, 1909 . V. 25, pp. 163-168.

355-Corona of Italian Lace Work. (Collection of Kursheedt Mfg. Co.)

356-Corte, Armenio.-Libro de Mostre di Ponti in Aere, Intitolato Corona de la Mostre. Opera nuoua et non piu veduta. Dedication Alla Magnifica et illustre Madonna Helena Barozza, honoratissima Consorte del Clariss. S. Antonio Zantani, Conte \& Caualiero . mio Signore . [with initial E]. mark of Vincenzo Valgrisi (Venice, 1548-73). Il fino del primo libro. $4^{\circ}$. Cuts. 16 leaves. V.\& A. M.

357-Corte, Armenio-Libro del Mostre di Ponti in aere, intitolato Corona de le Mostre. Opera Nuova et non piu veduta. Sans lieu ni date. In-4 oblong. Dédicace: Alla Magnifica et illvstre madonna Helena Barozza, honoratissima consorte del Clariss. S. Antonio Zantani Conte et Caualiero mio signore. La dédicace est signée: Armenio Corte. Page non cotée. Elle est blanche et au verso on voit la marque d'imprimeur bien connue: une lance tenue par deux mains et autour de laquelle sont enroulés un serpent et une branche de feuillage. Cette marque d'imprimeur paraît être celle de Valgrisius de Venise. On lit sur ce verso: Il fine del primo libro. Vente Benedetto Maglione, Paris, 1894, Vente Piot, 1891.

358-Cortyl, Eugène-La Dentelle à Bailleul. Bull. du Comité Flamand de France, 1903.

359-Costenoble, S. van-Kostclooze Nijverheidsschool voor het aanleeren der Mechelsche Kanterij. Malines, Steursbussers, n.d.

360-Cotillon-Vieilles dentelles. Journal des Dames et des Demoiselles. Jan. 16, 1899, Paris-Brissels.

361-Courteix, F.-Col, broderie, et dentellc. L'Ait décoratif, Dec., 1901, Paris. 362-Courteix, F.-Dentelles. Col. L'Art décoratif, 1903, Paris.

363-Courteix, F. et Prouvet-Dentelles.L'Art décoratif. Dec. 1901, Paris.

364-Courteix, Fernand-Dentelles. Art appliqué, 1re et 2e année, Paris.

365-Cousin, Jean-Le livre de lingerie, composé par maistre Dominique de Sera, Italien, enseignant le noble et gentil art de l'esguille, pour besongner en tous points: vtile et profitable à toutes dames et damoyselles, pour passer le temps et euiter oysiveté. Nouuellement augmenté et enrichi de plusieurs excelents \& diuers patrons, tant de point coupé, raiseau, que passement de l'invention de M. Tean Covsin, Peintre à Paris. A Paris, cliez Hierosme de Marnef \& la veufue de Guillaume Cauellat, au mont S. Hilaire à l'enseigne du Pelican, 1584, auec priuilège du Roy. Ce titre est inscrit dans le milieu de la page et tout autour sont disposées quatre gravures sur bois, dont la réunion forme cncadrement. Ces gravures sont rectangulaires et disposées, deux horizontalement en haut et en bas et 
deux verticalement à droite et à gauche. Dans celle qui est en haut, on remarque au milieu une tête cornue, et des deux côtés de cette tête, deux animaux fantastiques, tenant dans leurs bras une branche de feuillage. Dans celle qui est en bas, trois femmes travaillant; celle qui est au milieu de la composition, travaille à un métier de basse lisse. Celle de gauche a auprès d'elle un petit enfant, celle de droite s'occupe à un travail à l'aiguille. Les gravures verticales représentent à droite un homme coiffé d'une toque à plumes et tenant un métier devant lui, à gauche une femme travaillant à un métier à broder qu'elle tient sur ses genoux. Au verso de ce titre on lit: l'extrait du Privilège daté du sept septembre 1583. Les trois premiers feuillets du cahier $G$, d'un goût excellent, doivent seuls, ce nous semble, être du dessin de Jean Cousin. Pour s'en assurer d'une manière positive, il faudrait avoir vu l'édition antérieure de 1583 que cite d'après du Verdier, M. Brunet. (Manuel du Libraire, dernière édition, tome V, colonne 300.) La marque de Jérome de Marnef reproduite par Silvestre (Marques typographiques, $\mathrm{n}^{\circ} 812$ ) se voit sur le dernier feuillet de cet ouvrage, et s'il faut admettre comme le prétendent quelques auteurs que Jean Cousin donna le dessin de plusieurs marques de libraires, on pourrait compter au nombre de celles qu'il a inventées, celleci qui est en tout point digne d'une semblable attribution. Page non cotée. Le recto contient quatre bandes horizontales. Celle du haut renferme des oiseaux. Le verso contient deux dessins. Celui du bas présente les lettres I H S et M S E F. Aù bas de cette planche, dans l'exemplaire de le bibliothèque de l'Arsenal, qui a servi à la présente description, on lit à l'encre d'une écriture de l'époque le mot Fin. Ce qui tendrait à faire croire qu'il y a eu des éditions antérieures à celle-ci, comme semble du reste l'indiquer la phrase du titre: Nounellement augmenté et enrichi, ete. . . Dans le haut d'une page quadrillée, on voit à gauche, un exemple où par un trait continù à la plume, on indique la manière d'ébaucher un dessin à points comptés. A droite sur la même feuille la manière de terminer ce dessin, et de le mettre au net en noircissant chacun des carreaux par ou a passé le trait de plume. Verso, grande marque d'imprimeur que l'on peut lardiment attribuer à Jean Cousin, tant le style en est large et grandiose. Au centre de la composition, un cartouche ovale dans lequel on voit un pelican perché sur un tronc d'arbre. Son sang' s'échappe d'une blessure qu'il s'est faite à la poitrine avec son bec, et va nourrir trois de ses petits qui sont en bas à ses pieds. Deux grandes cariatides, une femme à droite, un satyre à gauche, s'appuient sur les côtés du cartouche et soutiennent d'un de leurs bras levé en l'air, un motif en rinceaux sur lequel sont assis deux petits enfants adossés. En bas deux autres enfants des deux côtés d'un cartouche, sur lequel se voit un mascaron. Seguin dans son livre sur la dentelle dit . . . notre grand peintre Jean Cousin a enrichi le recueil de l'Italien Dominique de Sera, publié à peu prés en 1584, de plusieurs planches de patrons de dentelles à l'aiguille de son invention. . . Nous ne pouvons, dit M. Duplessis dans le tome 9, du peintre graveur français (Continuation faite par lui de l'ouvrage de Robert Dumesnil) mettre au nombre des ouvrages 
composés entièrement par Jean Cousin, le volume suivant, dont M. de Montaiglon nous a revélé l'existence (Archives de l'art Français, documents, tome $V$, page 356 ) et que nous avons vu nous-même à la Bibliothèque de l'Arsenal.

366-Cox, Raymond-La Collection de Dentelles José Pasco. Revue de l'Art ancien et Moderne. V. 24, pp. 373-386, Paris, 1908.

367-Cox, Raymond-Les Dentelles précieuses. Revue de l'Art, 1903. V. 14, pp. 141-161.

368-Cox, Raymond-Le Musée Historique des Tissus de Lyons. Lyons, 1902. 369-Crane, Josepha-Broderie, dentelle. The Lady's Realm, July, 1898, London.

370-Crawford, E. W.-Original Hand-made Lace. Harper's Bazaar. V. 37, pp. 676-678, July, 1903.

371-Cronback, E.-Die österreichische Spitzenhausindustrie. 211 pp. 1907. Wiener staatswissenschaftliche Studien, Bd. 7, Hft. 1.

372-Curtis, E. A.-Needlework: Schedule III. exemplified and illustrated for teachers, and upper Standards in Schools. 30 Diagrams. 12mo. Lond., 1879. S. K. M.

373-Cushion Lace, How Invented. Sharpe. V. 40, p. 156.

374-Cushion Lace, How Invented. Eclectic Magazine. V. 52, p. 267.

375-Cushion Lace, How Invented. Godey. V. 63, p. 25.

376-Cushion Lace, How Invented. Chamber's Journal. V. 34, p. 332.

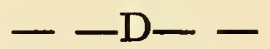

377-D., M. A. W.-Old Lace. Once a Week, March, 1865, London.

378-Daimeries, Mme.-La Dentelle en Belgique. Extr. Manuel sur le travail de la femme. Exposition de Chicago, 1893. Brussels, Impr. A. Lesigne, n. d.

379-Daimeries, Mme.-La Dentelle de Bruxelles. Extr. Annales de la Société d'archéologie de Bruxelles, 1892. Brussels, 1892.

380-D'Aleq-Album d'ouvrage de funtaisie des modes de saisons. Broderies Tapisseries, marqueterie de paille et de bois, Peinture sur bois et sur verre. Application Orientales, etc. 26 planches coloriés, réprésentant environ 200 objets différents avec 25 notices descriptives. En portefeuille in. $4^{\circ}$.

381-D'Aleq-Traité de la dentelle au Fuseau-Dentelles de Mirecourt, Valenciennes, Malines, Flandres, Bruxelles, Venise, dentelle cousue. Illustrée de 112 gravures sur bois.

382-Danieli, Bartolomeo-Fiore pretioso d'ogni virtue. Per le nobili et honeste donne con li disegni di recami sul velo la prima volta dati in luce $D a$ Bartolomeo Danielli In Siena, MDCX. $4^{\circ} .2$ pp., 11 engravings. Registro A, a, b, c. B. K. M.

383-Danieli, Bartlomeo-Libro di diversi disegni per Colari, Punti per Fazzoletti et Reticella di varie sorti fatto da Bartolomeo Danieli Recamatore. Sans date. In $4^{\circ}$ oblong. Ce titre est inscrit sur une coquille posée sur un culot de feuillage, entouré à droite et à gauche de deux rinceaux de feuillages entremêlé de branches de chêne garnies de leur's glands. En bas 
de la planche à la pointe à gauche: Agost ${ }^{\circ}$. Parisini Forma in Bologna. Gravures sur cuivre tirées au recto seulement et portant toutes en bas à la pointe soit à droite, soit au milieu de la planche, la signature: Bartolomeo Danieli F. Rien au verso. 23 planches de broderies. Les pages n'ont aucune cote. En résumé 24 feuillets dont 23 planches de broderies représentant des guipures et des modèles de dentelles. Vente Pirovano, Rome, 1901. Vente Destailleurs, 1895. Half bound. Ellis, London, 1918.

384 -Danieli, Bartolomeo-Libro di Diversi Disegni per Colari, Punti per fazzoletti, \& Reticelle di varie sorti. Fatto Bartolomeo Danieli Recamatore. Agost $^{\circ}$. Parisini forma in Bologna. [n.d.] $4^{\circ}$. Title and 22 plates, engraved. V.\& A. M.

385-Danieli, Bartholomeo--Danieli Bartholomeo Recamatore libro di diversi disegni per Collari, punti per Fazzoletti et Riticelle divarie sorte. .Agostino Parisini forma in Bologna. 15 leaves obl. 8vo, entirely engraved au burin, towards the end of the sixteenth century. Milan. Bib. Marquis Girolamo d'adda.

386-Danieli, Bartholomeo-Operetta d'intagliati lauori. In Bologna, August. Parisini et Gio. Batt. Negroponte forma, 1639.

387-Danieli, Bartholomeo-Vari disegni di Merletti inuentati é tagliati da Bartolomeo Danieli é dedicati all' Illma Sigra la sigra Barbera Rangona Mariscotta. Ce titre est au milieu d'un ovale entouré de rinceaux et de fleurs au haut duquel on voit des armoiries surmontées d'une icouronne. Le tout est entouré d'un trait car ré et de trois filets. Dans les encognures de ce rectangle oblong on voit de petits motifs rectangulaires formés également de rinceaux et de fleurs. Au bas de l'ovale central on lit: Agostino Parisini e. Gio. Battista Negroponte form. in Bologna, 1641. In-folio oblong, entièrement gravé sur cuivre. Dédicace, All. Illmio sig. Tomaso Cospi. Puis 5 lignes de texte finissant par les mots: e dedica Bartolomeo Danieli Bolognese. Cette dédicace est entourée d'un cadre rectangulaire en broderies, dont la bordure est découpée en dents de lambrequin. En haut au milieu de cet encadrement un écusson surmonté d'un casque avec rinceaux entourant l'écusson. En bas de la page à droite: In Bologna, 1639. Agont ${ }^{\circ}$. Parisini e. Gio. Batta Negroponte forma. Puis 12 planches de broderies inmprimêes seulement au recto et portant toutes au bas dans l'angle gauche: Bartolomeo Danieli F. Les ouvrages de dentelles de Danieli sont peu connus. Les dessins de cet artiste sont de la plus grande richesse. Les planches sont de grandes dimensions et ne mesurent pas moins de 30 cent. de large sur 19 de hauteur. Les 12 planches représentent 12 coins de mouchoirs ou de nappes en dentelles et guipures et 7 ornements divers. Vente Pirovano, Rome, 1901. Vente Destailleurs, 1895. 14 engravings. B. K. M.

388-Danish Embroidery. Delineator, V. 63, p. 473, March, 1904.

389-Davydoff, or Davindova. S.-La Dentelle Russe. Histoire, technique, statistique. Translated from the Russian under the author's direction. 80 plates, folio. Leipzig, Karl W. Hielsemann, 1895. B. M.

390-Davydoff or Davuidova, S. A.-Pycckoe Kypkebo. Yeopbi N. Ckoakn, pp. 7. pl. 50, 1909. Fol. \& $8^{\circ}$. 
391-Day, L. F. and Buckle, M.-Art in Needlework. Nation, V. 71, pp. 234-235, September 20, 1900.

392-Day, Lewis F. and Buckle, Mary-Art in Needlework. New York, Scribner's, 1908.

393-Dean, Samuel Bridge-The Anna Dike Scott Collection of Old Lace. Boston, April, 1905.

394-De-Chagrin, K.-Modeles pour la broderie au plumetis. 64 plates, 4to. St. Petersburg, 1890.

395-Decline in the Calais Lace Trade, The-Board of Trade Journal, May, 1893, London.

396-Dedekam, Hans-Norske folkebrodier. 50 plates, \$28.00. Albert Bonnier Publishing House.

397-De Greef, Guillaume-L'ouvriére dentelliére en Belgique. Brussels, 1870. 398-De Haerne, Mgr.-Discours pronon cé à la Chambre des Représentants, le 2 avril, 1884.

399-Dehowe, E.-Documents pour Broderies, Dentelles. St. Quentin, E. Dehowe, 1908.

400-Dengler, G.-Kirchenschmuch. Neue Folge. Sammlung von Vollagen fur kirchliche Stickerien, etc. (Text in German, French and English.) Obl. fol. Amberg, 1873. S. K. M.

401-Denicourt, Léon, at Caudry-Projets pour col et mouchoir en dentelle. Art appliqué. 2e année, Paris.

402-Denk-Denk's Kreuzstich-Monogramme. Obl. 8vo. Wien, (1885). S. K. M. 403-Dentelle aux fuseaux, La. Journal des Dames et des Demoiselles, March 1, 1900 , Brussels.

404-Dentelle, La.-Histoire, description, fabrication, bibliographie, ornée de cinquante planches photo-typographiques. Fac-simile de dentelles de toutes les époques; passements aux fuseaux, points coupés à l'aiguille, points de Venise, de Gènes, de France, guipures, Valenciennes, Malines, points d'Alençon, de Sedan, de Bruxelles, d' Angleterre, blondes, Chantilly, etc. Et de nombreuses gravures d'après les meilleurs maîtres des XVIe et XVIIe siécles. Paris, Rothschild, 1875. 4to.

405-Dentelle Irlandaise et des jour's à l'aiguille (point d'Alençon)—(woodeut illus. of materials, stitches, and designs.) 8vo. Paris, n.d. S. K. M.

406-Dentelle, La-(magazine). Paris.

407-Dentelle, La-Mustergultige Spitzen aus Deutschland, Frankreich und Italien vom 16 and 17. Jahrhundert. 500 Aufnahmen in Mappe. 80 Tafeln. From the catalogue of Karl W. Hiersemann, Leipzig.

408-Dentelle à la main et la loi Engerand, La-Musée Social, Feb., 1904, Paris. 409-Dentelles à l'aiguille et au fuseau en Points d'Angleterre et d'Irlande, exécutés dans les Couvente, etc., d'aprés les originaux conservés au South Kensington Museum à Londres. Paris, A. Calavas, 1892.

410-Dentelles anciennes de la ville de Genève. Album with 36 plates.

411-Dentelles anciennes, vieux Venice, guipures, Alenȩon, Malines, Argentan. Avec 52 figures sur 3 planches, folio. Paris, n.d. From the catalogue of Karl W. Hiersemann, Leipzig. 
412-Dentelles anciennes en genre venise en ce moment à Rome. 25 plates. Folio. Paris, 1891.

413-Dentelles de Belgique, Les-Album with 32 plates. Ch. Massin, Paris.

414 -Dentelle du Havre-Intermédiaire des Chercheurs et Curieux, 1896.

415-Dentelles du Musée de Cluny in Paris. 20 plates. Containing many examples of old and real hand-made laces. Patterns from the collection in the Musée de Cluny. Edinburgh, n.d., folio.

416-Dentelles du Musée Galliéra. I album with 36 plates.

417-Dentelles et Broderies-Le Marché alimentaire, Sept. 11, 1904, Brussels.

418-Dentelles et Guipures. 30 plates, P. Claesen, 1884. (Collection of Kursheedt Manufacturing Co., N. Y.)

419-Dentelle, La-Journal de la dentelle à la main. Mensuel. Paris, 1903-05.

420-Dentelles, Les-Journal des Demoiselles, 1843, Brussels.

421-Dentelle Renaissance, La-La Femme chez elle, Aug. 15, 1899, Paris.

422-Dentellières et Dentelles de Venise. Le Vie Heureuse, August, 1903, Paris.

423-Dentelliéres Malgaches. Le Matin, June 26, 1905, Paris.

424 De Ridder, M. R.-De I'enseignement professionnel dans ses rapports avec l'enseignement primaire en Belgiqne. Brussels, 1883.

425-Derode-Histoire de Lille, 1848.

426-Descriptive Catalogue of the Collections of Lace in the Victoria and Albert Museum, 1881.

427-Design Piracy-Co-operation needed for prevention, letter by Vivian Burnett, $N$. Y. Times, May 12, 8:7; letter from S. Lubarsky urges protection of lace designs, N. Y. Times, May 13, $10: 5$; European manufacturers guilty according to H. M. Heston, N. Y. Times, May 16, $14: 3$.

428-Designs-200 drawings for lace of various and elegant patterns. E. P. Dutton \& Co., New York.

429-Designs for Lace and Embroidery, in chalks and pencil. Bound in Volume. Fol. S. K. M.

430-Designs for Needlework. Craftsman, V. 13, pp. 226-228, November, 1907. 431-Designing in Cross-stitch. International Studio, V. 46, pp. 79-81, March, 1912.

432-Despierres, G.-Origine du poin d'Alençon. Alençon, 1882.

433-Desperres, Madme. G.-Histoire du Point d'Alençon depuis son origine jusqu 'à nos jours. (Plates and Vignettes.) 8vo. Paris, 1886, H. Laurens. S. K. M. B. M.

434 -Dessins Ornementaux dans les styles Louis XVI et Empire applicables à la peinture décorative et à l'ornementation des tissus. Nouvelles compositions par H. Frilling. Paris, n.d. One vol., folio, original boards in portfolio. 32 plates of textile ormamentation.

435-Destree-Tapisserie et Sculpture Bruxelloise à l'exposition d'art ancien à Bruxelles, organisée à Bruxelles, au cercle artistique et littéraire de Juillet à Octobre, 1905. Un volume in-folio de 95 pages de texte déscriptif avec figures de marques et monogrammes et 50 superbes planches en phototypie coloriée. Publié à 400 exemplaires.

436-Devonia-Honiton Lace-making. London, 1874. 8vo.

437-Devonshire, or Honiton Lace. 28 pp. London, 1889. 8vo. B. M. 
438-De Winne, Aug.-L'Industrie Dentelliére. Les Ouvrier's dentellier's. Le Peuple, May 8, 1903, Brussels.

439 -Dicks, Thos.-Is Real Lace a Luxury? The Home Woman, December, 1917, Toledo, Oliio.

440-Dictionnaire du Citoyen. Paris, 1761.

441-Didron, Ed.-Septième Exposition de l'Union centrale des Arts décoratifs, 1882. Rapport sur le 2e groupe: Tapisseries, Tissus, Broderies et Dentelles. Paris, A. Quantin, n.d.

442_-Dierolf, G.-La Dentelle française. A propos de l'Exposition du Musée Galliera. Le Gaulois, April, 1904. Paris.

443-Dietrich, Bernhard-Die Spitzenindustrie in Belgien und Frankreich zu Ende des XIXn Jahrhunderts.

444-Dietricl,, Frl. K.-Tauftuch in Leinenstickerei. Zeitschr. des Kunst-gew. -Vereins in München, 1883.

445-Dillmont, Th. de-Album de broderies au point de croix. Vol. 1, 32 plates; Vol. 2, 40 plates. P. Dollfus-Meig. (Collection of Kursheedt Manufacturing Co., N. Y.) 1886. S. K. M.

446-Dillmont, Thérèse de-Album de broderies au point de croix. 3 series, 1897, Mulhouse. Each series consists of text and plates in a portfolio. Soc. Anon. d'Industrie 'Textile.

447-Dillmont, Th. de-Album of Cross-stitch Embroidery. 52 plates. T. de Dillmont. (Collection of Kursheedt Manufacturing Co., N. Y.)

448-Dillmont, Thérèse de-Alplıabet de la brodeuse, lettres, chiffres, monogrammes et ornements à points comptés suivis d'une série de modèles avec calques pour broderie de blanc: 92 plates. Dornach, 1898, Soc. Anon. d'Industrie Textile.

449-Dillmont, Thérèse de-Alphabets et monogrammes, with supplement: 60 plates. Dornach, Pub. by Th. de Dillmont, 1897.

450-Dillmont, Thérèse de-L'ar't chrétien en Egypte. Motifs de broderie copte. 2 parts, 30 plates. Dormach, Pub. by Th. de Dillmont, 1897.

451-Dilmont, Thérèse de-La broderie Sur lacis. 2 series, 20 plates. Dornach, Pub. by Th. de Dillmont, 1897, (in two portfolios).

452-Dillmont, Thérèse de - La broderie au passé. 20 tracings in a portfolio. Dornach, Pub. by Th. de Dillmont, 1897.

453--Dillmont, Thérèse de-Le crochet. Dornach, 1897, Pub. by Th. de Dillmont.

454-Dillmont, Thérèse de-La DentelleRenaissance. Mullouse, Pub. by Th. de Dillmont, n.d.

455-Dillmont, Thérèse de-Eneyclopedia of Needlework. Mulhouse, 1907. New Edition. Pub. by Th. de Dillmont (D. M. C. Library).

456-Dillmont, 'Thérèse de-Encyclopedia of Needlework. Dornach, 1890, Pub. by Th. de Dillmont.

457-Dillmont, Thérèse de-Encyclopédie des ouvrages de dames. Paris, Ch. Delagrave, u.d.

458-Dillmont, Thérèse de-La Filet Richelien. Dornach, 1897, Pub. by Th. de Dillmont. 
459--Dillmont, Thérèse de-Filet Richelieu. Mulhouse, Pub. by Th. de Dillmont, n.d.

460-Dillmont, Th. de-20 plates of Cross-stitch Embroidery. Series 1 \& 2. (Collection of Kursheedt Manufacturing Co., New York.)

461-Dillmont, Th. de-Recueil d'ouvrages divers avec les fils et le coton, D.M.C. T. Dillmont. (Collection of Kursheedt Mfg. Co.)

462-Dilmont, Thérèse de-La soutache et son emploi. Mulhouse, Soc. Anon. d'Industrie Textile.

463-Dilmont, Thérèse de-Verlagen für Stickereien. (Bibliothek D.M.C. Dollfus-Meig \& Co.) Series 2-5. Mulhouse, 1900-1908.

464-D'Ivoy, P.-L'Art Industriel, la Dentelle. "L'Artiste," 6th Series, Vol. I., p. 66. 4to. Paris, 1857. S. K. M.

465-Documentary Post Cards-400 cards of the Museum of Decorative Art of Paris. Sloog, New York.

466-Documentary Post Cards-200 cards of lace specimens. Sloog, New York. 467-Document du Decorateur, Le-Receuil de Modeles pouvant être copiés ou interprétés. Peinture decorative, Tissus, etc. Paris, n.d. 3 vols., 2 folio, one 4to, original boards, in portfolio. 108 plates of drawings for craftsmen. Sloog, New York.

468-Documents et decorations moderne. Modèles de tissus. Tapis, étoffes de tentures, broderies, dentelles d'aprés les compositions de Bacard, Prenchais, Benedictus, etc. Un recueil in $4^{\circ}$ de 30 planches en couleurs.

469-Documents pour dessins de tissus. Series I, 19 plates, folio. Paris, 1894. Series G, 20 plates. Series M, 20 plates.

470-Dodd, A. B.-Royal School of Embroideries in Athens. Century, V. 72, pp. 120-126, May, 1906.

471-Dooley, W. H.-Knitting by Machinery. Textiles, 141-9.

472-Dooley, W. H.-Lace terms defined. Textiles, 150-7.

473-Douat, père Dominique-Méthode pour faire une infinité de desseins differens avec des carreaux, mi partis de deux couleur's par une ligne diagonale, ou observations du père Dominique Douat religieux, carme de la Province de Toulouse, sur un mémoire inséré dans l'histoire de l'academie Royale des sciences de Paris, l'année 1704, présenté par le Réverend père Sebastien Truchet, Religieux du même ordre, ancien Honoraire. A Paris chez Florentin de Laulne rue Saint Jacques, Claude Jombert rue Saint Jacques, André Cailleau à la place Sorbonne, MDCCXXII (1722). In- $4^{\circ}$. L'ouvrage va de la page 1 à la page 189 . Il se termine au recto de cette $189^{\circ}$ page au bas de laquelle on lit: De l'Imprimerie de Jacques Quillau, Rue Galande, 1722. Ce recueil contient des instructions à l'usage des architectes, peintres, brodeurs de tous ceux qui se servent de l'aiguille et autres. Bibliothèque de L'Arsenal.

474-Douglas, Mrs.- The Imperial Macramé Lace Book. Illustrations and Instructions: three series, 4to. London, (1879). S. K. M.

475-Doumert, A.-La Dentelle. Origines. Histoire. Lieux de production. Paris, Licène, Oudin et Cie. (1886). B. M.

476-Drahan, E.-K. K. Oesterr. Musem Stickmuster . . . mit Benützung der besten Vorbilder entworfen von E D. 8vo. Wien, 1873. S. K. M. 
477-Dreger, Dr. Moriz-Die Entwicklung der Spitze. Westermanns Illustrierte Deutsche Monatshefte, Novembre, 1901, Brunswick.

478-Dreger, Dr. Moritz-Entwicklungs-geschichte der Spitze mit besonderer Rücksicht auf die Spitzen-Sammlung des K. K. Oesterichischen Museum fur Kunst und Industrie in Wien. Wien, 1900. $8^{\circ}$.

479-Dreger, Moritz-Entwicklungs Geschicte der Spitze. V. 1-2, Vienna. A. Schroll \& Co., 1901. Contains some patterns from Pattern-book by "R. M."' published by Christoff Froschower.

480-Dreger, Dr. Moriz-Kunstlerische Entwickelung der Weberei und Stickerei. Vienna, K. K. Hof und Staatsdruckerei, 1904.

481-Dreger, Moriz-Ornamentale und Kunstgewerbliche Sammelinappe. Serie IX, Die Wiener Spitzenausstellung, 1906, in zwei tielen.

482-Dreger, Moriz-Die Spitzenausstellung in Östreichischer Museum. Kunst und Kunsthandwerk, 1906 . V. 9, pp. 366-426.

483-Dreger, Dr. Moriz-Die Textilausstellung des Leipziger Kunstgewerbemuseums. Kunst und Kunsthandwerk, Vienna, 1902.

484-Dreger, Moriz-Überblick über die Entwicklungsgeschichte der Spitze.

485-Dreger-Die Wiener Spitzenausstellung 1906. Exposition de Dentelles à Vienne en 1906 publié par le Musée Royal Autrichien d'art et d'industrie de Vienne. Deux volumes de 60 photographies donnant 206 reproductions documentaires de Dentelles avec texte descriptif et coup d'oeil sur l'évolution historique de la dentelle en 28 pages de texte et 45 reproductions.

486-Dryden, Miss-Article in Pall Mall Magazine, March, 1890.

487-Dryden, Miss Alice-Les Dentelles de Honiton. Revue des Revues. December, 1897, Paris.

488-Dryden, Alice-Flemish Lace. Pall Mall Magazine, V. 23, p. 91.

489-Dryden, Miss Alice-Honiton Lace.

490-Dryden, Alice-Honiton Lace, History of its Manufacture. Pall Mall Magazine, V. 11, p. 492.

491--Dryden, Miss Alice-The Lace of Flanders. Pall Mall Magazine, January, 1901, London.

492-Dryden, Miss Alice-Pillow Lace in the Midlands. Pall Mall Magazine, March, 1896, London.

493-Dublin Exhib, 1865-Illus. Cat. of the Dublin International Exhib. of 1865. Class 19 b. Lace and Embroidery. 8vo. Dublin, 1866. S. K. M.

494 -Dublin Exhibition, 1853-Irish industrial exhibition of 1853; Detailed Cat. of its contents, etc. Class 18. Lace and embroidery. 8vo. Dublin, 1854. S. K. M.

495-Dubochet, Léon-Dentelles et Dentellières. Le Siècle, Feb. 23, 1903, Paris. 496-Dubois-Variarum protractionum quas vulgo Maurusias vocant omnium anteliac excusarum libellus longe copiasissimus pictoribus, aurifabris, polymilariis, barbaricariis variisque id genus artificibus etiam acu operantibus utilissimus nuneque primen in lucem editus anno 1554. Balthazar Sylvius (Dubois) fecit. Jo. Theodoret, Jo. Israel de Bry excud. In 4to, ff. 23, copperplate. Paris, Bib. Nat. Milan, Bib. Belgiosa and Marquis d'Adda. 
497-Du Bois, Mrs. E. E.-Lace. Hours at Home, V. 3, pp. 226, 311.

498-Duchêne, Mlle. V. H.-Projet de chemin de table en dentelle. Art appliqué. 1re année. Nappe en dentelle. Art appliqué, 2e année, Paris. 499-Ducpètiaux-Mémoirs sur le pauperisme dans les Flandres. (Extrait du Bulletin de la Commission dentrale de statistique.)

500-Duguet, Camille-Femmes et dentelles. La Dentelle, 1904, Paris.

501-Duhayon-Rapport sur les Dentelles, Tulles, Broderies, et Passementeries. (Paris, Exposition Universelle de 1878.) Paris, 1880, 8vo.

502-Duplessis, G.-Articles in Revue des Arts Décoratifs, Feb. \& Mar., 1887. 503-Dupont-Auberville-Art Industriel. L'Ornement des Tissus. Recueil historique et pratique. Paris, Ducher et Cie, 1877, (Collection of Kursheedt Manufacturing Co., N. Y.)

504 -Dupont-Auberville-La Dentelle, XV et XVI siècles. Rouveyre. (Collection of Kursheedt Manufacturing Co., N. Y.) -Durand-See Armand-Durand.

505-Durer, Albert-Dessins de Broderies sur fond noir. in-40. Quatre pièces. (Bartch 140-141-142-143.)

506-Dussen, B. van der-L'Industrie Dentellière Belge. Brussels, 1860.

507-Dussen, Banoit van der-L'Industrie dentellière belge. Brussels, 1868.

508-Duval, Louis-Documents pour servir à l'Histoire de la Fabrication du Point d'Alençon. Extr. Bulletin Socièté historique et achéologique de l'Orne. Alençon, September, 1882.

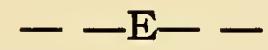

509-Earle, A. M.-Samplers. Century, V. 83, pp. 676-685, March, 1912.

510-Ebhardt, Franz-Book of Hardanger Work. 2d edition. (Collection of Kursheedt Manufacturing Co., N. Y.)

511-Echte Spitzen-oestereich. Paramente. (Collection of Kursheedt Manufacturing Co., N. Y.)

512-E'École de dentelles à Burano. V Venice, Kirchmayer et Scozzi.

513-Écoles dentellières en Autriche. Varia. Centralblatt für das Gewerbl. Unterrichtswesen in Österreich, XXI, Vienna, Alf. Hölder, 1903.

514-Edmonds, Kate Leila-Pillow Lace. The Lady's Realm, June, 1902, London.

515-Edson, Myra Burr-Devonshire Lace. The Art World, Dec., 1917, New York.

516-Egenolff, Chr.-Modelbüch aller Art Nehewercks und Stickens etc. 1527.

517-Egenolff, C.-Modelbuch, aller art Nehewercks und Stickens. Mit ettlichen newen künstlichen vormals verhaltenen Stucken und Stahelen. Als Venedigische Stern Und Gewirck. Uffder Laden Und nach der Zal. Die Welisch weiss Arbeit. Glattstich Creutzstich Stickwerck etc. Franckenfort a. M. Christ. Egenolff. 1533. $4^{\circ}$. 71 cuts. D. K. S.

518-Egenolff, C.-MOdelbůch, Nehwens, Stickens, vnd Wirckens. Getruckt zu Franckfort, Bei Christian Egenolffs Erben. $4^{\circ}$. 32 cuts. B. K. M.

519-Egenolffs, C.-Modelbüch, von erhabener unnd flacher Arbait, Auff der Ramen, Laden, und nach der Zale. Getruckt zu Franckfort, Bei Chris- 
tian Egenolffs, Erben. The date, 1537, occurs on one of the patterns. 4to. 32 leaves. 178 patterns. 62 gravures sur bois. Frankfort, 1537. 520-Egenolff, Chr._Modelbuch Welcher Ober vñ Niderlandischer Arbait. Franckfurt. Chr. Egenolff. $4^{\circ}$. 28 cuts. Sigs. A-G4. B. K. M.

521-Egenolff, C.-Modelbuch, aller art Nehwens vnd Stickens. Mit etlichen newen, Künstlichen, vormals verhaltenen Stucken vnd Stahlen, Als: Venedigsche Stern vnd Gewirck. Auf der Laden, vnd nach der Zal. Die Welsch, Weiss Arbeyt. Glattstich, Creutzstich, Stickwerck . . . Getruckt zu Franckfort, Bei Christian Egenolffs seligen Erben. $4^{\circ}$. 32 cuts. B. K. M.

-Egenolffs, Chr.-See Kunstgewerbe Museum zu Leipzig.

522-Egenolff, Chr.-Modelbveh aller art Nehwens vnnd stickens. Mit etlichen newen künstlichen vormals verhaltenen stücken, vnd staheln Als: Venedische stern vnnd Gewirck. Auff der laden vnd nach der Zal. Die Welsch, Weisz arbeit. Glattstich, Creutzstich, stickwerck . . . \& Franckfürt Bey. Christ Egenol. Erben, 1593. In- $4^{\circ}$ gothique. Le titre rouge et noir est orné d'un très joli bois représentant une assemblée de dames travaillant dans un jardin. En bas dans un encadrement formé par un trait carré, une femme travaillant à un métıer de haute lisse. Au milieu deux autres femmes regardant un homme debout qui s'adresse à elles. Au fond à droite une vieille femme filant une quenouille. Au verso du $4 \mathrm{e}$ feuillet du cahier H, un cœur percé et entouré des deux mains et des deux pieds de Notre-Seigneur pereés également. Au-dessous 2 fleurons et le millésime MDXCIII. Très joli livre, charmants motifs, pris à droite et à gauche dans différents ouvrages. Entrelacs, tapisseries, fleurons, alphabets, etc.

523-Einführung der Spitzen-Industrie in Wien. Mittheil. des K. K. oesterr. Museums für Kunst und Industrie, September, 1897, Vienna.

524 -Eitelberger, R. von-Original-Stickmuster der Renaissance in getruen Copien vervielfaltigt, ete. (Reproductions of $50 \mathrm{pp}$. of designs of lace and needlework, from original specimens in the Vienna Mus.) 4to. Wien, 1874. S. K. M.

525-E., K. A.-The Creeve Knitting Card. Kingstown, 1895. In British Museum.

526-Éléments d'enquète sur le rôle de la femme dans l'Industrie en Belgique. Brussels, A. Lesigne (1893).

527-Ellerbe, R. L.-Fostering Lace-making in Russia. Craftsman, V. 21, pp. 214-217, November, 1911.

528-Embroidery and Lace. The Saturday Review, Sept. 8, 1888, London.

529-Emden, Frieda van-The Old-Fashioned Sampler. The Art World, Dec., 1917, New York.

Encyclopaedias:-

530-Encyclopaedia Britannica ("Embroidery," Tol. TIII.; "Lace," Vol. XIV.) 9th edit. 4to. Edinburgh, 1875, et seq. S. K. M.

531- The English Cyclopaedia. ("Lace," Arts and Sciences, Tol. V.) 23 vols. 4to. Lond., 1854-62. S. K. M.

532- The Penny Cyclopaedia. ("Lace," Vol. XIII.) 29 vols. Lond., 1833-58. S. K. M. 
533- The Popular ("Embroidery," Vol. V., p. 151. "Lace," VIII., p. 598.) 14 vols. 8vo. Lond., 1874-76. S. K. M.

534 Encyclopedie; ou Dictionnaire raisonné des Sciences, etc. ("Dentelle," Vol. IV.) fol. Paris, 1751-80. S. K. M.

535-Engerand, Fernand-La Dentelle au Musée Galliera. Revue de l'Art Ancien et Moderne, V. 15, pp. 351-362.

536-Engerand, Fernand-La dentelle aux fuseaux en Normandie. (Musée social, May, 1901.)

537-Engerand, Fernand-La Dentelle de France. Le Correspondant, April 25, 1904, Paris.

538-Engerand, Fernand-L'Industrie de la Dentelle en Normandie. Revue des deux Mondes, April 1, 1900, Paris.

539-Engerand, Fernand-Proposition de loi. Pour la Dentelle. L'Ami de l'Oron, 1903-1905, Caen.

540-Engerand, Fernand-Proposition de loi relative à l'apprentissage de la dentelle à la main. Exposé des motifs, Jan. 28, 1903.

541-English Lace for New York-Vogue, April, 1917, New York.

542-Enquète sur la condition des class es ouvrières. Brussels, 1846.

543-Erculei, R.-Roma, Esposizione del 1887. Tessuti e Merletti. Catalogo, con brevi cenni sull' arte tessile in Italia. Roma, 1887, 8vo.

544-Errera, Madame Isabelle-Collection d'étoffes anciennes reunies et décrites. Catalogue orné de 420 photogravures exécutées d'après les clichés de l'auteur. Un volume In-80 carré de 200 planches de texte. Ouvrage très documenté donnant la déscription générale de cette importante collection léguée par l'Auteur aux Musées des Arts décoratifs du Cinquantenaire à Bruxelles.

545-Erwin, F. A.-Lace Workers of the Italian Quarter of New York. Craftsman, V. 12, pp. 404-409, July, 1907.

546-Esemplare che insegna alle donne el modo di cucire. Venetia, 1543. Quoted in Cat. Cappi of Bologna, 1829.

547-Experton (R.) — L'Tmpôt des Patentes et la fabrication de dentelles du Puy, 1861.

548-Exposé décennal de la situation du Royaume. Brussels, 1851, 1860, 1863.

549-Exposition de l'Union Centrale desArts décoratifs 1906. Les grandes collections de dentelles anciennes et modernes exposées au Pavillon de Marsan. 48 planches. Paris (1906).

550-Exposition des Dentelles, Rome, 1887. Catalogue des reproductions. 16 pp. Roma, 1887. 8vo. B. M.

551-Eyelet Embroidery and à Jour Work. Delineator, V. 64, pp. 262-263, August, 1904.

552-Eze, G.d'-Dentelle aux fuseaux. Journal des Dames et des Demoiselles, Jan. 16, 1900, Brussels.

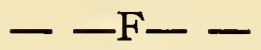

553-F., A.-Ein new modelbuch auff auzsnehen vnd porten wircken in der laden vnnd langengestell Gemert rnd gepessert mit 105. andern Modeln. Im iar. MDXXVij. (1527.) Petit in-4 $4^{\circ}$ Ce titre est dans un cadre 
rectangulaire formé par un trait carré, au haut d'une arcade à cintre surbaissé reposant sur deux colonnes, aux fûts desquels sont accrochés un écusson. En bas deux femmes de profil à gauche, travaillant chacune à un métier. 24 feuillets signés: A. F. Cet exemplaire 1527, ne paraît pas complet.

554 -F., A.-En newe Kunstlich Mœtdelboch alle Kunster zo branchen für snyczeller, Wapensticker, perten sticker, etc. Vnnd ouch fur sonferen vnd Frauwe nstlich vff. das neuwes gefonde, allen den gene di vpff Kunste verstat habe. Gedruckt zu Collen durch Peter Quentel im Dair MIXXIX. (1529). Petit in $-4^{\circ}$. Le volume est composé de 24 feuillets signés: A. F. entièrement remplis par des dessins de broderies, sauf le titre qui est au recto du premier feuillet et un portrait de Charles V, au verso de ce même feuillet. La dernière page comprend au recto un alphabet et au verso les armes de la ville de Cologne avec les mots: O Felix Coloniae. Vente Libre à Londres en 1862.

555-Fabrication du Tulle dans le Luxembourg, De la-Institut archéologique du Luxembourg. Annales, 1902.

556-Fage, René-Une boutique de marchand à Tulle au XVIIe siècle. Tulle, Crauffon, 1886.

557-Fage, René-Le Point de Tulle. Bull. Soc. Lettres. Sciences et Arts de la Corrèze. 1882, Tulle.

558-Faggotting Stitches used in Embroidery. Delineator, V. 64, pp. 780-781, November, 1904.

559-Falke, J.-Fransen und Quasten. Eine Passementerie-Studie "Blätter für Kunstgewerbe," Vol. IV., p. 1. 4to. Wien. 1875. S. K. M.

560-Falke, J.-Geschichtlicher Gang der Stickerei bis zu ihrem Verfall im Aufange des 16. Jahrhunderts. "Lützow, Zeitschrift für bildende Kunst," Vol. IV., pp. 233, 273. 4to. Leipzig, 1869. S. K. M.

561-Farcy, L. de-Broderies et tissus, conservés autrefois à la cathédrale d'Angers. "Revue de l'art chrétien." Vols. XXXIV., p. 270; XXXV., pp. 168, 299. 4to. Paris, 1884-5. S. K. M.

562-Farcy, L. de-La Mitre et la Chape. Brodées par M. L. Grosse, de Bruges. "Revue de l'Art chretien," vol. XXXV., p. 198. 4to, Paris, 1885. S. K. M.

563-Faure et Rapp-Compositionen für Spitzen in modernem Geschmack. Plauen, Chr. Stoll, n.d.

564-Fawcett, W.-Trish Lace-Making. The Independent, V. 74, pp. 158-159, Jan. 16, 1913.

565-Fédération Archéologique et Historique de Belgique. Congrés d'Enghein, 1898.

566-Fédération Archéologique et Historique de Belgique. Congrés de Bruges, 1902.

567-Félix Aubert-(Tapis, Dentelles etc.) L'Art décoratif, January, 1899, Paris.

568-Felkin, William-History of Machine-Wrought Hosiery and Lace Manufactures. London, 1867. 8vo. 
569-Felkin, W.-Hosiery and Lace (in "British Manufacturing Industries," edit. by G. P. Bevan). 16 mo. Lond., 1876. S. K. M.

570-Felkin, W.-Machine Wrought Lace, History of Trade in. Journal of Society of Arts, V. 4, p. 475.

571-Ferguson fils, S.-Les Dentelles aux fuseaux et les Dentelles mécaniques à l'Exposition de Londres de 1862. Amiens, T. Jeunet, 1863.

572-Ferrari-Origines de la dentelle de Venise et l'école de Burano. Venice, 1907.

573-Fartiault, François de-Histoire de la dentelle. Paris, 1843. 12 mo.

574-Few Remarks about Lace and Pattern Books, A. The Connoisseur, April, 1902, London.

575-Field, M. A.-Australian Lace-Crochet. 107 pp. Simpkin \& Marshall, 1909. $4^{\circ}$. B. M.

576-Figure Laces of Exquisite Type. The Upholsterer, New York, 1916. V. 64 , No. 4, pp. 72-74.

577-Fillebrown, Mrs. R. H. M.-Quaint Cross-stitch in New Patterns. Woman's Home Companion, V. 40, pp. 50-51, October, 1913.

578-Finch, L.-Sermon in Patchwork. Outlook, V. 108, pp. 493-495, Oct. 28, 1914.

-Finkel, Ostr.-See Boehn, Max von. No. 130.

579-Fiori di Ricami, nvova mente posti in luce, ne i quali sono varii, et diversi Disegni di lavori, Come merli, Bauari, Manichetti et altre sorte di opere che al presente sono in vsu, utilissimo ad ogni stato di donna. Bologne, 1591. 20 feuillets et 18 planches.

580-Firth, J. B.-Nottingham Lace and Fashion. The Economic Journal, December, 1893, London. V. 3, p. 709.

581-Fischbach, F.-Album für Stickerei. (Colored illus.) 4to. Wien, 1870. S. K. M.

582-Fischbach, Friedrich-Lace Album. London, 1884.

583-Fischbach, F.--Neue Muster für Stickerei und Haekel-Arbeiten von F. F. in Hanau. 16mo. Hanau, 1881. S. K. M.

584 -Fischer, Hugo-Technologische Studien im Sächsischen Erzgebirge. Leipzig, 1878. (Diagrams of lace stitches and patterns.)

585-Fischer, H.-Zur Technologie der Handspitzen. Der Civilingenieur, 1878, Leipzig.

586-Fleurs batiste. 65 photographs. P. Calavas. (Collection of Kursheedt Manufacturing Co., N. Y.)

587-Florimi, Mattheo-Fiori di Ricami nvovamente posti in lvee, ne i quali sono varii et diversi disegni di lavori, Come merli, Bauari, Manichetti, et altre sorte di opere che al presente sono in vsu utilissimo ad ogni stato di donne. In Fiorenza ad instanza di Mattheo Florimi. 1596. Petit in $4^{\circ}$ oblong. Vente Yemenitz. 24 plates and 2 leaves of text. Bibliothèque Nationale.

588-Florimi, Matteo-Fiori di Ricami nvovamente posti in luce. Ne i quali sono varii, et diversi disegni di lavori. Come Merli, Bauari, Manichetti, $\&$ altre sorte diopere, che al presente sono in vso, vtilissimi ad ogni stato 
di Domne. In Siena, Appresso Matteo Florimi, 1603. 4to. obl. 24 plates representiug lace. Collection Count Manzoni, Turin.

589-Florimi, Mattheo-Fiori di Ricami nuouamente posti in luce. Ne i quali sono varie et diversi disegni di lavori. Come merli, Bavari, Manichetti, et altre sorte di opere, che al presente sono in usu utilissimo ad ogni stato di Domne. In Siena, appresso Matteo Florimi. 1604. In-4ºblong. Ce titre est renfermé dans une petite bordure de nielles gravés sur bois. Rien au verso. Page non cotée. Dédicace, Alle gentillissime et virtuosissime Donne. Matteo Florimi. Rien au verso. Puis commencent les broderies. 18 pages, contenant des broderies, guipures ou dentelles. En résumé 20 feuillets dont 18 de planches de broderies. Vente Destailleurs.

590-Florimi, Mattheo-Gioiello della Corona per le nobili e virtvose Donne, Nel quale si dimostra altri nuovi bellissimi dissegni de tutte le sorte di mostre di Punti in aria, Punti tagliati et Punti a Reticello; Cosi per Freggi, come per Merli et Rosette che con l'aco si usano hoggidi per tutta Europa. Et molte delle quali mostre possono servire ancora per opere a Mazette. Novamente posto in luce con molte bellissime inventioni non mai piu usate, ne vedute. In Perugia apresso Pietro Paolo Orlando, 1594. Ad instantia di Matteo Florimi. In $-4^{\circ}$ oblong. Ce titre est renfermé dans une petite bordure de nielles gravés sur bois. Dédicace alla virtuosissima et ingegniosissima Donne Matteo Florimi. 37 pages contenant des broderies, des guipures ou dentelles au recto des pages. Ces planches sont pour la plupart tirées de la Corona de Vecellio, surtout des $3 e$ et $4 \mathrm{e}$ parties. On trouve même parmi ces modèles l'emblème du Renard et de la beauté, et la figure de Vesta. En résumé, 39 feuillets dont 37 de broderies. Vente Destailleurs, 1895. Une édition de 1596. Vente Pirovano, Rome, 1901.

591-Florini, M._Gioiello della Corona per le nobili, e virtuose donne. Nel quale si dimostra altri nuoui bellissimi dissegui di tutte le sorte di mostre di Punti in Aria, Punti tagliati, \& Punti à Reticello, cosi per Fregi, come per Merli, \& Rosette, che con l'Aco si vsano hoggidi per tutta Europa. Et molte delle quali mostre possono seruire ancora per Opere a Mazzette, Nouamente posto in luce con molte bellissime inuentioni non mai piu vsare, ne vedute. In Fiorenza, Appresso Francesco Tosi. MDXCVI. Ad instantia di Matteo Florini. $4^{\circ}$. Title, dedication, 30 leaves, cuts. V.\& A. M.

592_Florimi, Matteo-Gioiello della corona per le nobili é virtvose donne, Nel quale si dimostra altri nuovi bellissimi dessigni di tutte le sorte di Mostre di Punti in aria, Punti tagliati, et Punti a reticello, cosi per Fregi come per Merli et Rosette, che con l'aco si usano hoggidi per tutta l'Europa. Et molte delle quali mostre possono servire ancora per opere a Mazzette. Nuovamente posto in luce con molte bellissime inventioni non mai piu usate ne vedute. In Siena appresso Matteo Florimi, MDCIII (1603). In$4^{\circ}$ oblong. 48 planches gravées sur bois. 2ff. titre et dédicace. Dans la préface on parle d'éditions antérieures données par le même éditeur et on y trouve le passage survant: Non vi dovete maravigliare sio di nuovo mando fuori altre foggie di lavori . . . di numero et di vaghezza 
superiore a quelle che da me furone raceolte l'anno passato . . . Il y aurait done eu de cet ouvrage une édition de Florimi en 1602. Brussels, Bib. Royale.

593-Florimi, Matteo-Gioiello della Corona per le nobili e virtuose Donne. Nel quale si Dimostra altri nuovi bellissimi dessigni di tutte le sorte di Mostre di Punti in aria, Punti tagliati et Punti a Reticello, Cosi per Freggi come per Merli et Rosette, che con l'aco si usano hoggidi per tutta Europa. Et molte delle quali Mostre possona servire ancora per opere à Mazette. Nuovamente posto in luce con molte bellissime inventioni non mai piu usate, ne vedute. In Siena appresso Matteo Florimi, MDCIIII (1604). In-8 oblong. Ce titre est enfermé dans une petite gravure de nielles formant bordure. Dédicace: Alle virtuosissime et ingeniosissime Donne Matteo Florimi. 32 pages, contenant des broderies, guipures ou dentelles, imprimées seulement au recto des pages. Ces planches sont pour la plupart tirées de la Corona de Vecellio mais sont différentes de celles contenues dans le volume de ce même ouvrage et paru à Pérouse en 1594. En résumé 34 feuillets dont 32 de broderies. Vente Destailleur's.

594-Florimi, Matteo-Gioiello Della Corona Per le Nobili, E Virtuose Donne . . tagliati, \& Punti à Reticello, cosi per Fregi, come per Merli, \& Rosette, che con l'Aco si vsaro hoggidi per tutta Europa. Et molte delle quali Mostre possono seruire. Ancona per opere à Mazzette. Nouamente poste in luce con molte bellissime inuentioni non mai piu vsate, ne vedute. In Siena, Appresso Matto Florini. MDCIIII. $4^{\circ}$. Title, 1 p., 23 cuts. B. K. M.

595-Florio-A Worlde of Wordes. 1598.

596-Florio and Torreano-Dictionary. London, 1654 and 1659.

597-Foillet, Jacques-Nouveaux pourtraits de point coupé et dentelles en petite, moyenne et grande forme. Nouvelement inventez et mis en Lumiere. Imprimé à Montbeliard par Jacques Foillet, 1598, petit in- $4^{\circ}$, figure sur bois. Il se compose de 4 feuillets préliminaires (dont un blanc) pour le titre, un avertisement aux dames et demoiselles de 3 pages; et une Exhortation aux jeunes filles en vers. Ensuite viennent 84 feuillets signes B.-Y. par 4 (le dernier blane contenant chacun une planche de dentelle) Guilmard ne signale que 82 feuillets contenant 78 planches.

598-Foillet, Jaques-Nouveaux pourctraicts de point coupé et dantelles en petite moyenne et grande forme nouvellement inventez \& mis en lumiere Imprimé à Montbeliard par Jacques Foillet cloloxciix (1598). Small 4to, 82 ff., 78 plates. Frontispiece with borders composed of squares of point coupé. "Avertissement aux dames," of three pag'es, stating these works are all composed of "point devant l'esguille, de point en toille, en bouclages, \& de cordonnages." The writer gives patterns of roses of all sizes, "very little, middling, large, and very large," with from one to nine pertuis, or openings, holes. Also Carreaux in different forms, and lastly dantelles. 40 patterns of "roses," of point coupé. And 18 of "Carreaux," variously disposed. Then follow 20 patterns of lace, of "bien petites, moyennes, \& grosses," all "au point devant l'Esguille." At the end: "La fin courone l'œuvre." 'This is the earliest pattern-book in 
which the word "dantelle" occurs. Bib. Nat., Bib. de l'Arsenal, Bib. Ste. Geneviève.

599-Foillet, Jaques-Novveaux Povrtraicts de point covpé et dantelles en petite, moyenne et grande forme. Nouuellement inuentez et mis en lumière. Imprimé a Montbeliard Par Iaques Foillet, CIDIDXCIIX (1598). Au-dessous des mots, mis en luminère, dans le titre, on voit un mascaron à tête humaine dont les moustaches s'enroulent dans l'écusson qui renferme ce mascaron. Le titre est au centre d'un encadrement rectangulaire composé de petits carrés de guipure placés les uns à côté des autres. Rien au verso du titre. Aij, au recto de cette page: Avertissement aux dames et damoiselles. Au verso, suite de l'avertissement. Aiij, fin de l'avertissement. Au verso, pièce de vers intitulée: Exhortation aux ieunes filles, et finissant par les mots: Car la vertu est la vraye noblesse. La dernière planche n'est pas cotée. Elle porte en bas: La fin corone l'œuvre. En résumé 87 feuillets dont un titre et 83 planches de broderies. Vente $\mathrm{Ye}$ menitz, $\mathrm{n}^{\circ} 1105 \mathrm{du}$ catalogue, vendu 390 francs. Suivant le marquis d'Adda il y aurait de ce livre une réimpression en 1602 et 1622, même format, même nombre de feuillets et de planches. Il cite également une édition, où se trouveraient en tête les trois parties de l'ouvrage du Vinciolo. Les nouveaux pourtraicts imprimés à Montbeliard en 1598, c'està-dire le livre dont nous venons de donner la description en serait la quatrième partie qui semblerait être imprimée ici pour la première fois, Le catalogue d'une vente publique qui a eu lieu à Anvers le 29 mars 1864, sous le numéro 528, cite un bel exemplaire de ces quatre parties, Paris 1598, Montbelliard, Foillet, même date, reliées dans un seul volume et offrant ainsi tout ce que le Vinciolo a publié à différentes reprises. Vente Bancel, mai 1882, catalogue $\mathrm{n}^{\circ}$ 208, vendu 1.300 francs. Vente Foulc, June, 1914, No. 76, 3,650 francs. Bibliothèque Nationale.

600-Foillett, Jaques-New Modelbuch darinnen allerley ausgeschnittene Arbeit, in kleiner, mittelmässiger und grosser form erst neulich erfunden. Allen tugenden Frawen vnnd Jungfrawen sehr nutzlich. Gedruckt zu Mumpelgarten durch Jacob Foillet, 1598. Sm. 4to. (Woodeut patterns for lace.) Cited by Cav. Merli, in his Origine delle Trine. Cat. Evans, Strand. V. \& A. M.

601-Foillet, Jaques-New Modelbvch Darinnen allerley aussgeschnittene arbeit in Kleiner mittel massiger vnd grosserform, erst newlich, erfunden. Allen Tugendsammen Frawen vnnd Jungfrawen, sehr nutzlich. Gedruckt zu Basel, Mümpelgarten. In verlegung Ludwig Konigs, MDCI (1601). 3 ff. 1 folio blanc et 84 planches. Titre encadré, imprimé en rouge et noir. Les 2 feuillets qui suivent le titre, contiennent une épître allemande de Jacques Foillet à Sybylle, duchesse de Wurtemberg et de Teck, comtesse de Montbeliard, (épitre datée du 4 janvier 1598). Cet ouvrage est une édition allemande du livre de broderies que Jacques Foillet publia d'abord en français sous le titre Nouveaux pourtraicts de pont coupé ... \&. Catalogue Bancel. Bibliothèque du Baron James de Rothschild.

602-Foillet, Jacques-Das Musterbuch des Jacques Foillet, 1598. Berlin, E. Wasmuth, 1891. B. M. 
603-Foilett de Montbeliard, J.-Nouveaux pourtraicts de point coupé et dentelles en petite, moyenne et grande forme, nouv. inv. et mis en lumière par J. Foillet (Montbeliard 1598). Facsimile-reproduction, Berlin, 1891. 82 pages, 78 plates of patterns.

604-Fontaine, Angèle, at Levallois-Per ret-Mouchoir. Art appliqué, 2e année, Paris.

605-Forbes, Mrs. A. S. C.-Lace-making by Indian Women. Out West. V. 16, p. 613.

606-Foresto, Iseppo-Lo Splendore delle virtuose giovani con varie mostre di fogliami e punti in aere. Venezia. Per Iseppo Foresto in calle dell' acqua a S. Zulian all' insegno del Pellegrino, 1558. 16 plates. Cat Cicognara.

607-Forkel, A.-Die Arten der Spitze in moderner Bearbeitung. Plauen, C. Stoll, 1908.

608-Forkel, Albert-Moderne Zierformen für 'Textil-Industrie. Plauen, Chr Stoll, n.d.

609-Forkel-Photographs of Laces. 16 plates. (Collection of Kursheedt Manufacturing Co., N. Y.)

610-Fortunato, A.-Le Pompe di Minerva, per le nobili e virtuose donne, che çon industriosa mano, di trattenersi dilettano in far Rezze, maglia quadra, punti in aria, punti tagliati, punti a reticello, cosi per fregio, come per merletti e rosette di varie sorti, si come oggidi con l'aco di lavorar usati

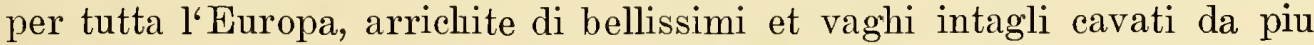
celebri autori di tal professione. In Pistoja, per Fier. A. Fortunato. In- $8^{\circ}$ oblong. Dédicace à : Catarina Giraldini in Cellesi, 20 augusto, 1642 . Cette description a été communiquée au marquis d'Adda, par le comte Manzoni qui a vu le livre à San-Marino, chez M. Parenti Bonelli.

611-Foster, Kate-Fifty Designs for Mexican Drawn-work. 1889.

612-Four Easter Crochet Ideas. Ladies Home Journal. V. 20, p. 48, April, 1903.

613-Fox, Catherine 'T. D.-The Woodward Collection of Old Lace. Reprinted from the Brooklyn Museum Quarterly, October, 1915.

614 -Fox, Edith Long-With the Devonshire Lace-makers. Cassell's Family Magazine, December, 1893, London.

615-Fozzi, P. P.-A book of models for point coupé and embroidery, published at Padua, October 1st, 1604, by Pietro Paolo Fozzi, "Romano." Musée de Cluny, Paris.

616-Fraipont-L'Art dans les travaux à l'aiguille un volume de 160 pages avec 39 dessins inédits de l'auteur et un album de 32 doubles planches en couleurs donnant les specimen de tissus de toutes les époques.

617-Franceschi Domenico de-Fede.-Opera nova intitolata La Fede. Dei Recami nella quale si contiene varie diverse sorte di mostre di punto scritto tagliato, in stuora, in Rede, opera non men necessaria che utile. In Venetia appresso Domenico de Franceschi in Frezzaria all. insegna della Regina. MDLXIIII. In- $4^{\circ}$. Riche encadrement au titre. Lucrèce instruisant ses femmes. Figures et paysage animé d'enfants et d'anges. On voit dans le présent titre le monogramme TvP ou TMP. 16 feuillets 
dont un titre gravé, 1 feuillet d'avant-propos, $A i j$, avec dessin au verso. 14 feuillets avec 29 planches au recto et au verso. Vente Santarelli. In 4to, ff. 16. In his Avis au Lecteur, Franceschi alludes to three other works he had published, styled La Regina, La Serena, and La Speranza. 618-Franceschi, Domenico de-Serena opera nova di recami, nella qvali si ritrova varie et diverse sorte di punti in stuora, et punti a filo et medesimamente di punto scritto et a fogliami et punto in stuora a scacchetti et alcuni groppi incordonati et rosete doue ogni virtuosa giouene facilissimamente fare ogni sorte di bellissimo lahoriero, opera non men vtile che necessaria. (Au-dessous de la gravure sur bois qui accompagne ce titre.) In Venetia appresso Domenico de Franceschi in Frezzaria all insegna della Regina MDLXIIII (1564). In-4ºblong. Au-dessous du titre, une marque d'imprimerie formé d'un cartouche de cuirs enroulés, au haut duquel on voit à droite et à gauche, un petit génie ailé. Au milieu de ce cartouche, un champ à 4 lobes, dans lequel on voit sur des nuages deux petits génies ailés, tenant des couronnes, élevées au-dessus de leurs têtes. Audessus d'eux on lit les mots Et animo et corpore. Au verso, une dédicace aux lecteurs, datée de Venise 12 octobre MDLXIII (1564). Puis les broderies. Done en tout 16 feuillets dont un titre et 29 planches de broderies. Vente Riva, 1856, vendu 245 francs. Vente Yemenitz, 1867. B. M.

619_Franceschi, D. de'.-Serena opera noua di recami, nella quale si ritroua varie \& diuerse sorte di punti in stuora, \& punti a filo, \& medesimamente di punto scritto \& a fogliami, \& punto in stuora a scacchetti, \& alcuni groppi incordonati, \& rosete, doue ogni virtuosa giouene potrà facilissimamence fare ogni sorte di bellissimo lauoriero. Opera non men vtile che necessaria. In Venetia, Appresso Domenico de' Franceschi, in Frezzaria, all' insegna della Regina M D LXIIII. 4. Title 1 p., 27 leaves.

620-Franceschi, D.-Serena opera nova di Recami, nella quale si retrova varie et diverse sorte di punti in stuora, etc. Obl. fol. Venezia, D. de Franceschi, 1564. Fac-simile re-print, 27 patterns, Ongania, Venice, 1879.

621-Eranceschi, F. di-Prima Parte de' fiori, e disegni di varie sorti di Ricami moderni come merli, bavari, Manichetti al presente sono in uso. In Venetia, Appresso Franceso di Franceschi Senese all' insegna della Pace 1591. Obl. 8vo, 20 ff., 17 plates in the style of Vecellio. Bib. de l'Arsenal. -Bib. Bodleian.

622-Franceschi, F. di-La vera perfettione del disegno di varie sorti di ricami \& di cucire ogni sorti de punti à foglami, punti tagliati, punti a fili \& rimessi, punti incrociati, punti à stuoro \& ogn' altre arte, che dia opera à disegni. E di nuovo aggiuntovi varie sorti di merli, e mostre, clie al presente sono in uso \& in pratica. In Venetia, Appresso Francesco di Franceschi Senese all' insegna della Pace. 1591. Obl. 8vo, 36 ff., 72 plates. Dedicated to "Signora Lucretia Contarini, per matrimonio Priula Nobile Gentildonna Venetiana,' by Giovamni Ostaus. A woodeut of Lucretia working witl her maidens, signed Jose Sol, 1557. Patterns, Small Squares, Gorgets, Youth, Paris, Pyramus and Thisbe, Arabesques, Grotesques, and an Alphabet. Bib. de l'Arsenal, Bib. Bodleian. S. K. M.

623-Franceschi, Francesco di--La Vera Perfessione del disegno di varie sorti 
di ricami e di cucire ogni sorte di punti a fogliami, punti tagliati, punti a fili e rimessi, punti incrotiati, punti a stuora e ogn'altra arte che dia opera a disegni, e di nuovo aggiuntoni varie sorti di merli e mostre che al presente sono in uso e in pratice. In Venetia appresso Francesco di Franceschi Senese all insegna della Pace, 1591. Reproduit et publié par Amand-Durand sous la direction de Emmanuel Bocher. Paris, 182...

624-France, Gio ${ }^{\circ}$. Libro delle mostre da cuser per le donna. Sans date. 16 gravures sur bois et 8 sur cuivre. Il est question de ce recueil dans les inscrizioni Venete du chevalier E. Cicogna, tome III, page 443.

625-Frano, Gio.-Libro delle mostre da ceuser per le donne. 1596.16 engravings on wood and 8 on copper. (Cited by Marquis d'Adda.)

626-Franco Giacomo-Nvova inventione De dinerse mostre cosi di punto in aere come di Retticelli hoggidi usate per tutte le parte del mondo. Con Merletti, Mostrette da Colari, e da Maneghi ${ }^{\text {ti }}$ et merli per cantoni da fazoletti. In Venetia, 1596. Con privilegio. Ce titre est inscrit dans un trait carré rectangulaire au-dessous duquel on lit à gauche: Giacomo Franco Forma. Il est entouré de cuirs enroulés, de fleurs, fruits, mascarons, etc. Page suivante cotée A. Dédicace: Alla molto Magnifica signora Adriana Palma. Verso. Fin de la dédicace signée: Giacomo Franco. $4^{\circ}$. Engraved title, 2 pp., 8 engravings and (?) 16 cuts. Sm. obl. This is apparently No. 62 in Mrs. Palliser's list. The title and six engravings are in the Victoria and Albert Museum.

627-Franco (Giacomo)-Nuova Inventione de diuerse mostre cosi di punto in aere come di Retticelli, etc. Sm. obl. 4to. Venice, 1596. Ongania reproduction, 1877.

628-Reproduction of this book by Ongania, 1878, at Metro. Mus.

629-Reproduction of this book by Ongania, 1887. S. K. M.

630-François, René-Fissay des merveilles de natvre et des plvs nobles artifices, pièce très nécessaire à tous ceux qui font profession d'éloquence par René François (Jésuite, nommé Etienne Binet) prédicateur du Roi, à Rouen chez Romain de Beauvais, près le grand portail Nostre-Dame et Jean Osmont, MDCXXI (1621). Article sur la broderie, page 532.

631-Frauberger, T.-Die Beziehungen der Fransen, der Knüpfarbeit und der posamenterie zu der Spitze und ihren Techniken. Kunstgewerbeblatt, 1893, Leipzig.

632-Frauberger, T.-Die "Exposition des Arts de la femme" in Paris. Kunstgewerbeblatt, December, 1892, Leipzig.

633-Frauberger, Tina-Handbuch der Spitzenkunde. Leipzig, E. A. Seemann, 1894. B. M.

634-Fréchon, Henri-Traité théorique et pratique de travaux à l'aiguille: couture, lingerie, tricot, crochet, tapisserie, coupe, modes, précis d'histoire du costume, repondant aux derniers programmes du travail manuel dans l'enseignement. Paris, 1913. Masson et Cie.

635-French and Flemish Laces, Special Display of-Bulletin of the Metropolitan Iruseum of Art, April, 1917, New York. p. 96.

636-French, New Art Lace. Craftsman, V. 10, pp. 129-133, April, 1906. 
637-French Patterns for Crochet and Lace Borders with instructions for workers. n.p., n.d. 4 to.

638-French, G. J.-Practical remarks on some of the minor accessories to the services of the church, etc. 16mo. Leeds, 1844. S. K. M.

639-French, G. J.-The Tippets of the Canons Ecclesiastical. Woodcuts. 8vo. London, 1850. S. K. M.

640-Frére-Orban-Discours prononcé à la Chambre des Representants. (Annales parlementaires, $1858-59$, p. 705.)

641-Friend, Margaret Alice-Laces from French Colonies. Vogue, Mar., 1916., New York.

642-Friling, H.-Nouveaux Documents d'Art dézoratif. Série 1-2. Brussels, P. Wytsman, 1898.

643-Frilling, H.- See "Dessins Ornementaux" ete.

644-Frutti, I.-Opera nuova intitvlata i frutti de i punti in stuora a fogliami nella qvale si ritrova varie et diverse sorte di mostre di punti in stuora, a fogliami et punti in gasii et in punti in trezola. Dove ogni bella et virtvosa donna potra fare ogni sorte di lauoro cise fazoletti, colari, maneghetti, merli, Frisi, Cauezzi, intimelle ouero Forette auertadure da camise, et altri sorti di lauori, come piu a piene potrai vedere, ne mai per l'adietro d'alcun altro fatte et post in luce. Opera non men bella che vtile et necessaria a ciascune virtvosa Gentildonna. In Vinegia, MDLXIIII (1564). Les mots I. Frutti au haut de la page sont inserits dans un petit cartouche rectangulaire orné de cuirs et de mascarons. Au-dessus des mots: In Vinegia un petit nielle gravé sur bois. Puis commencent les broderies, 30 planches composées uniquement de sujets de tapisserie dessinés, soit par point juxtaposés, soit par points dans des carreaux de papier quadrillé. 8vo, or In-4 $4^{\circ}$ oblong. Bibliothéque de L'Arsenal.

645-Furmbüchlein, Ein New-see Model-Büchli.

646-Fürst, R. H.-Das newe Modelbuch von schonen nadereyen Ladengewurck und Faterleins arbeit. Ander Theil. Ce titre est dans un cartouche des deux côtés duquel on voit une femme ailée dont le bas du corps se termine par des fruits. En bas autour d'une table, une société de trois femmes et de deux hommes. A gauche une femme travaillant à un métier sur lequel est tendu un réseau. A droite une femme tissant avec un petit métier posé sur la table. Au milieu une femme brodant à l'aiguille. Les deux hommes les considèrent. En bas, dans l'intérieur du dessin à gauche: L. B. Bëner, f. à droite zu finden in Nürnberg. Bey Paulus Fürsten Kunsth. Gravure sur cuivre. Préface. Verso, fin de la préface, se terminant par les mots: Rosina Fielena Furstinn. Fin de la dédicace par ces mots: Nurnberg den 20 martii 1666. R.H.F. Au verso, un sonnet. Ensuite les broderies. Les pages sont numérotées en haut à droite de 1 à 50 . En résumé 50 planches de broderies et 4 feuillets liminaires. Obl. 4to. Bibliothéque impériale de Berlin.

647-Furst (inn), R. H.-Das Neue Modelbuch von Schonen Naderenen Ladengewurck und Paterlemsarbeit. 46 plates of designs for lace work. Small oblong 4to, full vellum gilt. Nuremberg, 1666.

648-Furst, R. H.-Model Buchs, Tritter Theil. Frontispice. Dans un jardin, 
une femme travaillant au filet sur une table où se voient différents outils employés par les brodeuses. A droite, une colonne autour de laquelle est une banderolle sur laquelle on lit: Un bewegt ranicken tragt. En haut dans le ciel un oeil d'où s'échappent des rayons au milieu desquels on lit: Der arbeit nutz is Gottes schütz. En bas sur une banderolle blanche le titre ci-dessus: Model Buchs. Tritter 'Theil. Vogeln, Blumen, und Fruchten, Wie dieselbige zum Weiss, Nehen, Landengewebe, Creutz und Frantzosichen stiche strumpf, gestricke auch Geschnur Gewirck und geschlinge von Faterlein oderandern der gleichen Arbeit, nach eines jeglichen Belieben anzuwenden Gezeichnet und den Jenigens o zu solcher, arbeit lust haben, zu dienst ins kupffer versezt. Von und in Verlegung Rosina Helena Furstin. Nurnberg zu finden bey Paulus Fursten. Kunst und Buchhandel seel Wittib und Erben Gedruckt da selbst bey Christian Sigmund Froberg. Verso, fin de la dédicace par les mots: Deine in Ehren willige Dienerin. R.H.F. (Rosina Helena Furstin.) Nurnberg 10 Winter Monats. Im. 1675. Heil Jahre. Puis commencent les broderies numérotées en haut à droit en chiffres arabes. Les planches ne sont imprimées qu'au recto seulement. Celles numérotées 1, 2, 25, 27, 29, 30, sont de grandes planches plusieurs fois ployées sur elles-mêmes. 43 planches de broderies. Il y a des éditions qui portent au bas du titre: Gedruckt bey Christoff. Gerhard in Jahr 1676, au lieu de: Gedruckt Daselbst bey Christian Sigmund Froberg.

649-Fürst, R. H._Model-Buchs; dritter 'Theil. Von unterschiedlichen Vögeln Blumen, und Früchten, etc., nach eines jeglichen Belieben amzuwenden. 4 to. obl., engraved title and printed list: 42 wood plates, 4 large. Von und in Verlegung Rosina Helena Furtin. Nürnberg, P. Fürstin, 1676. S. K. M.

650-Furst, R. H.-Frontispice. Dans un parc au milieu d'une allé de peupliers, au bout de laquelle on voit un palais, une table ronde au second plan devant laquelle sont trois femmes travaillant à des ouvrages de broderies. L'une à droite à un petit métier, celle du milieu à un réseau. Au premier plan à gauche un homme vêtu à la Romaine, casque en tête, tient d'une main un sablier et un éperon. A droite une femme assise dans une grotte et personnifiant la paresse. A ses pieds un cochon ainsi que des débris de métiers et d'ustensiles servant à l'art de la broderie. Page non cotée. Des nurnbergischen model oder nahe Buchs Wierdtertheil Vorinnen unterschiedlich Model von Gestrick Genah zum abzelılen auch zum abriss genah selır dienlich zu gebrauchen, ingleichen, zu laden: gewurck sommer Gittern und seiden, genah Kreutzstück in Leinward oder Camfas auch zu Frantzosischer stuck Fatterleins arbeit in Geschnur und Gesehling strumpff und handschule zu stricken ungleicher flor genah auch auf Caton und leinwad zu machen zu glatt und erhobenen Caton stucken sehr nutzlich, zu gebrauchen. Inventirt una verlegt von Rosina Helena Furstin, in Nurnberg und zu finden bey ihr daselbst. Dédicace. Verso. Verso fin de la dédicace. Avertissement. Verso. Fin de l'avertissement. Puis les broderies, numérotées en haut à droite en chiffres arabes. Les pages 1, 2, 15 à 26, 28, 30 sont de grandes planches plusieurs fois ployées sur elles-mêmes. En tout 50 planches et 11 feuillets Limj. naires. 
651-Furst R. H.-Das neue Model Buch, zufinden Nurnberg bey Paulus Fursten Kunsthanal. Erster Theil. Ce titre est inscrit en haut sur une draperie soutenue par deux petits amours ailés. En bas un intérieur dans lequel on voit deux femmes à une table. Celle de gauche travaille à un filet, tendu sur un cadre. Celle de droit brode à l'aiguille. A leurs pieds un chien couché au-devant de la table. A droite un homme debout en costume Louis XIV. A gauche une femme assise dévidant de la laine. Au fond deux femmes dévidant également de la laine. In- $4^{\circ}$ oblong. Neues Modelbuch von Unterschiedlicher art der Blumen und anderer Genehten Model, nach itziger Manier, allen Liebhaberinnen. Dieser Kunst Zumbesten, vorgestellt, zu finden in Nürnberg bey Paulus Fursten Kunst und Büchlandern. Scel Wittib. und Erben, 1689. 4 parties en un volume in- $4^{\circ}$ oblong. Dans cette édition l'M du mot Modelbuch est une lettre ornée dans un carré où l'on voit le bouclier de Minerve, surmonté de la chouette symbolique. Dans d'autres éditions sans date, on voit, dans ce petit carré, les trois grâces enlacées au lieu du bouclier de Minerve, et on lit dans le titre: Zu finden in Nürnberg bey Paulus Fürsten Kunsthandlern, au lieu de Zu finden in Nürnberg bey Paulus Fürsten Kunst und buchlandern seel Wittib. und. Erben, 1689. Gesprach zwischen Jungfrauen, etc. Dialogue en vers entre deux jeunes filles, sur le sujet de travaux à l'aiguille. Ensuite les broderies. Chaque page est numérotée en haut à droite en chiffres arabes. Chaque dessin indique le nombre de lignes dont se compose le canevas. Ce sont des planches de tapisserie à points comptés. Les pages de 43 à 50 renferment des guipures. En résumé 50 planches de broderies et 10 feuillets liminaires. Cet important recueil de modèles de broderies et dentelles a pour auteur Rosina Helène Fürst parente de l'éditeur de Nuremberg. Le nom de Rosina Helène Fürst se lit à diverses dédicaces qui se trouvent dans les feuillets préliminaires des trois dernières parties. Collation de tout l'ouvrage. $1^{\text {re }}$ Partie. Frontispice, $3 \mathrm{ff}$. liminaires et 50 planches. II Partie. Frontispice, 3 ff. liminaires et 50 planches. III ${ }^{\mathrm{e}}$ Partie. Frontispice, 3 ff. liminaires et 50 planches. IV Partie. Frontispice, 10 ff. liminaires et 50 planches. Ensemble 193 planches gravées en taille douce et dont plusieurs se déplient. Une édition de ce recueil, aussi en 4 parties et avec 193 planches, avait déjà été publiée de 1666 à 1676.

652-Furst, R. H.-Neues Modelbuch von unterschiedlicher Art der Blumen, und anderer genehten Model, nach itziger Manier, Allen Lieblhaberinnen dieser Kunst Zumbesten, vorgestellt. Zu finden in Nürnberg, bey Paulus Fürsten, Kunst und Buchlandern Scel. Wittib und Erben, 1689. 4 parties en un vol. in- 4 obl. Cet important recueil de modèles de broderies et dentelles a pour auteur Rosina-Hélène Furst, parente de l'éditeur de Nuremberg. Le nom de Rosina-Hélène Furst se lit à diverses dédicaces qui se trouvent dans les ff. prélim. des 3 dernières parties. Collation, $I^{\text {re }}$ part. front. gravé, $9 \mathrm{ff}$. lim. imprimés et $50 \mathrm{pl}$ - - $\mathrm{II}^{\mathrm{e}}$ part. front., $3 \mathrm{ff}$. lim. et $50 \mathrm{pl}$.- $\mathrm{III}^{\mathrm{e}}$ part., front., $3 \mathrm{ff}$. lim. et 43 pl.-IV part., front., $10 \mathrm{ff}$. lim. et $50 \mathrm{pl}$. Ensemble $193 \mathrm{pl}$. dont plusieurs se déplient, gravées en taille-douce. Une édition de ce recueil aussi en 4 parties et avec 193 planches, avait déjà été publiée de 1666 à 1676. Vente Destailleurs, 1895. 
653-Fürst-Neues Modelbuch, von unterschiedlicher Art der Blumen, und anderer genehten Mödel, nach itziger Manier, allen Liebhaberinnen dieser Kunst zum besten, vorgestellet. Nürnberg bey Paulus Fürsten, 16761689. 1-3 (olne den 4.) Teil, mit 150 Tafeln.

654-Fürst-Neues Modelbuch . . . von Rosina Helena Fürstin (Nurnberg), bey J. C. Weigels Wittib. 1728.

655-Fuster, Charles—La Dentellière de Bruges (Poème). Paris au "Semeur," 1891.

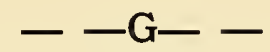

656-Gaby, R.-Écoles dentellières. La Justice sociale, March 24, 1901, Brussels.

657-Galvin, Norah Teresa, at Cork-Col et manche en dentelle. Art appliqué, 1 re année, Paris.

658-Gandini-Este Family, 1896.

659-Garfagnino, Porta-see Salviati, Joseph.

660-Gargano, Luchino-Pretiosa gemma delle virtvose donne, done si vedono bellissimi lauori di punto in aria, reticella, di maglia a piombini, disegnati, da Isabella Catanea Parasole è di nuovo, dati in luce da Lucchino Gargano con alcuni altri bellissimi lauori Nouamente inuentati. Stampata in Venetia ad instantia di Lucchino Gargano MDC (1600). Con Licenza de superiori. Dédicace, Alla illustriss. et eccellentiss, Signora e padrona mia osservandiss. la Signora Donna Gironima Colonna. Puis les broderies des feuillets, au nombre de 7. Secondo Libro della pretiosa Gemma delle virtvose donne, doue con nuova inventione si vedono bellissini lauori di varia sorti di merli grandi e piccioli, punti in aria, punti tagliati, punti a reticello, è Rosetti diuersi che con laco si usano hoggidi per tutta Europa, nouamente dato in luce, de Lucchino Gargano. Stampata in Venetia ad instantia de Lucchino Gargano. MDCI (1601). Dédicace, Alla Illustriss. et excellentiss. Signora e padrone mia oservandiss. la Signora Donna Gironima Colonna. Puis les broderies. Vente Santarelli.

661-Gar'sault, de-L'Art de la lingerie. Paris, 1871.

662-Gatta (Libraria de la.) - Opera nova di recami intitolata le Richezze delle bellissime et virtuosissime Donne, nella quale si ritrova varie sorti di punti tagliati et punti in aiere, dove facilissimamente \& senza fatica alcuna ogni virtuosa donna potra lavorare cavezzi di varie sorti. In Venetia l'anno M. D. LVIIII a la Libraria de la Gatta. Fol. 46 leaves, 3 parts in 1 vol.

663-Gaugain, Mrs.-Crochet D'Oyley Book. Nos. 1, 3. 1847.

664-Gaugain, J.-The Lady's Assistant for executing useful and fancy Designs in Knitting, Netting, and Crochet Work. Illus. 3 vols. in 4 obl. 16 mo. Edinburgh, 1844-6. S. K. M.

665-Gay, Victor et i)upont-Auberville-Catalogue descriptif des Tissus et Broderies exposés au Musée des Arts décoratifs en 1880. Paris, Imp. Publications périodiques, 1880.

666-Gebhard, E. L.-Samplers of the Other Days. American Homes, V. 10, pp. 24-5, January, 1913. 
667-Gedini, Giacomo-Libro novo, Chiamato Fior di Virtu. Qual insegna a cusir a ogni virtuosissima giovine che si diletta à imparare cioe Ponti Tagliati, ponti in stuora et ponti crosati et molti altri bellissimi lauori. In Venetia appresso Giacomo Gedini in Frezzaria al segno della Fede, MDLXXXIIII (1584). In- $4^{\circ}$. Ce titre est circonserit par une composition, où l'on voit en haut un entablement posant sur deux colonnes surmontées chacune d'une petite figure de femme brodant à l'aiguille. Au milieu du chapiteau, un homme travaillant à un petit métier qu'il tient des deux mains appuyé sur son genou. En bas de la composition et au-dessous du titre deux femmes travaillant, l'une à droite à un métier de basse lisse, l'autre à gauche à un petit métier posé devant elle sur une table. Elle est assise de trois quart à droite, En résumé, 20 feuillets dont 18 pages de broderies. Vente Destailleurs.

668-Gehäkelte Spitze nach einer Klöppelspitze. Daheim, Sept. 9, 1893, Leipzig. 669-Georgens-Das Flechtarbeiten. (Plates.) 2nd ed. 4to. Leipzig, 1877. S. K. M.

670-Georgens-Das Häkeln. (Plates.) 2nd ed. 4to. Leipzig, 1877. S. K. M. 671-Georgens-Die Kanevas-Stickerei. (Plates.) 2nd ed. 4to. Leipzig, 1877. S. K. M.

672—Georgens-Knüpfen und Durchziehen. (Plates.) 2nd ed. 4to. Leipzig, 1877. S. K. M.

673-Georgens, J. D.-Die Linienstickerei. Vorbilder für den modernen Gebrauch. (Plates.) 2nd ed. 4to. Leipzig, 1877. S. K. M.

674-Georgens-Nähen und Zuschneiden. (Plates.) 2nd ed. 4to. Leipzig,1877. S. K. M.

675-Georgens-Die Plattstickerei. (Plates.) 2nd ed. 4to. Leipzig, 1877. S. K. M.

676-Georgens, J. D.-Die Schulen der weiblichen Handarbeit. (Plates) 4to. Berlin, 1869. S. K. M.

677-Georgeus-Das Spitzennähen. (Plates.) 2nd ed. 4to. Leipzig, 1877. S. K. M.

678-Georgens-Das Stricken. (Plates.) 2nd ed. 4to. Leipzig, 1877. S. K. M. 679-Georgens-Toilette und Dekoration. (Plates.) 2nd ed. 4to. Leipzig, 1877. S. K. M.

680-Gerliez, H. de-(Homo \& Co.) Laces, etc. p. 17; 13 . (Collection of Kursheedt Manufacturing Co., N. Y.)

681-Germany, Industries-Lace makers complain on ground that soldiers buy Belgian product in preference to theirs. N. Y. Times, Apr. 28, $17: 2$; report of American Association of Commerce and Trade in Berlin on general economic conditions, May 21, II, 12:1.

682-Germany : Lace Industry. Board of Trade Journal, Aug. 22, 1901, London. 683-Gheltof, G. M., Urbani de-I. Merletti a Venezia. Venice, 1876.

684 Gheltof, G. M. Urbani de-A technical History of the Manufacture of Venetian Laces. Translated by Lady Layard, Venice, F. Ongania, 188г.

685-Gheltof, G. M., Urbani de-Trattato storico tecnico della Fabbrizaacione dei Merletti Veneziani. Venice, 1878. 
686-Giardinetto nuovo di punti tagliati et gropposi per exercitio et ornamento delle donne. Venetia 1542. Un volume in $-4^{\circ}$. Catalogue Cappi de Bologne. Bibliographie du marquis d'Adda. Bib. de l'Arsenal.

687-Gibson, M.-Book of Samplers. Woman's Home Companion, V. 39, p. 78, November, 1912.

688-Gittertyl Filet. Delineator, V. 65, pp. 112-114, January, 1905.

689-Givelet, C.-Les Toiles Brodées anciennes mantes ou courtes-pointes conservées à l'hôtel Dieu de Reims. 8vo. Reims, 1883. S. K. M.

690-Glafey, H.-Die Herstellung der Luftspitzen (Aetzspitzen). Dinglers Polytechnisches Journal, June 26, 1891, Stuttgart.

691-Glafey-Herstellung der Spitzen (Hand \& Machine). Verhandl. Ver. Beförd. Gewerbfleisses. Sitzungsb. November, 1915. pp. 119-144. 46 fig's.

692_Glüer, Louis-Colored Pattems for Cross Stitch Work. 4 photographs. (Collection of Kursheedt Manufacturing Co. New York.)

693-G. M.-Pour la Dentelle. Le Temps, June 4, 1905, Paris.

694 -Glen, Jean Baptiste de-Du debuoir des filles, Traicté brief et fort vtile, divisé en deux parties, la première est de la dignité de la femme, de ses bons départements et debuoirs, des bonnes parties et qualités requises aux filles qui tendent au mariage, l'autre traicte de la virginité de son excellence, des perfections nécessaires à celles qui en font profession, des moyens de la conserver et de plusieur's autres choses qui se verront plus à plein au sommaire des chapitres, par frère Jean Baptiste de Glen, docteur en Théologie, de la faculté de Paris et prieur des Augustins lez Liège. Item plusieurs patrons d'ouvrages pour toutes sortes de lingerie de Jean de Glen . . Le tout dédié à madame Anne de Croy, marquise de Renty . . . A Liège, chez Jean de Glen, 1597. Sur ce titre sont gravées les armes parlantes de Jean de Glen, trois glands en sautoir sur'montés d'une couronne de chêne. In- $4^{\circ}$ oblong. Au verso de ce titre sont les armes de Croy. Epître dédicatoire à Haute et puissante dame, madame Anne de Croy. Verso.-Fin de l'épître de dédicatoire signée: Frère Jean Baptiste de Glen.-Page non cotée. Du devoir des filles, partie première, traictant de la dignité de la femme, des bons debvoirs, qvalités, et parties des filles, tendantes an mariage. Avertissement aux lecteurs.-S'en suit le sommaire des chapitres. Puis 120 pages numérotées en haut au recto et an verso en chiffres arabes. Sign. A.P. A la suite 20 planches de broderies gravées sur bois en blane sur fon 1 noir et presque toutes empruntées aux ouvrages de Vinciolo, de Vecellio, etc. Nous reproduisons ici une note rédigée par $M$. Edouard Rahir, le savant bibliophile, dont l'érudition fait loi dans tout ce qui a trait à la connaissance du livre. Cette note a été rédigée pour le catalogue de la vente Destailleur's. "Ainsi que l'annonce le titre, l'ouvrage est divisé en deux parties distinctes, la première pour le devoir des filles, la seconde contenant les patrons de lingerie. La premiére partie divisée en deux livres, se compose de 8 feuillets liminaires dont 1 blanc et 120 fenillets chiffrés (sig. A. P). La collation de la seconde partie est plus difficile à établir. M. Brunet, M. de Reiffenberg, et tout récemment M. Van der Haeghen dans la Bibliotheca 
Belgica réclament pour cette partie 6 ff. de texte imprimé et 39 de planches de broderies. Cette collation ne concorde pas avec 4 exemplaires de cet ouvrage que nous avons collationnés et qui ne contenaient que 20 planches, sans les feuillets liminaires. Trois de ces exemplaires ont figuré aux ventes Libri, Yemenitz (ex. revendu chez Didot et Bieswald). Le quatrième est celui que nous décrivons. Est-ce à dire que tous ces exemplaires soient incomplets; nous ne le croyons pas, d'autant plus que trois étaient en ancienne reliure. Nous supposons plutôt qu'aux exemplaires décrits par MM. Brunet, Reiffenberg et Van der Haaghen, était ajouté un volume séparé ayant pour titre: singuliers et nouveaux pourtraits pour toutes sortes de lingerie, comprenant $6 \mathrm{ff}$. et 19 planches. Ainsi que l'observait le rédacteur du catalogue Libri, les deux ouvrages sont très différents l'un de l'autre." L'explication donné ici par M. Rahir est la vraie. Il y a deux livres faits par de Glen. L'un n'a que 19 planches et l'autre 20, ce qui fait 39 en les réunissant. Mais ce sont des ouvrages parfaitement distincts parus en la même année 1597. Nous donnons ci-dessous l'énoncé du titre du second. Le marquis d'Adda dans son étude sur les livres à dentelles parus en France, en Allemagne et en Flandre (Gazette des Beaux Arts, 1 novembre, 1864), corrobore l'opinion de M. Rahir. Vente Yemenitz. Vente Detailleurs, 1895.

695-Glen, Jean de-Les singuliers et nouveaux pourtraits, pour toutes sortes de lingeries de Jean de Glen, dediés à Madame Loyse de Perez; à Liége, chez Jean de Glen, l'an 1597. Obl., 39 plates, mostly borrowed from Vinciolo and Vecellio, as well as the title. Bibliothèque Royale de Bruxelles.

696-Godefroid Marguerite, at Reims-Col en dentelle. Mouchoir en dentelle et napperon. Art appliqué, 2e année, Paris.

697-Goldenberg, S. L.--Tace, its Origin and History. New York, Brentano, 1904. B. M.

698-Gorges, Mary-Irish Home Industries, Point-Lace. Chamber's Journal, August, 1898, London.

699-Gorman, A. L.-Teneriffe Lace. Harper's Bazaar, V. 37, pp. 778-779, 862863. August-September, 1903.

700-Gormont-Livre de Moresques, très utile et nécessaire à tous orfèvres, tailleurs, graveurs, painctres, brodeurs, lingères, et femmes qui besongnent de l'esguille. Paris, Gormont, 1546. In-folio, avec gravures sur bois.

701-Goubaud, Madame-Book of Guipure d'art. 98 Illus. 4to. Lond. (1869.) S. K. M.

702-Goubaud, Mme. A.-Book of Guipure d'Art. London, Ward, Lock \& Tyler, 1870.

703-Goubaud, Mme.-Crochet book. London, (1871). $8^{\circ}$.

704-Goubaud, Mme. A.--Pillow-lace Patterns, and Instructions in Honiton Lace Making. London, 1871.

705-Goubaud, Mme.--Point Lace Book. Instructions and Patterns. Illustrations. 8 v. Lond. n.d. (1882.) S. K M.

706-Government Lace School, France. Craftsman, V. 5, p. 77. 
707-Grabowskii, B. B.-Ajour or Toledo Embroidery. Harper's Bazaar, V.41, 1241-1243, December, 1907.

708-Grabowskii, B. B.-Hedebo and Mont Mellick Work Combined. Ladies' Home Journal, V. 23, p. 52, January, 1906.

709-Grafton, A. B.-Hindoo Laces at St. Louis Fair. Brush and Pencil 15: 165.

710-Grandes Collection de Dentelles Anciennes et Modernes, Les-Album with 60 plates.

711-Greef, G. de-L'Ouvriere dentelliere en Belgique. 127 pp. Bruxelles, 1888. $16^{\circ}$. B. M.

712-Griffin, L. B.-Norwegian Work on Collars. Harper's Bazaar, V. 38, pp. 714-716, July, 1904.

713-Griffin, L. B.-Household Laces. Harper's Bazaar, V. 37, pp. 373-375, April, 1903.

714-Griffin, L. B.-Practical Lace-Making. Harper's Bazaar, V. 35, pp. 659661, November, 1901.

715-Griffin, Montagu-Lace-making in Treland. The Month, March, 1891, London. V. 71, p. 340.

716-Groh, St.-Ungar. dekorative Kunst. 110 plates, folio. Budapest, 1907. Tafelbezeichngn. in engl., deutsch und ungar.

717-Grosch, H.-Gammel norsk vaevekunst i farvetrykte gjengivelser. 20 plates, \$3.20. Albert Bonnier Publishing House.

718-Grosch, H.-Norsk Folkeindustri. Broderier. Tidsskrift for Kunstindustri, 1888, Copenhagen.

719-Guichard, Edouard et Darcel A.-Les Tissus anciens reconstitués à I'Aide du Costume, des Miniatures, et de Documents inédits. Paris, 1878. 50 plates, folio.

720-Guillemont, M.-L'Exposition des Arts de la Femme au Musée des Arts Décoratifs. Art et Décoration, 1911, V. 29, pp. 137-156.

721-Guillot, Ernest-L'Ornementation des Origines au XVIIIe Siècle.

722-Guipure, gravures burin-In the Bib. Imp. (Gravures, L. h. 4. c.) is a vol. lettered "Guipure, gravures burin," containing a collection of patterns engraved on copper, 43 plates, four of which are double, pasted in the book without title or date. Pomegranates, narcissus, lilies, carnations, most of them labelled, "Kreutzstick, Frantzösischenstick, and Fadengewürck" (thread work), the number of stitches given, with Clocks (Zwickel) of stockings and other patterns. Bien que sous un titre français, ce livre paraît être d'origine allemande.

723-Guthrie, J. W.-Lace-making Among the Indians. Outlook, V. 66, pp. 5962, September 1, 1900.

\section{$--\mathrm{H}--$}

724-Haberlandt, Michael-Textile Volkskunst aus Osterichisch. Vienna. J. Lowy, 1912.

725-Hadley, S.-Bits to Make for Christmas. Ladies' Home Journal, V. 20, p. 23, September, 1903. 
726-Hadley, S.-Edgings and Insertions in Modern Lace. Ladies' Home Journal, V. 18, p. 19, July, 1901.

727-Hadley, Sarah-Hardanger Book. (Collection of Kursheedt Mfg. Co., N. Y.)

728-Hadley, S.-How to Make Flemish Lace. Ladies' Home Journal, V. 19, p. 20, August, 1902.

729-Hadley, S.-How to Make Royal Battenberg Lace. Ladies' Home Journal, V. 19, p. 27, October, 1902.

730-Hadley, S.-How to Make Russian Lace. Ladies' Home Journal, V. 19, p. 22, July, 1902.

731-Hadley, Sarah-Irish Lace. D. S. Benett. (Collection of Kursheedt Mfg. Co., N. Y.)

732-Hadley, S.-Irish Needle-point Lace. Ladies' Home Journal, V. 23, p. 57, June, 1906.

733-Hadley, Sarah_The Lace Maker Magazine, Vol. 1-12. D. S. Benett. (Cok lection of Kursheedt Manufacturing Co., N. Y.)

734 -Hadley, S.-Marie Antoinette Lac ` Work. Ladies' Home Journal, V. 19, p. 18, May, 1902.

735-Hadley, S.-Needle Honiton Lace. Ladies'Home Journal, V. 19, p. 20, September, 1902.

736-Hadley, S.-Needle Point Lace. Ladies' Home Journal, V. 19, p. 20, June, 1902.

737-Hadley, S.-New Handkerchiefs in Modern Lace. Ladies' Home Journal, V. 18, p. 19, April, 1901.

738-Hadley, S.-Using up Old Pieces of Lace. Ladies' Home Journal, V. 25, p. 43, November, 1908.

739-Haebler, O.--Barbes à la Main. 100 Originalaufnahmen Geschmacksrichtung des XVIII Jahrhunderts. 40 Tafeln. 1910.

740-Haebler, O.-Der Spitzenzeichner. Ca. 200 Originalentwürfe: Aus der Praxis-für die Praxis. 20 Tafelin. Plauen, 1910 (?).

741-Hagen, L.-Zur Entwickelungsgeschichte der Klöppelspitze. Zeitsch. des Bayr. Kunst-gew.-Vereins in München, 1895.

742-Hailstone, Lilla-Catalogue of Collection of Lace. London, 1868.

743-Hailstone, S. H. Lilla-Designs for Lace Making. 40 tinted plates. London, E. J. Francis, 1870.

744-Hailstone, Mrs. S. H. Lilla-Illustrated Catalogue of ancient framed Needlework Pictures. London, Baines \& Scarsbrook, 1897.

745-Hairs, Charles-The crochet collar book. London (1846). $8^{\circ}$.

746-Hale, Lucretia Peabody-Art Needlework.

747-Hale, L. P.-Designs in outline for Art Needlework. Accompanied with instructions in drawing, etc., patterns. 8vo. Boston (U. S.) 1879.

747a-Hale, L. P.-Plain Needlework, Knitting, ete. Plates. 8vo. Boston (U. S.) 1879.

748-Hale, Lucretia Peabody-Point Lace, a Guide to Lace Work. Boston, S. W. Tilton \& Co., 1879.

749-Hall, Herbert J. \& Buck, Nertice M. C.-Handicrafts for the Handirapped. Moffat, Yard \& Co., New York, 1916. 
750-Hammett, Lydia C., at Taunton-Dentelle de Honiton. Ait appliqué, 2e année, Paris.

751-Hammett, Lydia C., at Taunton-Projets de dentelles. Art appliqué, 1re année, Paris.

752-Han, W. and Raben, G.-Modelbůch Neuw allerart Nehens vñ Stickens, Yetsund wider mit Modlen vnd Stahlen. Allen Steinmetzen, Seidenfrickern, vnnd Neterin, sehr nutzlich vnnd lustig zi̊ gericht. Gedruckt zi Franckfurt am Mayn durch Weygand Han vnd Georg Raben. 1562. $4^{\circ}$. B. K. M.

753-Handarbeit-Spitze in Klöppelmanier. Daheim, July 8, 1893, Leipzig.

754-Handicraft in Massachusetts. Nation, V. 78, pp. 489-490, June 23, 1904.

755-Handkerchiefs in Princess Lonise Lace. Delineator, V. 64, p. 1012, December, 1904.

756-Hand-made Laces. (1890.) Cited on Bodleian Library Handlist of printed books on lace.

757-Haner, J. L. K.-In Defence of Samplers. Journal of Home Econ., V. 1, pp. 354-355, October, 1909.

758-Hardanger Lace. Delineator, V. 63, pp. 670-671, 872-873, April-May, 1904.

759-Hardouin, Mme.-Album de Broderie et de Filet. Manufacture Parisienne des Cotons L. V. et M. F. A.

760-Hardouin, Mme.-Album de Dentelle de Venise.

761-Hardouin-Album de Guipure d'Trlande, 4 vols. (Collection of Kursheedt Mfg. Co., N. Y.)

762-Harris, E.-New Duchesse Lace. Ladies' Home Journal, V. 23, p. 70, April, 1906.

763-Harris, E.-Novel Laces. Harper's Bazaar, V. 38, pp. 69-71, January, 1904.

764-Harris, Wm. Lanrel-Laces and their affiliation with architecture. Illus. Amer. Architect, New York, 1917. fo V. 112. pp. 363-371.

765-Harrison, C. C.-Woman's Handiwork in Modern Homes. Scribners, New York, 1882. (Collection of Kursheedt Manufacturing Co.)

766-Harth, Mrs. Ernest-English Laces.

767-Harth, Mrs. Ernest-Irish Laces. The Girl's Own Paper, Ang. 29, 1891, London.

768-Harth, Mrs. Ernest-Spanish, Greek, Maltese and Polish Laces. The Girl's Own Paper, April 4, 1891, London.

769-Hartshorne, C. H.-English Nedieval Embroidery. (Illus.) 16 mo. Lond., 1848.

770-Hastings, School of Art-Cat. of Lady Brassey's Loan Exhib. of ancient and modern lace, fans, ete. 8vo. Hastings (1882). S. K. M.

771-Haussmann, Nicolaus-Eyn new Modelbuch anff aussnehen vnd borten wircken yn der Laden vñ langen gestell, Gemert vnd gebessert mitt. 105. andern Modeln. N. H. Anno domini 1525. (On back of title-page) : Eyn Model Buchleyn darauss leychtlich das gewurck dises nach angezeygten Formen, erlernet werden mag. Gedruck. yn der Fürstlichen Stadt Zwickan durch Jorg Gastcl, 1525. 4. Title and 16 leaves (incomplete). Said by 
Professor E. Kumsch to be the oldest Pattern-book of needlework known; although obviously a new edition of one still older. Six of the plates are copied by Claude Nourry (Lyons, c. 1530). It is described in "Kunst und Handwerk" VI, p. 512, 1903. D. K. S.

772-Havard, Henri-Dictionnaire de l'ameublement. Paris.

773-Hawkins, D. W.-Old Point Lace, and how to copy and imitate it. 8vo. Lond., 1878. S. K. M.

774-Head, Mrs.-A Collection of English Samplers. The Connoisseur, March, 1902, London.

775-Head, Mrs.-A Note on Lace Bobbins. Connoisseur, V. 10, pp. 154-156.

776-Head, R. H.-Some Notes on Lace Bobbins. The Reliquary, July, 1900, London. V. 40, p. 172.

777-Heiden, Max-Aus der Spitzensammlung des Kunstgewerbemuseums zu Berlin. Kunstgewerbeblatt, 1888, Leipzig.

778-Helbing, Dr. K.-Spitzen-Album. Vienna, v. Waldheim, 1877.

779-Helbing, K.-Spitzen Album. 20 blatt Lichdrucke mit 45 Spitzmustern, nach den originalen herausgegeben von Dr. K. H. fol. Wien, 1882. S. K. M.

780-Helmers, R. J.-Model Buck (Neues) (Anderer Theil) von unterschiedlicher Art von schöen Nädereyen Fadengewürck und Paterleins-Arbeit. Obl. 4to. Nürnberg, 1665. S. K. M.

781-Helmin, Fr. Margaretha-Künst und fleissübende Nadel Ergotzungen oder Neu er fundenes, Nah und Stick Büch Vorin dem solche schone Wissenchafft lieben dem Frauen zimmer allerhand zu vielen sachen an standige muster und kisse nach der neuesten Façon (sic) zu deren nuklichen badienung vorges tellt von Fr. Margaretha Helmin zu finden in Nurnberg. Bey. Joh. Christoph Weigel. In- $8^{\circ}$ oblong. Le titre se trouve dans un entourage composé de roses, de tulipes, de fleurs liées en bas par un nœud de rubans. Préface de deux pages, terminée par un cul-de-lampe gravé sur bois. A la fin de cette préface est le chiffre 52, qui est celui du nombres des planches de broderies. La première est un alphabet à points comptés. Des modèles de tapisserie dont une grande planche ployée. Des planches pour des petites broderies sur mousseline. Une suite de grandes broderies pour soie, satin, modèles de rinceaux, vases, coupes, fruits, modèles de robes brodées, etc. Gravure sur cuivre, XVII siècle.

782-Helmin, F. M.--Continuation der kunst-und fleisz-übenden Nadel-Ergötzung oder des neu ersonnenen besondern Nehe-Buchs dritter Theil, worinnen fleiszige Liebhaberinnen deeser nöthig und nützlichen Wissenchaft, ihr kunstliches Nadel-Exercitium, beij unterschiedlich vorfallenden Belegenheiten zu haben allerhand noch nie vorgekonene Muster zu Desó gebrauch, vorlegt und en die Hand gegeben werden von Fr. Margaretha Helmin, zu finden in Nürnberg bei Joh Christoph Weigel. Nürnburg. No date. Oblong fol. Copper plates. V. \& A. M.

783-Hempel-_Spitzen und Spitzen-Motive. Plauen, C. Stoll, 1909.

784-Hénon, Henri-Exposition de Bruxelles, 1897. Rapports du Jury Classe 154. Rapport de M. Hénon. Calais, Impr. des Orphelins, 1897. 
785-Hénon, Henri-Exposition de 1900 à Paris. Rapports du Jury, Classe 84. Rapport de M. H. Hénon. Paris, Impr. Nationale, 1901.

786-Hénon, Henri-L'Industrie des Tulles et Dentelles mécaniques dans le Department du Pas de Calais, 1815-1900. Paris, Belin Frs., 1900.

787-Henry, A.-Dentelles à fils tirés de Dinant. Annales Soc. archéol. de Namur, 1891, Namur.

788-Hesson, Addie E.-Fancy Work, 1905.

789-Hieronimo, da Ciuidal di Frioli, Fra-Triompho di lavori a fogliami di i quali si puo far ponti in aere. Opera di Fra Hieronimo da Ciuidal di Frioli de l'ordine de i serui de osseruantia. Cum gratia et privilegio per anni. XI. Ce titre est inscrit sur le bas de la page, entre trois gravures sur bois. Celle du haut qui occupe toute la largeur de la page, représente un bas-relief antique. Une femme couronnée de lauriers, est traînée de droite à gauche dans un char attelé de deux licornes, et entourée de plusieurs femmes portant des couronnes de feuillage à la main. En tête du cortège, deux autres femmes, dont l'une joue de la trompette. Des deux bois latéraux qui encadrent le titre, l'un celui de gauche représente une femme de profil à droite assise et montrant un ouvrage de broderie a deux petits enfants debout à ses pieds. L'autre celui de droite représente une femme assise, de profil à gauche, montrant également un ouvrage de broderie, à une femme debout à côté d'elle. Dédicace: Alla Magnifica et illustra signora, La signora Isabella Contessa Canossa Fra Hieronimo da Ciuidal di Frioli. Page non cotée, Alla Medema. Fin au verso. Page non cotée, L'autor de l'opera parla. C'est l'avis au lecteur. Au verso, une marque d'imprimeur d'un superbe caractère. Dans un cartouche entouré de cuirs enroulés, un lion passant de profil à droite, debout et tenant de ses deux pattes de devant une épée devant lui. Audessous du cartouche: In Padoa, per Jacobo Fabriano, ad instantia de Fra Hieronimo da Ciuidal di Frioli, de l'ordine de i sevui di Osservantia, MDLV (1555). 22 dessins de broderies. En somme 14 feuillets dont 11 de dessins. Voir le catalogue du Maréchal d'Estrées, tome I, $\mathrm{n}^{\circ} 8843.4^{\circ}$ or $8^{\circ}$ oblong. Bibliothèque de L'Arsenal. Bib Comm. Bologna.

790-Hill, E.-Abigail's Sampler: poem. St. Nicholas. V. 28, pp. 306-307. February, 1901.

791-Hind, C. L.-The Progress of the Industrial Arts-Lace. Art Journal, 1891, pp. 87-92.

792-Hirth, Geo.-Album for Ladies' Work, 1882.

793-Histoire de la Dentelle-par M. de-(Fertiault). Paris, Dépôt Belge, 1843.

795-Historische und die neuzeitliche Spitze in Muster-Beispielen, Die-24 Tafeln. Plauen, C. Stoll. 1909.

796-Hoare, Kath. L.-The Art of Tatting. Illus. London, etc. 1910. la. $8^{\circ}$. 797-Hochfelden, Brigitta-Ebhardt's Handarbeiten, das Klöppeln.

798-Hochfelden, Brigitta—Die Händchenspitze. (Point Lace).

799-Hoechstaedter, J. N.-Broderie Russe et Hongroise.

800-Hoepli, Ulrico-Pizzi antichi di Cesare Vecellio con una introduzione di A. Melani. Milan, U. Hoepli, 1886. See 1816.

801-Hoffman, Julius-Auswahl von Motiven aus: “Der Moderne Stil." 1906. 
802-Hofmann, Prof. R.-Moderne Spitzen, entworfen in der Königlichen Kunstschule für Textilindustrie in Plauen. Plauen, C. Stoll. 20 plates.

803-Hofman, R.-Muster für Textil-Industrie, série v. Plauen, Chr. Stoll, n.d. 804-Hofman, R.-Muster für 'Textil-Industrie, serie ii. Plauen, C. Stoll, n.d.

805-Hofman, R.-Spitzen aus dem Museum der Königl. Kunst-Schule für Textil-Industrie zu Plauen i. V. Plauen, Chr. Stoll, n.d.

806-Hofman, R.-Stilisirte Pflanzenforme, etc. . . série i, Spitzen. Plauen, Chr. Stoll, n.d.

807-Hofmann, R.-Weltausstellung, Paris, 1900. Die Vogtländische SpitzenStiekerei und Gardinen-Industrie. Flauen, C. Stoll, n.d.

808-Hoffman, H.-New Modelbüch, allen Nägerin, unnd Sydenstickern selır nutzlich zü branchē, vor nye in Druck aussgangen dureh Hans Hoffman, Burger und formschmeider zu Strassburg. At the end, Zu Strassburg Gedruckt am Kommarekt durch Jacob Frölieh. 1556. 4to. A to $\mathrm{G}$ in fours. (28 leaves.) Title printed in red and black. On it a woodcut of two women, one engaged in embroidery, the other fringing her some stuff. The last leaf (Giiii.) has on the recto a woodeut of a woman at a frame, the verso blank. Mr. E. Arnold.

809-Hoffman, Wilhelm-Gantzen Modelbuch Kunstlieher und lustiger Bistrung und muster. . . . \& Dureh Willhelm Hoffman Formenschneidern. Franefort. MDCVII (1607.) Ouvrag'e contenant des modèles d'eneognures et de frises pour broderies. Dessins blanes sur fond noir. Ces modèles sont très remarquables. En 1876, le musée de Vienne en a reproduit 20 pièces, dont 1 serie dans le S. K. M. Toire Guilmard.

810-Hoffmann, Wilhelm-Gantz new Modelbuch, Ki̊nstlicher vnd lustiger Visirung vnd Muster von allerhand schöner, artiger Ziogen vnd Blumwerek, zu jetzt gebräuehlichen, zierlichen. Italianischen, Frantzösischen, Teutchen vnd Fngelländischen Oberschlägen; So wol Sendenstickern, Sammetschneidem, vnd Natherinnen, als auch Sehreinêrn, Bilthauern vnd dergleiehen so zu soleher Künstlicher Arbeit lust vnd gefallen tragen, fiorgeriffen vnd fơr Augen gestellt Dureh Wilhelm Hoffman Formensehmeidern. Getruckt zu Franckfurt am Mayn, in Verlegung gemeltes Wilhelm Hoffmanns. M. DC.VIT. Fol. Title and 18 euts. (Munster reproduction.)

811-Hoffman, Wilhelm-Newes vollkommenes Modelbuch von vierhundert sehönen Ausserwehlten, Künstlichen vnd aussgesehnittenen, so wol Italiänischen, Frantzösischen, Niderländisehen, Engelländisehen, als Teutschen mödeln, dergleichen zuvor niemals gesehen worden, zugeriehtet, vnd jetzund zum Ersten mal, in dieser bequemliehen Form in Truek gegeben. Allen Nähterin, Seidenstickerin, Sehreinern, Steinmetzen, auch züehtigen: Frawen vnd Jungfrawen, zu Nutz vnd freundliehem Wolgefallen. Getruckt zu Franckfurt am Mayn, in Verlegung Wilhelm Hoffmanns, Anno 1604. Fol. Title and 17 euts. (Wasmuth reproduction.) Reprinted, 1878. Also reprinted Berlin, 1871 and 1891. 1891 reprint in B. M.

812-Hoffman, W._Gantz new Modelbuch, künstlieher und lustiger Visirung und Muster von allerhand sehöner, artiger Zügen und Blumwerck, etc. 
plates, including title.) Obl. fol. Franckfurt an Mayn, W. Hoffman, 1607. Reprint, Ongania, Venice, (1878.) S. K. M.

813-Hofer, Hans (Briefmaler)-New Formbuechlein der Weyssen Arbeyt. Augsburg, 1545. Quer-4. 40 doppelseitig bedruckte Bll. mit 80 Stickmustern.

814-Holme, Charles-Peasant Art in Austria and Hungary. The Studio, 1911. 815-Holme, Charles-Peasant Art in Russia. Special Number of the International Studio, 1912.

816-Holme, Charles-Peasant Art in Sweden, Lapland and Iceland. The Studio, 1910.

817-Homann, Elizabeth-Spitzenstudien aus Venedig. Kunstgewerbeblatt, November, 1896, Leipzig.

818-Honiton Lace-Article from the "Gentleman's Magazine," Jan., 1871. 8vo. London, 1871. S. K. M.

819-Honiton Lace. Every Saturday. V. 10, p. 275.

820-Honiton Lace-The Leisure Hour, August, 1869, London. V. 18, p. 539.

821-Honiton Lace-The Gentleman's Magazine, January, 1871, London.

822-Honiton Lace-The Saturday Review, Jan. 28, 1888, London. V. 65, p. 101.

823-Honiton Lace and the Technical Grant. Saturday Review, December, 1891, London.

824 -Honiton lace book, The: the second and enlarged edition of Honiton lacemaking. London (1875). $8^{\circ}$.

825-Honiton lace-making. London, (1873). $8^{\circ}$

826-Hooper, E. M.-Teaching a Child to Sew. Ladies Home Journal. V. 17, p. 32, November, 1900.

827-Hope, Mrs. G. C.-Six Square Doyleys in Crochet. (1848.)

828-Housiaux, Émile-Une Société belge-américaine. L'Industrie dentellière et l'église catholique. Le Peuple, Aug. 11, 1903, Brussels.

829-How Cushion Lace Was Invented. Chamber's Journal, Nov. 24, 1860, London.

830-How, J. W.-Florentine Bags. Harper's Bazaar. V. 45, p. 423. Sept. 1911.

831-Howarth, M.-How to Care for Real Lace. Harper's Bazaar. V. 46, p. 639. December, 1912.

832-Hrdlicka, J.-Col, éventail, ete. L'Art décoratif, November, 1901, Paris. 833-Hrdlicka, J.-Entwürfe Für Moderne Spitzen. Stuttgart, 1902. 30 plates. 8:34-H. S., Huquet y Crexells-Pilar. Historia y Technica del Encaje, 172 pp., 34 plates, Madrid, 1914.

835-Hubert, E.-Le voyage de Joseph II dans les Pays-Bas en 1781.

8:36-Hudson (O.)-Report on cotton print works and lace-making. See First report of Department of Practical Art, 1853, pp. 367-368. 8vo. Lond., 1853.

837-Huish, Mareus B.-Samplers and Tapestry Embroideries. 2 editions. Longmans Green \& Co., 1900.

838-Hunter, George Leland-Laces, Their Origin, Design and Manufacture. Good Furniture, April, 1917. Vol. 8, pp. 199-212. 


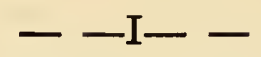

839-Ilg, Albert-Geschichte und Terminologie der alten Spitzen. Vienna, Leh. mann and Wentzel, 1876. Contains the introduction verbatin of "Patternbook" by "R. M."' published by Christoff Froschower, Zurich.

840 - Improved state of the plan for establishing manufactories of Blond and Black silk and thread Lace, An. No place or date.

841-l'Industrie de la dentelle en Bohème. Revue Scientifique, 1903.

842-l'Industrie dentellière-La dentelle à la main. Pour éviter sa déchéance. Un concours. Bull. Métiers d'art, 1905. Brussels.

843-Ingalls, J. F.-Hand book of crochet and knitted lace. J. F. Ingalls, Lynn, Mass., 1883. (Collection of Kursheedt Manufacturing Co.)

844-Irish Lace-The Magazine of Art, August, 1883, London. V. 6, p. 438.

845-Irish Lace. The Spectator. V. 56, p. 864.

846-Irish Lace-Report of Committee on Education. London, 1887, fol. B. M. 847-Irish Lace at the Mansion House-The Saturday Review, July, 1883, London.

848-Irish Lace Making-The Saturday Review, July 7, 1888, London.

849-Irwin, Elisabeth A.-Lace Makers of the Italian Quarter of New York. Craftsman. V. 12, pp. 404-409.

850-Italienisches Spitzenmuster aus dem Anfange des XVII. Jahrhunderts. Blätter für Kunstgewerbe, 1877, Vienna.

851-I., Jr., W. M. (W. M. Ivins, Jr.) - "Ornament" and the Sources of Design in the Decorative Arts. Bulletin of the Metropolitan Museum of Art, New York, February, 1918. p. 35.

\section{- - J - -}

852_Jackson, Mrs. F. Nevill-Cravats. The Connoisseur, August, 1904, London. V. 1, pp. 226-232.

853-Jackson, Mrs. F. Nevill-Ecclesiastical Lace, Ancient and Modern. Burlington Magazine. V. 4, pp. 54-64.

854-Jackson, Mrs. F. Nevill-The Evolution of Alençon Lace. Connoisseur, 1901. V. 1, pp. 219-223.

855-Jackson, Mrs. F. Nevill-A History of Hand-made Lace. London, L. Upcott Gill, 1900. B. M.

856-Jackson, Mrs. F. Nevill-Human Figures in Lace. Connoisseur. V. 4, pp. 183-187.

857-Jackson, Mrs. F. Nevill-Lace of the Van Dyke Period. Connoisseur. $V$. 2, pp. 106-115.

858-Jackson, Mrs. F. Nevill-On the Wearing of Old Lace. The Lady's Realm, August, 1899, London.

859-Jackson, Mrs. F. Nevill-The Romance of Lace. The Lady's Realm, January, 1902, London.

860-Jackson, Mrs. F. Nevill-Royal Lace. The Ladies Field, June, 1904, London.

861-Jackson, Mrs. F. Nevill-Ruffs. The Connoisseur, July, 1903, London. 
862-Jackson, Mrs. F. Nevill-Wedding Veils. The Lady's Realm, June 1899, London.

863-Jacques, G. M.-Nouvelles dentelles viennoises. L'Art décoratif, May, 1902, Paris.

864-Jamnig, C. and Richter, A.-Die Technik der geklöppelten Spitze. Original Entwürfe und Ausführungen nach Spitzensorten systematisch geordnet, etc. (41 photo. plates, with text.) fol. Wien, 1886 or 1885. S. K. M.

865-Jamnig, Carl and Richter, Adelaide-Vienna Manual.

866-Jannasch, R.-Die Textilindustrie bei den Ur-und Natur-völkern.

867-Jean le Maistre Tailleur-Recueil de Plvsievrs pièces de pourtraicture, très vtiles \& nécessaires généralement à tous Orfeures, Tailleur's, Graueurs, Damasquineurs, Sculpteurs, Paintres, Brodeurs, Tapissiers, Tissotiers, Couturiers, Lingières, et autres. A Lyon, par Iean Le Maistre Tailleur, d'histoires, demeurant en rue mercière et par Anthoine Voulant, 1565. Sur ce titre un médaillon ovale contenant une Minerve, en casque et cuirasse, de $3 / 4$ à droite, tête de profil de ce côté, une lance à la main, dont la pointe s'appuie par terre, au bas du tronc d'un olivier. Un des rejetons de cet olivier s'enlace autour de la lance de cette déesse. A gauche un dragon fantastique. Sur la bordure du médaillon, qui est partagée en six compartiments, on voit un mouton, une branche d'arbre, une corne d'abondance, un paon, deux épées croisées et un serpent. Au milieu de la page et coupés en deux par le médaillon, les mots: De grand-Labeur. Vient.-Abondance. Bibliothèque Nationale.

868-Jessen, Dr. P.—Das Stickmusterbuch des Andreas Bretschneider. Kunstgewerbeblatt, 1891, Leipzig.

869-Jesurum, Michel-Angelo-Cenni storichi sull' industria dei Merletti. Venice, 1873.

870-Jesurum Reproductions-since 1910. In J. P. Morgan Library.

871-Jobin, B.-New Künstlichs Modelbuch, von allerhand artlichen vn gerechten Modeln auff der Laden zu wircken, oder mit der zopffnot creutz vnd Judenstich vnd anderer gewonlicher weifs zu machen : Allen model Würckerin, Naderin vnd solcher modelarbeit geflissenen Weibebildern sehr dieustlich vnnd zu andern mustern anleytlich vnnd verstandig. Auff ein newes weder getrückt vnd mit vielen newer model gemehret. Mit Rom. Keys. May. Freyheit. Bey B. Jobin. (Strasburg.) In $-4^{\circ}$ oblong. 48 feuillets, le dernier est blanc. Un titre, un feuillet, contenant des vers et 45 planches de broderies imprimées au recto seulement.

872-Jobin, B.--New Künstlichs Modelbuch. Von allerhand artlichen vñ gerechten modëln, auf der Laden zu wircken, oder mit der Zopffnot, Kreutz vnd Judenstich vnd anderer gewonlicher weiss zu machen; Allen Modelwurckerin Räderin vnd solcher Modelarbeyt geflissenen Weibsbildern sehr dienstlich vnd zu andern Mustern anleytlich vnd vorstandig. Dissmals erstlich gegenwärtiger fleissiger gestalltantag geben mit Keys. Maÿ. Freiheyt. Bey B. Jobin. 1579. $4^{\circ} 45$ cuts. B. K. M.

873-Jobin, B.-New Künstlichs Modelbuch-[Another edition of No. 872.] 1589. B. K. M. 
874-J Jobin, B.-New Künstlichs Modelbuch-[Another edition of No. 872.] Auff ein newes wider getruckt vnd mit vielen newer Mödel gemehret- mit- Röm. Keys. May. Freyheit. Bey B. Jobin. 1600. (Strassburg.) 4to. obl. 45 plates. B. K. M.

875-Jobin, Bernhart-New Modelbuch fon Allerhand sonderbarn schonen modeln von der ietz gebreuchliche durch geschnittener arbeit durch h. Vinciolo ein venediger angeordnet. Jetzt aber allen Frawen Jungfrawen Naherinnen und dergleichen Kunstgeflissen en Personen zu sondern vorstand auffs new mit vermehrung und besserung viler schoner und lustiger modeln in truck gefertiget und an tag gebracht. Mit. Rom. Keyserlicher Majestat freyheit. Getruckt zu Strasburg bei Bernhart Jobin. Anno 1592. In- $8^{\circ}$ oblong. Titre imprimé en ronge et noir, au milieu d'un encadrement formé de modèles de point coupé et de dentelles. Rien au verso. ):(2 Le verso et le recto de cette page contiennent une dédicace aux femmes. Des deux côtés de cette dédicace au verso et au recto, deux petits nielles verticaux rectangulaires. ):(3 Planche de broderie. Bibliothèque Nationale.

876-Jobinus-New Modelbuch von allerhand sonderbarn schonen modeln von jetz gebreuchliche durch geschnittener arbeit durch h. Vinciolo ein venediger angeornet. Jetzt aber allen Frawen Jungfrawen naherin vnd der gleichen Kunstgeflissenen Personen zu sonderm verstand auffs new mit vermehrung vnd besserung viler schoner und lustiger Modeln in 'Truck gefertiget iend an tag gebracht. Mit Rom. Keyserlicher Mayestat freyheit. Getruckt zu Strasburg bey Jobinus Erben, an 1596. In- $8^{\circ}$ oblong. Titre rouge et noir dans un encadrement formé de petits carreaux et bandes de guipure. Rien au ver'so. Page suivante cotée $):(2$. Une pièce de vers. Ter'so, fin de la pièce de vers. Puis commencent les broderies imprimées seulement au recto, sauf aux 6 dernières planches où le verso en contient aussi. Ces broderies reproduisent presque toutes des motifs de Vinciolo. 44 feuillets et 48 planches de broderies. B. M.

877-Johmson-Browne, E. F.-On Lace-Making in Belgium. The Catholic World, July, 1900, New York. V. 71, pp. 443-459.

878-Johnston, Mrs. J. B.-A Short Historical Sketch on Lace. New York, 1895.

879-Jones, O.-Grammar of ornament. (Embroidered and woven fabrics, Plates 50, 51, 52 and 55,) 2 vols, fol. Lond., 1856. Other editions. Fol. Lond., 1865 and 1868. S. K. M.

880-Joor, H.-Decoration of Darning. Delineator. V. 79, p. 411, May, 1912. 881-Jorsin \& Sauvage-Esquisses [Paris, 19..?].

881a-Jorsin \& Sauvage-Formes d'Orient à l'usage des dessinateur's en broderie des fabricants de dentelles et de soieries [Paris, 19..?].

882_-Jouclard, Mlle. A. L., at Paris-Ridean et brise-bise. Art appliqué, 1re année, Paris.

883-Jourdain, M.-Alençon. Connoisseur. T. 14, pp. 92-96, 145-148.

884-Jourdain, M.-Argentan Lace. Connoisseur. T. 15, pp. 117-122.

885-Jourdain, M.-Brussels Lace. Connoisseur. T. 20, pp. 195-201. 
886-Jourdain, M.-C'utwork and Punto in Aria. Comoisseur. V. 11, pp. 13$17,98-103$.

887-Jourdain, M._Drawn Thread Work and Lace. Comoisseur, 1904. V. 10, pp. 235-237.

888-Jourdain, M.-English Lace. Connoisseur. V. 16, pp. 151-154.

889-Jourdain, M._English Pillow Lace. Connoisseur. V. 20, pp. 266-270. April, 1908 and following issues.

890-Jourdain, M.-English Pillow Lace. Connoisseur. V. 21, pp. 81-86.

891-Jourdain, M._-English Pillow Lace. Connoisseur. V. 30, pp. 266-270. April, 1908 and following issues.

892_-Jourdain, M._Gold and Silver Lace. Connoisseur. V. 17, pp. 9-12, 9296.

893-Jourdain, M.-Italian Lace. Art Workers Quarterly. V. 3, No. 11, pp. 105-109.

894 Jourdain, M.-Italian Pillow Lace. Connoisseur, 1906. V. 15, pp. 171-175.

895-Jourdain, M.-Lace as worn in England until the Accession of James 1st. Burlington Magazine, 1906. V. 10, pp. 162-168.

896- Jourdain, M.-The Lace Collection of Mr. Arthur Blackborne. Part I. The Burlington Magazine, September, 1904. Part II, Later Punto in Aria. The Burlington Magazine, October, 1904, London.

897-Jourdain, M.-Lace in the Collection of Mrs. Alfred Morrison at Fouthill. Burlington Magazine, 1903. V. 2, pp. 95-103.

898-Jourdain, M.-Lace Making in Spain and Portugal. Connoisseur, 1903. V. 7, pp. 244-247, Part I; V. 8, pp. 9-12. Part II.

899-Jourdain, M.-Mechlin and Antrerp Lace. Connoisseur, 1907. V. 19, pp. 103-108.

900-Jourdain, M.-Milanese Lace. Connoisseur. V. 16, pp. 36-41.

901-Jourdain, M.—Old Lace, a Hand-Book for Collectors. London, B. T. Batsford, 1908. B. M.

902_Jourdain, M._Point de Venise à Réseau. Connoisseur, 1905. V. 13, pp. 40-43.

902a-Jourdain, M.-Valenciennes Lace. Connoisseur. V. 13, pp. 81-84, 169170 .

903-Jourdain, M.-Tenetian Needlepoint Lace. Connoisseur. V. 12, pp. 145151, 241-246.

904-Joyce, T. A.-Central African Embroidery. Burlington Magazine. V. 21, pp. 80-91, May, 1912.

905 - Juillien, Mme. H. H. de-Manuel de dentelles aux Fuseaux. Neuchâtel, Switzerland.

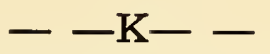

906-Kahrn, A.-New Model buch Darinnen zum nelıen allerhandt schone newe Modelen zu finndenn seinn. Durch Andream Kahrn zi̊ Kuppfer gebraclıt. Anno Dōi 1626. Title and 49 engravings, signed A. K. B. K. M.

907-Kalesse, E.-Romische Stickereinen. "Kunst und Gewerbe," Vol. XIX., p. 44. 4to. Nürnberg, 1885. S. K. MI.

908-Kantwerk uit het laatst der 17e eeuw. Amsterdam, 1877. 
909-Kantwerkschool on der de Zinspreuk: "Doet wel en ziet niet om." Gevestigd to Sluis, in Zeeland, 5de-9de Verslag (1858-1862). (Middlebourg, J. C. et W. Altorffer.)

910-Katalog der in Germanischen Museum befindlichen Gewebe und Stickereien, etc. Nuremberg, 1869. 20 plates.

911-Kaufmann, Hartwig-Battist-Taschentuch mit Nadelspitze ausgefuhrt zu Schneeberg. Zeitschr. des Bayr. Kunstgew. Verein in Munchen, 1889.

912-Kay, P.-Embroidered Filet Curtains. Harper's Bazaar. V. 40, pp. 561563, June, 1906.

913-Kellogg, C.-Artistic Household Needlework. Harper's Bazaar. V. 40, pp. 271-273, March, 1906.

914-Kellogg, Charlotte-Women of Belgium. Funk \& Wagnalls, 1917, New York.

915-Kendrick, A. F.-English Embroidery. London, G. Newnes, 1904.

916-Kerzman, M. L.-Drawn work. N. Bristow, N. Y., 1883. (Collection of Kursheedt Manufacturing Co., N. Y.)

917-Kerzman, M. L.-Fine Crochet Work. N. Bristow, 1883. (Collection of Kursheedt Manufacturing Co.)

918-Kerzman, M.L.-How to Crochet. N. Bristow, 1883. (Collection of Kursheedt Manufacturing Co.)

919-Kerzman. M. L.-Maltese or Hair-pin Crochet Work. N. Bristow, 1883. (Collection of Kursheedt Manufacturing Co.)

920-Kerzman, M. L.-Miscellaneous Designs for Crochet Work. N. Bristow, 1883. (Collection of Kursheedt Manufacturing Co.)

921-Kerzman, M. L.-Twine Crochet Work. N. Bristow, $1883 . \quad$ (Collection of Kursheedt Manufacturing Co.)

922-K., F.-Question of Lace Making. International Studio. V. 47, pp. 324326, October, 1912.

923-King, Eleanor G., at Bradford-Barbe. Art appliqué, 1re année, Paris.

924-Kingsley, R. G.-Flemish embroideries, old and new. "The Art Jour." 1887. S. K. M.

925-Kingsley, R. C.-A Lace School at Bruges. Art Journal, 1887, pp. 81-84, V. 39.

926-Kissell, Mary Lois-Papago and Pima Indians. An account of original point lace. Published in pamphlet form by the Museum of Natural History, N. Y.

927-Kleinpaul, Dr. Joh.-Sächsische Reliefspitzen-Klöppelei. Illustrirte Zeitung, April 18, 1901, Leipzig.

928-Klickmann, F.-The Modern Crochet Book. (1914).

929-Klöppelei-Daheim, 1895, Leipzig.

930-Klöppelspitzen; hrsg. von der Kgl. Zeichenschule für Textilindustrie u. Gewerbe zu Schneeberg. Plauen, C. Stoll, 1912 (?).

931-Knitter's Note-book. 62 pages. London, 1890. In British Museum.

932-Knobe, B. D.-Lace-makers of Belgium. Woman's Home Companion, V. 31, p. 47, August, 1904.

933-Koch, Marie-Hardanger Art Embroidery. (Collection of Kursheedt Manufacturing Co., N. Y.) 
934-Kohlsaat, Amy M.-Old Iace Manual. New York, privately printed, 1910. 935-Kossatchewa, O. P.-Ukrainskie ornament. (Plates.) Fol. Kiejv, 1877. 936-Koula, Jan-Choix de Broderies populaires tchèques du Musée Industriel Náprstek. Prague, F. Simacka, 1893.

937-Kraft, Prof. Max-Die neue Klöppelmaschine von Aug. Matitsch. Dinglers Politechnisches Journal, May 28, 1897, Stuttgart.

938-Kral, Joseph-De la dentelle au, fuseau en Bohême (en tchèque). Vrychnově, Ch. Rathouského, 1894.

939-Krame, Mrs. T.-Circular Drawn-work. Ladies Home Journal, V. 23, p. 58, June, 1906.

940-Kretz, Fr.-Kapitola o Krajkářstvi ceskoslovenském (De la dentelle tchèque ou slave). Cesky̆ Lid (Le Peuple tchèque), 1899, Prague.

941-Kretz, Franz-Maerish-Slovakische Hauben. Vienna, Ant. Schroll \& Co., 1902.

942-Kretz, Franz-Slowakische Netzarbeiten. Zeitschrift für österreichische, Volkskunde, 1901, Vienna.

943-Kreuzmann, Moritz-Dentelles Veritables. Nouveau Choix de Points divers. 30 planches. Zurich.

944-Kuehn, N.-Colored Patterns for Cross-stitch Work. 9 photographs. (Collection of Kursheedt Manufacturing Co., N. Y.)

945-Kuehn, N.-Cross-stiteh embroidery book. Vols. 221, 1892, 12. Kuehn, Berlin. (Collection of Kursheedt Mamufacturing Co.)

946-Kumsch, E.-Das alteste aller bekannten Modelbucher. Kunst und Kunsthandwerk, N. 12, 1903 . Vienna.

947-Kumsch, E.-Laces and Embroidery on Linen, 16, 17 and 18 Centuries. 50 plates.

948-Kumsch, E.-Spitzen und Weiss-Stickerei. 50 plates. Stengel \& Markert, 1889. (Collection of Kursheedt Manufacturing Co.)

949-Kůnig, L.-Fewrnew Modelbuch, Van allerhandt Kůnstlicher Arbeidt, namlich Gestrickt, Aussgezogen, Aussgeschnitten, Gewiesslet, Gestickt, Gewirckt, vnd Geneyt; von Wollen, Garn, Faden, oder Senden; auss der Laden, vnd Sonderlich auss der Ramen. Yetzt Erstmals in Teutschlandt an Tag gebracht: Zu Ehren vnd Gliocklicher zeitvertriebung allen dugenesamen Frawen, vnd Jungfrawen, Nåtherinen, auch allen andern, so lust zu solcher Ko̊nstlicher Arbeit haben, sehr dienstlicht. Getruckt zu Basel, In verlegung Ludwig Künigs. M.D.XCIX. $4^{\circ}$. Title page and 3 cuts (incomplete). V. \& A. M.

950-Künig, Ludwig-Fewrnew Modelbuch von allerhandt KünstlicherArbeidt, nämlich Gestricht, Aussgezogen Aussgeschnitten, Gewiefflet, Gesticht, Gewirckt, und Geneyt : von Wollen, Garn, Faden, oder Seyden : auff der Laden, und Sonderlich auff den Ramen, Jetzt Erstmals in Teutschlandt an Tag gebracht: Zu Ehren und Glūcklicher Zeitvetreibung allen dugentsamen Frawen, und Jungfrawen Nächerinen, auch allen andern, so lust zu solcher Kunstlicher Arbeit haben sehr dienstlich. Gertruckt zu Basel. In verlegung Ludwig Kūnigs MDXCIX. Small obl., 33 ff., 32 plates. Frontispiece border of point coupé. Title in Gothic red and black. Patterns, 
mostly borders, number of stitches given, "Mit xxxxvii., Bengen," etc. In$4^{\circ}$. Bib. Nat.

951-Künig (Konig), Ludwig-Schon Neues Modelbuch von allerley lüstigen Modeln naazu nehen Zuwurcken vn Zusticken gemacht in Jar. Ch. 1599. Gemacht zu Basel. In verlegung Ludwig Konigs. Anno MDXCIX (1599). In- $4^{\circ}$ oblong. 36 feuilles imprimés au recto seulement et contenant 70 modèles de broderies. Sur le titre gravé sur bois, il y a 7 femmes travaillant.

952-Kunstgewerbe-Museum zu Leipzig. Egenolff, Chr. Modelbüch aller Art Nehewercks, etc., herausgegeben unter Redaction des Prof. M. zur Strassen. Dresden, G. Gilbers, 1880.

953-Kunstgewerbe-Schule (Königl.) z u Dresden. Katalog der Bibliothek, IX Textilarbeiten. Dresden, W. Hoffman, 1896.

954-Lace-20 photographs. (Collection of Kursheedt Manufacturing Co., N. Y.)

955-Lace-25 Photographs. P. Calavas. (Collection of Kursheedt Manufacturing Co., N. Y.)

956-Lace-35 photographs. P. Calavas. (Collection of Kursheedt Manufacturing Co., N. Y.)

957-Lace-Part XII. of "The Industrial Arts." (South Kensington Mus. Art Handbooks.) 8vo. "Lond., 1876.

958-Lace. Art Journal, V. 17, p. 86.

959-Lace (Filet brodé). The Connoisseur, September, 1902, London.

960-Lace. Every Saturday, V. 5, p. 729.

961-Lace. Knickerbocker, V. 64, p. 127.

962-Lace. Leisure Hour. V. 19, p. 388.

963-Lace. Once a Week, May 9, 1868, London. V. 18, p. 413.

964-Lace Ancient and Modern. Victoria, V. 23, p. 145.

965-Lace and Bric-à-brac. Blackwood's Edinburgh Magazine, January, 1876, Edinburgh, V. 119, p. 59.

966-Lace and Embroidery. Saturday Review, T. 66, p. 305.

967-Laces and Embroideries. Godey, V. 57, p. 155.

968-Lace and Embroidery Association-Appoints committee to keep in touch with work of Secretary McAdoo's Commission scheduling St. Gall embroideries. N. Y. Times, May 12, 14:4.

969-Lace and Embroidery Association tells of concessions made by government in Nottingham cases, N. Y. Times, May 16, 18:4.

970-Lace and Embroidery Review, The-New York, Clifford \& Lawton.

971-Lace and its Varieties. Chamber's Journal, July 1, $1891 . \quad$ London and Edinburgh. V. 68, p. 362.

972-Lace and Lacemaking-From Chamber"s "Repository of Instructive and amusing Tracts.", 8vo. (1847) S. K. M.

973-Lace Cap and Slipper Piece for the Baby. Ladies' Home Journal, V. 20, p. 42, October, 1903. 
974-Lace Collection of Mr. Arthur Blackborne, The-Burlington Magazine, V. 5, pp. 557-569; V. 6, pp. 18-20, 123-135, 384-390.

975-Lace Dress, A-(Robe Empire en Point de Lille). The Connoisseur, October, 1902, London.

976-Lace Fanciers' Directory.

977-Lace-French manufacturers increase prices, N. Y. Times, Nov. 21, III, $8: 3$. 978-Lace Industry of Calais, The-Journal of the Society of Arts, Oct. 8, 1897, London, V. 45, p. 1135.

979-Lace in the Tenements-Charities, V. 14, p. 1036.

980-Lace Makers-Served out; or The two Lace Makers. By the author of "Harvest Time at Agsdon." 32 pages. 1879. In British Museum.

981-Lace-making as a Fine Art. The Edinburgh Review, January, 1872, Edinburgh.

982-Lace-Making at Nottingham. Eclectic Magazine, V. 99, p. 755.

983--Lace Making by North American Indians. American Artist, Vol. 3, No. 19.

984-Lace-Making in Treland. Saturday Review, V. 66, p. 23.

985-Lace Making, Past and Present. The Artist, 1902, London.

986-Lace Manufacturies at Nottingham. Penny Magazine, V. 12, p. 113.

987-Lace Merchant of Namur, a Tale. Blackwoods, V. 44, p. 245.

988-Lace of Assam-Journal of the Society of Arts, V. 49, p. 192.

989-Laces-Fashion developments, pictures of samples from H. B. Claflin's, N. Y. Times, July 5, VIII, 8:3; raise in price due to war, Aug. 6, $13: 3$; new high record in prices, Ang. 26, 11:3; big demand will keep domestic plants busy, Sept. 26, $12: 3$; buyers displeased at false war scare, Sept. $26,13: 8$.

990-Lace, Sale of Heirlooms at Woman's Exchange. N. Y. Times, Feb. 7, 5:3. 991-Lace-The Case of the Lacemaker's in relations to importation of Foreign Bone Lace. (Parliamentary Paper). 8vo. Lond., 1898. S. K. M.

992-Lace-The Queen Lace Book: a historical and descriptive account of all the lrand-made antique Laces of all countries. Illus. 4to. Lond., 1874. S. K. M.

993-Lace Trade and Factory Act. New Quarterly, V. 9, p. 112.

994-Lace Trade and Factory Act. Reprinted from the New Quarterly Review, revised and enlarged, 3 d edition. London, 1860. B. M.

995-Lace Trade-Conditions. N. Y. Times, Oct. 10, $15: 4$; French laces will be scarce, due to war, N. Y. Times, Nov. 25, $15: 4$.

996-Lace Trade-General Purposes Committee, Education Committee, and School of Art Committee of Nottingham Corporation confer on need of technical training in lace trade on request from Federation of Lace and Embroidery Employers' Associations, N. Y. Times, August 12, II, $5: 3$.

997-Lace Trade-Import statistics, N. Y. Times, Oct. 16, $5: 3$.

998-Lace Trade-Some manufacturers sell goods by mail, N. Y. Times, May 14, I, 11:2; buyers report heavy inc reases in prices, May 26, $17: 6$; D. T. Bidwell says Italians give America credit for saving industry in Venice from annihilation by war, June 21, $9: 2$. 
999-Lace Vestment, Representing Scenes from the Old Testament. Connoisseur, Vol. 4, p. 64, 1903.

1000-Ladies' Guide to Elegant Lace Patterns. Gloucester, Mass., 1883.

1001-Lady's Album of Fancy Work. London, 1850. 4to.

1002-Lady's Lace Book, The-London, Ward, Lock and Co., 1882.

1003-Laimoxen, B.-See Sibmacher, J.

1004-Laimoxen, B.-Schönn neues Modelbuch von allerley lüstigen Mödeln naczunehen zu würken un zu sticke; gemacht im Jar Ch. 1597, zu Nürmberg, bey Balthaser Laimoxen zu erfragen. Obl. fol., $27 \mathrm{ff.} 5$ sheets, title-page, and poem, signed J. S. (Johann Sibmacher). Mr. Gruner has communicated to us a work with the same title, dated 1591. Berlin, Royal Library.

1005-Laimoscen, Balthasar-Schon newes Modelbuch von allerley lüstingen Modeln noezunehen zu würcken vn zu sticke. Gemacht in Jar Chr. 1597. Zu Nurmberg bei Balthasar Laimoscen zuer fragen. In- $4^{\circ}$ oblong. Edition originale de ce beau livre de modèles de broderies est de la plus grande rareté. L'exemplaire est complet et consiste en un titre. 4 feuillets de texte, et 35 planches gravées contenant chacune 2 modèles de broderies. Mme. Bury-Palliser dans sa bibliographie n'indique que 27 feuillets. Suivant elle, il y aurait au Musée des arts et de l'industrie de Dresde, un ouvrage allemand portant le même titre avec la date de 1591. Bibliothèque Impériale de Berlin.

1006-Lalande, Pierre-Le Point d'Alençon. Le Monde Moderne, May, 1901, Paris.

1007-Lalor, Mrs. Power-The Irish Papal Jubilee Lace. The Magazine of Art, April, 1888, London, V. 11, p. 200.

1008-Lambert, Miss-Church needlework. 8vo. Lond., 1844.

1009-Lançon, Mlle., Inspectrice du Travail à Tunis, Service Economique Indigène, Galerie d'Orléans-Dentelle Tunisienne.

1010-Land der Spitzen (Burano), Das-Daheim, Jan. 12, 1889, Leipzig.

1011-Lantsheere, Carlier de-Dentellesà la Main-véritables-Points de France et Venise. Plauen, C. Stoll.

1012-Lantsheere, Carlier de-Dentelles à la Main-Galliéra, Paris. Plauen, C. Stoll.

1013-Lantsheere, Carlier de-Dentelles à la Main, Cluny, Paris. Plauen, C. Stoll.

1014 -Lantsheere, Carlier de-Dentelles à la Main anciennes, du Musée des Arts Décoratifs, Paris. Plauen, C. Stoll.

1015-Lantsheere, Carlier de-Les Dentelles à la Main. Paris, A. Calavas, 1906. B. M.

1016-Lantsheere, A. Carlier de-Dentelles à la Main du Musée Historique des Tissus de Lyon, 26 Tafeln. Plauen, C. Stoll.

1017-Lantsheere, Carlier de-Les dentelles à la main; dentelles aux fuseaux; dentelles à l'aiguille; dentelles à points mélangés. 135 planches. Publié sous le patronage du Gouvernement Belge. Brussels, 1907, folio.

1018-Lapauze, Henri-L'Art de la Dentelle française. Femina, April 15, 1904. 
1019-Lapauze, Henri-Exposition de l'Art de la Dentelle française au Musée Galliéra. Rapport général. Paris, Libr.-impr. Réunies, 1904.

1020-Lapauze, Henri-Mélanges sur l'Art français. L'Art de la Dentelle française. Paris, Hachette et Cie., 1905.

1021-Laprade, Laurence de-A propos d'une Nappe de Dentelle. Art et Décoration, 1912, V. 32, pp. 47-50.

1022-Laprade, Laurence de-La dentelle à la Main-la Broderie ajourée, la Guipure, au Musée Galliéra, Paris, 1904.

1023-Laprade, Laurence de-Dessins de Filet Modern. Art et Décoration, 1912, V. 31, pp. 59-68.

1024 -Laprade, Mme. L. de-Le Point de France et les Centres dentelliers au 17 e et 18 e Siècles. Paris, Roths child, 1905. B. M.

1025-Laprade, Laurence de-Le Point de Venise. Art et Décoration, 1912, Vol. 31, pp. 159-164.

1026-La Salle, Philippe de-Musée historique des tissus de Lyon. Calavas, Paris, 1906. 35 pages. (Collection of Kursheedt Manufacturing Co., N. Y.)

1027-Latomus, S.-Schön newes Modelbuch von 500 schönen aussor wählten, Kunstlichen, so wol Italiähnischen, Frantzösischen, Niederländischen, Engelländischen, als Teutschen Mödeln, Allen, Näher . . . hstichern, \&c., zu nutz. At the foot of last page recto is, "Franckfurt am Mayn, bey Sigismund Latomus, 1605." Small obl. 100 plates and coloured title-page with figures.

1028-Latomus, S.-Schön newes Modelbuch, Von hundert vnd achtzig schönen kunstreichen vnd gerechten Mödeln, Teutsche vnd Welsche, welche auff mancherley Art Können geneet werden, als mit Zopffnath, Creutz vnud Judenstich, auch auff Laden zu wircken: Dessgleichen von ausserlesenen Zinnigen oder Spitzen. Frandfurt a M., 1605.

1029-Latomus, S.-Schön newes Modelbuch Von 500 schönen ausserwehlten Kunstlichen so wol Italianisch en Franzosischen, Niderlandischen, Engellandischen als Teutchen Mödeln, Allen Näherin Seydenstrickern, etc., zu nutz. Getruckt zu Franckfort am Meyn durch Sigismundum Latomum, Im Jahr 1606. $\quad 8^{\circ}$. (Sheet K missing.) $\quad$ B. K. M. Bibliothèque Nationale. Nuremberg, German Museum.

1030-Latomus, S.-Schön newes Modelbuch, Von hundert vnd achtzig schönen kunstreichen vnd gerechten Mödeln, Teutsche vnd Welsche, welche auff mancherley Art können geneet werden, als mit Zopffnath, Creutz vnnd Judenstich, auch auff Laden zu wircken: Dessgleichen von ausserlesenen Zinnigen oder Spitzen. Allen Seydenstickern, Mödelwirckerin, Näderin, vnd solcher Arbeitgeflissenen Weibsbildern sehr dienstlich, vnd zu andern Mustern anleytlich vnd verstendig. Franckfurt am Mayn, in Verlegung Sigismundi Latomi. M.DC.VII. (1607.) Small 4to obl. 180 patterns. On the title-page are two ladies, one working at a pillow, the other at a frame; in the back-ground, other women employed at various works. Another copy dated 1629. Stockholm Royal Library.

1031-Latomus, Sigismund-Schon newes Modelbuch von 500 schonen aus ser wechlten Künstlicher so wol Italianischen, Frantzosichen Nider landisch- 
en, Engellandischen, als Teutschen modeln allen natherin seydenstickern et zu nutz. Getrucht zu Francfort em Mayn durch Sigismundum Latomus. Im Jahr 1608. Titre moitié ronge, moitie noir inscrit dans un encadrement orné de volutes et de fruits. Les mots Schon newes Modelbuch, sont en haut de l'encadrement au milieu dans un cartouche. En bas à gauche une femme tenant un miroir. Au-dessus de sa tête une étoile lumineuse avec le mot visus. A droit une femme tenant un oiseau sur le poing,avec au-dessus de sa tête une toile d'araignée, et le mot Tactus. En bas au milieu, dans un cartouche ovale, un homme à gauche assis de profil á droit et travaillant à un métier. A droite deux femmes assises, un métier sur leurs genoux. Au fond d'autres ouvrières. Au premier plan un chat. En tout 96 pages dont un titre et 95 planches de broderies, imprimées au recto seulement. Il y a une édition de 1605, au musée allemand de Nuremberg et une de $160 \bar{\gamma}$, contenant 180 patrons à la Bibliothèque Royale de Stockholm. Bibliographie de Mme. Bury-Palliser. Bibliothèque Nationale.

1032-Latomus, Sigismund-Schon newes Modelbuch, Ton Zwey hundert vnd Achtzig. . Mödeln. Getruckt zu Franckfurt am Mayn bey Sigismundi Latomi S. Erben. M.D.CXXIX. (1629.) $4^{\circ}$. Title and 58 cuts. B.K.M.

1033-Lavington, Clara, at Leeds-Dessin pour éventail en dentelle. Art appliqué, 1re année, Paris.

1034-Lawrence, Ellen-Priscilla Bobbin Lace Book. The Priscilla Publishing Co., Boston.

1035-Lay, F. and Fischbach, F.-Südslavische ornamente, gesammelt und herausgegeben von F. L. 4to. Hanau am Main. n.d. S. K. M.

1036-Le Breton, G.-Les Dentelles anciennes, etc. In l'Union centrale des Arts décoratifs: Les Arts du Bois, ete. pp. 199-219. (Illus.) 4to. Paris, 1883. S. K. M.

1037-Le Breton, Gaston-La Tissuterie ancienne. Les Dentelles et les toiles peintes et imprimées à l'Exposition de l'Union centrale. Gazette des BeauxArts, 1883, Paris.

1038-Lefébure, Auguste-L'Art dans le dessin et la fabrication de la Dentelle. (Album de la Dentelle. Exposition Internationale de Liége, 1905. Numéro spécial de La Dentelle, 1905.)

1039-Lefébure, A.-Dentelles et guipures anciennes et modernes. Paris, 1904. B. II.

1040-Lefébure, Ernest-Broderie et Dentelle. Paris, Picard et Kaan.

1041-Lefébure, Ernest-Broderies et Dentelles. Paris, 1887, 1 vol., 8vo, paper covers. B. M.

1042_-Lefébure, Ernest-Dentelles à l'Exposition Universelle Internationale de 1900 à Paris. Paris, 1900.

1043-Lefébure, Ernest-L'écharpe en blonde polychrome offerte à l'impératrice de Russie. Revue des Arts décoratifs, 1900, Paris.

1044-Lefébure, Ernest-Embroidery and Lace; their Manufacture and History from the remotest antiquity to the present day. Translated by Alan S. Cole. London, H. Grevel \& Co., 1888. B. M. 
1045-Lefébure, Ernest-Exposition de 1889, à Paris. Rapports du Jury International. Classe 34. Rapport de M. Ernest Lefébure. Paris, Impr. nationale, 1891.

1046-Lefébure, Ernest-Les Points de France. 'Translated by Margaret 'T. Johnstou. New York, 1912.

1047-Lefébure Laboulaye (C. P.)-Dictionaire des Arts et Manufactures, etc. (Broderie et Dentelle, Vol. I.) Plates, 3 vols. 8vo. Paris, 1852-61. S. K. M.

1048--Leftwich, Arabel-Point Lace. The Lady's Realm, Jauuary, 1897, London.

1049-Leland, C. G.-Art Work Leaflets. No. 4. Art Work on Linen. 4 to. N. Y. 1881-82. S. K. M.

1050-Lemaire, Gustave-Exposition de Liége en 1905. Comité Spécial de la Dentelle. Discours prononcé à la séance d'installation, le 18 mai, 1904. Brussels.

1051-Lemaire, Henri-La Dentelle. Paris, 1902. About 1500 designs in all. 1052-Lemaire, Henri-Dentelles inédites. Dessins nouveaux. (Paris, Rouveyre.)

1053-Lemaire, Henri (dessinateur)-Documents et Modèles utilisables dans toutes les industries d'Art. L'Industrie dentellière. Recueil de 1600 documents. Publiés en 130 Planches. Reproductions de dentelle véritable depuis le XVe siècle jusqu'à 1904, et Esquisses originales pour dentelle mécanique. Paris, Ed. Rouveyre, n. d.

1054 -Lemaire, Henri-La fleur appliquée à l'industrie des Tulles etc. (Paris, Rouveyre.)

1056-Lemaire, Hemri-Motifs variés pour Rideaux, Broderies, Dentelles, etc. (Paris, Rouveyre.)

1057-Leneveux, Mme. Louise-Histoire de la Dentelle. Joumal des Demoiselles, 1846, Brussels.

1058-Le Roy de Sainte-Croix, Dr.-Parement d'Autel ancien en Dentelle et Broderie appartenant à Mrs. Hailstone, etc. Paris, Em. Leroux, 1874.

1059-Lescure, A.-Collection A. Lescure-Gestickte Koragen mitte des 19. Jahrhunderts. Plauen, C. F. Schulz \& Co., 1910.

1060-Leslie, Marion-A Spinning and Weaving School. The Lady's Realm, September, 1899, London.

1061-Lessing (J.)-Muster altdeutscher Leinenstickerei. 4 parts. (44 plates of designs for needlework, including alphabets.) 4to. Berlin, 1878-82. S. K. M.

1062_Lessing, Julius-Muster altdeutscher Leinenstickerei. Erste und zweite Sammlung, Berlin, Fr. Lipperheide, 1897.

1063-Lesson in Darning Filet Net. Craftsman, V. 23, pp. 356-359, Dec., 1912. 1064 -Levetus, A. S.-Austrian Peasant Lace. International Studio, V. 27, pp. 209-218.

1065-Levetus, A. S.-The Revival of Lace Making in Hungary. International Studio, 1910, V. 42, pp. 30-35.

1066-Levetus, A. S.-Some Modern Austrian Pillow and Point Lace. International Studio, V. 18, pp. 163-173. 
1067-Levetus, A. S.-Some Modern Austrian Pillow and Point Lace. The Studio, 1905, London.

1068-Levetus, A. S.-The State Schools for Lace-Making in Austria. The Studio, 1905, London.

1069-Levetus, A. S.-State Schools of Lace-Making in Austria. International Studio, 1905, V. 27, pp. 19-30.

1070-Librairie des Arts Décoratifs-Choix de Dentelles (Part of the Lyon's Collection: points d'Alençon, de Valenciennes, de Malines, de Bruxelles, etc.) 26 plates, Paris.

1071-Lichtwark, Alfred-Heinrich Steyner's Modelbuch. Kunstgewerbeblatt 1887, Leipzig.

1072-Liedts-Anciennes dentelles belges formant la collection de Feu Madame Augusta Baronne Liedts et donnée au Musée de Gruuthuus à Bruges. Publié en 1889. Un volume in folio de 185 superbes planches en phototypie, le portrait de la donatrice et les tables. Ouvrage capital sur les anciennes dentelles belges qui ne fut pas mis dans le commerce et qui ne fut tiré qu' à 75 exemplaires.

1073-Liedts, Baron-Catalogue du Musée Gruuthuuse à Bruges. Bruges, 1880 . 1074-Liége, Exposition de-Les Dentelles de Belgique. Paris, 1905. B. M. 1075-Lindsey, B.-Irish Lace. 33 pp. Dublin, 1886. 8vo. B. M.

1076-Lipperheide, Frieda-Häusliche Kunst. Berlin, Fr. Lipperheide, 189193.

1077-Lipperheide, Frieda-Muster altitalienischer Leinenstickerei. Erste und zweite Sammlung. Berlin, Fr. Lipperheide, 1883-1892.

1078-Lipperheide, F.-Old Ttalian Patterns for Linen Cross-stitch Work. 30 plates. Ber. Lipperheide, 1882. (Collection of Kursheedt Manufacturing Co., N. Y.)

1079-Lipperheide, Frieda-Das Spitzenklöppeln. Berlin, Fr. Lipperheide, 1898.

1080-List of Books on Lace and Needlework in the National Art Library, A(South Kensington Museum). London, Geo. E. Eyre \& W. Spottiswoode, 1879.

1081-List of Books and Pamphlets in the National Art Library, South Kensington Museum, A-Part II. Lace and Needlework. London, Eyre \& Spottiswoode, n.d.

1082-Liste des Linges et des Ornaments préeieux d'église, dont on peut faire l'acquisition, ete. (vente en Belgique à la suite de la suppression des couvents, 1775.) n.p. n.d̉.

1083-Little Lace Girl, The-By the author" of "The Conceited Pig." London, 1848. In British Museum.

1084 -Livre de figures ponctuées contenant plusieur's dessins pour apprendre à marquer le linge, à faire de la broderie et de la tapisserie. In $-4^{\circ}$ de $40 \mathrm{ff}$. Les rectos sont des planches gravées. Manuel du Libraire de Brunet. Vente Lavallière. Vente Mac-Carthy.

1085-Lockwood, M. S.-Lace Dreams in Woven Thread. Cosmopolitan, V. 20, p. 177. 
1086-Lockwood, M. S. and Glaiser, E.-Art Embroidery; a treatise on the revived practice of Decorative Needlework, 19 col. plates. 4to. Lond., 1878.

1087-Lodian, L.-Virgin Lace (lace-bark) of the Tropics. Scientific American, V. 92, p. 304, April 29, 1905.

1088-Loeben, Max Georg von-Der Absatz der Plauener Spitzen nach den Vereinigten Staaten von Nord-Amerika. Dresden, V. V. Böhmert, 1905.

1089-London Exhibition, 1851; Reports of the Juries, Class XIX, Tapestry, Lace and Embroidery, etc. pp. 460-476. London, 1852.

1090-London Exhibition Reports-French. Vol. V. Dentelles, Tulles et Broderies, par F. Aubrey. 8 vols. 8vo. Paris, 1854-60.

1091-London Exhibition, 1862 ; Reports of the Juries, Class XXIV. Tapestry, Lace and Embroidery. London, 1863.

1092-London Exhibition-France: Commission Supérieure. Rapports. (Dentelles et Broderies, p. 73.) 8vo. Paris, 1872.

1093-London Exhibition-Reports. Division II., Part IX. Needlework in Schools. 4to. Lond., 1871.

1094-London Exhibition-Reports. French. Dentelles, Broderie, Passementes et Tapisserie, Vol. V., p. 201. 7 vols. 8vo. Paris, 1862-64.

1095-London Exhibition, 1871-Reports. Fine Art Div'n. Part IV. Lace; Embroidery, ete. 4to. Lond., 1871.

1096-Loon, Ernest van-De Kantindustrie in Frankrijen Italie. 'S. Gravenhage, 1907.

1097-Lord, K.-Honiton and the Revival of Lace-making in Devon. Craftsman, V. 17, pp. 444-451, January, 1910.

1098-Lord, Katherine-How to make Irish Laces at Home. Craftsman, 1910, V. 18, pp. 492-496.

1099-Lord, Katherine-A Lesson in Making Filet Lace. Craftsman, 1909, V. 17, pp. 208-214. November.

1100-Lord, Katherine-Real Lace. The Delineator, June, 1917, New York. V. 90, pp. 32-3.

1101-Loubier, Jean-Ein Venezianisches Modelbuch von Jahre, 1559. Z. und sch. f. Bücherfreunde, V. 1, pp. 85-91.

1102-Louvre, Musée des Arts Décoratifs. Les Dentelles anciennes du Musée. 1906. fol.

1103-Lovett, Eva-An Italian Lace School in New York. New York, 1906. International Studio, V. 29, pp. 12-19, July.

1104 -Lovett, Eva-The Lace Collection of the Metropolitan Museum of Art. International Studio, 1906. V. 29, pp. 71-76, 80-85. Brush and Pencil. V. 18, p. 10.

1105-Lovett, Eva-Lace and Lace-Making at Pratt Institute. International Studio, New York, 1907. V. 32, pp. 58-61. August.

1106-Lowe, G. A.-Filet Lace-making at Home. Harper's Bazaar. V. 43, pp. 280-281, March, 1909.

1107-Lowe, G. A.-Simple Cut-work Designs. Harper's Bazaar. V. 43, pp. 507-509, May, 1909. 
1108-Lowes, Mr's. Emily L.-Chats on Old Lace and Needlework. London, T. F. Unwin, 1908. B. M.

1109-Lucretia Romana-Corona delle nobili et virtuose donne. Libro terzo. Nel quale si dimostra in varii dissegni tutte le sorti di Mostre di punti tagliati e punti in aria, punti Fiamengli, punti a Retcello, e d' ogn' altra sorte, Cosi per Fregi, per merli e Rosette, che con Aco si viano hoggidi per lutta l'Europa. E molte delle quali Mostre porsono Serviri aneora per opera à Mozzete. Con le dichiarationi a le Mostre a' Lavori fatti da Lugretia Romana. In Venetia, appresso Allessandro de Vecchi, 1620. 27 ff., obl. 8vo. V.\& A. M.

1110 -Lucretia Romana-Corona delle Nobili et Virtuose Donne, Libro primo, nel quale si dimostra in varij Dissegni tutte le sorti di Mostre di punti tagliati, punti in Aria, punti Fiamenghi, punti a reticello, e d' ogni altre sorte, cosi per Freggi, per Merli, e Rosette, che con l' Aco si usano per tutta l'Europa. E Molte delle quali Mostre possono servire ancora per opere a Mazzete. Con le dichiarazioni a le Mostre, a Lavori fatti da Lugretia Romana. In Venetia appresso Alessandro de Veceli MDCXXV. Si vendono in Venetia al Ponte de' Baretteri alla libreria delle tre Rose. Lady Wilton in her Art of Neecilework, quotes a copy dated 1620. Obl. 4to, ff. 27. Vienna, Imperial Library.

See "Corona" of Vecellio of 1844.

1111-Lucretia Romana-Ornamento nobile per ogni gentil matrona. Dove si contiene Bavari, Frisi, d'infinita bellezza, Lavori per linzuoli, Traverse é Facuoli, Piena di Figure, Ninfe, satiri, Grotesche, Fontane, musiche, Caccie di Cervi, ucelli et altri animali. Con ponti in aria fiamenghi et tagliati con adornamenti bellissimi, da imparare per ogni virtuosa Donna che se diletta di perfettamente cucire. Opera per Pittori, scultori et Disegnatori giovevoli alle lor profession lavori. Fatta da Lucretia Romana, il quinto volume di suei lavori. Dedicato alle virtuose donne. In Venetia, appresso Lessandro (sic) de Vecchi, MDCXX (1620). In-folio. 4 $4^{\circ}$. Audessous des mots, virtuose donne, une gravure sur bois, entourée des quatre côtés par des bandes rectangulaires renfermant des petits motifs de broderies. Dans l'intérieur de ces bandes une femme vêtue à l'antique, debout sur une tortue, symbole de la bonne ménagère et tenant à la main une pelote de fil. A gauche deux femmes qui brodent, à droite un sculpteur qui termine une statue de Minerve. Rien au verso. Page suivante au-dessus de la broderie que contient cette page, on lit dans une tablette rectangulaire: Ornamento delle donne di, singolar bellezza, che in tutta Europa, si osserva, di far in varie foggie. Con altri cinque libri fatti da Lucretia Romana, Opera vtile a Pitori, scultori, \& disegnatori, piena di animal, bellissimi, vasi, fontane, caccie, musica \& fiori di varie sorti, \& di dinerse compartimenti bellissimi. Le volume se compose de 20 feuillets chiffrés, les 10 premier's signés A. A10. Le premier feuillet comprend le titre, orné d'une figure sur bois encadrée de dentelles et les 19 autres contiennent 20 beaux modèles de dentelles gravées sur bois sur fond noir et imprimés sur le recto de chaque feuille dont le verso est blanc, sauf les deux dernier's qui occupent le recto et le verso du $20^{\circ}$ feuillet. 20 cuts. Vente 
Benedetto Maglione, Paris, 1894. T'he bavari are executed in three different stitches: punto d' aieri, p. fiamingo, and p. tagliato. 'This author and Vecellio give Flemish patterns (punti Fiamenghi). They consist mostly of rosettes and stars (gotico). Brussels, Bib. Royale.

1112-Lucretia Romana-Ornamenti nobili per ogni gentil matrona dove si contiene vavari. Venice, 1876 , reprinted by Ongania from the edition of 1620 . Metro. Mus.

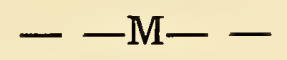

1113-M., F.-See Metropolitan Museum.

1114 -M., R.-see S., R. M.

1115-Macramé Lace, a knotted Trimming, ete. By the Silk worm (the Silkworm Series). 8vo. Lond. (1875). S. K. M.

1116-Macramé lace book, The: containing full and clear instructions for making this handsome and useful trimming. London. (1877). $8^{\circ}$.

1117-Madritum-Reglamento para la escuela de encajes en Madrid. Madrid, 1784. $8^{\circ}$.

1118-Malıaffy, Amada-Priscilla Drawn-TWork Book.

1119-Making of Bobbin-lace, The-Illus. Decorative Furniture. New York, 1916. $4^{\circ}$. V. 30, No. 1, p. 47.

1120-Making of Lace. Dublin University. V.54, p. 678.

1121-Making of Lace. Eclectic Review. T. 135, p. 37.

1122-Making of Lace. Galaxy. V. 6, p. 118.

1123-Making of Lace. Godey. V.51, pp. 330 and $365 ; 545$ and $566 ; 337$.

1124-Making of Lace. Living Age, 112:541.

1125-Making of Lace. Penny Magazine. V. 9, p. 186.

1126-Making of Lace. Practical Magazine. T.4, p. 204.

1127-Mali, Marie-La Dentelle américaine. La Réforme, April 4, 1899, Brussels.

1128-Mali, Marie-La Dentelle belge. L'Art moderne, Jan. 8, 1899, Brussels. 1129-Mali, Marie-La Dentelle belge. La Réforme, Dec. 22, 1898, Brussels.

1130-Malines-Photographs of lace, etc. exhibited at l'Institut des Beaux Arts, 1872. S. K. M.

1131-Manley, L.-Lace Work. Harper's Bazaar. V. 42, pp. 1134-1135, Nov. 1908.

1132-Manning, A. F.-Tempting Bits of Cross-stitch. Good Housekeeping. V. 53, pp. 279-281, August, 1911.

1133-Manteuffel, E. von-Album altdentscher Leinenstickerei. 50 plates. 8vo. Harburg, a.d. Elbe, 1883. S. K. M.

1134 -Manteuffel, Erna von-Filet-Guipure-Album. Marburg a/Flbe, G. Flkan, n.d. 60 plates.

1135-Marez, G. des-Les Dentelles de N.D. des Sept. Douleur's à l'Égliee des Richesclaires à Bruxelles. Brussels.

1136-Marguet, A. and Dauphinot, A.-Trésor de la Cathédrale de Reims. (Eccle. Lace and Fmbroidery.) 4to Paris. 1867. S. K. M.

1137-Marie Antoinette Shawl. International Studio. V. 32, sup. 61-63, Aug. 1907. 
1138-Mariage, J. B.-Société d'agriculture, des sciences et des arts de l'arrondissement de Valenciennes.

1139-Marriott, J. H.-Old Lace and How to Collect it. Connoisseur. V. 1, pp. 34-38.

1140-Marsland \& Co._New Registered Designs in Crochet. 1853.

1141-Martin, J.—Schön Newes Modelbuch von allerley lustigen Mödeln naazůnehen zuwůrcken vn zůsticke gemacht im Jar. Ch: 15.99. Gedruckt zu Strassburg, bey Jost Martin am Kornmarckt. In verlegung Ludwig Kঃnigs von Basel. Anno M.DCVI. $4^{\circ}$. 40 leaves. B. K. M.

1142-Martin, J. Schön Newes Modelbuch, etc.-[Another edition of No. 1141.] $4^{\circ}$. 40 leaves. Sigs. A-K4. 1619. (Rosenthal Sale Catalogue.)

1143-Marvin, Helen-The Beautiful Art of Sweden. The Lace Maker. Sara Hadley, Editor. 34 West 22nd Street, New York.

1144 -Marvin, H.-Five Crocheted Caps. Womans Home Companion. V. 41, p. 32, February, 1914.

1145-Marvin, H.-For Baby in Warm Weather. Womans Home Companion. V. 40, p. 32, July, 1913.

1146-Marvin, H.-New Heavy-thread Tatting. The Woman's Home Companion. V. 40, p. 29, May, 1913.

1147-Marvin, H.-Old-fashioned Knitted Quilts. Womans Home Companion. V. 41, p. 55, April, 1914.

1148-Marvin, H.-Practical Crocheted Table-mats. Womans Home Companion. V. 40, p. 29, February, 1913.

1149-Mason, Edith, at Taunton-Dentelle, Bolero, dentelle Honiton. Projet de dentelles de Honiton. Art appliqué, 1re année, Paris.

1150-Mason, Edith-Honiton Lace. Art Workers' Quarterly. V. 2, No. 8, pp. 144-146.

1151-Masters, E. T.-Drawn Linen Work. 117 pages. London, 1890. B. M.

1152-Matériaux pour servir à l'histoire de la dentelle en Belgique. Bruxelles, 1908 , etc. $4^{\circ}$. . planches.

1153-Matitsch, H.-The Matitsch Lace-Making Machine. Scientific American Supplement. V. 59, pp. 24372-24373.

1154 Maynard, A.-Christmas Gifts in Crochet. Ladies Home Journal. V. 20, p. 27, October, 1903.

1155-Mayol, Jehan-Sensuyuent lis patrons de messire Antoine Belin, Reclus de sainct Martial de Lyon. Item plusieurs autres beaulx Patrons nouveaulx, qui ont este inventez par Jehan Mayol Carme de Lyon. On les vend à Lyon, chez le Prince. n.d. Small 8vo, 6 ff., 85 plates. Copy at the Arsenal has $12 \mathrm{ff}$. The same device of the printer in the frontispiece and at the end of the book. "Finis." One of the patterns represents St. Margaret holding the cross to a dragon, but in these four books the designs are copied from each other, and are many of them repetitions of Quinty. Bib. Ste. Geneviève.-Bib. de l'Arsenal.

1156-M., C. E.-Hints on ornamental needlework as applied to eccle. purposes. Plates. 16mo. Lond. (1843.) S. K. M.

1157-McCutcheon-Mexican Drawn-work. 1893. (Collection of Kursheedt Manufacturing Co., N. Y.) 
1158-McGrath, A. K.-New Darned Work from Tuscany. Ladies Home Journal. V. 28, p. 27, August, 1911.

1159-Mee, C.-Crochet explained and illustrated. Pls. 12mo. Lond. 1846. S. K. M.

1160-Melani, A.-Pizzi moderni (Riviera. Venice. Bologna). La Lettura, March, 1904, Milan.

1161-Melani, A.-Svagli artistici Femminili dove si parla di Ricami, di Pizzi, ete. Milan, Ulrico Hoepli, 1891 and 1892, pp. 348. B. M.

1162-Meredith, Mrs.-The Lacemakers. (Account of the effort to establish lace-making in Treland.) 8vo. Lond. 1865. S. K. M.

1163-Merli, A.-Origine delle Trine a filo di Refa. Genoa, 1864. METROPOLITAN MUSEUM OF ART (BULLETINS) LACE NOTES BY F. M.

1164 -Vol.1.1905-6. March, Page 64, Met. Mus. Lace Collection.

1165- May, Page 89, Met. Mus. Lace Collection.

1166- J June, Page 99, Met. Mus. Lace Collection.

1167- Dec., Page 166, Gift-Hamilton Cary.

1168-Vol. 2. 1907-June, Page 108, Gift-Mrs. A. S. Wheeler. Handkerchief. 1169- July, Page 128, Gift-Mrs. Wm. K. Vanderbilt, Royal christening Robe.

1170- August, Page 143, Mrs. Duval, Point de Sedan

1171-Vol. 3. 1908-August, Page 156, Met. Mus. Lace Collection .

1172- October, Page 190, Gift-Mrs. Edward Luckemeyer.

1173- N November, Page 200, Nuttall Collection.

1174-Vol.4. 1909-May, Page 87, Blackborne Collection.

1175- July, Page 133, Van Rensselaer Collection.

1176-Vol. 5. 1910-- June, Page 151, Seligman Collection.

1177- - -Page 258, Harriman Collection.

1178-Vol. 6. 1911-October, Page 198, Loans, Blumenthal, Greenleaf.

1179-Vol. 8. 1913-May, Page 110, Bequest-Mrs. Harriette Goelet; Gift-Mrs. Russell Sage.

1180- August, Page 182, Gift-Mrs. Edward S. Harkness, Miss Tuckerman, Mrs. R. W. Moore.

1181-Vol. 9. 1914-July, Page 165, Gift-Mrs. Wm. Bliss, Mrs. Fletcher, Mr. Thatcher Adams.

1182- December, Page 261, Flemish Laces.

1183-Vol. 11. 1916-March, Page 73, Gift-Mrs. Henry S. Redmond.

1184 June, Page 138, Needle and Bobbin Club.

1185-Vol. 12.1917-January, Page 3, Gifts-Mrs. Wm. P. Douglass, Point de France.

1186- February, Page 40, Gifts-Mrs. R. T. Auchmuty.

1187- April,Page 96, French and Flemish Laces.

1188- May, Page 105, Gift-Mrs. Joseph Pulitzer, Flemish Lace.

1189- August, Page 169, Hearn Bequest of Laces.

1190- December, Page 246, Rearrangement of Laces. 
1191-Vol. 13. 1918-April, Page 95, An Important Loan of Lace.

1191a-Vol. 14. 1919-June, Page 130-A Summer Exhlibition of Tapestry and Lace.

1192-Metropolitan Museum of Art-Photographs of Lace.

1193-Metropolitan Museum of Art, The Textile Collection and its Use. Supplement to the Bulletin of the Metropolitan Museum of Art. May, 1915.

1194-Meuer, M.-Altarschmuch. 8vo. Leipzig, 1867.

1195-Meyer, D.-Zierat Buch, von allerhandt Kutschnur, Schleyer deckel, Krägen, Leibgürtel, Passimenten, Händschug, Wehrgeheng und Schubenehen, Messerscheyden, Secklen, Früchten, Blumen und ands, mehr. Allen Perlenbefftern, Nederin, Lehrinngen und andern welche lust zu dieser Kunst tragen, sehr nützlich. Inn diese Format zusammen ordiniert und gsetzt durch Daniel Meyer Mahlern. 1ster Theil. 1618. Franckfuhrt am Mayn, bey Eberhardt Kusern zu finden. $11 \mathrm{ff} ., 9$ plates. In-8vo.

1196-Meyer, F. J.-Flower and Fruit Basket in Cross-stitch. Ladies Home Journal. V. 31, p. 32, August, 1914.

1197-Mezzara, Paul, at Paris-Dentelles. Art Appliqué, 1re année, Paris.

1198-Michel, W.-Neue Schlesische Spitzen. Dekorative Kunst, Jahrg. 15, pp. 377-380. Munich, 1912.

1199-Mickel, A.-Simple Problems in Applied Design for Art Needlework. Manual Training. V. 16, pp. 164-168, November, 1914.

1200-Migem, Em. van-Exposition Universelle d'Anvers, 1894. Classe 36. Dentelles, etc. Rapport. Brussels, A. Lesigne, 1896.

1201-Migeon, Gaston-Les Arts du Tissu. Paris, Renouard, 1909.

1202-Mignerac, Mathias-Lace Patterns. Paris, 1605.

1203-Mignerak, Matthias-La pratique de l'aigville indvstrievse du très excellent Milour Matthias Mignerak. Anglois, ouvrier fort expert en toute sorte de lingerie. Où sont tracez diuers compartimens de carrez tous differans en grandeur et invention, auec les plus exquises bordures, desseins d'ordonances qui se soient veuz iusques à ce iourd'hui tant poetiques, historiques, qu'autres ouurages de poinct de rebord. Ensemble les nouuelles inuencions françoises pour ce qui est de divotion et contemplation. A la très Chrestienne Roine de France et de Navarre. Auec priuilège du Roy, 1605. A Paris Per Jean Le Clerc rue St. Jean de Latran à la Salamandre Roialle. Sur le titre un Frontispice. Deux femmes Diane et Pallas tenant des métiers dans leurs mains. En haut les armes de France et de Navarre, soutenues par de petits amours. En bas des amours qui filent et qui dévident. Entre les branches d'une paire de ciseaux, il y a un coussin à dentelle avec un carré de lacis en voie d'exécution et dont le modèle est une marguerite. On lit en haut: Petrus Firens fecit. I. Le Clerc excudit. Dédicace à la Reine Marie de Médicis. Discours en vers sur le lacis. En somme 4 ff. préliminaires et 72 planches de broderies, dentelles ... The patterns consist of the Queen's arms and cypher, 4 Scripture subjects: Adam and Eve, the annunciation, Ecce Homo, and Magdalen; 4 Elements, 4 Seasons; Roman Charity, Lucretia, Venus, and "Pluye d'or ;' 6 Arbes à fruit, 6 pots à fleurs, 30 Carrés grands, moyens et petits ; 6 Bordures, and, what is quite a novelty, 6 "Passements faits au fuseau" 
the first mention of pillow lace in any of the French pattern-books. Vente Libri, Vente Yemenitz, 1859, Vente Pichon, 1869. Bib. Baron J. Pichon, Cat. d'Estrées, Bib. Nat.

1204-Miles, Roger-La Dentelle. Transformation progrèssive des $15 \mathrm{me}$ et $16 \mathrm{me}$ siècles. 500 reproductions documentaires (Allemagne, France, Italie, Aubes, Berthes, bordures, carrés, Collerettes, Feuillages, Fraises, Gorgerines. Manchettes, Mouchoirs, Pertuis, etc. Un volume in $-4^{\circ}$ illustré de 80 planches.

1205-Milroy, M. E. W.-Home Lace Making. London, Scott, Greenwood \& Co., 1906. B. M.

1206-Mincoff, Elisabeth, and Marriage, M. S.-Pillow Lace-a practical Handbook. London, J. Murray, 1907. B. M.

1207-Minerva-Zierlich-webende Minerva oder neu-erfundenes Kunst, und BildBuch der Weber, und Zeichner-Arbeit, etc. (Johann Christ. Weigel). n.d.

1208-Ministère de l'Industrie et du Travail-Recensement général des industries et métiers. Brussels, 1896.

1209-Minkus, Fritz-Oesterreichische Spitzen. Vienna, F. Wolfrum \& Co. 1907.

1210-Minne, Jenny-Les Dentelles de Belgique à l'Exposition de Liège (Album de la Dentelle. Liège, 1905). Numéro spécial de La Dentelle, 1905, Paris.

1211-Minne, Jenny_Le Palais de la Femme. (Album de la Dentelle. Liège, 1905). Numéro spécial de La Dentelle, Paris, 1905.

1212-Minne-Dansaert, Mlle. Jenny-Rapport sur les dentelles et les broderies, addressé à la Commission de l'Exposition de Chicago. Brussels, 1894.

1213-Mitford, E. B.-Lace and Lace Workers of Flanders, etc. Sunday Magazine. V. 34, p. 927.

1214-Model-Büchli._1529 Ein new getruckt model Büchli auff auss nehen vnnd bortten wircken ynn der laden vnnd langenn gestell. Ganntz gerecht nach abteilung der feden tzal. (Rosenthal Sale Catalogue.) Said by Rosenthal to be the only known copy, and hitherto undescribed. He reproduces the title. Designs copied later by Claude Nourry (Lyons, c. 1530) and Basset (Frankfurt, 1569). See Jörg Gastel, of which this is a later edition with a new titlepage.

1215-Model-Buchli-Vol. 1, Title 32 pages and fly: 32 woodeuts, obl. 4 to. No. 41 in E. F. Strange bib.; No. 293 in Fairfax Murray sale. Metro. Mus.

1216-Model-Buchli-Vol. 2, Ein New Furm Būchlein. n. d. Title and 32 pages, 45 cuts, 4to. No. 25 in E. F. Strange bib.; in Rosenthal sale cat.: No. 292 in Fairfax Murray sale. Metro. Mus.

1217-Modelbüch; Zweiter. Theil: Franckfurt am Mayn, 1569. 4to, ff. 44. Nos. 36 and 37 are cited by the Marquis d'Adda.

1218-Model-Buch, Neu-Neu Model-Buch, darinnen allerley gettung schöner Modeln der neuen, etc. Probably a reprint. 27 plates. Lindau am Bodensee, n.d.

1219-Modelbuch welscher ober vnd niderlaen discher arbait. Gedruckt zu Francfort. Petit in $-4^{\circ}$. Sans date (vers 1550). Titre et 39 planches. 
La signature D est double, mais les modèles ne sont pas les mêmes. Catalogue Tross, 1867.

1220-Modelbüch Welscher, Ober und Niderlandischer Arbait. Getruckt zü Franckfort. No date, but probably at least as early as 1530. 4to. 20 leaves.

1221-Modenwelt, Die-Muster altdeutscher Leinenstickerei. Dritte Sammlung, herausgegeben von der Redaction der Modenwelt: und Vierte Sammlung herausgegeben von der Redaction der Modenwelt. Berlin, Fr. Lipperheide, 1893.

1222-Moderne Compositionen für Spitzen. Plauen, Chr. Stoll, n.d.

1223-Modernes Kunstgewerbe. Spitzen. Illustrirte Zeitung, June 6, 1901, Leipzig.

1224-Modernes Kunstgewerbe. Neue Spitzen. Illustrirte Zeitung, May 29, 1902, Leipzig.

1225-Modern Lace Making, 1901. (Collection of Kursheedt Manufacturing Co., N. Y.)

1226-Modern Lace-making. Delineator. V. 63, pp. 122-123: 300-301: 10581059. V. 64, pp. 260-261, January, February, July, August, 1904.

1227-Modern Lace-making. Delineator. V. 65, p. 115, January, 1905.

1228-Molded Lace. Independent. V. 71, pp. 217-218, July 27, 1911.

1229-Moleon, V. de-Notice sur la Dentelle. Dictionnaire de la Conversation, au mot "Dentelle."

1230-Monsarrat, J. G.-Oriental Darned Work. Ladies Home Journal. V. 23, p. 66, March, 1906.

1231-Monte, Il-Il Monte, opera nova di recami, intitolata il monte. Nella quale si ritroua varie et diversi sorti di mostre di punti, in aere a fogliami. Dove le belle et virtuose donne potrano fare ogni sorte di lauori accomodate alla uera forma, misura, et grandezza che debbono essere ne mai piu par la dietro da alcuno vedute. Opera non men bella che vtile et necessaria. Petit in- $4^{\circ}$. An-dessous de ce titre, une grande marque d'imprimeur représentant un oiseau de proie, les serres sur une biche. Tout autour des oiseaux voltigeants. Cette composition est renfermée dans un cartouche, formé de cuirs enroulés et de mascarons et entourée d'une banderole sur laquelle on lit: Virtuta parta, non sibi tantum. Au-dessus: In Venetia. En Résumé: un titre et 15 feuillets dont 29 de planches de broderies. Bibliothèque de l'Arsenal.

1232-Monte, Il-Il monte, opera nova di recami dove trovansi varie mostre di punto in aero. Venezio 1557. 16 feuillets et 30 planches. Cicognara. Bibliothèque du Vatican.

1233-Monte-Il Monte. Opera Nova Di Recami, Intitvlata Il Monte Nellaquale Si ritroua, varie \& diuerse sorti di mostre, di punto in aiere, à fogliami, Doue le belle, \& uirtuose donne potramo fare ogni sorte di Lauoro, accommodate alla nera forma misura, \& grandezza, che debbono essere, ne mai piu per l'adietro da alcuno uedute. Opera non men bella che vtile e necessaria. Nihil difficile uolenti. In Venetia, L'Anno MDLVII. $4^{\circ}$. Title and 39 cuts. B. K. M. 
1234-Monte-Il Monte, ete.-[Another edition of No. 1233.] Opera Noua Di Recami intitolata ... Doue le belle, \& uirtuose Donne potramo fare ogni sorti di lauoro .... (ete.). In Venetia. n.d. B. K. M.

1235-Moody, A. Penderel-Devon Pillow Lace. London, Cassell \& Co., 1908. B. M.

1236-Moody, A. Penderel-Lace Making and Collecting. 111 pp. Cassell, 1909. B. M.

1237-Moore, N. H.-Early Laces. St. Nicholas. V. 31, pp. 290-295, Feb. 1904. 1238-Moore, N. H.-Lace Book. Dial. V. 37, p. 427, Dec. 16, 1904.

1239-Moore, M. Hudson-The Lace Book. London, Chapman \& Hall, 1905. B. M.

-Later Edition-Hodder \& Stoughton, 1908. B. M.

1240-Moore, Mrs. N. H.-Lace-maker. St. Nicholas. V. 34, pp. 816-817, July, 1907.

1241-Morasso, Mario-L'Arte dei Merletti a Venezia. Emporium, 1902, Bergamo.

1242-Morasso, Mario-I Merletti Veneziana nella storia e nella vita. Regina, 1904, No. 3, Naples.

1243-Morisset, Blanche and Henriette, at Paris-Chemin de table. Art appliqué, 2e année, Paris.

1244 -Morris, E.-Cut-work Table Linen. Harper's Bazaar. V. 40, pp. 654656, March, 1909.

1245-Morton, R.-How to Take Care of Lace Curtains. Country Life. V. 15, p. 16, November, 1908.

1246-Mosse, Gebr.-Art, Linen and Lace.

1247-Most Beautiful Laces in America: pictures. Ladies Home Journal. V. 18, p. 201, September, 1901.

1248-Mouchoir en guipure. Arte Italiana, 1901, No. 10, Milan.

1249-Mount, M. W.-Oriental Designs in Table-linen. Woman's Home Companion. V. 31, p. 33, January, 1904.

1250-M., R.-Nüw Modelbüch, allerley gattungen Däntelschnür, so diser zyt in hoch Tütschlanden geng und brüchig sind, zu underricht jren Leertöchteren unnd allen anderein schurwirckeren zu Zurych und wo die sind, yetz nüwlich zübereit, und erstmals in truch verfergket durch $R$. M. No place or date, but as appears, both from the title and preface, to be printed at Zurich, by Christopher Froschover. The date probably from 1530 to 1540. 4to. 24 leaves. On the title a woodeut of two women working at lace pillows. Vienna Library, Royal Library, Munich.

1251-M., R.-Froschower, (Pub.) - Bobbin Lace Patterns, by R. M. Zurich, 1560 .

1252-Muentz, Eugene-Tapisseries, Broderies et Dentelles. Paris, Librairie de l'Art, 1890. 43 pages. In British Museum.

1253-Müller, C.-New Modelbůch Von vilen artigen vnd Kunstreichen Modeln zůgericht, Allen Nåjerin, Seidenstricken, vnd andern so sich künstlichs nåyens, wirgkens oder stickens, auch frembder Züg oder Moritzgen gebrauchen, sehr dienstlich, auch vormals dergleichen nie in Truck ausgangen. 
M.D.LXXII. [On last page a printer's device, a naked man holding an arrow] Getruckt zu Strassburg am Kornmarckt bey Christian Müller [Cypher C K and a knot.] $4^{\circ}$. Cuts. B. K. M.

1254-Muller, Mlle. M.-Col; éventail. L'Art décoratif, 5e année, Paris. Munster Reproduction-See No. 810.

1255-Murphy, B.-Search for Old Lace in Venice. Catholic World. V. 22, p. 852.

1256-Murphy, S. J.-Report on the lace industry in France and Belgium, 1887. Fep. fol. S. K. M.

1257-Murphy, S. J.-Extracts from the (above) report. 8vo. Waterford, 1887. S. K. M.

1258-Musée de Cluny-Catalogue du Musée de Cluny, à Paris.

1259-Musterbuch für Stickerei. 36 plates. Plauen, C. Stoll. (Collection of Kursheedt Manufacturing Co., N. Y.)

1260-Musterenwürfe für Stickereien, Spitzen und Gardinen, preisgekrönt, etc. Zweite, von 19 auf 30 Tafeln vermehrte Auflage. Plauen, Chr. Stoll, n.d. 1261-Myra-Crochet Edgings. London, 1888, etc. $8^{\circ}$. B. M.

1262-Myra-Harlequin Crochet. Designs for needlework. 64 pp. London, 1888. $8^{\circ}$. B. M.

1263-Myra's Knitting-books. London, 1889. In British Museum.

1264 -Myra \& Son-Antique and Modern Point Lace. (The Silkworm Series.) London, (1888). $12^{\circ}$.

1265-Myra \& Son-Devonshire or Honiton lace. (The Silkworm Series.) London (1888). $12^{\circ}$.

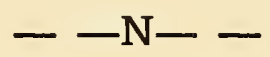

1266-Naber, J. W. A.-Dentelles anciennes et modernes au Musée des Arts à Haarlem. Haarlem, 1903. In British Museum.

1267-Naber, Johanna W. A.-Oude en nieuwe Kantwerken. Haarlem, H. Kleinmann \& Co., 1903.

1268-Naguet, F.-Broderie et Dentelles. L'Art, 1889. V. 46, pp. 3-6.

1269-Nákladem Městského prúmysloveho musea v Hradci Král. (Dentelles d'après d'anciens modèles à Vamberg. Publiées par le Musée Industriel de Hradec Králové).

1270-Nanduti or Spider-web Lace of Paraguay. Bulletin International Union of American Republics. V. 29, p p. 570-576, September, 1909.

1271-National Art Library, South Kensington Museum. A list of books and pamphlets illustrating part 2 lace and needle work. 86 pages. Eyre \& Spottiswoode, London, 1888.

1272-Natural History of Dress, The-VII, Lace. The Leisure Hour, June, 1870, London.

1273-Needle and Brush-Butterick Publishing Co. (Collection of Kursheedt Manufacturing Co., N. Y.)

1274 -Needlecraft-Nos. 13, 15, 19, 21, 23, 27, 41, 43, 49, 51, 64. Manchester School of Embroidery. (Collection of Kursheedt Mfg. Co., N. Y.) 
1275-Neh-und Strickbuch (neues) für das schöne Geschlecht, etc. (27 plates of designs for Samplers and other needlework.) Obl. fol. Nürnberg und Leipzig, 1874. S. K. M.

1276-Neil, M. H.-Washing and Ironing Lace. Delineator. V. 75, p. 326, Apr. 1910.

1277-Netto, J. F.-Wasch-Bleich-Platt-und Naeh-Buch, zum Selbstunterricht fur Damen. (Plates). Obl. fol. Leipzig, 1796. S. K. M.

1278-Netto, J. F.-Zeichen-Mahler-und Stickerbuch zur selbstbelehrung für Damen welche sich mit diesen Künsten beschastigen von J. F. Netto Leipsick, 1795. In-folio oblong. 24 planches, avec nombreux modèles de broderies à exécuter sur soie. Chaque planche est en double, en noir et en couleur.

1279-Netto, J. F. and F. L. Lehmann-Neuestes Toilettengeschenk der StrickStick-, Näh-und anderen weib lichen Arbeiten auf das Jahr 1811 und 1812, mit Aufsätzen über Anwend, d. höheren Kunst und über Gegenstände des weibl. Berufs und Verwaltung d. Hauswesens. Mits 18 schwarzen und kolor. Tafeln. Dasselbe auf das Jahr 1814 u. 1815. Mit 32 kolor. u. schwarzen Kupf. Leipzig.

1280-Newbery, F. H.-Work of Ann Macbeth. International Studio, V. 18, pp. 40-49, November, 1902.

1281-New Cross-stitch in Italian Design. Ladies Home Journal, V. 31, p. 38, November, 1914.

1282-New Modelbuch von allerhandt Art nehens und Stickens. Frankfurt a/M. Niclas Bassee, 1571.

1283-New Things in Crochet. Ladies' Home Journal, V. 29, p. 30, July, 1912. 1284 -New Things in Fancy Crochet. Ladies' Home Journal, V. 28, p. 29, Aug. 1911.

1285-New Furmbuhclin, Ein-Sans lieu, ni date. In- $4^{\circ}$ gothique. $p$ n c. 4 bandes d'arabesques. Au verso 4 bandes d'arabesques noires sur un fond blanc quadrillé très fin. $B$. Sur un fond quadrillé on lit en gothique les mots : so ir um mir bleybet. Au verso: un mein wort um eudz. $p n c$. Bleyben Werdet ir bittu. Au verso, Was ir wolt und es. $p n c$. Wirt eudz mi derfart. Au verso, Denn feid lass idz. $p n c$. Eühz meinen fridgeb. $A u$ verso, ich, eudz midzt gebidh eudz. $C$. Wie die welt gibt. Au verso, Tholus aber. $p n c$. Lettres. Verso lettres. $p n c$. Lettres. Verso lettres. $p n c$. Lettres majuscules. Verso Hatt und wer midz sihrt der. $D$. Rinceaux. Verso rinceaux. $p n c .3$ bandes de rinceaux en hauteur, arabesques. Verso 4 bandes d'arabesques. $p n c .4$ bandes d'arabesques en hauteur, chasse au cerf. Verso 3 bandes de Groteschi. p n c. 4 bandes de Groteschi. Verso bandes d'arabesques. E. Groteschi. Arabesques. Verso, idem. Volume extrêmement rare. Non cité. Paraissant avoir été publié vers 1530. Le titre est imprimé en grosses lettres de forme. Les modéles de dentelles sont au nombre de 40 , tous à exécuter au lacis, gravés assez grossièrement ces modèles sont remarquables par leur tournure archaïque. Ce sont surtout des bandes et ornements avec rinceaux et grotesques inspirés de la sculpture. On y trouve aussi un alphabet et des prière n'occupant pas moins de 16 pages. Sur une des planches, une prière cette 
inscription: VAHMIS. Vente Destailleurs, 1895. See No. 1221. Bibliothèque Nationale.

1286-Nieder, Marie-Sonnen-Spitzen-Teneriffa Arbeit. 1906.

1287-Niemann, Ernst-Die Spitzenklöppelei im Erzgebirg. 5 dessins de G. Mandlick. Daheim, Dec. 21, 1901, Leipzig.

1288-Normal programm der K. K. Fachschulen für Spitzenklöppelei. Zentralblatt für das gewerbl. Unterrichtswesen in Osterreich. Vienna, Alf. Hölders, 1903.

1289-North Ayrshire Lace Curtain Co.-Novelties for 1901 in lace curtains. Darvel (Nottingham pr.) (1901) la. 80.

1290-Nottingham Lace, W. S. Elliott's Designs. Artist, V. 26, p. 99, New York. 1291-Nottingham Lace Edgings-The Artist, March, 1900, London.

1292-Nottingham Lace: Its History and Manufacture. Blackwood's Edinburgh Magazine, October, 1882, Edinburgh or London.

1293-Nottingham Lace-making. Scientific American Supplement, V. 64, p. 387, December 21, 1907.

1294-Nottingham--Patterns of Nottingham Lace, referred to in the Mar. Report of the Nottingham School of Design, 1850. (73 patterns in a folio cover.) S. K. M.

1295-Nottingham Statistics of the Bobbin Net Trade, etc. Fol. (Nottingham) 1833-6. S. K. M.

1296-Nourry, Claude, dict le Prince-La Fleur des patrons de lingerie, à deux endroitz, à point croisé, à point couché et à point picqué en fil d'or, fil d' arget et fil de soye ou aultre en quelque ounraige que ce soit en comprenant l'art de broderie et tissuterie. On les vend à Lyon en la maison de Claude Nourry dict le Prince. In $4^{\circ}$. Ce titre est circonscrit par une composition, où l'on voit en haut un entablement demi-circulaire posant sur deux colonnes surmontées chac une d'une petite figure de femme brodant à l'aiguille. An milieu, un homme travaillant à un petit métier qu'il tient des deux mains, appuyé sur son gənou. En bas de la composition et audessous du titre, deux femmes travaillant, celle de droite à un métier de basse lisse, celle de gauche à un petit métier posé devant elle sur une table. Elle est assise sur une chaise de trois quart à droite. Dans les médaillons ronds qu'on voit au milieu des colonnes, à gauche un lion surmonté de trois fleurs de lys, à droite un cœur surmonté d'une couronne. Cette premièr page est cotée $A$. Rien au verso. Dans certains exemplaires, ce verso est quadrillé. A u verso d'un page, on voit un cœur surmonté d'une couronne dans un écusson au-dessous duquel est un lion couché et rugissant. Cette marque d'imprimeur est dans un encadrement rectangulaire sur la bordure duquel on lit: Cor contritum et humiliatum devs non despiciet, Psalmo 50. En résumé, 12 pages dont 21 planches de broderies. Dans certains exemplaires la marque d'imprimeur est modifiée. Le cœur surmonté d'une conronne est placé su centre d'une couronne d'épines, autour de Inquelle s'enroule une banderolle sur laquelle on lit: Cor contritum et humiliatum deus non despiciet. Le lion est ou-dessous, comme ci-dessus. Le tout est entouré d'un trait carré 
rectangulaire et d'un filet. Aux quatre coins intérieurs de cet encadrement une fleur de lys. Vente Destailleurs, 1895.

1297-Nourry, C.--La fleur des patrons de lingerie, a deux endroitz, a point croise, a point couche, et a point picque, en fil dor, fil dârget, \& fil de soye, ou aultre en quelque ouurage que ce soit, en comprenant lart de broderie et tissuterie. On les vends a Lyō en la maisō de Claude nourry, dict Le Prince. (Cocheris reproduction.)

1298-Nourry, Claude, dic le Prince-Livre nouneau dict Patrons de lingerie; c'est assavoir à deux endroitz, à point croisé, point couché, et point picqué, en fil d'or, d'argent, de soye, ou aultre, en quelque ouurage que ce soit: en comprenant l'art de broderie et tissuterie. On les vend à Lyon en la maison de Claude Nourry dic le Prince. Sans date. In $-4^{\circ}$ gothique. Ce titre est dans un encadrement formé par deux colonnes, surmontées d'un fronton demicirculaire et décoré en haut, à droite et à gauche, par des rinceaux de feuilliges, sur le fût de ces colonnes et attachés par des rubans deux écussons. Dans celui de gauche on voit un lion, et au-dessus trois fleurs de lys. Dans celui de droite un cœur surmonté d'une couronne. En bas au-dessous du titre, deux femmes travaillant. Celle de droite de profil à gauche à un métier à ruban posé devant elle, sur une table. L'autre est à moitié cachée par un métier auquel elle travaille. Page non cotée. Au verso de cette page dans un écusson formé par des cuirs enroulés, un cœur' surmonté d'une couronne, le tout dans une couronne d'épines autour de laquelle, s'enroule une banderole, sur laquelle on lit: Cor contritum, et humiliatum deus non despiciet. Ps. 50. Au-dessous un lion couché. Cette marque d'imprimeur est entourée d'un trait carré et d'un filet. En résumé 24 pages dont 45 planches de broderies. Vente Yemenitz, Vente Destailleurs.

1299-Nourry, Claude-See Saincte Lucie.

1300-Nouveaux Portraits de Point coupé et Dentelles en petite, Moyenne et grande Forme. Nouvellement inventé et mis en lumière. Montbeliard, 1598.

1301-Nulle, Mevrouw, L. W.-Handleiding tot het vervaardigen van duchesskant; leerbock der nederlandische Kantwerkschool, met inleiding van A. E. von Saher. Haag, 1907.

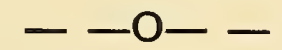

O'Brien, see Vere, No. 1855.

1302-Old Lace. Once a Week, V. 12, p. 288.

1303-Old Lace-(Lace Flounce, Blonde, worn by the Empress Eugenie). The Connoisseur, March, 1902, London.

1304 Old Laces. 35 photographs. P. Calavas. (Collection of Kursheedt Manufacturing Co., N. Y.)

1305-Old Venetian Point Lace. Magazine of Art, V. 7, p. 66.

1306-Old World Laces. Harper's Bazaar, V. 33, pp. 1081-1084, Aug. 25, 1900. -Ongania Reproductions-See Nos. 627, 628, 629, 812, 1112, 1321, 1357, $1369,1370,1371,1372,1402,1412,1627,1629,1631,1735,1812,1816,1823$, 1827, 1832, 1839, 1954, 1957. 
1308-Oriental Lace-exhibition at the National Arts Club, N. Y. Times, Mar. $30,10: 5$.

1309-Origine de la dentelle de Venise et l'école de Burano. Venice, 1897.

1310-Omamentation for Textiles. Neue farbige Vorlagen für die Textil-Industrie. Plauen, n.d. One vol., obl ong folio, original boards. 24 plates with 2,3 or 4 designs in colors.

1311-Ornamento delle belle et virtuose donne. Opera nova nella qualle troverrai varie sorti di frisi, con li quali si potra ornat ciascuna donna et ogni letti con ponti tagliati, ponti gropposi, et ogni altra sorte di ponti per fare quelle belle opere che si appartengono alle virtuose et lodevoli Franciulle. Libro primo. In $-4^{\circ}$. Sans lieu, ni date. Ce titre est inscrit dans un cartouche blanc, dont les bords sont ornementés de cuirs enroulés. En bas une femme de la haute société, assise à droite de profil à gauche, un ouvrage sur ses genoux, montre du doigt, la main étendue, une broderie posée sur les genoux d'une ouvrière assise près d'elle sur une chaise. A gauche de la composition une troisième femme regarde également cet ouvrage. En bas au premier plan à leurs pieds, une corbeille. Rien au verso. 12 feuillets formant un caliier de 12 pages non cotées. Au verso de la dernière page on lit: Alle virtuose et nobili donne. Au-dessous une petite tête d'enfant ailée et dix lignes de texte finissant par ces deux vers: Quelle che questo libro compraranno, Mai facie di cuser si trouaranno. En résumé, 12 pages dont 21 planches de broderies. Catalogue Destailleurs. On a scutcheon. "Libro Primo." Lib. Victoria, and Albert Museum. See Pagan.

1312-Ornamento delle belle et virtuose donne, etc.-32 leaves, with woodcut designs on both sides. Venetian, 16 th cent. Sm. 4 to. n.p., n.d. S. K. M.

1313-Ornamento delle belle donne et virtuose: Opere in cui troverai varie sorti di frisi con li quali si potra ornar ciaseun donna. Ven. 1544. Quoted in Cat. Cappi, of Bologna, 1829.

1314-Ornamento Nobule per Ogni Gentil Matrona, dove si Contiene Bavari, frisi d'Infinita Bellezza Lauroi, per Linzuoli Traverse, e Facuoli, etc., Opera per Pittori, Scultori et Dis egnatore gioneuole, etc. 19 plates of designs for Lace, etc. Printed in facsimile of the original of 1620. Folio, Venice, 1876.

1315-Ornements remarquables de l'Exposition industrielle des ouvrages de femmes en 1881, publiés par le Ministere d'Agriculture, etc. Obl. fol. Budapest, 1882. S. K. M.

1316-Ostaus, Vean-Le Trésor des patrons, contenant diverses sortes de broderies et lingeries pour coudre avec grande facilité et pour ouvrer en diverses sortes et picquer avec l'esguille, pulvériser, par dessus et faire ouvrages de toutes sortes de points par Jean Ostaus, Lyons, Ben, Rigaud, 1580. In $-4^{\circ}$.

1317-Ostaus, Jean-Le Trésor des patrons, contenant diverses sortes de broderies et lingeries pour coudre avec grande facilité et pour ouvrer en diverses sortes de piquer avec l'esguille, pulveriser par dessus et faire ouvrages de toutes sortes de points \&ct par Jean Ostaus, Lyon, Ben. Rigaud. 1581, in 4-to. Quoted in Art. "Tricot et Travaux des Dames." 
1318-Ostaus, Jean-Le Trésor des patrons, contenant diverses sortes de broderies et lingeries pour coudre avec grande facilité et pour ouvrer en diverses sortes et picquer avec l'esguille, pulvériser par dessus, et faire ouvrages de toutes sortes de points par Jean Ostaus. Lyon, Ben, Rigaud, 1585. In $-4^{\circ}$. Mentionné dans la Bibliothèque Française de Du Verdier. Edition de Rigoley de Juvigny. Tome 2, page 485, art. Jean Ostaus.

1319-Ostaus, Giovanni.-La vera perfettione del disegno di uarie sorti di ricami, \& di cucire ogni Sorta di punti a fogliami, pūti tagliati punti a fili \& rimessi, pūti incroaciati, Pūti a struora \& ogn' altra arte, che dia opera a disegni. Fatto nouamēte per Giouanni Ostaus. Vittoria. [Mark, with motto Ego sum via et veritas.] Con gratia \& priuilegio dell' Illustriss. Senato Venetiano per Anni X. In Venetia, appresso Giouanni Ostaus. 1564. [Dedication to Signora Lucretia Contarino.] $8^{\circ}$. Cuts. B. K. M.

1320-Ostaus, Giovanni-La vera perfettione del disegno, di varie sorti di ricami, et di cucire ogni sorte di punti a fogliami, punti tagliati. punti a fili, et rimessi, punti nicrociati, punti a stuora, et ogn'altra arte, che dia opera a disegni. Fatto Nuovamente per Giovanni Ostaus. Vittoria. Con gratia et privilegio dell'Illustriss. Senato Venetiano per anni X. In Venetia appresso Giovanni Ostaus, 1567. In $4^{\circ}$ oblong. Sur ce titre un médaillon ovale, contenant une femme debout de trois quart à droite, la tête presque de face, tenant d'une main sa jupe, de l'autre un cœur enflammé. Au fond la mer sillonnée de vaisseaux. A gauche un tertre avec un trone d'arbre. On lit autour de cette figure diverses inscriptions et sur un livre ouvert en bas à gauche à ses pieds: Dum tempus abemus oferemur Bonum. Sur la bordure du médaillon: Ego sum via et veritas. Dédicace: Alla clarissima signora Lvcretia Contarini. Une lettre i gravée sur bois. Verso, une gravure sur bois représentant Lucrèce Romaine entourée de ses femmes. A droite un guerrier dans une porte. Signée en bas à gauche dans l'intérieur du dessin: José Sal. 1557. (Joseph Salviati, plus connu sous le nom de Porta Garfagnino). Deux sonnets en regard l'un de l'autre. Celui de gauche, Alla Clairissima signora Lucretia Priuli. Celui de droite: Sonetto alle saggie et Virtuose donne. Verso, préface aux lecteurs: Alli saggi et giuditiosi lettori. La dernière page non cotée mais numérotée $L X X I X$ a au verso un fleuron qui est le même, que celui que porte le titre avec en haut les mots A B C D E Tutti sono quaderni. Et on bas: Stampato in Venetia per Giovanni Ostaus, MDLXVII (1567). 73 planches de broderies. Cet ouvrage est certainement un des plus beaux et des plus intéressants de cette série. On y trouve des modèles pour tous les genres de travaux à l'aiguille. On remarque parmi les planches des sujets mythologiques, des grotesques, des rinceaux d'ornements, des frises, des scènes de chasse, des paysages, le tout d'un goût exquis. Trente-deux planches seulement ont trait aux broderies. Vente Benedetto Maglione, Paris 1894, Vente Pirovano, Rome, 1901. Vente Destailleurs, 1895.

1321-Ostaus, Gio.-Le Vera Perfettione del disegno di varie sorti di Recami et di cucire, punti a fogliami, punti tagliati, punti a fili, et rimessi punti in crusiati, punti a stuora, et ogni altra arte che dia opera a disegni. 35 
designs for lace, etc. Facsimile reprint of the original edition of Venice, 1567. Small oblong 4to. Venice, 1878. Ongania. Metro. Mus. S. K. M. 1322-Ostaus, Gio.--[Another edition.] 1584. See Valvassore. See 1320.

1323-Ostaus, Gio.-[Another edition.] La vera perfettione del disegno di varie sorte di ricami \& di cucire ogni sorta di punti à fogliami . . . E di nuouo aggiuntoui varie sorti di merli, e mostre che al presente sono in vso \& in practica. In Venetia, Appresso Francesco di Franceschi Senese all' insegna della Pace. 1591. Registro ABCDE. Tutti sono quaderni. In Venetia, MDXC. The edition of 1564 is the earliest hitherto described. See 1320. V.\& A. M.

1324-Ostaus, Giovanni-La vera perfezione del Disegno per punti e ricami. Reproduced under direction of Elisa Ricci. Bergamo, 1909.

1325-Österreichisches Museum (K. K.) Genälıte Spitzen. Bordure XVI. Jahrhundert. Blaetter für Kunstgewerbe, 1875, Vienna.

1326-Österreichisches Museum (K. K.) Original Stickmuster der Renaissance, etc. $2 d$ edition, Vienna, R. v. Waldheim, 1880.

1327-Österreichisches Museum (K. K.) 'Tauftuch, XVII. Jahrhundert aufgenommen von Marianne Fürst (filet brodé). Blaetter für Kunstgewerbe, 1876, Vienna.

1328-Österreichisches Museum (K. K.) Venetianische Musterblätter aus dem XVI. Jahrhundert für Passementerie-Arbeiten und verwandte Techniken (Le Pompe, Venice, 1562, Lib. II). Vienna.

1329-Oswald-Manufacture Royale de Dentelles de Bruxelles.

1330-Ouvrières en dentelles dans l'Erzgebirge, en Saxe. Magasin Pittoresque, 1848.

1331-Overloop, E. van-Au Pays de la Dentelle (Belgique). (Album de la Dentelle. Exposition, Liége, 1905). Numéro spécial de La Dentelle, Paris, 1905.

1332-Overloop, Eugène van-Catalogue des Ouvrages se rapportant à l'Industrie de la Dentelle. Brussels, Hayez, 1906.

1333-Overloop, Eugène van-Dentelles anciennes des Musées Royaux des Arts Décoratifs et Industriels à Bruxelles. Brussels, Gran Oest \& Cie., 1911. 100 plates, folio.

1334-Overloop, Eugène van-Dentelles de la Collection Alfred Lescure. Brussels, Grau Oest \& Cie, 1914.

1335-Overloop, E. van-Matérioux pour servir à l'histoire de la dentelle en Belgique, 1908.

1336-Overloop, E. van-Musées Royaux du Cinquantenaire. Industries d'Art Brussels, 1906.

1337-Overloop, E. van-Nos Collections de Tissus, de Broderies et de Dentelles. Bull. Musées Royaux des Arts décoratifs et industriels. October, 1903, Brussels.

1338-Overloop, E. van-Nos Dentelles. Bull. des Musées Royaux des Arts décoratifs et industriels, April, 1904, Brussels.

1339-Owen, Mrs. H.-Illum. Book of Needlework; comprising Knitting, Netting, Crochet, and Embroidery. Plates. 8vo. London, 1847. S. K. M. 


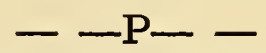

1340-P., A. R.-Allerhand Mödel zum Stricken und Nähen. 1 Theil. 24 plates signed A. R. P. (also Sampler Alphabet.) Obl. sm. Fol. n.p. 1748. S. K. M.

1341-Pagan, Matheo-Giardinetto nuovo di punti tagliati et gropposi per exercitio et ornamento delle Donne. Alle belle et vertudiose (sic) donne Matheo Pagan. Venise, 1543. Un volume in $4^{\circ}$. 24 feuillets sur bois, modèles de broderies. Collection du baron Davillier.

1342-Pagan, M.-Giardinetto novo di pvuti tagliati Et gropposi per exercitio et ornamento delle donne. Au-dessous de ce titre un médaillon ovale, avec une bordure dans laquelle on lit: Senza di me l'huom fassi à dio riballo. Dans l'intérieur du médaillon une figure de femme représentant la Foi. Elle est agenouillée de profil à droite, tenant des deux mains devant elle un calice surmonté d'une hostie. Près d'elle la croix, dans le fond un soleil rayonnant, à gauche un rideau. Au verso de ce titre, une dédicace: Alla Signora Lucretia Romana Matio Pagan salute. Puis commencent les Broderies. Au verso un sonnet, commençant par les mots: Alle belle et virtvose donne Mattio Pagan. Au- dessous du sonnet: Stampato in Venegia per Matthio Pagan in Frezaria, in le case noue il qual tien per insegna la Fede MDXLIIII (1544). En résumé, 24 feuillets, dont un titre et 44 dessins de broderies. In- $4^{\circ}$. Bibliothèque Nationale.

1343-Pagan, Mathio- Giardinetto novo di punti tagliati et gropposi per exercitio et ornamento delle Donne. A la fin: Stampato in Venetia per Mathio Pagan,1548.

1344 - Pagan, M.-Giardineto novo di Punti tagliati et gropposi, per esurcitio et ornamento delle donne. At the end, Venetia, Mathio Pagan in Frezzaria, in le case nove (tien per insegna della Fede) MDLI. Dedication, Alla signora Lucretia, Romana Mathio Pagan, salute. Florence. M. Bigazzi.

1345-Pagan, Mathio-Giardinetto novo di punti tagliati et gropposi per exercitio et ornamento delle donne. A la fin: Stampato in Venegia per Matthio Pagan, in Frezaria in le case nove il qual tien per insegna la Fede, MDLIV.

1346-Pagan, Matthio-Giardinetto novo, etc. (Same as 1345). 1556. Vente Bancel.

1347-Pagan, Matthio-Giardinetto novo di Punti Tagliati Et gropposi per exercitio et ornamento delle donne. A la fin: Stampato in Venegia per Matthio Pagan, in Frezaria, in le case none il qual tien per insegna la Fede, MDLVII (1557). Une édition de 1558. Vente Piot, 1891.

1348-Pagan, Matthio-La gloria e l'honore de Ponti Tagliati e ponti in aere, opera noua, Et con somma diligentia posta in luce. In Venetia per Mathio Pagano in Frezzaria, all' insegna Della Fede, MDLIIII (1554). Petit in$4^{\circ}$. Ce titre est inscrit au haut de la page dans un cartouche entouré de cuirs et suspendu par un anneau à un fronton architectonique, supporté par deux colonnes. En bas, entre ces colonnes, un paysage dans lequel on voit trois femmes. Celle du milieu debout entre ses deux compagnes tient à la main une bande de broderie. Les deux autres assises s'occupent à des 
travaux d'aiguille. Gravure sur bois. Au verso, dédicace: All. illvstriss: et excellen. signora, la signora Vittoria Francese Duchessa d'Vrbino, dignissima Matthio Pagano Sal. Au bas de cette dédicace la date: Di Venetia, alli XXV, di maggio, MDLIIII (1554). Page non cotée. Au verso de cette feuille la marque de l'imprimerie de Mathio Pagan. C'est un médaillon ovale dans la bordure duquel on lit: Senza di me l'Huom Fassi a dio Ribello. Dans l' intérieur du médaillon une figure de femme représentant laFoi. Elle est agenouillée de profil à droite, tenant des deux mains devant elle, un calice surmonté d'une hostie. Près d'elle la croix. Dans le fond un soleil rayonnant. A gauche une draperie. Magnifique gravure sur bois, du style le plus pur. En résumé 16 feuillets, dont 29 planches de broderies. Dans un des catalogues de la librairie Rahir. on lit. Exemplaire précieux dans la couverture originale de publication. Le premier plat de la couverture est orné d'un grand bois représentant l'intérieur d'un magasin de dentelles à Venise au xvi ${ }^{\circ}$ siécle. Le deuxiéme plat porte un autre bois représentant le pouvoir de l'amour. Ces deux bois accompagnés de légendes et d'inscriptions xylographiques, sont compris dans de larges bordures. Vente Piot, 1891.

1349-Pagan, Matthio-La gloria et l'honore di Ponti Tagliati a fogliami, delli quali tu potraifare ponti in aere ponti in stiora a fogliami: opera nova et con somma diligentia posta in luce. In Venetia per Mathio Pagan, in Frezzaria all' insegno della Fede, 1556 . In- $4^{\circ}$. La présente édition ne diffère de la précédente que par l'énoncé du titre et le millésime. Vente Bancel, 1882.

1350-Pagan, M.-La Gloria et l' honore de ponti tagliati et ponti in aere Venezia per Mathio Pagan in Frezzeria al segno della Fede. 1558. 16 plates. Dedicated to Vittoria Farnese, Duchess of Urbino. Cat. Cicognara.

1351-Pagan, M.-La Gloria et L'Honore de Ponti Tagliati, e Ponti in Aere, Opera noua \& con somma diligeritia posta in luce. In Venetia per Mathio Pagan in Frezaria al segno della Fede. M. D. LVIII. Fo. Title, dedication, $16 \mathrm{ff}$. (Quaritch reproduction.) Said to be from the only copy known (1884).

1352-Pagan, M.-L'honesto Essempio del vertuoso desiderio che hanno le donne di nobile ingegno circa lo imparare i punti tagliati e fogliami. In Venetia per Mathio Pagan in Frezaria al segno della Fede, M.D.L. In the V. and A. Museum is a copy dated 1550. Quoted by Cav. Merli. See Mrs. Bury Palliser's bibliography.

1353-Pagan, Matthio-L'honesto essempio del vertuoso desiderio che hanno le donne di nobile ingegno. Punto tagliato a fogliami. Venice, 1878. Reprint of edition of 1550. 31 plates of patterns. Metro. Mus.

1354 -Pagan, Matthio-L'honesto essempio del uertuoso desiderio che hanno le donne di nobil' ingegno circa Io imparare i punti tagliati a fogliami. In Venetia per Matthio Pagan in Frezzaria al segno della Fede, MDLIII (1553). Au-dessous de ce titre une marque d'imprimeur rectangulaire, dont l'intérieur est à quatre lobes et sur la bordure ovale intérieure de laquelle on lit: Senza di me l'Huom Fassi a Dio ribello. Dans le milieu des quatre lobes, un paysage où l'on voit une femme se dirigeant vers la 
droite la tête de trois quart à gauche. D'une main, elle tient un calice surmonté d'une hostie, de l'autre une croix sur la branche horizontale de laquelle on lit le mot: Fede. Au verso d'une page, dans un médaillon ovale, la Foi de profil à droite à genoux, tenant des deux mains un calice, surmonté d'une hostie. La sainte croix est par terre à côté d'elle. Sur la bordure du médaillon on lit: Senza di me l'Huom Fassi à Dio ribello. En tout 16 feuillets dont 24 planches de broderies. Bibliothèque Nationale.

1355-Pagan, Matthio-L'honesto essempio del uertuose desiderio, che hanno le donne di nobil' ingegno circa Io imparare i punti tagliati a fogliami. In Venetia per Matthio Pagan in Frezaria, al segno della Fede, 1556. In- $4^{\circ}$. Même titre que dans l'édition précédente, $\mathrm{n}^{\circ} 110$. Rien au verso. Ensuite 29 planches disposées sur 14 feuillets et le recto du dernier feuillet. Elles représentent de magnifiques modèles tous différents de ceux qu'on voit dans l'édition ci-dessus. Le verso du dernier feuillet contient la figure qui se trouve sur le titre de l'édition de 1553 citée ci-dessus $\mathrm{n}^{\circ}$ 110 et qui était la marque typographique de l'éditeur Pagan.

1356-Pagan, Matthio-Opera nova di varie disegni, utili a ciascheduna persona laquale si diletti de cusire, recchamare e designare intitulata: Specchio di vertu. In Venetia, per Matthio Pagano in Frezzaria, all insegna della Fede, 1554. In- $4^{\circ}$. Cet ouvrage curieux doit être une édition très augmentée de "Il specchio di pensieri" publié à Venise en 1540. Il est orné d'un titre gravé, sur lequel on remarque quatre figures sur bois. La première représente un gentilhomme faisant l'achat d'une broderie; la seconde une ouvrière travaillant le tissu à broder sur un métier de basse lisse ; la troisième des ouvrières occupées à broder au crochet, la quatrième une marchande en inspection chez ses ouvrières. Ces figures nous fournissent des renseignements curieux sur l'industrie de la broderie à cette époque. Le volume contient en outre $23 \mathrm{ff}$. imprimés où se trouvent des modèles de dessins de guipures et de points coupés du plus beau style Italien. Cette édition comprend done en tout $24 \mathrm{ff}$. Elle est de la plus grande rareté, car ni Brunet, ni ses continuateurs n'en font mention. Vente Bancel, 1882.

1357-Pagan, M.--Opera nova composta per D. da S. detto il Franciosino; dove si insegna a tutte le nobili et leggiadre giovanette di lavorare di puti: Cusire; Recamare, et far tutte qlle belle opere, etc. Venegia, M. Pagan, 1546. Facsimile reprint, Ongania, Venezia, 1879. S. K. M. Metro. Mus.

1358-Pagan, Matthio_Ornamento delle belle \& virtuose Donne, opera nvova nella quale trouerai varie sorti di frisi, con li quali si potra ornar ciascuna donna \& ogni letto con ponti tagliati, ponti gropposi, \& ogni altra sorte di ponti, per far tutte quelle bella opera che si appartengono alle virtuose \& Lodenoli Fanciulle. In Venetia, MDXLIIII. Petit in $-4^{\circ}$. Ce titre est inscrit dans un motif gravé sur bois, et le même qui est décrit cidessus. Verso, une dédicace: Alle virtuosiss. Sorella et nobiliss. Gentildonne di Candia. Petronilla et Catarina d'armer, Mattio Pagano Salute. Madonne, Mattio Pagan. Au-dessous de cette pièce de vers: Stampato in Venetia per Mattio Pagan. In Frezeria in le casa nuova, il 
qual tien per insegna, La Fede. En tout 24 feuillets, contenant un titre et quarante-cinq planches de broderies imprimées au recto et au verso. Au ver'so d'une page, une pièce de ver"s commençant par les mots: Alle Belle et Virtuose. Bibliothèque Nationale.

1359-Pagan, Mathio-Ornamento delle belle et virtuose donne, Opera nvova nella quale trouerai varie sorte di frisi con liquali si potra ornar ciascuna donna et ogni lettra con ponti tagliati, ponti gropposi, é ogn'altra sorte diponti per far tutte le belle opere che si appertengono alle virtuose et Lodeuoli Fanciulle. Petit in $-4^{\circ}$. In Venetia per Mathio Pagano, in Frezzaria, all', insegna della Fede, 1554. 'Titre, préface, 45 planches et une pour la souscription. Catalogue Tross, 1867.

1360-Pagan, Mathio--Il specchio di pensiere delle belle et Virtudiose donne, dove si Vede varie sorti di ponti, cioe Ponti tagliati, ponti groposi, ponti in Rede, a ponti in stiora, MDXLIIII (1544). Stampato in Venetia per Mathio Pagan. In Frazaria in le case noue qual tien per insegna: la Fede. Ce titre est inscrit sur une draperie flottante, fixée en haut par trois clous, et encadrée dans deux bandes rectangulaires horizontales et deux bandes rectangulaires verticales. Dans la bande horizontale supérieure on remarque au milieu, deux mains se tenant serrées l'une l'autre et surmontées du mot Fede. Dans la bande horizontale du bas on voit une femme assise de trois quart à droite, accoudée sur un vase et tenant d'une main un calice surmonté d'une hostie, de l'autre une croix appuyée sur son épaule. Les deux bandes verticles renferment des modèles de broderies au point compté. Page non cotée, verso. A droite de ce verso un vase. A gauche une femme posant une couronne sur la tête d'un jeune homme agenouillé, les mains jointes. Page non cotée, verso, deux mains jointes l'une dans l'autre dans le bas de la broderie. Page non cotée. Une sirène au bas d'une broderie. Verso, au bas des broderies à gauche une femme, à droite un page, tous les deux tenant une fleur gigantesque. Page non cotée, verso. Une femme personnifiant la foi, agenouillée de profil à gauche au pied d'une croix. Elle a une main posée sur sa poitrine, de l'autre elle élève en l'air, au-dessus de sa tête un calice. Dans le fond et se détachant sur le ciel, le mot Fede. En résumé 16 feuillets, dont un titre, et 29 planches de broderies. Bibliothèque Naticnale.

1361-Pagan, Matthio-Il specchio di pensieri delle belle et virtudiose donne dove si vede varie sorti di ponti, cive Ponti tagliati, punti gropposi, ponti in Rede, et ponti in stiora, MDXLVIII (1548). Stampato in Venetia per Mathio Pagan, in Frezzaria, in le case nuove qual tien per insegna, la Fede. In- $4^{\circ}$. 16 feuillets. Mentionné dans la bibliographie du marquis d'Adda. Rome, Bib. Prince Massimo.

1362-Pagan, M.--Il, Spechio di Pensieri della Belle et Virtudiose Donne, dove si vede varie sorti de Ponte, cioe Ponti Taliati, Ponti Groposi, Ponti in Rede e Ponti in Stiora. Venet. M. Pagan. 1550. 4. Cuts. 16 leaves. Vente Pirovano, Rome, 1901.

1363-Paganino, Alex.-Burato, con nova maestria gratiose donne. Novo artificio vi apprto. Accio che voi piu Accommodatamente possiati mostrare quanto valglia. 
Lo ingegno vostro ne lavori, e ornamenti de camise et

Aletri rechami questo sie che da questo artificio

Potreti sempre cavare con la penna tute quante

Quelle cose come figure fiori; et altri omamati che

Voi voretti cavare. Avertedovi che quelle tele piu

Large serve a cauare ponti scritti. Opera certamente

Non esser stata piu in luce et che a voi sera di

Grandissima facilitta a i vostri lauori piu che alcuna

Altra che per sin aqui sia fatta come voi medesimi

Vedretti operandola.

Petit in- $4^{\circ}$. Au-dessous de ce titre une gravure sur bois d'un faire assez grossier entourée d'un trait carré et d'un filet. On voit quatre femmes dans une chambre, occupées à différents travaux. Au fond, une d'elles est derrière un métier à haute lisse, une autre à gauche au premier plan travaille à un petit métier à rubans placé devant elle sur une table. Une troisième à droite au premier plan, de profil à gauche, est en train de coudre une étoffe posée sur ses genoux. 33 planches, quelques unes portant seulement un quadrillage déstiné à être rempli, d'autres avec quelques figures tracées. P. Alex. Pag. Benacenses. F. Bena. V. V. (Toscolano. Alex. Paganini, vers 1525.) Vente Benedetto Maglione, Paris. 1894. Vente Pirovano, Rome, 1901. Foulc Sale, Paris, June, 1914, No. 457.

1364-Paganino, Alex.-Burato . . . questi sono quattro fogli, con mostre, di tela chiara, a quadretti, per fare opera di punto in varie larghezze ove mareata gradamente l'opera piu o meno fitta . . . P. Alex. Pag. (Paganinus.) Benaccensis F. Bena. V. V. Sans date. Catalogue Cicognara.

1364a-Paganino, Alex.-Il Burato-Libro di ricami. Reproduced under direction of Elisa Ricci. Bergamo.

1365-Paganino, Allesandro-Libro primo di rechami p. elquale se impara in diuersi modi l'ordine e il modo de recamare cosa non mai piu fatta ne stata mostrata, el qual modo se in segna al lettore soltando la carta. Opera noua. Ce titre est circonscrit par une composition où l'on voit en haut un entablement demi-circulaire posant sur deux colonnes, surmontées chacune d'une petite figure de femme, brodant à l'aiguille. Au milieu un homme travaillant à un petit métier qu'il tient des deux mains appuyé sur son genou. En bas de la composition et au-dessous du titre, deux femmes travaillant l'une à droite à un métier de basse lisse, l'autre à gauche à un petit métier à rubans posé devant elle sur une table. Elle est assise sur une chaise de trois quart à droite. Dans les médaillons ronds qu'on voit au milieu des colonnes, deux têtes à la Romaine se faisant face. Dédicace: Allessandro Paganino al lettore. Suite de la dédicace. Verso, fin de la dédicace. Dans le bas de ce verso, quatre femmes, chacune dans un compartiment formé par une arcade et travaillant à des travaux d'aiguille. En haut à gauche, c'est une femme assise à un métier, une chandelle à ses pieds. A droite une femme travaillant à un métier, posé debout devant elle. En bas à gauche une femme ponçant un modèle. A droite une femme décalquant un dessin. Page non cotée. 
-Au verso on lit: P. Alex. Pag. Benacenses. F. Bena, V.V. Vente Pirovano, Roma, 1901, catalogue $\mathrm{n}^{\circ} 384$. Bibliothèque Nationale.

1366-See 1365-Libro secondo di rechami p. el quale se impara in diuersi modi ordine é il modo de recamare cosa non mai piu fatta ne satta mostrata, el qual modo se insegna al lettore voltando la carta. Opera Noua. Même titre, même gravure Frontispice que ci-dessus. Verso, même dédicace. Aij, verso même gravure sur bois. Page non cotée. Au verso de cette dernière page on lit: P. Alex. Pag. Benacensis. F. Bena, V. V.

1367-See 1365-Libro terzo de rechami . . . \& Nous savons que cette troisième partie existe, mais ne l'ayant jamais vue nous ne l'indiquons ici que pour mémoire.

1368-See 1365-Libro quarto de rechami, p. elquale se impara in diversi modi l'ordine e il modo de recamare cosa non mai piu fatta ne stata mostrata, el qual modo se insegna al lettore vol tando la carta. Opera noua. In- $4^{\circ}$. Même description que le $\mathrm{n}^{\circ}$ ci-dessus décrit. Un cahier de 20 feuillets avec signature. AAAAI, AAAAX, même titre, même lettre de Paganino, et même figure au verso du $2^{\circ}$ feuillet que pour le Livre Primo. Suivent imprimés au recto des feuillets, 18 superbes modèles de travaux à l'aiguille gravés en bois d'un genre absolument différent de ceux qui se trouvent dans le Libro Primo. A la fin: P. Alex. Pag. Benacenses. F. Bena. V. V. s. d. Vente Pirovano, Roma. 1901. Foulc Sale, June, 1914, Paris, No. 457.

1369-Paganino, A.-Libro Primo. De rechami p elquale se impara in diversi modi lordine e il modo de recamare, cosa nō mai piu fatta ne stata mostrata, el qual modo se insegna al lettore voltando la carta. Opera noua. [On last page] P. Alex. Pag. Benacenses. F. Bena. V. V. $4^{\circ} .2$ pp., 31 leaves of cuts. (1527.) (Ongania reproductions.) S. K. M.

1370-Paganino, A.-Libro Secondo . . . Burato. $4^{\circ}$. Title and 20 leaves of cuts. (1527.) (Ongania reproduction.) See 1366.

1371-Paganino, A-Burato--Libro Terzo. $4^{\circ}$. Title and 20 leaves of cuts. (1527.) (Ongania reproduction.) See 1367.

1372-Paganino, A.-Burato-Libro Quarto. $4^{\circ}$. Title and 20 leaves of cuts. (1527.) (Ongania reproduction.) See 1368.

1373-Paganino, Alex.-Liber Primo de rechami per el quale se impara in diversi modi l'ordine e il modo de recamare, etc. 28 plates. Facsimile of the original of $15-$ ?. 3 vols. in 1 , royal 8 vo.

1374-Paganino, A.-Libro questo di rechami per el quale se impara in diversi modi l'ordine e il modo de recamare, cosa non mai più fatta n'è stata mostrata. By Alessandro Paganino. 20 plates, with a long explanation how these works are done. Rome, Bib. Prince Massimo.

1375-Pagès, L.-Les Écoles de dentelle. Le Cours de dessin de la Chambre Syndicale. La Dentelle, April, 1905, Paris.

1376-Pagès, L.-Les grandes écoles de dessin. (Album de la Dentelle. Exposition, Liége, 1905.) Numéro spécial de La Dentelle, April-SeptemberOctober, 1905, Paris.

1377-Pairault, Mme. Veuve et fils-Facsimiles and reproductions of old pattern books. 
1378-Paleografia artistica nei codici cassinesi applicata ai lavori industriali, La -Merletti dalla Tav. 1 alla Tav. 20. Montecassino, 1888-1896.

1379-Palliser, Mrs. Bury-A descriptive catalogue of the lace and embroidery in the South Kensington Museum, with illustrations. London, 1871, 8vo.

1380-Palliser, Mrs. Bury-A descriptive Catalogue of the Lace in the South Kensington Museum. London, 1873. 14 plates, 73 pages. 2 edit.

1381-Palliser, Mrs. Bury-Descriptive Catalogue of Lace in the South Kensington Museum. 3d edition, revis ed and enlarged by A. S. Cole, London, 1881, G. E. Eyre \& W. S. Spottis woode, 21 plates, 144 pages. B. M.

1382-Palliser, Mrs. Bury-Guide to the ancient and modern Lace in the International Exhibition. London, 1874.

1383-Palliser, Mrs. Bury-Histoire de la Dentelle. Traduit par Gedeon de Clermont-Tonnere. Paris, 1892. 16 plates in color, 161 wood engravings.

1384-Palliser, Mrs. Bury-History of Lace. All the Year, V. 36, pp. 249, 294, 350.

1385-Palliser, Mrs. F. Bury-History of Lace. Eclectic Magazine, V. 65, p. 326. 1386-Palliser, Mrs. F. Bury-History of Lace. Every Saturday, V. 6, p. 201. 1387-Palliser, Mrs. F. Bury-History of Lace. Living Age, V. 98, p. 535.

1388-Palliser, Mrs. F. Bury-History of Lace. Quarterly, 125:166.

1389-Palliser, Mrs. Bury-History of Lace. London, C. Low, Son \& Marston, 1865. 460 pages, 17 plates, 1 port.

1390-Palliser, Mrs. F. Bury (Fanny Marryat) - A History of Lace. London, Sampson, Low, Son \& Marston, 1869. 422 pages, 17 plates, 2nd edition.

1391-Palliser, Mrs. F. Bury-A History of Lace. 3d edition, London, 1875.

1392_Palliser, Mrs. F. Bury-A History of Lace, entirely revised-by M. Jourdain and Alica Dryden. London, Sampson Low, 1902. B. M.

1393-Palliser, Mrs. Bury-Lace. The Magazine of Art, November, 1878, London, V. 1, p. 179.

1394-Palliser, Mrs. F. Bury-Lace. Quarterly Review, July, 1868.

1395-Palliser, Mrs. F. Bury-Notes on the History of Lace, to which is added a Catalogue of Specimens of Lace Selected from the Museum at South Kensington, etc. London, 1872, 8vo.

1396-Palliser, Mrs. Bury-Report on Lace, Net, Embroidery and Smallware Manufactures, Class 33. (Paris, Univ. Exhibit., 1867.) Vol. 3, p. 109. 7 vols., 8vo. London, 1868-69.

1397-Palliser, Mrs. F. Bury-Reports of the U. S. Commissioners, Lace, Net, Embroidery and Trimmings, Vol. 3, p. 109, 6 vols., 8vo, Washington, 1870. S. K. M.

1398-Parasole, Elisabetta Catanea-Fior d'ogni Virtv per le nobile et honeste matrone, doue si verdono bellissimi lauori di ponto in aria, reticella, di maglia et a piombini dissagnati, da Isabetta Catanea Parasole. In Roma apresso Antonio Fachetti. MDCX (1610). Con Licenza de superiori. In- $4^{\circ}$ oblong. Au-dessus de l'adresse de l'éditeur les armes d'Espagne, surmontées d'une couronne. Autour de l'écusson qui contient ces armes, 22 petits drapeaux piqués dans cet écusson, 11 de chaque côté. Rien au verso. Les pages sont numérotées en haut à droite en chiffres arabes, et il y a l'explication de chaque dessin. 2 Dédicace: Alla se- 
renissima Princepessa Donna Elisabetta Borbona d'Austria, Principessa Spagna, 14 lignes se terminant par les mots: Di Roma a di 5 di marzo 1610. Elisabetta. Catanea Parasole. Puis les broderies. Au-dessous les mêmes armes que sur le titre et au-dessous: Stampato in Roma appresso Antonio Fachetti MDCX. 37 très beaux modèles de dentelles et de broderies, coins de mouchoirs et autres objets de lingerie. Vente Destailleurs, 1895.

1399-Parasole, Isabella C.-Modeles de dentelles et de broderie. Sans lieu ni date. In $-4^{\circ}$ oblong, cartonne. 31 planches (B-H par 4 , I par 3 ). Ces planches font sans doute partie d'un ouvrage publiés par Isabella C. Parasole. Foulc Sale, Paris, June, 1914, No. 461, frs. 180.

1400-Parasole, Isabetta Catanea-Pretioso Gemma Delle Virtuose Donne Doue si vedono bellissimi lauori di punto in aria, reticella, di maglia, e piombini, disegnati da Isabella Catanea Parasole. E. di nuouo dati in luce da Lucchino Gargano, con alcuni altri bellissimi lauori nuouamente inuentati. Stampata in Venetia, Ad instantia di Lucchino Gargano. M. D. C. Con Licenza de' Superiori. $4^{\circ}$. Title, dedication, 18 leaves of cuts.

1401-Parasole, Isabelle Catanea-Pretiosa gemma delle virtuose dame. Done si vedono bellissimi lauori di punto in aria, reticella, di maglia e piombini, desegnati da I. C. Parasole. E di nuovo dati in luce de Lucchino Gargano, 1618, con alcunti altri bellesimi lauori monamente inuentati. Venice, L. Gargano, 1600. Reprinted in Venice, 1879. S. K. M. Metro. Mus.

1402_Parasole, Isabella Catanea-Secondo Libro della Pretiosa Gemma Delle Virtuose Donne. Doue con nuoua inuentione si vedone bellissimi Lauori di varie sorti di Merli grandi, e piccioli, punti in aria, punti tagliati, punti à reticello, e Rosetti diuersi, che con l'aco si vsano loggidi per tutta Europa. Nouamenta dato in luce da Lucchino Gargano. Stampata in Venetia, Ad instantia di Lucchino Gargano, MDCI. $4^{\circ}$. Title, dedication, 17 leaves of cuts. (Ongania reproduction.)

1403-Parasole, I. C.-Gemma pretiosa delle virtuose donne, dore si vedono bellisimi lavori de Ponti in Aria, Reticella, di Maglia, e Piombini disegnatida Isabella Catanea Parasole. In Rome, appreso Guliegno Facciotti, 1625. $4^{\circ}$. Title and 34 cuts. B. K. M.

1404 -Parasole, Isabella Catanea-Specchio delle virtuose done. Venice, 1594 and Rome, 1595.

1405-Parasole, Isabella Catanea-Specchio delle virtuose donne. Done si vedono bellissimi lavori di punto in aria, reticella, di maglia e piombini, designati da Isabella Catanea Parasole. Roma, appresso Antonio Facchetti, 1598. In $-4^{\circ}$ oblong, 1 feuillet de titre, 30 feuillets de modèles. Vente Foulc.

1406-Parasole, E. C.-Specchio delle virtuose donne. Dove si vedono bellissimi lavori. di ponto in aria, reticella, di maglia et piombini. Disegnati da Isabetta Catanea Parasole. Roma, appresso Antonio Facclietti, 1598. One volume in $4^{\circ}$, oblong cartonné. Un feuillet de titre, un feuillet blane et 38 feuillets chiffrés contenent autant de modèles de dentelles, broderies, coins de mouchoirs, ete. Foule Sale, Paris, June, 1914, No. 459, Frs. 500. 
1407-Parasole, Isabella Catanea-Studio, Delle Virtuose, Dame, Doue si vedono bellifsimi lauori di punto in aria reticella, di maglia. Diffeganti da Ifabetta Catanea Parafole. In Roma, Appreffo Antonio Facchetti. M.D.XCVII. Con Licenza De' Superiori. $4^{\circ}$. 36 leaves consisting of title page, 2 dedications (In Spanish and Italian) To Dona Joana de Aragon y Cordona, whose coat of arms is on the title page. 33 plates This is the only copy known of the original edition. Stranges Trans. Bib. Soc. VII. 254-257. Metro. Mus.

1408-Parasole, Isabella Catanea-Studio delle virtuose dame; Roma, Antonio Fachetti, 1597. Quaritch's reprints of rare books, II. London, 1884. obl. $12^{\circ}$.

1409-Parasole, Isabetta Catanea-Studio delle Virtuose Dame. Doue si vedono bellissimi lauori di punto in aria, reticella, di maglia. Dissegnati da Isabetta Catanea Parasole. In Roma, Appresso, Antonio Facchetti. M.D.XCVII, Con Licenza de' Superiori. $4^{\circ}$. Title, 2 dedications (in Spanish and Italian). $33 \mathrm{ff}$. S. K. M.

1410-Parasole, E. C.-Theatro delle nobile et Virtuose donne, dove si rappresentano Varij Disegni di Lauori nouamente Inventati et disegnati da Elisabetta Catanea Parasole Romana. Ce titre est ornementé de la même façon que celui de l'édition de 1616. Ta senle différence est dans la date de la signature 1636 au lieu de 1616 et dans la dédicace au recto de la page suivante: Al magnifico Giovanni Orlandi da Giacomo Marcucci, au lieu de: Alla Serenissima Principessa donna, \& \&. Ce titre est inscrit dans une tablette entourée de rinceaux, et au-dessus d'un socle en maçonnerie au milieu duquel on voit en bas dans un cartouche ovale, un buste de femme, ayant autour du cou une vaste fraise goudronnée. En haut audessus du titre au milieu, un écusson armoirié. Cet écusson est dans un cartouche, sur lequel deux femmes sonnant de la trompette ont une main posée. De petitis gênies, tenant l'un compas, l'autre une règle, une plume et un encrier agrémentent cette composition g'ravée sur cuivre. En bas sur un rebord du socle qui supporte ce dessin, on lit à gauche: In Roma l'anno 1616, con Licentia de superiori.

1411-Parasole, E. C.-Teatro delle nobili et virtuose donne, dove si rappresentano varij disegni di lavori novamente inventati et disegnati da Elisabetta Catanea Parasole Romana. In $-4^{\circ}$ oblong. Dédicace: Alla serenissima Principessa Donna Elisabetta Borbona d'avstria, Principessa di Spagna . . . et finissant par les mots: Di Roma a di 5. di Marzo, 1616. Other editions, 1620, 1625 and 1636. The last is dedicated to the Grand Duchess of Tuscany, and has the Medici and Della Rovere arms in the title-page. Obl. 4to, 47 ff., 46 plates, beautifully executed, the titles printed to each plate, as "Lavori di punti in aria, Merletti di ponti reticella, Merletti a piombini," etc. Chacune des broderies imprimées seulement au recto des pages, porte en haut l'indication du genre de travail qu'elle représente. Après la planche 50, une page non cotée. C'est une grande planche repliée en trois, dite: Le grand mouchoir. Vente Santarelli. Vente Benedetto Maglione Paris, 1894. Une édition de 1619, vente 
Piot, 1891. Florence, Bib. Prof. Santerelli. Milan, Bibliothèque de l'Ambroisienne. Rome, Bibliothèque de Prince Massimo.

1412-Parasole, Isabella Catanea-Teatro delle nobili et virtuose dame dove si rappresentano varij desegni di lauori honamente inventati et disegnati da I. C. Parasole. Roma, 1616. Reprinted in Venice, 1891, by Ongania.

1413-Parasole, E. C.- Theatro delle nobili et virtuose donne dovi si rappresentano Varij disegni di Lauori nouamente inventati et disegnati da Elisabetta Catanea Parasole Romana. In Roma l'anno 1620. In $-4^{\circ}$ oblong. Frontispice gravé au burin avec les armes de Médicis et de la Rovère plusieurs fois répétés dans un cartouche avec des amours dans les poses les plus charmantes et d'un si beau style que nous inclinons fort à croire qu'il fut exécuté au siècle précédent pour un tout autre ouvrage. On y trouve la devise: Nisi canant qui fortia quid isti gerunt. In Roma l'anno 1620. Mauritio Bona in Piazza Navona. 49 feuillets dont deux pour le titre et la dédicace. La grande planche de la fin, repliée en trois est un vrai chef-d'œuvre de xylographie. Les planches sont au nombre de 45, imprimées au recto seulement. Foulc collection accounted for only 40 plates, June, 1914. Paris, No. 460, frs. 600.

1414 -Paris_Souvenir de l'Exposition de 1839. Par J. Dumas. Fol. Paris, n. d. S. K. M.

1415-Paris Exhibition, 1855-Reports. French. Reports du Jury mixte international. (Dentelles, Vol. 2, p. 1100.) 2 vols. 8vo. Paris, 1856. S. K. M.

1416-Paris Exhibition, 1867-Reports. French, Dentelles, Tulles, Broderies et Passementeries. Vol. IV., p. 231. 13 vols. 8vo. Paris, 1868. S. K. M.

1417-Paris Exhibitions, 1878-Rapports des Membres des Jurys, etc. (Belgian) sur l'Exposition universelle de Paris en 1878. (Dentelles et Broderies, vol. III., p. 491.) 5 vols. 8vo. Bruxelles, 1879-80. S. K. M.

1418-Parkes, Kineton-Occupations for Gentlewomen. I. Lace Work and Embroidery. Atalanta, November, 1894, London.

1419-Parsons, E.-Cutwork or Renaissance Embroidery. Woman's Home Companion. V. 31, p. 22, March, 1904.

1420-Pasini, T.-Fiori di ricami nuovamente posti in luce ne i quali sono varii, et diversi dissegni di lavori; Come Merli, Bauari, Manichetti, \& altre sorti di opere, che al presente sono in uso, utilissimi al ogni stato di Donne. Seconda Impressione. Obl. 8vo, 20 ff., 18 plates like Vecellio, one "bavaro." Mostly indented patterns on black grounds. Bologna, 1596. Bib. de l'Arsenal.

1421-Passerotti, A.-Passerotti Aurelio Pittore Bolognese dissegnatore e miniatore figlio di Bartolommeo Passerotti circa al 1560. Libro Primo di lavorieri alle molto illustre et virtuosissime gentildonne Bolognesi. Libro secondo alle molto magnifici et virtuosissimi signori Bologne, n.d. In fol. obl. $67 \mathrm{ff}$. , including two dedications and a frontispiece. Designs for embroidery, etc., drawn with a pen. In the title-page of the first book is the device of a sunflower, "Non san questi occhi volgere altrove." Catalogue Cicognara.

1422-Passerotti, Aurelio.-Libro di Lavorieri Alla Serenissīma sig-ra Margarita Gonzaga da Este Duchessa di Ferrara, Patrona Colendissima. In 
Bologna. Appresso Fausto Bonardi, Con licenza de' Superiori. M.D.XCI. 4․ Dedication dated "17 Agosto 1591," signed "A. P." Cuts (with several shields of arms). B. K. M.

1423-Patching, John F.-Lace in Interior Decoration. Illus. Good Furniture Mag. Grand Rapids, 1918. V. 10, p. 307-316.

1425-Patterns of cutworkes-Here followeth certaine patternes of Cutworkes; and but once printed before. Also sundry sorts of spots, as flowers, birds, and fishes, \&. Londres, 1632. In- $4^{\circ}$. 33 patrons et le titre. Bibliothèque Bodleyenne d'Oxford.

1426-Pattern Book. Published by O. Foelix in Cologne, 1527.

1427-Pattern Book. Published by Wilhelm Vosterman, Antwerp, 1542.

1428-Patterns of Nottingham Lace. March, 1850.

1429-Patterns-Patrons pour brodeurs, lingières, massons, verriers, et autres gens d'esperit; nouvellement imprimé, à Paris, rue Saint-Jacques, à la Queue-de Regnard M.DLXIIII. (1564.) Quoted by Willemin. See 1566, 1567 and 1568.

1430-Pattern Book-An extensive Collection of upwards of 150 Original Drawings, mostly in pen and ink, of various designs, including a few executed in water-colors, mounted on toned paper. From the library of H. R. H. The Duchess of Gloucester.

1431-Pattern Book-A series of about 220 drawings in sepia of Patterns of Lace, Embroidery, etc., on 80 leaves. Circa, 1830.

1432-Patterns for Needlework.-Muster altdeutscher und moderner Stickereien Herausgegeben von Frau M. Beeg-Aufsess, etc. 30 colored plates. Fol. Leipzig, 1883. S. K. M.

1433-Pattison, H.-Crochet Applique Lace. Harper's Bazaar.. V. 42, pp. 12311233, December, 1908.

1434 - Pattison, H.-Crocheted Doilies. Harper's Bazaar. V. 45, p. 129, March 1911.

1435-Pavot, T.-Dentelle du Havre. Intermédiare des Chercheurs, 1896, Paris. 1436-Peacock, N.-New Movement in Russian Art. International Studio. V. 13, p. 268-276, June, 1901.

1437-Pegg, Wm. H. at Nottingham-Projet d'un éventail en dentelle. Art appliqué, 2e année, Paris.

1438-Pelegrin, Francisque-La fleur de la science de Portraicture Et patrons de broderie; façon arabique et Italique. Cum privilegio Regis. Ce titre est inscrit en lettres gothiques au haut de la page. Au-dessous une gravure sur bois, représentant une femme presque nue, portant sur les épaules une sorte de chasuble transparente lui descendant jusqu'aux genoux. Elle se dirige vers la gauche, retournant la tête de trois quart à droite, cette tête couronnée de rayons lumineux. Elle tient de la main droite sur son épaule un joug et de l'autre une banderole sur laquelle on lit: Exitus acta Probat. Ses cheveux dénoués flottent sur son dos. Ses pieds sont enchaînés à un gros boulet qu'elle traîne derrière elle. A gauche des tiges de plantes qui s'élèvent droites hors du sol, et sont terminées par des fleurettes à quatre pétales. En suyt le priuilège. Francoys par la grâce de Dieu Roy de France, au preuost et bailly 
de Paris ou ses lyeutenans et à tous noz autres justiciers, salut et dilection. Reçue avons l'humble supplication de nostre cher et bien amé Francisque pelegrin de Florence, contenant que pour tousiours décorer, publier, et à coustre l'art et science de pourtraicture. Il auec grant peine, et labeur fait, inuenté et composé Ung liure de feuillages, entrelatz, et ouuraiges moresques et damasquins, leql il desireroit vouletiers faire imprimer et mettre en lumière. Doné à Bordeaulx le xBii iour de Jung. Par le Roy a nostre relation. Barillon. Ce présent liure a esté imprimé à Paris, par Jacques Nyuerd le IX jour d'aoust. L'an de grâce mil cinq ces XXX pour noble home messire Francisque Pelegrin de Florence. On les vend à Paris en la grant rue Saint Anthoyne deuant les Tournelles. Au logis de Monseigneur le Conte des Larpes. Par messire Francisque Pelegrin de Florence. In- $4^{\circ}$. Soixante-deux feuillets cotés de 2 à 62 avec cinquante-neuf planches représentant des moresques. Le titre est gothique. La date de 1530 de ce volume est bien plus ancienne que celle du Vinciolo, 1587 que M. Alvin nous donne pour le plus ancien livre de ce genre imprimé à Paris. No animals or natural objects. At plate 33, surrounded by arabesques, is an $\mathrm{N}$, the initial of the printer. Bibliothèque de l'Arsenal.

1439-Pellegrin, Francisque-La Fleur de la Science de Pourtraicture. Patrons de Broderie. Façon arabicque et ytalique. 1530. Réimpression en facsimile, avec introduction par Gaston Migeon, conservateur des objets d'art au Musée du Louvre, Jean Schemit, Paris, 1908, in 4to, en cartonnage en percaline.

1440-Pellegrino-Splendore della virtvose Giovanni dove si contengono molte et varie mostre di fogliami, Cioe punti in aere et punti tagliati bellissime et con tale artificio che li punti tagliati serueno alli punti in aere et da qvelle che sopragasi far si possono medesimamente, molte altre. In Venegia appresso Iseppo Foresto in calle dell'acque a san Julian, All'insegna del Pellegrino (1557). In-4\%. Au-dessous du titre au milieu, et au-dessus de l'adresse de l'éditeur, un fleuron entouré de cuirs, représentant un pèlerin, son bâton sur l'épaule, se dirigeant dans la campagne, de gauche à droite. Autour du fleuron on lit les mots: Non habemus hic civitatem permanentem sed futuram inquirimus. Au verso mne dédicace, Iseppo Foresto a i lettori. Une lettre ornée, un $\mathrm{V}$ entre les branches duquel on aperçoit un forgeron assis devant une enclume et frappant avec son marteau. Cette lettre est en tête de 17 lignes de texte finissant par les mots: . . gli anni Nostri Lunghi et felici. En résumé 16 feuillets, dont un titre et 29 planches de broderies. Bibliothèque Nationale.

1441-Pellegrino--Splendore delle virtuose Giovanni, dove si contangono molte et varie mostre fogliami. Cioe punti in aere et punti tagliati bellissimi, $\&$ con tale artificio che li punti tagliati serueno alli punti in aere, et da qvelle che sopragasi far si possono medesimamente molte altre. In Venetia per Iseppo Foresto in calle dell'acqua a san Zulian, all'insegna del Pellegrino, 1558. In-4 ${ }^{\circ}, 16$ feuillets. Catalogue Cicognara.

1442-Perry, W. C.-Needlework as an Art. From the "National Review," August, 1886. 8vo. Lond. 1886. S. K. M. 
1443-Peterborough-Cat. of the tercentenary of Mary, Queen of Scots Exhib., 1887. (Lace, Needlework, etc., p. 23.) 8vo. Peterborough, 1887. S. K. M. 1444-Peuchet-Dictionnaire Universel de la Géographie Commerçante. 1789.

1445-Pfnor, R.-Ornementation usuelle de toutes les Époques dans les Arts Industriels et en Architecture. (Plates 6, 15, 16, 46, 68.) 2 vols. 4 to. Paris, 1866-67. S. K. M.

1446-Photographs of Laces. 1879. (Collection of Kursheedt Manufacturing Co., N. Y.)

1447-Photos. of Lace, Nat'l Art Library, S. Kensington Coll'n. of Italian (Venetian, Genoese, etc.) Flemish (Brussels, Mechlin, etc.) French, English and Irish Lace. Contained in portfolios. No. 428. S. K. M.

1448-Piece of Old Lace, A.-(Argentan, XVITth century.) The Connoisseur, March, 1902, London.

1449-Pillow Lace-Maker. Every Saturday. V. 10, p. 325.

1450-Pin-money Made with the Needle. Ladies Home Journal. V. 21, p. 22, January, 1904.

1451-Pinson, Paul-Dentelle du Havre. Intermédiare des Chercheurs, 1896, Paris.

1452-Piot, C.-Quelques notes concernant des Brodeur's Belges du XV siècle et du siècle suivant. "Bull. des Commissions Roy. d'art et d'Archéol." Vol. II, p. 295. 8vo. Bruxelles, 1863. S. K. M.

1453-Plantadis, J.-L'art de la Dentelle en France. Revue Universelle, September, 1904, Paris.

1454 -Politique-Ordonnantie-raekende-de - koop-lieden-en-Werckstersder-spelle-werck, Kanten,-binnen Cortryck. Courtrai, (1765).

1455-Pollen, Mrs. J. H.-Ancient Lace in the Royal Museums, Brussels. Burlington Magazine, 1912. V. 21, pp. 328-334.

1457-Pollen, Mrs. J. H.-Early Designs in Lace-making. Burlington Magazine. V. 19, pp. 73-79, May, 1911.

1458-Pollen, Mrs. J. H.--Seven Centuries of Lace. London, W. Heineman, 1908. B. M.

1459-Pollock, Elizabeth, at Londonderry—Cols en dentelles au crochet. Eventail en dentelle. Art appliqué, $2 \mathrm{e}$ année, Paris.

1460-Polonaise Lace, Book of, by the Silkworm. (The Silkworm Series.) 8 vo. Lond. (1875). S. K. M.

1461-Pompe, Le-Le Pompe, opera nova nella quale si ritrovano varie \& diverse sorti di mostre per poter far cordelle ouer Bindelle d'oro, di seta, di Filo, ouero di altra cosa dove le belle et virtuose Donne potranno fare ogni sorte di lanore; cioe merli di diuerse sorte, Cauezzi, Colari, Maneghetti, \& tutte quelle cose que li piaceranno. Opera non men bella che utile et necessaria, Et non piuveduta in luce. In Venetia, MDLVII (1557). Catalogue Cicognara. Bibliothèque du Vatican.

1462-Pompe, Le-Le Pompe, opera nova nella quale si ritrovano varie \& diverse sorti di mostre per poter far cordella ouer Bindelle d'Oro, di seta, di Filo, ouero di altra cosa dove le belle et virtuose Donne potranno fare ogni sorte di lauore; cioe merli di diuerse sorte, Cauezzi, Colari, Maneghetti, \& tutte quelle cose que li piaceranno. Opera non men bella che 
utile et necessaria, Et non piu veduta in luce. In Venetia, MDLVIII (1558). Petit in- $4^{\circ}$. Au-dessous du titre une marque de libraire formée par un assemblage de bouts de rubans enlacés, sur lesquels on lit M. Jesus. F. En tout 14 pages dont un titre, en tout vingt-six planches de dentelles. Bibliothèque Nationale.

1463-Pompe.-Le Pompe Opera Noua Nellaquale Si Ritrouano Varie \& diuerse sorti di mostre, per poter jar Cordelle, ouer Bindelle, d'Ore, di Sera, di Filo, onero di altra cosa. Doue le belle \& virtuose Donne potranno fare ogni sorti di lauoro, cioè Merli de diuerse sorte, Cauezzi, Collari, Maneghetti, \& tutte quelle cose che li piaceranno. Opera non men bella, che vtile, \& necessaria. Et non piu veduta in luce. [Mark of the brothers Sessa of Venice.] MDLVIII. Si vendeno alla Libraria della Gatta. $4^{\circ}$. 31 cuts. B. K. M.

1465-Pompe, Le.--Le Pompe, opera nova, nella qvale si ritrovano varie et diuerse sorti di mostre per poter far cordelle, ouer Bindelle d'oro, di seta, di Filo, ouero di altra cosa. Dove le belle et virtuose donne potranno fare ogni sorte di lauoro cioe merli di diuerse sorte, cauezzi, Colari, maneghetti, $\&$ tutte quelle cose le piacceranno. Opera non men bella che vtile et necessaria, et non piu veduta in luce. In Venetia, MDLIX (1559).Petit in- $4^{\circ}$. $\mathrm{Au}$-dessous du titre un fleuron ovale, dans lequel on voit un vautour debout sur le cadavre d'une biche qu'il tient dans ses serres. Sur une banderole qui serpente autour du cartouche, on lit les mots: Virtute Parta, Non Sibi Tantum. Page non cotée. Le verso de cette page est blanc, et on lit au milieu de cette page: Si vendano alla libreria della Gata. En tout, 16 pages dont un titre et 30 planches de broderies. Vente Piot, 1891. Bibliothèque de l'Arsenal.

1466-Pompe Le-Le pompe, libro secondo, opera nvova nella quale si ritrovano varie et diverse sorti di mostre per poter far cordelle, ouer Bindelle d'Oro, di seta di Filo, ouero di altra cosa. Doue le belle \& virtuose donne potranno fare ogni sorte di lauoro cioe merli di diuerse sorte, Cauezzi, Colari, maneghetti, \& tutte quelle cose che li piaceranno. Opera non men bella che utile et necessaria. Et non piu veduta in luce. In Venetia, MDLX (1560). Sur cette page qui est en largeur et non en hauteur comme dans la première partie un fleuron ovale dans lequel on voit un Pégase volant dans les airs de gauche à droite. Impresa of the printer and below, In "Venetia 1560." Obl. 8vo, 6 or 16 pages. 29 plates. Mrs. Stisted's copy is dated 1562, and there is one at Vienna, in the Imperial Library, of the same date. Bib. de l'Arsenal.

1467-Pott, A.-Neue Zierschriften fior Weiss-und Kunst-Stickerei. (54 pp. of examples.) Fol. Hamburg, 1869. S. K. M.

1468-Pourtraicts de Venise, point coupé-P. De Sajow. (Collection of Kursheedt Mfg. Co., N. Y.)

1469-Pratt, L. M.-Lace Collar. The Art Worker's Quarterly, July, 1902, London.

1470-Prévot-Éventail. L'Art décoratif, February, 1902, Paris.

1471-Prévot, Gabriel et Gaston Devresse-Motifs modernes. Série TV. Dentelles et Broderies d'Art. Plauen, Chr. Stoll, n.d. 
1472-Prévot, Gabriel-Stores, dentelles et broderies style moderne. 3 séries, Paris, A. Calavas.

1473-Prévot, S.-Modern Designs for Lace. Nottingham.

1474-Priestman, M. T.-Artistic Darning. Handicrafts in the Home, 194-198.

1475-Priestman, M. T.-Needle-craft in Curtains. Country Life, V. 12, p. 364. July, 1907.

1476-Priestman, M. T.-Old Time Handicraft Revived. Harper's Bazaar, V. 42, pp. 905-907, September, 1908.

1477-Priestman, M. T.-Suggestions for Darning. American Homes, V. 8, pp. 134-136, April, 1911.

-Prince, Le-See Nourry, Claude.

Prince, Le-See Sainte-Lucie, Pierre.

1480-Princess Louise Lace. Delineator, V. 64, pp. 586-587: 782-783, OctoberNovember, 1904.

1481-Priscilla Crochet Book, The-Ed. E. A. Taylor. 1913.

1482-Priscilla Cross-stitch Book-Boston. (Collection of Kursheedt Mfg. Co., New York.) 1912.

1483-Proceedings of the Society of Designers-Nottingham Lace with W. Stewart Elliott's designs. The Artist, October, 1899, London.

1484-Production of Lace. Nation, V. 80, pp. 158-159, February 23, 1905.

1485-Programma der Nederlandsche Kantwerkschool, Gesticht door Jhr. Ernest van Loon. Apeldoorn, P. C. Ackerman, 1802.

1486-Protection of Lace-Making in England. Saturday Review, V. 72, p. 691. 1487-Pulszky, C. de-Acta nova Musei Nat. Hungarici. Tom II. Ornaments de l'Industrie domestique de la Hongrie. (Planches.) Fol. Budapest, 1878. S. K. M.

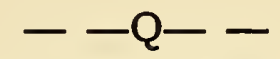

Quaritch Reprints-See Nos. 1351, 1408.

1488-Queen Lace Book, The-Part I. Mediaeval Lacework and Point Lace. London, "The Queen's" Office, 1874. B. M.

1489-Quentel, P-Eyn new kunstlich boich, etc. Gedruckt in Collen durch P. Quentell, 1527. (Facsimile reproduction.) Ornaments, patterns and letters for needlework. Sm. 4to. Leipzig, (1882). S. K. M.

1490-Quentell,Peter-Eyn new Kunstlich boich dair yn E. vnd rrr viij figurem, monster ad stalen befonden, wie man na der rechter art, laufferwerk, spansche stiche mit dernalen vort op der Kamen, und vp der laden, borden, wirken sall wilche stalen all-tzo samen verbessert synt vnd vil kunstlicher gemacht da dye eirsten ze sere nutzlich allen wapensticker frauwen ionferren und met ger dair ufs kunst licht lich tzu leren. Gedruckt tzu Collen up dem Dœm Hoff. durch Peter Quentell. Anno MDXXXjj. (1532.) Ce titre est dans une bordure ornementée, où l'on voit quatre femmes et un homme ocupés à des travaux d'aiguille et de passementerie. Le volume est composé de 24 feuillets signés A. F. entièrement remplis par des dessins de broderies, sauf le recto du premier feuillet qui contient le titre ci-dessus et le verso qui contient un portrait de Charles V assis, Veñte Santarelli. 
1491-Quentell, Peter-Ein new Kunstlich Modelbüch dair yn meir, dan sechs hundert figurenn monster a der stalen befonden, wie mann na der rechter art Perlenstickers, Lauffer werck spansche stiche, mit der nalen vort up der ramen unnd up der laden, borden, wircken sall wilche stalen altzo samen verbessert synt vn vill Kunstlicher gemacht dan die eirste mit vil meir neuwe stalen hier by gesatzt,ze. Sere nutzlich allen wapensticker frauwen ionfferenn und metger dair usz solch Kumst lichtlich tzo luren.--Ung nouviau libure anec pluseurs sciences et patrons qui n'ont point estes encore imprimes. Gedruckt tzo Collen up dem Dœmhoff. durch Peter Quentell. Im jair MDXXXVI. (1536). In-4 gothique. Au-dessous de ce titre, trois compartiments, celui du milieu encadré par deux colonnes. Dans le compartiment de gauche une femme assise de profil à droite et travaillant à un métier. Dans celui du milieu une femme assise de trois quart à droite et cousant. Dans celui de droite une femme travaillant à un petit métier à rubans. Le verso de cette page est occupé par une gravure sur bois qui sert de titre à plusieurs autres livres à dentelles, notamment au Pierre Quentel de 1527. C'est un fronton circulaire posant sur deux colonnes surmontées chacune d'une petite figure de femme brodant à l'aiguille. Au milieu un homme travaillant à un petit métier qu'il tient des deux mains appuyé sur un genou. En bas deux femmes travaillant, l'une, celle de droite à un métier de haute lisse, l'autre, celle de gauche à un petit métier posé devant elle sur une table. L'intérieur de la page, à l'endroit où devait être imprimé le titre est blanc. Puis commencent les broderies. Au verso de la dernière page, les armoiries de la ville de Cologne, représentant deux animaux fantastiques. Celui de droite à tête de lion, celui de gauche à tête d'aigle. On voit sur l'écusson central les couronnes des trois Rois, et cet écusson est surmonté d'un casque héraldique. En bas sur une tablette: O Felix Coloniae. En résumé, 52 pages dont 101 planches de broderies. Vente F. Didot, 1879.

1492-Quentell, P._Eyn New Künstich Modelbuech, daryñ vill schöner Staelen begriffen die ietzundt auff des newst unnd noch nye in druckt ausgangen als Rörtgens werck, Lōbartisch vn uberlegt werck, auch wapenstickers vn Schnitzlers, frauwen vn Junckfrauwen fust nutzlich darauf zu lernen, ec. Gedruckt au Coln durch Peter Quentell. Im iair 1544. Vng nouveau liure avec plusieurs sciences et patrons qui nont poinct este encore imprimees. $4^{\circ}$. Title page and 6 leaves. B. K. M.

1493-Quentel, P.-Ein new kunstlich Modelbuch . . ., etc. Exemplaire absolument semblable à celui est décrit ci dessus, avec cette différence qu’il est daté de 1545. Les cotes des pages ne sont pas en caractéres gothiques comme dans l'autre exemplaire. Vente Didot, 1879. Vente Destailleurs, 1895. P. Quentel a été longtemps considéré comme le plus ancien éditeur de livres à dentelles. On a de lui un livre de broderie publié en 1527. Ce livre fut réimprimé en 1529, 1532 et 1544. Cette dernière édition, celle qui nous occupe ici a été décrite exactement pour la première fois dans le catalogue de la vente Didot.

1494 -Quentel, Peter-Modellbuch (Ornamente und Stickmuster). Nach der 
höchst seltenen Cölner Ausgabe (1527-29) auf 80 Tafeln in Lichtdruckreproduktion lierausgegeben. Leipzig, 1880.

1495-Quentel, Peter-1527-1529, Musterbuch für Ornamente und Stickmuster. Leipzig, A. M. Götze, n.d. Kunstgewerbe-Museums zu Leipzig.

1496-Qui laborat orat (travail de la Dentelle). Dublin University Magazine, December, 1869, Dublin.

1497-Quignon, G. H.-La Dentelle Chantilly. Established by the Duchesse de Longueville.

1498-Quinty, Pierre-Liure nouveau et subtil touchant lart et science tant de brouderie, fronssures, tapisseries come aultres mestiers qun fait alesguille, soit au petit mestier, aultelisse ou sur toille clerc, tresvtile et necessaires a toutes gens usans des mestiers et ars dessuld ou semblables ou il y ha $\mathrm{C}$ et xxxviij, patrons de diuers ouvraiges faich per art et proportion. En primere a culoge (Cologne) par metrepiere quinty (Pierre Quinty), demorant denpre leglie de iii Roies. Petit in- $8^{\circ}$. Ce titre est disposé dans un rectangle blanc entouré d'un trait carré. Dans ce rectangle une composition gravée sur bois. Voir ci-dessus la description de cette composition. Verso. Des armoiries des deux côtés desquelles sont deux animaux fantastiques, celui de droite à tête de lion, celui de gauche à tête d'aigle. Oll voit sur l'écusson central les couronnes des trois Rois, et cet écusson est surmonté d'un casque héraldique. En bas de la composition une petite tablette rectangulaire sur laquelle on lit: O Felix Colonia, 1527. Puis commencent les broderies imprimées au recto et au verso.-Une page non cotée, alphabet gothique à fond de canevas, allant de la lettre $\mathrm{A}$ à la lettre P. Verso, fin de cet alphabet.-Une page non cotée, alphabet en capitales droites à fond de canevas.-Verso, alphabet en capitales droites, les lettres d'impression sur fond blanc. En résumé, 22 feuillets avec 42 planches. Bibliothèque Nationale.

\section{- - R- -}

1499-R., J. S.-Nottingham Lace Edgings. The Artist, March, 1900, London. 1500--R., Mme. de-Traité de la dentelle aux fuseaux, dentelles de Mirecourt, de Valenciennes, de Malines, de Flandre, de Bruxelles, de Venise, 1879.

1501-Ramsey, A. R.-Masterpiece of Mary Queen of Scots. Ladies' Home Journal, V. 17, p. 13, June, 1900.

1502-Rapport général sur la situation de l'industrie et du commerce dans le ressort de Saint-Nicolas. année, 1872.

1503-Rasmussen, S.-Klöppelbuch. Eine Anleitung zum Selbstunterricht in Spitzenklöppeln. Plates. 4to. Kopenhagen, 1884. S. K. M.

1504-Rasmussen, Sara-Notiser om Point de Venise og Point de France. Tidsskrift for Kunstindustri, 1889, Copenahagen.

1505-Real Lace, A Hint to Collector's-The Connoisseur, November, 1905, London.

1506-Reboul-Mémoire historique sur le Tulle et les Dentelles mécaniques de Calais, Préface de M. Passy. Calais, L. Fleury, 1885.

1507-Rechami, de-Per elquale se impara in diversi modi, l'ordine el il modo de recamare,etc. Reprint. n.p. n.d. 
1508-Recueil factice de 126 planches de dentelles de broderie et points coupés. En un vol. in-4.

1509-Redmond, L. M.--Lace in the Household. House Beautiful, V. 28, pp. 1820. June, 1910.

1510-Regnal, Georges-La cause de la vraie dentelle française. Simple Revue, May, 1904, Paris.

1511-Reiffenberg, di-Notice sur la Dentelle. Dictionnaire de la Conversation, etc., au mot "Dentelle."

1512-Reiser, D. H.-New Russian Drawn-work. Ladies' Home Journal, V. 23, p. 64, March, 1906.

1513-Renner, Henry-Zeichnungen für Spitzen und Stickereien. Zurich, M. Kreutzmann, 1911.

1514-Reusens-Album de l'art Ancien à l'Exposition de Bruxelles, 1884. La Dentelle Notice par le chanoine Reusens. In folio de 7 pages de texte et 30 planches en phototypie reproduisant les plus beaux spécimens des dentelles qui ont figurées à l'Exposition.

1515-Revival of the European Lace-industry. Review of Reviews, V. 35, pp. 607-608, May, 1907.

1516-Revolte des Passements, 1660, La-By a friend of Mme. de Sevigné.

1516a-Revue des Deux Mondes-L'industrie de la dentelle en Normandie, 1re avril, 1900.

1517-Reynolds, L. A.-A Lesson in the Making of Honiton Lace. Art Workers' Quarterly, V. 4, No. 13, pp. 40-43.

1518-Rhead, G. Wolliscroft-History of the Fan in Ancient and Modern Times. Magnificently illustrated with 27 full-page colored illustrations, 127 fullpage illustrations in black and white. London, 1910.

1519-Rheden, Klaus von-Brabanter Spitzen. Velhagen \& Klasings Monatshefte, Jahrg. 16, pp. 145-156. Bielefeld, 1902.

1520-Rhone, Fabrication de la Dentelle dans le Departement du, et les departements limitrophes. (Maison Dognin et Cie.) 4to. Lyons, 1862. S. K. M.

1521-Riano, J. F.-Catalogue of the Art Objects of Spanish Production in the S. Kensington Mus. (Class X. Lace.) 8vo. London, 1872. S. K. M.

1522-Riano, J. F.-The Industrial Arts in Spain. (Lace). 8vo. (Lond.), 1879. S. K. M.

1523-Ribello-Trionfo di Virtv, Libro novo da cusir, nel qual si contengono molti et diuerse sorti di fogliami del quale ogni gentil et virtuosa Madonna se potra servire. In far Ponti a fili, Ponti cruciati, ponti intrezola, ponti instura, ponto scritto tirar in opera cuchiar, Terser è molti altri ponti come a loro piacera. Ce titre est dans un cartouche ovale, formé de cuirs enroulés et décoré sur les côtés de guirlandes de fruits et de fleur's. Audessous une composition gravée sur bois. On voit à gauche une femme de la haute société, assise sur une chaise de bois, dont le dossier est décoré de sculptures. D'une main, elle tient une étoffe posée sur' ses genoux, de l'autre elle indique un ouvrage posé sur les genoux d'une autre femme assise prés d'elle à droite. Deux autres femmes complètent cette composition. Celle qui est à l'extrémité de droite, a également sur ses genoux un ouvrage représentant des entrelacs et elle se penche à gauche pour regarder 
le travail que fait sa compagne. Le parquet est formé de carreaux blancs et noirs et on voit un panier en osier, contenant du linge et des étoffes. $A u$ fond un paysage. Au verso d'un page, une grande marque de libraire gravée sur bois. Une femme à genoux de profil à droite, tenant des deux mains devant elle un calice. Près d'elle couchée par terre la SainteCroix. Médaillon ovale, entouré d'une bordure sur laquelle on lit: Senza di me l'huom fassi à dio Ribello. En tout un titre et 15 feuillets, donc 16 feuillets dont 28 planches de broderies. B. M.

1524-Ricami per Biancheria, 200 incisioni e testo esplicativo. Fratelli Trevas, Editori. Milan.

1525-Ricci, Elisa-Antiche trine Italiane. Bergamo. Instituto Italiano d'Arti Grafiche, 1908. B. M.

1526-Ricci, Elisa-Old Italian Lace. 2 vols. London, W. Heineman. Philadelphia, J. B. Lippincott Co., 1913.

1527-Ricci, Elisa-Peasant Art in Italy. Special Number of the International Studio, 1913.

1528-Ricci, E.-Revival of Needle-work in Italy. International Studio, V. 52, pp. 197-206, May, 1914.

-Ricci, E.-See Nos. 1324, 1364a, 1805a, 1813, 1894.

1529-Ricci, Leone-Catalogue of the Leone Ricci collection of old Lace. Classified, described and catalogued by Sara Hadley. New York, Metropolitan Art Association, 1915.

1530-Richard, J. M.-Mahaut, Comtesse d'Artois, etc. (1302-1329.) (Needlework.) 8vo. Paris, 1887. S. K. M.

1531-Rieger, F.-Rieger"sche. Modèles de broderie en noirs et enluminés. (18 plates.) Obl. fol. Mannheim. 1808. S. K. M.

1532-Rieujeyroux, A. de-Traité de la Dentelle au Fuseau. 1879.

1533-Riotor, Léon-La concours de dentelles de l'Union Centrale des Arts Décoratifs. L'Art décoratif, 1905, Paris.

1534 -Riotor, Léon-Les Dentelles de l'École des Arts et Métiers de Vienne. L'Art décoratif, October, 1900, Paris.

1535-Ripley, C.-Lace and Lace Making, Court of the Connoisseur; the Lineage of Laces. Good Housekeeping, V. 63, pp. 54-55, October, 1916.

1536-Risa, Dr. A.-Schlesische Spitzen. Mittheil. des Kais. Fr. Jos. Muséum für Kunst und Gewerbe. Troppau, 1899-1900.

1537-Rizzardi, Gio. Dominico-Giardino, nel quale si dimostra varij. disegni per far Ricami et altri lauori che con lago hoggidi si usano. Padoua. Gio. Dominico Rizzardi, 1607. 32 feuillets y compris le titre et 3 feuillets de dédicace et de vers à la signora Isabella Francazani Alecarda. Les planches ainsi que le cartouche ornementé du titre sont imprimés seulement au recto. Vente Santarelli.

1538-Robie,V.-Quest of the Quaint. Bypaths in Collecting, 496-516.

1539-Robinson, F. Mabel-Irish Lace. The Art Journal, 1887, London, V. 39, p. 144.

1540-Robinson, F. Mabel-The Lace School at Burano. The Magazine of Art, April, 1884, London. V. 7, p. 257. 
1541-Robinson, F. Mabel-Old Venetian Point. The Magazine of Art. December, 1883, London.

1542-Robson, Isabel Stuart-England's Oldest Handicrafts-Hand-made Lace. The Antiquary, July, 1898, London.

1543-Rock, Dr.--Introduction to Textile Fabrics at South Kensington Museum.

1544--Rock, Rev. Dr.-Wextile Fabrics, a Descriptive Catalogue of the Collection of Church Vestments, Dresses, Silk Stuffs, Needlework, and Tapestries, in the South Kensington Museum. 20 full-page plates, some colored. Thick royal 8vo. London, Published for the Committee, 1870.

1545-Rocker, E.-Crochet Doilies. Delineator, V. 79, pp. 222-223, March, 1912. 1546-Rocker, E.-Latest Crochet Collars. Delineator, V. 79, p. 338, Apr., 1912. 1547-Rocker, E.-Narrow Crochet Edgings. Delineator, V. 79, p. 143, Feb. 1912. 1548-Rocker, E.-Venetian Lace Crochet. Delineator, V. 79, p. 65, Jan., 1912.

1549-Roger-Millès-Comment discerner les styles? Études sur les formes et les décors dans les objets d'art... dentelles, etc. Paris. Ed. Rouveyre, n.d.

1550-Roger-Millès-Comment discerner les styles? La Dentelle. Transformations progressives XVIe et XVIIe siècles. Paris, Ed. Rouveyre, n.d.

1551-Rogge, Elizabeth, et A. von Saher-Tentoonstelling van Kunstnaaldwerk in het Museum van Kunstnijiverheid to Haarlem, 1904. Amsterdam, Scheltema \& Holkema, n. d.

1552-Romanelli-Marone, Giacinta-L'Arte delle Trine in Italia. Il Secolo XX, January, 1903.

1553-Romanelli-Marone, G.-Trine a Fuselli in Italia. Manuali Hoepli. Milano, 1902. B. M.

1554-Ronaldson, Miss-Lady's Book of Crochet Work. 1848.

1555-Ronse, Alfred-Discours prononcé le 15 mars, 1884, au conseil communal de Bruges.

1556-Rosevear, E.-A Manual of Needlework and Knitting. 136 pages. London, 1894. In British Museum.

1557-Rosevear, E.-Needlework, Knitting and Cutting Out. London, 1894, 3 parts. In British Museum.

1558-Rosevear, E.-Needlework and Knitting for Older Girls, etc. 3 parts, London, 1894. B. M.

1559-Rotherham, Jeremiah \& Co.-Lace curtains : new designs for 1898. London, (1898). 1a. 8vo.

1560-Rottigni-Marsilli, Ctessa G.-Una grande Industria Artistica Italiana. I Merletti di Venezia. L'Italia Moderna, 1904, No. 6, Rome.

1561-Rottigni-Marsilli, Giannina-Seritti Vari. Rome Union Coop. Editrice, 1896.

1562-Rouaix, P.-Dictionnaire des Arts décoratifs à l'usage des artisans, etc. (Broderie et Dentelle.) 8vo. Paris, 1886. S. K. M.

1563-Rouaix, P.-Les Styles. 700 gravures classées par époques. (Embroidery) fol. Paris, 1886. S. K. M.

1564-Rousseau, Eugène-Dans la Cité binchoise. L'industrie de la dentelle. Le Peuple, Sept. 12, 1904, Brussels.

1565-Royal Trousseaux-The Lady's Realm. September, 1889, London. 
1566-Ruelle, Jehan-Patrons pour Brodeur's, Lingières, Massons, Verriers et autres gens d'espirt, nouvellement, Imprimé à Paris, Par Jehan Ruelle. Encadrement du titre absolument le même que dans l' No. 1567. Le titre est également le même. Page non cotée, au verso trois petites gravures sur bois, tirés de la Vie de Notre-Seigneur. En haut, les femmes au SaintSépulchre. En bas à gauche Jésus apparaissant à ses disciples, à droite Jésus et les compagnons d'Emmaüs. En tout un titre, et 23 feuillets dont 31 planches de gravures. See No. 1429. B. M.

1567-Ruelle, Veuve Jean-Patrons pour Brodeurs, Lingières, Massons, Verriers et autres gens d'Espirt. A Paris, pour la Veuve Iean Ruelle, Rue S. Jacques à l'enseigne Sainct-Nicolas. Ce titr'e est inscrit dans un rectangle en hauteur, entouré de trois filets et encadré par un entourage de cuirs roulés et de rinceaux. De chaque côté de cette composition, une femme en cariatide, portant sur sa tête un chapiteau, sur lequel s'appuie la base d'une arcade ogivale. Sur ces chapiteaux se voient également une petite femme assise, tenant d'une main une plume, de l'autre un livre ouvert. En bas, au milieu, un mascaron, entre deux petits enfants et des chimères grotesques, portant sur leurs têtes des couronnes à pointes. En tout, un titre et 23 feuillets dont 31 planches de gravures. Bib. de l'Arsenal. 11,954 (with D. de Sera.) See No. 1429. Bibliothèque de l'Arsenal.

1568-Ruelle, V. Jean-Pattern Book, Paris, 1564, 23 pages, 32 plates. See No. 1429.

1569-Rupprecht, M. A. and Haffner, J. C.-Verschiedene Modell zum Stricken und Nähen. Obl. 4to. Augspurg, n.d. (18th century). S. K. M.

1570-Ruutz-Rees, J. E.-Home decoration; art needlework and embroidery, etc., 8vo. N. Y., 1881. Another edit. 8vo. N. Y. 1884. S. K. M.

1571-Ryland, Clarice, at Handsworth-Col de dentelle. Projet d'un voile de mariage. Art appliqué, 2e année, Paris.

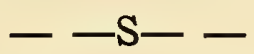

1572-S., A. M. (Mary Sharp)-Point and Pillow Lace. E. P. Dutton \& Co., London, 1899. B. M.

1573-S., A. M.-Point and Pillow Lace. Nation, V. 70 p. 18, Jan. 4, 1900: Athenaeum, V. 2, pp. 651-652, Nov. 17, 1900. Magazine of Art, V. 25, pp. 227-230, March, 1901. See Sharp, Mary.

1574 S.-M. de-Epaulettes de Dentelle. Journal des Dames et des Demoiselles, March 1, 1902, Brussels.

1575-S., R. M.-Nuw Modelbuch, allerley gattungen Dantelschnur so diser zyt in hoc Tütschlanden geng und brüchig sind zu vnderricht jven Leertochteren vnnd allen anderen schurwürkeren zu Zurych, vnd wo die sind, yetz nuwlich zubereit, vnd estmals in Truck, verfergket durch R. M. S. Petit in $-4^{\circ}$. $24 \mathrm{ff}$. Très rare. Sorti probablement des presses de Froschovern. Les $2 \mathrm{ff}$. liminaires, contiennent le titre avec une gravure représentant deux dames faisant de la dentelle, et une préface. Les feuillets $I$ à XIX chiffrés, contiennent de nombreux modèles gravés sur bois et les trois derniers la table. Catalogue Tross, 1870. New Modelbuch. "Printed at Zurich, by Christoph. Froschowern. About The year, 1560." 
S.,-R. M. see M,-R.

1577-S., T. E. D.-Buckinghamshire Lace. Atalanta, November, 1896, London.

1578-Sachs, Phyllis G., at London-Projet de col et barbe. Art appliqué, lre année, Paris.

1579-Sainte-Croix, Dr. Lè Roy de-Parement d'Autel ancien en Dentelle et Broderie, appartenant a Mrs. Hailstone. 8vo. Wakefield and Paris. 1874. S. K. M.

1580-Sainte Lucie, Pierre de-La fleur des patrons de lingerie à deux endroits, à point croisé, à point couché et à point picqué en fil d'or, fil d'argent et fil de soye ou aultre en quelque ouuraige que ce soit en comprenant l'art de broderie et tissuterie. Imprimées à Lyon en lai maison de Pierre de Sainte Lucie, dict le Prince près Nostre dame de Confort. In- $4^{\circ}$. Ce titre est dans un encadrement absolument pareil à celui qui est décrit ci-dessus. La seule différence est que cette première page n'est pas cotée A comme elle l'est dans l'édition ci-dessus et qu'il y a au verso un dessin de broderie. Page non cotée, verso. Au verso de cette page, une marque d'imprimeur, représentant un rocher, surmonté d'une ville forte. A gauche un homme cherche à monter le chemin escarpé qui mène à cette ville. Près de sa bouche on lit le mot spero. A droite dans une grotte, une furie la tête et les bras entourés de serpents. Au-dessous de cette marque: Imprimé à Lyon par Pierre de saincte Lucie dict le Prince, 1549. 8vo, 12 ff., 21 plates. Frontispiece. Title in Gothic letters, with woodcuts representing people at work. Below two women sitting at frames; above, two others; and between, a man with a frame in his hand. On each side a shield, one with crowned heart, on the other a lion, three fleurs de lys in chief. Patterns mediæval.. Silvestre gives 1530 to 1555 as the date of Pierre de Saincte Lucie. Voilà donc dit M. le marquis d'Adda, dans sa bibliographie, le premier volume de ce genre imprimé à Lyon et antérieur de 36 ans à l'ouvrage d'Ostaus, Trésor des Patrons, que M. Alvin nous donne non seulement pour le premier livre sur ces matières publié à Lyon, mais encore pour le premier en date de toute la France. Bound in one volume with the three following. (Nos. 16, 17 and 18.) -Catalogue des Livres provenant de la Bibliothèque de M. L. D. D. L. V. (Duke de La Vallière). Paris, 1763. T. xi., No. 2,204. Bibliothèque Sainte-Geneviève.

1581-Sáincte Lucie, Pierre de-Lyure noumeau dict patrons de lingerie: c'est assauoir à deux endroitz, à point croisé, point couché, et point picqué en fil d'or, d'argent, de soye et aultre en quelque ouurage que ce soit: en comprenant l'art le broderie, et tissuterie. On les vend à Lyo chez Pierre de Saicte Lucie, prés. nostre Dame de Confort. C'est absolument le même exemplaire que celui de l'edition de Claude Nourry décrit ci-dessus même nombre de pages, mêmes dessins de broderies, mêmes cotes par cahiers de 4 pages. Au verso de la dernière page la marque d'imprimeur est différente. Ici c'est une sorte d'Ecusson dans une couronne de branchages; au-dessous de cette couronne et enlacée avec elle une banderole sur laquelle on lit: Oculi mei semper ad Dominum. Psal. 24. Au bas une main tenant un bassin circulaire dans lequel on voit deux yeux. 40 wood- 
cut lace designs, engraved title, and printer's mark, 16th century. 8vo. Lyons, n.d. See also Belin, A. S. K. M.

1582-Saincte Lucie, Pierre de-Livre nouueau dict patrons de lingerie, c'est assauoir à deux endroitz à point croisé, point couché et point picque en fil d'or, d'argent, de soye et aultre en quelque ouvrage que ce soit, en comprenant l'art de broderie et tissoterie. Imprimé à Lyon, chez Pierre de Saincte Lucie, près Nostre Dame de Confort. In $-4^{\circ}$. Ce titre est dans un encadrement absolument pareil à celui de l'édition de Claude Nourry. La seule différence est que cette page n'est pas cotée A comme dans la susdite édition, et qu'il y a ici au verso un dessin de broderie. Les cotes des pages sont exactment les mêmes, et leur nombre également. Au verso de la dernière page, une marque d'imprimeur représentant un rocher surmonté d'une ville fortifiée. A gauche un homme cherche à monter le chemin escarpé qui mène à cette ville. Près de sa bouche on lit le mot: Spero. A droite dans une grotte, une furie, la tête et les bras entourés de serpents. 8 vo, 24 ff., 44 plates. Frontispiece. Title in Gothic letters; the same shields; two women at work. Patterns mediæval. At the end the same device. The copy of the Arsenal is a different impression. Instead of "Imprimes," \&c., we have, "On les vend," etc. Cat. d'Estrées. Bib. de l'Arsenal. Bib. Sainte Geneviève.

1583-Sainte Lucie, Pierre de-

Patrons de diuerses manières,

Inuentez très subtilement

Duysans à Brodeurs et Lingières,

Et à ceux lesquelsz bravement

Veullent par bon entendement

User d'antique et Roboesque

Frize et moderne proprement

En comprenant aussi moresque,

A tous massons, menuisiers et ver riers,

Feront proffit ces pourctraitz largement

Aux orpheures et gentilz tapissiers

A ieusnes gens aussi semblablement

Oublier point ne veulx aucunement

Contrepointiers et les tailleurs d'ymages.

Et tissotiers lesquels pareillement

Par ces patrons acquerront héritages.

Imprimées à Lyon par Pierre de Sainte-Lucie, dict le Prince, près Nostre -Dame de Confort. Ce titre est dans le même encadrement que celui décrit ci-dessus avec cette différence que la page n'est pas cotée AA, comme elle l'est dans l'édition ci-dessus. Non cotée. S'ensuyent les $\mathrm{Pa}$ trons de Messire Antoine Belin reclus de Sainct Martial de Lyon. Item plusieurs autres beaux patrons nouneaulx qui ont été inventez par Jehan Mayol Carme de Lyon. On les vend à Lyon chez le Prince. Ce titre est dans un encadrement formé de deux collonnes autour desquelles tourne un rinceau de feuillage. Au milieu de la page une marque d'imprimeur représentant un rocher surmonté d'une ville fortifiée. A gauche un 
homme cherche à monter le chemin escarpé qui mène à cette ville. Près de sa bouclıe on lit le mot: Spero, à droite dans une grotte, une furie, la tête et les bras entourés de serpents. Au verso un quadrillé, sans dessin de broderie. 8vo, 16 ff., 31 plates. Title in Gothic letters. Patterns mediæval. The copy at the Arsenal is a later impression. "On les vend a Lyon, par Pierre de Saincte Lucie, en la maison du deffunct Prince, pres," etc. It has only 12 ff., and 23 plates. Bibliothèque de Sainte-Geneviève.

1584-Sainte Lucie, Pierre de-

Patrons de diuerses manières,

Inuentez très subtilement

Duysans à Brodeurs et Lingières,

Et à ceux lesquelsz bravement

Veullent par bon entendement

User d'antique et Roboesque

Frize et moderne proprement

En comprenant aussi moresque,

A tous massons, menuisiers et verriers,

Feront proffit ces pourctraitz largement

Aux orpheures et gentilz tapissiers

A ieusnes gens aussi semblablement

Oublier point ne veulx aucunement

Contrepointiers et les tailleurs d'ymages.

Et tissotiers lesquels pareillement

Par ces patrons acquerront héritages.

On les vend à Lyon, par Pierre de Saincte Lucie.

En la maison du deffunct Prince, près Nostre-Dame de Confort.

Quelques exemplaires portent au lieu des trois dernières lignes ci-dessus: Imprimées à Lyon par Pierre de Sainct-Lucie, dict le Prince, près NostreDame de Confort. C'est absolument le même livre que celui décrit ci-dessus, sauf les différences dans l'énoncé du titre. Bibliothèque de L'Arsenal.

-Nos. 1580-1584 bound in 1 vol. Ellis (London) Cat. No. 177, 1918.

1585-Sainte Lucie, P. de-Patrons de divers manières, etc. Sm. obl. 4to. Lyons, Pierre de Ste. Lucie, 1590. 11 tracings of these patterns by C. E. Clerget. S. K. M.

1586--Sainte Lucie, Pierre de-La vera perfettione del disegno, di varie sorti di recami, et di cucire ogni sorte di punti a fogliami, punti tagliati, punti a fili \& rimessi, punti incrociati, punti a stuora \& ognaltre arte che dia opera a disegni a di nuovo aggiuntoui varie sorti di merli, e mostre che al presente sono in vso pratica. In Venetia Appresso Francesco di Franceschi, senese all' insegna della Pace, 1591. In-4 ${ }^{\circ}$ oblong. Sur le titre un fleuron, représentant une femme assise, tenant d'une main une branche d'olivier, de l'autre une torche allumée dont la flamme repose sur' le sol. Dedicace: Alla Clarissima signora Lvcretia Contarini. Verso, une gravure sur bois, représentant Lucrèce Romaine entourée de ses femmes. A droite un guerrier dans une porte. Signée en bas à gauche dans l'intérieur du dessin: 
José Sal. 1557. (Joseph Salviati, plus connu sous le nom de Porta Garfagnino.) Deux sonnets en regard l'un de l'autre. Celni de gauche: Alla Clarissima signora Lucrecia Priuli. Celui de droite: Sonetto alle saggie et Virtuose donne. Verso, préface aux lecteurs: Alli saggi et giuditiosi lettori. La dernière page non cotée, mais numérotée LXXVIIII, a au verso: Registro, A B C D E Tutti sono quaderni. Puis au-dessous un cartouche dans lequel on voit la Paix personnifiée par une femme tenant d'une main une branche d'olivier, de l'autre une torche, la flamme renversée. An-dessous on lit: In Venetia M D X C. Cette date ne concorde pas avec celle du titre. Il pourrait done se faire qu'il y ait eu une édition antérieure en 1590. 73 planches de broderies. Catalogue Yemenitz. Catalogue Riva. Bibliothèque de L'Arsenal. Bibliothèque Nationale.

Sainte Lucie-See A. Belin and Johan Troulon.

1587-Salwen, Ebba-Russische Franenarbeiten. Plauen, C. Stoll, 191(?).

1588-Sammlung neuer Muster zum Sticken in Plattstich und Tambourin gezeichnet von einer Hamburgerin. 1822, 1824, 1827 und 1828. Mit zus. 66 Taf. in Kpist. Qu.-fol. Hamburg.

1589_Sammlung von Spitzenmustern nach Originalen des XIV., XV. und XVI. Jahrhunderts. Berlin, Ernst Wasmuth, 1882.

1590-Samplers of our Lovely Ancestresses. Book Buyer, V. 22, pp. 216-220. April, 1901.

1591-Saunier, Charles-Broderies et Dentelles. L'Art décoratif, August, 1891, Paris.

1592-Saward, Blanche C.-Church Festival Decorations, and papers on fancy and art work in The Bazaar, Artistic Amusements, The Girl's Own Paper.

1593-Scailquin-Enquète scolaire sur l'enseignement professionnel et littéraire donné dans les ateliers d'apprentissage et les écoles dentellières. Brussels, 1884.

1594-Scantlebury, E. E.-Old and Rare Samplers. House Beautiful, V. 32, pp. 138-139, October, 1912.

1595-Schaarschmidt, M.-Ornamentik der Gegenwart. Plauen, n.d. One vol., oblong folio, original boards. 24 plates with 2,3 or 4 designs in colors.

1596-Schartzemberger, Johan-

Ain New Formbüchlin hin ich gnandt

Allen Künstlern noch vnbekandt

Sih mich. lieber Kauffer recht an

Findst drefflich, in dieser Kunffstan,

Schon gschnierlet gebdglet, auf glade,

Und gold auch schon vos premen stadt.

Es gibt dir ain prem umb ain Kleydt.

Wenn mans recht aussainander schneydt

Das kanst schneyden auss der Ellen

Von Samat Seyden wie mans wolle,

Ich mag braucht wern in allem landt,

Wenn man mich ersucht mit verstandt.

One volume petit in $-8^{\circ}$ oblong. Le titre ci-dessus est au millieu de la page 
dans un rectangle blanc entouré en haut et sur les côtés de rinceaux. On remarque en haut à gauche les armes d'Autriche, à droite celles d'Espagne. En bas trois compartiments formés par des ares surbaissés reposant sur des colonnes. Dans celui de gauche, une femme travaillant à un petit métier de basse lisse, dans celui du milieu un homme brodant, dans celui de droite deux femmes travaillant à l'aiguille. Tout l'exemplaire est composé de planches où le dessin est en blanc, s'enlevant sur un fond rouge brique. Le texte, les explications et la notice sont imprimés en noir. Gedruckt in der Keiserlichen Reichstatt Augsburg durch Johan Schartzemberger Formschneyder 1534. 20 feuillets non cotés et 38 planches de broderies. Graceful arabesque borders. Bibliothèque Nationale.

1597-Schinnerer, L.-Lehrgänge für Weisstickerei und Knupfarbeit nebst einem Anhang stilvoller Handarbeiten. Stuttgart, Deutsche Verlags Anstalt, 1893.

1598-Schirek, Carl-Zur Geschichte der Spitzenerzeugung in Mähren. Mittheil. des Mährischen Gewerbe Museums in Brünn, 1895, No. 7.

1599-School of Art Needlework, South Kensington-Cat. of special exhib. of Needlework. 8vo. Lond., 1881. S.K. M.

1600-Schorn, O. von-Die Spitzen geschichtliches und technisches. Kunst und gewerbe, Vol. VIII., p. 331. 4to. Nürnberg, 1874. S. K. M.

1601—Schramm, E. K.-Die alte Töndernsche Spitzenindustrie. Daheim, April 15, 1905, Leipzig.

1602-Schroedter, A.-Neue Muster für Schnur Stickerei, 4to. Frankfurt, n.d. S. K. M.

1603-Schultz, C. F.--Sammlung der Wertvollstern Spitzen Östreichischer Paramento. Plauen, C. F. Schnlt \& Co., 1907.

1604, Schultz, H.--Muster-Sammlung alter Leinen-stickerei. Sm. 4to. Leipzig. 1887. S. K. M.

1605-Schütte, Marie-Alte Spitzen. Berlin, R. C. Schmidt \& Co., 1914.

1606-Schütte, Marie-Alte Spitzen, am Anlass der Spitzenausstellung im staedtischen Kunstgewerbe Museum zu Leipzig 1911 herausgegeben. Three large portfolios with superb plates.

1607-Scott, Anna Dike-The A. D. Scott Collection of Old Lace, a Catalogue. Boston, Thomas Todd, 1905.

1608-Scott, E.-Flowers in Point Lace. Pub. by Wm. Barnard. obl. 4to. Lond., (1873). S. K. M.

1609-Scott, Gladys Annie, at Londonderry-Projets de dentelles modernes. Art appliqué, 2e année, Paris.

1610-Search for Old Lace in Venice, A-The Catholic World, March, 1876, New York.

1611-_Sebillot, Paul-Légendes et curiosités des métiers-Les Dentellières. Paris, Ern. Flammarion, n.d.

1612--Sedeyn, Emile-La Dentelle Française au Musée Galliera. L'Art décoratif, May, 1904, Paris.

1613-Sedgwick, Miss-A series of upwards of 160 original pen and ink drawings of designs for lace, in various styles, 1828. 
1614-Seemann, E. U.-Ein new Modelbüch, etc. durch Heinrich Steyner. Augsburg, 1534-Facsimile edition, Leipzig, E. U. Seemann, 1889.

Seemann Reproductions-See Nos. 1614, 1714.

1615-Seguin, J.-La Dentelle, histoire, description, fabrication, bibliographie. Woodcuts and 50 Phototypographic plates. fol. Paris, 1875. S. K. M.

1616-Seguy, E. A.-Ornamentation for Textiles. Paris, n.d. One vol. folio, original boards. 20 plates in black and colors, with $4,6,8$ or 9 designs.

1617-Seigfried, L. M.-Braids for Lace-Making. Harper's Bazaar, V. 33, pp. 2262-2263, Dec. 29, 1900.

1618-Seigfried, L. M.-Lace-making. Harper's Bazaar, V. 35, pp. 176-177, June, 1901.

1619-Seigfried, L. M.-Lace-making as an Art. Harper's Bazaar, V. 33, pp. 1403-1407; V. 34, pp. 246-247; pp. 1002-1003, Sept. 29, 1900, Jan. 26, 1901, Apr. 13, 1901.

1620-Seigfried, L. M.-Lace Work. Harper's Bazaar, V. 38, pp. 814-816, August, 1904.

1621-Seillac, Léon de-La Gréve des Tullistes de Calais. Musée social, No. 4, 1901, Paris.

1622-Selmersheim, Mme. Pierre, at Paris-Cols et empiècements en dentelle et broderie. Art appliqué, 1re année, Paris.

1623-Senneville, P.-Patrons de broderies. Gazette des Beaux-Arts, 1873, Paris.

1624-Sera, Domenico da-Libbretto novellamête côposto p. maestro Domenico da Sera detto il Franciosino: dove si appara et insegna a tutte le nobili et leggiadre giovanette di lavorare di ogni sorte di punti: Cusire, reccamare, et ultimatamête far tutte qlle vaghe et belle opere: che si appartêgono alle vertuose et lode voli fanciulle: et quai se diletta no di far con le sue mani alcuna gentilezza: et oltre dicio il detto libretto e molto utile a gli tessadri; che sogliono lavorare di seta. Stampato in Leone, MD et XXXII, del mese Aprile. In $4^{\circ}$ gothique. Ce titre est inscrit dans le milieu de la page, voir le $\mathrm{n}^{\circ}$ ci-dessus pour la description des gravures sur bois qui ornent ce titre. Ce sont identiquement les mêmes. Verso, l'avis au lecteur au-dessous duquel on voit trois petites gravures sur bois. Celle de gauche représente un carré dans lequel on voit une rose, celle de droite un carré dans lequel on voit un œillet de poète. Celle du milieu est un écusson avec une croix et le monogramme de Dominique de Sera. Au verso d'une page, une ballade de 28 vers avec le refrain: A gens qui besongnent de l'aiguille. Au-dessous de la Ballade, la devise: Mieulx que jamais. Et au-dessous: Imprimé à Lyon, L'an de grâce mil cinq cens trente et deux, le xij jour du mois d'auril. Domenicus de Celle fecit. 40 planches de broderies. Edition inconnue d'un ouvrage infiniment rare, dont Brunet n'indique qu'une édition de 1583 avec un titre en Français cité par Du Verdier. Vente Benedetto Maglione, Paris, 1894.

1625-Sera, D. de-Le livre de Lingerie, composé par Maistre Dominique de Sera, Italien, enseignant le noble \& gentil art de l'esguille, pour besongner en tous points : utile \& profitable à toutes Dames \& Damoyselles, pour passer le temps, \& euiter oysiveté. Nouvellement augmenté, \& enrichi, de 
plusieurs excelents \& divers patrons, tant du point coupé, raiseau, que passement, de l'invention de M. Jean Cousin, Peintre à Paris. A Paris. Chez Hierosme de Marnef, \& la veufve de Guillaume Cauellat, au mont S. Hilaire à l'enseigne du Pelican. 1584. Avec privilege du Roy. In the Cat. d'Estrées, No. 8848, is Livre de Pourtraicture de Jean Cousin. Paris, 1637, in 4 fig. 4to, 28 ff., 51 plates of mediæval design. Frontispiece, three women and a child at work, on each side of the title a man and a woman at work under a trifoliated canopy. He gives at least eighty designs for the use and singular profit of many, "hommes tant que femmes." Below, "Finis coronat opus." Then follows a "Balade" of 28 lines. On the last page, the impresa of Cavellat, a pelican in its piety, "Mors in me vita in me." Bib. de l'Arsenal.

1626-Sera, D de.-Opera nouva, doue si insegna a tutte le nobili et leggiadre giovanette di lavorara di ogni sorte, di punti, cusire, reccamere,

Vinet. M. Pagan et G. da Fontaneto di Monferrta, 1543. $4^{\circ}$. Title and 38 cuts.

1627-Sera, D. de-Opera nova, etc. 1543. Ongania Reproduction of No. 1626. 1628-Sera, Domenico da-Fede Opera Noua composta per Domenica da Sera, detto il Franciosino: dove si insegna a tutte le nobili et leggiadre giouanette di lauorare di ogni sorte di punti: Cusire, Recamare, et far tutte qlle belle opere, che si appartengono alle virtnose fanciulle: e qual si dilettano di far co le sue mani alcuna gentillezza, et canchora, molto vtile a gli tessadri che fogliono lauorara di seta, stampato in Venegia per Matio Pagan, sta in Fregeria e Gulielmo da Fontaneto di Monferrato MDXXXXVI. Petit in $-4^{\circ}$. Ce titre est inscrit sur une draperie décorée en bas par une bordure de petits glands et fixée en haut par trois nœuds à un encadrement formé de rinceaux, en haut duquel on voit une petite figure de femme représentant la Foi, agenouillée de profil à gauche et tenant des deux mains devant elle un calice surmonté d'une hostie. Sur les côtés des petits amours debout ou assis sur les rinceaux. Dans le bas une tablette rectangulaire. Sur cette tablette on voit à droite une femme travaillant à un métier de basse lisse. A gauche une autre femme assise, ayant un ouvrage de broderie sur ses genoux et mesurant avec un compas, un modèle que lni présente une femme debout devant elle. Au haut de ce titre, au-dessus de l'encadrement au milieu le mot Fede. En résumé 24 pages dont 46 planches de broderies. Domenico da Sera, publia dès 1532 à Lyon un recueil de patrons de dentelles. Vente Destailleurs, $\mathrm{n}^{\circ} 1623$ du catalogue. Il y aurait une première édition en 1543. Voir catalogue Pirovano, Rome, 1901. Vente Destailleurs, 1895.

1629-Sera, Domenico, da-Opera noua composta per Domenico da Sera detto il Franciosino: doue si insegna a tutte le nobili \& leggiadre giuanette di lauorare di ogni sorte di pūti: Cusire: Recamare, \& jar tutte q̄lle belle opere: che si appartengono alle virtuose fanciulle e quarsi dilettano di far cō le sue mani alcuna gentilezza \& e anchora molto vtile a gli tessadri che sogliono lavorare di seta. Stampato in Vinegia per Matio Pagan sta in frezeria e Gulielmo da Fontaneto di Monferrato. M.D.XXXXVI. $4^{\circ}$.leaves. Small, 45 plates. Reprinted by Ongania in 1879. 
1630-Serena-Opera nova di recami (punti in chiaro e punti a filo). 1564.

1631-Serena-Opera nova di recami nello quale si ritrova varii \& diverse sorte di punta in stuora \& punti a filo. 1564. Ongania Reproduction, 1879.

1632-Sharp, Mary-Point and Pillow Lace. London, J. Murray, 1905. B. M. See S., A. M.

1633-Shepard-Wolff, Hanna MacLaren-Photographs of lace handkerchiefs made by Mrs. Shepard-Wolff, who spent 3,000 hours in the work finished in $1910.16 \times 16$ inches, mounted.

1634-Sherren, E. F.-The Art of Torser. 1849.

1635-Shoninger Bros.-Government inquiry of alleged undervaluations in lace cases being made. N. Y. Times, May 28, VII, $6: 6$.

1636-Shorleyker, Richard-Here foloweth certaine patternes of Cut-workes: newly invented and never published before. Also sundry sorts of spots, as flowers, Birdes and Fishes \&c. and will fitly serve to be wrought, some with Gould, some with silke, and some with crewell, in coullers: or otherwise at your pleasure. And never but once published before. London Printed in Sho-lane at the signe of the Faulcon, by Rich. Shorleyker. $4^{\circ}$. Title, 24 leaves, cuts; 1 p. conclusion. Musée Royale, Brussels.

1637-Shorleyker, Richard-Here followeth certaine patternes of Cut-workes; and but once Printed before. Also sundry sorts of Spots, as Flowers, Birds, and Fishes, \&c., and will fitly serve to be wrought, some with Gould, some with Silke, and some with Gewell or otherwise at your pleasure. London: Printed in Shoe-lane, at the signe of the Faulcon, by Richard Shorleyker. 1632. Obl. 4to. The copy in the Bodleian is probably due to the above. It has no date and varies in title: "Newly invented and never published before," with "crewell in coullers," etc; and "Never but once published before." Printed by Richard Shoreleyker. 33 patterns and title. In the possession of Mrs. Marryat. "Maes y dderwen."-Bib. Bodleian.

1638-Shorleyker, Richard-A Schole-House for the Needle: Teaching by sundry sortes of patterns and examples of different kindes, how to compose many faire workes: with an addition, newly invented: placed in the beginning of the second booke, which being set in order and form, according to the skill \& understanding of the workwoman; will no doubt yeeld profit unto such [as] live by the Needle, and give good content to adorne the worthy. London Printed in Sho-Lane at the Faulcon by Richard Shorleyker, 1624. (On the second title) And are to be sould by John Gresmand in Paules-alley at the sign of the Gunne. $4^{\circ}$. 2 titles, 6 pp. introduction, dialogue in verse, 32 leaves, cuts. Musée Royale, Brussels.

1639-Shorleyker, Richard-A Schole Howse for the Needle. Teaching by sundry sortes of patterns and examples of different kindes, how to compose many faire workes; which being set in order and forme according to the skill and understanding of the workwoman will, no doubt yield profit unto such as live by the needle and give good content to adorne the worthy. London printed in Shoe Lane at the "Faulcon" by Richard Shorleyker, 1632. To the Reader. Gentle Reader, I would have you know that the Diversities of Examples which you shall find in this "Schoole-howse for the 
Needle" are only but patternes which serve but to helpe and inlarge your invention. But for the disposing of them into forme and order of Workes that I leave to your own skill and understanding. And againe for your behoafe $I$ have in the end of this booke made two scales or checker patternes which by enlarging or contracting into greater or lesser squares you may enlarge or make lesser any of the saide patternes and examples in the booke or any other whatever.

1640-Shrimpton, L.-How to Know Good Embroideries. Country Life. V. 23, pp. 59-60, January, 1913.

1641-Sibmacher, Johann (Recueil de modèles pour le broderies et la tapisserie) sans lieu ni date-li- $4^{\circ}$ oblong. cartonné. Ce volume, incomplet des 2 premiers et du dernier feuillets fait partie de l'édition de 1597. Il renferme encore 2 feuillets de texte et 34 planches de modèles differents de ceux donnés dans le recueil ci-après. Allemagne. Foulc Sale, June, 1914, No. 371, 110 fr's.

1642-Sibmacher, J.-Modelbuch in Kupfer gemacht. Nuremberg, 1601. In-4². Première édition de cet ouvrage. Jean Sibmacher le graveur en avait publié déjà un autre en 1597. Bibliothèque Royale de Bruxelles.

1643-Sibmacher, J.-Modelbuch in Kupfer gemacht, etc. (Copper-plate engravings for lace latterns, etc., 19 plates only.) Obl. 4to. Nürnberg, 1601. S. K. M.

1644-Sibmacher, J.-Modelbuch in Kupfer gemacht Nürmberg, bei Michel Kuisner, 1601, by J. Sibmacher. The Victoria and Albert Museum possesses a copy of this edition in a contemporary binding of leather, stamped with small running ornament, a central arabesque, and the words Modelbüch1601. Brussels, Bib. Roy.-8847.

1645-Sibmacher, Johann-Newes Modelbuch In Kupffer gemacht darinen allerhand'arth newer model von dün mittel, vnd dick aufzgeschidener arbeit auch andern kunstlichen Nehwerck zu gebrauchen mit uleisz Inn drück verfertigt. Mit. Rom. Kay. May Freyheit. Nurnberg, MDCI (1601). In $-4^{\circ}$ oblong. Ce titre est dans un cartouche, décoré de mascarons, de têtes d'anges ailés. On voit en haut à gauche assise sur les rinceaux du cartouche, une femme une aiguille à la main, un métier tambour sur ses genoux. A droit une autre femme également assise, un métier réseau sur ses genoux. En bas sur une petite étiquette collée sur la page on lit: Zu Nurmberg Bey. Balthaser Laimoxen zuerfragen. Avertissement au lecteur. Au bas duquel on lit: Johann Sibmacher Gradirer und Burger das elbsten. Rien au verso. Page non cotée. En haut de la page dans un cartouche décoré à droite et à gauche de têtes ailées, 4 vers allemands. Audessous de ce cartouche trois femmes dans un jardin. Celle du milieu est assise au pied d'un arbre contre lequel elle s'adosse. Elle travaille à un ouvrage de broderie. Au-dessous d'elle sur le terrain on lit le mot Industria. Celle de droite de profil à gauche, personifie l'ignorance comme l'indique le mot ignavia, qu'on voit à ses pieds. La troisième femme de profil à droite personnifie la sagesse, et on lit à ses pieds le mot. sophia. Au-dessous de cette gravure on lit: Cum Privilegio Ro. Cœs. Majestatis. Johan Sibmacher Noriberg fecit et excudit. Aij, dialogue entre l'indus- 
trie, l'ignorance et la sagesse. Avertissement au lecteur. Puis commencent les broderies. Chaque page en contient deux, l'une au-dessus de l'autre. 58 planches. En résumé, un titre, un frontispice, huit feuilles de texte et 58 planches de broderies. Un certain nombre de ces dessins sont inspirés de la Corona de Vecellio. Vente Tross, 1866, Vente Destailleurs, 1895.

1646-Sibmacher, Johann-Newes Modelbuch In Kupfer gemacht, darinnen allerhand art newer Model von Dün Mittel vnd Dick. auszges chnidener arbeit auch andern Kunstlichen Nelı werck zu gebrauchen, mit vleisz. Inn druck verfertig. Mit. Rom. Kaij. mai j. Freiheit. Nurnberg, MDCIIII (1604). Même édition que celle décrite ci-dessus avec un millésime différent 1604 au lieu de 1601 et en plus après le titre une épitre à Marie Elisabeth, comtesse Palatine du Rhin, Nuremberg, le 3 mars 1601. Vente Piot, 1891. Stockholm. Royal Library. In the same library is a work, without titlepage or date, for "broderies et de tous autres besongnant à l'aiguille," by Hieronymus Cock, containing, with designs of every description, a few patterns for Spanish point of great beauty. Obl. 4to, 58 plates carefully engraved upon copper. Title-page surrounded by a richly ornamented border, with two figures, one sewing, the other at embroidery; also a second ornamented frontispiece, J. Sibmacher, citizen and engraver. Nuremberg, German Museum.

1647-Sibmacher, J.-Newes Modelbuch in Kupfer gemacht, etc. (Copper-plate engravings for lace patterns, etc., 37 plates only.) Obl. 4to. Nürnberg, 1604. Facsimile reprint (two titles and 58 designs). Obl. 4to. Edited by Dr. J. D. Georgens, Berlin, 1874. Facsimile reprint (two titles and 36 designs.) Berlin, 1881. S. K. M.

1648-Sibmacher, Johann-Newes Modelbuch in kupffer gemacht. Darnen allerhanf Arth Newer Model von Dun, Mittel und Dick ausgeschnidener Arbeit auch andern Kunstlichen nehwerck zu gebrauchen, mit vleisz in Druck verfertigt Nurnberg, 1602. In- $4^{\circ}$, oblong cartonne. Ce volume se compose du titre gravé ci-dessus, contenu dans un grand cartouche, de 2 feuillets imprimés de dédicace à la Princesse Marie Elizabeth, pfalsgrave du Rhin, d'une figure ou se voient dans un jardin les 3 personnages Sophia, Industria et Ignavia qui ont ensemble un entretien fort interessant, qui occupe les 5 feuillets suivants. Enfin après un faux titre viennent les planches de modèles de broderie au nombre de 57 (sur 58, le dernier manque); chaque planche offrant 2 ou plusieurs dessins. Foulc sale, June, 1914, No. 372, 450 frs.

1649-Sibmacher, Johann-[Another edition.] Jn Kupffer gemacht . . Nürnberg, MDCII. Johann Sibmacher. Mit. Rom: Kaij: Maij Freyheit. B. K. M.

1650-Sibmacher, Johann-Diese nachfolgende Model Konnen auff mancherley Arth genåhet werden, Als mit der Zopffnath, Glatt, oder Creutz vnd Judenstich, auch auff der Laden zu wircken, vnd sonderlich zu důnn aussgesschnittener Arbeit, wie es etliche nennen, fůrnemlich zu gebrauchen, \&c. This titlepage also is found with the 35 plates of the 1597 edition described above. "Schön Neues Modelbuch," etc.

1651-Sibmacher, J.--Schön Neues Modelbuch von allerley lustigen Mödeln nạch= 
zunehen Zuwürcken vin Zustickē: gemacht in Jar Ch: 1597. Zu Nürmberg bey Balthaser Caimoxen Zuerfragen. Io. Sibmacher f. $4^{\circ}$. Engraved title and 35 plates. The titlepage has the monogram. B. K. M.

1652-Sibmacher, J.-Schön neues Modelbuch von allerley lustigen Mödeln naczunehen zu würcken un zu sticke, (Copper-plate engravings for lace patterns, etc., 20 plates only). Obl. 4to. Nurnberg, 1597. S. K. M.

1653-Sibmacher, J.-Schön neues Modelbuch, etc. 1597. Facsimile reproduction of the above complete, 35 plates and engraved title. Obl. 4to. Wien, 1866.

1654 -Sibmacher-Osterreichisches Museum (K. K.) Hans Sibmacher's Stick —und Spitzenmusterbuch, 1597. Facsimile, 3d edition, Vienna, Carl Gerolds Soln, 1882.

1655-Sibmacher-Stick-Muster, nach Motiven aus dem 16 ten Jahr hundert von Hans S. . . . herausgegeben und in Farben gesetzt von Theodor Wendler. 4to. Berlin, 1882. S. K. M. See 1654.

1656-Sibmacher-Another Facsimile reproduction of No. 1651. Obl. 4to. Berlin, 1885. S. K. M. See 1652.

1657-Sibmacher, Joh._Stich und Spitzen-Musterbuch. 1597; reprinted 1887. Sibmacher-See Laimoxen.

1659-Sigismund-Schon newes Modelbuch von hundert und achtzig shonen Kunstreichen und gerechten Model, teusche und welsche auff mancherley Art konnen geneet werden, etc. Franckfurt am Mayn, in Verlegung Sigismund-1607. Petit in $4^{\circ}$ dérelié. Recueil d'un titre et 50 planches de modèles de broderies et dentelles. Le titre est légèrement colorié et orné d'une gravure sur bois représentant l'interieur' d'un atelier ou des femmes font de la broderie. Le dernier feuillet est coupé vers le milieu. Foulc Sale, June, 1914, No. 394, 95 frs.

1660-Silljan, Elise-Norwegian Lace and Embroidery.

1661-Singleton, Esther-Lace and Lace-making. The Mentor, May, 1917, New York.

1662-Sketchley, R.E.D.-Buckinghamshire Lace. Art Journal, June, 1905, pp. 177-181.

1663-Smith, K. L.-Revival of Fireside Industries. New England Magazine, n.s., V. 29, pp. 442-449, December, 1903.

1664 -Smith, L. A.-Lace-makers of Belgium. Current Literature. V. 31, p. 723, December, 1901.

1665--Sociedad Española de Amigos del Arte. Madrid-Artes Gráficas "Maten" Paseo del Prado, 34, 1915.

1666-Société de l'art ancien en Belgique-Broderies, etc. Plates with letterpress. Fol. Bruges. (1883). S. K. M.

1667-Somascho, G. A.-Nova Esposizione de Recami et Dessegni. Alla Molto Illustre Signora Ippolita Manfredi. In Venetia. Appresso Giacomo Antonio Somascho. (c. 1602.) 4². 14 leaves, engraved. V. \& A. M.

1668-Somascho, Giac. Ant.-Nova esposizione de Recami et Dessegni. In Venetia. Facsimile.

1669-Sombart, W.-L'industrie à domicile. (Extrait du Handwörterbuch der Staatswissenschaften.) 
1670-Something about Lace. The Catholic World, April, 1873, New York.

1671-Soulier, Gustave-La Broderie et la Dentelle à l'Exposition (Paris, 1900). Art et Décoration, 1901, Paris.

1672-Soulier, Gustave-Dentelles. L'Art décoratif, March, 1902, Paris.

1673-South Kensington Museum-Catalogue.

1674-South Kensington Mus.-Cat. of the special exhib. of works of art on loan, 1862. (Tissues, ete. p. 249, by Rev. D. Rock.) 8vo. London, 1863.

1675-S. K. Museum Cat. of the special loan exhib. of Decorative Art Needlework made before 1800. Photos. 4to. Lond. 1874.

1676-S. K. Museum.-Classified list of photographs of works of decorative art in the South Kensington Museum, and other collections. (Lace, p. 288.) 8vo, London. 1887.

1677-South Kensington Museum-Kendrick's Catalogue of Samplers in the South Kensington Museum.

1678-South Kensington Museum-List of Books on Lace: Victoria and Albert Museum. 85 pp. London, 1888. 8vo. B. M.

1679-South Kensington Museum-List of Samplers in the Victoria and Albert Museum. (Board of Education, S. Kens.) London, 1906. 8vo.

1680-South Kensington Museum-Photos. of embroidery, ete. A series, consisting of 78 specimens, exhibited at the S. K. Mus. during the special loan exhibition of Decorative Art Needlework, 1873.

1681-South Kensington Museum-Photos. Mechlin lace, 18th century in S. K. Mus. 10 photos. Russian lace belonging to the Duchess of Edinburgh. 16 photos.

1682-South Kensington Museum-Portfolios of Industrial Art. Colored illus. fol. Lond. 1881, ete.

1683-South Kensington Museum-The Industrial Arts. (Lace, p. 257). Illus. (S. K. Mus. Art Handbooks.) 8vo. London. 1876.

1684 -South Kensington Museum, London, Supplemental Descriptive Catalogue of Specimens of Lace 46 pages, 1891. B. M.

1685-Sparrow, W. S.-Leek School of Embroidery and its Work. Magazine of Art. V. 26, pp. 550-554, October, 1902.

1686-Specchio, Il-Di pensiere, delle belle donne dove si vede varie sorti di punti, cioè, punti tagliati, gropposi, \&c. Venetia, 1544. In 4to. Quoted in Cat. Cappi, of Bologna, 1829.

1687-Specifications relating to lace-making, etc., Abridgements of-London, 1879.

1688-Specimen of Point Lace made at the Convent of Poor Clares, Kenmare, County Kerry. The Art Workers' Quarterly, July, 1902, London.

1689-Spellewerk-Blaetter für Kunstgewerbe, 1878, Vienna.

1690-Spitze, die historische und neuzeitliche-29 Lichtdrucktafeln. Plauen, 1910.

1691-Spitzen, Alte-30 Blatt Photographien nach Originalen, Venezianische, Guipure-, Valenciennes-und a. Spitzen. Fol. (Paris) Nachbildgn. hervorragend schöner Stücke.

1692-Spitzenfächer. Illustrirte Zeitung, March 23, 1878, Leipzig. 
1693-Spitzenkragen im Charakter der venetianischen Relief-Spitzen, entworfen von Prof. J. Storck, ausgeführt von Jos. Stramitzer in Wien. Blaetter für Kunstgewerbe, 1879, Vienna.

1694 Spitzenklöppeln,-Vom-Daheim, 1883, No. 9, Leipzig.

1695-Spitzenmappe. Chr. Stoll, Plauen, 1909. 72 pages. (Collection of Kursheedt Mfg. Co., N. Y.)

1696-Spons's Encyclopaedia of the Industrial Arts, Manufactures and Commercial Products - (Lace, Division IV., p. 1200.) 8vo. London, 1879-80. S. K. M.

1697-Staffe, Baronne-Les Hochets féminins. La Dentelle, etc. Paris Ern. Flammarion, n.d.

1698-Staines, F. J.-Nottingham Lace Edgings. The Artist, March, 1900. London.

1699-Stanley, K.-Needlework and Cutting; being hints, etc., for the use of Teachers. (Illus.) 8vo. Lond. 1883. S. K. M.

1700-Stassof, W.-L'Ornement National Russe. Broderies, Tissus, Dentelles. (Coloured illus., text in Russian and French.) Fol. St. Petersburg, 1872. S. K. M.

1701-Statutender Vereeniging "De Nederlandsche Kantwerkschool" te's Gravenhagen, gesticht door Jhr. Ernest van Loon.

1702_Staub, George-Pattern Book. St. Gall, 1593.

1703-Stegmann,H. E. L.-Stickerein, Spitzen und Pasamentierarbeiten. Nuremberg, 1901.

1704-Sterling, A.-Antique and Modern French Lace. Chautauquan, V. 34, pp. 580-584, March, 1902.

1705-Sterling, A.-Cut-works, New and Old. Chautauquan, V. 35, pp. 496-501, August, 1902.

1706-Sterling, Ada-Dilettanteism of Fine Lace. New York, "Evening Post," Saturday, Feb. 9, 1901.

1707-Sterling, A.-French Lace, Antique and Modern. Chautauquan, V. 34, p. 580.

1708-Sterling, Ada-Italian Laces Old and New. Chautauquan, V. 34, pp. 16-21. 1709-Sterling, A.-Making of Venice Lace. Chautauquan, V. 34, p. 243-246.

1710-Sterling, A.-Plea for American Needlecraft. Atlantic, V. 86, pp. 557562, October, 1900, same cond. Current Literature, V. 29, pp. 607-608, November, 1900.

1711-Stevens, Amy, at Battersea-Dessin pour ombrelle en dentelle de Carrickmacross. Art appliqué 1re année, Paris.

1712-Stewort, F. and M. E. Bradley-Decorations for Towels. Good Housekeeping, V. 54, pp. 98-102, January, 1912.

1713-Steyner, H.-Ein New Modelbůch auff die Welschen monier. Gedruckt zu Augspurg durch Heinrich Steyner. M. D. XXXIIII. 4. Title and 55 cuts.

1714-Steyner, H.—Ein New Modelbüch, etc., 1534. Seeman Reproduction of No. 1713. Leipzig. 1889. See 1614.

1715-Stick-Album des "Berliner Modenblatt." Sammlung farbiger Muster- 
blätter für Handarbeiten. (Patterns for needlework.) Fol. Berlin, (1880.)

1716-Stilarten der Spitzen, in verschiedener Auffassung und neuer Combination. n.t.p. Plauen, C. F. Schultz \& Co., 1908 (?). 18 pages. (Collection of Kurscheedt Mfg. Co., N. Y.)

1717-Stocking, Mary E.-Hand-made Laces. Pratt Institute Monthly, V. 8, No. 4, February, 1900, pp. 83-88.

1718-Strange, Edward F.-Early Pattern-Books of Lace, Embroidery and Needlework. Transactions of the Bibliographical Society, December, 1904, London.

1719-Strange, E. F.-Needlework at the Liverpool School of Art. International Studio, V. 24, pp. 147-149, December, 1904.

1720-Strassen, Melchior zur-Spitzen des 16. bis 19 . Jehrhunderts aus den sammlungen des Kunstgewerbe Museums zu Leipzig. Leipzig, L. W. Hiersemann, 1899.

1721-Strassen, zur-Spitzen, Ornamentale und Kunstgewerbliche Sammelmappe. Series 4 \& 5, 25 plates each. Hiersemann, Leipzig, 1893-1894. (Collection of Kursheedt Manufacturing Co.)

1722-Strauben, G.-New Model Buch darimnen allerley Gattung schöner Modeln der newen aussgeschitnen Arbeit auff Krägen, Hempter, Jakelet und dergleichen zu newen, so zuvor in Teutschlandt nicht gesehen. Allen thugentsamen Frawen und Jungkfrawen, Nätterinnen, auch allen audern so lust zu solcher kunstlichen Arbeit haben, sehr dienstlich. Getruckt in uerlegung George Strauben, von S. Gallem, Anno 1593. Printed for the publisher, G. Strauben. A reprint of the third book of Vecellio's Corona. V. \& A. M.

1723-Stringher, Vittorio-L'industria dei merletti nelle campagne, Pp. 75. Rome, G. Bertero, 1893. B. M.

1724 Studies in Modern Lace Making. 1898. (Collection of Kursheedt Manufacturing Co., N. Y.)

1725-Sturgis, Russell-A study of the Artists' way of working. New York, Dodd, Mead and Co., 1905.

1726-Sybil Carter Indian Mission and Lace Industry, Tle-(New York, March, 1905.)

1727-Sylvia-Book of Macramé Lace. Containing Illus. of many new and original designs. 8vo. London, 1883. S. K. M., B. M.

1728-Szontagh, A. von-Die Csetneker Spitzen. Plauen, O. Haebler, 1911.

\section{$-\mathrm{T}-$}

1729-T.-Ueber Styl in der Spitzen-Industrie. Blaetter für Kunstgewerbe, 1875, Vienna.

1730-Tabin, B.-New Kunstlichs Modelbuch Von allerhand artlichen vn gerechten Moledn auff der Laden zu wircken, oder mit der zoppffnot. Creutz vnd Judenstich vnd anderer gewonlicher weifs zu machen: allen modelwurckerin, Naderin, vnnd solcher Modelarbeit geflissenen Weibsbildern sch $r^{*}$ dienstlich vnnd zu andern mustern an leytlich vnnd verstandig. Auff ein newes wider getruckt vnd mit vielen newer model gemehret. Mit

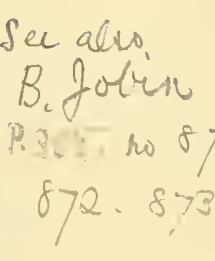


Rom. Keys May. Freyheit. Bey. B. Tabin, 1582. In $-4^{\circ}$ oblong. 48 feuillets, le dernier est blanc. Un titre, un feuillet contenant des vers et 45 planches de broderies, imprimées au recto seulement. Musée des arts et de l'industrie de Dresde.

1731-Tabin, B.-New Kunstlichs Modelbuch, von allerhand artlichen vn gerechten Modeln, auff der laden zu wircken, oder mit der Zopffnot Creutz vnd Jndenstich vnd anderer gewonlicher weifs zu machen: Allen model wurckerin, Naderin vnnd solcher modelarbeit geflissenen Weisbildern, schr dienstlich, vnnd zu andern mustern and leytlich vnnd verstandig. Auff ein newes wider getruckt vnd mit vielen newer model gemehret. Mit Rom. Keys. May. Freyheit. Bey. B. Tabin, 1588. In- $4^{\circ}$ oblong. Titre inscrit sur une double tablette occupant le haut de la page et entourée de cuirs roulés, de rinceaux, de fruits, de petits génies. En bas dans une chambre des femmes travaillant à l'aiguille. L'une d' elles à gauche, de profil à droite, son chien à ses pieds montre une pièce d'étoffe à une femme debout qui se penche vers elle. Au même plan et à côté une femme assise vue de dos. Au fond deux femmes travaillant près d'une fenêtre où se voit un homme accoudé. Gravure sur bois de Tobias Stimmer. A2, page encadrée par un nielle sur bois. Piêce de ver's sur deux colonnes. Verso fin de la pièce de ver's. En résumé 48 pages dont un titre, une feuille pour les vers et une page blanche à la fin. 45 planches de broderies imprimées au recto seulement. Bibliothèque Nationale.

1732-Tack-Discours prononcé à la Chambre des Représentants le 2 avril, 1884. 1733-Tagliente, Antonio-Esempio di ricami. Venice, 1528.

1734-Tagliente, G. A.-Esemplario Nuouo Che Insegna A Le Donne a cuscire ... Stampato in Vinegia per Giouanantonio et $i$ Fratelli da Sabbio. MDXXXI. $4^{\circ} .55$ cuts, etc. B. K. M.

1735-Tagliente, G.-Esemplario nuovo che insegna a le Donne a cuscire, a raccamare et a disegnare a ciascuno etc. Vinegia, 1531. (Facsimile reprint, Roy. 8vo. Ongania, Venice, 1879.) S. K. M. Metro. Mus.

1736-Tagliente, Giovanni Antonio-Opera nuova che insegna alle donne a cusire a raccamare, et a disegnar, a ciascuno Et La ditta opera sara di molta utilta ad ogni artista, per esser il disegno ad ognuno necessario, laqual é intitolato essempio di reccami. Con gratia et Privilegio, MDXXVII. Ce titre est en haut d'une page au bas de laquelle on voit quatre compartiments, deux en haut, deux en bas. Dans celui d'en haut à gauche, deux femmes assises et travaillant à l'aiguille, une troisième femme debout à gauche, tenant un panier à la main. Dans le compartiment de droite, deux femmes assises et travaillant à un métier. Dans le compartiment du bas à gauche, une femme montre un ouvrage de broderie à un homme coiffé d'une toque à plumes. Près d'eux une femme assise. Dans le compartiment de droite, une femme travaillant à un métier. Toute cette composition y compris le titre est entourée d'une trait carré et d'un filet. Verso Un homme barbu, vêtu à l'antique, est assis de profil à droite sur un tertre. Il tient des deux mains, levées devant lui un sextant avec lequel il vise le ciel, où l'on voit la lune et les étoiles. A ses pieds à droite, un compas, un livre et une planche sur laquelle sont des figures de géométrie. Dédicace: A 
qualcunque nobili et illustre Madonna et a ciascun altro moderato et candido lettore, Giovanni, Antonio Tagliente. Page divisée en quatre compartiments carrés. Dans celui du haut à gauche, des fleurs, dans celui de droite un gland de chêne et des feuilles. Dans les deux du bas des entrelacs. On lit au bas de cette page 5 lignes de texte. Page non cotée, verso, un phylactère avec les mots: La virtv al Huomo sempre li rista ne morte nel po privar di questa. Sur un autre phylactère: Tu vedi. Page non cotée, des phylactères portant. Occhi piangete, acopagnate il core. Inclita virtus. Verso.-Page non cotée, verso._Le verso précédent et le recto de la page suivante ne font qu'un seul et même dessin: Orphée charmant les oiseaux et les animaux. Verso, une tortue dans une guirlande de feuillage, entourée de rubans. Au-dessous sept lignes de texte. Au verso, un médaillon rond dont la bordure renferme un entrelac. Dans le milieu de ce médaillon des animaux antour d'un lac. Une licorne plonge sa corne dans l'eau et se désaltère. En lıaut sur un phylactère les mots : Virtus impavida. En bas six lignes de texte, Vente Bertin. Vente Yemenitz. Bibliothèque Nationale.

1737-Tagliente, Giovanni Antonio-Opera nova che insegna a le donne, a cuscire, a raccamare, et a disegnare ciascuno. Et la detto opera sara di grande utilita ad ogni artista per esser il dissegno a ogni uno necessario, laqual e intitolata, Esempio di raccami. 4to, 23 ff. 36 plates. Title in red Gothic letters; beneath four woodcuts representing women at work. Dédicace de 33 lignes de texte. A qualcunque nobile et illustre madonne \& a ciascun altro moderato et candido lettore, Giouanni, Antonio Tagliente. Then follows a most miscellaneous collection of what he terms, in his dedication "fregi, frisi, tondi maravigliosi, groppi moreschi et arabeschi, ucelli volanti, fiori, lettere antique, maiuscoli, \& le francesche," etc., three pages very much like the pictures in a child's spelling book, rounds (tondi) for cushions, and two pages representing hearts and scrolls; hearts transfixed, one with an arrow, another with a sword, a third torn open by two hands, motto on the scroll. Then follow six pages of instructions, from which we learn the various stitches in which these wonderful patterns may be executed, "damaschino, rilevato, a filo, sopra punto, ingaseato, Ciprioto, croceato pugliese, scritto incroceato, in aere, fatto su la rate a magliata, desfilato, \& di racammo," to be sewn in various coloured silks, gold and silver thread, or black silk, for "collari di huomo \& di donna, camisciole con pettorali, frisi di contorni di letti, entemelle di cuscini, frisi di alcun boccassina, \& scufie," etc. On the last page, "Stampa in Vineggia per Giovan Antonio Tagliente \& i Fratelli de Sabbio. 1530." Brunet gives an edition dated 1528. Page non cotéé, finissant par les mots: Stampato in Venegia per Giouantonio Taglienti \& i fratelli da Sabbio, MDXXX (1530). En tout 28 feuillets. 47 planches de modèles. Tagliente est aussi l'auteur d'un traité de calligraphie contenant divers ornements et chiffres entrelacés, qui se retrouvent dans ce volume de dentelles. Vente Destailleurs, 1895. Vente Foule, 1914, Paris, frs. 500. Cav. Merli, 1528 (?) Genoa. Bib. Nat.

1738-Tann, S. H.-Drawn Thread Work. The Art Workers' Quarterly, October, 1903, London. 
1739-Tariff, protest-Lace and Embroidery Importers' Association of New York on appraisement of Swiss embroideries, N. Y. Times, May 31, $13: 3$.

1740-Taylor, Eliza A.-Priscilla Irish Lace Book.

1741-Taylor, J.-Glasgow School of Embroidery. International Studio, V. 41, pp. 124-134, August, 1910.

1742-Tebbs, Augusta Louisa-The Art of Bobbin Lace. London, Wm. Barnard, 1860. Later edition-Chapman \& Hall, 1907. B. M.

1743-Tebbs, Louisa and Rosa-The Art of Bobbin Lace. Supplement. London, 1911.

1744-Tebbs, Louisa A.-The New Lace Embroidery. 1905, London. B. M.

1745-Tebbs, L. A.-New Punto Tagliato Embroidery. 3rd ed. 1908.

1746-Teneriffe Lace-Making-Healy Method. (Collection of Kursheedt Manufacturing Co., N. Y.)

1747-Teschendorff, T.-Kreuztichmuster fur Leinenstickerei. Heft 1:10 Farbendrucktafeln. Folio. Berlin, 1879.

1748-Teschendorff, Toni - Kreuzstich-Muster für Leinenstickerei. Berlin, E. Wasmuth, 1884 and 1891. 10 color plates.

1749-Testard, Maurice-Joannés Chaleyé et la Dentelle du Puy. Art décoratif, Paris, 1913. Vol. 29, pp. 51-60.

1750-Thys, Ch. M. T.-Broderies et Tissus anciens, trouvés à Tongres. (Acad. d'Archéologie de Belgique.) 8vo. Anver's, 1869. S. K. M.

1751-Tincker, M. A.-Lace. Catholic World, V. 17, p. 56.

1752-Tixier, E., at Paris-Éventail. Art appliqué, 1 re année, Paris.

1753-Tobin, Jeanie, at Cork-Dentelles au crochet. Projets de dentelles. Art appliqué, 1re année, Paris.

1754 -Tordois, M.-Coup d'Oeil sur Valenciennes de l'an IX à l'an XIII.

1755-Toretto, Giuseppe-Lucidario di Ricami di Giuseppe Toretto or Torello Venezia, 1556. In $-4^{\circ}$. Catalogue de Lucques, 1816.

1756-Torond, H.-Designs for Crochet. No date.

1756a-Touche, Victor-Handbook of Point Lace. London, Wm. Barnard, 1869. Illus.

1757-Townsend, L.-Collecting Old Samplers. American Homes, V. 10, pp. 361362, October, 1913.

1758-Tozzi, Paolo_Ghirlanda di sei vaghi fiori scielti da piu famosi Giardini d'Italia, raccolti da Pistro Paolo Tozzi. Primo libro. Belle lettere Moderne mansioni dotte sententie leggiadri lauori noui merli usati numeri. In Padoua alla libreria del Giesu. Con Privilegio. In- $8^{\circ}$ oblong. Les mots Pietro Paolo Tozzi sont inscrits dans une guirlande de fleurs des deux côtés de laquelle on voit deux moutons, l'un à droite, l'autre à gauche. Dédicace: Alla molto $\mathrm{Ill}^{\mathrm{r}}$ a Rever ${ }^{\text {da }}$ Sigra $^{\text {ra }}$ Maria Ginevra Macchiavelli signora Mia Colendissima ... di Padoua il di 1 octobre, 1604. Pietro Paolo Tozzi. Romano. Avertissement au lecteur. F. Paolo Frassinelli da Bologna dell' ordine di sant' agortino. Cinq pages renferment des instructions et des formules de salutations propres à chaque situation sociale, à chaque degré de la hiérarchie, une instruction pour la tenure des livres, une table de multiplication, ete. Puis commence la série des modéles d'écriture, d'alphabets, sur le recto de chaque page, le tout dans des encadre- 
ments de dentelles, de guipure, qui font de ce livre un véritable livre ì dentelle, rentrant dans le cadre bibliographique que nous étudions dans le présent ouvrage. Ces planches sont toutes numérotées en bas dans l'intérieur de l'ancadrement, par les chiffres arabes de 1 à 42. La dernière planche porte: Fine delle Tavola. La planche 40 est chiffrée par erreur 36. Les modèles d'écriture sont l'œuvre de Ant. Bertozzi et Seb. Zanella. M. le marquis d'Adda, dans sa bibliographie, en signale une autre édition de 1616. Vente Piot, $n^{\circ}$ 217. Une autre édition de 1621. Vente Destailleurs, 1895. Vente Eugène Piot, 1891. $4^{\circ}$. 14 pp. of text, 40 engravings.

1759-Tozzi, Fr.-Gioiello della Corona per le nobili è virtvose donne nel quale si dimostra altri nuoui bellissimi dissegni di tutte le sorte di Mostre di Punti in aria Punti tagliati et Punti à Reticello, cose per Freggi come per Merli et Rosette che con l'aco si vsano hoggidi per tutta Europa. Et molte delle quali Mostre possono servire ancora per Opere a Mazette. Nouamente posto in luce con molte bellissime inventioni non mai piu usate ne vedute. In Fiorenza apresso Fr. Tozzi, 1594. In $4^{\circ}$ oblong. 2 feuillets imprimés suivis de 23 planches et à la fin d'une grande planche pliée qui représente une broderie ombrée, sur un fond clair quadrillé. Le marquis d'Adda dans sa bibliographie mentionne de ce livre une édition de 1593. Vente Solar. Vente Libri, 1862.

1760-Tozzi, P. P.-Instructione delle Inscrittione, etc. (Each alphabet, ete. is surrounded by designs for lace or cut-work.) Obl. 4to. Padua, 1604. S. K. M.

1761-Tracy, Theo.-The Renaissance of Aristocracy's Lace. The 20th Century Home, February and March, 1904, London.

1762-Traité de la Dentelle irlandaise et das Jours à l'aiguille (Point d'Alençon). Paris, Fr. Ebhardt, n.d.

1763-Tranter and Adams-Roumanian Knitting Cards. 1891. B. M.

1764 -Treadwin, Mrs.-Antique Point and Honiton Lace. London; Ward, Lock \& Tyler, 1873. 100 illus., 4to.

1765-Treadwin, Mrs.-Antique, Point, and Honiton Lace. 100 illus. 4to. Lond. (1874). S. K. M.

1766-Trine Irlandesi, Lavori in Applicazione, Ricamo a punto piatto. Milan, Fratelli Treves, 1892.

1767-Trionfo di Virtv, Libro novo da cusir, nel qual si contengono molti et diuersi sorti di fogliami del quale ogni gentile et virtuosa Madonna se potra servire. In far ponti a fili, Ponti cruciati, Ponti in Trezola, ponti in stura, ponto seritto tirar in opera, Cuchiar, tesser é molt'altri ponti come a loro piacera. Venetia, 1559. In- $4^{\circ} .16$ feuillets. Bibliographie du marquis d'Adda. Bibliothèque Cicognara, An Vatican.

1768-Trobridge, G.-Vanished Art: Embroidery on Muslin. Magazine of Art, V. 26, pp. 199-201, March, 1902.

1769-Troulon, Jehan-Patrons de diuerses manières.

Inventez très subtilement,

Duysans à Brodeurs et Lingières.

Et à ceux lesquelsz bravement.

Veullent par bon entendement. 
User d'antiques et Roboesque.

Frize et moderne proprement.

En comprenant aussi Moresque.

A tous massons, menusiers, et verriers.

Feront proffit ces pourtraictz largement.

Aux orpheures et gentilz tapissiers.

A ieusnes gens aussi semblablement.

Oublier point ne veulx aucunement.

Contrepointers et les tailleur's d'ymages.

Et Tissotiers lesquelz pareillement.

Par ces patrons acquerront héritages.

Le sire Jehan Troulon dict de bourgogne a esté.

Inventeur de ces présens patrons.

Pareillement sont.

Adioustez plusieurs beaulx ouuraiges par messire.

Antoine Belyn, Recluz de Saint Martial de Lyon.

Petit in- $4^{\circ}$. Ce titre coté en bas $A A$, est dans un encadrement formé de rinceaux, de fleurons et de feuillage. S'ensuyuet les patrons de messire Anthoine Belyn, recluz de sainct Marcial de Lyon. Item plusieurs aultres beaux patrons nouueaulx qui ont esté inuentez par frère Jehan Mayol, Carme de Lyon. Ce titre coté $E E$, est dans un encadrement formé de deux colonnes autour desquelles tourne un rinceau de feuillage. En bas une bande rectangulaire au milieu de laquelle est un petit écusson blane soutenu à droite et à gauche par deux petits amours nus et ailés. Au-dessous du titre un écusson comprenant un cœur surmonté d'une couronne. En dessous un lion rampant. Autour de l'écusson et du lion, une bordure rectangulaire sur laquelle on lit: Cor contritum et humiliatum deus non despicies. Psalmo 50. Au verso broderie. Vente Destailleurs. Il y a à la Bibliothèque Mazarine, une plaquette dans laquelle se trouve cette dernière partie. Le titre est le même mais l'intérieur de l'encadrement offre quelques différences qui feraient croire à une autre édition. On voit dans celle-ci au milieu, au-dessous du titre, dans un trait carré et un filet rectangulaire en hauteur, un écusson au milieu d'une couronne de feuilles en bas dans un plat que tient une main deux yeux, et au-dessous enroulé dans le bas de la couronne de feuilles un phylactère sur lequel on lit: Oculi mei semper ad Dominum, Psal. 24. En bas un sujet religieux gravé sur bois, en haut au-dessus du titre, le père Eternel entouré d'anges. Vente Destailleurs, 1895. See A. Belin and Saincte Lucie.

1770-Truchet, le Révèrend père Sebastian-see Douat.

1771-Trust de Dentelle Belge, Le-La Gazette, Dec. 2, 1902, Brussels.

1772-Tuquet, Marcel-Compositions pour dessins de rideaux. 3 series. Paris, A. Calavas, n.d. 18 plates in each series.

1773-Turgan-Fabrique de dentelles O. de Vergines et soeurs, ancienne maison Vanderkelen-Bresson à Bruxelles. (Les Grandes Usines), Paris.

1774-Turgan-Les Grande Usines. Les Dentelles, Vol. V. p. 229 ; VI. p. 237. 8 vols., 8vo. Paris, 1863-68. S. K. M.

1775-Tyrsova, R.-O. obrozeni lidového vy̆siváni. (Dentelles et Broderies de Bohème). Cesky Lid (Le Peuple tchèque), 1899, Prague. 
1776-U-La Belgique dentellière. Bruxelles Féminin, Jan. 15, 1903, Brussels.

1777-Ubisch, E. von-Über Spitzenbücher und Spitzen. In Reportorium für Kustweissenschaft, 1893 . V. 16, pp. 88-99.

1778-U. S. Bureau of manufactures-Machine-made lace industry in Europe. Wash. 1905.

1779-U. S. Dept. of commerce and labor-Lace industry in England and France. Washington, 1909.

1780-_ Urbani de Gheltoff, G. M.--Les Arts industriels à Venise, au Moyen Age et à la Renaissance. Traduction de Alf. Cruvellié. Venice, Usiglio \& Diena, 1885.

1781-Urbani de Gheltof, G. M.-I Merletti a Venezia. Venice, 1876.

1782-Urbani de Gheltof, G. M.-Trattato storico tecnico della fabbricazione dei merletti Veneziani. C. tavole. Venezia, 1878.

1783-Urbani de Gheltof, G. M.--Trattato storico tecnico della fabbricazione dei Merletti veneziani. (Venezia-Burano.) Con tavole. Sm. 4to. Venezio, 1878. English translation by Lady Layard. "A Technical History of the manufacture of Venetian Laces." Illustrations. Sm. 4to. Venice, 1882. S. K. M.

1784 -Urbani de Gheltoff, G. M.--Traité historique-technique de la fabrication des dentelles venitiennes (Venise-Burano). Édition française revue par M. Le Monnier. Venice, F. Ongania, 1893.

1785-Ure, A.-Dictionary of Arts, Manufactures and Mines. (Lace Manufacture, Vol. II.) 3 vols. 8 vo. Lond. 1867. S. K. M.

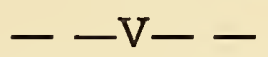

1786-Valverde, Marqués de-Catálogo de la Exposición de Lenceria y Encajes Españoles del siglo XVI al XIX.

1787-Van de Casteele, De-Un fil de l'ancienne industrie dentellière à Liége. Bull. Institut archéol. liégois. 1885, Liége.

1788-Van de Wiele, Margaret-Le "point" de Flandre par Natalis (pseudon.) Le Peit Bleu, Dec. 8, 1898, Brussels.

1789-Van Holsbeek-L'industrie dentellière en Belgique. Étude sur la condition physique et morale des ouvrières. Brussels, 1863.

1790-Van Meerton, W. A. B.-Penelope of Maandwerk aan het Vrouwelijk Geslacht toegewijd betattende de beschrijving en afbeelding van allerhande soorten van Vrouwelijke handwerken benevens eenige lektur over onderwerpen uit den vrouwelijken Kring. Profusely illustrated with a great number of colored plates of embroidery, tapestry, etc. 8 volumes. Amsterdam, 1829.

1791-Van Schoel, Henrico-Fogliami diversi nouamete posti in luce. Opera vtiliss-ma e necessaria p. li racamatori, serittoriorij. et lauoranti di ebano et intagliator de lego Orefici, Argentarii, et altre arte, diuerse. Henrico van schoel excudit Roma S. A. (circa 1580.) Recueil de 31 plan- 
ches d'ornements dessinés dans la seconde moitié du XVI ${ }^{\circ}$ siècle et gravées au trait. C'est une réunion de modèles pour les fabricants de dentelles, les écrivains, les artistes mosaïqueurs en ébène et en cuivre, les orfèves, les bijoutiers, etc.

1792-Vaulabelle, Alfred de-La Dente'le. Le Rappel, April 12, 1903, Paris.

1793-Vaulabelle, Alfred de-Industrie du Tulle et de la Blonde. Cosmos, Oct. 11, 1890, Paris.

1794-Vauxcelles, Louis-Broderies, Dentelles et Passementeries de Fernand Courteix. La Femme d'aujourd'hui, 1904, No. 7, Paris.

1795-Vavassore, G. A. (?) - Burato... con nova maestria, gratios donner novo artificio vi apporto. A second edition without date. 4to, ff. 59; frontispiece, ladies at work, verso, Triumph of Fame. Four books of designs of great elegance and taste. The Marquis d'Adda assigns them to Vavassore.

1796-Vavassore, Giovanni Andrea-Esemplario di lauori: che insegna alle done il modo e ordine di lauorare; cusire et racamare, et finalmente far tutte qlle opere degne di memoria, lequale poz fare una donne virtuosa con laco in manno. Et vno documento che insegna al compratore accio sia ben seruito. A la fin du volume on lit: Stampata in Vineggia per Giouanni Andrea Vauassore detto Guadagnino, ne li amni del signore, MDXXX (1530) a di XXII Nouembrio. Cet exemplaire est le même que celui de l'Esemplario di Lavore de Zoppino avec une date d'une année postérieure 1530, au lieu de 1529. Vente Bancel, 1882.

1797-Vavassore, G. A.-Exemplario di lauori, che insegna alle donne il modo et ordine di lauorare, cusire et raccamare, et finalmete far tutte qlle opere digne di memoria, lequale po fare una donna virtuosa con laco in mano et uno documeto che insegra al copratore accio sia ben seruito. In$4^{\circ}$. Le mot exemplario . . . est tiré en noir ; le reste du titre est en rouge. Ce titre est au milieu de la page, entouré des quatre côtés par six compositions gravées sur bois. Trois en haut, une sur chaque côté vertical et une plus grande en bas. On remarque en haut à gauche, une femme de profil à droite travaillant à un métier de basse lisse. Au milieu une femme présentant un ouvrage de broderie à un homme qu'on voit à droite, coiffé d'un bonnet à plumes. A droit une femme assise devant une table sur laquelle est posé un petit métier à broder. Dans les compositions des côtés, on remarque à droit un homme assis de profil à gauche, une toque à plumes sur la tête, travaillant à un ouvrage posé devant lui sur un pupître. A gauche une femme assise de face, brodant à un métier posé devant elle. Dans la composition du bas, on voit une femme assise sur une cliaise, de face, travaillant à une ouvrage de broderie posé sur ses genoux. Une autre femme assise près d'elle à droite, lui offre une aiguille. En bas de cette composition, on lit au milieu: Fiorio Vauassore fecit. Au verso on lit sept lignes commençant par les mots... Documento per el compratore et au-dessous a qualun que nobile et illustre Madone, et a ciascun altro moderato e candido lettore, Giouan Andrea Vauassore detto Guadagnino. S. Puis commencent les broderies. AXIII, ver'so. Le verso de cette page et le recto de la page suivante, ne forment qu'une seule feuille ployée 
en deux qui constitue le milieu du volume et qui contient un sujet représentant Orphée charmant les animaux. Alphabet de capitales droites. Page non cotée, 30 lignes de texte, au-dessous desquelles on lit: Stampato in Vineggia, per Giouanni Andrea Vauassore, detto Guadagnino, ne li anni del signore MDXXXI a di X Marzo. 26 Feuillets dont un titre au commencement, une page à la fin dont le recto contient la suscription cidessus et 24 planches de broderies imprimées au recto et au verso. Troisième édition de ce recueil. Bibliothèque Nationale.

1798-Vavassore, G. A.-Esemplario di Lauori che insegna alle donne il modo e ordine di lauorare, cusire e racamare . . . fiorio Vauasore fecit (1531). $4^{\circ}$. 40 cuts. B. K. M.

1799-Vavassore, G. A.-Esemplario di lauori: che insegna alle donne, il modo et ordine li lavorare, cusire et raccamare et finalmente, far tutte quelle opere digne di memoria: lequale po fare una donna virtuosa con laco in mano et uno documento che insegna al compratore accio sia ben seruito. A la fin: Stampato in Veneggia per Giouanni Andrea Vauassore detto Guadagnino, ne li anni del nro Signore MDXXXij a di primo augusto. Quatrième édition de ce recueil. Voir pour la description de ce volume celle que nous donnons ci-dessus les deux sont identiques et ne diffèrent que par le millésime. Vente Destailleurs, 1895. Vente Pirovano, Rome, 1901. $4^{\circ}$. Cuts (26 leaves). Sig. A-1-XIII. Another copy of this book, 47 plates, in Cat. of Weyhe, N. Y., No. 20, 1918. Metro. Mus.

1800-Vavassore, G. A.-Esemplario di lavori che insegna aele donne il modo et ordine di lauorare, cusire, e raccamare e finalmete far tutte qlle opere degne di memoria: lequale po fare una donna virtuosa con laco in mano et uno documento cle insegna al compratore accio sia ben seruito. A la fin: Stampato in Veneggia per Giovanni Andrea Vauassore, detto Guadagnino et Florio Fratello, nelli anni del nostro Signore, MDXXXXIII. A di XIII Marzo. Cinquième édition de ce recueil. Voir pour la description de ce volume celle que nous donnons ci-dessus. Les deux sont identiques et ne diffèrent que par le millésime. Catalogue Cappi de Boulogne. Catalogue de la vente Seillières, par Porquet, 1890.

1801-Vavassore, G. A.-Esemplario di lavori: che insegna alle dōne-il modo e ordine di lavorare: cusire: e racāmare: e finalmēte far tutte qulle opere degne di memoria: lequale po fare una donna virtuosa con laco in mano. Et uno documento che insegna al cōpratore accio sia ben servito. In 8vo, 25 ff., printed on both sides, 48 plates. Title in red Gothic characters, framed round by six woodcuts similar to that of Vosterman; at the foot, "fiorio Vavasore fecit." There is no date to this copy; but in the library of Prince Messimo, at Rome, is a copy dated Venice, 18 Feb., 1546, containing 50 plates; and Brunet quotes an edition, "Stampato in Vinezia, 1556 ;" Cav. Merli also possesses an edition of the same date. Mr. E. Arnold has also a copy with the same date. The patterns are medixeval, on black grounds, with counted stitches, a large flower pot, mermaid, Paschal lamb, and a double plate representing Orpheus playing to the beasts. Bib. Nat. Grav.

1802-Vavassore, G. A.-Esempalrio di lavori: che insegna alle donned il modo 
et ordine di lavorare, cusire et raccare et finalment far tutte quelle opere degne di memoria. Lequale por fare una donna virtuosa con laco in mano. Et uno documento che insegna al compratore accio sia ben servito. A la fin: Stampato in Vineggia per Giouanni Andrea Vauassore detto Guadagnino. Nelli anni del nostro Signore MDXXXXVI. A di XVIII Febraro. Sixième édition de ce recueil. Voir pour la description de ce volume celle que nous donnons ci-dessus (MDXXXXIII). Les deux sont identiques et ne diffèrent que par le millésime. Vente Libri, 1857, Vente Destailleurs, 1895. $4^{\circ}$. Cuts (26 leaves). (Rosenthal Sale Cat.)

1803-Vavassore, G. A.-Essemplario novo di piu di cento variate mostre di qualunque orte bellissime per cusire intitolato Fontana di gli essempli. Oblong 8vo. No date. 16 ff., 28 plates. In the frontispiece is a fountain with the motto, "Solicitudo est mater divitiarum," and on each side of the fountain-"Donne donzelle ch, El cusir seguite-Per farvi eterne alla, Fonte venite." On the back of the frontispiece is the Dedication, headed, "Il Pelliciolo alla molta magnifica Madona Chiara Lipomana;"' the page finished by a sonnet; in the last leaf, "Avviso alle virtuose donne et a qualunque lettore Giovanni Andrea Vavassore detto Guadagnino." Says he has "negli tempi passati fatto imprimere molto e varie sorte d'essemplari di mostre," etc. At the foot "Nuevamente stampeto." This work is also described by Count Cicognara with the same title, only with the date 1550. In this last edition the author writes his name Valvassore. Catalogo ragionata dei libri posseduti dal Conte di Cicognara. Pisa, 1821. Bib. Nat. In the Bibliotheca Communitativa, Bologna, is a copy of the same date.

1804-Vavassore, G. A.-Essemplario novo di piu di cento variato mostre di qualunque sorte di Telissime per cusire, intitulato Fontana de gli Essempli. Au-dessous de ce titre est un grand fleuron représentant un vase dont la panse est décorée de têtes d'enfants qui crachent par leurs bouches de minces filets d'eau. Ces filets sont recueillis par de petits enfants assis, ou debout par terre autour du vase. En haut une banderolle sur laquelle on lit: Solicitudo est mater Divitiarum. Des deux côtés du vase les vers suivants: Donne et donzelle che el cusir seguite, Per farvi eterne alla fonte venite. Au verso une dédicace: Il Pellicolo alla mostro magnifica Madonna Lipomana Signora et Patrona honorandissima. Puis 17 lignes de texte et au-dessous 14 vers disposés 7 à droite, 7 à gauche. Puis commencent les broderies. Page non cotée. Sur ce recto on lit: Alle virtuose donne et a qualunque lettore Giouanni Andrea Valvassore detto Guadagnino. S. 17 lignes de texte au-dessous desquelles on lit: Nouamente stampato per Giuanni Andrea Valuassore detto Guadagnino MDL. En résumé 16 pages dont 27 planches de broderies à cause du dessin double qui occupe deux pages. Catalogue Cicognara, Cicognara en donne une description détaillée. Vente Destailleurs, 1895. Bibliothèque Nationale.

1805-Vavassore, G. A.-Esemplario di lavori: che insegna alle donne il modo et ordine di lauorare, cusire et raccamare, e finalmete far tutte quelle opere degne di memoria, lequale po fare una donna virtuosa con laco in mano. Et uno documento che insegna al copratore accio sia be servito. 
A la fin: Stampato in Vineggia per Giovaini Andrea Valuassore detto Guadagnino. 1552. Septième édition de ce recueil. Voir pour la description de ce volume celle que nous donnons ci-dessus (MDXXXXVI). Les deux sont identiques et ne diffèrent que par le millésime. Tross, catalogue de 1867.

1805a-Vavassore, G. A.-Essemplario di lavori, etc. Reproduced under direction of Elisa Ricci. Bergamo.

1806-Vavassore, G. A.-Libro secondo di Bellissime et variate mostre, intitulato, fior de gli Essempli, nouamente dato in luce. In $-4^{\circ}$ oblong. $\mathrm{Au}$-dessous de ce titre, un fleuron composé d'une tablette, sur laquelle sont des fruits, grenades, melons, raisins, le tout surmonté d'une palme, et de branches chargées de fruits. A gauche de ce fleuron on lit: Leggiadre donne che desiate honore, et à droite, Del cusir vostro non lasciate il fiori. $\mathrm{Au}$ verso : Il Pellicolo alla Clarissima Madonna Chiara Lippomana sua osservandissima. Puis quatorze lignes de dédicace. Sur une $22^{\circ}$ feuille correspondant au titre, on lit: Alle virtuose donne et à qualunque Lettore Giovanni Andrea Vauassore detto Guadagnino. S. Puis 16 lignes de texte et au-dessous: Nouamente Stampato per Giouanni Andrea Vauassore, detto Guadagnino et Florio Fratello. Vente Yemenitz, Venetia, 1550. Bibliothèque Nationale. S. K. M.

1807-Vavassore, Giovanni-Antonio, known as Zoan Andrea and GuadagninoLa Fior de gli esempli, la Corona di ricami. 1550.

1808-Vavassore, Giovanni-Antonio-Fontana de gli esemplio. 1546.

1809-Vavassore, G. A.-Opera nova universal intitulata, Corona di Raccami, dove le venerande donne e fanciulle, trovarono di varie opere per far colari di camisiola et torniaenti di letti etemella di cuscini boccasini : schufioni : cordilli di piu sorte. Et molte opere per reccamatori et per dipitore et porevesi: de laqual opere e vero essempli ciascuno le potra pore in opera secondo el suo bisogno. Con gratia. Nouamente stampata ne la inclita citta di Vineggia per Giovanni Andrea vavassore detto Guadagnino. $\mathrm{s}$ d. In $4^{\circ}$. Le titre entièrement xylographié est inscrit à mi-page et est surmonté d'un petit sujet au point compté, sur fond de tapisserie. Le tout est renfermé dans un encadrement formé de quatre bandes rectangulaires, deux horizontales, deux verticales, renfermant des rinceaux et des ornements. Dans l'une de ces bandes verticales, on remarque les initiales: G. A. V. qui est le monogramme de Giovanni Andrea Vavassore. Dans le coin de la dernière page on lit: Finisce il libro intitulato Corona di Racami. En résumé 26 feuillets dont un titre et 51 planches de broderies. Il existe des exemplaires où le verso du titre n'a pas de broderies. Dans ce cas il y a toujours 26 feuillets, mais il n'y a plus que 50 planches de broderies. Vente Pirovano, Rome, 1901. Vente Destailleurs, 1895. Bibliothèque Nationale.

1810-Vavassore, Gio. A.-Opera nova Universal intitulata corona di ricammi; Dove le venerande donne e fanciulle: troveraño di varie opere $p$ fare colari di camisiola \& torniāenti di letti èternelle di cuscini boccasini schufioni: cordlli di piu sorte; et molte opere per recāmatori $p$ dipitore poreuesi: de lequale opere o vero esempli ciascuno le potra pore in opera secōdo 
el suo bisogno: con gratia novamente stampata ne la inclita citta di vineggia per Giovanni Andrea Vavassore detto Guadagniō. 36 pp., sm. 4to. 13 ff., 52 designs. Library V. \& A. M.-Venice, Lib. St. Mark.Milan, Bib. Marquis d'Adda.

1811-Vavassore, G. A., detto Guadaguino-Opera nova, etc... dove le venerande donne et fanciulle trovaranno di varie opere et molte opere per recamatori et per dipintori, etc. Nuovamente stampata, etc. A little of everything in this volume. Zoan Andrea Vavassore was the pupil in drawing and engraving of Andrea Mantegna. So greedy was he of gain as to obtain for him the name of Guadigno, in Venetian patois, "covetous." Milan, Bib. Marquis G. d'Adda.

1812-Vavassore, And. detto Guadagnini-Opera Nuova Universale, intitulata Coronna di Ricammi dove le venerande donne e fanciulle trovarono di varie opere per far colari di camisiola, etc. Facsimile of the original of 1546 (?) with 40 plates. Venice, 1878. Sm. 4to. Ongania, 36 pp. S. K. M. Metro. Mus.

1813-Vavassore, G. A.-Opera nuova universale intitolata corona di Ricami, Bergamo, 1910. Reproduced under direction of Elisa Ricci.

1814 -Vavassore, G. A.-La vera perfettione del disegno di uarie sorti di ricami et di cucire ogne sorte di punti a fogliami, punti tagliati, punti a fili, et rimessi, punti introciati, punti a stuora, \& ogn'altro arte che dia opera a disegni. In Venetia, presso gl'heredi de Luigi Valuassori è Gio. Domenico Micheli, 1584. Al segno del l'Ippogrifo. In $4^{\circ}$ oblong. Il y aurait une édition de 1585. (Rahir, catalogue Destailleurs.) Bibliothèque Nationale.

1815-Vecellio, C.—Corona delle nobile et Virtuose donne, Libro primo (e secondo) nel quale si dimostra in varij dissegni tutte le sorti di Mostre di Punti Tagliati, Punti in aria, Punti a reticello, et d'ogni altra sorte, cosi per Freggi, come per Merli et Rosette, che con l'aco si usano per tutta l'Europa. In Venetia appresso Giorgio Angelieri a instantia di Cesare Vecellio. (1591.) In-4\% oblong. Titre différent vente Yemenitz. Un exemplaire de cet ouvrage mais daté de 1592, se trouve à la Bibliothèque de l'arsenal. Un exemplaire de cette même date 1592 est passé dans la vente Santarelli faite par monsieur Danlos. Vente Foulc, 1914.

1816-Vecellio, C.-Corona delle nobili etc. Marzo, 1591. Ongania reproduction, 1876. (There is also a Hoepli reproduction of this book.)

1817-Vecellio, C.-Corona delle nobili et virtvose donne, libro primo Nel quale di dimostra in varij dissegni tutte le sorte di Mostre di Punti tagliati, Punti in aria, Punti a reticello è dogni altra sorte cosi per Freggi, come per Merli et Rosette che con laco si vsano hoggidi per tutta l'Europa. Et molte delle quali mostre possono seruire ancliora per opere à Mazette. Aggiuntoui in questa Terza impressione molti bellissimi disegni non mai piu veduti. Petit in- $4^{\circ}$ oblong. Au-dessous de ce titre une marque d'Imprimerie. C'est un Cartouche ovale dans la bordure duquel on lit: Voluptatum et malorum effetur dissipatio. Dans ce Cartouche un oiseau regarde de profil à gauche des serpents qui grouillent à ses pieds. Le cartouche qui renferme cet oiseau, est entouré de cuirs, de mascarons, de petits 
amours et à droite et à gauche des femmes assises qui travaillent à le'aiguille. Au-dessous de cette marque d'imprimerie on lit: Con Privilegio. In Venetia appresso Cesare Vecellio in Frezzaria nelle case de Preti. 1591. Dédicace. . . Alla clarissima et illustrissima Signora Viena Vendramina Nani .. Finissant au verso par les mots: Di Venetia a di Genaro. 1591, et signée Cesare Vecellio. Gravure sur bois représentant une femme debout sur une tortue, de face, une main tenant un peloton de fil, l'autre main levée en l'air, l'index étendu. Au fond deux femmes assises, travaillant à l'aiguille et un sculpteur à une statue. Cette composition est entourée en haut et sur les côtés de bandes de guipures. Au-dessus de cette gravure on lit: Conviensi che la della donna la bonta et non la bellezza sia divulgata. Au verso un dessin de broderie Corona delle nobili et virtuose donne, Libro secondo. Nel quale si dimostra in varij dissegni tutte le sorte di mostre di Punti Tagliati, Punti in aaria, puntia à reticello, è d'ogni altra sorte, cosi per Freggi, come per Merli et Rosette, che con laco si vsano hoggidi per tutta l'Europa. Et molte delle quali mostre possono servire anchora per opere a Mazette. Aggiuntoui in questa Terza impressione molti bellissimi ricami non piu vedette. Même marque d'imprimerie que dans le livre premier ci-dessus, même libellé du Privilège, même date. Même dédicace qu'au livre premier ci-dessus. Corona delle nobili et virtuose donne, Libro Terzo, nel quale si dimostra in varij dissegni molte sorti di mostre, di Punto in aria, Punti Tagliati, Punti a reticello, et ancora di picciole cosi per Freggi, come per merli et Rosette, che con laco si vsano hoggidi, per tutta l'Europa. Con alçune altre noue inventioni di Bauari all' usanza Venetiana. Opera nouva e non piu data in luce. Même marque d'imprimerie que dans le livre premier, ci-dessus, même libellé du Privilège. Dédicace: . . . Alla clarissima et illustrissima Signora Viena Vendramina Nani. Finissant au verso par les mots: Di Venetia, a di. 15 Giugno. 1591, et signée: Cesare Vecellio. Feuille quadrillée indiquant la manière de piquer un dessin et de le réduire ou agrandir par les carreaux de proportion. Avertissement aux femmes sur la manière de travailler. On pourrait conclure de l'énoncé des trois titres cidessus, que cette édition serait la troisième en date. Bib. Nationale.

1818-Vecell, Cesare.-Corona delle nobili et virtuose donne. Libro Primo, Secondo, Terzo. 1592. P. 77.

1819-Vecellio, C.-Corona delle nobili et virtuose donne. Libro primo. Nel quale si dimostra in varij Dissegni, tutti le sorti di Mostre di punti tagliati, punti in aria, punti à Reticello, e d' ogni altra sorte cosi per Freggi come per Merli, \& Rosette, che con l' Aco si usano hoggidì per tutta l'Europa. Et molte delle quali Mostre possono servire anchora per Opere à Mazzette. Aggiuntivi in questa Quarta impressione molti bellissimi dissegni non mai più veduti. Then follows the printer's impresa of the stork and serpent, with a lady at work on each side, and below-Con privilegio. In Venetia, Appresso Cesare Vecellio in Frezzaria nelle Case de' Preti. 1592. Which is repeated in the 2nd and 3rd Books. Obl. 4to, $32 \mathrm{ff} ., 28$ plates. Dedication of Vecellio "Alla Clarissima, et Illustrissima Signora, Viena Vendramina Nani, dignatissima Consorte dell'Illust-smo Sig. Polo Nani, il 
Procurator di S. Marco." Signed: Venice, Jan. 20, 1591. Beautiful designs, among which are three corners for handkerchiefs, the last lettered: "Diverse inventioni p. cantoni dee fazoletti." On Plate 3, within a point coupé border, is a statue of Venus standing upon a tortoise, with other figures.

1820-Vecellio, C.—2nd Book-See 1819-Corona delle nobili et virtuose donne. Libro secondo. Nel quale si dimostra in varij Dissegni, tutte le sorti di Mostre de punte tagliati, punti in aria, punti à Reticello, e d' ogni altra sorte, cosi per Freggi, come per Merli, \& Rosette, che con l' Aco si usano hoggidi per tutta l'Europa. Et molti delle quali Mostre possono servire anchora per Opere à Mazzette. Aggiuntivi in questa Quarta Impressione molti bellissimi dissegni non mai più veduti. Con Privilegio. In Venetia, Appresso Cesare Vecellio, in Frezzaria nelle Case de' Preti. 1592. 28 ff., 26 plates. The dedication of this and the next book, though differently worded, are addressed to the same lady as the first. This is dated Jan. 24, 1591. Among the patterns are two designs for handkerchiefs, and on the last plate a statue of Vesta, within a point coupé border.

1821-Vecellio, C.-3rd Book-See 1819-Corono delle nobili et virtuose donne. Libro terzo. Nel quale si dimostra in varii dissegni molte sorti di Mostri di Punti in Aria, Punti tagliati, Punti a reticello, and ancora di picciole; cosi per Freggi, come per Merli, \& Rosette, che con 1' Aco si usano hoggidi per tutta l'Europa. Con alcune altre inventione di Bavari all' usanza Venetiana. Opera nouva e non più in luce. Con privilegio. In Venetia Appresso Cesare Vecellio, stà in Frezzaria nelle Case de' Petri. 1592. Dedication dated June 15, 1591 . Vecellio says he has added "alcune inventioni di bavari all' usanza nostra." In the copy (Bib. de l'Arsenal. 11,955 bis) are added instructions to transfer the patterns upon parchment without injuring the book. The last plate shows how to reduce the patterns and how to prick them. This is sometimes given at the end of the first book instead of the third. $28 \mathrm{ff}$., 26 plates, two of bavari. On Pl. 27, woman with a torch and Cupid. At Pl. 28, in a point coupé border, is a fox holding the bust of a lady, the conceit of which is explained by the verses that sense is better than beauty:-La Corona de Vecellio est de beaucoup le plus important et le plus célèbre des livres offrant des modèles de dentelles. Cette quatrième édition est plus complète que les précédentes. Les trois parties renferment respectivement 27.26 et 28 planches. Foulc Sale, Paris, June, 1914, frs. 980. Le Gioiello ne parut que l'annee suivante. Bib. de l'Ar'senal. V. \&. A. M.

1822-Vecellio, C.-[Another edition.] In Venetia, Appresso Cesare Vecellio, in Frezzaria nelle Case de' Preti, 1593 . See 1819. B. K. M.

1823-Vecellio, C.-[Another edition.] In Venetia, Appresso Cesare Vecellio, in Frezzaria nelle Case de i Preti, $1593 . \quad$ (Ongania reproduction.) See 1819.

1824-Vecellio, Cesare-Gioello della corona per le nobili e virtuose donne. Libro quarto. Nel quale si dimostra altri nuovi bellissimi Dissegni di tutte le sorte di Mostre di Punti in Aria, Punti tagliati \& Punti à Reticello; così per Freggi, come per Merli, \& Rosette, che con l'Aco si usano hoggidì per 
tutta l' Europa. Et molte delle quali mostre possono servire anchora per opere à Mazzette Nuovament posto in luce con molte bellissime inventioni non mai più usate, nè vedute. Con privilegio. In Venetia, Appresso Cesare Vecellio, in Frezzaria nella Casa de i Preti. 1594. Same impresa of the stork and serpent. Dedicated to the Sign. Isabella Palavicina Lupi Marchesa di Soragana, dated "Venetia alli 20 Novembrio 1592." Cesare Vecellio. 30 plates. P. 78. (Part 4 of the "Corona" with which it is often bound up.) Vecellio, author of the Corona and Gioiello, also published a work on costume styled Degli Habiti Antichi et Moderni. In Venezia, 1590. Presso Damian Zenero. In the frontispiece is a salamander; on the last leaf a figure of Vesta. It has been reproduced by F. Didot, Paris. The Bib. de l'Arsenal possesses two copies of the Corona. The Library of Rouen (No.1,315) has a volume containing the Corona and Gioiello. Book 1 "quarta Imp.," Book 2 " ultima," both dated 1594; and Book 3 "quinta," 1593. 'The Gioiello, 1593. In the Bodleian is a copy of the three books, date 1592; and another, date 1561, was in the possession of the late Mr's. Dennistoun of Dennistoun. At Venice, in the Doge's Library, is a volume containing the three books of the Corona and the Gioiello, dated 1593. Mrs. Stisted, Bagni di Lucca, also possesses the three books of the Corona, dated 1597, and the Gioiello, 1592. At Bologna the Library has one volume, containing the first and second books only, evidently the original impressions. The titles are the same as the above, only to each is affixed, "Opera nuova e non più data in luce," and "Stampata per gli Hered' della Regina. 1591. An instantia di Cesare Vecellio, Stà in Frezzaria.' 'The same Library also possesses a volume, with the three books of the Corona, the first and third "ottava," the second "quarta," and the Gioiello, "nouvamente posto in luce." All "In Venetia appresso gli heredi di Cesare Vecellio, in Frezzaria. 1608." At Vienna, in the new Museum for Art and Industry, is a copy of the five books, dated 1601 . Cav. Merli cites from a copy of the four books, dated 1600 . The various impressions, therefore, date from 1591 to $1608 . \quad$ We see these different parts, like those of Vinciolo and all these old collections, have been printed and reprinted independently of each other, since the third part was at its fifth impression in 1593, while the first, which ought to have preceded it, was only at its fourth in 1594. Rouen, Bib. Bound in one vol. with the three parts of the Corona.

1825--Vecellio, C.--Corona delle nobili et virtuose donne, Libro Primo, nel quale si dimonstra in varij dissegni tutte le sorti di mostre di punti tagliati, punti in aria, punti a reticello e d'ogni altra sorte, cosi per Freggi, come per Merli et Rosette che con laco si usano hoggidi per tutta l'Europa. Et molte delle quali mostre possono servire ancora per Opere a Mazetti. Aggiuntovi in questa quarta Impressione molti bellissimi dissegni non mai piu veduti. Même marque d'imprimerie que dans le livre premier même libellé du privilège avec la date de 1595, au lieu de 1591. Même dédicace. Même gravure sur bois. Corona del nobili et virtuose donne, Libro secondo, nel quale si dimostra in varij dissegni tutte le sorti di mostre de punti Tagliati, punti in aria, punti a Reticello, e d'ogni altra sorte, cosi per 
Freggi, come per Merli et Rosette, che con l'aco si usano hoggidi per tutta l'Europa. Et molte delle quali mostre possono servire ancora per Opere à Mazetti. Aggiuntovi in questa quarta Impressione molti bellissimi dissegni non mai piu veduti. Même marque d'imprimerie, même libellé du privilège, avec la date de 1597, au lieu de 1591. Même dédicace que dans le livre deux. A la fin une figure dans un médaillon avec le mot Vesta dans un encadrement de dentelles. Corona delle nobili et virtuose donne, Libro Terzo, nel quale si dimostra in varij dissegni tutte le sorti di Mostre di punti tagliati, punti in aria, punti a Reticello e d'ogni altra sorte, cosi per' Freggi come per Merli et Rosette,e, che con l'aco si usano hoggidi per tutta l'Europa. Con alcune altre nuove inventioni di Bauari all uzanza Venetiana. Opera nuova e non piu data in luce. Même marque d'imprimerie que dans le livre premier, même libellé du privilège avec la date de 1597, au lieu de 1591. Même dédicace que dans le livre trois. A la fin une figure en médaillon dans un cadre de dentelles représentant le renard et le buste accompagnée d'un sixain. Gioiello della Corona per le nobile e virtvose donne, Libro quarto, nel quale si dimostra altri nuovi bellissimi disegni, di tutte le sorti di Mostre, di punti in aria punti Tagliati, et punti a Reticello cosi per Freggi come per Merli et Rosette che con laco si usano hoggidi per tutta Europa, et molte delle quali mostre possono servire ancora per opere a Mazetti, nouamente posto in luce con molto bellissimi inventioni non mai piu usate ne vedute. Même marque d'imprimerie que dans le livre premier. Même libellé du privilège avec la date de 1596. Dédicace: Alla illustrissima sig-ra Padrona Colendissima la sig. Isabella Pallavicina Lvpi marchesa meritissima di Soragna. Finissant au verso par les mots: Di Venetia alli 20 novembrio 1592, et signée: Cesare Vecellio. Puis commencent les broderies. Vente Benedetto Maglione. Paris, 1894.

1826-Vecellio, C.-Corona delle nobili et virtuose donne. Libro quinto. Nel quale si contengono molti, \& varij Dissegni di diuersi sorti, \& specialmente che seruono per Bauari ch' in Venetia si costumano, \& in molte altre parti del mondo. Opera molto vtile. . . . Nuouamente posto in lvce. Con privilegio. In Venetia, appresso Cesare Vecellio,in Frezaria nelle Case de Reuer. Preti di S. Moise. 1596. $4^{\circ}$. 10 cuts.

1827-Vecellio, C.-Corona delle nobili et virtuose, etc. 1596. Ongania Reproduction of No. 1826.

1828-Vecellio, C.-Corona delle nobili et virtvose donne, Libro primo, nel quale si dimostra in varij dissegni, tutte le sorti di Mostre, Punti tagliati, punti in aria, punti a reticello, et d'ogni altra sorte cosi per Freggi, come per merli et Rosette che con laco si usano hoggidi per tutta Europa. Et molte delle quali mostre possono servire ancora per Opere a Mazette. Aggiutoui in questo quarta impressione molti bellissimi disegni non piu verduti. Même exemplaire que le précédent avec des différences insignifiantes principalement dans les cotes. Vente Piot, 1879. Bibliothèque Nationale.

1829-Vecellio, C.-Corona delle Nobili et virtvose donne, Libro Primo nel quale si dimostra in varij dissegni, tutte le sorti di Mostre, di punti tagliati, punti in aria, punti a reticello, a d'ogni altra sorte cosi per Freggi, come per Merli et Rosette, che con laco si usano hoggidi per tutta l'Europa. 
Aggiuntoui in questa quarta impressione molti bellissimi dissegni non mai piu verduti. Même exemplaire que celui décrit ci-dessus avec cette seule différence que le libellé du privilège en est daté de 1598. Vente Yemenitz, 1867. Vente Bancel, 1882.

1830 - Vecellio, C.—Corona delle nobili et virtvose donne, Libro primo, nel qual si dimostra in varij dissegni tutte le sorti di Mostre di punti tagliati, punti in aria, punti a reticello e d'ogni altra sorte cosi per Freggi come per Merli et Rosette, che con l'aco si vsano hoggidi per tutta l'Europa. Et molte delle quali mostre possono seruire ancora per opere a Nazette. Agguiuntoui in questa quarta impressione molti bellissimi dissegni non mai piu veduti, Con privilegio. Même exemplaire que celui décrit ci-dessus avec cette seule différence que le libellé du privilège est daté de 1600 .

1831-Vecellio, C.-Corona delle nobili et virtvose donne, Libro primo nel, qual si dimostra in varij dissegni, tutte le sorti di Mostre di punti tagliati, punti in aria, punti a Reticello è d'ogni altra sorte, cosi per Freggi, come per Merli et Rosette, che con l'aco si usano hoggidi per tutta l'Europa. Et molte delle quali mostre possono seruire ancora per opera et Mazette. Aggiontavi in questa ottaua impressionne molti bellissimi dissegni non piu veduti. D'après l'énoncé du titre cette édition serait la huitième. Même exemplaire que celui décrit ci-dessus avec cette seule différence que le libellé du privilège est daté de 1600. Bibliotlıèque Nationale.

1832-Vecellio, C.-[Another edition.] In Venetia, Appresso Cesare Vecellio, in Merzaria, 1600. (Ongania reproduction.) See 1831.

1833-Vecellio, C._Corona Della Nobili / / Et Virtuose Donne / / Libro Primo / / Nelqual fi dimoftra in varij Diffegni, tutte le forti di Moftre di punti tagliati / / punti in aria, punti à Reticello, e d'ogn'altra forte cofi per Fregi, come per / / Merli, e Rofette, che con l'Aco fi ufano hoggidi per tutta l' Europa / / Et Molte delle quali Mostre Poffono feruire ancora per Opere à Mazette / / Aggiontoui in quefta Ottaua Imprefsione molti bellifsimi Diffegni non piu veduti / / Con Privilegio / / In Venetia. Appreffo Cefare Vecellio, in Merzaria 1601 / / Metro Mus.

1834-CoronaDelle Nobili // Et Virtuose Donne / / Libro Terzo. Metro. Mus. See 1833.

1835-Corona Delle Nibili // Et Virtuose Donne // Libro Quarto. Metro. Mus. See 1833. B. K. M.

1836-Vecellio, C.-[Another edition.] In Venetia, Appresso gli heredi di Cesare Vecellio, in Merzaria. 1608. See 1833. V.\& A. M.

1837-Vecellio, C.-Corona delle nobile, et virtuose Donne. Libro primo, Venetia, 1592. Gioiello della Corona per le nobili, et virtuose Donne, Libro secondo, 1592; Libro terzo, 1592. Libro quarto, Venetia, 1608. 4 parts complete. Obl. 8vo. Venice, 1592-1608. S. K. M.

1838-Vecellio, C.-C Corona delle nobile, etc. Another edition (imperfect) of part 4. See No. 1837. S. K. M.

1839-Vecellio, C.-Facsimile reprint of the above. Libro primo, ed. 1600. Libro secondo, ed. 1600, Libro terzo, ed. 1600, Libro quarto ed. 1593. Ongania, Venice, 1876. S. K. M. See 1837. Metro Mus. 
1840-Vecellio, C.-Another facsimile reprint of the Libro primo ed. 1600, with title of edition. 1593. Ongania, Venice, 1879. S. K. M.

1841-Vecellio, C.-Another edition or early reprint of the Libro terzo of the same work published "in Venetia, Appreso Alessandro de Vecchi, 1620." Obl. 8vo. Venice, 1620. S. K. M.

1842-Vecellio, C.-Corona delle nobili et virtvose donne, Libro Primo, nel quale si dimostra in varij dissegni tutte le sorte di mostre di punti tagliati, punti in aria, punti Fiamenghi, punti a Reticello, e d'ogni altra sorte, cosi per Freggi, per Merli et Rosette che con l'aco si usano hoggidi per tutta l'Europa. Et molte delle quali mostre possono seruire ancora per Opere Mazette, con la dichiarationi a le mostre a lauori fatti da Lugretia Romana. Au-dessous de ce titre une gravure sur bois représentant une femme debout sur une tortue, de face, une main tenant un peloton de fil, l'autre main levée en l'air l'index étendu. Au fond deux femmes assises, travaillant à l'aiguille et un sculpteur à une statue. Cette composition est entourée en haut et sur les côtés de bandes de guipures. Au-dessus de ce bois on lit: Conviensi che la donna la bonta et non la bellezza sia divulgata. Au-dessous de la gravure: In Venetia appresso Alessandro de Vecchi 1620. Vendesi in Roma al magazino della Venetia. Dédicace: Alla Clarissima et illustrissima signoraViena Vendramina Nani. Finissant au verso par les mots: Di Venetia el di 20 marzo, 1591, et signée Cesare Vecellio. Un cartouche ovale contenant le portrait de Marie d'Aragon, de profil à gauche. Coiffée d'une résille,en buste, posé sur un piédouche. Au bas du chignon à droite, dans intérieur de l'ovale du cartouche, une couronne, au tour de la bordure du médaillon, on lit: D. Maria Aragonia. Ce cartouche est ornementé de grotesques, d'anges ailés, de chimères. Au bas est une tablette sur laquelle on lit: Aetatis suae anno. XXXIX. A droite et à gauche des bordures verticales de guipures, En haut du cartouche on lit: Conviensi che la donna, la bonta et non la Bellezza sia divulgata. Rien au verso. Puis commencent les broderies. Chaque planche porte en haut la mention du genre de broderies représenté, et en bas l'usage qu'on en fait et la partie desvêtements à laquelle cette broderie est destinée. Corona delle nobili et virtvose donne, Libro secondo, nel quale si dimostra in varij dissegni tutte le sorti di mostre di punti tagliati, punti in aria, punti Fiamenghi, punti a Reticello, e d'ogni altra sorte, cosi per Freggi, per Merli é Rosette, che con l'aco si usano hoggidi per tutta l'Europa. Et molte delle quali mostre possono servire ancora per opere à Mazette con le dichiarationi a le mostre a lavori fatti da Lugutia Romana. Même gravure sur bois que ci-dessus première partie. On lit au-dessous: In Venetia appresso Alessandro de Vecehi 1617. Si Vendono in Venetia al Ponte de Baretteri, alla libreria delle tre Roie. Dédicace: Alla Clarissima et illustrissima signora Viena Vendramina Nani. Finissant par la date de 1591 et la signature Cesare Vecellio. Page avec le buste de Marie d'Aragon décrit ci-dessus première partie. Puis commencent les broderies. Corona delle nobili et virtuose donne, Libro Terzo, nel qual si dimostra in varij dissegni tutte le sorti di Mostre di punti tagliati, punti in aria, punti Fiamenghi, punti a Reticello et d'ogni altra sorte, cosi per Freggi, 
per Merli et Rosette, che con l'aco si usano per' tutta l'Europa, et molte delle quali mostre possono servire ancora, per opere a Mazette, con le dechiarationi a le mostre a lavori fatti da Lugretia Romana. Au-dessous de ce titre même gravure sur bois que ci-dessus première partie. Au-dessous de cette gravure: In venetia appresso Alessandro de Vecchi 1620. Si Vendono in Venetia, al Ponte de Barettori, alla Libreria delle tre Roie. Dédicace: Alla Clarissima et illustrissima signora Viena Vendramina Nani. Finissant par la date 1591 et la signature Cesare Vecellio. Puis commencent les broderies. B. M.

1843-Vecellio, C.-Corona delle nobile et Virtuose donne, Libro primo nel quale si dimostra in varij dissegni tutte le sorti de Mostre di punti Tagliati, punti in aria, punti Fiamenghi, punti a reticello, a d'ogni altra sorte, cosi per Freggi, per Merli et Rosette, che con l'aco si usano hoggidi per tutta l'Europa. Con le dechiarationi a le mostre a lavori fatti da Lugutia Romana. Au-dessous du gravure: In Venetia Appresso Alessandro de Vecchi MDCXXV. Si Vendone in Venetia al Ponte de Baretteri, alla Libreria delle tre Roie. Même dédicace, même cartouche avec le buste de Marie d'Aragon que dans la première partie du numéro ci-dessus, mêmes cotes des pages. La seconde partie a le même titre, la même marque d'imprimerie, le même privilège, la même dédicace que ci-dessus. Puis commencent les broderies. La troisième partie a le même titre, la même marque d'imprimerie, le même privilège, la même dédicace que ci-dessus. Puis commencent les broderies. La quatriême partie a le même titre, la même marque d'imprimerie, le même privilège, la même dédicace que ci-dessus. Puis commencent les broderies. Ce volume comprend 116 feuillets. Les trois premières parties en ayant 28 chacune, et la quatrième 32. In Emmanuel Bocher's opinion this is the same book as that of the same title and date listed under Lucretia Romana: here described in greater detail, especially with reference to the different parts. Vente Destailleurs, 1895. Bibliothèque impèriale de Vienne.

1844-Vecellio, Cesare-Corona delle Nobili et Virtuose Donne, libro primo. Nel quale si dimostra in varii Dissegni tutte le sorti di Mostre di punti tagliati, punti in Aria, punti Fiamenghi, etc., cosi per Freggi, per Merli, e Rosette, che con l'Aco si usano hoggidi per tutta l'Europa. In Venetia, Appresso Alessandro de' Vecchi, 1625. Oblong 8vo, woodcut on title, portrait of Lucretia Romana, and 24 woodcut pages of designs for lace and needlework, half calf. Ellis (London) Cat. No. 177, 1918. See note above, and No.1110 by Lucretia Romana.

1845-Vecellio, Cesare-Corona delli nobili et virtuse donne. 1630, reprinted 1879.

1846-Vecellio, Cesare-Costumes anciens et modernes. Habiti antichi e morderni, etc. Paris, Fernin Didot frères et fils, 1859-1860.

1847-Vecelli, C.-Die Krone der kunstfertigen Frauen. 1691. Berlin, 1891. In British Museum.

1848-Venetian Patterns-12 leaves of woodcut designs, each with headings from a 16 th century Lace pattern book. Sm. 4to. n.d. S. K. M.

1849-Venetian Point Lace. Delineator, V. 64, pp. 116-117, July, 1904. 
1850-Venetian, 16th Cent.-Für Passementerie Arbeiten und verwandte Techniken. Nach dem Original-musterbuche im Besitze der Bibliothek des k.k. Oesterr. Museums . . Obl. 8vo, Wien, 1879. S. K. M.

1851-Venetianer Spitzen (Punto tirati) aus dem 16. Jahrhundert. Blaetter für Kunstgewerbe, 1879, Vienna.

1852-Vera perfezione del disegno, La, etc. Sm. obl. 4to. Venice, F. Senese, 1591. 23 tracings of the patterns. See Clerget. S. K. M.

1853-Vereeniging "De Nederlandsche Kantwerkschool" te's Gravenhage. Verslag over 1902, tot September, 1903. Amsterdam, van Ipenbuur \& van Seldam, n.d.

1854-Verein zur Hebung der Spitzenindustrie in Österreich. Kunst und Kunsthandwerk, 1904.

1855-Vere, O'Brien, Mrs. Robert-Limerick Lace. Irish Homestead, August, 1897.

1856-Verhaegen, Pierre-L'industrie dentellière en Belgique. La Réforme sociale, May 16, 1902. Paris.

1857-Verhaegen, Pierre-Les Industries à domicile en Belgique, T. IV, La Dentelle et la Broderie sur tulle, 2 vol. Brussels, Office de Public. et Société belge de librairie, 1902. B. M.

1858-Verhaegen, Pierre-Royaume de Belgique, Ministère de l'Industrie et $d u$ Travail, Office du Travail. Les Industres à Domicile en Belgique, Bruxelles 1902. Vol. IV \& V, La Dentelle et la Broderie sur Tulle, Tomes 1 et 2. Published by J. Lebeque \& Cie., Brussels, rue de la Madeleine 46, 1902; or Oscar Schepens \& Co., Rue Treurenberg, 16, Brussels.

1859-Verkauf inländischer Spitzen. Kunst und Kunsthandwerk, 1903, Vienna. 1860-Verneuil, M. P.-Un concours de napperons à l'Union centrale des Arts décoratifs. Art et décoration, 1903, Paris.

1861-Verneuil, P.-L'École de Dentelles de Vienne. Art et décoration, 1903, V. 14 , pp. 265-272.

1862-Verwaetermeulen, Ant.-Bloemwerk-Valencijnsch Kantwerk te Teper. La revue Bishorf. Termes, August, 1902. Bruges, Année 1901, No. 10 et 18.

1863-V.-H-Les Dentelles. Histoire. Fabrication, etc. Journal des Dames et des Demoiselles, 1859-1860 Brussels.

1864 -Vienne Exhibition, 1873-Rapport de la Delegation ouvrière française. Rapport du Delegue Lyonnaise sur la Passementerie à la barres. 8vo, Paris, 1874. S. K. M.

1865-Vigouroux, Louis-Rapport fait au nom de la Commission du Commerce et de l'Industrie chargée d'examiner la proposition de loi de M. Fernand Engerand, relative à l'apprentissage de la dentelle à la main. Chambre des Deputés, June 12, 1903, Paris.

1866-Vigouroux, Louis_La Dentelle à la Main. Revue Bleue, Feb. 11, 1905, Paris.

1867-Villedon de Courson, Ctesse de-La Dentelle. Mois littéraire et pittoresque, February, 1904, Paris.

1868-Vinciolo, Federic-Les excellents eschantillons, patrons et modelles du Seigneur Federic de Vinciolo Venitien, pour apprendre à faire toutes sortes d'ouvrages de Lingerie, de Poinct couppé, grands et petits passe- 
ments à jour, et dentelles exquises. Dediez à la Royne. A Paris. Chez la Veufve Jean le Clerc, ruë Sainct Jean de Latran, à la Salamandre Royalle. Avec Privilege du Roy, 1623. In 4to, 56 ff. The old frontispiece and same. Page Aij. Avertissement au lecture. Au verso, 4 vers dans le bas de la page. Dedication to the Queen, Anne of Austria. The Goddess Pallas invented "les ouvrages de lingerie, le poinct couppé, les grands and petits passements à jour, toutes sortes de dentelles, tant pour se desennuyer que se parer, par l'artifice de ses ingenieuses mains. Araciné s'y adonna, and bien qu'inferieure se voulant comparer à elle \& en venir à l'experience, mais sa presomption fut chastiée." Many illustrious ladies lave delighted in this "honneste exercise." Fastrade and Constance, wives of the Emperor Charlemagne and of King Robert, "s'employèrent de cette manufacture, and de leurs ouvrages ornèrent les églises \& les autels." This royal "mestier" has reached perfection through the works of Vinciolo. I reprint and again increase his work, which I dedicate to your Majesty,to whom I presume they will be agreeable; the subject of which it treats is "une invention de déesse \& une occupation de Roynevous estant autant Royne des vertus que vous l'estes de deux royaumes." Signed, "La Veufve de feu Iean le Clere." Page Aiiij. Same Sonnet aux Dames et Damoiselles. Au verso extrait du Privilège. Puis commencent les broderies. Page Oiiij, Alphabet. Privilege for six years, dated Paris, last day of March, 1623. 55 ff., 58plates, 24 ouvrages de point couppé and 8 of "Passements au fuzeau" and alphabet. Cat. d'Estrées. Bibliothèque Nationale, Bib. Imp. Grav. Brussels Bib. Royal.

1869-Vinciolo, F.-New Modelbuch darinen allerly Gottung schoner Modeln der newen auss geschitnen arbeit auff Kragen Hempter, Jakelet und Dergleichen zu newen, so zuvor in Teutschlandt nicht geschen. Saint Gall, 1593. In $-4^{\circ}$. Traduction du $3^{\circ}$ livre de Vinciolo.

1870-Vinciolo, F.-New Modelbuch Von allerhand sonderbarn schönen Mödeln von der jetzt gebreuchliche' durch geschnittener Arbeit. Durch H. Vinciolo ein Venediger angeordnet. Yetzt aber allen Frawen, Jungfrawen, Nåherin vnd dergleichen Kunstgeflissenen Personen zu sondern verstand auffs new mit vermehrung vnd besserung viler schỏnen vnd lustiger Mo̊deln in Truck gefertiget vnd an tag gebracht. Mit Ro̊m: Keyserlicher Mayestat Freyheit. Getruckt zu Strassburg bey B. Jobins Erben. An. 1596. $4^{\circ}$. Titlepage, 2 pp. text (a poem signed J. D. E.), cuts. V. \& A. M.

1871-Vinciolo, F.-Les secondes œvvres et svbtiles inventions de lingerie du seigneur Federic de Vinciolo Venitien, dédiées à Madame, sœur uniqve du Roy. Où sont représentées plusieurs figures de reseau, nombre de carrez tous differents le tout de poinct conté auec autres nounelles sortes de bordures non encore veues. A Paris, Par Iean Le Clers rue Sainct Jean de Latran, à la Salemendre, 1594. Auec Privilége du Roy. Ce titre est au milieu d'un encadrement en haut duquel on voit dans un écusson en losange, surmonté d'une couronne royale, les armes de France et de Navarre avec une cordelière de veuve. Des deux côtés de cet écusson une femme tenant un métier sur ses genoux. Au-dessous sur les côtés verticaux de l'encadrement, à droite et à gauche, un enfant dans des rinceaux. En bas 
deux autres enfants couclrés et au milieu un cartouche, dans lequel on lit: Auec Privilège du Roi. Aij, avertissements au lecteur. Au verso le portrait de Catherine de Bourbon, de trois quart à gauche, une fraise autour du cou, deux colliers sur la poitrine. Médaillon ovale, sur la bordure duquel on lit: Catherine de Bovrbon, sœur unieque du Roy. Aiij, dédicace. Verso un sonnet. Page non cotée, sonnet aux Dames et Damoiselles. Verso, Extrait du Privilège daté de: Mante le 13 iour de juillet 1593. M. d'Adda dans sa bibliographie mentionne une édition de 1595 et une de 1598.

1872-Vinciolo, F.-Les secondes œurues et subtiles inuentions . . . le tout de poinct conté auec autres sortes de Carrez de nouuelle inuention non encores veus A Paris, Par Ican le Clerc, ruë Sainct Iean de Latran, à la Salamandre. 1599. Portion of Titlepage and some cuts are in the V. \& A. M.

1873-Vinciolo,F.-Les secondes œuvres, et subtiles inventions de Lingerie du Seigneur Federic de Vinciolo Venitien; nouvellement augumenté de plusieurs carrez de point de rebort. Dediée à Madame, sœur unique du roy. $\mathrm{Ou}$ sont representees plusieurs figures de Reseau, nombres de Carrez et Bordures tous differents, le tout de poinct conté, avec autres sortes de Carrez de nouvelles inventions non encore vues. A Paris. Par Jean le Clere, rue sainct Jean de Latran, à la Salemandre, 1613. Avec privilege du Roy. A scarce and valuable volume, the fullest edition of the second part of Vinciolo's work. 4to, $68 \mathrm{ff}$., 61 plates. It contains a Sonnet aux Dames \& Damoyselles. The author's address to the reader, and a Dedication to "Madame, sœur unique du roy" (Catherine de Bourbon, sister of Henry IV, married, 1599, to the Duc de Bar), signed by Le Cler'c. On the second plates are her arms, a lozenge, France and Navarre witlr crown and cordelière, and the same lozenge, also surmounts the decorated frontispiece, supported on either side by a genius (?) working at a frame and point coupé drapery. 7 Scripture subjects: The Salutation, St. Sacrement, Passion, Crucifixion, Adoration of the Kings, etc.; the number of the stitches given to each. 2 Stomacher's, and various patterns of "carrez" and borders. 2 of "Point de rebort." Le nombre des points est partout indiqué. M. Brunet, Manuel du Libraire. "Edition la plus complète de la deuxième partie des dessins de Vinciolo. Elle contient outre les feuillets préliminairies, 61 planches en grande partie différentes des précédentes et l'on y a ajouté le discours du lacis en ver's. Nous en avons vu un exemplaire daté de 1612 et un de 1603." Vente Pirovano, Rome, 1901. Vente Pichon, 1869. Vente Yemenitz, 1867. Bibliothèque publique de Rouen.

1874 -Vinciolo, F.-1st Edition, 1st Part. Les singuliers et nouveaux pourtraicts et ouvrages de Lingerie Servans de patrons à faire toutes sortes de poincts, couppé, Lacis \& autres. Dedie ala Royne. Nouvellement inventez, au proffit \& cōtentement, des nobles Dames \& Damoiselles \& autres gentils esprits, amateurs d'un tel art. Par le Seigneur Federick de Vinciolo Venitien. A Paris. Par Iean le Clere le ieune, ruē Chartiere, au Chef Sainct Denis. 1587. Avee privilege du Roy. 
1875-2nd Part. See 1874. Les singuliers et nouveaux pourtraicts et ouvrages de Lingerie ou est representé les sept planettes, \& plusieurs autres figures $\&$ portraitz servans de patrons à faire de plusieurs cortes de Lacis. Nouvellement inventez, au proffit \& cōtentment des nobles Dames \& Damoiselles \& autres gentils esprits, amateurs d'un tel art. Par le Seigneur Federic de Vinciolo Venitien. A Paris. Par Iean le Clere le ieune, ruë Chartiere, au Chef Sainct Denis. 1587. Avec privilege du Roi. (At the end.) Privilege for nine years to "Iean le Clere le ieune, 'tailleur d'histoires,' à Paris," signed 27 June, 1587. “De l'Imprimerie de David la Clerc Rue Frementel à l'Estoille d'Or.', 4to. 'The first part consists of $40 \mathrm{ff} ., 36$ of patterns and 4 preliminary pages. P. 1. The title-page with decorated border, in which are two ladies at work. (See Title-page of this work.) P. 2. Dedication of "Le Seigneur Federic de Vinciolo aux Benevolles Lecteurs." P. 3. Dedication "A la Royne," Louise de Vaudemont, by Le Clerc. Signed last day of May, 1587. P. 4. A Sonnet. Then the 36 patterns set off in white on a black ground, viz., 20 "Ouvrages de point Couppé," The first plate with the double $\lambda \lambda$, according to the fashion introduced by Francis I. of using Greek monograms, standing for Queen Louise. On the second page are two escutcheons, one of France, the other with the letter $H$ for Henry III. Then follow eight "Passemens de point Couppé," which are succeeded by eight more "Ouvrages de point Couppé." Part 2, $24 \mathrm{ff}$. Same decorated frontispiece and 22 plates of subjects in squares for stitches like the German patterns of the present day. These consist of the Seven Planets, Sol, Luna, Mars, Mercury, Jupiter, Venus and Saturn. Four in squares of various designs; two of Amorini shooting stags and birds; Neptune and the winds; an arabesque with impresa of a column with circle and double triangle; five borders and squares, and two "bordures à carreaux," diamond-shaped meshes. The last page contains the Extract from the Privilege. This is the original edition of Vinciolo, of which we know but one copy existing-that in the Library at Rouen. Bury-Palliser. It was followed the same year by two other editions, with alterations. Cette édition, comme encadrement du titre, comme disposition des feuillets, comme côtés des pages, comme millésime est identiquement pareille à celle que nous venons de décrire (2 edit.) Elle ne diffère que par l'énoncé des deux titres, celui de la première partie et celui de la seconde dont les rédactions ne sont pas les mêmes. Nous donnons ici ces deux titres, par lesqnels on reconnaîtra facilement l'édition présente. Quoique portant le même millésime cet exemplaire est bien celui d'une seconde édition parue la même année 1587. On lit en effet dans l'énoncé du titre de la première partie . . . Nouuellement inventez ... \&. E. Bocher. Vente Techner. We have received notice of there being a copy of the original edition at Turin, in the Library of the University. Biblio. Rouen. Both parts in one vol.

1876-Vinciolo, F.-2nd Edition-1st Part. Les singuliers et nouveaux pourtraicts pour les ouvrages de Lingerie. Nouvellement augmentez de plusieurs differens pourtraits servans de patrons à faire toutes sortes poincts couppé, Lacis, et autres reseau de poinct conté. Dedié à la Royne. Le 
tout inventé, au proffit \& contentement des nobles Dames \& Damoiselles \& autres gentils esprits, amateurs d'un tel art. Par le Seigneur. Federic de Vinciolo Venitian. A Paris. Par Iean le Clerc le ieune, ruë Chartiere, au Chef Sainct Denis, pres le college de Coqueret. Avec privilege du Roy. 1587.

1877-2nd Part. See 1876.-Les singuliers et nouveaux pourtraicts pour les ouvrages de Lingerie ou avons augmēté plusieurs nouveaux \& differens portraitz de reseau, tout point conté, plusieurs nouvelles bordures et autres sortes differentes. Nouvellement inventez au proffit \& cōtentement des nobles Dames \& Damoiselles \& autres gentils esprits amateurs d'un tel art. Par le Seigneur Federick de Vinciolo Venitian. A Paris. Par Iean le Clere le ieune, Ruë Chartiere, au Chef Sainct Denis, pres le college de Coqueret. Avec privilege du Roy. 1587. 1st Part, $40 \mathrm{ff}$. The same frontispiece, dedications, date, and sonnet, as the first, the same number of patterns, only the eight styled in the first "Passemens" are here all called, like the others, "Ouvrages" de point couppé. 2nd Part, 32 ff. This part has 30 patterns, comprising the 24 of the first edition, and six additional ones, consisting of squares and two hunting subjects. Sur la dernière page au recto, l'extrait du Privilège, finissant par les mots: ès lettres patentes, données à Paris, ce vingt septième iour de juin 1587, de l'Imprimerie de Dauid. Le Clerc Rue Frementel à l'estoile d'or. Vente Pirovano, Rome, 1901. Bibliothèque Nationale.

1878-Vinciolo, F.-3rd Edition, Parts 1 and 2, No. 1-Les singuliers et nouveaux Pourtraicts, du Seigneur Federic de Vinciolo Venitien, pour toutes sortes d'ouvrages de Lingerie. Dedie a la Royne. Derechef et pour la troisieme fois augmentez Outre le reseau premier et le point couppé et lacis, de plusieurs beaux et differens portrais de reseau de point cōté avec le nombre des mailles, choze non encor venue ni inventée. A Paris. Par Iean le Clerc le ieune, ruë Chartiere, au Chef Sainct Denis, pres le college de Coqueret. Avec privilege du Roy. 1587. This must be the first impression of the third edition. Brussels, Biblio. Royal.

1879-Vinciolo, F.-3rd Edition, No. 2, 1st Part-Les Singuliers / / Et Novveaux Pour // Traicts, du Seigneur Federic // de Vinciolo Venitien, pour toutes / / fortes d'ouurages de Lingerie / / Dedie a la Royne // Derechef et Pour la // Troisiesme fois Augmentez // outre le refeau premier / / le point couppé lacis, / / deplufieurs beaux differens portrais de refeau // de point coté, avec le nombre des mailles, chofe // non encor' vene ny inuentée. A PARIS / / Par Iean le Clerc le Ieune, au mont Saint // Hilaire, au Chef Sainct Denis / / pres le Clos Bruneau // Avec privilege du Roy. 1588. 1re partie. Même encadrement pour le titre que dans l'édition de 1587. Au verso de cette page le portrait gravé sur bois de Henri III. Dans un médaillon ovale, entouré d'un trait et d'un filet, ce portrait est de face, la tête de trois quart à gauche, coiffé d'un bonnet orné d'une plume sur le devant et d'un gros bouton en pierrerie. Au cou le cordon du Saint-Esprit. On lit sur la bordure du médaillon: Henri III. D. G. Franc. et Polon. Rex. Ce portrait se détache au milieu d'une couronne formée de deux branches de laurier, liées en bas 
par un ruban. Au-dessous, au bas de la page un quatrain entouré sur trois côtés par une petite frise gravée sur bois. Aij, avertissement au lecteur. Au verso de cette page, le portrait de la reine Louise de Lorraine. Elle est de face, la tête de trois quart à droite, une fraise autour du cou, manches à crevés, deux rangs de perles sur la poitrine. Dans la bordure du médaillon on lit: Lodoica Lotharinga Fr. Re. Le tout se détache au milieu d'une couronne formée de deux branches de laurier, liées en bas par un ruban. Au-dessous, au bas de la page un quatrain entouré sur trois côtés, d'une petite frise gravée sur bois. Aiij, dédicace à la Reine. Rien au verso. Aiiij, sonnet aux Dames et Damoiselles. Verso. Extrait du Privilège finissant par les mots: De l'imprimerie de Dauid Le Clere, rue $\mathrm{S}$. Iacques au petit Bec deuant le collège de Marmouttier. Quelque sexemplaires de cette même édition de 1588 portent à la fin du privilège cette adresse qui diffère de celle ci-dessus, De l'Imprimerie de David Le Clere, rue S. Jacques aux trois Mores, 1587. Rien au verso. Puis commencent les broderies imprimées seulement au recto des pages. Vente Destailleurs, 1895. Metro. Mus.

1880-2nd Part. See 1879-Les singuliers et nouveaux pourtraicts, du Seigneur Federic de Vinciolo Venitien, pour toutes sortes d'ouvrages de Lingerie. Dedié a la Royne. Derechef et pour la troisiesme fois augmentez, outre le reseau premier \& le point couppé \& lacis, de plusieurs beaux et differens portrais de reseau de point cōté, avec le nombre des mailles, chose non encor veuë, ny inventée. A Paris. Par Iean le Clerc le ieune, au mont Saint Hilaire, au Chef Sainct Denis, pres le Clos Bruneau. Avec privilege du Roy. 1588. Au verso broderie. Puis commencent les pages de broderies au recto et au verso sauf quelques-unes qui au verso sont simplement quadrillées. Nous indiquerons cette particularité. L, Lij, Liij, Liiij.-M, Mij, Miij, Miiij.-N, Nij, Niij, Niiij.—O, Oij, Oiij, Oiiij.-P, le verso de cette page est quadrillé. A partir de cette côte tous les versos sont quadrillés jusqu'à la fin mais sans dessins. Pij, Piij, Piiij.-Q, Qij, Qiij, Qiiij.-R, Rij, Riij, Riiij.-S, Sij, Siij, Siiij.-T, Tij, Tiij. Page suivante non cotée. Au recto un écusson dans lequel on voit à gauche trois fleurs de lys, puis un aigle, et un saint Michel à cheval. L'écusson est surmonté de la couronne Royale et le tout est entouré de deux colliers, celui de saint Michel, et celui du Saint-Esprit. Vente Destailleurs, 1895. This must be subsequent to the Brussels impression, as Jean le Clere has changed his address. In the third edition, dorso of pp. 1 and 2, we have the addition of portraits of Louise de Vaudemont and Henry III., with a complimentary stanza of four lines under each. In his Advertisement au lecteur, Vinciolo says that having promised, since the first impression of his book, to give a "nouvelle bande d'ouvrages," and not to disappoint certain ladies who have complained that he has not made " $\mathrm{du}$ reseau assez beau à leur fantaisie," I have wished for the third time to place before their eyes many new and different patterns of "reseau de point conté que j'ay cousus et attachez à la fin de mes premières figures," beneath which I have put the number and quantity of the stitches. Same dedication and sonnet as before. Privilege for nine years dated Paris, 25 May, 1587. "De 
l'Imprimerie de David le Clere, ruë S. Jacques, au petit Bec, devant le College de Marmouttier." 1st Part, 40 ff., 36 plates, 27 of point couppé, two stomachers, and seven "Passemens" de point couppé; the same lettered "Ouvrages" as in the preceding impression. 2nd Part, 36 ff., 50 plates. The thirty already published in the second edition, after which follow the twenty additional of "reseau de point conté" announced in the Preface, consisting of " 6 Quarrés, 2 Coins de Mouchoir, 2 Bordures, 6 animals: Lion, Pelican, Unicorn, Stag, Peacock, and Griffon"; and the Four Seasons. "Déesse des fleurs, representant le Printemps," etc. These last twenty have the number of stitches given. On the last page is an escutcheon with the arms of France and Poland. Bib. Ste. Geneviève (with 1 part). Bib. Nat. Grav. (with 1 part).

1881-Vinciolo, F.-3rd Edition, No. 3, Parts 1 and 2.-A later impression still. Same title, date, portraits, dedication, and sonnet, only the Privilege is dated "ce douzième jour" de Novembre 1587. De l'Imprimerie de David le Clerc, Rue S. Jaques, aux trois Mores." 34 ff., 30 plates, 1st part; 50 plates in 2nd. See 1879. Bib. de l'Arsenal.

1882-Vinciolo, F.-4th Edition, Parts 1 and 2.-Les Singuliers / / Et Novveaux Pourtraicts, Du Seigneur Federic // de Vinciolo Venitien, pour toutes / / fortes d-ounrages de Lingerie / / DEDIE A LA ROYNE / / DERECHEF ET POUR LA / / Quatrieme Fois Augmentez / / outre le refeau premier le point couppé lacis // de piufieurs beaux differens portrais / / de refeau de point conté, avec le nombre des mailles, chose non encor // vêne ni inuentée // A THURIN // Paris- Par Eleazaro Thomyfi // 1589. Metro. Mus. In- $4^{\circ}$ en deux parties. Même encadrement du titre que dans l'édition de 1587. Aij, le portrait de Henri III et son entourage, le même que celui décrit dans l'édition de 1588. Au verso, avertissement au lecteur. Aiij, le portrait de la Reine et son entourage, le même que celui décrit dans l'édition de 1588. Au verso, dédicace à la Reine finissant par les mots: Ce 12 juillet 1589. Vostre très humble et très obeyssant seruiteur et subiect Fleazaro Thomisi. Aiiij, sonnet aux dames et damoiselles. La première partie de 44 feuillets, contient 33 planches non compris le frontispice et les portraits de Henri III et de sa femme. La seconde de 42 feuillets et de 36 planches. E. Bocher. Described in Cat. Cicognara with the date 1658. The 1st part $44 \mathrm{ff}$. and 39 plates; the 2 nd with 36 plates. The copies of Vinciolo in the Bodleian bear the dates of 1588,1603 , and 1612 . Baron Pichon has a copy of an impression of 1612. One at Bordeaux, in the Bib. de la Ville, is dated 1588. In a book sale at Antwerp, March, 1864, there was sold the following:-Lot 528. Livre de Patrons de Lingerie dedié a la Royne, nouvellement invente par le seign' Frederic de Vinciolo, Venitien. Paris, Jean le Clerc, 1598.-Les singuliers et nouveaux pourtraicts pour toutes sortes d'ouvrages de Lingerie. Paris, Ibid., 1598. - Les secondes cuvres et subtiles inventions de Lingerie. Paris, Ibid., 1598. - Nouveaux pourtraicts de Point coupé et Dantelles en petite moyenne et grande forme. A. Montbeliard, Jacques Foillet, 1598. 4 tom. 1 vol. in-4. v. anc. fig. sur bois. It went for 440 franes to a Mr. Ross. We do not know the editions of 1598. 
As M. Leber observes, the various editions of Vinciolo, published by Le Clere and his widow, from 1587 to 1623 , and perhaps later, are only impressions more or less varied of the two distinct books, the one of point coupé, the other of lacis. The work of Vinciolo has been reprinted in several countries. In England it has been translated and published by Wolfe. At Liége, by Jean de Glen. Mr. Douce says that it was reprinted "at Strasburg, 1596, and at Basle, 1599, with a second part, which is rare, and sometimes contains a portrait by Gaultier of Catherine de Bourbon." In the Bib. Nat. a volume headed Vinciolo (Federigo) Peintre Venetien et ses imitateurs contains, with "La pratique," etc., of Mignerak a German copy of the "nouveaux pourtraits," the work printed by Ludwig Künigs, at Basle, 1599 and a German work headed "Broderies sur filet," 50 plates engraved upon copper. Bury-Palliser. Catalogue Cicognara, Brussels, Bib. Roy.

1884-Vinciolo, Fde.-Les singuliers et novveavx povtraicts . . . pour toutes sortes d'ouurages de Lingerie ... Derechef et povr la qvatrieme fois avgmentez, etc. Sm. 4to. Lyons (L. Odet), 1592. S. K. M.

1885-Vinciolo, F.-3rd Edition, No. 4, Parts 1 and 2.-Les singuliers et nouveaux pourtraicts, du Seigneur Frederic de Vinciolo, Venitien, pour toutes sortes d'ouvrages de Lingerie. Dedie à la Royne Douairière de France. De Rechef et pour la troisiesme fois augmentez, outre le reseau premier \& le point couppé \& lacis, de plusieurs beaux \& differens portrais de reseau de point cōté, avec le nombre des mailles, chose non encore veuë ny inventée. A Paris. Par Iean le Clerc, ruë Saint Jean de Latran, à la Salemandre. Avec privilege du Roy. 1595. This impression is dedicated to Louise de Vaudemont, now "Reine Douairière," Henry III. having died in 1589. British Museum-Grenville Lib.

1886-Vinciolo, F.-Les singvliers et novveaux porrtraicts du seigneur federic de Vinciolo, Venitien pour toutes sortes d'ouurages de Lingerie. Imprimé à Bâsle par Lory Roy, 1599. In- $8^{\circ}$ oblong. Ce titre est dans un encadrement rectangulaire, formé par de petits carrés et des bandes de guipure. Puis les broderies, copiées des ouvrages français du Vinciolo. Elles sont tirées en largeur au lieu d'être en hauteur. En somme, 52 feuillets dont un titre et 52 planches de broderies. Vente Yemenitz. Catalogue du Borluut. B. M.

1887-Vinciolo, Federic.-Les Singuliers Et Nouneaux Pourtraicts Dw Seignevr Federic de Vinciolo Venitien, pour toutes sortes d'ouurages de Lingerie. Dedie A La Royne Douariere De France Derechef Et Pour La Troisiesme Fois Augmentez outre le reseau premier \& le point couppé \& lacis, de plusieurs beaux \& differens portrais de reseau de point cōté, auee le nombre des mailles, chose non encor' veuë ny inuentée. A Paris Par Iean le Clerc, ruë Saint Iean de Latran, à la Salemandre. Avec priuelege du Roy. 1601. [Extraict du Priuilege. De l'Imprimerie de Dauid le Clerc, Rue Frementel au petit Corbeil.] $4^{\circ}$. Title, Coat of Arms, 3 pp. text, 64 cuts. B. K. M. 
1888-Vinciolo, F.-Les singuliers et nouveaux pourtraicts du seigneur Federic de Vinciolo, Venitien pour toutes sortes d'ouvrages de lingerie, dediée à la Reine douairiere de France, de rechef et pour la troisieme fois augmentez Outre le reseau premier et le point coupé et lacis, de plusieurs beaux et différents portraits de reseaux, de point compté avec le nombre de mailles, chose non encore veue, ni inventée. A Paris pour Jean le Clerc, rue St. Jean de Latran, à la Salamandre Royalle, avec Priuilège du Roi, 1603. In $-4^{\circ}$ en deux parties. Même encadrement pour le titre que dans l'édition de 1587. Au verse le portrait de Henry III. Aij, l'avertissement au lecteur, au verso le portrait de la Reine. Aiij, dédicace à la Reine. La Première partie comprend 40 feuillets. La Deuxième partie comprend 32 feuillets.

1889-Vinciolo, F.-Les singvliers et novveaux Pourtraicts du Seigneur Féderic Vinciolo Venitien pour toutes sortes de Lingerie, Dédie à la Royne, De rechef et pour la cinquième fois augmentez oultre le réseau premier et le point couppé \& lacis de plusieur's et beaux et différents pourtraits de réseau de point compté avec le nombre des mailles, choses non encore veue ni inuentée. A Lyon par Leonard Odet, MDCTIT (1603). 2 parties en 1 volume in $4^{\circ}$. Part 1.-Title, Portrait, 5 pp., and 42 leaves of cuts. Part II.-Title, 1. p. text, 68 cuts. E. F. Strange. Même encadrement du titre que dans l'édition de 1587. Cette feuille est cotée A. Rien au verso. A2, portrait de Henri IV, remplaçant celui de Henri III. II est de trois quart à gauche, col blanc, cuirasse avec écharpe blanche, dans un médaillon ovale. Sur la bordure du médaillon: Henri IIII, par la grâce de Dieu, Roy de France et de Navarre. Ce médaillon est au milieu d'une couronne, formée de deux branches de laurier liées en bas en sautoir. Verso, une planche de broderie prise dans un autre ouvrage que les Vinciolo antérieurs et d'un tout autre caractère. Ce sont trois bandes horizontales de point compté. Dans celle du milieu, on voit un aigle et deux chiens.- $L, L 2, L 3$, au verso une broderie guipure qui semble prise dans un autre ouvrage que dans les Vinciolo antérieurs. L4, alphabet, rien au verso. Belin, 1911. B. K. M.

1889a-Vinciolo, F.-Les sinvliers et novveaux Pourtraicts du seigneur Federic Vinciolo Venitien pour toutes sortes d'ouurages de Lingerie, dédie à la Royne, de rechef et pour la cinquieme fois augmentez outre le reseau premier et le point couppé et lacis de plusieurs beaux et differents pourtraits de réseau de point compté avec le nombre de mailles, choses non encore veue ni inuentée. A Lyon, par Leonard Odet, MDCII (1603). M2, sonnet aux dames et damoiselles. V4. Au verso de cette page, une tablette noire sur laquelle se détachent en blanc les lettres d'un alphabet majuscule. Elle est entourée de deux branches de laurier en sautoir. Depuis la cote $\boldsymbol{M} 3$, toutes les pages ont des broderies au recto et au verso. Celles des versos sont prises dans différents recueils, et entre autres dans La vera perfettione del disegno de J. Ostaus. En tout 80 feuillets et 115 planches de broderies. Vente Yemenitz, Vente des Barreaux-Bernard, 1879. Vente Seillieres, 1890. Vente Coste, Vente Destailleurs, 1895. [Another edition, with the plates in different order.] See 1889. Vente Benedetto Maglione, 1894. B. K. M. 
1890-Vinciolo, F.-Les singvliers et nouveaux povrtraicts du seignevr Federic de Vinciolo Venitien pour toutes sortes d'ouurages de Lingerie. Dédié à la Royne douairiere de France de rechef et pour la troisieme fois avgmentez outre le réseau premier et le point couppé et lacis, de plusieurs beaux et différents portraits de reseau, de point conté auec le nombre de mailles, chose non encore veue, ny inuenté. A Paris pour Iean Le Clerc, rue S. Jean de Latran à la Salemendre Royalle. Auec privilège du Roy, 1606. Ce titre est sur une page cotée $A$. Au verso de cette page le portrait de Henri III. Ici la couronne formé de deux branches de lauriers qu'on voit dans les éditions de 1588 et 1589 est remplacée par une couronne formée de fruits et de fleurs entrelacées. Les 4 vers qui sont en bas, sont d'une écriture plus grosse que dans l'édition de 1588 et ne sont pas comme dans cette édition entourés de frises gravées sur bois. Page suivante cotée $A i j$, même avertissement au lecteur. Seulement, en haut la frise sur bois de l'édition de 1588 est remplacée ici par un petit êcusson aux armes de France, surmonté d'une couronne Royale, et deux anges ailés, s'appuyant de chaque côté sur cet écusson. A droite et à gauche le motif se termine par une corne d'abondance. Verso, le portrait de la Reine. Aiij, dédicace à la Reine, verso. Aiiij, sonnet aux dames et damoiselles, verso. Puis commencent les broderies imprimées seulement au recto des pages. 36 planches dans cette première partie. Bib. Nationale.

1891-Vinciolo, 3rd Edition, No. 5, Parts 1 and 2-The same title as that of 1595 —differing only in date. Privilege for six years, "donné à Mantes, le 3 Juillet 1593." At the foot, "De l'Imprimerie de David le Clere au Petit Corbeil 1606." The 1st part has 32 ff. and 36 plates; 32 "Ouvrages de poinct couppé," and 4 stomachers. The 2 nd part 46 plates, same as those of 1588, only four less. On the last page the escutcheon of France and Navarre.

1892-Vinciolo, F.-Les singuliers et nouveaux Pourtraicts du seigneur Federic de Vinciolo, Venitien pour toutes sortes d'ouurages de lingerie . . . de rechef et pour la troisième fois augmentez outre le reseau premier et le point couppé et lacis, de plusieurs beaux et differens pourtraits de reseau, de point compté ... Paris, Pour Iean Le Clerc, 1612. 2 parties en 1 volume in $4^{\circ}$. Vente de M. le baron Pichon, Paris, Potier, 1869. Cat. of Weyhe, N. Y. No. 20, 1918.

1893-Vinciolo Seig. Frederic.-Les singuliers et nouveaux pourtraicts pour toutes sortes d'ouvrages de lingerie. A Thurin par Eleazaro Thomysi. 1658. Seconde édition avec la date de Thurin. Elle est la reproduction exacte de celle de 1589, aussi de Thurin. Quant aux planches elles sont les mêmes sauf quelques différences insignifiantes. In- $8^{\circ}$ oblong, divisé en deux parties. La première est de 44 feuillets contenant 39 planches non compris le Frontispice, et les portraits de Henri III et de sa femme. La seconde de 42 feuillets et de 36 planches. Nous croyons avec M. Alvin dit le marquis d'Adda que ces dates et le nom de l'imprimeur sont faux, et nous ajouterons qu'il est peu probable qu'un éditeur puisse de son vivant rééditer un ouvrage à 69 ans de distance. Catalogue Cicognara. 
1894 -Vinciolo, Federico-I singolari e nuovi disegni per lavori di biancheria. Under direction of Elisa Ricci. Bergamo, 1909.

1895-Viti de Marco, Marchesa Etta de-Pescocostanzo and its Lace-Makers. The Monthly Review, March 1904, London.

1896-Voshage, Adèle-Das Spitzenklöppeln, 2d edition. Leipzig, Eng. Twietmeyer (1894).

1897-V. T., Alcide-Dentelle du Havre (Résponse). Intermédiare des Chercheurs et Curieux, 1896, Paris.

1898-Vosterman, Guillaume-Ce est ung tractat de la noble art de l'eguille ascanoir ouuraiges despaine et toz traictz moult proffitable po lingeries et ouuriers de culetes, a ussy pour tyseurs de damas, Teincturiers et Brodeurs contenat cent et trente huyct Figures perfectement mises. Ainsi q non point les subtilz engins. Mais les jeunes filles et enfans en peuuent en brief acquerre grand'science et estre parfaictz en brief temps. Imprimé à Anvers par moy Guillaume Vosterman. Sans date. Un rectangle circonscrit lui-même par une composition où l'on voit en haut un chapiteau, posant sur deux montants en forme de colonnes surmontés chacun d'une petite figure de femme brodant à l'aiguille. Au milieu du chapiteau un homme travaillant à un petit méticr qu'il tient des deux mains appuyé sur son genou. En bas de la composition et au-dessous du rectangle dans lequel est inscrit le titre, deux femmes travaillant, l'une à droite à un métier de basse lisse, l'autre à gauche à un petit métier posé sur une table devant elle. Elle est assise sur une chaise de trois quart à droite. Dans les ronds qui sont au milieu des colonnes, on voit à gauche un écusson avec les couronnes des trois Rois, à droite un autre écusson où figure un oiseau. Au verso de cette page une gravure sur bois. Dans un intérieur, un homme son bonnet sur la tête, son épée au côté, est assis sur un banc de bois à large dossier. De face la tête légèrement penchée de trois quart à gauche, il a une main posée sur l'épaule et la poitrine d'une jeune femme assise à gauche à ses pieds. Celle-ci tient d'une main, une paire de ciseaux, de l'autre une broderie, qu'elle appuie sur ses genoux croisés. A gauche une vaste corbeille, et au fond une baie ouverte divisée en deux par une colonne. Au-dessous de cet alphabet on lit: She prent tot Antwerpen in die Camerstrate in den gulden cen horanbp. imp. Willem Vosterman. Ce livre est une copie du Pierre Quentel de 1527. Voir ci-dessous. C'est également le même livre sous un titre différent que celui décrit ci-dessus. Alphabet quadrillé. Alphabet sur fond blanc. Bib. Nat.

1899-Vostermans, Villm-A new Traatys as cocernynge the excellency of the nedle Worcke, spanisshe stitche and we avynge in the frame very necessary to all Theym, wiche desyre The perfect Knowledge of seamstry, quiltinge and brodry worke coteinynge an. CXXX. VIIJ figures or tables so playnli made et lettout in portrature. The whiche is difficyll natolp for craftz mebut also gentleweme ioge damosels That therin may obtayne greate conynge delyte and pleasure, These boekes be to sell at Andwarp in the golden Unycorne at Villm Vorstermans. Ce titre est coté $a$. Il est inscrit dans une composition absolument pareille à celle qui entoure le titre du volume intitulé. "Ce est un tractat de la noble art de l'équille." Le 
verso est également la reproduction du verso de ce susdit livre. Che prent tot Antwerpen in die Camerstrate in den gulden cen horanbp. imp. Willem Vosterman. 8vo, 24 ff., 46 plates. Title in Gothic letters, with figures. P. 1, dorso: Woodeut of a woman at work and a man sitting by her side. Patterns mediæval, small black squares, arabesques, etc. Vorsterman worked from 1514 to 1542 . Silvestre, Marques Typographiques des imprimeurs en France, depuis, 1470. Bibliothèque de l'Arsenal.

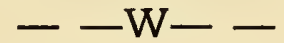

1900-Waite, M.-Knitting Cards for Standards III and IV, Leeds 1891. B. M. 1901-Walford, L. B.-Lace Camisole. Century. V. 61, pp. 178-186, Dec, 1900. 1902-Walter, M. L.-Lessons in Buttonhole Making and Fancy Stitching. Ladies Home Journal. V. 20, p. 51, February, 1903.

1903-Warée, A.-Les Dentelles vraies. Exposition internationale de Chicago, 1893.

1904 -Waring, J. B.-Masterpieces of Industrial Art at the International Exliibition, 1862 (Belgian lace, vol. II., plate 109.) 3 vols. fol. Lond., 1863. S. K. M.

1905-Warleigh, H. F. R. A.-Full Directions for Knitting Edgings. 72 pages. London, 1894. B. M.

1906-Washable Crocheted Pendants. Harpers Bazaar. V. 44, p. 729, December, 1910.

Wasmutlı Reproductions. See Nos. 269, 602, 811.

1907-Watreman-Fardle Facions, 1555

1908-Webb, R., of Nottingham-A Note on Nottingham Lace. The Artist, April, 1901, London.

1909-Weigel--Wol-andstandige und Nützen-bringende Frauen. zimmer Ergœtzüng. Par. a. Bur. Nurnberg. Weigel. s.d. In-folio oblong. 50 planches de broderies en taille douce, dont la majeure partie sont grandes et repliées. Vente Yemenitz, 1867.

1910-Weigel, J. Chr.--Zierlich webende Minerva, oder neu erfundenes Kunstund Bild-Buch der Weber- und Zeichner-Arbeit, worinnen treue Anweisung geschieht, wie man kunslich wirken und schöne Arbeit verfertigen soll, von der vierschäfftigen en, bis auf zwey und dreissig-schafftige. Nurnberg (Johann Christoph Weigel). No date. 40 plates in sheets. S. K. M.

1911-Weigel, Johann Christoph-Zierlich webende Minerva oder neu-erfundenes Kunst und Bild Buch, der Weber und ziechner arbeit Worinnen treue anweisung geschicht wie man Kunstlich wircken und schone arbeit verfertigen soll von der vier schafftigen an bis auf zwey und dreissig: schafflige, ingleichen, doppel. Colnische fuss zeppiche, gesteint oder geschacht auch gebrochene und hin und wieder arbeit von allerhand schonen zugen und bildern nach lauterauserlesenen und wol probirten strïcken zu machen, Welchem noch bey gefüger. Ein aus führlich und deutlicher Bericht von Klein und gross gezogener arbeit so wol niederlandisch als auf schlecht nicht weniger allerhand schone mit galanten blum, werck oder andern Figuren prangende Teppiche nach den patronen oder Formen auf 
Teppiche und damast zu verfertigen der gleichen noch nie anslicht gekommen heraus gegeben von Einem, Liebhaber dieser Wissenschafft der seinem Rechsten zu diener beflissen. Nürberg Verlegts Johann Christoph Weigel Kunst handler. 5 pages indiquant la manière de faire les points. Cet exemplaire paraît incomplet.

1912-Weitz-Spitzen Motive. Plauen, C. Stoll.

1913-Weldon's Practical Carrickmacross Lace--Book 200, Vol. 17, 39 designs. (Collection of Kursheedt Manufacturing Co., N. Y.)

1914 -Werder, L. Otto-Types modernes pour Dentelles-Broderies, Serie 1-2. Plauen, C. Stoll, 1898.

1915-Werder-Dentelles nouvelles, 2 serien a 20 Tafeln. Plauen, C. Stoll. 1898. 1916-Werder, at Saint Gall-Dentelle. L'Art décoratif, December, 1899, Paris.

1917-Werner, M.-Teil eines Faechers. Irische Spitze. Kunstgewerbeblatt, August, 1890, Leipzig.

1918-Wertman, A. O. L.-Relief Crochet. Woman's Home Companion. V. 31, p. 41, February, 1904.

1919-Westlake, N. H. J.-Souvenir of the exhibition of Christian art at Mechlin, Sept., 1864. (Plates 5 and 6. Needlework.) 4to. London and Oxford, 1866 . S. K. M.

1920-Whishaw, Bernard-Illustrated Descriptive Account of the Museum of Andalucian Pottery and Lace, antique and modern. London, Smith, Elder \& Co., 1913.

1921-Whishaw, Bernard \& Ellen-Puntas and Passementerie. Connoisseur. V. 24, pp. 82-88.

1922-Whishaw, B. and Ellen M.-Punto de Aguja and Point d'Espagne. Connoisseur. V. 26, pp. 51-55, January, 1910 and following.

1923-Whitby, J. E.-A Beautiful Specimen of Lace. (Grande pièce à personnages de la collection Montefiore au Musée du Cinquantenaire à Bruxelles). The Ladies Field, June, 1904, London.

1924 -Wiener Spitzenausstellung, 1906, Die-Herausgegeben von k.k. Osterr. Museum fur Kunst und Industrie in Wien. 60 plates, folio. Leipzig, 1906. Einleitung von M. Dreger "Überlick über die Entwicklungsgeschichte der Spitze."

1925-Wilkinson, M. E.-Art Needlework and Design. Point Lace. London, Scott, Greenwood \& Son, 1907.

1926-Wilkinson, M.-Table Laces. Harper's Bazaar. V. 37, pp. 1209-1211, December, 1903.

1927-Wilson, L. B.-Buttonhole Stitch as Applied to Venetian Ladder Work. Ladies Home Journal. V. 24, p. 43, February, 1907.

1928-Wilson, L. B.-Five Good Doily Designs. Ladies Home Journal. V. 20, p. 31, August, 1903.

1929-Wilson, L. B.-Good Eyelet Embroidery. Ladies Home Journal. V. 26, p. 37, April, 1909.

1930-Wilson, L. B.-Italian Cut-work. Harper's Bazaar. V. 38, pp. 90-92, January, 1904.

1931-Wilson, L. B.-New Australian Crochet. Ladies Home Journal. V. 28, p. 53, October, 1911. 
1932-Wilson, L. B.-New Designs in Filet Crochet. Ladies Home Journal. V. 28, p. 24, August, 1911.

1933-Wilson, L. B.-New Irish Princess Lace. Ladies Home Journal. V. 26, p. 51, January, 1909.

1934 -Wilson, L. B.-Roman Cut-work. Ladies Home Journal. V. 24, p. 55, January, 1907.

1935-Wilson, L. B.-Venetian Crochet. Ladies Home Journal. V. 29, p. 41. February, 1912.

1936-Wilton, Countess of-The Art of Needlework from the earliest ages. 8vo. London. 1844. S. K. M.

1937-Winser, Margaret-Elementary Course in Lace-making. 1913.

1938-Wintin, J.-Lace Trade Calculator. London, 1897, etc. 8vo. B. M.

1939-Wolf, J.-Translation of Vinciolo by J. Wolf. New and singular patternes and workes of Linnen. Serving for patternes to make all sortes of Lace edging and Cut-workes. Newly invented for the profite and contentment of Ladies, Gentlewomen, and others that are desirous of this Arte. London: Imprinted by J. Wolfe and Edward White, 1591. Owned in 1919 by Mr. W. A. White, N. Y.

1940-Wonderful Laces, Mrs. Leland Stanford's. Ladies Home Journal. V. 22, pp. 24-25, July, 1905.

1941-Woodward, M. E.-A Text Book on Cluny and Torchon Laces. For sale by Sara Hadley.

1942-Woodward, P.-Handbook to the law of copyright in registered Designs, with special application to class 9, lace. 92 pages. Nottingham, 1891. B. M.

1943-Wright, Agnes F.-Lace in Interior Decorations. House and Garden. V. 32, pp. 50-51, 68, November, 1917.

1944 -Wyatt, Sir M. D.-Industrial Arts of the Nineteenth Century, at the Great Exhibition, 1851. (Lace and Embroidery.) 2 vols. fol. London, 1851-53. S. K. M.

\section{- - - -}

1945-Yoni-Beaugourdon-Carton pour dentelle. L'Art décoratif, March, 1902, Paris.

1946-Yorke, Harry W., at Nottingham-Projets de rideaux de dentelles. Art appliqué, 1 re année, Paris.

1947-Youghal Lace. International Studio. V. 20, pp. 212-215, September, 1903.

1948-Youmans, E. A.-Making of Lace. Popular Science Monthly. V. 8, p. 521.

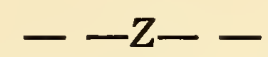

1949-Ziegler d'Ulm, Marx-Weber Kunst und bild Buch. (Livre de point coupé et dessins de broderie par Marx Ziegler d'Ulm). Augsbourg. Koppmeyer, 1677. In $-4^{\circ}$ oblong. Planches gravées sur bois. Vente Yemenitz, 1867. 1949a-Zoppino, Niccolo-Convivo de le belle donne. With 22 leaves of designs. Venice, 1531. 
1950-Zoppino, Nicolo-Convivio delle belle donne, dove con li nuovi raccami ... Finisce il convivio delle ... Nuovamente stampato in Vinegia, per Nicolo d'Aristotle, detto Zopino del mesede d'Agosto MDXXXII. In- $4^{\circ}$. Sur le titre, marque d'imprimerie du Zoppino. (Saint-Nicholas.) Epître de Zoppino. Alle gentille donne ... Fin de l'épitre, au verso. Ici commencent les broderies. 24 feuillets. Exemplaire chez le peintre, Chevalier Bertini à Milan. Oxford, Bib. Bodleian.

1951-Zoppino, Nicolo-Esemplario di lavori: dove le tenere fanciulle \& altre donne nobile potranno facilment imparare id modo \& ordine di lavorare, cusire, racamare, \& finalmente far tutte quelle gentillezze \& lodevoli opere, le quali pò fare una donna virtuosa con laco in mano, con li suoi compasse \& misure. Vinezia, per Nicolo D'Aristotile detto Zoppino MDXXIX. 8vo. 46 plates. The $\mathrm{Cav}^{\mathrm{re}}$ Merli quotes another edition, date 1530 , in the possession of the Avvocate Francesco Pianesani, and another he believes of 1529. Paris, Bib. de l'Arsenal. 11,952.

1952-Zoppino, Nicolo-Esemplario di lavori; doue le tenere fanciulle \& altre done nobile potranno facilmete imparare il modo et ordine di lauorare, cusire, raccamare, et finalmente far tutte quelle gentilezze et lodeuili opere, le quali po fare una donna virtuosa co laco in mano, con li suoi compasse et misure. A la fin, au verso du dernier feuillet: Finisce il libro intitulato, Esemplaro de lauori. Stampato in Vinegia per Nicolo d'Aristotile, detto Zopino, MDXXIX (1529), del mese di Agosto. Petit in $4^{\circ}$. Ce volume est composé d'un titre imprimé en rouge et noir dans un frontispice gravé sur bois, d'un feuillet contenant une épître de Nicolo Zoppino, all. virtuosi et gentillissimi lettori ... et de 26 feuillets contenant les modèles de broderie imprimés au recto et au verso. Vente Libri. Bibliothèque Boldeienne d'Oxford.

1953-Zoppino, N.-Essemplario di lauoi doue le tenere fanciulle \& altre donne nobile potranno facilmente imparare il modo \& ordine di lauorare e cusire: raccammare: finalmente far tutte quelle gentilezze et lodeuili opere: lequali po fare una donna uirtuosa con laco in mano: con li suoi compassi \& misure. [At the end] Finnisse el libro intitulato Exemplario di lauori. Stampato in Vinegia per Nicolo d' Aristotile detto Zoppino. MDXXX. $4^{\circ}$. Cut. 51 leaves.

1954-Zoppino, Nicolo-Esemplario di lauori doue le teners fanciulle. 1530. Ongania Reproduction, 1878.

1955-Zoppino, Nicolo-Gli vniversali di tutti e bei dissegni, Raccami et moderni lauori quali un bello inteletto humano un pellegrino ingegno si de huomo come di Donne (pro). Con l'aco in mano, in questa nostra etade lo deuolmente, Nuovamente stampato et muti in luce, MDXXXII (1532). Ce titre est dans un entourage formé de petits bois rectangulaires. En haut aux angles une tête de femme. Celle de drooite de profil à gauche, celle de gauche de profil à droite. En bas deux terms formant cariatides. Page suivante au recto, dédicace: Alle virtuosi giovanni et gentillissime fanciulle di Raccami et lauori Moderni studiosissime Nicolas Zoppino. s. d. $64 \mathrm{ff}$. avec planches de broderies et dentelles gravées sur bois. Au verso de la derniére page, un petit bois représentant un évêque assis, sa crosse à 
la main. Une femme à gauche à genoux lui offre une corbeille de fruits. Au-dessons: Pinisce gli universali di Tutti e bei dissegni. Raccami et moderni lauorni stampati per Nicolo d'Artistotile detto Zoppino. Del mese di Agosto. Vente Piot, 1891.

1956-Zoppino, Nicolo._Gli vniversali de i belli Recami antichi, e moderni, ne iquali un pellegrino ingegno si di huomo come di donna, potra in quest nostra eta con l'ago uertuosamente esercitarsi. Non anchora da alcuni altri dati in luce, MDXXXVII (1537). A la fin: Finisce gli vniversali de i belli Recami antichi e moderni stampati per Nicolo d'Aristotile detto Zoppino del Mese di Marzo, MDXXXVII (1537). In-4 ${ }^{\circ}$. Il se compose de 20 or $25 \mathrm{ff}$. non chiffrés et contient 37 grandes figures sur bois de dentelles, travaux à l'aiguille et autres compositions avec figures d'hommes, de femmes et d'animaux. Le titre est encadré par une large bordure historiée et sur le sur le verso se trouve une épitre du Zoppino: A gli veruosi Giouanini et gentilissime Fanciulle. Vente Pirovano, Rome, 1901. Milan, Cavaliere Bertini.

1957-Zoppino, N.-Gli universali de i belli Recami antichi, et moderni; etc. (49 pp. of lace designs and titles.) Venice, 1537. (Facsimile reprint. Ongania, Venice, 1876). S. K. M. Metro. Mus.

1958-Zoppino, N.-Gli Universali de i belli Recami antichi e moderni ne i quali un pellegrino ingegno, si di huomo come di donna, potra in questra nostra eta con l'ago uertuosamente esercitar si non anchora da alcuni altri dati in luce. 49 designs for lace work. 1537, facsimile reprint Venice, 1877. Folio.

Zoppino.-See Aristotile, Nicolo d'. 
? 


\section{INDEX OF BOBBIN LACE GROUNDS AND FILLINGS}

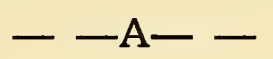

PAGE

Abruzzian Lescatelle-Line C, Col. 16........................ 131

Abruzzian Mezza Cambruccia-Line A, Col. 16. ................. 90

Abruzzian or Pescolane Cross Pattern-Line B, Col. 16 . . . . . . . . . . . . 110

Abruzzian Piscitelli-Line D, Col. 16. . . . . . . . . . . . . . . . . . . . . 150

Abruzzian "Point and Flat"-Line H, Col. $16 \ldots \ldots \ldots \ldots \ldots \ldots \ldots \ldots$

Alost, Square-meshed Valenciennes of Bruges, Ypres and (braided 4 or $41 / 2$

times)-Line D, Col. 7. . . . . . . . . . . . . . . . . . . 140

Alost, Square-meshed Valenciennes of Ypres and (braided 5 or $51 / 2$ times) -

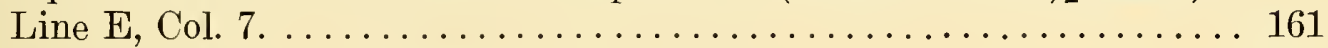

Antwerp; Potten Kant; Flemish-Line F, Col. 4................. 180

Armelle, Thin Cluny Petals, Leaves, Armeletta, Grains, Seeds, Wheat Ears,

Paddles-Line C, Col. 15. .......................... 130

Armeletta, Thin Cluny Petals, Leaves, Armelle, Grains, Seeds, Wheat Ears,

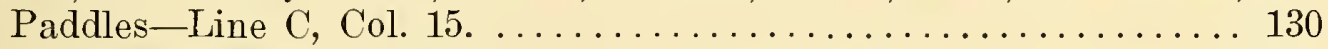

Araignées Carrées en Tulle Double, Les-Line H, Col. 2 . . . . . . . . . . . . 220

Araignées Rondes, Les; Round Spiders in Twice-twisted Hole Ground-

Line G, Col. 2. . . . . . . . . . . . . . . . . . . . . . . . . . . 199

Arras; Tulle Ground; Lille; Filoche; Fond Clair; Fond Simple; Brabant;

Trolly Net; Töndern; Marche; Point de Hollande; Dutsche Slag-

Line F, Col. 3. .............................. 179

Arras: see also Réseau Simple-Line G, Col. 6. . . . . . . . . . . . . . . 204

\section{$--\mathrm{B}--$}

Bailleul, Round-meshed Valenciennes of Harlebeke, Bruges, Courtrai,

(braided 4 times) (often twice, Dentelle épiscopale)-Line G, Col. 11. 209

Bar, Hexagonal Devonshire Filling-Line B, Col. 9 . . . . . . . . . . . . . 102

Bars and Cutworks, "Bohemian Edged" Devonshire-Line D, Col. 10..... 143

Bars and Cutworks, Devonshire Winkie Pin-Line C, Col. 10.......... 124

Binche, Virgin Ground, Pin Check, Pink Check, Ornamental Ground, Cinq

Trous, Point Carré-tLine A, Col. 2.................. 71

Binche Mode-Line E, Col. 10............................ 164

Binche Spiders, Round, Open-eyed Brabant, Oeil de Perdrix, Réseau Rosacé,

Point de Flandre-Line G, Col. 4 ................... 201

"Bohemian Edged"' Devonshire Bars and Cutworks-Line D, Col. 10. . . . 143

Bohemian Ground-Line G, Col. 5 ......................... 203 
Brabant, Arras, Tulle Ground, Lille, Filoche, Fond Clair, Fond Simple, Trolly Net, Töndern, Marche, Point de Hollande, Dutsche Slag-Line F, Col. 3 .

Brabant, Binche Spiders, Round, Open-eyed, Oeil de Perdrix, Réseau Rosacé, Point de Flandre-Line G, Col. 4

Brick, Devonshire, Mignonnette-Line C, Col. 8.

Brides, Fond de-Line H, Col. 221

Bruges, Round-meshed Valenciennes of Harlebeke, Bailleul, Courtrai (braided 4 times) (often twice, Dentelle épiscopale)_Line G, Col. 11. 209

Bruges, Square-meshed Valenciennes of Alost, Ypres and (braided 4 or $41 / 2$ times)-Line D, Col. 7.

Bruges (?), Tulle (2 twists)_Line E, Col. 3.

Brussels; Droschel; Vrai Réseau (fait sans épingles); Drochel-Line B, Col. 3.

Brussels; Droschel; Vrai Réseau; Point d'Angleterre Net; Drochel-Line C, Col. 3 .

Buckingham: see also Réseau Simple-Line G, Col. 6. ................. 204

Buratto; Filet-Line E, Col. 5 .

Byzantine, Medici, Florentine Knots-Line H, Col. 13. 234

Chantilly; Star Mesh; Double Ground, Point de Paris; Point de Six; Eternelle; Point Double; Trenne; Fond Chant; Grammont; Engelsche Grond-Line A, Col. 5.

Cinq Trous; Binche; Virgin Ground; Pin Check; Pink Check; Ornamental Ground; Point Carré-Line A, Col. 2.

Thin Petals, Leaves, Armelle, Armeletta, Grains, Seeds, Wheat

Ears, Paddles-Line C, Col. 15. ........................ 130

Courtrai, Round-meshed Valenciennes of Bailleul, Harlebeke, Bruges, (braided 4 times) (often twice, Dentelle épiscopale)_Line G, Col. 11. 209 Courtrai, Square-meshed Valenciennes of Menin and (braided 3 or $31 / 2$ times)-Line C, Col. 7. ........................... 121

Cross Pattern, Abruzzian or Pescolane-Line B, Col. 16. ........... 110

Cushion, Devonshire-Line B, Col. 8........................ 101

Cutwork Net, Devonshire-Line G, Col. 8. .................... 206

Cutworks, "Bolıemian Edged" Devonshire Bars and-Line D, Col. 10. .... 143

Cutworks, Devonshire Winkie Pin Bars and-Line C, Col. 10. .......... 124

Cutworks, Triangular, Fan-shaped Points d'Esprits or-Line A, Col. 15...

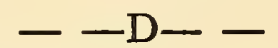

Demi-Marguerites-Line F, Col. 15

Demi-Point; Net Stitch, Lattice Ground, Toilé Ouverte, Point Réseau-Line A, Col. 1.

Dentelle épiscopale; Round-meshed Valenciennes of Harlebeke, Bruges,

Bailleul, Courtrai (braided 4 times) (often twice, Dentelle épiscopale)

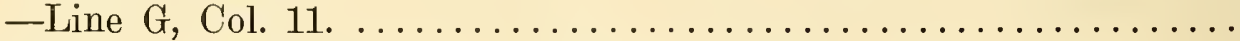

Devonshire Bars and Cutworks, "Bohemian Edged"-Line D, Col. 10. ... 143 
Devonshire Brick; Mignonnette-Line C, Col. 8. . . . . . . . . . . . . . . . 122

Devonshire Cushion-Line B, Col. 8. . . . . . . . . . . . . . . . . . . . . 101

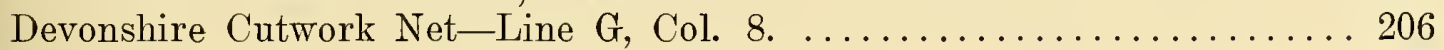

Devonshire Diamond Filling-Line A, Col. 10. ................ 82

Devonshire Double Ground Pin-Line C, Col. 9. ................. 123

Devonshire Four Pearl Filling-Line A, Col. 9. ................ 80

Devonshire Hexagonal Bar Filling-Line B, Col. 9. . . . . . . . . . . . . . 102

Devonshire Honeycomb Filling-Line E, Col. 9. . . . . . . . . . . . . 163

Devonshire Mignonnette; Devonshire Brick-Line C, Col. 8. . . . . . . . . 122

Devonshire Pin Filling-Line A, Col. $8 \ldots \ldots \ldots \ldots \ldots \ldots \ldots \ldots \ldots \ldots \ldots$

Devonshire Point d'Esprit Net-Line H, Col. 8. .............. 227

Devonshire Second Swing Filling-Line E, Col. $8 \ldots \ldots \ldots \ldots \ldots \ldots \ldots \ldots$

Devonshire Swing Filling; Spot Stitch-Line F, Col. 8. ............. 184

Devonshire Taunton-Line D, Col. $8 \ldots \ldots \ldots \ldots \ldots \ldots \ldots \ldots \ldots \ldots \ldots$

Devonshire Toad-in-the-Hole--Line F, Col. 10. .................. 187

Devonshire Wall Filling-_Line G, Col. 10. .................... 208

Devonshire Winkie Pin Bars and Cutworks-Line C, Col. 10. . . . . . . . . . 124

Devonshire Wire Ground-Line G, Col. 9. ................... 207

Diamond Filling, Devonshire-Line A, Col. 10............... 82

Dice Holes; Slanting Hole-Line B, Col. 12. .................... 105

Dieppe Ground; Twice-twisted Hole Ground; Hole Stitch with Twicetwisted Thread; Löcherschlag mit Zweimal gedrehten Fäden-Line

H, Col. 1. .................................. 219

Dieppe, Petits Pois de-Line E, Col. 2.................... 156

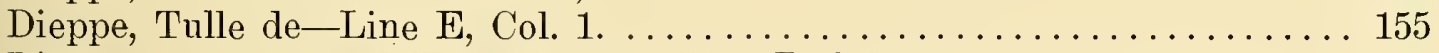

Dieppe Three-Thread Valenciennes--Line F, Col. 17. .............. 196

Double Ground; Star Mesh; Chantilly; Point de Paris; Point de Six; Eternelle; Point Double; Trenne; Fond Chant; Grammont; Engelsche Grond-Line A, Col. 5.

Double Ground Pin, Devonshire-Line C, Col. 9. ................. 123

Double Picots-Line D, Col. 15. ............................. 149

Droschel; Brussels; Vrai Réseau (fait sans épingles); Drochel-Line B,

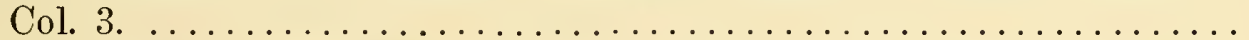

Droschel; Brussels; Vrai Réseau; Point d'Angleterre Net; Drochel-Line C, Col. 3. ................................. 117

Droschel de Bruxelles; Drochel-Line D, Col. 3. .................. 136

$\mathrm{Du}$ Puy Point de Paris Variation or Lock Stitch; Torchon Mode-Line H,

Col. 6. ....................................... 225

Du Puy, Tulle-Line B, Col. 1. . . . . . . . . . . . . . . . . . . . . . . . 94

Dutsche Slag; Arras; Tulle Ground; Lille; Filoche; Fond Clair ; Fond Simple; Brabant; Trolly Net; Töndern; Marche; Point de Hollande-Line F, Col. 3.

\section{$--\mathrm{E}--$}

Einfacher Gittergrund; Plain Lattice Ground; Filet-Line D, Col. 5. .... 138 Einfacher Löcherschlag; Plain Hole Ground; Torchon; Réseau StitchLine C, Col. 1. 
Eisgrond, Malines, Mechlin, Fond de Glace, Ijsgrond-Line A, Col. 3.

Engelsche Grond; Chantilly; Star Mesh; Double Ground; Point de Paris; Point de Six; Eternelle; Point Double; Trenne; Fond Chant; Gram-

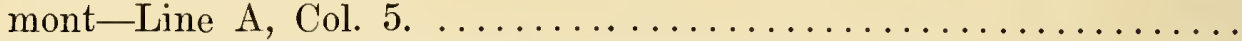
Épiscopale, Dentelle; Round-meshed Valenciennes of Bailleul, Harlebeke, Bruges, Courtrai (braided 4 times) (often twice, Dentelle épiscopale)

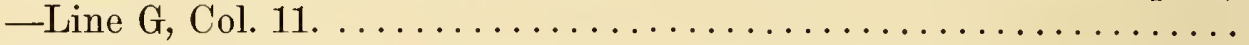

Eternelle; Chantilly; Star Mesh; Double Ground; Point de Paris ; Point de

Six; Point Double; Trenne; Fond Chant; Grammont; Engelsche Grond-Line A, Col. 5. ....................... 75 Eyeless Spiders; Fond de Neige-Line H, Col. 4. ................ 222

$$
-\mathrm{F}--
$$

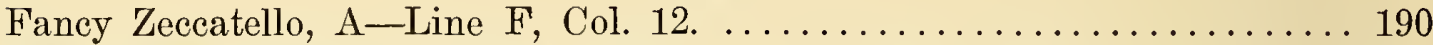

Fan-shaped, Triangular Points d'Esprits or Cutworks-Line A, Col. 15... 89 Fat Maltese Petals, Leaves, Seeds, Grains, Wheat Ears, Paddles-Line B, Col. 15. . . .................................. 109

Filet, An Italian—with Toile Dots-Line D, Col. 14. . . . . . . . . . . . . . . . 148

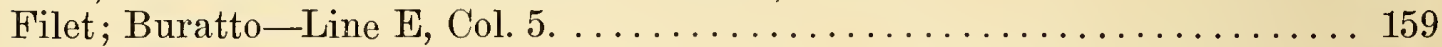

Filet; Plain Lattice Ground; Einfacher Gittergrund-Line D, Col. 5 . . . . 138

Filet; Un Fond Hollandais-Line F, Col. 5. .................... 181

Filoche; Brabant; Arras; Tulle Ground; Lille; Fond Clair; Fond Simple; Trolly Net; Töndern; Marche; Point de Hollande; Dutsche SlagLine F, Col. $3 . \ldots \ldots \ldots \ldots \ldots \ldots \ldots \ldots \ldots \ldots \ldots \ldots \ldots \ldots \ldots$

Fish with Two Horizontal Bars-Line G, Col. 16. .............. 214

Five or Six Sided Milanese Mesh-Line H, Col. 11. .............. 231

Flemish; Potten Kant; Antwerp-Line F, Col 4. .................. 180

Flemish; Trolle Kant; Fond Armure, Spinnekop-Line D, Col. 2. . . . . . 135

Flemish Filling, A; Lille Mode, A-Line D, Col. 4. . . . . . . . . . . . 137

Flemish Filling-Line H, Col. 9. ........................ 229

Florentine, Byzantine, Medici Knots-Line H, Col. 13. ............... 234

Fond Armure; Flemish; Trolle Kant, Spinnekop-Line D, Col. 2. . . . . . 135

Fond Chant; Chantilly; Star Mesh; Double Ground; Point de Paris; Point de Six; Eternelle; Point Double; Trenne; Grammont; Engelsche

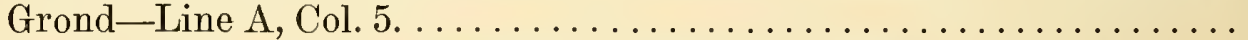

Fond Chant (Palliser) ; Point de Paris ; Fond Clair-Line C, Col. 11...... 125

Fond Clair; Point de Paris; Fond Chant (Palliser)-Line C, Col. 11. .... 125

Fond Clair; Arras; Tulle Ground; Lille; Filoche; Fond Simple; Brabant; Trolly Net; Töndern; Marche; Point de Hollande; Dutsche Slag-

Line F, Col. 3. ................................. 179

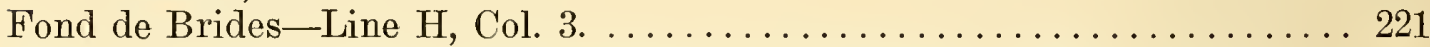

Fond de Glace; Malines; Mechlin; Ijsgrond, Eisgrond-Line A, Col. 3. . . . 73

Fond de la Vierge; Virgin Ground; Ornamental Ground; Point Carré-Line

B, Col. 2. .................................. 95

Fond dé Milan; Old Buckingham-Line C, Col. 5. ................. 119

Fond de Neige; Eyeless Spiders-Line H, Col. 4. . . . . . . . . . . . . 222

Fond de Neige; Punto di Néve--Line A, Col. 18. ............... 93 
Fond Hollandais, Un; Filet-Line F, Col. 5.

Fond Simple; Arras; Tulle Ground; Lille; Filoche; Fond Clair; Brabant;

Trolly Net; Töndern; Marche; Point de Hollande; Dutsche Slag-

Line F, Col. 3.

Four Pearl Filling, Devonshire--Line A, Col. 9.

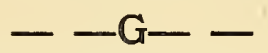

Gand, Square-meshed Valenciennes of Menin, Ghent or (braided 2 or $2 \frac{1}{2}$ times)-Line B, Col. 7. .......................... 100

Gekreuzter Gittergrund; Lattice Ground (3 twists)-Line B, Col. 5. ...... 98

Gelosia; Rose Ground; Scandinavian Ground; Point du Mariage; Tulle Double--Line C, Col. 4.

Genoese Grilled Six Leaved Marguerite-Line C, Col. 18. ............. 133

Genoese, or Reticello Mode-Line $\mathrm{H}$, Col. $5 \ldots \ldots \ldots \ldots \ldots \ldots \ldots \ldots . \ldots \ldots 24$

Genre Valenciennes; Tulle de Vienne-Line G, Col. 1. ................ 198

German or Russian Torchon-Line D, Col. 12. ................. 145

Ghent, Square-meshed Valenciennes of Menin, Gand or (braided 2 or $2 \frac{1}{2}$

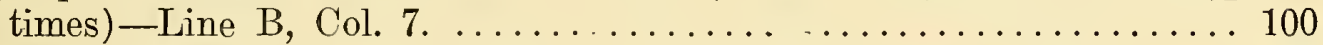

Einfacher Gittergrund; Plain Lattice Ground; Filet-Line D, Col 5. .... 138

Gekreuzter Gittergrund; Lattice Ground (3 twists)-Line B, Col. 5. ..... 98

Grains, Fảt Maltese Petals, Leaves, Seeds, Wheat Ears, Paddles-Line B,

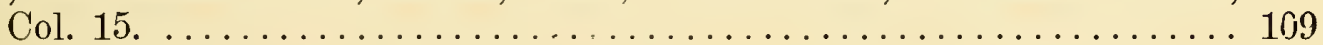

Grains, Thin Cluny Petals, Leaves, Armelle, Armeletta, Seeds, Wheat Ears, Paddles-Line C, Col. 15.

Grammont; Chantilly; Star Mesh; Double Ground; Point de Paris; Point de Six; Eternelle; Point Double; Trenne; Fond Chant; Engelsche Grond-Line A, Col. 5.

\section{$-\mathrm{H}--$}

Harlebeke, Round-meshed Valenciennes of Bruges, Bailleul, Courtrai, (braided 4 times) (often twice, Dentelle épiscopale)-Line G, Col. 11. 209 Hexagonal Bar Filling, Devonshire-Line B, Col. 9. . . . . . . . . . . . . 102 Hollandais, Un Fond, Filet-Line F, Col. 5. . . . . . . . . . . . . . . . . . . 181 Hole Ground, Plain, Torchon; Réseau Stitch; Einfacher Löcherschlag-

Line C, Col. 1. ................................ 114

Hole Ground, Twice-twisted, Dieppe Ground, Hole Stitch with Twice-twisted

Thread, Löcherschlag mit zweimal gedrehten Fäden-Line H, Col. 1.. 219

Hole Ground, Twisted, Tulle Double, Maglia di Spagna-Line D, Col. 1. . . . . 134

Holes, Dice; Slanting Hole-Line B, Col. 12. . . . . . . . . . . . . . . . . . . . 105

Hole, Slanting; Dice Holes-Line B, Col. 12. ................... 105

Hole Stitch with Twice-twisted Thread; Dieppe Ground; Twice-twisted Hole Ground; Löcherschlag mit zweimal gedrehten Fäden-Line H, Col. 1. ........................................ 219

Honeycomb Filling, Devonshire-Line E, Col. 9............... 163 Honfleur, Square-meshed Valenciennes of (braided 1 or $11 / 2$ times)-Line

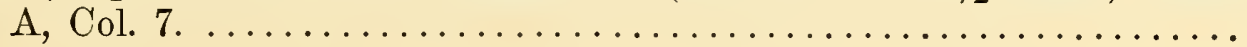




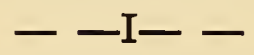

PAGE

Ijsgrond, Malines, Mechlin, Fond de Glace, Eisgrond-Line A, Col. 3...... 73

Irish Ground-Line G, Col. 13......................... 211

Italian Filet with Toile Dots, An-Line D, Col. 14. ............... 148

Italian Ground, A Spotted-Line B, Col. 14. .................. 107

Italian Open-eyed, Cable-like Spiders-Line F, Col. 14. . . . . . . . . . . . 193

Italian Six Legged Spiders with Ribbons-Line H, Col. 14. . . . . . . . . 235

Italian Spider with Eye, An-Line C, Col. 14. . . . . . . . . . . . . 129

Italian Spiders with Four Twisted Horizontal Bars-Line E, Col. 14. . . . . 171

Italian Spiders with Two Horizontal Bars-Line G, Col. 14. . . . . . . . . . 212

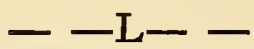

Lattice Ground; Demi-Point; Net Stitch; Toilé Ouverte; Point Réseau-

Line A, Col. 1. ......................... 70

Lattice Ground; Gekreuzter Gittergrund (3 twists)_Line B, Col. 5. . . . . . . 98

Lattice Ground, Plain; Einfacher Gittergrund; Filet-Line D, Col. 5. . . . . . 138

Leaves, Fat Maltese Petals, Seeds, Grains, Wheat Ears, Paddles-Line B,

Col. 15. . . . . . . . . . . . . . . . . . . . . . . . . . . . . . . . . . . 109

Leaves, Thin Cluny Petals, Armelle, Armeletta, Grains, Seeds, Wheat Ears,

Paddles-Line C, Col. 15. ......................... 130

Lescatelle, Abruzzian-Line C, Col. 16.................... 131

Lille; Arras; Tulle Ground; Filoche; Fond Clair; Fond Simple; Brabant;

Trolly Net; Töndern; Marche; Point de Hollande; Dutsche Slag-

Line $\mathrm{F}$, Col. $3 . \ldots \ldots \ldots \ldots \ldots \ldots \ldots \ldots \ldots \ldots \ldots \ldots \ldots \ldots \ldots$

Lille: see also Réseau Simple-Line G, Col. 6. .................. 204

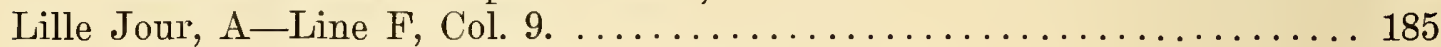

Lille Mode, A; Flemish Filling, A.-Line D, Col. 4. . . . . . . ..... 137

Löcherschlag-Line $\mathrm{F}$, Col. 6. . . . . . . . . . . . . . . . . . . . . . 182

Löcherschlag mit zweimal gedrehten Fäden; Dieppe Ground; Twice-twisted

Hole Ground; Hole Stitch with Twice-twisted Thread-Line H, Col. 1. 219

Lock Stitch or Du Puy Point de Paris Variation; Torchon Mode-Line H,

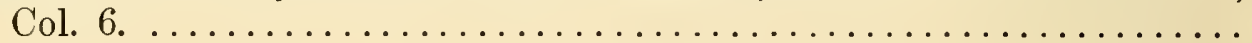

\section{$--\mathrm{M}--$}

Maglia di Spagna; Redina-Line F, Col. 1. . . . . . . . . . . . . . . . . 177

Maglia di Spagna; Twisted Hole Ground; Tulle Double-Line D, Col. 1.. . . . 134

Malines; Mechlin; Ijsgrond; Fond de Glace, Eisgrond-Line A, Col. 3. . . . 73

Maltese, Fat Petals, Leaves, Seeds, Grains, Theat Ears, Paddles-Line B,

Col. 15. . . . ............................... 109

Marche; Arras; Tulle Ground; Lille; Filoche; Fond Clair; Fond Simple;

Brabant; Trolly Net; Töndern, Point de Hollande; Dutsche Slag-

Line F. Col. 3. . . . . . . . . . . . . . . . . . . . . . . . . . . . . . 179

Marche: see also Réseau Simple-Line G, Col. 6. ................ 204

Marguerites à Centre de Toile-Line E, Col. 18. ................. 176

Marguerites à Six Pétales (one sided joint)-Line E, Col. 15. . . . . . . . . 173 
Marguerites Centres à Huit-Line G, Col. 15. . . . . . . . . . . . . . . 213

Marguerites, Demi- -Line F, Col. $15 . \ldots \ldots \ldots \ldots \ldots \ldots \ldots \ldots \ldots \ldots \ldots \ldots$

Marguerites, Genoese Grilled Six Leaved_Line C, Col. 18. ............ 133

Mechlin; Malines; Ijsgrond; Fond de Glace, Eisgrond-Line A, Col. 3. . . . . 73

Medici, Florentine, Byzantine Knots-Line H, Col. 13. ............. 234

Menin, Square-meshed Valenciennes of Courtrai and (braided 3 or $31 / 2$

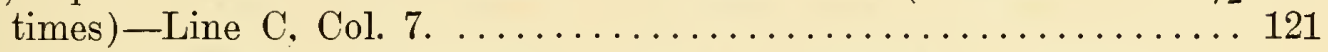

Menin, Square-meshed Valenciennes of Ghent or Gand and (braided 2 or $21 / 2$ times -Line B, Col. 7. . . . . . . . . . . . . . . . . . . 100

Mezza Cambruccia, Abruzzian-Line A, Col. 16................. 90

Mignonnette; Devonshire Brick-Line C, Col. 8. . . . . . . . . . . . . 122

Milanese Mesh, Five or Six-Sided-Line H, Col. 11. ................ 231

Mille Pattes, Les-Line F, Col. 2. ....................... 178

Moulinet-Line B, Col. 18. ............................ 112

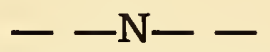

Net Stitch; Demi-Point; Lattice Ground Toilé Ouverte; Point Réseau-Line A, Col. 1.

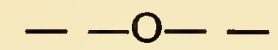

Oeil de Perdrix, Round, Open-eyed, Brabant, Binche Spiders, Réseau Rosacé; Point de Flandre-Line G, Col. 4. ................. 201

Old Buckingham; Fond de Milan-Line C, Col. 5. ................. 119

Open-eyed, Round, Brabant, Binche Spiders; Oeil de Perdrix; Réseau Rosacé; Point de Flandre-Line G, Col. 4. ................. 201 Ornamental Ground; Binche; Virgin Ground; Pin Check; Pink Check; Cinq Trous; Point Carré-Line A, Col. 2. ................ Ornamental Ground; Virgin Ground; Fond de la Vierge; Point Carré-

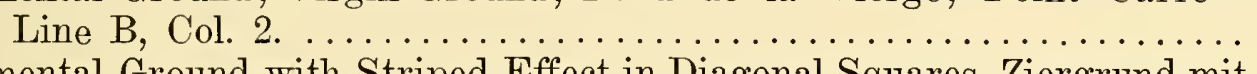

Ornamental Ground with Striped Effect in Diagonal Squares, Ziergrund mit Streifen-Musterung in Karo-Einteilung-Line D, Col. 6. . ........ 139 Ornamental Ground with Zigzag Diagonal Stripes; Ziergrund mit StriefenMusterung in Zacken-Einteilung-Line E, Col. 6. ........... 160

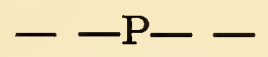

Paddles, Fat Maltese Petals, Leaves, Seeds, Grains, Wheat Ears-Line B, Col. 15. ...................................... 109

Paddles, Thin Cluny Petals, Leaves, Armelle, Armeletta, Grains, Seeds, Wheat Ears-Line C, Col. 15. ....................... 130

Pescolane or Abruzzian Cross Pattern-Line B, Col. 16. ............... 110

Petals, Fat Maltese Leaves, Seeds, Grains, Wheat Ears, Paddles-Line B, Col. 15.

Petals, Thin Cluny Leaves, Armelle, Armeletta, Grains, Seeds, Wheat Ears, Paddles-Line C, Col. 15. 
Petits Pois de Dieppe-Line E, Col. 2.................... 156

Picots, Double-Line D, Col. 15. ............................ 149

Picots, Point de Tresse with Knotted-Line E, Col. 13. ............... 169

Picots, Point de Tresse with Plain-in Side Joints-Line C, Col. 13. . . . . . . 128

Picots, Point de Tresse with Plain, Side-Line D, Col. 13. ............ 147

Picots, Point de Tresse with Plain-inLower Joints-Line B, Col. 13. .... 106

Picots, Valenciennes-Line F, Col. 13. ...................... 192

Pin Check; Binche; Virgin Ground; Pink Check; Ornamental Ground, Cinq Trous; Point Carré-Line A, Col. 2. ................. 71

Pin Filling, Devonshire-Line A, Col. 8. .................. 79

Pink Check; Binche; Virgin Ground; Pin Check; Ornamental Ground; Cinq Trous; Point Carré-Line A, Col. 2. .................. 71

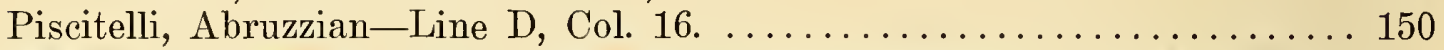

Plain Hole Ground; Torchon; Réseau Stitch; Einfacher Löcherschlag-Line C, Col. 1. ................................ 114

Plain Lattice Ground; Filet; Einfacher Gittergrund-Line D, Col. 5. .... 138

Plain Side Picots, Point de Tresse with-Line D, Col. 13. ............ 147

Plain Torchon Spiders-Line E, Col. 4........................ 158

"Point à la Vierge" nach Slavischer Art; Slavonian Style Virgin Point-

Line C, Col. 6. .............................. 120

"Point and Flat," Abruzzian-Line H, Col. 16. ................. 238

Point Carré, Binche; Virgin Ground; Pin Check; Pink Check, Ornamental

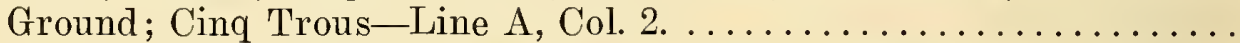

Point Carré; Virgin Ground; Ornamental Ground; Fond de la Vierge-

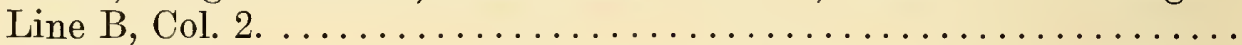

Point d'Angleterre Net; Brussels; Droschel; Vrai Réseau; Drochel-Line C, Col. 3. .................................. 117

Point d'Esprit Net, Devonshire-Line H, Col. 8. ..................227

Point de Flandre, Round, Open-eyed Brabant, Binche Spiders, Oeil de Perdrix, Réseau Rosacé-Line G, Col. 4. .................201

Point de Hollande; Arras; Tulle Ground; Lille; Filoche; Fond Clair, Fond Simple; Brabant; Trolly Net; Töndern; Marche; Dutsche SlagLine F, Col. 3.

de Paris; Chantilly; Star Mesh; Double Ground; Point de Six; Eternelle; Point Double; Trenne; Fond Chant; Grammont; Engelsche

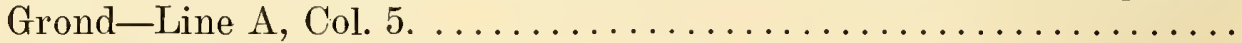
Point de Paris; Fond Clair; Fond Chant (Palliser)-Line C, Col. 11. . . . . . 125 Point de Paris Variation, Du Puy or Lock Stitch; Torchon Mode-Line H, Col. 6. ................................... 225

Point de Paris Variation with Tressed Sides-Line E, Col. 11. ........ 166 Point de Paris Variation, Redina or Tulle Double-Line D, Col. 11. ....... 144 Point de Six; Chantilly; Star Mesh; Double Ground; Point de Paris; Eternelle; Point Double; Trenne; Fond Chant; Grammont; Engelsche Grond-Line A, Col. 5. ....................... 75

Point de Tresse with Knotted Picots-Line E, Col. 13. . . . . . . . . . . . . 169

Point de Tresse with Plain Side Picots-Line D, Col. 13. . . . . . . . . . . . . 147

Point de Tresse with Plain Picots in Lower Joints-Line B, Col. 13. . . . . . . 166 
Point de Tresse with Plain Picots in Side Joints-Line C, Col. 13. . . . . . . . 128

Point Double, Chantilly, Star Mesh, Double Ground, Point de Paris, Point de Six, Eternelle, Trenne, Fond Chant, Grammont, Engelsche Grond-

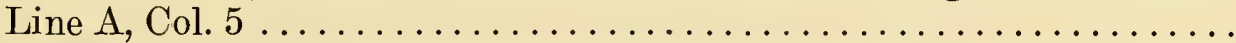

Point du Mariage; Rose Ground; Scandinavian Ground; Gelosia; Tulle Double-Line C, Col. 4 ........................... 118

Point du Mariage fait à la Torchon au Demi-Point-Line A, Col. 6...... 78

Point Jeunet ou Genêt; Scotch Broom Stitch; Ziergrund mit Schrägstreifen-

Musterung-Line C, Col. 2

Point Réseau; Net Stitch; Demi-Point; Lattice Ground; Toilé Ouverte-

Line A, Col. $1 \ldots \ldots \ldots \ldots \ldots \ldots \ldots \ldots \ldots \ldots \ldots \ldots \ldots \ldots \ldots \ldots \ldots \ldots \ldots \ldots \ldots$
Points d'Esprits, Triangular, Fan-Shaped Cutworks or-Line A, Col. $15 \ldots$

Potten Kant; Flemish; Antwerp-Line F, Col. 4

Punto di Néve; Fond de Neige-Line A, Col. 18

\section{$-\mathrm{R}-$ -}

Redina; Maglia di Spagna-Line F, Col. 1

Redina or Tulle Double Point de Paris Variation-Line D, Col. 11 . . . . . 144

Réseau Rosacé; Round, Open-eyed Brabant, Binche Spiders; Oeil de Perdrix; Point de Flandre-Line G, Col. 4. ................. 201

Réseau Simple, Analogue à Celui de Lille, d'Arras, de Marche, de Töndern, de Buckingham-Line G, Col. 6..................... 204

Réseau Stitch; Plain Hole Ground; Torchon; Einfacher Löcherschlag-Line C, Col. 1.

Réseau, Vrai (fait sans épingles); Brussels; Droschel; Drochel-Line B,

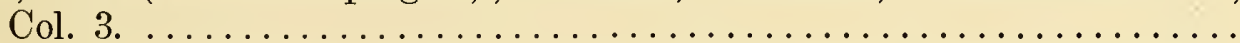

Réseau, Vrai; Brussels; Droschel; Point d'Angleterre Net; Drochel-Line C, Col. 3.

Reticello or Genoese Mode-Line H, Col 5.

Rose Ground; Scandinavian Ground; Point du Mariage; Gelosia; Tulle Double-Line C, Col. 4. ........................... 118

Round-meshed Valenciennes (singly twisted joint, centuple braid) (Bruges has triple braid) -Line G, Col. 7. . . . . . . . . . . . . . . . 205

Round-meshed Valenciennes of Harlebeke, Bruges, Courtrai, Bailleul (braided 4 times) (often twice, Dentelle épiscopale)-Line G, Col. 11. 209

Round, Open-eyed, Brabant, Binche Spiders; Oeil de Perdrix; Réseau Rosacé; Point de Flandre-Line G, Col. 4. ................... 201

Round Spiders in Twice-twisted Hole Ground; Les Araignées Rondes-Line G, Col. 2. ................................. 199

Round Valenciennes (doubly twisted joint, triple braid)-Line H, Col. 7... 226 Russian or German Torchon-Line D, Col. 12. .................. 145

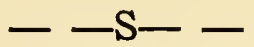

Scandinavian Ground; Rose Ground; Point du Mariage; Gelosia; Tulle Double-Line C, Col. 4.............................. 118 Scotch Broom Stitch; Point Jeunet ou Genêt; Ziergrund mit Schrägstreifen -Musterung-Line C, Col. 2. 
Second Swing Filling, Devonshire-Line E, Col. 8.

Seeds, Fat Maltese Petals, Leaves, Grains, Wheat Ears, Paddles,-Line B, Col. 15. 162

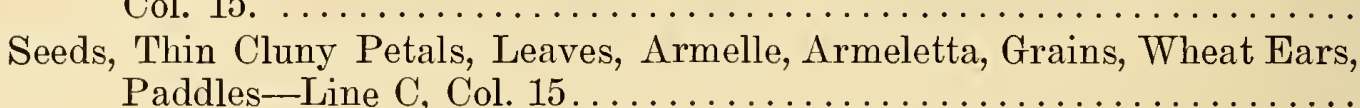
Paddles-Line C, Col. 15............................ 130

Six or Five Sided Milanese Mesh--Line H, Col. 11. ................. 231

Slanting Hole; Dice Holes-Line B, Col. 12. . . . . . . . . . . . . . . . . . 105

Slavonian Style Virgin Point, "Point à la Vierge" nach Slavischer Art-

Line C, Col. 6. ............................. 120

Spagna, Maglia di, Twisted Hole Ground; Tulle Double-Line D, Col. 1. . . 134

Spider, An Italian, with Eye-Line C, Col. 14. ................... 129

Spiders, Eyeless; Fond de Neige-Line H. Col. 4. . . . . . . . . . . . . . . 222

Spiders in Twice-twisted Hole Ground, Round; Les Araignées Rondes-

Line G, Col. 2. . . . . . . . . . . . . . . . . . . . . . . . . . . . 199

Spiders, Italian, Open-eyed, Cable-like-Line F, Col. 14. . . . . . . . . . . 193

Spiders, Italian Six-Legged, with Ribbons-Line H, Col. 14. .......... 235

Spiders, Italian, with 4 twisted Horizontal Bars-Line E, Col. 14. . . . . . . 171

Spiders, Italian, with 2 horizontal Bars-Line G, Col. 14. ........... 212

Spiders, Plain Torchon-Line E, Col. 4..................... 158

Spiders, Round, Open-eyed, Brabant, Binche; Oeil de Perdrix; Réseau Ro-

sacé; Point de Flandre-Line G, Col. 4. ................... 201

Spinnekop; Flemish; Trolle Kant; Fond Armure-Line D, Col. 2. . . . . . . 135

Spot Stitch; Devonshire Swing Filling-Line F, Col. 8. . . . . . . . . . . . 184

Spotted Italian Ground, A-Line B, Col. 14. .................... 107

Square-meshed Valenciennes of Alost and Ypres (braided 5 or 51/2 times) -

Line $\mathrm{E}$, Col. 7. ............................ 161

Square-meshed Valenciennes of Bruges, Ypres and Alost (braided 4 or $41 / 2$

times)_Line D, Col. 7. ........................... 140

Square-meshed Valenciennes of Courtrai and Menin (braided 3 or $31 / 2$ times)

_Line C, Col. 7. ............................. 121

Square-meshed Valenciennes of Honfleur (braided 1 or 11/2 times)-Line A,

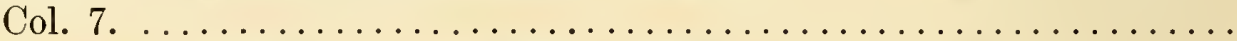

Square-meshed Valenciennes of Menin, Ghent or Gand (braided 2 or 21/2

times) -Line B, Col. 7. .......................... 100

Star Mesh; Chantilly; Double Ground; Point de Paris; Point de Six; Eter-

nelle; Point Double; Trenne; Fond Chant; Grammont; Engelsche

Grond-Line A, Col. 5. ............................ 75

"Sunspots"_-Line H, Col. 12 .............................. 232

Swing Filling, Devonshire, Spot Stitch-Line F, Col. 8. . . . . . . . . . . . 184

Swing Filling, Devonshire Second-Line E, Col. 8. ............... 162

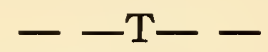

Taunton, Devonshire--Line D, Col. 8......................... 141

Thin, Cluny Petals, Leaves, Armelle, Armeletta, Grains, Seeds, Wheat Ears,

Paddles-Line C, Col. 15. ........................... 130

Toad-in-the-Hole, Devonshire-Line F, Col. 10. .................. 187 
Toilé Ouverte, Net Stitch; Demi-Point; Lattice Ground; Point Réseau-

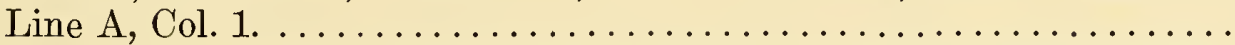

Töndern; Arras; Tulle Ground; Filoche; Fond Clair; Fond Simple; Brabant; Trolly Net; Marche; Point de Hollande; Dutsche Slag, LilleLine F, Col. 3.

Töndern: see also Réseau Simple-Line G, Col. 6. ................ 204

Torchon-Line E. Col. 12. ................................ 167

Torchon Mode, Lock Stitch or Du Puy Point de Paris Variation-Line H, Col. 6.

Torchon; Plain Hole Ground; Réseau Stitch; Einfacher Löcherschlag-Line C, Col. 1.

Torchon, Russian or German-Line D, Col. 12.

Torchon Spiders, Plain-Line E, Col. 4.

Trenne; Chantilly; Star Mesh; Double Ground; Point de Paris; Point de

Six; Eternelle; Point Double; Fond Chant; Grammont; Engelsche

Grond-Line A, Col. 5.

Trentino-Line A, Col. 14.

Tresse, Point de, with Knotted Picots-Line E, Col. 13. ............ 169

Tresse, Point de, with Plain Picots in Lower Joints-Line B, Col. 13. . . . 106

Tresse, Point de, with Plain Picots in Side Joints-Line C, Col. 13. ..... 128

Tresse, Point de, with Plain, Side Picots-Line D, Col. 13. . . . . . . . . . . . . 147

Tresses with Open Hooked Joints_Line H, Col. 17. ................ 239

Triangular, Fan-Shaped Points d'Esprits or Cutworks-Line A, Col. 15. . . 89

Trolle Kant; Flemish; Fond Armure; Spinnekop-Line D, Col. 2. ....... 135

Trolly Net; Arras; Tulle Ground; Lille; Filoche; Fond Clair; Fond Simple;

Brabant; Töndern; Marche; Point de Hollande; Dutsche Slag-Line

F, Col. 3.

Trude "A" Ground (original) (American)_Line A, Col. 4. ........... 74

Trude "B" Ground (original) (American)_Line B, Col. 4. ........... 97

Trude "C" Ground (original) (American)_Line D, Col. 9. .......... 142

Trude "D" Ground (original) (American)_Line A, Col. 11. ............ 83

Trude "E" Ground (original) (American)_Line B, Col. 11. . . . . . . . . . . 104

Trude "F", Ground (original) (American) -Line F, Col. 11. ........... 189

Trude "G" Ground (original) (American)-Line A, Col. 12. . . . . . . . . 84

Trude "H" Ground (original) (American)_Line C, Col. 12. .......... 126

Trude "I" Ground (original) (American)-Line A, Col. 13. ............ 85

Trude "J" Ground (original) (American)_Line H, Col. 15. ............ 237

Trude " $K$ " Ground (original) (American)_Line E, Col. 16. .......... 174

Trude "L" Ground (original) (American)-Line F, Col. 16. ........... 195

Trude " $N$ " Ground (original) (American)_Line A, Col. 17. ........... 91

Trude "O" Ground (original) (American)_Line B, Col. 17. ............. 111

Trude "P" Ground (original) (American) —Line C, Col. 17. ........... 132

Trude " $Q$ " Ground (original) (American)—Line D, Col. 17. .......... 151

Trude "R" Ground (original) (American)_Line G, Col. 17. ........... 215

Trude "S" Ground (original) (American)_Line D, Col. 18. ............. 153

Trude "T" Ground (original) (American)-Line G, Col. 18. ........... 217

Tulle (Bruges?) (2 twists) —Line E, Col. 3. . . . . . . . . . . . . . . . . . . 157 
Tulle (5 twists) - Line G, Col. 3.

Tulle de Dieppe-Line E, Col. 1.

Tulle de Vienne; Genre Valenciennes-Line G, Col. 1.

Tulle Double Done on the Square-Line F, Col. 18.

Tulle Double or Redina Point de Paris Variation-Line D, Col. 11.

Tulle Double; Rose Ground; Scandinavian Ground; Point du Mariage; Gelosia-Line C, Col. 4.

Tulle Double; Twisted Hole Ground; Maglia di Spagna-Line D, Col. 1. ...

Tulle Du Puy_Line B, Col. 1.

Tulle Ground; Arras; Lille; Filoche; Fond Clair; Fond Simple; Brabant; Trolly Net; Töndern; Marche; Point de Hollande; Dütsche SlagLine F, Col. 3.

Twice-twisted Hole Ground; Dieppe Ground; Hole Stitch with Twice-twist-
ed Thread; Löcherschlag mit zweimal gedrehten Fäden-Line H, Col.

Twice-twisted Hole Ground; Dieppe Ground; Hole Stitch with Twice-twist-
ed Thread; Löcherschlag mit zweimal gedrehten Fäden-Line H, Col. 1.

Twice-twisted Virgin Point-mit zweimal gedrehtem Schlusschlag-Line B, Col. 6.

Twisted Hole Ground; Tulle Double; Maglia di Spagna-Line D, Col. 1. ...

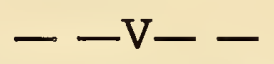

Valenciennes, Dieppe Three-thread-Line F, Col. 17.

Valenciennes, Genre; Tulle de Vienne-Line G, Col. 1.

Valenciennes Mixte-Line F, Col. 7.

Valenciennes Picots-Line F, Col. 13.

Valenciennes, Round (doubly twisted joint, triple braid)-Line H, Col. 7...

Valenciennes, Round-meshed (singly twisted joint, centuple braid) (Bruges has triple braid)-Line $G$, Col. 7 .

Valenciennes, Round-meshed of Harlebeke, Bruges, Courtrai, Bailleul (braided 4 times) (often twice, Dentelle épiscopale)-Line G, Col. 11. .....

Valenciennes, Square-meshed of Alost and Ypres (braided 5 or $51 / 2$ times) Line E, Col. 7.

Valenciennes, Square-meshed of Bruges, Ypres and Alost (braided 4 or $41 / 2$

times)-Line D, Col. 7.
Valenciennes, Square-meshed -Line C, Col. 7.

Valenciennes, Square-meshed of Honfleur (braided 1 or $1 \frac{1}{2}$ times)-Line A, Col. 7.

Valenciennes, Square-meshed of Menin, Ghent or Gand (braided 2 or $21 / 2$

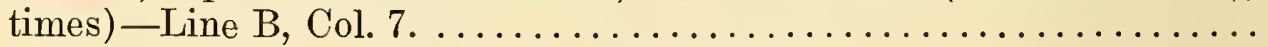

Vienne, Tulle de; Genre Valenciennes-Line G, Col. 1. . . ............ 198

Virgin Ground; Ornamental Ground; Fond de la Vierge; Point Carré-Line B, Col. 2.

Virgin Ground; Pin Check; Pink Check; Ornamental Ground; Binche; Cinq Trous; Point Carré-Line A, Col. 2.

Virgin Point, Slavonian Style; "Point à la Vierge" nach Slavischer ArtLine C, Col. 6. 
Virgin Point, Twice-twisted-mit zweimal gedrehtem Schlusschlag-Line B, Col. 6. .................................. 99

Vrai Reseau (fait sans épingles); Brussels; Droschel; Drochel-Line B,

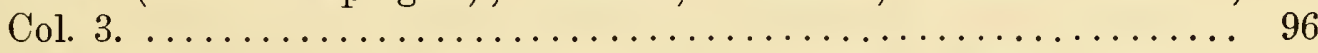

Vrai Réseau; Brussels; Droschel; Point d'Angleterre Net; Drochel-Line C, Col. 3 .

\section{$--\mathrm{W}--$}

Wall Filling, Devonshire-Line G, Col. 10. .................. 208 Wheat Ears, Fat Maltese Petals, Leaves, Seeds, Grains, Paddles-Line B, Col. 15. ...................................... 109 Wheat Ears, Thin Cluny Petals, Leaves, Armelle, Armeletta, Grains, Seeds, Paddles-Line C, Col. 15. ........................ 130 Winkie Pin Bars and Cutworks, Devonshire-Line C, Col. 10. . . . . . . . 124 Wire Ground, Devonshire-Line G, Col. 9. .................. 207

$$
--\mathrm{Y}--
$$

Ypres, Square-meshed Valenciennes of Alost and (braided 5 or $51 / 2$ times) -Line E, Col. 7. .............................. 161 Ypres, Square-meshed Valenciennes of Bruges, Alost and (braided 4 or $41 / 2$

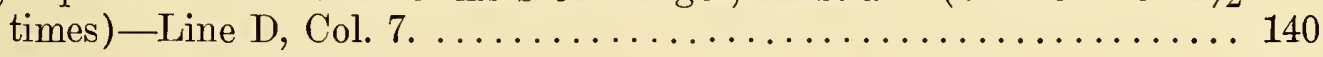

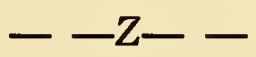

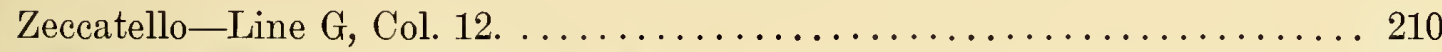

Zeccatello, A Fancy-Line F, Col. 12....................... 190

Ziergrund mit Schrägstreifen-Musterung, Scotch Broom Stitch; Point Jeunet ou Genêt-Line C, Col. 2. ....................... 115 Ziergrund mit Streifen - Musterung in Karo - Einteilung; Ornamental Ground with Striped Effect in Diagonal Squares-Line D, Col. 6. .. 139 Ziergrund mit Streifen-Musterung in Zacken - Einteilung; Ornamental Ground with Zigzag Diagonal Stripes-Line E, Col. 6. ........ 160

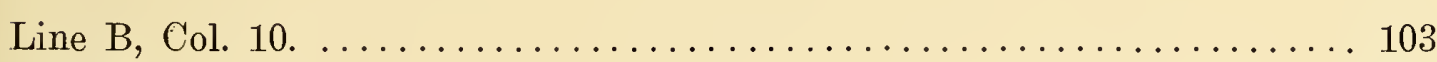

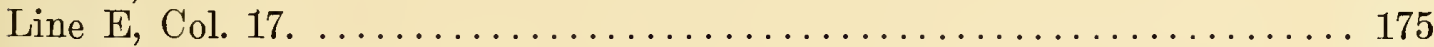

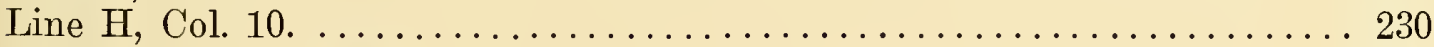

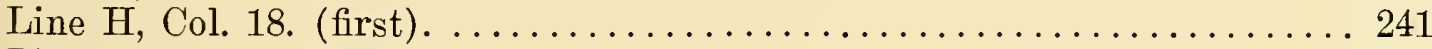

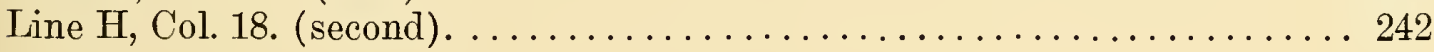





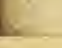



AN INDEXED, COMPARATINE SAMPLER OF 145 BOBBIN LACE, GROUNDS AND FILLINGS
MADE TO THE SCALE OF NO. 70 D.M.C. LIEN THREAD AND JOINE BY PILLOW-WROUCHT BANDS OF CLOTH.STITCH

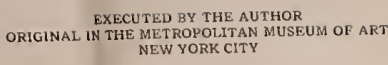
MADE IN NEW YORK, 1912-171

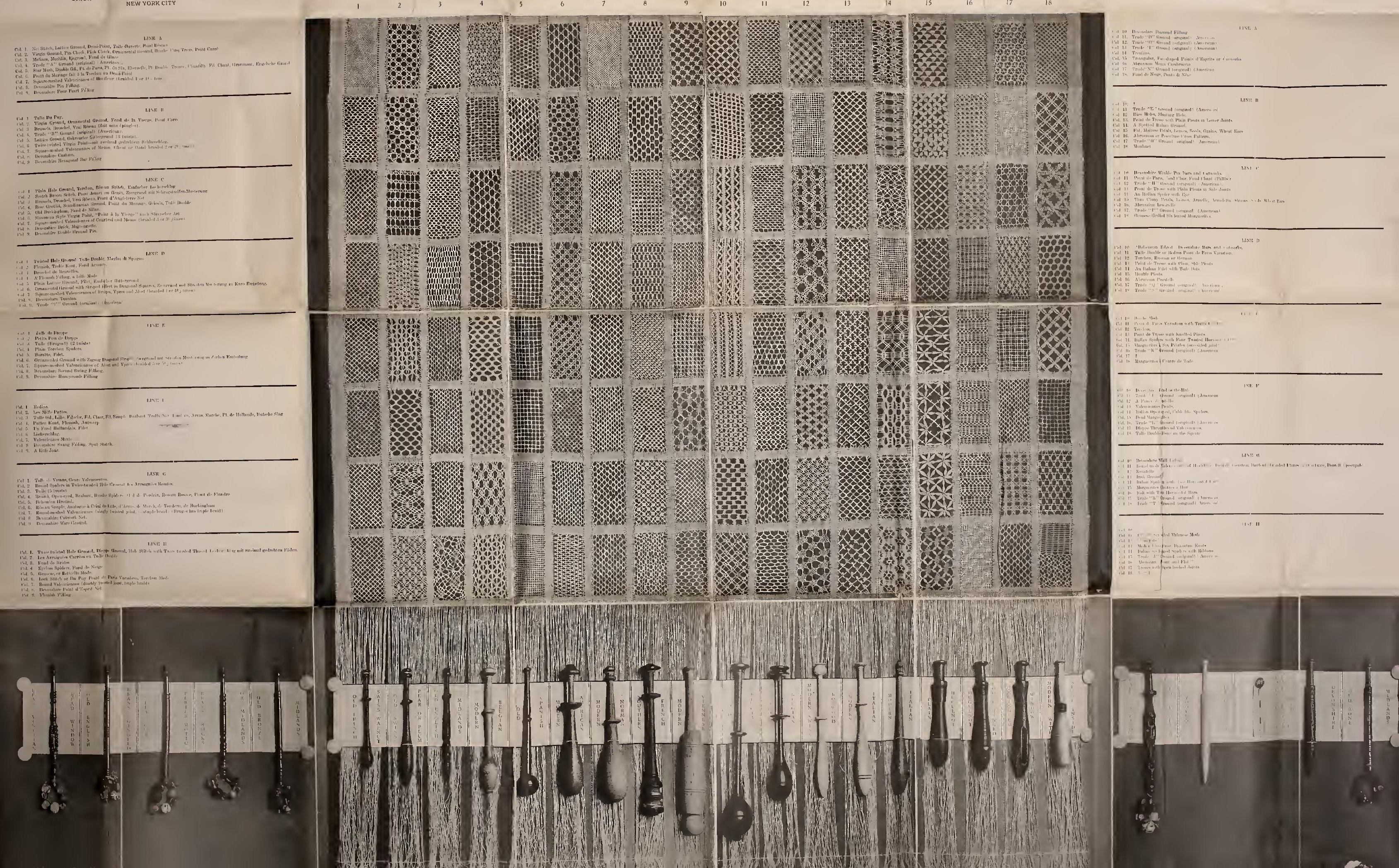


